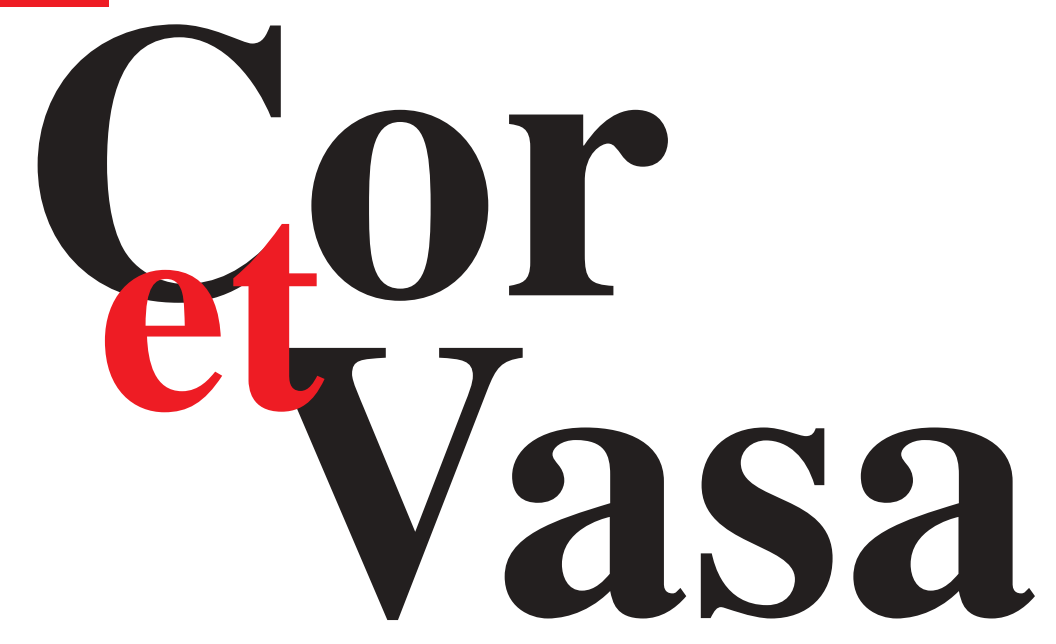

Abstrakty XV. výročního sjezdu České kardiologické společnosti, 13.-16. května 2007, Brno 


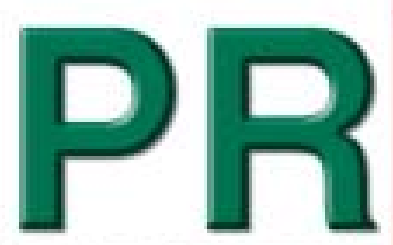

PERINDOPRIL

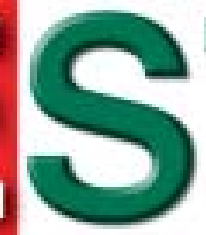
m

\section{.}

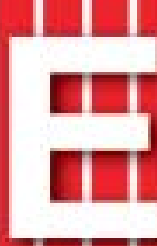

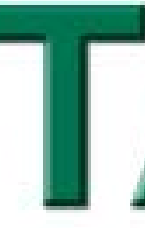
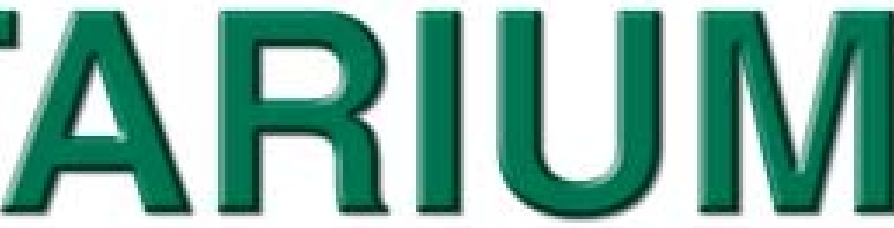

\section{Záruka dobrého tlaku}

\section{$180 \mathrm{~mm} \mathrm{Hg}$}

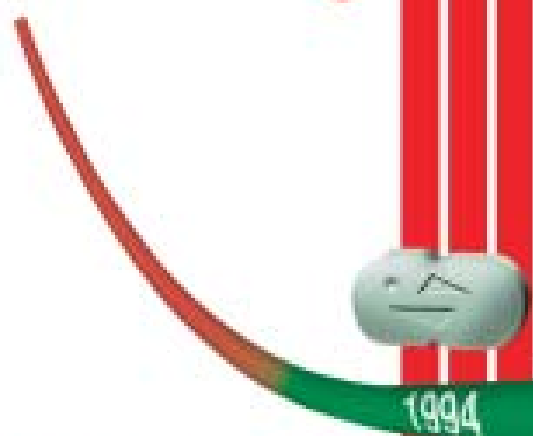

\section{$120 \mathrm{~mm} \mathrm{Hg}$}
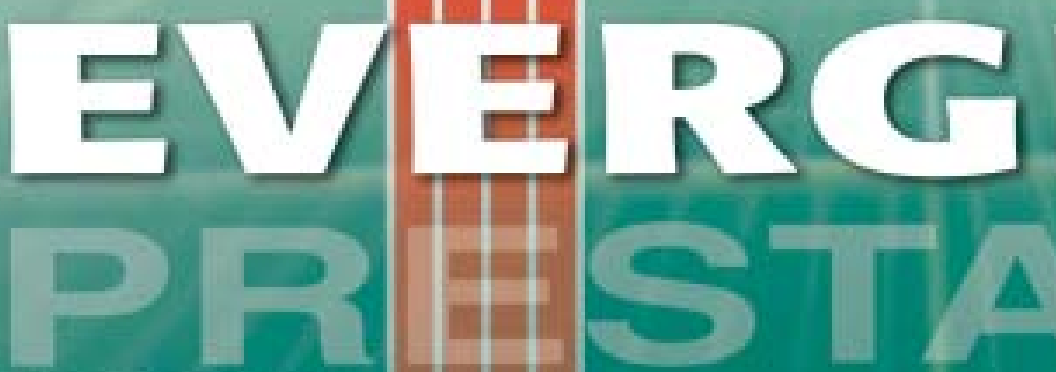

BUDOUCNOSt]

\section{7

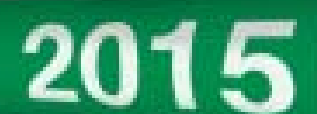

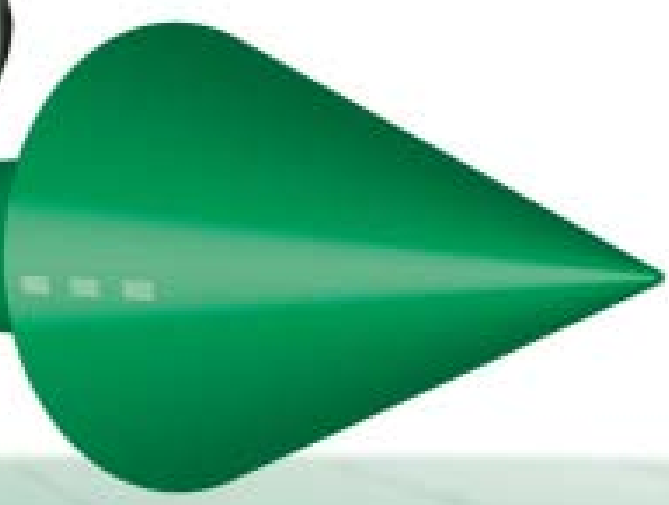
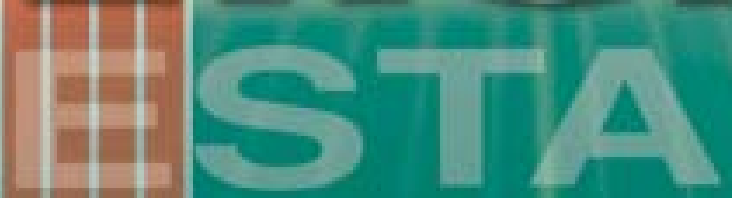

PERINDOPFIL

Zkrácená informace o prípravku

Prestarium je dlouhodobě působící inhibitor ACE. Složení: perindoprilum erbuminum 4 mg nebo 8 mg v jedné tabletě. Indikace: Hypertenze. Srdeční selhání. Snižení rizika kardiálních přihod u pacientů s anamnézou infarktu myokardu a/nebo revaskularizace. Sekundární prevence CMP v kombinaci s indapamidem. Dávkování: Hypertenze: Doporučená úvodní dávka je 4 mg jednou denně ráno. V př́padě potřeby mưže být dávka zvýšena na 8 mg. Srdeční selhání: Léčba se zahajuje dávkou 2 mg denně. Obvyklá udržovací dávka je 2-4 mg denně. ICHS: Léčba by měla být zahájena v dávce 4 mg jednou denně po dobu dvou týdnů, poté by měla být dávka zvýšena na 8 mg jednou denně s ohledem na funkci ledvin. Prevence CMP: Léčba se zahajuje dávkou 2 mg denně po dobu 2 týdnů, poté by měla být dávka zvýšena na 4 mg denně na dobu dalších 2 týdnů, následně by měl být přidán indapamid. Starší pacienti: Léčba se obvykle zahajuje dávkou 2 mg denně. Renální selhání: Dávkování je nutno přizpưsobit clearance kreatininu. Kontraindlkace: Podávání dětem, těhotným a kojicím ženám, angioneurotický edém v anamnéze, přecitlivělost. Upozornění: Symptomatická hypotenze je vzácná. Při renální insuficienci a renovaskulární hypertenzi je nutno sledovat renální funkce. Nežádoucí účinky: Nejčastěji byly pozorovány kašel, dušnost, nauzea, zvracení, bolest břicha, poruchy chuti, průjem, zácpa, kožní vyrážky, svědění, hypotenze, poruchy nervového systému (např. bolest hlavy, závrat', parestezie). Interakce: Nedoporučuje se současné použití s kalium šetřicími diuretiky nebo doplňky draslíku. Balení: 30 tablet. Uchovávejte při teplotě do 30 C. Držittel rozhodnutí o registraci: Les Laboratoires Servier, 22, rue Garnier, 92200 Neuilly-sur-Seine, Francie. Registrační číslo 58/712/92-C; 58/391/03-C. Před předepsáním připravku si přečtěte Souhrn údajů o prípravku. Datum poslední revize textu 20. 9. 2006. Přípravek je k dispozici v lékárnách na lékařský předpis. Připravek je částečně hrazen z prostředků veřejného zdravotního pojištění.

Servier s.r.o., Klimentská 46, 11002 Praha 1, tel.: (+420) 222118 307, fax: (+420) 222118 300, www.servier.cz * 气 SERVIER 


\section{Našli jsme pro vás}

správnou kombinaci

\section{PRESTARIUM"COMBI}
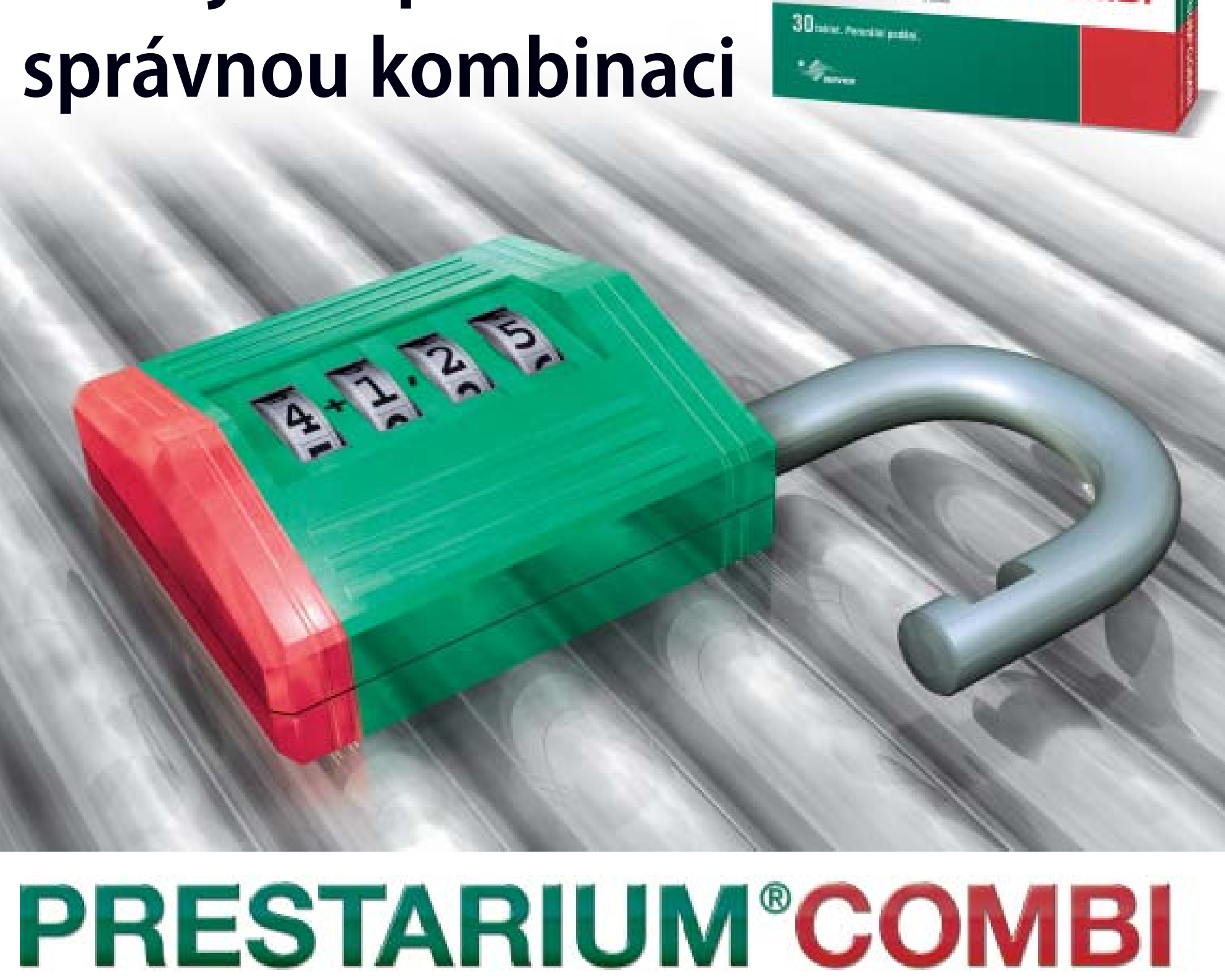

perindopril $4 \mathrm{mg}$ + indapamid 1,25 mg

\section{otevírá novou dimenzi kontroly TK}

Zkrácená informace o prípravku Prestarium ${ }^{\circledR}$ Combi:

Prestarium ${ }^{\circledR}$ Combi je kombinací dlouhodobě pưsobícího inhibitoru ACE s diuretikem. Složenl: Perindoprilum erbuminum 4,00 mg (odpovídajicí 3,338 mg perindoprilu) a indapamidum 1,25 mg v jedné tabletě. Terapeutické indikace: Léčba esenciální hypertenze; prípravek Prestarium ${ }^{\circledR}$ Combi je indikován u pacientů, u kterých není krevní tlak dostatečně kontrolován prì léčbè samotným perindoprilem. Dávkováni a đuisob podán: Obvyklá dávka Prestaria Combi je jedna tableta denně v jedné dávce, nejeépe ráno pred jíllem. U pacientư s renální insuficiencí kteřímají clearance kreatininu $>30 \mathrm{~m} / \mathrm{min}$ a $<$ než $60 \mathrm{~m} / \mathrm{min}$, se doporučuje zahájení léćby adekvátní dávkou volné kombinace. U pacientů s clearance kreatininu > $60 \mathrm{ml} / \mathrm{min}$ změna dávkování není nutná. Kontraindikace: těžká renálni insuficience (clearance kreatininu pod $30 \mathrm{~m} / \mathrm{min}$ ), precitlivělost na perindopril nebo jiné inhibitory ACE a na sulfonamidy, angioneurotický edém v anamnéze, těhotenství, kojení, podávání dětem, hepatální encefalopatie, závažné poškození jaterních funkcí, hypokalémie. Prípravek se obvykle nedoporučuje u bilaterální stenózy renální artérie nebo artérie solitární ledviny a prì zvýšené plazmatické hladině drasliku. Prestarium ${ }^{\circledR}$ Combi by neměl byt pouzíván u dialyzovaných pacientư a pacientu s neléčeným dekompenzovaným srdečním selháním. Varování a zvlašstní opatfenf pro použzt: Kombinace perindoprilu a indapamidu nevylučuje moznost vzniku hypokalémie, zvláště u diabetikư nebo u pacientů s renálním selháním. Stejně jako u jiných antihypertenziv s obsahem diuretika by mělo být prováděno pravidelné sledování plazmatických hladin drasliku. Prèd zaháiením léćby u starších pacientư by měla být vyšeťena renální funkce a kalémie. Je nutné pravidelné sledování plazmatické hladiny sodiku, které musí být u starších pacientú a u pacientu s cirhózou častěsiś. Sledování glykémie je nutné u nemocných s diabetem, zváśšè u nemocných s hypokalémií. Interakce: Nedoporučuje se současné podávání s lithiem, s kalium šetríícími diuretiky a solemi draslíku, a dále s prípravky bezantiarytmického úćinku prodlužující QT interval nebo způsobujicí torsades de pointes (astemizol, bepridil, erytromycin i.v., halofantrin, pentamidin, sultoprid, terfenadin, vincamin). Nežadouc' účinky: hypokalémie (hladina drasliku < 3,4 mmol/; zváástè u diabetiku nebo u pacientů s renálním selháním, u vysoce rizikových populací jako jsou staršía/nebo podyyživení jedinci, kteří prípadně uźíiají najednou více léku, pacienti s cirhózou, s edémem a ascitem, koronární pacienti a pacienti se srdečním selháním), zácpa, sucho v ústech, nevolnost, bolest v epigastriu, anorexie, abdominální bolest, poruchy chuti, suchý kašel, hypotenze, kožní reakce, poruchy nervového a svalového systému. Uchováván:: Uchovávejte prí teplotě do $30^{\circ} \mathrm{C}$. Držttel rozhodnut́ o registraci: Les Laboratoires Servier, 22, rue Garnier, 92200 Neuilly - sur Seine, Francie. Registračñ ćíslo: 58/264/02-C Datum poslední revize texul: 7. 9. 2005. Před predepsáním príipravku si přěčěte Souhrn údajü o prípravku. Prípravek je k dispozici v lékárnách na lékařský predpis. Přípravek je částečně hrazen z prostréedku veřejného zdravotního pojsištění.

$$
\text { 芷 } \cong
$$




\title{
Abstrakty XV. výročního sjezdu České kardiologické společnosti, 13.-16. května 2007, Brno
}

\author{
Za obsahovou stránku abstraktů odpovídají autoři.
}

\section{DIABETES MELLITUS A VSTUPNÍ HLADINA SÉROVÉ GLYKEMIE U PACIENTÜ PO AKUTNÍM INFARKTU MYOKARDU}

\author{
ADÁMKOVÁ R, TOMÁŠEK A, JANOUŠEK S, \\ TƯMOVÁ J, ČERMÁKOVÁ Z, ŠPINAR J \\ Interní-kardiologická klinika, \\ Oddělení klinické biochemie, FN Brno, Brno
}

Úvod: Vysoká hladina vstupní sérové glykemie při akutním infarktu myokardu (AIM) je častá a je spojena se zvýšeným rizikem smrti pacientů, at již se známým diabetes mellitus (DM) či bez něho. Data $z$ poslední doby ukazují vyšší prevalenci abnormálního glukózového metabolismu u pacientů bez známého DM při vzniku AIM.

Cíl: Zjistit vztah mezi vstupní hodnotou sérové glykemie při AIM a střednědobou prognózou pacientů $\mathrm{s}$ předchozí diagnózou DM, zejména pak pacientů bez známého DM, ale $\mathrm{s}$ hladinou sérové glykemie $\mathrm{v}$ diabetickém rozmezí.

Soubor a metodika: Základní soubor tvořili všichni pacienti přijatí na naši koronární jednotku v letech 2003 a 2004, jednalo se o 870 pacientů (605 bez DM a 265 /30,5\%/ s diagnózou $\mathrm{DM})$, tito byli retrospektivně analyzováni po dobu 6 měsíců.

Výsledky: Během sledování, 78 nediabetických pacientů $(12,9 \%)$ a 53 diabetiků $(20,0 \%)$ zemřelo $(p=0,007)$. Ze 605 nediabetických jedinců, 66 (10,9\%) mělo vstupní hladinu sérové glykemie $11,1 \mathrm{mmol} / 1$ nebo vyšší, a mortalita těchto pacientů byla srovnatelná s těmi, kteří měli již známý DM (30,3\% vs. $20,0 \%)$.

Závěr: Vstupní hladina sérové glykemie po AIM je nezávislým prediktorem střednědobé mortality u všech pacientů, diabetiků i nediabetiků. Jedinci bez známého DM a vstupní hladinou sérové glykemie $11,1 \mathrm{mmol} / 1$ nebo vyšší při AIM měli mortalitu zvýšenou obdobně jako jedinci s DM. Vstupní hladina glykemie může sloužit $\mathrm{k}$ identifikaci jedinců $\mathrm{s}$ vyšším střednědobým rizikem mortality, zvláště nediabetiků.

\section{PRVNÍ ZKUŠENOSTI KOMBINOVANÉ TERAPIE U PACIENTÚ S IDIOPATICKOU PLICNÍ ARTERIÁLNÍ HYPERTENZÍ}

\section{AL-HITI H, MELENOVSKÝ V, KETTNER J, MÁLEK I}

Klinika kardiologie, Koronární jednotka, IKEM, Praha

Idiopatická plicní arteriální hypertense (IPAH) je progresivní onemocnění charakterizované vysokou plicní arteriální rezistencí (PAR), která vede $\mathrm{k}$ přetížení pravé komory srdeční, dysfunkci a terminálně $\mathrm{k}$ selhání.

Díky novým možnostem léčby pomocí prostanoidů, blokátorů endotelinových receptorů a inhibitorů fosfodiesterázy 5, lze ovlivnit nejen symptomy těchto závažně nemocných, ale i plicní hypertenzi (PH) a další prognózu.
Cílem našeho sdělení je popsat akutní a střednědobý efekt kombinované terapie inhalačním prostacyklinem a sildenafilem u nemocných s velmi závažnou prekapilární PH.

U dvou pacientů s IPAH a ND III. st. klasifikace NYHA, $\mathrm{s}$ pouze přechodným zlepšením při terapii iloprostem, byl proveden akutní hemodynamický test s podáním $20 \mathrm{mg}$ sildenafilu p. o. po předchozí inhalaci $5 \mu \mathrm{g}$ iloprostu. Po podání sildenafilu byl prokázán protrahovaný pokles středního tlaku v arteria pulmonalis o dalších 15 a $12 \mathrm{~mm} \mathrm{Hg}$, bez ovlivnění středního systémového arteriálního tlaku. Následně těmto pacientům byla podávána tato kombinovaná terapie s příznivým efektem ve smyslu zlepšení tolerence zátěže, dokumentována 6minutovým testem chůze (90 a 70 m).

Kombinovaná terapie PAH. Ta se jeví jako nejnadějnější pro možnost současného ovlivnění několika patofyziologických cest. Na druhé straně musí být tato léčba přísně individuální podle stavu pacienta a výsledku akutního hemodynamického vyšetření.

\section{THE EFFECT OF ELASTIC BANDAGE OF THE LOWER LIMBS, ON BLOOD PRESSURE AND BAROREFLEX}

\section{AL-KUBATI M, FISER B}

Department of Physiology and Ist Internal Cardiovascular Clinic, St. Anna University Hospital, Masaryk University, Faculty of Medicine, Brno

Objective: To examine the effect of Elastic Bandage (EB) of the lower limbs on blood pressure (BP), heart rate (HR) and cardiac baroreflex sensitivity (BRS in $\mathrm{ms} / \mathrm{mmHg}$, and BRSf in $\mathrm{Hz} / \mathrm{mmHg}$ ) derived from spectral analysis of BP fluctuations and HR.

Methods: We studied 10 healthy normotensive volunteers of age $30 \pm 5$ years (mean $\pm \mathrm{SD}$ ). We recorded beat-to-beat arterial blood pressure: systolic (SBP), dyastolic (DBP), mean (MBP); and inter-beat-interval (IBI in ms) with breathing controlled by metronome. Measurements were repeated 4 times (Finapres Ohmeda): 1.: in supine position (SP) without bandage; $2 .:$ suddenly after 20 seconds of the standing (S) from the SP; 3.: in SP with the bandage and 4.: in $\mathrm{S}$ with the bandage (each measurement lasted $5 \mathrm{~min}$. the rest before measurment in SP 25 min, intervals between SP and $\mathrm{S}$ positions were $20 \mathrm{sec}$ ). We used spectral analysis to determine BRS and BRSf. The values from the first measurment were taken as baseline values.

Results: When compared with the baseline values we found that the increase in HR during S with $\mathrm{EB}(p=0.009)$ is less than the increase during $\mathrm{S}$ without $\mathrm{EB}(p=0.001)$. Less decrease in SBP, DBP, and MBPs $(p=0.011, p=0.0004$, and $p=0.001$ consequently), during $\mathrm{S}$ with $\mathrm{EB}$ than the decrease during $\mathrm{S}$ without $\mathrm{EB}: \mathrm{SBP}, \mathrm{DBP}$ and $\mathrm{MBP}(p=0.014, p=0.001$ and $p=0.002)$. The BRS (ms/mmHg) was less impaired during S with $\mathrm{EB}(p=0.21)$ than during S without $\mathrm{EB}(p=0.01)$. No significant changes were found in the BRSf $(\mathrm{Hz} / \mathrm{mmHg})$. 
Conclusions: We found that in orthostatism, decrease in baroreflex sensitivity during elastic bandage of the lower limbs is less; increase in heart rate is less and decrease in the blood pressure is less than during standing without EB. Those results indicate the use of the elastic bandage to avoid the neural sympathetic response to gravitional stimulus in persons with orthostatic intolerance.

\section{ZMĚNY VYBRANÝCH ECHOKARDIOGRAFICKÝCH PARAMETRŮ FUNKCE PRAVÉ KOMORY PO PLICNÍ ENDARTEREKTOMII}

AMBROŽ D, PALEČEK T, LINDNER J, JANSA P, ASCHERMANN M, LINHART A

II. interní klinika kardiologie a angiologie,

Klinika kardiovaskulární chirurgie, VFN a 1. LF UK, Praha

Úvod a cíl studie: Plicní endarterektomie (PEA) je léčebnou metodou volby $\mathrm{u}$ nemocných $\mathrm{s}$ chronickou tromboembolickou plicní hypertenzí (CTEPH). Úspěšná PEA vede k signifikantnímu poklesu, resp. normalizaci tlaků $\mathrm{v}$ plicnici a redukci velikosti původně dilatované pravé komory (PK). Cílem naší práce bylo posoudit vývoj některých echokardiografických parametrů funkce PK časně po provedení PEA.

Metody: Studijní skupinu tvořilo 19 nemocných s CTEPH (53 \pm 14 let, 15 mužů), kteří byli echokardiograficky vyšetřeni před jedním měsícem a jeden měsíc po úspěšné PEA. Kromě posouzení systolického tlaku v plicnici (PASP) a enddiastolického rozměru PK (EDD PK) byly hodnoceny tyto parametry systolické funkce PK: frakční změna plochy PK (FAC PK) a amplituda systolického pohybu trikuspidálního anulu (TAPSE). Dále byl hodnocen Teiův index PK, který by měl odrážet její globální funkci.

Výsledky: Po PEA došlo k signifikantnímu poklesu PASP z $90 \pm 19$ mm Hg na $34 \pm 17$ mm Hg a významnému zmenšení PK EDD z $47 \pm 5 \mathrm{~mm}$ na $30 \pm 6 \mathrm{~mm}$ (vše $p=0,001$ ). Zároveň došlo $\mathrm{k}$ signifikantnímu zlepšení FAC PK z 0,22 $\pm 0,09$ na $0,34 \pm 0,01$ a rovněž Teiův index významně vzrostl z 0,43 $\pm 0,10$ na 0,24 $\pm 0,09$ (vše $p=0,001$ ). V kontrastu s tím byl zaznamenán zřetelný pokles TAPSE z $14 \pm 3 \mathrm{~mm}$ na $11 \pm 3 \mathrm{~mm}(p=0,001)$.

Závěr: Studované echokardiografické parametry systolické funkce PK - FAC PK a TAPSE - vykazují odlišný vývoj časně po provedení PEA. Tento rozdíl je pravděpodobně podmíněn negativním vlivem kardiochirurgického výkonu, vyžadujícím perikardiotomii na systolický pohyb trikuspidálního anulu. TAPSE se proto jeví jako nevhodný ukazatel systolické funkce PK u těchto nemocných. Zlepšení hodnot Teiova indexu by mohlo ukazovat na zlepšení globálnî funkce PK, diskutabilní je však ovlivnění tohoto parametru výraznou redukcí afterloadu PK po PEA.

\section{OPAKOVANÉ TROMBÓZY VE STENTU PR̆I DEFICITU ANTITROMBINU III, JAKO DŮSLEDKU PROTRAHOVANÉ TERAPIE HEPARINEM}

\section{ANDRÁŠOVÁ A, OSMANČÍK P}

III. interní-kardiologická klinika, FN KV a 3. LF UK, Praha

Naše sdělení se zabývá 81letým pacientem, který byl na našî́ kliniku přeložen 2. 2. $2005 \mathrm{z}$ periferní nemocnice. V ní byl hospitalizován pro Q-infarkt myokardu přední stěny od 29. 1. 2005 a kromě aspirinu léčen kontinuálním i. v. nefrakcionovaným heparinem (UFH). U nás echokardiograficky zjištěna těžká dysfunkce levé komory s ejekční frakcí 30-35 \%. Následně 4. 2. 2005 provedena koronarografie s nálezem nemoci 3 tepen - RIA $90 \%$, RC $70 \%$, ACD $90 \%$, RPLD 90 \%. Terapie UFH byla ukončena po koronarografii 4. 2. 2005; 11. 2. 2005 byla provedena PCI dvou lézí na ACD s implantací stentů a zahájena standardní léčba duální antiagregační medikací (aspirin + clopidogrel), s odstupem elektivní PCI se stentem na RIA. V průběhu 10 dnů došlo $\mathrm{u}$ pacienta $\mathrm{k}$ recidivujícím trombózam ve stentu, $1 \times$ na $\mathrm{ACD}$ a $2 \times$ na RIA. Poslední koronarografie a PCI 21. 2. 2005. Kromě duální antiagregační léčby podáván opět i. v. kontinuálně UFH. Hemokoagulační vyšetření prokázalo výrazné snížení hodnot antitrombinu III (AT-III, 21. 2. $200531 \%$ ), normální hodnoty proteinu $\mathrm{C}$ a $\mathrm{S}$, lupus antikoagulans negativní. Po substituci AT-III dávkou 2500 jednotek 21. 2. 2005 vzestup hodnot na 81 \% náležitých hodnot. 25. 2. 2005 ukončení léčby i. v. UFH. Od té doby pacient již zcela bez recidivy stenokardií, EKG taktéž bez dalších recidiv ischemie po zbytek hospitalizace, 4. 3. 2005 propuštěn do ambulantní péče.

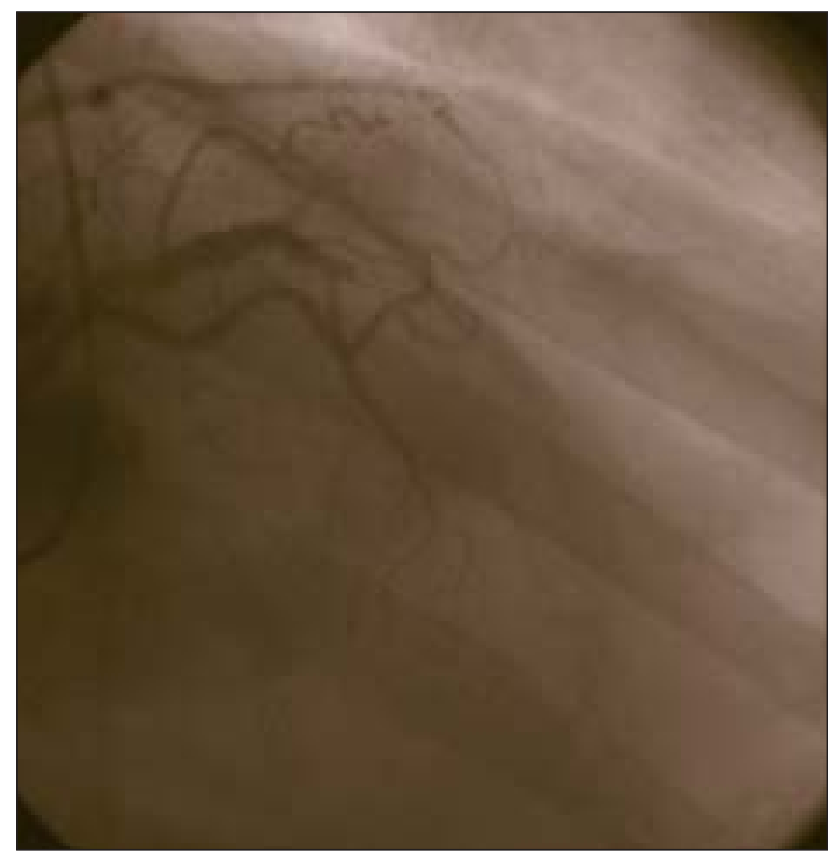

Naše kasuistika popisuje případ recidivujících trombóz ve stentu $u$ pacienta $s$ hyperkoagulačním stavem při depleci antitrombinu III, navozeného dlouhodobou léčbou i. v. UFH. Na arteficiální depleci AT III u pacientů na delší dobu podávaném i. v. UFH je nutno vždy myslet, zejména pro jednoduchost monitorace AT III a snadnost jeho substituce.

Sdělení je doplněno bohatou obrázkovou dokumentací (katetrizační nálezy, EKG, hodnoty koagulace a agregace).

\section{AKUTNÍ INFARKT MYOKARDU U MLADÉHO MUŽE S KOMBINOVANOU HEREDITÁRNÍ TROMBOFILIÍ}

\section{ASCHERMANN O \\ Kardiologické oddělení, Nemocnice Na Homolce, Praha}

Úvod: Akutní infarkt myokardu u mladých jedinců je nozologická jednotka v mnohém odlišná od problematiky AIM ve vyšším věku. Patofyziologicky zásadně převažuje problematika arteriální trombózy při trombofilním stavu vs. aterosklerotické postižení u starších jedinců.

Kasuistika: Předkládáme případ pacienta bez rizikových faktorů aterosklerózy, nekuřáka (!) referovaného na naše pracoviště pro STEMI přední stěny. Koronarograficky byl prokázán trombotický uzávěr odstupového segmentu ramus interventricularis anterior. Byla provedena direktní koro- 
nární angioplastika s implantací koronárního stentu s podáním GP IIb/IIIa inhibitorů (pro masivní nálož trombů) s dosažením kompletní reperfuze - TIMI III flow.

Další průběh onemocnění byl nekomplikovaný, enzymatická odezva byla středně velká, echokardiograficky byla jen mírně snížena systolická funkce LK. Následné doplněné hematologické vyšetření potvrdilo závažnou kombinovanou hereditární trombofilii v podobě mutace genu pro MTHFR, dále mutace Leidenská i mutace protrombinová, vše v heterozygotní formě, byla doporučena prevence TEN podáváním Anopyrinu 100 mg a Plavixu 75 mg trvale. V dalším sledování (12 M) trombotické příhody nerecidivovaly, došlo $\mathrm{k}$ postupné normalizaci EKG-křivky i systolické funkce LK.

Závěr: AIM v mladém věku nejsou procentuálně časté, nicméně velmi rizikové pro pacienta při podcenění situace s ohledem na neuvažovanou kardiální etiologii obtíží a současně i s možností komplikace průběhu při masivní prrítomnosti koronárních trombů, zhoršujících šanci na dosažení kompletní reperfuze myokardu. U těchto jedinců je indikováno doplnění podrobného hematologického vyšetření k posouzení prrítomnosti trombofilních stavů.

\section{REHABILITACE POMOCÍ NíZKOFREKVENČNÍ ELEKTRICKÉ STIMULACE (NFES) KOSTERNICH SVALŨ U PACIENTA S IMPLANTOVANÝM KARDIOSTIMULÁTOREM. KASUISTIKA*}

BALCÁRKOVÁ P, DOBŠÁK P, FRANTISOVÁ M, ŠPINAROVÁ L, VÍTOVEC J, SIEGLOVÁ J, AL-MAHMODI N

I. interní-kardioangiologická klinika, Klinika funkčni diagnostiky a rehabilitace, FN u sv. Anny, Brno

*Podpořeno IGA MZČR 7983-3 a MSM 0021622402.

NFES kosterních svalů je nová rehabilitační metoda pacientů s pokročilým chronickým srdečním selháním (CHSS). Přítomnost kardiostimulátoru (PM) je uváděna jako jedna z kontraindikací jejího využití.

Popisujeme př́ipad 47letého pacienta s CHSS (EF $20 \%$, NYHA IV), s implantovaným PM v režimu DDD, zařazeným na čekací listině pro transplantaci srdce, který absolvoval 5týdenní program NFES stehenních a lýtkových svalů (ELPHA 2000 Danmetr; 1 hodina denně, 7 dní v týdnu; $10 \mathrm{~Hz}$ ). Před započetím tréninku jsme provedli kontrolu PM, během každé aplikace NFES jsme sledovali srdeční rytmus pomocí monitorování EKG. Každý týden jsme metodou izometrické dynamometrie hodnotili maximální svalovou sílu (Fmax; N) a vrcholový moment síly (PTmax; Nm) m. quadriceps femoris dx a sin (MQFdx,sin). Systolický a diastolický tlak krve jsme měřili denně před cvičením a po cvičení. U našeho pacienta jsme nepozorovali žádné nežádoucí účinky, dưvodem ukončení stimulace byla transplantace srdce. Nedošlo ke změnám EKG-křivky během aplikace NFES, ani k výkyvům tlaku krve. Po 5 týdnech NFES kosterních svalů došlo ke zvýšení svalové síly obou MQF (MQFdx: $\delta F \max =$ $86 \mathrm{~N}, \delta \mathrm{PT} \max =36,5 \mathrm{Nm}$. MQFsin: $\delta \mathrm{Fmax}=24,4 \mathrm{~N}, \delta \mathrm{PTmax}$ $=10,24 \mathrm{Nm})$. Díky výraznějšímu zlepšení svalové síly na MQFdx se po 5 týdnech NFES prakticky smazal rozdíl mezi svalovou silou pravé a levé dolní končetiny ( $\delta \mathrm{Fmax}=78,5 \mathrm{~N}$, na počátku vs. $\delta F \max =16 \mathrm{~N}$ na konci tréninku). Prospěch NFES u pacientů s CHSS již prokázaly dřivější studie. U našich pacientů s implantovaným PM zatím tato metoda nebyla využívána, v zahraničí již vznikají první studie. U našeho prvního pacienta jsme nepozorovali nepříznivý vliv aplikované NFES kosterních svalů na implantovaný PM. Pokračujeme v náběru dalších pacientů a jejich sledování.

\section{PREVALENCE AND PREDICTIVE FACTORS \\ OF HEART FAILURE AFTER NON ST SEGMENT ELEVATION MYOCARDIAL INFARCTION*}

BARTHEZ O, EICHER J, ZELLER M, COTTIN Y, DOBŠÁK P, SIEGELOVÁ J, WOLF J

Centre de Cardiologie Clinique et Interventionelle, Hopital du Bocage, Dijon, France,

Klinika funkční diagnostiky a rehabilitace,

FN U sv. Anny, Brno

\section{*Support: MSM0021622402.}

Introduction: Coronary artery disease is the most frequent etiology of heart failure $(\mathrm{HF})$ and the prevalence of HF after ST segment elevation myocardial infarction is estimated between 18 and $37 \%$. Little is known about the prevalence of $\mathrm{HF}$ complicating Non ST Segment Elevation Myocardial Infarction (NSTEMI). The aim of the present study was 1 . to establish the proportion of HF patients two years after a NSTEMI and 2. to determine the risk factors associated with this complication.

Methods: Patients were selected from the RICO survey database. The patients who had been admitted for NSTEMI in the ICU of Dijon hospital between November 2003 and July 2004, who were living in the city of Dijon and its suburbs, and whose LVEF at discharge was > 45\% were included. Clinical examination, echocardiography and NT-proBNP level evaluation were performed on average 27 months after the acute coronary syndrome.

Results: 105 patients were included : mean age was $64 \pm$ 1.2 years, $75 \%$ were men. At follow up, 14 patients (13\%) presented with symptoms of HF. They had a lower LVEF (38 \pm 2 vs $60 \pm 1 \%, p<0.001)$ and higher NT-proBNP levels (1631 $\pm 706 \mathrm{pg} / \mathrm{ml}$ vs $304 \pm 87 \mathrm{pg} / \mathrm{ml}, p<0.05)$ than the others. In univariate analysis, factors associated with $\mathrm{HF}$ were age (70 \pm 4 vs $62 \pm 1$ yrs, $p=0.045)$, prior coronary artery bypass (36 vs 9\%, $p=0.016$ ), LVEF on admission (52 \pm 2 vs $62 \pm 1 \%$, $p<0.001$ ), lesion of the left anterior descending coronary artery (100 vs $73 \%, p=0.035$ ), glomerular filtration rate (54 \pm 6 vs $71 \pm 3 \mathrm{ml} / \mathrm{min}, p=0.035)$ and plasma level of NT-proBNP on admission (356 \pm 93 vs $144 \pm 44 \mathrm{pg} / \mathrm{ml}$, $p<0.001)$. Plasma concentrations of biological markers of myocardial infarction, door to balloon delay, proportion of complete revascularization and pharmacological treatment did not differ statistically between $\mathrm{HF}$ patients and others. In multivariate analysis, NT-proBNP level on admission was the only predictive factor of $\mathrm{HF}$ after a NSTEMI, independently of age, LVEF, renal function and number of coronary artery lesions.

Conclusion: HF is a frequent complication of NSTEMI. NT-proBNP level could help to identify high risk patients for this complication.

\section{PODÍL BORRELIOVÉ INFEKCE NA ROZVOJI DILATAC̆NÍ KARDIOMYOPATIE. PILOTNÍ STUdIE}

BARTU゚NĚK P, VEISER T, TÁBORSKÝ M, HULÍNSKÁ D

IV. interní klinika, VFN, Kardiologické oddělení, Nemocnice Na Homolce, Národní laboratoř pro Lymeskou borreliózu, SZÚ, Praha

Východiska a cíl: Postižení srdce označované jako lymeská karditida (LK) v průběhu Lymeské borreliózy (LB) se vyskytuje na rozdíl od postižení kưže, kloubů a nervového systému relativně vzácně, v evropských zemích činí < 4 \% ze všech takto nemocných. Bezesporu však patři mezi diagnosticky 
nejsvízelnější. Zatímco v USA je podle písemnictví převaha forem s dominancí AV blokád, v našich poměrech je jednoznačná převaha nemocných s projevy různě frekventních arytmií. Autoři sdělení věnovali pozornost formě, která patří mezi nejvzácnější projevy LK, totiž dilatační kardiomyopatii (DKMP). Cílem bylo objasnit etiologickou účast borreliové infekce na rozvoji DKMP, která je dosud předmětem kontroverzních názorù.

Metody a soubor nemocných: Celkem bylo do studie zařazeno 33 nemocných s DKMP, z toho bylo 23 mužů a 10 žen s průměrným věkem 57,7 roku (rozmezí 24-76 let). Při průkazu borreliové infekce (BI) byla u všech krevních vzorků použita metoda ELISA NRLB KC 90, ke konfirmaci metoda Western blot a následně průkaz DNK patogenní borrelie metodou PCR. Bioptický materiál byl vyšetřen elektronmikroskopicky s cílem průkazu spirochéty v myokardu.

Výsledky: Pro nepřítomnost známek Bb vyřazeno ze studie celkem 16 nemocných. Do studie bylo zahrnuto celkem 17 nemocných, 4 ženy, 13 mužů s průměrným věkem 58 roků (rozmezi 43-76 let), u nichž byla prokázána přítomnost $\mathrm{Bb}$ průkazem DNA patogenních borrelií, resp. elektronooptickým průkazem spirochét v bioptickém vzorku myokardu.

Závěr: Nálezy získané v průběhu studie potvrdily, že BI se velmi pravděpodobně podílela na rozvoji dilatační kardiomyopatie. Lze postulovat, že ve většině případi̊ šlo bud o inaparentní průběh LB či nedostatečně léčenou kožní formu této nemoci.

\section{KASUISTIKA PACIENTA S PADÁKOVOU MITRÁLNÍ CHLOPNÍ}

\section{BELZA T, NEDBAL P, HRABOŠ V, HOLM F}

Kardiologické oddělení, Krajská nemocnice Liberec, Liberec

Padáková mitrální chlopeň je poměrně vzácná vrozená vý vojová vada mitrálního chlopenního komplexu, při níž je funkčně zachován jen jeden papilární sval, který se upíná na oba cípy chlopně, zatímco druhý papilární sval je rudimentární; vzniká tak obraz závěsů padáku. Tato morfologie může vést ke vzniku jak mitrální stenózy, tak i regurgitace, či kombinace obou. Často je spojena s jinými anomáliemi - abnormálním odstupem a/nebo průběhem koronárních tepen, supravalvulárním mitrálním ringem a koarktací aorty (= Shoneův sy).

$\mathrm{V}$ našem sdělení popisujeme případ pacienta $\mathrm{s}$ významnou mitrální vadou na podkladě padákové morfologie mitrálního aparátu. Diagnóza byla stanovena až po komplexním kardiologickém vyšetření, byly zjištěny i anomálie v průběhu koronárních tepen a koronární ateroskleróza. Pacient byl indikován k chirurgickému řešení.

\section{ANEURYZMEKTOMIE A REMODELACE LEVÉ KOMORY V NEMOCNICI NA HOMOLCE}

BENEDÍK J, ČERNÝ Š, MICHEL M, BENEŠOVÁ M, KRUPIČKA J, NEUŽIL P, JEHLIČKA P

Kardiochirurgické oddělení, Nemocnice Na Homolce, Praha

Cil: V prezentaci zhodnotíme střednědobé výsledky pacientů operovaných pro výdut levé komory za období od 1. 5. 2002-31. 12. 2006.

Soubor a metody: Za sledované období bylo operováno celkem 65 pacientů s výdutí levé komory. U tří se jednalo o samostatný výkon bez revaskularizace, u 12 byl výkon proveden v kombinaci s chlopenní operací, ale bez doprovodné revaskularizace. Nejčastější další výkon byla plastika mitrální chlopně
(19), dále plastika trikuspidální chlopně (13) a operace MAZE (9). U 52 nemocných se jednalo o výdut přední stěny a hrotu, u 13 o výdut dolní stěny. V 88 \% byla provedena endoventrikuloplastika, u ostatních prímá sutura. U 9 nemocných byla zavedena IABK elektivně, u 3 po neúspěšném odchodu z MO. U sedmi byla připojena levokomorová elektroda a u 3 byla provedena kryodestrukce po předoperačním mapování.

Výsledky: Průměrný věk operovaných byl 64,5 $\pm 9,2$ (28-81 let), v souboru bylo 24 žen (37 \%). Do 30 dnů zemřelo 5 pacientů $(7,7 \%)$ a v následném období další 4 . Nejvyšší mortalita byla $\mathrm{v}$ podsouboru kombinovaných výkonů společně se dvěma chlopněmi a MAZE procedurou. Šest nemocných jsme revidovali pro krvácení, jednoho pro ischemii, u 5 byla nutná sekundární sutura. Raná infekce se vyskytla u 8 nemocných, z toho u 4 se jednalo o mediastinitidu. Nejčastější pooperační komplikace byla fibrilace síní 21 (32\%). Novou implantaci stimulátoru potřebovali 4 a dialýzu přechodně 5 nemocných. U 6 vzniklo pooperační multiorgánové selhání a u jednoho proběhla CMP. Podle srovnání TTE pozorujeme zlepšení funkce LK (předoperační, dimise, kontrola) (33,6-40,3-39,9) a rovněž zlepšení funkční výkonnosti NYHA a subjektivního zhodnocení nemocných.

Závěr: Přes menší soubor pacientů můžeme prezentovat příznivé střednědobé výsledky resekcí výdutí levé komory. Jako jednoznačný prediktor mortality se ukázaly výkony kombinované s operacemi více chlopní.

\section{HODNOCENÍ ETIOLOGIE A PATOLOGIE POSTIŽENÍ MITRÁLNÍ CHLOPNĚ: ECHOKARDIOGRAFICKÝ A CHIRURGICKÝ POHLED}

BENEŠOVÁ M, KRUPIČKA J, ČERNÝ Š, BENEDÍK J, JEHLIČKA P, DOUBEK D, POPELOVÁ J, JIRÁSEK V, MACHÁČ M

\section{Kardiochirurgické oddělení, Nemocnice Na Homolce, Praha}

Úvod: Onemocnění mitrální chlopně nemá jednotnou př́činu. Určení etiologie a mechanismu mitrální regurgitace je důležité pro odhad přirozeného vývoje, rizika komplikací, mortality. Podle etiologie a patologie mitrálního postižení chirurg volí rozdílné operační přístupy.

Cíl: Zjistit přesnost hodnocení etiologie a mechanismu mitrální regurgitace na základě předoperačního echokardiografického vyšetření v porovnání s peroperačním nálezem chirurga. U jednotlivých podskupin zjistit podíl mitrálních plastik a náhrad.

Soubor a metodika: Retrospektivně jsme zhodnotili soubor 421 pacientů operovaných pro mitrální vadu na našem pracovišti v období IV/2002-XII/2005. Etiologii a mechanismus mitrální regurgitace popsaných kardiologem na základě echokardiografického vyšetření jsme porovnali s nálezy popsanými chirurgem v operačních protokolech. Porovnali jsme procenta provedených mitrálních plastik $\mathrm{v}$ jednotlivých podskupinách.

Výsledky: Podskupiny podle etiologie vyjádřené $\mathrm{v} \%$ (ECHO/chirurg): revmatická 26/26, degenerativní 49/54, ischemická $16 / 13$, funkční $4 / 2$, infekční $2 / 2$, vrozená $1 / 1$, jiná $1 / 1$. Vedoucí mechanismus regurgitace (patologie) vyjádřené v \% (ECHO/chirurg): cípy 56/54, šlašinky $1 / 1$, anulus $8 / 15$, papilární svaly $1 / 1$, myokard $16 / 12$, postižení více komponent 15/16, jiné $1 / 1$. Počet provedených mitrálních plastik podle etiologie (\%): revmatická 24 , degenerativní 91 , ischemická 95, funkční 100, infekční 89 , vrozená 84 , jiná 33 .

Závěr: Echokardiografické hodnocení etiologie a mechanismu mitrální regurgitace je spolehlivé $s$ trendem mírně nadhodnocovat ischemickou etiologii a závažnost postižení mitrálních cípů. Odchylky echokardiografického a chirurgického pohledu jsou dány možnostmi obou metod a mo- 
hou být ovlivněny i odlišnými podmínkami při vyšetřování. Technická proveditelnost mitrální plastiky se liší podle etiologie mitrálního onemocnění.

\section{SESTERSKÁ SEKCE}

\section{MITRÁLNÍ VALVULOPLASTIKA - SOUBOR > 400 NEMOCNÝCH}

\section{BENEŠOVÁ V, KÁNSKÝ O \\ Kardiologie Na Bulovce s. r. o., Praha}

Valvuloplastika mitrální chlopně je metoda, při které se stenotické mitrální ústí rozšírí speciálním balonkovým katetrem. PTMV (perkutánní transluminální mitrální valvuloplastika) je dnes standardní způsob léčby mitrální stenózy. Náš soubor představuje 428 nemocných, kteří v letech 1990-2006 podstoupili tento katetrizační výkon. Jedná se o 103 mužů a 325 žen, jejichž průměrný věk byl 57 let (25-83 roků). Vzhledem k 17 letům zkušeností s PTMV a $\mathrm{k}$ celkovému počtu pacientů jsme se pokusili o rekapitulaci našich výsledků. Zjistili jsme, že 73 nemocných bylo znovu vyšetřeno transseptální katetrizací, 8 nemocných se vrátilo k rePTMV a u 62 nemocných byl proveden kardiochirurgický výkon. Nejvíce výkonů PTMV bylo uskutečněno v prvních letech, později jejich počty poklesly a ustálily se na $17 /$ rok. Výskyt onemocnění MS se v populaci sice zmenšil, ale nevymizel docela (ani při masivním použivání ATB v medicíně obecně). Revmatická etiologie zůstává nejčastější př́ičinou mitrální stenózy. Se stoupajícím průměrným věkem jsou další přičinou degenerativní změny chlopní. Zaznamenali jsme také nárůst nemoci u mužů.

\section{INTERVENČNÍ LÉČBA ILEOFEMORÁLNÍ HLUBOKÉ ŽILNÍ TROMBÓZY NA II. INTERNÍ KLINICE VFN}

BERAN S, CHOCHOLA M, VAŘEJKA P, HELLER S, SKALICKÁ L, JIRÁT S, PROCHÁZKA P, MRÁZEK V, LINHART A

\section{II. interní klinika kardiologie a angiologie,} angiologická JIP, VFN a 1. LF UK, Praha

Úvod: Akutní hluboká žilní trombóza (HŽT) je závažné onemocnění s velkým dopadem na morbiditu a mortalitu. Roční incidence HŽT v běžné populaci je v rozmezí 1-3 na 1000 jedinců za rok. V ČR je ročně diagnostikováno až 25000 případů HŽT. Závažným dopadem HŽT je, kromě rizika smrti při fatální plicní embolii (PE), rozvoj posttrombotického syndromu (PTS). Symptomy PTS jsou vyjádřeny až u 90 \% pacientů s ileofemorální HŽT léčených standardní antikoagulační terapií. Rozvoji PTS může předejít pouze rychlá a účinná rekanalizace žilního řečiště.

Cíl: Krátkodobé a střednědobé výsledky intervenční léčby ileofemorální HŽT.

Soubor a metodika: Retrospektivně byl zhodnocen soubor 106 pacientů léčených lokální katetrovou trombolýzou $\mathrm{s}$ následnou implantací stentu $\mathrm{v}$ případě př́tomnosti významné stenózy. Průměrný věk při HžT byl 33,6 (13-72).

Výsledky: Ve skupině 106 pacientů léčených lokální trombolytickou terapií pro ileofemorální HŽT došlo k rekanalizaci pánevního řečiště v 97 př́ipadech $(91,5 \%$ ), z toho kompletní rekanalizace v 73 případech $(75,3 \%)$ a inkompletní v 24 prípadech $(24,7 \%)$. Implantace stentu byla provedena u 78 pacientů a celkem bylo implantováno 123 stentů.

$\mathrm{K}$ recidivě HŽT klinicky nebo sonograficky došlo u 15 pacientů ze 106 sledovaných (14,2\%) při průměrné době sle- dování 28,4 měsíců. Doba od TL do retrombózy byla průměrně 10,5 měsíce, ale u 7 pacientů se jednalo o časnou retrombózu do 14 dnů od intervence. Reintervence provedena u 7 pacientů. Symptomy PTS udává 20 pacientů (18,7 \%), z toho $\mathrm{v} 7$ př́padech se jedná o pacienty s retrombózou.

Krvácivé komplikace s nutností náhrady krevních derivátů se vyskytly pouze u 2 pacientů $(1,9 \%)$.

Závěr: Endovaskulární léčba hluboké ileofemorální žilní trombózy je bezpečná a efektivní metoda rekanalizace žilního řečiště.

\section{LEVÁ RADIÁLNİ TEPNA JAKO STANDARDNÍ PR̆ÍSTUP KE KORONÁRNÍM KATETRIZACÍM A INTERVENCÍM}

\section{BERNAT I, ŠKVAŘILOVÁ M, PAĎOUR M}

Oddělení intervenční kardiologie,

Karlovarská krajská nemocnice a. s., Karlovy Vary

Úvod: Radiální přístup má minimální výskyt lokálních komplikací a pacientům umožňuje po výkonech větší komfort než př́istup femorální. Levá radiální tepna se však dosud v intervenční kardiologii používá spíše výjimečně.

Cíl: Zavést tento přistup na našem pracovišti a vyhodnotit prvních pět měsíců výkonů prováděných $\mathrm{z}$ levé radiální tepny.

Metody a výsledky: V období 8.-12. měsíce 2006 jsme provedli 346 katetrizací (51 \% všech) a 102 intervencí (42\%) radiálním př́istupem primárně zleva. Důvodem 39 (11\%) výkonů $z$ pravé radiální tepny byl kromě leváků nejčastěji patologický Allenův test vlevo a krátká LHK u výrazně obézních. Průměrný věk pacientů byl 63 let, mužů bylo $69 \%$, $>75$ let $22 \%$ (> 80 let $8 \%$ ), < $160 \mathrm{~cm} 18 \%$, BMI > $3513 \%$ a $5 \%$ pacientů bylo po CABG. Technický neúspěch vyžadující konverzi na femorální př́stup byl celkově $5,2 \%$, v posledních dvou měsících $2,9 \%$. Akutních intervencí jsme provedli 65 (64 \%), z toho u STEMI 29 (28 \%). Lokální hemostázu jsme u všech pacientů prováděli ihned po výkonu na sále pomocí TR Bandu (Terumo) bez závažné komplikace. Jedenkrát při použití nehydrofilního delšího sheathu $(23 \mathrm{~cm})$ byla komplikací trombóza levé radiální tepny. Jiné závažné komplikace se v souvislosti s těmito výkony během hospitalizace nevyskytly. Celková doba výkonu i radiační čas se během uvedeného období postupně zkracovaly a v posledních dvou měsících se již významně nelišily od femorálního přístupu.

Závěr: Levá radiální tepna je podle našich zkušeností výhodnou a bezpečnou přístupovou tepnou $\mathrm{k}$ rutinní levostranné srdeční katetrizaci i intervenčním výkonům na věnčitých tepnách, včetně pacientů se STEMI. Pacienti s dominantní pravou rukou, kterých je výrazná většina, tento přístup jednoznačně upřednostňují vzhledem $\mathrm{k}$ minimálnímu omezení všech jejich pohybových aktivit po katetrizačním výkonu. Péče o tyto pacienty po výkonech je méně náročná než po výkonech $z$ tř́sla.

\section{SESTERSKÁ SEKCE}

\section{MECHANICKÉ KOMPLIKACE ICHS}

\section{BERNÁŠKOVÁ K, KALINOVÁ J}

Kardiologie na Bulovce s. r. o., Praha

Ischemická choroba srdeční se dnes projevuje jinak než dříve. Je to způsobeno především intervenční katetrizační léčbou. Přesto se komplikace nacházejí stále. Často jsou způsobeny pozdním příchodem nemocného, kdy kauzální léčba (zprůchodnění tepny) přináší jen suboptimální výsledek, nebo již není možná. 
Pokud se nemocný dostaví pozdě, a nelze již myokard zachránit, dochází k rozvoji jizvy. Morfologicky se může projevi i ztrátou ušlechtilého tvaru komory: hovoříme o aneuryzmatu.

$\mathrm{V}$ místě jizvy a aneuryzmatu se mohou tvořit tromby. Rozsáhlé jizvy myokardu vedou k dysfunkci levé komory Někdy se akutní projevy infarktu skrývají za CMP. V případě akutního infarktu myokardu může docházet k rupturám. Nacházíme ruptury septa nebo volné stěny. Ruptura volné stěny vede $\mathrm{k}$ zaplavení perikardu krví a k akutní tamponádě vede obvykle ke smrti nemocného. Pokud ruptura probíhá postupně a okolní perikard reaguje srůsty, mưže se později vytvořit pseudoaneuryzma.

Ruptura papilárního svalu vede k masivní mitrální regur gitaci a obvykle končí smrtí nemocného, dřive než je možný akutní kardiochirurgický výkon. Perikarditida patří k relativně méně závažným stavưm.

\section{TĚŽKÉ AKUTNÍ SELHÁNÍ LEDVIN S NUTNOSTÍ HEMOELIMINAČNÍ METODY U NEMOCNÝCH S AKUTNÍM INFARKTEM MYOKARDU}

BĚLOHLÁVEK J, ŠKULEC R, KOVÁRNÍK T, DYTRYCH V, LINHART A

II. interní klinika kardiologie a angiologie, VFN a 1. LF UK, Praha

Úvod: Výskyt těžkého akutního selhání ledvin s nutností hemoeliminační metody u nemocných s akutním infarktem myokardu není v literatuře podrobněji popsán. Na našem oddělení používáme kontinuální hemoeliminační metody (CRRT - continuous renal replacement therapy) v péči o kriticky nemocné pacienty s akutním selháním ledvin od listopadu 2001.

Metody: Retrospektivní zhodnocení výskytu těžkého akutního selhání ledvin (TASL) v souvislosti $\mathrm{s}$ akutním infarktem myokardu (AIM) analýzou souboru všech konsekutivních nemocných, kteří byli od listopadu 2001 do konce roku 2006 na našem oddělení ošetřeni CRRT.

Výsledky: Z celkového počtu 81 pacientů s TASL ošetřených pomocí CRRT prodělalo AIM 24 (32\%) nemocných. Nemocní s AIM i bez AIM byli obdobného věku (66 vs. 64 let) i pohlaví (63 vs. 65 \% mužů). Oproti ostatním nemocným s TASL s nutností hemoeliminační metody měli nemocní s AIM častěji cukrovku (75 vs. $67 \%$ ), častěji měli chronickou renální insuficienci (46 vs. $42 \%$ ), častěji prodělal kardiopulmonální resuscitaci (38 vs. $25 \%$ ), častěji trpěli septickou komplikací (42 vs. 18 \%), byli častěji léčeni katecholaminy a jejich stav častěji vyžadoval umělou plicní ventilaci. Mortalitu měla tato podskupina nemocných lepš (zemřelo 9 z 24 vs. 26 z 57 pacientů, resp. 37,5 vs. 46 \%).

Závěr: V naší analýze jsme se pokusili charakterizovat podskupinu nemocných s AIM, jejichž stav si během hospitalizace vyžádá použití CRRT. Jedná se o skupinu vysoce rizikových nemocných, ale jejich prognóza je přes řadu očekávaných komplikací přijatelná.

\section{TKÁŇOVÝ FAKTOR, METALOPROTEINÁZY A SOLUBILNİ LIGANDA CD40 U PACIENTÚ S AKUTNIIM KORONÁRNÍM SYNDROMEM*}

BIS J, VOJÁČEK J, DUŠEK J, ŠŤÁSEK J, PECKA M, ANDRÝS C

\section{I. interní klinika,}

II. interní klinika - Oddělení klinické hematologie, Ústav klinické imunologie a alergologie, FN Hradec Králové, Hradec Králové

*Podpořeno grantem IGA NR/8131-3.
Cíl: V naší práci jsme se zaměřili na stanovení změn plazmatických hodnot solubilní ligandy CD40 (s1CD40), extracelulární matrixové metaloproteinázy 2, 3 a 9 (MMP-2, MMP-3 a MMP-9), tkáňového inhibitoru metaloproteináz 2 (TIMP-2), tkáňového faktoru (TF) a vysoce senzitivního C-reaktivního proteinu (hs-CRP) u nemocných s akutním koronárním syndromem a se stabilní koronární nemocí a dále jsme zhodnotili vzájemné vztahy uvedených působků.

Metodika: Ve skupině A - 28 osob (věk 62,6 \pm 10,3 let, 19 mužů, 9 žen), byli nemocní s akutním koronárním syndromem (nemocní s infarktem myokardu nebo s nestabilní anginou pectoris) a ve skupině $\mathrm{B}-24$ nemocných (věk $62,3 \pm 8,1$ let, 21 mužů, 3 ženy), se stabilní ischemickou chorobou srdeční. Porovnávány byly hladiny v periferní krvi (PV), koronárním sinu (CS), kmeni levé koronární tepny (ACS), ve skupině A byl odběr za 7 dní.

Výsledky: Signifikantně vyšší hodnoty ve skupině A byly v hladinách TF $(239,0 \pm 99,3$ pg/ml vs. $164,3 \pm 114,2$ pg/ml; $p=0,016)$ a MMP-9 (815,5 \pm 451,8 mg/1 vs. 504,8 \pm $245,7 \mathrm{mg} / 1 ; p=0,0038)$. Signifikantně vyšší byl transkoronární gradient slCD40 (rozdíl mezi kmenem ACS a CS) mezi skupinami A a B. Mezi CS, PV a kmenem ACS nebyl u jednotlivých pacientů nalezen rozdíl v hladinách TF, MMP-2, MMP-3, MMP-9 a TIMP-1; 7. den byl pozorován nesignifikantní pokles TF, hodnoty metaloproteináz a TIMP se neměnily, hladina slCD40 nesignifikantně stoupala.

Signifikantní lineární korelace byla nalezena mezi hodnotami TF a hsCRP, a mezi TF a slCD40. Hladina MMP-9 signifikantně pozitivně koreluje s hladinou hsCRP. Transkoronární produkce TF (rozdíl mezi kmenem ACS a CS) statisticky významně lineárně koreluje s hladinou MMP-9.

Závěr: Hodnoty TF a metaloproteináz jsou zvýšeny u pacientů s akutní koronárním syndromem systémově a nikoliv jen v lokální cirkulaci. Zjistili jsme transkoronární vzestup ukazatele interakce destiček popisované slCD40.

\section{DLOUHODOBÝ VÝSKYT REVASKULARIZACİ PO AKUTNÍM INFARKTU MYOKARDU. 5LETÉ VÝSLEDKY STUDIE PRAGUE-2}

BÍLKOVÁ D, KOČKA V, WIDIMSKÝ P, PĚNIČKA M, NOVÁK M, LANÍKOVÁ M, GROCH L, ŽELÍZKO M, BUDĚŠÍNSKÝ T, ASCHERMANN M

\section{Kardiocentrum, FN KV, Praha,}

I. interní-kardioangiologická klinika, FN u sv. Anny a LF MU, Brno, I. interní klinika, FN Hradec Králové a LF UK, Hradec Králové, II. interní klinika kardiologie a angiologie, VFN a 1. LF UK, Praha

Primární PCI zlepšuje časnou prognózu ve srovnání s trombolýzou, méně je však známo o dlouhodobé prognóze a následných revaskularizacích po infarktu myokardu léčeným primární PCI vs. trombolýzou.

Soubor byl tvořen 850 pacienty s akutním infarktem myokardu s elevacemi ST (STEMI), zařazenými do studie PRAGUE-2. Pacienti byli randomizováni do dvou větví - transport do intervenčního centra k PCI (n = 429) vs. trombolýza v nejbližší nemocnici ( $\mathrm{n}=421$ ). Randomizace probíhala v období od září 1999 do ledna 2002. Dlouhodobé kontroly pacientů byly prováděny do konce února 2006, průměrná délka sledování byla 58 měsíců (v rozmezí 43-70 měsíců). Data byla zjištována při kontrolách prováděných v primárních nemocnicích a v PCI centrech nebo telefonicky prostřednictvím vyplnění dotazníků. Pokud nebylo možné navázat kontakt prrímo s pacientem, byly informace získávány od rodinných příslušníků, oslovením ošetřujícího kardiologa, internisty či praktického lékaře. Dalším zdrojem informací byly databáze zdravotních pojištoven. Sledována byla nová 
koronární revaskularizace (PCI nebo bypass) po akutní fázi STEMI.

Zda během sledování byla provedena chirurgická či katetrizační revaskularizace se podařilo $\mathrm{s}$ jistotou zjistit u 74,1 \% pacientů. Během celého období se podrobilo koronární intervenci $50 \%$ pacientů léčených v akutním stadiu farmakologicky, v invazivní větvi byla následující koronární intervence provedena u 30,9\% pacientů $(p<0,001)$. Srdeční bypass podstoupilo $17,8 \%$ pacientů ze skupiny TL vs. $16,6 \%$ pacientů ze skupiny PCI $(p=0,74)$.

Primární PCI významně snižuje nutnost další perkutánní revaskularizace po akutním infarktu myokardu ve srovnání s trombolýzou, není však rozdíl v četnosti chirurgických revaskularizací.

\section{PERKUTÁNNA KORONÁRNA INTERVENCIA NECHRÁNENÉHO KMEŇA ACS. 1-ROČNÝ FOLLOW-UP}

BLAŠKO P, VESELKA J, ZEMÁNEK D,

DUCHOÑOVÁ R, HÁJEK P, MALÝ M, TESǍ̆ D

Kardiologie, Klinika zobrazovacích metod, FN Motol, Praha

Ciel práce: Sledovat výskyt úmrtia, revaskularizácie a cievnej mozgovej príhody u pacientov po PCI (perkutánna koronárna intervencia) kmeňa ACS (arteria coronaria sinistra) bez predchádzajúcej revaskularizácie.

Súbor a metodika: 50 pacientov s významnou stenózou kmeňa ACS bez predchádzajúcej revaskularizácie bolo liečeno PCI s použitím DES (drug eluting stentu) $(\mathrm{n}=25)$ a BMS (bare metal stentu) $(\mathrm{n}=25) \mathrm{v}$ našom centre $\mathrm{v}$ období medzi októbrom 2004 a novembrom 2006. Následne boli pozvaní na kontrolné vyšetrenie s rekoronarografiou 4. a 9. mesiac a telefonická kontrola bola dohodnutá po 1 roku.

Výsledky: TLR (total lesion revascularization) v našej skupine bola $10-\%$ pre restenózu, u $4 \%$ z nich bola indikovaná k chirurgickej revaskularizácii. Mortalita bola 2-\% v súbore, jednalo sa o jedného pacienta po vysadení duálnej antiagregačnej liečbe s dokumentovanou trombózou v stente.

Infarkt myokardu v zmysle minimálnej myokardiálnej lézie bol zaznamenaný u $18 \%$ pacientov. U $6 \%$ pacientov bol periprocedurálny IM bez ST-elevácií. Cievna mozgová príhoda nebola zaznamenaná $\mathrm{v}$ našom súbore.

Záver: Jednoročné sledovanie $\mathrm{v}$ našom centre poukazuje na nevýznamné rozdiely medzi oboma skupinami, zahrňujúce smrt, cievnu mozgovú príhodu, infarkt myokardu a revaskularizáciu po PCI kmeňa ACS.

\section{PERKUTÁNNÍ VALVULOPLASTIKA AORTÁLNÍ CHLOPNĚ U NEMOCNÉ V KRITICKÉM STAVU. KASUISTIKA}

\section{BLAŠKO P, FIEDLER J, ČERNÁ D, VESELKA J}

\section{Kardiologie, FN Motol, Praha}

Úvod: Balonková valvuloplastika aortální chlopně (BAV) $\mathrm{u}$ dospělých s degenerativní kalcifikovanou stenózou se používá zřídka u inoperabilních pacientů ve velmi vážném stavu.

Cíl práce: Popisujeme případ 73leté nemocné s kritickou aortální stenózou, jejíž tíže byla stanovena až v preterminálním stavu na oddělení ARO. Podrobně je dokumentován rozsah těžké systolické dysfunkce a doprovodného srdečního selhání i při absenci koronární choroby, stejně jako rozvoj multiorgánového selhání. Echokardiografické ukazatele před výkonem a po výkonu byly srovnány s pitevním nálezem.
Popis hospitalizace a výkonu: Nemocná byla přijata pro celkové zhoršení stavu na interní oddělení, byla hypotenzní, anurická $\mathrm{s}$ hyperlaktátemií $\mathrm{v}$ progresi stavu přeložena po dvou dnech bez stanovené příčiny na oddělení ARO. Až zde byla diagnostikována kritická aortální stenóza a těžká systolická dysfunkce (pomocí TTE a TEE). V návaznosti na koronarografii byla provedena úspěšná BAV se zvětšením AVA z 0,3 na $0,9 \mathrm{~cm}^{2}$ a odpovídajícím poklesem transvalvulárního gradientu. I přes technicky úspěšné provedení BAV nemocná za 52 hodin umírá na refrakterní multiorgánové selhání. Sekce je v naprosté shodě s echokardiografickým vyšetřením a prokazuje zdařilý výsledek BAV.

Závěr: V námi prezentované kasuistice dokumentujeme př́ípad degenerativní aortální stenózy, která vedla $\mathrm{k}$ rozvoji srdečního a následně i multiorgánového selhání, jež i přes technicky úspěšnou valvuloplastiku skončilo úmrtím. Práce dokládá schůdnost provedení BAV i u podobně kriticky nemocných a především nutnost včasné diagnózy a indikace $\mathrm{k}$ ní.

\section{STANOVENÍ ZMĔN PRIMÁRNÍ HEMOSTÁZY MODIFIKOVANÝM VYŠETR̆ENÍM AGREGACE TROMBOCYTỦ A KOMERČNÍM ANALYZÁTOREM PFA-10O K RACIONALIZACI LÉČBY LDL-AFERÉZOU U NEMOCNÝCH S FAMILIÁRNÍ HYPERCHOLESTEROLEMIÍ*}

BLAŽEK M, BLÁHA M, MALÝ J, BLÁHA V,
CERMANOVÁ M, SLOVÁČEK L, PECKA M

II. interní klinika - Oddělení klinické hematologie.

Klinika gerontologická a metabolická,

FN Hradec Králové a LF UK, Hradec Králové

*Práce je podpořena granty:

IGA MZ CR č./8505-3; č./8062-3; č./9103-4;

MZO 00179906; MSM 0021620820.

Cil: LDL-aferéza je metoda extrakorporální eliminace LDL-cholesterolu, používaná u pacientů se závažnou hyperlipidemií, která je rezistentní na farmakoterapii a dietní opatření. $Z$ dlouhodobého hlediska jsou ukazatele aktivity aterogeneze jasné (zobrazovací metody), chybí vhodné markery aktuálního stavu. Vyšetření funkčních změn trombocytů před LDL-aferézou a po LDL-aferéze je potencionálně rychlé a př́nosné pro zprostředkované sledování aktivity aterogeneze, a tím přínosné $\mathrm{k}$ optimálnímu vedení léčby LDL-aferézou.

Soubor a metodika: Sledujeme 9 pacientů s FH (4 ženy, 5 mužů), medián věku 55 let, $z$ nich 2 homozygoti. Vyšetř̌ení agregací trombocytů byla prováděna standardním zpo̊sobem na agregometru APACKS-4 (Helena Laboratories). Předně jsme provedli standardní spektrum agregačního vyšetření, kde jediné změny byly naznačeny po stimulaci ADP. Proto jsme dále vyšetřili agregace s použitím 3 různých ředění ADP - konkrétně 2,5 $\mu \mathrm{M}, 1,25 \mu \mathrm{M}$ a 0,625 $\mu \mathrm{M}$. Současně bylo použito vyšetření analyzátorem Dade Behring PFA-100 (Německo), který umožňuje měřit destičkami zprostředkovanou hemostázu $\mathrm{z}$ nesrážlivé krve.

Výsledky: V modifikovaných testech agregace trombocytů dochází po aferéze ke zmenšení strmosti agregační křivky a ke snížení maximální amplitudy $(p<0,05)$. Nebyly rozdíly mezi homozygoty a heterozygoty. Ve všech případech analýzy PFA-100 se po separaci hodnoty CT (closure time) prodloužily, avšak míra prodloužení CT po procedurách nedosáhla statistické významnosti $(p<0,14)$.

Závěr: Procedura LDL-aferézy u nemocných s FH zlepšuje poměry primární hemostázy. Modifikovaná vyšetření agregace trombocytů by mohla být dalším ukazatelem vhodným ke sledování aktivity procesu a k optimálnímu vedení 
léčby aferézou. Vyšetření analyzátorem PFA-100 se podle prvních zkušeností zdá samostatně nevhodné.

\section{EXTRAKORPORÁLNÍ ELIMINACE LDL-CHOLESTEROLU POMOCÍ ADSORBÉRU LIPOCOLLECT 300*}

BLÁHA M, BLAŽEK M, BLÁHA V, MALÝ J, SOLICH P, ŠATÍNSKÝ D, SOLICHOVÁ D, FILIP S, ŠIROKÝ O, ŽÁK P

II. interní klinika, Oddělení klinické hematologie, FN Hradec Králové a LF UK, Katedra analytické chemie, Farmaceutická fakulta UK, Hradec Králové

*Podporováno grantem IGA MZ ČR č. 9103-4.

Cíl: V př́ípadě homozygotní familiární hypercholesterolemie (FH) je nutná extrakorporální eliminace LDL-cholesterolu. Popisujeme zkušenosti s prvním typem adsorbéru, obsahujícím pouze anorganické substance.

Materiál a metodika: Předchozí nejlepší sorbenty byly animálního původu, později s jiným organickým základem. Kolona Lipocollect obsahuje pouze anorganické substance, které by měly být bezpečné a trvanlivé (neimunizují a vylučují prakticky některé další vedlejší reakce, které byly občas působeny jinými absorbery). Po prvé lze vše sterilizovat teplem. Adsorbér Lipocollect (Medicollect, Germany) pracuje na tomto principu: polotekutá hmota - mikrokuličky křemičitého gelu, které jsou porézní, mají otvory; v mikrootvorech je vázána kyselina polykarbonová. Negativní náboj reverzibilně váže partikule LDL-cholesterolu a VLDL-cholesterolu.

Výsledky: U pacienta s homozygotní $\mathrm{FH}$ bylo provedeno 8 procedur s uvedeným adsorbérem. Bylo dosaženo snížení LDL-cholesterolu o 74,63 $\pm 3,69 \%$ pưvodní hladiny. Léčebné procedury probíhaly bez vedlejších příhod, pacient je dobře toleroval a nebyly zjištěny klinicky významnější změny základních biochemických parametrů. Kolona je lehce zařaditelná do soustavy primárního a sekundárního př́istroje tak, jak provádíme u LDL-aferézy. Uvolnění reverzibilní vazby LDL-cholesterolu $\mathrm{z}$ kolony je dokonce jednodušší, provádí se pouhým 1M NACl.

Závěr: Adsorbér Lipocollect byl použit po prvé v ČR. Jeví se jako účinný, bezpečný a levnější než LDL-aferéza pomocí kolon s živočišnými protilátkami. Přesnější hodnocení bude možné podle dalších výsledků.

\section{TO THE BIOINDICATORS OF ATHEROSCLEROSIS ACTIVITY: SIGNIFICANCE OF ENDOGLIN LEVEL*}

BLÁHA M, CERMANOVÁ M, BLÁHA V, JAROLÍM P, ANDRÝS C, BLAŽEK M, MALÝ J, SMOLEJ L, ZIMOVÁ R, ŘEHÁČEK V

II. interní klinika, Oddělení klinické hematologie, FN Hradec Králové a LF MU, Department of Pathology, Brigham and Women's Hospital, Harvard Medical School, Boston, USA

*Supported by the research task MH CZ MZO 00179906.

Background: Still, there are no suitable markers for extracorporeal elimination of LDL-cholesterol in familial hypercholesterolemia $(\mathrm{FH})$ which would reliably determine the therapy intensity immediately after the procedure and would be able to show activity of atherosclerosis.

Methods: An ideal tool for immediate evaluation would be a serum marker, levels of which would correlate with disease activity and reflect an improvement after elimination therapy. In a previous study, we found that the levels of P-selectin, MCP-1, hsCRP and CD40L were reduced after LDL apheresis. Although the post-elimination decreases in all four markers reached statistical significance, we speculated that endoglin levels could represent an even more effective tool for evaluation of treatment efficacy.

Alltogether 40 examinations of endoglin level in 11 patients with severe $\mathrm{FH}$ and long-term treatment $(4.5 \pm 2.8$ years) by extracorporeal elimination (LDL-apheresis and haemorheopheresis) were done. We measured sCD105 levels immediately before and after two consecutive elimination procedures.

Results: Baseline serum sCD105 levels were significantly higher in the patients than in the control group. The decrease in SCD105 after both LDL-elimination series was also statistically significant. Endoglin level normalized after procedures in all of 40 but one measurements.

Conclusion: We conclude that soluble endoglin levels are increased in patients with severe familial hyperlipidemia and decrease after extracorporeal elimination what is the first observation. Endoglin can therefore serve as a useful marker for evaluation of the treatment efficacy and decreased atherosclerosis activity in patients with familial hyperlipoproteinemia treated by extracorporeal LDL-cholesterol elimination.

\section{LIPOPOLYSACHARIDE BINDING PROTEIN (LBP) AS A MARKER OF ATHEROSCLEROSIS IMPROVED BY THERAPEUTICAL INTERVENTION IN END STAGE RENAL DISEASE PATIENTS*} BLÁHA V, DUSILOVÁ-SULKOVÁ S, MISTRÍK E,
ANDRÝS C, SOLICHOVÁ D, ZAHRADNÍK J, HÁJKOVÁ B, SOBOTKA L

Klinika gerontologická a metabolická, Oddělení klinické imunologie a alergologie, FN Hradec Králové a LF UK, Hradec Králové

*Supported by research projects MSM 0021620820, MSM 0021620819, IGA MH CR NR/9259-3.

Background: LBP represents a link between cardiovascular disease and chronic inflammation caused by endotoxin producing microorganisms. It is a member of cellular signaling pathways of specific host immune/inflammatory responses to atherogenesis.

Aim: End stage renal disease (ESRD) patients are well known to suffer greatly from cardiovascular diseases (CVD) caused by excessive atherosclerosis. We measured LBP in ESRD patients after intervention to improve their general status.

Methods: 97 patients were studied. Among them were 43 patients with ESRD $(63.9 \pm 12.7$ y, 21 women, 22 men $)$ on chronic hemodialysis without any apparent acute disease or infection. The controls were 54 healthy individuals (33 men and 21 women, $36.7 \pm 9.5$ y) without any CVD or atherosclerotic risk factors. The 3 -months intervention consisted in improving the performance of dialysis or sanation of chronic infective foci.

Results: The serum LBP in ESRD vs. controls was significantly higher $(13.88 \pm 6.32$ vs. $4.94 \pm 3.2 \mu \mathrm{g} / \mathrm{ml}, p<0.001)$, and significantly decreased after the intervention $(5.32 \pm$ $3.2 \mu \mathrm{g} / \mathrm{ml}, p<0.001)$. There was no significant change in $\mathrm{CRP}$ (before /after intervention $6.26 \pm 3.37 / 7.17 \pm 4.12$ $\mathrm{mg} / \mathrm{L}$ ) or serum lipoproteins (total cholesterol, LDL, HDL, TAG). We found no significant correlation between LBP and CRP or any of the serum lipoproteins.

Conclusion: Therapeutical intervention in ESRD patients with CVD and low-level chronic inflammation might improve the course of atherosclerosis marked by serum LBP. 


\section{COMBINED TREATMENT OF RESISTANT HYPERCHOLESTEROLEMIA BY LDL-APHERESIS, STATIN AND EZETIMIBE*}

BLÁHA V, VYROUBAL P, BLÁHA M, HAVEL E, SOLICHOVÁ D, HYŠPLER R, ZAJÍC J, BLAŽEK M, ZADÁK Z

Klinika gerontologická a metabolická, II. interní klinika, FN Hradec Králové a LF UK, Hradec Králové

*Supported by research projects IGA MH CR Nr./8497-3, 1A/8689-4.

Background: Treatment with extracorporeal elimination technique - LDL (low-density lipoprotein) - apheresis (LA), or combined therapy of ezetimibe with $\mathrm{HMG-CoA}$ reductase inhibitor (statin) is indicated in patients with resistant heterozygote $[\mathrm{FH}]$ or homozygote [HoFH]) familial hypercholesterolemia. Experience concerning the use of ezetimibe in combination with LDL-apheresis is limited.

Methods: Patient with resistant hypercholesterolemia ( $\mathrm{n}=$ 11,5 women, 6 men, age 21-60 y, among them patients with $\mathrm{HoFH} \mathrm{n}=3$ ) were treated by diet, statin (simvastatin $40 \mathrm{mg}$ or atorvastatin 40-80 mg daily) and LA. Cell-free plasma has been sampled after centrifugation by Cobe-Spectra. LA was performed using a) cascade filtration (filters Evaflux 4A, Kuraray $^{\circledR}, \mathrm{n}=4$ ) or b) LDL-immunoadsorption (filters Pockard ${ }^{\circledR}$, $\mathrm{n}=7$ ). The effect of combined treatment by ezetimibe (Ezetrol ${ }^{\circledR}$ $10 \mathrm{mg}$ daily) was evaluated after 1, 6 and 12 months.

Results: Combined treatment with ezetimibe enabled to reach lower serum LDL-cholesterol after each of LA (1.15 \pm 0.89 vs $0.81 \pm 0.38 \mathrm{mmol} / \mathrm{l})$. Ezetimibe treatment after 12 months combined by LA and statin significantly decreased serum LDL-cholesterol (-20.6\%). Treatment was effective even in two HoFH patiens. Two patients $(1 \times \mathrm{HoFH}, 1 \times \mathrm{FH})$ did not respond to ezetimibe therapy. Among them, one $\mathrm{FH}$ patient was extra cholesterol synthesizer, and a defective response to ezetimebe is supposed in the other $\mathrm{HoFH}$ individual.

Conclusion: A combined treatment with ezetimibe and statin should be used in responding patiens with severe hypercholesterolemia treated by LDL-apheresis.

SESTERSKÁ SEKCE

\section{SEKUNDÁRNí A tERCIÁlNí PREVENCE V ORDINACI PRAKTICKÉHO KARDIOLOGA. JE SPECIALIZOVANÁ SESTRA PR̆ÍNOSEM?}

\author{
BOUCHAL P, JELÍNKOVÁ L, MICHLOVÁ K
}

Kardiologická ambulance, FN Brno, Brno

Sdělení má 3 části. V úvodní je zamyšlení 1 . autora nad svou pozicí při práci $\mathrm{v}$ ordinaci $\mathrm{u}$ nemocných $\mathrm{v}$ sekundární a terciální prevenci, tedy po revaskularizaci, při srdečním selhání.

V sekundární péči ověřil ve své praxi efektivitu práce vyškolené sestry, která provádí samostatně edukační pohovory po revaskularizačním výkonu se zaměřením na nefarmakologické aspekty léčby. Ve 2 . části sdělení podává specializovaná sestra přehled své práce a své osobní zkušenosti.

Jinak je koncipovaná úloha sestry při sledování nemocných se srdečním selháním.

Na doporučení lékaře sama aktivně provádí základní kontrolu oběhové kompenzace a s výsledky svých návštěv seznamuje lékaře a domlouvá s ním další postup.

O tomto způsobu monitorování nemocných se srdečním selhání a o svých vlastních zkušenostech přednese 3. autor - specializovaná sestra 3. část přednášky.

Závěrem se autor zabývá jak potřebou kvalitního vzdělání sester v této oblasti, tak i ekonomickým dopadem pro všechny zúčastněné strany. Pro nemocného i zdravotní pojištovnu je totiž tato aktivita bezpochyby prospěšná, pro lékaře, bohužel, při absenci možnosti tyto výkony vykázat, je stále v oblasti svého „hobby“. Je potřebné učinit aktivní kroky k vytvoření možnosti, jak postavení specializace v této části ambulantní kardiologie institualizovat, navrhnout formy vzdělávání pro sestry, a ve svém konečném stavu také moci tuto práci vykazovat zdravotním pojištovnám. Dosažení tohoto stavu se stane přínosem pro všechny čtyři strany: 1. lékař šetří čas; 2. nemocný má méně rehospitalizací a lepší komunikační zázemí; 3. sestra má samostatnou a zodpovědnou práci; 4. pojištovna ušetří za rehospitalizaci.

Autor navrhuje pracovní skupině ČKS Ošetřovatelství $\mathrm{v}$ kardiologii zahájení postupných kroků $\mathrm{k}$ realizaci tomuto, ve světě již ověřenému způsobu, uplatnění specializovaných sester v péči o kardiologicky nemocné.

\section{SESTERSKÁ SEKCE}

\section{MŮŽE SESTRA SAMOSTATNĚ PROVÁdĚT KONTROLY PACIENTŮ S IMPLANTOVANÝM KARDIOSTIMULÁTOREM?}

\section{BRABCOVÁ D}

Kardiologie, MEDISCAN GROUP, s. r. o., Praha

V našem kardiologickém diagnostickém centru provádíme kontroly pacientů s implantovaným kardiostimulátorem, které máme dlouhodobě v lékařské péči a které jsme sami diagnostikovali. Úzce spolupracujeme s III. interní kardiologickou klinikou, FN KV v Praze 10, kam odesíláme pacienty $\mathrm{k}$ implantacím i výměnám. Tímto postupem odlehčujeme ambulanci kliniky. Pacienty kontrolujeme $2 \times$ ročně.

Naši lékaři a sestry jsou na klinice zaškoleni na arytmologickém sálku a na ambulanci a po zvládnutí i technického ovládání přístrojů pracují samostatně.

V našem centru sestry kontrolují pacienty s jednodutinovým kardiostimulátorem, jednou samostatně, jednou s lékařem. Lékař je $\mathrm{k}$ dispozici $\mathrm{v}$ sousední ordinaci a pokud je problém - porucha komfortu a nebo změna stavu pacienta - je přivolán a řeší situaci.

Prezentace zahrnuje informace o kardiostimulátoru, stručné indikace $\mathrm{k}$ implantaci, klinický obraz, zmiňuje se o technice implantace a následném režimu. Důraz je na práci sestry při kontrolách $\mathrm{v}$ ordinaci a je zakončena kasuistikou.

\section{SESTERSKÁ SEKCE}

\section{EXTRAKCE TRVALÝCH ENDOKARDIÁLNÍCH ELEKTROD, NAŠE ZKUŠENOSTI S RF SYSTÉMEM PERFECTA}

BRADA J, KRÁLOVEC Š, HOLÝ F,

NEUŽIL P, TÁBORSKÝ M, ŠEDIVẢ L

\section{Kardiologické oddělení, Nemocnice Na Homolce, Praha}

$\mathrm{V}$ našem sdělení popisujeme naše zkušenosti $\mathrm{s}$ RF bipolárním extrakčním systémem PERFECTA. Tento systém využívá dvojice elektrod umístěných na distálním konci extrakčního sheatu a radiofrekvenční energie $\mathrm{k}$ uvolnění srůstů, které u chronických endokardiálních elektrod brání snadné a bezpečné extrakci. Na př́kladech $z$ našeho pracoviště představujeme technické řešení zákroku.

RF extrakční systém PERFECTA napomáhá $k$ bezpečnějšímu a účinnějšímu kompletnímu vyjmutí stimulačního systému, a to i u pacientů s dlouhodobou historií zavedené trvalé endokardiální stimulace. 


\section{RUTINNÍ UŽITÍ TRANSRADIÁLNÍHO PR̆ÍSTUPU U PCI - CESTA K DOSAŽENÍ NULOVÝCH LOKÁLNÍCH KOMPLIKACÍ}

BRANNY M, INDRÁK J, ČERNÝ J, VODZINSKÁ A, NYKL I, JANUŠKA J, KUČERA D

Kardiocentrum, Nemocnice Podlesí a. s., Třinec

Cil práce: Celkový výskyt krvácivých komplikací v místě vpichu během PCI se vyskytuje v 5-15\%. Nejčastějšími pozitivními prediktivními faktory jsou: diametr punkčího kanálu a intenzita antiagregační, resp. antikoagulační lečby. Cílem práce bylo zjistit rozdíl ve výskytu a závažnosti krvácivých komplikací v místě vpichu u pacientů řešených transradiálním a transfemorálním přístupem v reálné každodenní praxi.

Soubor a metodika: Šest intervenčních kardiologů Z „high volume center“ [> $1700 \mathrm{PCI} / \mathrm{rok}$ ], každý s individuální zkušeností více než 600 PCI, v období od 1. 1.-31. 12. 2006 provádělo PCI u neselektované populace konsekutivních nemocných transradiálním a transfemorálním přístupem. Celkově bylo retrospektivně hodnoceno 1787 pacientů, 57,9 \% z nich byli nemocní řešení pomocí femorálního přístupu, zbývajících 42,1 \% se podrobilo transradiální PCI. Oběma skupinám byla před zahájením PCI podána adjustovaná dávka UHF $70 \mathrm{j} / \mathrm{kg}$, všichni nemocní byli předléčeni kombinací ASA + thienopyridin, 84 [4,7\%] nemocných dostalo blokátory IIb/IIIa receptorů.

Výsledky: Ve skupině nemocných léčených transradiálně nebyla zaznamenána žádná krvácivá komplikace v místě vpichu. Ve skupině $\mathrm{s}$ femorálním přístupem jsme zaznamenali 7 [0,7\%] krvácení v místě vpichu, které si vyžádaly podání krevních derivátů, 3 [0,3\%] nemocní se podrobili neodkladné revizi místa vpichu.

Závěr: Rutinní použití transradiálního přístupu u PCI vede $\mathrm{k}$ výraznému snížení rizika závažného krvácení $\mathrm{z}$ místa vpichu. Tento prospěch je zejména patrný u nemocných s agresivní antiagregační terapií.

\section{DYNAMICKÁ SUBVALVÁRNÍ OBSTRUKCE U AORTÁLNÍ STENÓZY}

\section{BRTKO M, TUNA M}

Kardiochirurgická klinika,

FN Hradec Králové a LF UK, Hradec Králové

Subvalvární obstrukce u významné stenózy aortální chlopně je způsobena výraznou hypertrofií mezikomorového septa a systolickým dopředným pohybem předního cípu mitrální chlopně a/nebo jeho závěsného aparátu. Podle našich zkušeností se vyskytuje zhruba u $4 \%$ pacientů přicházejících k operaci s aortální stenózou. Jedná se většinou o starší ženy s výrazně hypertrofovanou levou komorou, která má malý enddiastolický objem a normální nebo supernormální ejekční frakci. Jde o onemocnění velmi zákeřné; v naprosté většině případů není subvalvární obstrukce patrná předoperačně ani po provokačních manévrech a objeví se až pooperačně po snížení afterloadu nahrazením chlopně protézou.

Vyvolávajícími momenty subvalvární obstrukce $\mathrm{v}$ pooperačním období jsou hypovolemie, tachykardie, fibrilace síní, inotropní podpora či intraaortální balonková kontrapulsace. Subvalvární obstrukce v pooperačním období vede $\mathrm{k}$ hemodynamické nestabilitě a může být příčinou úmrtí nemocného. Je tedy zřejmé, že je třeba na tuto diagnózu myslet při echokardiografickém předoperačním vyšetření pacienta a snažit se identifikovat její prediktory.
Máme-li na základě předoperačního ultrazvukového vyšetření důvodné podezření na vznik subvalvární obstrukce v pooperačním období (nebo je-li subvalvární obstrukce přítomna již před operací), indikujeme společně $s$ náhradou aortální chlopně i operaci podle Morrowa (septální myektomii). Alternativou mưže být alkoholová septální ablace před operací chlopně a v druhé době pak izolovaná náhrada chlopně protézou. Alkoholová septální ablace prováděná při vzniku obstrukce $\mathrm{v}$ bezprostředním pooperačním období je podle našich $\mathrm{zku}$ šeností velmi rizikovým výkonem. Při konzervativním postupu léčíme obstrukci v pooperačním období volumexpanzí, snažíme se vysadit inotropní podporu a udržet sinusový rytmus, a dovolí-li to hemodynamická situace, podáváme betablokátory.

\section{VÝVOJ POČTU A CHARAKTERISTIK HOSPITALIZACÍ PRO KARDIOVASKULÁRNÍ ONEMOCNĚNII V ČESKÉ REPUBLICE V LETECH 1986-2005}

\author{
BRUTHANS J, HOLUB J, KAMBERSKÁ Z
}

Klinika preventivní kardiologie, IKEM, Praha

Cíl: Analýzou trendů hospitalizací můžeme lépe určit vliv epidemiologických a léčebných faktorů na KV morbiditu a mortalitu a aktuální potřebu zdravotní péče pro pacienty s KV chorobami.

Soubor a metodika: Data o KV hospitalizacích v letech 1986-2005 jsme získali z Národního registru hospitalizovaných (dříve informační systém Hospitalizace) ÚZIS. Analyzovali jsme hospitalizace ukončené propuštěním nebo úmrtím s první diagnózou, vykázanou v VII. kapitole (390-459) 9. revize MKN či v IX. kapitole (I00-I99) 10. revize. Tyto údaje jsme porovnali s vývojem mortality, hlavních KV rizikových faktorů a spotřeby zdravotních služeb ve stejném období

Výsledky: Celkový počet KV hospitalizací trvale stoupal z 248206 na 383049 hospitalizací/rok, zkracovala se ošetřovací doba a hospitalizační letalita, zvyšoval se věk hospitalizovaných. Počet AIM zprvu klesal, v posledních 6 letech se zvyšoval a v roce 2005 téměř dosáhl výchozích hodnot (27 054 hospitalizací), rychle se snižovala délka hospitalizace a hospitalizační letalita (ze 17,3 na $7,1 \%$ ). Po vzestupu $\mathrm{v}$ devadesátých letech počet hospitalizací pro AP po roce 2000 klesal. Nejvýrazněji stoupal počet hospitalizací pro srdeční selhání (z 3990 na 31013 ) a pro poruchy srdečního rytmu (z 10291 na 45 619), převažovala fibrilace a flutter síní (26 503 v roce 2005). Hospitalizační letalita srdečního selhání klesala (z 21,4 na 12,1\%). Počet hospitalizovaných s akutními CMP se zvyšoval $\mathrm{v}$ devadesátých letech, posledních 8 let je stacionární (ze 33484 na 45 843), pokles letality se zpomalil. Počet hospitalizovaných pro chronickou ICHS (I25) se nezměnil (61 522 v roce 2005).

Závěr: Vývoj hospitalizací pro KV choroby byl ovlivněn jejich prevalencí a změnami v léčbě. Největší pokrok byl dosažen u ACS. Výrazně přibývá hospitalizací pro srdeční selhání a poruchy rytmu. To si vyžádá změnu v prioritách a postupech lůžkové i ambulantní péče.

\section{NAŠE ZKUŠENOSTI S PODÁVÁNÍM LEVOSIMENDANU U PACIENTU S DEKOMPEZACÍ SRDEČNIIHO SELHÁNÍ}

BRYCHTA T, TESÁK M, ZATOČIL T, MAŇOUŠEK J, LUDKA O, ŠPINAR J

Interní-kardiologická klinika, FN Brno, Brno

V období od 1. 1. 2006 do 31. 12. 2006 byl na jednotce intenzivní péče (JIP) naší kliniky podán 19× u 18 konseku- 
tivních pacientů levosimendan. Jednalo se o pacienty s akutní dekompenzací chronického srdečního selhání různé etiologie. Nejednalo se o akutní srdeční selhání u akutního koronárního syndromu, který se na naší klinice řeší na koronární jednotce.

Soubor pacientů: $n=19$, muži 12 (64\%), ženy 7 (36 \%); průměrný věk pacientů 60,2 (24-82).

Dưvody srdečního selhání: 1. dilatační kardiomyopatie (DKMP) 8×; 2. chronická ischemická choroba srdeční (ICHS) - akutní dekompenzace chronického srdečního selhání vyžadující hospitalizaci na JIP 8×; 3 . chlopenní vada $2 \times$.

Osud pacientů: hospitalizační mortalita: 4 pacienti (22 \%), 6měsíční mortalita: 9 (50\%), posthospitalizační mortalita 5 (35\%), průměrná EF LK při podání levosimendanu $23 \%$.

Nutnost podpory oběhu katecholaminy (noradrenalin) 13 pacientů $(73 \%)$.

Autoři popisují heterogenní soubor pacientů významně symptomatických s těžkou dysfunkcí LK vyžadující komplexní intenzivní péči na JIP. Celková mortalita tedy není překvapující, levosimendan byl podáván jako „bridge“ $\mathrm{k}$ další komplexní léčbě včetně zařazení pacientů do programu OTS. Největší profit a zároveň nejmenší mortalitu měli pacienti s dg. DKMP mladého věku s těžkou dysfunkcí LK. Jejich EF LK byla v době podání hodnocena $17 \%$. Tito pacienti nevyžadovali současné podání katecholaminů.

\section{ŽIVOT OHROŽUJÍCÍ KOMPLIKACE „NEVINNÉ VADY“ NA BIKUSPIDNÍ AORTÁLNİ CHLOPNI. KASUISTIKA}

BRYCHTA T, ZATOČIL T, NEČASOVÁ A,

MAŇOUŠEK J, ČERNÝ J, SMEJKAL P, DOUBEK R

Interní-kardiologická klinika, Oddělení klinické hematologie, Gynekologicko-porodnická klinika, FN Brno, Brno

Abnormní aortální (Ao) chlopeň, bikuspidní či funkčně bikuspidní, je v populaci nejčastější chlopenní abnormita (1-2\%). Tato vada není zařazená mezi vrozené srdeční vady (VSV), kam se řadí pouze kritická Ao stenóza. Tato vada se vyvíjí v „degenerativní“ Ao stenózu, nebo Ao regurgitaci, popř. v kombinovanou vadu. Dále je nebezpečná pro riziko vzniku infekční endokarditidy (IE) i při nevýznamné vadě.

Autoři předkládají kasuistiku pacientky s bikuspidní Ao chlopní se závažnými komplikacemi. 24letá pacientka sledovaná pro hemodynamicky středně významnou kombinovanou Ao vadu s maximálním gradientem $40 \mathrm{~mm} \mathrm{Hg}$ a regurgitací II. stupně, v dlouhodobém vývoji bez progrese vady, poučována o nutnosti prevence IE. Na podzim roku 2004 prodělala drobný infekt horních cest dýchacích provázený mírným zvýšením teplot (TT). Od ledna 2005 opět TT, v únoru byla vyšetřena pro pozitivitu hemokultur a trvající subfebrilie a při TEE zjištěna IE na Ao chlopni. V dalším vývoji došlo ke vzniku subaortálního abscesu. Byla indikována náhrada Ao chlopně. Operace byla počátkem dubna 2005. Bezproblémové zotavení dokázala graviditou potvrzenou počátkem ledna 2006.

$\mathrm{Z}$ důvodu gravidity byla změněna antikoagulační léčba na nízkomolekulární heparin. Od 8. týdne gravidity docházelo k vzestupu gradientu na Ao protéze a k dalšímu zvyšování docházelo při každé další kontrole. Byla vyloučena trombóza protézy. Gradient na Ao protéze se zvýšil až na $85 \mathrm{~mm} \mathrm{Hg}$, Gravidita probíhala bez větších potíží, V 35. týdnu gravidity však došlo $\mathrm{k}$ náhlé hepatopatii, která progredovala do hodnot ohrožující matku i plod, proto byla gravidita $\mathrm{z}$ vitální indikace pro matku i plod ukončena sekcí ve 35. týdnu. Po porodu byla matka převedena zpět na warfarin, hepatopatie i gradient na Ao protéze rychle ustoupil a dítě, dcera, po přechodném pobytu v inkubátoru nejeví žádné poškození.

\section{JE PUNKCE PERIKARDU RIZIKOVÝ VÝKON?}

BRZEK V, LONSKÝ V, ŠIMKOVIČ D, HAMAN L

Kardiochirurgická klinika, Chirurgická klinika, I. interní klinika, FN Hradec Králové, Hradec Králové

Úvod: Punkce perikardu je považována za život zachraňující výkon při tamponádě srdeční. V literatuře je popisována jako vcelku jednoduchý výkon s poznámkou opatrnosti během výkonu pro možné poranění srdce. Jiné komplikace nejsou v literatuře zmiňovány a ani možné poranění srdce není nikterak rozvedeno.

Kasuistika: V naší kasuistice bychom chtěli uvést příklad možných komplikací při punkci perikardu především jako zdroj poučení.

U 52letého pacienta byla provedena radiofrekvenční ablace pro opakované paroxyzmy fibrilace síní s nutností farmakoverzí. Za 24 hodin po výkonu bylo pro bolesti na hrudi a symptomy výpotku v perikardu provedeno ultrazvukové vyšetření srdce, které potvrdilo tekutinu v perikardu. Byla provedena drenáž hemoragického výpotku opakovanými vpichy. Poté se klinický stav pacienta stabilizoval. Za 12 hodin došlo $\mathrm{k}$ progresi hypotenze. Podle ultrazvukového vyšetření bylo $\mathrm{v}$ perikardu stejné množství výpotku jako před punkcí. Postupně bylo odsáto $1000 \mathrm{ml}$ hemoragického výpotku. Pro pokračující krvácení indikována operační revize. Během operační revize zjištujeme, že katetr prochází bránicí asi do poloviny výšky brániční plochy pravé komory a je zaveden do pravé komory. Katetr, který byl zaveden asi $3 \mathrm{~cm}$ v pravé komoře, byl opatrně odstraněn a otvor přešit stehem s teflonovou podložkou. Protože vpich prochází poměrně nízko bránicí, pronikáme do dutiny břišní a zjištujeme, že katetr proniká asi $4 \mathrm{~cm}$ od okraje levým jaterním lalokem - ošetřeno opichy.

Pacient byl extubován 4 hodiny po výkonu. Katecholaminová podpora byla vysazena 30 hodin po výkonu. Pacient časně rehabilitoval a propuštěn do domácího ošetřování byl 7. pooperační den.

Závěr: Operační řešení, na první pohled jednoduché, je však zatíženo rizikem ruptury prokrvácené svaloviny pravé komory s možnými fatálními důsledky pro pacienta.

\section{PR̆ÍSPĔVEK KE STANOVENÍ „OPTIMÁLNİHO “ ATRIOVENTRIKULÁRNÍHO INTERVALU POMOCÍ TRANSTORAKÁLNÍ IMPEDANČNÍ KARDIOGRAFIE U PACIENTŮ SE SICK SINUS SYNDROMEM KORIGOVANÝM PM DDD}

BUCHTOVÁ K, NOVÁK M, KAMARÝT P, LIPOLDOVÁ J, HOMOLKA P*, VYKYPĚL T, SIEGELOVÁ J*

I. interní-kardioangiologická klinika, *Klinika funkční diagnostiky a rehabilitace, FN u sv. Anny, Brno

Cîl: 1. Stanovit pomocí impedanční kardiografie (IKG) optimální atrioventrikulární interval (AVI) podle maximálního (max) srdečního výdeje (cardiac output - CO). 2. Posoudit, zda při stimulaci AOO je CO větší než při DOO.

Pacienti a metody: 34 pacientům (pac), 19 mužům a 15 ženám, prům. věku 10,6 roků, se sick sinus syndromem SSS (u 9 pac ischemické, u 25 pac \pm 70 neischemické etiologie) stanoven vleže, při normálním dýchání $\mathrm{CO}$ pomocí IKG (Task Force Monitor CNSystems, Rakousko). PM programován: DDD, 80. min ${ }^{-1}$ (aby byla zajištěna konstantní frekvence stimulace), AVI 75, 100, 120, 140, 160, 180, 250 a $300 \mathrm{~ms}$ (AVI programovány randomizovaně). Vyrovnávací období 2 min, měřené období 2 min. U 10 pac proveden retest při jednom $z$ AVI. 
Výsledky: Maximální $\mathrm{CO}$ při jednotlivých $\mathrm{AV}$ intervalech, D00, 80. $\mathrm{min}^{-1}(\mathrm{n}=34)$

AVI [ms] $75 \begin{array}{lllllllll}75 & 100 & 120 & 140 & 160 & 180 & 250 & 300 ; \max \end{array}$ CO u n pac 194131700 .

Retestem potvrzena reproducibilita naměřených hodnot $\mathrm{s}$ rozdílem $\pm 0,11 \cdot \mathrm{min}^{-1}$.

Diskuse: Při experimentálním prodlužování AVI u pac se SSS dochází jednak ke změně síňového příspěvku (zvýšení snížení), a jednak ke změně QRS (plně uchvácený, splynulý QRS při D00, spontánní QRS při A00). Obě změny ovlivňují CO. Neočekávaným výsledkem je velký počet pac s „optimálním“ krátkým AVI (vedoucí k sekvenční stimulaci D00 s možným vznikem dysfunkce komorové kontrakce). Otaznou zůstává i definice optimálního AVI.

Závěr: U pacientů se SSS stanoven impedanční kardiografií „optimální“ interval AV podle maximálního CO. Vykazoval zřetelné interindividuální rozdíly ( $\mathrm{v}$ souhlase $\mathrm{s}$ jinými metodami). Nepotvrzen vyšší CO při stimulaci A0O oproti D00.

\section{ÚLOHA TKÁŇOVÉHO DOPPLEROVSKÉHO VYŠETŘENÍ U SRDEČNÍ RESYNCHRONIZAC̆NÍ LÉC̆BY}

BULAVA A, HUTYRA M, MAREK D, LUKL J

\section{I. interní klinika, FN Olomouc a LF UP, Olomouc}

Úvod: Srdeční resynchronizační léčba (SRL) je dnes již zavedenou metodou nefarmakologické léčby chronického srdečního selhání. Vyšetření tkáňovou dopplerometrií (TDI) mělo za cíl snížit procento non-responderů SRL a je všeobecně považováno za „citlivější“ než pouhá šíŕka komplexu QRS.

Cíl: Zjistit, zda TDI sníží procento non-responderů SRL.

Metody: Pacienti indikovaní k SRL podstoupili echokardiografické vyšetření vč. TDI před SRL, bezprostředně po ní a za 12 měsíců. Byla sledována řada parametrů, vč interventrikulárního mechanického zpoždění a septo-laterálního zpoždění.

Výsledky: Do studie bylo zařazeno 102 pacientů (69 ICHS 33 DMKP) průměrné NYHA třídy $3,2 \pm 0,4 \mathrm{~s}$ ejekční frakcí levé komory (EF LK) $23 \pm 7 \%$ a šíŕkou QRS $173 \pm 23$ ms. Po 12 měsících došlo $\mathrm{v}$ celém souboru k signifikantnímu zlepšení NYHA tř́dy na $2 \pm 0,5$ a EF LK se zvýšila na $37 \pm 11 \%$ Dále došlo k významnému zmenšení enddiastolických i endsystolických objemů LK, zmenšení levé síně a mitrální regurgitace. $70 \%$ pacientů bylo po 12 měsících sledování shledáno klinickými respondery SRL, u $57 \%$ pacientů jsme zaznamenali nárůst EF LK o $\geq 30 \%$ původní hodnoty a $31 \%$ pacientů mělo EF LK normální nebo téměř normální ( $\geq 45 \%)$. Multivariantní analýza neidentifikovala žádný z parametrů TDI, který by dokázal předpovědět reverzní remodelaci LK.

Závěr: Přes existenci sofistikovaných zobrazovacích echokardiografických metod, neexistuje dosud parametr, který by spolehlivě předpověděl pozitivní klinickou reakci na SRL nebo reverzní remodelaci LK.

\section{ANALÝZA SOUBORU PACIENTŮ S FIBRILACÍ SÍNÍ LÉČENÝCH AMBULANTNÍMI KARDIOLOGY V ČESKÉ REPUBLICE}

BULKOVÁ V, FIALA M, CHOVANČÍK J, WICHTERLE D, ČIHÁK J, BRANNY M, KAUTZNER J

I. interní klinika, FN Olomouc a LF UP, Olomouc, Klinika kardiologie, IKEM, Praha

Cílem práce: Analýza demografických a medicínských dat od neselektovaných pacientů (pac) s diagnózou fibrilace síní (FS) léčených běžnými metodami.
Metody: Retrospektivní data za dva roky byla získána pomocí dotazníku zaslaného obvodním kardiologům v ČR. Do studie bylo zahrnuto 306 pac (94 Ž, $64 \pm 11$ let), s potvrzenou diagnózou FS.

Výsledky: Paroxyzmální FS mělo 141 (46\%) pac, persistentní FS 77 (25\%) pac a permanentní FS 88 (29\%) pac. Nejčastějším kardiovaskulárním onemocněním spojeným s FS byla hypertenze u 220 (72\%), dále ICHS u 83 (27\%) a DM u 82 (27\%). Palpitace mělo 91 (29\%) pac, následovaly dušnost u 53 (17\%), palpitace a dušnost u 20 (6\%), srdeční selhání u 13 (4\%) a únavnost s nevýkonností u 17 (\%) pac. Symptomy chyběly u 122 (39\%). Rozměr levé komory (LK) v diastole byl $54 \pm 6 \mathrm{~mm}$, EF LK byla $55 \pm 11 \%$ a přičný rozměr levé síně byl $47 \pm 7 \mathrm{~mm}$. Permanentní FS byla spojena s nižší EF LK proti paroxyzmální FS $(51 \pm 13 \%$ vs. $58 \pm 9 \% ; p<0,001)$. Antikoagulační léčbu mělo 273 pacientů (89\%), warfarin užívalo 229 (75 \%) a ASA 44 (14\%). Antiarytmika (AA) bralo 275 (90\%); 1 AA mělo 94 (30\%), 2 AA 168 (55 \%) a 3 AA 13 (4\%). Komplikace související s léčbou amiodaronem vznikly u 24 pac. Alespoň jednu EKV mělo 167 (55 \%), farmakologickou kardioverzi 106 (35\%) pac. Alespoň jednu hospitalizaci pro FS mělo 144 (47\%) pac, délka hospitalizace činila 4,2 $\pm 3,2$ dne. Pro kardioembolizační příhodu bylo hospitalizováno 25 (8\%) pacientů, délka hospitalizace činila 8,2 $\pm 2,9$ dní. Dokonaná CMP se vyskytla v 8 př́padech, TIA v 16 případech a jiná embolická příhoda v 5 př́ípadech.

Závěr: Analýza souboru ukázala dobrou kvalitu léčby pacientů s FS obvodními kardiology. Jedná se především o dobře kontrolovanou antikoagulační a AA léčbu. Tato studie ukázala potřebu dlouhodobé prospektivní studie, která by umožnila analyzovat účinnost a bezpečnost jednotlivých léčebných postupů v léčbě FS.

\section{HODNOCENÍ PROPUSTNOSTI MIKROVASKULÁRNİHO PROSTORU (BLUSH) METODOU DENZOGRAFIE U AKUTNÍHO INFARKTU MYOKARDU, LÉČENÉHO DIREKTNÍ PCI. POROVNÁNÍ S VÝVOJEM BIOCHEMICKÝCH MARKERŮ AIM}

BUNČEK L, HERMAN A, ŠMORANC P, VARVAŘOVSKÝ I, MATĚJKA J, ROZSÍVAL V, STEINHART L

Kardiologické oddělení Interní kliniky, Krajská nemocnice Pardubice, pracoviště invazivní kardiologie, Kardio-Troll, Pardubice,

Radiologická klinika, FN Hradec Králové, Hradec Králové

Propustnost mikrovaskulárního prostoru (BLUSH) oblasti levé a pravé koronární arterie lze hodnotit pomocí dilučních křivek průtoku kontrastní látky tkání. Vlastní hodnocení je prováděno pomocí software, vyvinutého $\mathrm{Z}$ výpočetního prostředí MATLAB-The Math Works Inc.

K hodnocení byla zvolena základní projekční sít o rozměru $6 \times 8$ "region of interest“ (ROI), která pokrývá plochu projekce celého př́slušného koronárního řečiště. Propustnost se stanoví z poměru ROI s prokazatelnými dilučními křivkami $\mathrm{k}$ celkovému počtu ROI přehledné projekce /(počet ROI s dilučními křivkami/48) × $100 \% /$.

Normální distribuce kvantitativně hodnocené BLUSH odpovídá zhruba Gaussovu rozložení: nemocné lze rozdělit do kvartil podle rozsahu počtu automaticky hodnocených ROI s hodnotitelnými dilučními křivkami $<8 \%$ - velmi nízká propustnost, nefunkční stav mikrovaskulárního řečiště, 8-20\% - významné poškození mikrovaskulárního řečiště, 20-35 \% - mírné poškození a > 35 \% - minimální poškození mikrovaskulárního řečiště).

Autoři popisují soubor 40 nemocných léčených přímou PCI pro akutní STE infarkt myokardu. Kvantitativní hodno- 
ta myokardiální perfuze je porovnávána s rychlostí ústupu ST-elevací na EKG a velikostí infarktu myokardu podle biochemických markerů (TnI, CK, CK-MB, hsCRP) v intervalech: při přijetí, po provedení intervence, za 6 a 12 hod. po intervenci. Součástí hodnocení angiografického nálezu byl počet postižených cév a hodnocení TIMI průtoku před provedením intervence a po provedení, hodnocení ejekční frakce, mitrální regurgitace a vlastní hodnocení BLUSH po provedení intervence.

Závěr: Hodnocení propustnosti mikrovaskulárního řečiště metodou digitální denzografie v porovnání s vývojem biochemických markerů AIM poskytuje nové informace o závažnosti poškození myokardu levé komory srdeční u nemocných s AIM léčených dPCI.

\section{SESTERSKÁ SEKCE}

\section{ORGANIZACE PÉČE O PACIENTY SE SYNKOPOU}

CETLOVÁ I, VLAŠÍNOVÁ J, NOVÁČKOVÁ J, PRACHAŘOVÁ I

Interní-kardiologická klinika, FN Brno, Brno

Synkopa je definovaná jako náhlá, krátká ztráta vědomí a posturálního tonu se spontánní úpravou, bez neurologických reziduí. Jejím podkladem může být celá řada stavů, které vedou za určitých okolností $\mathrm{k}$ neúplně vyjádřené synkopě (závratě, pocit nejistoty). Podle různých zdrojů tvoří synkopální stavy 1-6 \% nemocničních hospitalizací za rok a $3 \%$ hospitalizací na jednotkách intenzivní péče. Vyskytuje se u $3 \%$ mužů a 3,5 \% žen.

Mezi vyšetřovací metody $u$ pacientů se synkopou patří i test na nakloněné rovině (HUT - head-up till test). Pomocí tohoto testu se diagnostikuje vazovagální synkopa, častá hlavně u mladších pacientů.

$\mathrm{Na}$ naší klinice je ročně vyšetřeno tímto testem přes 300 pacientů.

V našem sdělení chceme prezentovat zkušenosti se sledováním pacientů s diagnózou vazovagální synkopa. Instruktáže sestrou o režimových opatřeních, pohovory s lékařem, možnosti farmakoterapie, intervaly kontrol.

\section{PROFYLAKTICKÁ APLIKACE INTRAAORTÁLNÍ BALONKOVÉ KONTRAPULSACE (IABK) - ZBYTEČNĚ PODCEŇOVANÁ POMOC}

COUFAL Z, FIALA T, GŘIVA M, NÁPLAVA R, MATĚJOVSKÁ P

Interní klinika IPVZ, pracoviště invazivní a intervenční kardiologie, Krajská nemocnice T. Bati, a. s. Zlín, Zlín

Cîl: Průkaz přínosu profylaktického používání intraaortální balonkové kontrapulsace (IABK) u perkutánní koronární intervence (PCI).

Soubor a metodika: IABK je nejrozšířenější mechanickou podporou selhávající funkce LK využívaná v intervenční kardiologii především u akutních stavů. Dříve sloužila převážně jako doplňková metoda ke zlepšení průtoku revaskularizovanou oblastí myokardu až po vlastní PCI. V některých případech je žádoucí zvýšení koronární perfuze již v době intervence, a proto je racionální použít IABK profylakticky již před vlastním výkonem na koronárních tepnách. Autoři přinášejí analýzu 110 konsekutivních pacientů Z vlastního pracoviště $z$ let 2002-2006, řešených za použití IABK. Pacienti byli rozděleni do dvou kohort: soubor A před zavedením profylaktického používání IABK, soubor B s cíleně indikovaným profylaktickým používáním IABK.
Výsledky: Soubor A: 2002-2005, 76 pacientů, $z$ toho $1 \times$ profylaktické použití (1,3\%), hospitalizační mortalita $46 \%$. Soubor B: 2006, 34 pacientů, $z$ toho $9 \times$ profylaktické použití (26,4\%), hospitalizační mortalita $14 \%$.

Závěr: Pacienti indikovaní k PCI s profylakticky zavedenou IABK mají lepší celkovou prognózu. Dále autoři dokumentují signifikantně kratší dobu ponechání kontrapulsačního balonu i celkově kratší dobu hospitalizace pacientů v souboru nemocných s profylakticky aplikovanou IABK.

Již $\mathrm{z}$ této nevelké sestavy pacientů lze doporučit profylaktické používání IABK.

\section{GENERÁCIA AORTÁLNYCH KONEKTOROV - STREDNEDOBÉ VÝSLEDKY}

\section{ČANÁDYOVÁ J, MOKRÁČEK A, ŠETINA M, PEŠL L}

Kardiochirurgické oddělení, Kardiocentrum, Nemocnice České Budějovice, České Budějovice

Úvod: Cielom práce bolo angiografické zhodnotenie priechodnosti aortálnych konektorov II. generácie po 6 mesiacoch a klinické výsledky pacientov v strednedobom pozorovaní.

Súbor pacientov: Od 09/2002-06/2003 bolo použitých 45 konektorov St. Jude Medical II. generácie u 39 pacientov. 33 pacientov podstúpilo kontrolné angiografické vyšetrenie po 6 mesiacoch.

Výsledky: Včasná oklúzia konektoru bola zistená u 1 pacienta, nepriechodnost 2 konektorov a 1 žilného štepu bola zistená pri 6-mesačnej angiografickej kontrole.

Záver: 88,9-\% priechodnost konektorov po 6 mesiacoch je porovnatelná s priechodnostou centrálnych anastomóz žilných štepov šitých konvenčnou chirurgickou technikou.

\section{NAŠE SKÚSENOSTI S IMPLANTÁCIOU STENTGRAFTOV DO HRUDNEJ A BRUŠNEJ AORTY 2001-2006}

\section{ČANÁDYOVÁ J, MOKRÁČEK A, PEŠL L}

Kardiochirurgické oddělení, Kardiocentrum, Nemocnice České Budějovice, České Budějovice

Úvod: Cielom práce bolo zhodnotit naše 6-ročné skúsenosti s použitím stentgraftov pri liečbe ochorení hrudnej a brušnej aorty.

Súbor pacientov: V rokoch 2001-2006 sme v Kardiocentre České Budějovice implantovali stentgrafty 24 pacientom s priemerným vekom 61,6 rokov.

V 9 prípadoch sa jednalo o chronické aneuryzmy brušnej aorty, $6 \times$ sme implantovali stentgrafty $\mathrm{u}$ pacientov $\mathrm{s}$ akútnou disekciou typu $B$.

Výsledky: Celkovo sme implantovali 46 stentgraftov, počas hospitalizácie zomreli 3 pacienti (12,5\%).

Záver: Endovaskulárna liečba aorty sa zdá byt bezpečnou alternatívou chirurgickej liečby hlavne u polymorbidých rizikových pacientov nevhodných $\mathrm{k}$ chirurgickému riešeniu.

\section{SESTERSKÁ SEKCE}

\section{KOMPLEXNÍ INTENZIVNÍ PÉČE U PACIENTA PO AKUTNÍM Q-INFARKTU MYOKARDU V KARDIOGENNIIM ŠOKU. KASUISTIKA}

ČAPKOVÁ M, ČEPÁKOVÁ D, PAVLÍČKOVÁ L, ROKYTA R, SÝKOROVÁ I

Kardiologická jednotka intenzivní péče, FN Plzeñ, Plzeñ 


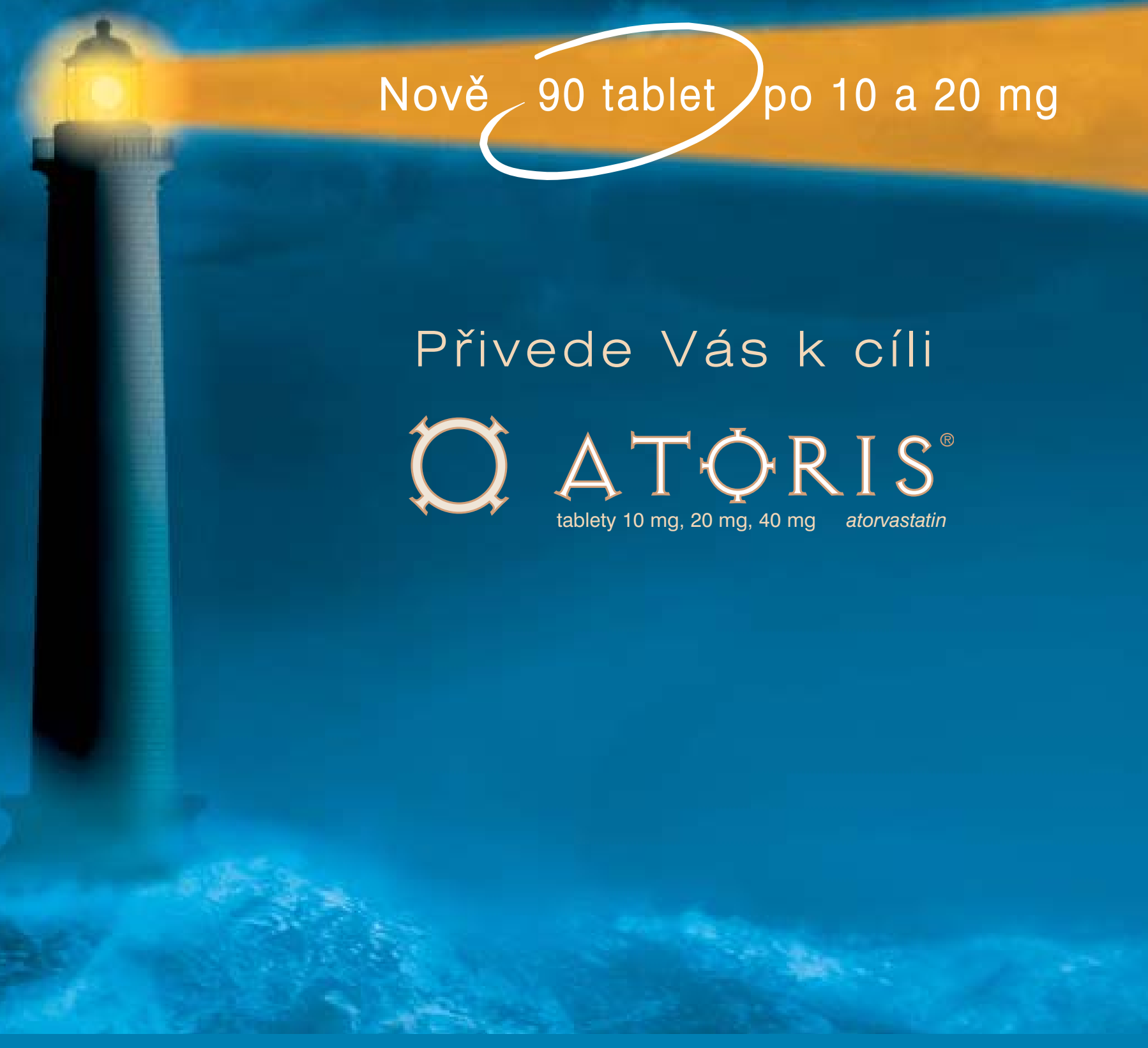

Základní informace pro předpis léčivého př́pravku (pripraveno podle schváleného Souhrnu údajů o prípravku)

Kvalitativní a kvantitativní složení: Atoris 10: Atorvastatinum calcicum 10,36 mg v 1 potahované tabletě (což odpovídá $10 \mathrm{mg}$ atorvastatinu), Atoris 20: Atorvastatinum calcicum 20,72 mg v 1 potahované tabletě (což odpovidá 20 mg atorvastatinu), Atoris 40: Atorvastatinum calcicum 41,44 mg v 1 potahované tabletě (což odpovídá 40 mg atorvastatinu).

\section{Indikace}

Atoris je indikován se současně navrhovanou dietou k léčbě pacientů se zvýšenými hladinami celkového cholesterolu, LDL-cholesterolu, apolipoproteinu B a triglyceridü, a ke zvýšení HDL-cholesterolu u pacientu s primární hypercholesterolemií a se smišenou (kombinovanou) hyperlipidemií, zvýšenými hladinami triglyceridü a u pacientů s dysbetalipoproteinemií, pokud dieta nevedla $\mathrm{k}$ dostatečnému úćinku.

Atoris je též indikován ke snižení celkového cholesterolu a LDL-cholesterolu u pacientů s homozygotní familiární hypercholesterolemií, pokud dieta a jiná nefarmakologická léčebná opať̌ení nevedla k dostatečnému účinku.

U pacientủ s kardiovaskulárním onemocněním a/nebo dyslipidémií je Atoris indikován k sekundární prevenci kombinovaného rizika smrti, nefatálního infarktu myokardu, srdeční zástavy a rehospitalizace pro anginu pectoris.

Dávkování a zpúsob podání

\begin{tabular}{|lr|}
\hline Počáteční dááka & $10 \mathrm{mg}$ \\
\hline Maximální dávka & $80 \mathrm{mg}$ \\
\hline
\end{tabular}

Běžně se léčba zahajuje $10 \mathrm{mg}$ atorvastatinu $1 x$ denně. Úprava dávkování následuje individuálně podle výchozich výsledkü LDL-cholesterolu, v porovnání s cílovými hladinami LDL-cholesterolu a podle reakce pacienta na léčbu. Uprava dávkováni se provádí s odstupem 4 týdnů a déle. Maximální dávka je 80 mg atorvastatinu 1x denně. Uživání není závislé na denní době či príjmu potravy.

Kontraindikace: Precitlivělost na jakoukoli složku připravku, aktivní jaterní onemocnění či nevysvětlené přtrvávajicí zvýšení transmináz v séru na více než trojnásobek normálních hodnot, těhotenství a kojení. Zvlaštní upozornění: Pr̆ léčbě atorvastatinem mǔže dojit ke zvyšsení hodnot jaterních enzymů v séru. I když je toto zvy̌sení u vêtšiny pacientů malé a nemá žádný klinický význam, doporučuje se sledovat aktivitu jaternich enzymù v séru před zahájením léčby a během léčby. Je-li zjjštěnno zvýšení hodnoty aspartátaminotransferázy (AST) a/nebo alaninaminotransferázy (ALT) nad hodnotu trĭkrát vyšší než horní hranice normálních hodnot, je třeba léčbu atorvastatinem ukončit. Objeví-li se symptomy myopatie, doporučuje se stanovit hodnotu kreatinkinázy (CK) v séru. V prípadě významného patologického zvy̌šeni aktivity kreatinkinázy je třeba léčbu ukončit. Interakce: Současné uživání atorvastatinu a cyklosporinu, antibiotik (erythromycin, clarithromycin, quinupristin a dalfopristin), inhibitorů proteázy, azolových antimykotik nebo nefazodonu, dále pak fibrátů nebo niacinu mưže mít za následek zvy̌šení hodnoty atorvastatinu v séru, které může vést ke vzniku myopatie s rozpadem svalovích buněk (rhabdomyolýzou) se selháním ledvin. Současné uživání atorvastatinu a warfarinu může zyyšovat vliv warfarinu na koagulační parametry. Těhotenství a kojenf: Atorvastatin je $v$ době

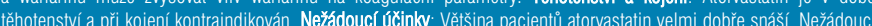
účinky jsou obvykle mírné a prechodné. Prí klinických studích ukončila léčbu kvưli nežádoucím účinkỉm souviseícím s atorvastatinem méně než 2 \% pacienti̊: Mezi nejobuyklejě̌i nežádouci účinky patři: zácpa nauzea nadýmání, bolesti

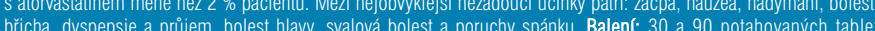
po $10 \mathrm{mg}$ a $20 \mathrm{mg}$ a 30 potahovaných tablet po $40 \mathrm{mg}$. Uchovávání: Žádné zvláštní podminky uchovávání. Doba použitelenosti: Atoris 10, 20: 18 měsícü, Atoris 40: 2 roky

Dřive než prípravek předepišete, seznamte se, prosím, s úplným Souhrnem údajư o prípravku (SPC).

Datum poslední revize textu SPC Atoris 10, 20, 40: 7. 9. 2005

Držitel rozhodnutí o registraci: KRKA, d.d., Novo mesto, Slovinsko

Registrační čislo: Atoris 10: 31/021/05-C, Atoris 20: 31/022/05-C, Atoris 40: 31/323/05-C Léčivý prípravek je vydáván pouze na lékařský předpis.

Léčivý prípravek je hrazen z prostředkư veřejného zdravotního pojištění.

Neprètržitá veřejná informační služba - tel./zázn./fax: 221115 150, e-mail: info@krka.cz

Kontaktní adresa:

KRKA zastoupení pro ČR

Sokolovská 79/192

18600 Praha 8 - Karlín

tel.: +420 221115115

fax: + 420221115116

www.krka.cz 
V kasuistickém sdělení prezentujeme průběh intenzivní péče u 33letého dosud vážněji nestonajícího kuřáka. Na KJIP byl přivezen $\mathrm{z}$ nemocnice Klatovy zaintubován po KPR pro primární fibrilaci komor při akutním IM s ST-elevacemi v oblasti přední stěny LKS. Byla provedena urgentní koronarografie s primární PCI těsné stenózy RIA s implantací stentu.

V našem sdělení popisujeme komplexní léčbu u ventilovaného pacienta až do jeho plného uzdravení se zaměřením na:

- popis diagnostických metod - invazivní hemodynamika,

- intraaortální balonkovou kontrapulsaci a léčebnou hypotermii,

- zavádění a pozdější odstranění tracheotomie,

- rehabilitaci (nácvik soběstačnosti, sociální kontakt, vliv rodiny, postupná fyzická zátěž)

Celková doba hospitalizace na KJIP byla 20 dní; 18. den se podařilo pacienta úplně odpojit od ventilátoru. Velkou oporou byla pacientovi jeho rodina, které byly návštěvy umožňovány prakticky neomezeně s přihlédnutím $\mathrm{k}$ provozu na KJIP. Stav pacienta se plně stabilizoval a byl přeložen zpět do odesílající nemocnice na standardní interní lưžko. Pět měsíců po propuštění $z$ KJIP je zdravotní stav pacienta uspokojivý. Uvádíme samotnou diskusi s pacientem o jeho uzdravování, pocitech a současném životním stylu. Využíváme toho i $\mathrm{k}$ př́mé edukaci pacienta.

\section{COMPARISON OF ABSOLUTE RISK \\ FOR CARDIO-VASCULAR EVENTS BETWEEN "WHITE“ AND "BLUE" COLLAR WORKERS - EXPERIENCE FROM SLOVAKIA}

\section{ČAPRNDA M, LIETAVA J, DUKÁT A, FODOR J}

II. interná klinika FN a LF UK,

FNsP Bratislava, Bratislava, SR, Heart Institute,

University of Ottawa, Ottawa, Canada

Introduction: Estimation of absolute risk for cardiovascular death (SCORE 2005) is recently basic stratification procedure in decision for therapy of arterial hypertension and dyslipidemia in primary and secondary prevention. Extrapolation of AR on age of 60 years allows to compare also cohorts with different age.

Methods: We examined 1241 „blue collar“ workers (786 males, 455 females) in factory Duslo Šala (project Omron) $(42.8 \pm 9.90 \mathrm{yrs})$ and 296 „white collar“ workers (100 males and 196 females) from Slovak National Bank and Prvá stavebná sporitelna (project Whico) $(40.1 \pm 8.83 \mathrm{yrs})$.

Results: White collars exhibited significantly lower absolute risk extrapolated to age of 60 years both in males (3.8 \pm 1.86 vs $5.3 \pm 2.63 ; p<0.001)$ and females $(1.6 \pm 0.79$ vs $2.1 \pm 1.45 ; p<0.01$ ). Risk of males in both groups was twice as high as females. „White collar“ workers had signi-
Moreover, males in the both groups had almost twice higher risk in comparison with females.

\section{RELATIONSHIP OF THYROID HORMONES TO OXIDATIVE STRESS IN SLOVAK FEMALES}

\section{ČAPRNDA M}

II. interná klinika FN a LF UK,

FNsP Bratislava, Bratislava, SR

Introduction: Atherosclerosis and its complications constitute the most common causes of death in developed countries. This disease is associated with multiple risk factors. Hypo- and hyper-thyroidism are well known causes of atherosclerosis. Smoking is another important risk factor of atherosclerosis, causing increase of oxidative stress. However, the exact relationship of thyroid hormones and oxidative stress is not yet known.

Methods: We examined 110 randomly selected females divided into smoking (18) and non-smoking (92) subgroups. Determination of free T4 and TSH hormones and antiTPO antibodies was done by standard methods.

Results: Smoking and nonsmoking females haven't any significant difference in level of free T4 $(13.4 \pm 5.1$ vs 14.0 \pm 3.6 ; NS $)$ and TSH $(2.59 \pm 2.33$ vs. $6.79 \pm 18.65$; NS $)$ hormones and antiTPO $(20.4 \pm 14.4$ vs. $19.1 \pm 6.2$; NS $)$. However, we found significant correlations between free $\mathrm{T} 4$ and uric acid $(\mathrm{r}=0.23 ; p<0.01)$, HDL cholesterol $(\mathrm{r}=-0.20$; $p<0.05)$ and oxidized LDL cholesterol $(\mathrm{r}=0.49 ; p<0.05)$ and between TSH and uric acid ( $\mathrm{r}=-0.22 ; p<0.05)$, total cholesterol $(\mathrm{r}=0.19 ; p<0.05)$, LDL cholesterol $(\mathrm{r}=$ $0.22 ; p<0.05)$ and oxidized LDL cholesterol $(\mathrm{r}=-0.19$; $p<0.05$ ).

Conclusions: Females with higher TSH levels had tendency to have higher levels of total and LDL cholesterol. However, high free T4 values in combination with low TSH values would lead to increased oxidative stress, marked by higher level of uric acid and oxidized LDL cholesterol.

SESTERSKÁ SEKCE

\section{VYUŽITÍ HEMODYNAMICKÉ PODPORY U VYSOCE RIZIKOVÉ PCI}

\section{ČÁPOVÁ M, VOKOUNOVÁ M}

Kardiologické oddělení, Masarykova nemocnice, Ústí nad Labem

Cílem sdělení je podělit se o naše zkušenosti s mechanickou podporou srdce, $v$ našem př́ipadě IMPELLA, při využití u pa-

Tabulka k abstraktu MUDr. Čaprndy

\begin{tabular}{|c|c|c|c|c|c|c|}
\hline & \multicolumn{3}{|c|}{ SBP [mmHg] } & \multicolumn{3}{|c|}{ DBP [mmHg] } \\
\hline & „White“ & „Blue“ & Sign. & „White“ & „Blue“ & Sign. \\
\hline Males & $119.8 \pm 12.2$ & $130.0 \pm 18.4$ & $p<0.001$ & $79.7 \pm 9.7$ & $86.1 \pm 10.5$ & $p<0.001$ \\
\hline Females & $114.8 \pm 14.3$ & $123.8 \pm 18.9$ & $p<0.002$ & $75.8 \pm 9.2$ & $80.6 \pm 10.2$ & $p<0.001$ \\
\hline Sign. & $p<0.001$ & $p<0.001$ & & $p<0.01$ & $p<0.001$ & \\
\hline
\end{tabular}

ficantly lower blood pressure, however, females in both groups had lower systolic (SBP) and diastolic blood pressure (DBP) about $5 \mathrm{mmHg}$ compared to males (Table).

Conclusion: „White collar“ workers exhibited significantly lower absolute risk for cardiovascular death and lower blood pressure in comparison with „blue collars“ of analogous age. cientů s velmi rizikovou PCI, kdy jiná forma revaskularizace vzhledem $\mathrm{k}$ neúměrnému riziku není možná.

Naše skromné zkušenosti naznačují, že systémy pro mechanickou podporu srdce nám dovolí provést PCI i u těžce oběhově nestabilních nemocných, kdy nám neúměrné riziko nedovolovalo provést PCI. 
Závěry: Tyto výsledky naznačují, že u chirurgicky vysoce rizikových pacientů je CAS bezpečnou a účinnou metodou léčby.

\section{ÚLOHA SESTRY PR̆I PREVENCI KONTRASTNÍ NEFROPATIE U PACIENTŮ PODSTUPUJICIICH ANGIOGRAFICKÉ VYŠETR̆ENÍ S PR̆ÍPADNOU INTERVENCÍ NA KORONÁRNÍCH TEPNÁCH. ROZPOZNÁNÍ RIZIKOVÝCH PACIENTŮ A JEJICH PR̆ÍPRAVA K VÝKONU}

\section{ČERNÁ B}

\section{II. interní oddělení, Městská nemocnice Ostrava, Ostrava}

Kontrastní látky podávané v průběhu angiografických vyšetření u pacientů podstupujících srdeční katetrizaci mohou způsobit akutní zhoršení renálních funkcí až jejich selhání, zvyšují nemocniční morbiditu, prodlužují pobyt v nemocnici a zvyšují náklady na léčbu. Mohou vést $\mathrm{k}$ chronickému renálnímu selhání s potřebou nákladné následné péče, výskytem řady komplikací s významně zvýšenou úmrtností. Riziku vzniku postižení jsou vystaveni především nemocní s diabetem a preexistujícím ledvinným onemocněním. Jediným účinným opatřením je prevence. Sesterský personál, ošetřující pacienta před vyšetřením $\mathrm{v}$ době jeho pobytu na katetrizačním sále $\mathrm{v}$ průběhu výkonu i po něm, se významně podílí jak na včasném rozpoznání ohrožených - na jejich adekvátní přípravě před vyšetřením či výkonem - tak po něm, což významným způsobem snižuje riziko rozvoje ledvinného postižení a jeho následky.

\section{KAROTICKÉ STENTOVÁNÍ U VYSOCE RIZIKOVÝCH PACIENTŨ: 3ODENNÍ SLEDOVÁNİ}

ČERNÁ D, VESELKA J, DUCHOŇOVÁ R, BLAŠKO P, ZEMÁNEK D, FIEDLER J, HÂJEK P, MALÝ M, CELERÝN Š, TOMAŠOV P

Kardiovaskulární centrum, Oddělení kardiologie, FN Motol, Praha

Úvod: Implantace stentu do karotické tepny (CAS) je alternativou chirurgické endarterektomie především u vysoce rizikových pacientů.

Metodika: Analýza registru vysoce rizikových pacientů, u kterých bylo provedeno CAS v posledních 12 měsících. Kritéria pro zařazení do studie byla symptomatická stenóza $>50 \%$ nebo asymptomatická stenóza > $70 \%$. Klinická kritéria pro vysoce rizikové pacienty jsou: věk $>79$ let, významná kontralaterální karotická stenóza nebo okluze, endarterektomie v minulosti, ischemická cévní mozková příhoda $\mathrm{v}$ posledních 6 měsících, plánovaná kardiochirurgická revaskularizace, choroba více tepen při selektivní koronarografii, chirurgická koronární revaskularizace, nebo infarkt myokardu v minulosti, těžká plicní ventilační porucha nebo renální insuficience, vše v souladu s vyřazovacími kritérii studie NASCET.

Výsledky: Bylo provedeno 77 intervenčních procedur s implantací 78 stentů u 65 pacientů ( 25 mužů, $68 \pm 9$ let). Všechny výkony byly provedeny za použití protektivních systémů. Technická úspěšnost byla $100 \%$. Stenóza před intervencí a po intervenci (podle NASCET) byla $81 \pm 8 \%$, resp. $3 \pm 7 \%$. Medián skiaskopického času byl 7 minut (3-30 min). Celkový počet významných nežádoucích cerebrovaskulárních příhod (smrt, iktus nebo infarkt myokardu) byl 6,5 \%. U všech pacientů, kromě jednoho $(0,7 \%)$, neurologické příznaky odezněly během 48 hodin. Během 30denního sledování se nevyskytl žádný infarkt myokardu. Jeden pacient zemřel náhlou smrtí $(0,7 \%)$.

\section{RUTINNÍ AMBULANTNÍ PCI V PODMÍNKACH ČR. REGISTR KARDIOCENTRA NEMOCNICE PODLESÍ-TR̆INEC}

\section{ČERNÝ J, BRANNY M, INDRÁK J, JANUŠKA J,} VODZINSKÁ A, NYKL I

Kardiologie, Kardiocentrum Podlesí a. s., Třinec

Cíl: Sledování rozdílu počtu komplikací u pacientů propuštěných domů v den transradiální PCI a pacientů zůstávajících „do druhého dne“.

Soubor: Kardiocentrum Podlesí, Třinec patří počtem provedených katetrizací $\mathrm{k}$ největším katetrizačním laboratořím v ČR. V roce 2006 z celkového počtu 4757 katetrizací (selektivní koronarografie, PCI, PTSMA, nekoronární intervence) připadá 1787 na PCI - u 752 (42,1\%) PCI byl použit transradiální př́stup. 498 pacientů bylo propuštěno v den transradiální PCI, 254 bylo hospitalizováno „do druhého dne“.

Metodika sledování: Sledované parametry: bolest + otok v místě vpichu, krvácení vyžadující transfuzi nebo chirurgickou revizi, bolest na hrudi, rehospitalizace $z$ jakéhokoliv důvodu v období 0-6 a 6-24 hodin po PCI u obou skupin. $\mathrm{U}$ pacientů propuštěných $\mathrm{v}$ den PCI byl použit telefonický follow-up, u pacientů zůstávajících do druhého dne lékařské vyšetření v intervalu 18-24 hodin po PCI.

Výsledky: V obou skupinách nebyly shledány rozdíly ve výskytu komplikací v intervalech 0-6 a 6-24 hodin po PCI. V období 0-6 hodin byl výskyt komplikací 1,97\%, v období 6-24 hodin nebyly zaznamenány žádné komplikace.

Závěr: Doporučujeme použití ambulantního přístupu k PCI pro velkou, avšak selektovanou část populace.

\section{FIBRILÁCIA PREDSIENÍ U PACIENTOV PO IMPLANTÁCII PREDSIEŇOVÉHO KARDIOSTIMULÁTORA}

\section{ČERVEŇ J, KOLLÁR J, MOKÁŇ M}

I. interná klinika,

Mestská fakultná nemocnica, Martin, Martin, SR

Úvod: V liečbe a prevencii rekurencie fibrilácie predsiení (FP) spojenej so symptomatickou dysfunkciou sínusového uzla je jednou $\mathrm{z}$ možností kombinovaného prístupu k tomuto ochoreniu fyziologická kardiostimulácia samotná alebo v kombinácii s farmakologickou liečbou. Prediktory recidívy FP a efekt stimulácie zostávajú nadalej predmetom diskusií.

Ciel: Analýza FP u pacientov po implantácii predsieňového kardiostimulátora (AAI KS) vo vztahu ku: 1. pohlaviu, 2. predimplantačnému výskytu $\mathrm{FP}, 3$. hodnote vlny $\mathrm{P}$ IEGM, 4. hodnote chronického prahu (CHP), 5. poruche AV prevodu.

Súbor a metodika: Prospektívna štúdia u 144 pacientov s AAI KS, M 69, medián veku - 70 rokov, medián follow-up 96 mesiacov. Predimplantačný výskyt paroxyzmálnej FP bol 14,6 \%. Testovaný AV prevod v čase implantácie bol primeraný.

Výsledky: 1. NS vztah medzi pohlavím a FP, 2. pozitívna korelácia medzi FP predimplantačne a recidívou FP postimplantačne $(p<0,001), 3$. negatívna korelácia medzi hodnotou vlny $\mathrm{P}$ a FP postimplantačne $(p<0,05)$, 
4. pozitívna korelácia medzi $\mathrm{CHP}$ a $\mathrm{FP}$ postimplantačne $(p<0,05)$, 5. NS vztah medzi poruchou AV prevodu a výskytom FP postimplantačne. Permanentná FP postimplantačne sa objavila u $7 \%$ pacientov. Porucha AV prevodu mala incidenciu 0,7\%.

Záver: Podla uvedených pozorovaní je najvýznamnejším prediktorom vývoja FP po implantácii predchádzajúci výskyt FP. Korelácia s velkostou vlny $\mathrm{P}$, resp. CHP, by mohla poukazovał na vplyv štrukturálnych zmien svaloviny predsiení popri postihnutí samotného sínusového uzla. Nesignifikantný vztah $\mathrm{k}$ poruche $\mathrm{AV}$ prevodu $\mathrm{v}$ súbore, na rozdiel od niektorých literárnych údajov, môže mat pôvod v rôznej etiológii konduktívnej poruchy. Fyziologická AAI KS (finančne menej náročná ako dvojdutinová KS) spolu s farmakologickou liečbou u symptomatickej dysfunkcie sínusového uzla s paroxyzmálnou FP je akceptovatelná pri starostlivom výbere pacientov.

\section{RESYNCHRONIZAČNÍ LÉČBA SRDEČNIIHO SELHÁNÍ: ENDOVAZÁLNÍ VS. EPIKARDIÁLNÍ STIMULACE LEVÉ KOMORY}

ČIHÁK R, BLÁHOVÁ M, RIEDELBAUCHOVÁ L, BYTEŠNÍK J, VANČURA V, PIRK J, KAUTZNER J

Klinika kardiologie, Klinika kardiochirurgie, IKEM, Praha

Úvod: Resynchronizace srdce je standardní součástí nefarmakologické léčby srdečního selhání. U části pacientů však nelze zavést funkční stimulaci levé komory (LK) přes větve koronárního sinu a je indikována stimulace epikardiální. Porovnali jsme oba způsoby stimulace LK.

Metodika: U souboru I (81 pacientů, 12 žen, průměrný věk $64 \pm 9$ let) byla během roku 2006 úspěšně zavedena kompletní resynchronizační léčba endovazálně. U souboru II (15 pacientů, 2 ženy, průměrný věk $69 \pm 9$ let) byla použita epikardiální stimulace LK z minitorakotomie po neúspěšné endokardiální implantaci či ze sternotomie při současném dalším kardiochirurgickém výkonu, implantace pak byla dokončena standardním způsobem.

Výsledky: Průměrná ejekční frakce (EF) LK se v obou souborech nelišila (EF LK $24 \pm 7$ vs. $24 \pm 5 \%$, NS), v souboru I byla výraznější dilatace levé komory (EDD LK $72 \pm 9$ vs. $66 \pm 6 \mathrm{~mm}, p<0,01)$. Stimulační práh byl při endokardiální stimulaci nižší než při epikardiální $(1,4 \pm 0,7$ vs. $2,4 \pm 1,1 \mathrm{~V} / 0,5 \mathrm{~ms}, p<0,01)$, odpor byl srovnatelný (903 \pm 590 vs. $691 \pm 375$ ohm, NS), stejně jako velikost vlny $\mathrm{R}(15 \pm 8$ vs. $16 \pm 10 \mathrm{mV}, \mathrm{NS})$. U souboru I bylo výraznější výchozí rozšíření komplexu QRS (216 \pm 34 vs. $175 \pm 32$ ms, $p<0,01)$, šíře QRS př́ biventrikulární stimulaci se výrazně nelišila (151 \pm 24 vs. $145 \pm 18 \mathrm{~ms}$, NS).

Závěry: Resynchronizací srdce s použitím endovazálnî i epikardiální stimulace LK lze dosáhnout snížení šíře QRS, které je však při endovazálním zavedení výraznější. Při endovazální stimulaci LK jsou také př́iznivější stimulační parametry. Porovnání dopadu obou způsobů implantace na symptomatologii a morbiditu nemocných vyžaduje další sledování.

\section{D MAPOVACÍ METODY PR̆I KATETRIZAC̆NÍ ABLACI PRO FIBRILACI SÍNÍ}

\section{ČIHÁK R, WICHTERLE D, MLČOCHOVÁ H, KAUTZNER J}

Klinika kardiologie, IKEM, Praha

Úvod: Při ablaci pro fibrilaci síní (FS) je důležitá navigace katetru v levé síni (LS). K tomu se používají non-fluoro- skopické 3D mapovací metody, nejčastěji pak CARTO a NavX. Porovnali jsme akutní výsledky získané s použitím obou metod.

Metodika: Do studie jsme zahrnuli 41 pacientů, kterým byla v období 7-12/2006 provedena ablace pro paroxyzmální či chronickou FS. V sudé dny týdne jsme používali CARTO (24 pacientů, 6 žen, věk $57 \pm 10$ let), v liché dny NavX (17 pacientů, 6 žen, věk $56 \pm 9$ let). U všech pacientů bylo před ablací provedeno CT vyšetření LS při výkonu intrakardiální echokardiografie. Ablaci jsme provedli katetrem s chlazeným hrotem. Cílem byla úplná antrální izolace všech PZ u paroxyzmální FS, doplněná o linie v LS a ablaci frakcionovaných potenciálů u chronické FS.

Výsledky: Doba výkonu byla při použití CARTO i NavX srovnatelná (257 \pm 55 vs. $249 \pm 47 \mathrm{~min}$, NS), stejně jako skiaskopický čas ( $27 \pm 8$ vs. $32 \pm 14$ min, NS). Počet aplikací i celková doba aplikace RF energie byla vyšší ve skupině NavX $(97 \pm 45$ vs. $81 \pm 27$ aplikací, resp. $2871 \pm 979$ vs. $2402 \pm 763$ vteřin, $p<0,05)$. Doba do získání podrobné geometrie LS se v obou skupinách nelišila. Hlavní výhodou současné verze systému NavX je zobrazení ablačního i všech mapovacích katetrů a možnost mapy frakcionovaných potenciálů. Přínosem systému CARTO je pak možnost integrace s CT-obrazem a přesnější zobrazení strukturálního postižení síně (voltážová mapa).

Závěry: Doba výkonu i skiaskopický čas s použitím CARTO a systému NavX jsou srovnatelné. Obě metody jsou př́nosné při provádění ablací pro fibrilaci síní.

\section{ČASNÁ INDIKACE K OBOUSTRANNÉ MECHANICKÉ SRDEČNÍ PODPOR̆E PO SRDEČNÍ OPERACI. KASUISTIKY}

DOBIÁŠ M, ROMANIV S, DEMEŠ R, LINDNER J, SEMRÁD M, STŘíTESKÝ M

Klinika anesteziologie, resuscitace a intenzivní medicíny, I. chirurgická klinika, II. chirurgická klinika kardiovaskulární chirurgie, VFN a 1. LF UK, Praha

Připravenost celého týmu lékařů kardiocentra na možné pooperační komplikace je jednou z podmínek komplexní péče o stále více nemocné pacienty indikované $\mathrm{k}$ chirurgickému řešení srdečních onemocnění. Na základě 3 kasuistik pacientů s rozdílnými indikacemi k operaci (ICHS s těžkou systolickou dysfunkcí LK, konstriktivní perikarditida, variantní angina pectoris refrakterní na terapii) chceme poukázat na možná pooperační rizika a možnost jejich řešení pomocí včasné indikace $\mathrm{k}$ biventrikulární srdeční podpoře, jako možného řešení v dané kritické situaci. Pacienty jsme po konzultaci s týmem lékařů kardiocentra IKEM přeložili při vyčerpání farmakologických i nefarmakologických terapeutických možností k implantaci biventrikulární srdeční podpory Thoratec, jako mostu $\mathrm{k}$ transplantaci. U všech pacientů byla následně provedena s časovým odstupem ortotopická transplantace srdce a všichni pacienti byli posléze propuštěni domů.

\section{NOVÁ STRATEGIE V PR̆ÍSTUPU \\ K ASYMPTOMATICKÝM STENÓZÁM KAROTID PR̆I SOUČASNÉ CHIRURGICKÉ REVASKULARIZACI MYOKARDU}

\section{DOBIÁŠ M, RUBEŠ D, MATIAS M, STŘÍTESKÝ M}

Klinika anesteziologie,

resuscitace a intenzivní medicíny, VFN a 1. LF UK, Praha

Úvod: Optimální strategie u pacientů se současnou ICHS indikovanou $\mathrm{k}$ chirurgické revaskularizaci myokardu (ACB) 


\section{(5NM) ST. JUDE MEDICAL}
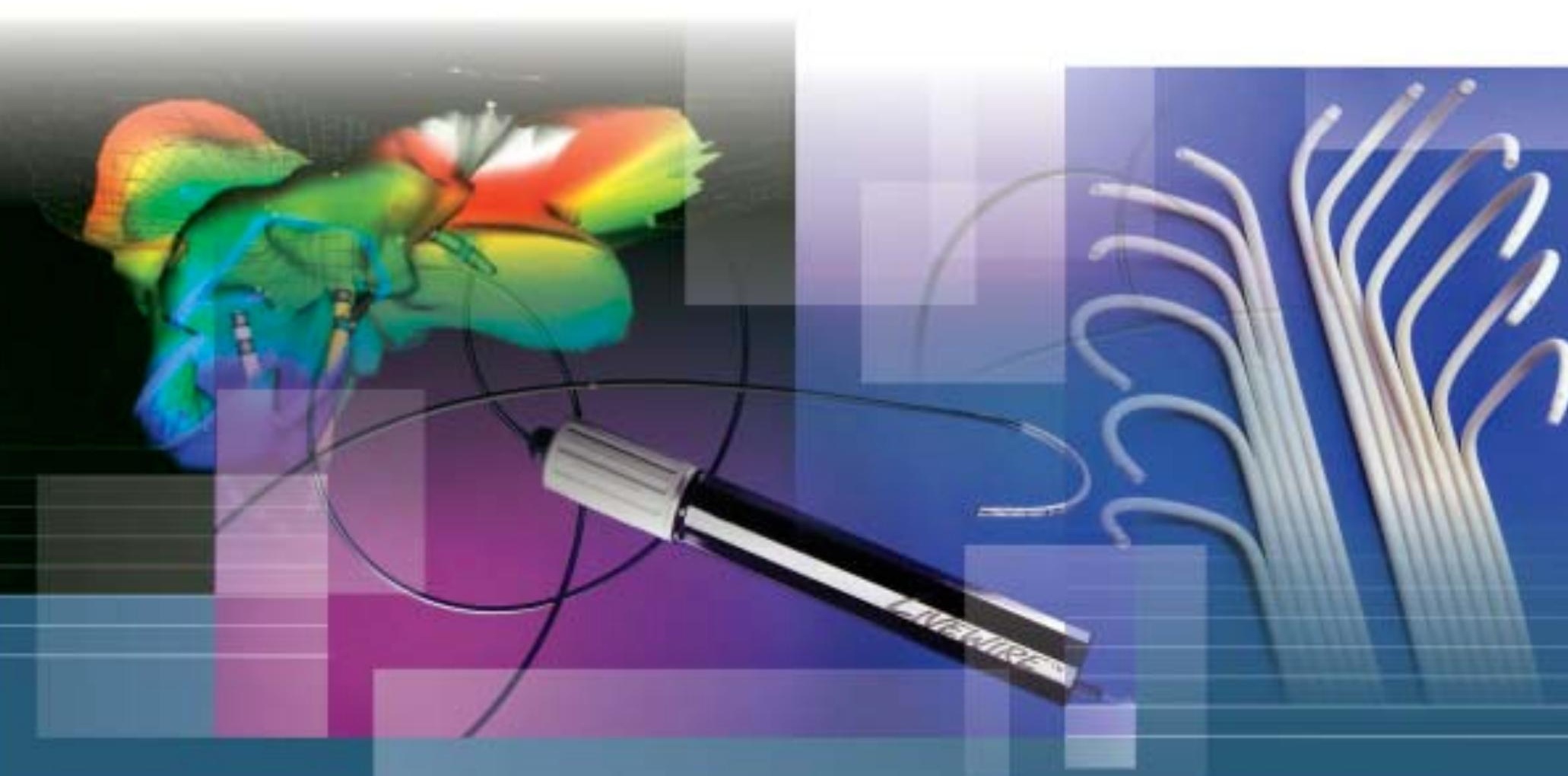

Elektrofyziologické katetry

- Response ${ }^{\mathrm{Tm}}$

- Supreme ${ }^{\mathrm{Tm}}$

- Livewire $^{\mathrm{Tm}}$

- Inquiry ${ }^{\mathrm{Tm}}$

- Therapy $^{\mathrm{Tm}}$

\section{Zavaděče}

\section{D navigační systémy} EnSite ${ }^{\circledR}$

- NavX'TM mapovací systém

- Array $^{\mathrm{Tm}}$ katetry

- Fast-Cath ${ }^{\mathrm{Tm}}$

- Swartz ${ }^{\mathrm{Tm}}$ 
a významným asymptomatickým aterosklerotickým postižením karotid zůstává nejednoznačná. Současná data ukazují na významnost předoperačního zhodnocení funkční vazoreaktivity pomocí TCD (transkraniální duplexní sonografie) a její vztah k pooperačním cerebrovaskulárním příhodám u pacientů indikovaných $\mathrm{k}$ ACB se současnou stenózou karotidy.

Metodika: Prospektivní pilotní studie. Pacienti s předoperační unilaterální či bilaterální stenózou vnitřní karotidy nad 70 \% byli vyšetřeni pomocí TCD k detekci funkční vazoreaktivity. Jako test byla zvolena přechodná hyperkapnie (test zástavy dechu na tolerované období - BHI). Endarterektomie karotidy nebyla provedena $\mathrm{v}$ prrítomnosti vazomotorické rezervy $(\mathrm{BHI}>0,69)$. Peroperačně byly monitorovány průtokové rychlosti a. cerebri media (ACM) pomocí TCD. U pacientů byla pooperačně sledována 30denní incidence neurologického postižení typu 1 (CMP, TIA).

Výsledky: 22 konsekutivních pacientů s jednostrannou (nebo oboustrannou) stenózou vnitřní karotidy nad $70 \%$ bylo předoperačně vyšetřeno; 3 pacienti měli sníženou vazomotorickou rezervu $(\mathrm{BHI}<0,69) \mathrm{v}$ teritoriu ACM a podstoupili endarterektomii karotidy před ACB. Dalších 19 pacientů mělo zachovalou vazoreaktivitu $(\mathrm{BHI}>0,69) \mathrm{v}$ teritoriu ACM a byla $u$ nich provedena revaskularizace myokardu bez endarterektomie karotidy za pečlivého monitorování TCD v hemodynamicky rizikových fázích operace. Během 30denního pooperačního sledování se ani u jednoho pacienta nevyskytlo neurologické postižení typu 1 .

Závěr: Tato pilotní studie ukazuje na možnou strategii při rozhodování u pacientů s ICHS a významnou asymptomatickou stenózou karotidy indikovaných k chirurgické revaskularizaci myokardu.

\section{POSTIŽENÍ PRAVÉ KOMORY U FABRYHO CHOROBY}

DOSTÁLOVÁ G, PALEČEK T, KUCHYNKA P, KARETOVÁ D, BULTAS J, LINHART A

II. interní klinika kardiologie a angiologie, VFN a 1. LF UK, Praha

Úvod: Fabryho choroba $(\mathrm{FCH})$ je na chromosom $\mathrm{X}$ vázané onemocnění, charakterizované střádáním substrátu, ceramidtrihexosidu, v mnoha orgánech a tkáních těla. Hlavní manifestací kardiálního postižení FCH je hypertrofie levé komory (LK), jejíž systolická funkce zůstává zachována. Postižení pravé komory (PK) u FCH nebylo dosud v dostupné literatuře popsáno.

Cíl studie: Pomocí echokardiografického vyšetření charakterizovat morfologické a funkční změny PK u nemocných s prokázanou $\mathrm{FCH}$.

Metody: Retrospektivně byla analyzována data 79 nemocných \pm 6 let, 31 mužů), u kterých bylo v rámci rutinního echokardiografického $\pm \mathrm{FCH}$ (41 vyšetření) provedeno hodnocení funkce a morfologie PK. Sledovanými parametry PK byly enddiastolický rozměr PK (PKEDD), tlouštka stěny PK (PKWT) a systolický pohyb trikuspidálního anulu (TAPSE), jako index systolické funkce PK.

Výsledky: Průměrné hodnoty sledovaných parametrů PK činily $3 \mathrm{~mm}$. Hypertrofie PK, definovaná $\pm 2,0 \mathrm{~mm}$ a TAPSE $24 \pm 5 \mathrm{~mm}$, RVWT 5,6 \pm RVEDD $23 \pm 5 \mathrm{~mm}$ byla přítomna u 28 jedinců (35\%). Systolická dysfunkce PK, definovaná $>$ RVWT jako TAPSE $<19 \mathrm{~mm}$, se vyskytla pouze u 1 nemocného. Významná korelace byla nalezena mezi PKWT a tlouštkou mezikomorové přepážky $(r=0,72)$ a tloušt'kou zadní stěny LK ( $\mathrm{r}=0,63)$. PKWT také významně korelovala s věkem pacientů $(r=0,52)$.

Závěr: Hypertrofie $\mathrm{PK}$ je $\mathrm{u}$ jedinců $\mathrm{s} \mathrm{FCH}$ poměrně častým nálezem. Její výskyt narůstá s věkem nemocných a stu- peň zesílení stěny PK odpovídá tíži hypertrofie LK. Velikost PK a její systolická funkce nejsou při $\mathrm{FCH}$ postiženy. Tyto nálezy ukazují, že postižení $\mathrm{PK}$ je u FCH podobné známým morfologickým i funkčním změnám LK.

\section{SESTERSKÁ SEKCE}

\section{PROGRAM REHABILITACE PACIENTŮ S ICHS}

DOUPALOVÁ P, BENUŠOVÁ I, SOVOVÁ E, KALETOVÁ M, BURIÁNKOVÁ I, VLADAŘOVÁ Š, BAJOREK J

\section{I. interní klinika, FN Olomouc a LF UP, Olomouc}

Cílem programu rehabilitace je trénink srdečního a oběhového systému a zvýšení fyzické zdatnosti pacienta po prodělaném infarktu myokardu.

Soubor a metodika: Program probíhá od ř́jna roku 2006. $\mathrm{V}$ rámci edukace sekundární prevence oslovujeme pacienty hospitalizované na naší klinice pro akutní srdeční př́ihodu a nabízíme jim možnost zařazení do rehabilitačního programu. Pacienti jsou rozděleni do dvou skupin podle bydliště. Vstupním vyšetřením je spiroergometrie k nastavení zátěže. Podle výsledku spiroergometrie se rozhodne forma rehabilitace - cvičení na rotopedu, chůze $\mathrm{s}$ krokoměrem nebo nordic walking. První skupina pacientů cvičí doma. Druhá skupina dochází na Kliniku tělovýchovného lékařství, kde cvičí na rotopedu pod dohledem fyzioterapeuta. Délka cvičebního cyklu je tříměsíční, poté následuje kontrolnî spiroergometrie. Zatím bylo aktivně osloveno 89 pacientů (70 M, 19 Ž), z nichž mělo zájem o rehabilitace 24 pacientů $(27 \%)-19$ M, $5 \check{Z}$.

Závěr: Zájem o aktivní posilování svého zdraví projevuje pouze minimum pacientů. Je třeba neustálým působením zvyšovat compliance pacientů $\mathrm{k}$ aktivní účasti na léčbě.

\section{SESTERSKÁ SEKCE}

\section{ZAVEDENÍ LEVÉHO RADIÁLNÍHO PR̆ÍSTUPU NA NAŠEM PRACOVIŠTI A JEHO VÝHODY PRO PACIENTA A OŠETR̆UJíCÍ PERSONÁL}

\section{DRTINOVÁ E, ONDRÁČKOVÁ M, VLKOVÁ M,} ZEMANOVÁ J, KLESLOVÁ L, KVAPILOVÁ V, BERNAT I

Oddělení intervenční kardiologie,

Karlovarská krajská nemocnice a. s., Karlovy Vary

Radiální přístup je alternativou femorálního přístupu ke katetrizačním a intervenčním výkonům na koronárních tepnách. Výhodou je časná mobilizace pacienta po výkonu a výrazně menší výskyt lokálních komplikací. Výkony $z$ levé radiální tepny jsou pak výhodné u praváků, nebot ještě více usnadňují spolupráci s pacientem po výkonu a u nemocných po CABG není komplikované vyšetřit levou mammární tepnu. Vytvořili jsme proto podložku ke katetrizačnímu stolu $\mathrm{s}$ opěrkou pro levý loket, aby bylo možné provádět výkony přes levou radiální tepnu $\mathrm{z}$ místa velmi blízkému běžnému femorálnímu přístupu. Příprava pacienta na sále trvá pouze o 3-5 minut déle než u femorálního přístupu. Hydratace pacienta a někdy i jeho sedace $\mathrm{v}$ př́padě úzkosti jsou důležitou součástí prevence spasmů. Po katetrizačním výkonu je vždy ještě na sále odstraněn $z$ ruky zavaděč a přiložen kompresivní nafukovací umělohmotný pásek (TR Band). Nekomplikovaný pacient může ihned po výkonu chodit po pokoji, kompresivní pásek je odstraňován zpravidla 3 hodiny po diagnostické katetrizaci a 5 hodin po intervenčních výkonech. Levý radiální přístup výrazně 
usnadňuje práci ošetřujícímu personálu po výkonu pro značnou soběstačnost pacienta, dále mj. není potřeba kontrolních náběrů krve na APTT po intervenčních výkonech. Za posledních 5 měsíců roku 2006 jsme provedli polovinu našich výkonů radiálním přístupem ( $\mathrm{z}$ toho 89 \% zleva), včetně intervencí u akutních infarktů s elevacemi ST. Jedinou vážnější komplikací ze 346 výkonů byla trombóza levé radiální tepny po použití delšího nehydrofilního zavaděče.

Závěr: Levá radiální tepna představuje pro většinu našich pacientů nejvhodnější př́ístup $\mathrm{k}$ věnčitým tepnám pro vysoký stupeň jejich soběstačnosti po katetrizačních a intervenčních výkonech a minimum lokálních komplikací. Pro ošetřující personál je následná péče o tyto pacienty výrazně snazší než péče po výkonech $z$ femorálního přístupu.

\section{HODINOVÉ AMBULANTNÍ MONITOROVÁNÍ KREVNÍHO TLAKU V NEMOCNICI NOVÉ MĚSTO NA MORAVĔ (V ROCE 2006) - LÉČÍME NA ÚROVNI?}

DVOŘÁČEK J

Interni oddělení, Okresní nemocnice

Nové Město na Moravě, Nové Město na Moravě

Cíl: Hypertenze je nejčastějším kardiovaskulárním onemocněním. K diagnostice, léčbě a prognóze hypertenze slouží také 24hodinové ambulantní monitorování krevního tlaku. Cílem práce bylo shrnout indikace k 24hodinovému ambulantnímu monitorování krevního tlaku, prováděném v nemocnici Nové Město na Moravě, ověřit si kontrolu hypertenze našich pacientů a srovnat si některé jejich charakteristiky s hypertoniky léčenými $\mathrm{v}$ obecné populaci a na specializovaném pracovišti. Závěrem demonstruji křivky charakteristické pro některé patologické nálezy (hypotenzi, dekompenzovanou či neléčenou hypertenzi, kolísání krevního tlaku, nedostatečný 24hod. účinek antihypertenzní léčby).

Soubor a metodika: Retrospektivně jsem analyzoval všechna provedená měření v nemocnici Nové Město na Moravě v roce 2006 - celkem 378 . Rozdělil je na skupiny podle indikace (vyšetření pro suspektní hypertenzi, kontrola již známé hypertenze, vyšetření pro presynkopální a synkopální stavy a ostatní). $Z$ celkového počtu pacientů monitorovaných pro kontrolu již známé (a medikamentózně léčené) hypertenze jsem vypočítal podíl kompenzovaných pacientů a zároveň provedl rozdělení na podskupiny podle počtu užívaných antihypertenziv. Procentuální zastoupení jsem porovnal s uváděnými procenty $u$ hypertoniků léčených v obecné populaci a na specializovaném pracovišti (IKEM).

Výsledky: Naši pacienti monitorovaní pro kontrolu již známé (a medikamentózně léčené) hypertenze byli kompenzováni v 69 \% (v obecné populaci 38,1 \%, IKEM 75,1\%). Léčba monoterapií - 29,3 \% (47,3\%, resp. 19,2\%), kombinací 2 léků - 29,7 \% (35,0 \%, resp. 33,3\%), kombinací $\geq 3$ léků - 41,0 \% (17,7 \%, resp. 47,5\%).

Závěr: $Z$ výsledků je možno usuzovat na dobrou kontrolu hypertenze našich pacientů. Na těchto hodnotách má určitě podíl spektrum odesílajících ošetřujících lékařů (kardiolog zhruba ve 50-55 \% - internista ve 30-35 \% - praktický lékař v $15 \%$ ).

\section{SRDEČNÍ SELHÁNÍ A MORTALITA V ZÁVISLOSTI NA BODY MASS INDEXU}

DVOŘÁKOVÁ E, ADÁMKOVÁ R, MIKLÍK R, TOMÁŠEK A, ŠEBO M, ŠPINAR J

Interní-kardiologická klinika, FN Brno-Bohunice, Brno
Cîl: Stanovit roční mortalitu u pacientů hospitalizovaných na naší klinice s dg. chronického srdečního selhání (CHSS), zjistit, zda je tato roční mortalita významně ovlivněna jejich body mass indexem (BMI).

Soubor: Pacienti hospitalizovaní na Interní kardiologické klinice FN Brno v období 1. 10. 2004-31. 12. 2005, kteří měl jako hlavní či jako vedlejší dg CHSS, a kteří měli současně zadán BMI. Jejich mortalita byla ověřena ke dni 31. 12. 2006.

Výsledky: Celkový počet pacientů odpovídajících uvedeným kritériím byl 539 (354 mužů, 185 žen). Průměrný věk byl 68 let, průměrný BMI byl 28,39 (u žen 28,51, u mužů 28,30), max. BMI byl 47,33 a min.15,43. Podvýživu mělo 8 pacientů normální BMI byl u 139 pacientů, ostatní pacienti trpěli nadváhou či obezitou. Jako etiologie CHSS byla uvedena ICHS u 384 pacientů, dilatační KMP u 80 pacientů, HT (bez ICHS) u 38 pacientů a chlopenní vada u 21 pacientů. Celková ročn mortalita činila 18,36 \%, k 31. 12. 2006 pak zemřelo 36 žen $(19,46 \%)$ a 63 mužů $(17,8 \%), p=0,63$. Roční mortalita $\mathrm{u}$ pacientů s podvýživou byla $75 \%$ (zemřelo 6 pacientů $\mathrm{z} 8$, $p<0,001$, pacienti s normální váhou zemřeli v 26,6 \% př́ipadů, $p=0,03$, pacienti s nadváhou v $17,8 \%, p=0,68$, s obezitou I. stupně v $22,96 \%, p=0,23$ ), s obezitou II. stupně v $5,4 \%$, $p=0,04$ a u III. stupně obezity byla mortalita $12,3 \%, p=0,55$. Muži, trpící podvýživou měli 60\% mortalitu, $p=0,015$, ženy trpící podvýživou pak 100\% mortalitu, $p<0,001$.

Závěr: Roční mortalita $u$ pacientů s CHSS dosahovala 18,36 \%. Téměř tř́i čtvrtiny z našich pacientů trpělo některou $z$ forem nadváhy či obezity, což ovšem nebylo spojeno se signifikantní vyšší úmrtností ve srovnání s pacienty, jež nadváhou netrpěli. Naopak pacienti, kteři měli BMI pod 18,5 umírali signifikantně více, tento trend byl vyjádřen pouze u pacientů ženského pohlaví. U mužů nebyla prokázána souvislost mezi úmrtnosti a jejich BMI.

\section{SESTERSKÁ SEKCE}

\section{INVAZIVNÍ LÉČBA SRDEČNÍHO SELHÁNİ INTRAAORTÁLNII BALONKOVOU KONTRAPULSACI}

\section{DVOŘÁKOVÁ L}

Kardiocentrum - katetrizační laborator̆,

Krajská nemocnice Liberec, Liberec

Intraaortální balonková kontrapulsace (IABK) se v dnešní době řadí mezi standardní invazivní metody dočasné mechanické podpory selhávajícího krevního oběhu. Má své nezastupitelné místo $\mathrm{v}$ intervenční léčbě akutního srdečního selhání, infarktu myokardu a kardiogenního šoku.

Tato metoda se užívá nejen na kardiochirurgických pracovištích, ale i na jednotkách intenzivní a resuscitační péče, koronárních jednotkách a v katetrizačních laboratořích. Jejím principem je synchronizované nafukování a vyfukování balonku v sestupné aortě během srdeční akce. Augmentace diastolického tlaku v aortě má za následek zvýšení koronárního průtoku a zlepšení kontraktility myokardu, desuflace balonku na začátku systoly přispívá k zlepšení srdeční práce. Konečným výsledkem IABK je zvýšení minutového výdeje srdečního. Od ledna roku 2004 do konce roku 2006 byla použita IABK u 67 pacientů.

\section{PR̆ÍNOS PULSNÍ TKÁŇOVÉ DOPPLEROVSKÉ ECHOKARDIOGRAFIE V DIAGNOSTICE POZDNÍHO POŠKOZENÍ FUNKCE MYOKARDU PO ONKOLOGICKÉ LÉČBĔ V DĚTSTVÍ*}

\author{
ELBL L, POZDÍŠEK Z, HRSTKOVÁ H, KALA P, ŠPINAR J
}

Interní-kardiologická klinika, 1. dětská klinika, FN Brno, Brno 
$(\mathrm{SD} \pm 19) \mathrm{ml} / \mathrm{s}$ na $329(\mathrm{SD} \pm 32) \mathrm{ml} / \mathrm{s}(34 \%, p<0,0001)$.

Cil práce: Cílem práce bylo stanovit přínos pulsní tkáňové dopplerovské echokardiografie (PW-TDI) v detekci pozdního poškození funkce myokardu u nemocných léčených v dětství pro malignitu.

Soubor nemocných: Vyšetřili jsme 72 nemocných (34 chlapců a 36 dívek) ve věku $15 \pm 3$ roků. Kontrolní soubor tvořilo 70 dobrovolníků (33 chlapců a 37 dívek) ve věku $15 \pm 2$ roků.

Metody vyšetření: Echokardiograficky byla stanovena EF LK. Pomocí PW-TDI jsme stanovili maximální systolickou rychlost (Smax) pohybu laterální a septální části mitrálního prstence a vypočetli průměrnou hodnotu (Smean).

Výsledky: Soubory se nelišily v hodnotě EF (pacienti $64 \pm 3 \%$, kontroly $64 \pm 3 \%$ ). Hodnoty Smax byly v obou skupinách v septální oblasti nižší ve srovnání s laterální $(p<0,0001)$. Obě hodnoty Smax i hodnota Smean byly u nemocných sníženy ( $p<0,0001$ ), ve srovnání s kontrolami 50 nemocných (69\%) bylo léčeno antracykliny, 22 nemocných (31\%) obdrželo chemoterapii bez antracyklinů. Obě podskupiny se nelišily v EF ani v hodnotách Smax a Smean, které byly shodně sníženy ve srovnání s kontrolami $(p<0,001)$. Nenalezli jsme vztah mezi věkem, BSA, BMI, pohlavím a rychlostí pohybu mitrálního prstence. V kontrolním souboru parametr $\mathrm{S}$ koreloval s $\mathrm{EF}$ a tepovou frekvencí. Tento vztah jsme nenalezli v souboru nemocných. Nebyla nalezena korelace ke kumulativní dávce antracyklinů a k době sledování od chemoterapie.

Závěry: 1. Uvedené nálezy podporují přínos stanovení longitudinální funkce LK pomocí PW-TDI v detekci pozdního poškození myokardu po chemoterapii v dětství. 2. I přes normální hodnoty EF LK je longitudinální funkce významně snížena ve srovnání s kontrolním souborem. 3. Výsledky překvapivě ukazují, že léčba antracykliny pravděpodobně nemusí být zásadním faktorem ovlivňujícím pozdní toxicitu chemoterapie.

\section{VÝZNAM GRADIENTU A PLOCHY CHLOPENNÍHO ÚSTI PRO STANOVENÍ ZÁVAŽNOSTI AORTÁLNİ STENÓZY}

ENDRYS J, ŠŤÁSEK J, BIS J

\section{I. interní klinika, FN Hradec Králové, Hradec Králové}

Cíl: Nejčastěji užívaný parametr pro hodnocení významnosti aortální stenózy (AS) je tlakový gradient (GR), protože je snadno měřitelný. Jeho kvadratická závislost na průtoku ústím (PÚ) je však méně často známa, a proto se podceňuje. PÚ je nestálý a mění se mimo jiné prací, rozčilením, srdečním selháním a léky. Pokusili jsme se proto srovnat stabilitu hodnot GR a plochy aortálního ústí (PAÚ) při změnách hemodynamiky.

Soubory a metodika: Vyšetřili jsme 17 nemocných s valvulární stenózou aorty (AS). Průměrný věk byl 56 let (5-82). Během diagnostické katetrizace byl aortální GR měřen dvěma katetry simultánně v dutině před zúženou chlopní a za zúženou chlopní. Minutový objem (CO) byl měřen barvičkovou dilucí nebo termodilucí bud' současně nebo bezprostředně po měření GR. PAÚ byla vypočítána podle Gorlinova vzorce $\mathrm{v}$ indexované formě. Hodnoty jsme měřili v klidu a po ovlivnění dobutaminem (5-15 $\mu \mathrm{g} / \mathrm{kg} / \mathrm{min})$ nebo izoprenalinem $(0,7 \mu \mathrm{g} / \mathrm{kg} / \mathrm{min}) .15$ nemocných bylo se stopovou nebo žádnou aortální regurgitací. Dva měli regurgitaci 1/4 stupně. Párový $t$-test jsme použili pro statistické hodnocení.

Výsledky: U všech nemocných s AS stoupnul střední GR z 33 (SD $\pm 4,6)$ na $57 \mathrm{~mm} \mathrm{Hg}(\mathrm{SD} \pm 8,1)(73 \%, p<0,0001)$. CO se zvýšil z 5,13 (SD $\pm 0,39)$ na 6,93 1/min (SD $\pm 0,58)(35 \%$, $p<0,0001$ ). Systolický aortální průtok (SAP) se zvětšil z 244

Naproti tomu se PAÚ významně nezměnila: $z$ výchozí hodnoty $0,53(\mathrm{SD} \pm 0,07)$ na $0,52(\mathrm{SD} \pm 0,08) \mathrm{cm}^{2} / \mathrm{m}^{2}(p=0,6)$.

Závěr: Vypočítaná PAÚ se ukázala jako stabilní údaj, který byl prakticky nezávislý na hemodynamických změnách, zatímco GR se velmi významně (kvadraticky) měnil v závislosti na aortálním průtoku. Spoléhání na GR v hodnotách $50 \mathrm{~mm} \mathrm{Hg} \mathrm{a} \mathrm{nižších} \mathrm{je} \mathrm{podle} \mathrm{našich} \mathrm{zkušeností}$ nejčastějším zdrojem velmi závažných chyb v indikaci chirurgického řešení SA.

\section{RECIDIVUJÍCí SUBMASIVNí PLICNí EMBOLIZACE JAKO PARANEOPLASTICKÝ PROJEV OKULTNIIHO KARCINOMU ŽALUDKU}

FEDORCO M, BULAVA A, RICHTER D, HEINC P, LUKL J, ŠKARDA J

I. interní klinika, Ústav patologie,

FN Olomouc a LF UP, Olomouc

Referujeme případ 35letého pacienta přijatého na JIP interní kliniky pro 14denní anamnézu recidivujících synkop předcházených atakami námahové dušnosti. Před přijetím bylo provedeno CT angio plic (single slice CT), neprokazující př́ipadnou masivní plicní embolii (PE). Transtorakální echokardiografické vyšetření (TTE) prokázalo obraz akutního cor pulmonale (enddiastolický rozměr PK $40 \mathrm{~mm}$ (PLAX), vrcholový gradient trikuspidální regurgitace $80 \mathrm{~mm} \mathrm{Hg}(\mathrm{A} 4 \mathrm{CH}), 12$ svodové $\mathrm{EKG}$ sinusovou tachykardii se zátěží pravé komory a obrazem SI QIII TIII, laboratorně byly pozitivní D-dimery (1 $915 \ldots$ 9218 ng/ml [0 ... 400]). Pro oběhovou nestabilitu, přes negativní nález na CT angio plic (mono slice CT) a výše uvedené nálezy, byla podaná systémová trombolýza. 8 hodin od podání pacient po protrahované resuscitaci umírá pod obrazem kardiogenního (zvýšení afterloadu PK) a hypovolemického šoku při komplikujícím krvácení z horní části trávicího traktu.

Sekčně byla potvrzená mnohočetná nádorová embolizace do periferních větví obou plicních arterií, dilatované pravostranné srdeční oddíly. Překvapivě jako zdroj krvácení byla nalezena erodovaná arterie $\mathrm{v}$ difuzně zhrubělé a změněné stěně žaludku. Histologicky byl stanoven generalizovaný difuzní exulcerovaný adenokarcinom žaludku z prstenčitých buněk s mnohočetnými metastázami v regionálních lymfatických uzlinách a ve slezině.

Souhrn: Recidivující submasivní PE může být prvním projevem maligního onemocnění. CT angiografie plicnice zůstavá zlatým standardem v diagnostice PE. Ale negativní výsledek tohoto vyšetření, zvláště na single slice přístroji, nesmí vést $\mathrm{u}$ pacienta s typickou anamnézou a charakteristickými nálezy pomocných vyšetření $\mathrm{k}$ mylnému vyloučení diagnózy PE.

\section{ECHOKARDIOGRAFICKÉ MONITOROVÁNÍ LÉČBY INFEKČNÍ ENDOKARDITIDY}

\section{FEUEREISL $\mathrm{R}$}

\section{Oddělení neinvazivní kardiologie,}

Kardiologie na Bulovce, Praha

Monitorování léčby infekční endokarditidy (IE) začíná včasnou diagnostikou nemoci. Ta se opírá o klinický a mikrobiologický nález a především o nález echokardiografický (echkg), který je považován za zlatý standard. Ačkoliv nález útvarů na chlopních nemusí vždy nutně znamenat IE, jde nepochybně o nejcennější metodu při rozpoznání IE a jejích komplikací. Echkg. vyšetření (TTE a především TEE) má být provedeno co nejdřive, při prvním podezření na IE. Je nutné, aby 
vstupní vyšetření bylo pečlivě dokumentováno, nebot slouží jako referenční. Za optimální je považován digitální záznam vybraných neupravených dat na standardních nosičích (CD, DVD) a kontinuální videozáznam celého vyšetření. Echkg by měla být provedena tam, kde bude pacient léčen a obrazová dokumentace by ho měla provázet po celou dobu léčení. Echkg vyšetření informuje ošetřujícího lékaře o funkčním stavu chlopní, závěsného aparátu, vývoji vegetací a o hemodynamických parametrech srdeční činnosti. Při nepříznivém vývoji onemocnění umožňuje detekovat tvorbu abscesů, destrukci vaziva a stěny srdeční s vývojem píštěle nebo pseudoaneuryzmatu nebo vznikající dehiscenci chlopenní protézy. Mezi časné komplikace IE řadíme především septickou embolizaci, jejíž pravděpodobnost lze echkg částečně odhadnout. Mezi pozdější komplikace řadíme subvalvulární šíření infekce s tvorbou abscesu, který je jednoznačnou indikací ke konzultaci kardiochirurgického pracoviště. Důležitou úlohou echkg je předejít rozvoji rozsáhlé destrukci vazivové tkáně a stěny srdeční, které jsou kardiochirurgicky obtížně a omezeně řšsitelné a včas odhalit malou účinnost antibiotické léčby a předejít rozvoji syndromu multiorgánového selhání, který se pravidelně objevuje v terminálních stadiích IE.

Vyléčený pacient zůstává nadále rizikový, recidivy IE jsou časté. Každý pacient po překonané IE musí být dispenzarizován a echkg kontrolován.

\section{PŘIČCINY RECIDIV ARYTMIE PO ABLACI PŨVODNĔ PAROXYZMÁLNÍ FIBRILACE SÍNÍ - POSUN OD EKTOPICKÉ AKTIVITY KE KOMPLEXNÍMU LEVOSINNOVÉMU ARYTMOGENNÍMU SUBSTRÁTU}

FIALA M, CHOVANČÍK J, WOJNAROVÁ D,

NEVŘALOVÁ R, MORAVEC R, SZYMECZEK H, NEUWIRTH R, JIRAVSKÝ O, NYKL I, BRANNY M

Kardiologické oddělení, Nemocnice Podlesí a. s., Třinec

Cíl: Prezentace klinických a elektrofyziologických nálezů a výsledků opakované ablace po ablaci primárně paroxyzmální fibrilace síní (PFS).

Metodika: Ze 342 pacientů (pac) s první ablací pro PFS mělo opakovanou ablaci $72(21 \%)$ pac $(16 \check{Z}, 53 \pm 11$ let $)$ v 90 výkonech. Druhé výkony se provedly po $13 \pm 11$ měsících, 3. výkony po $12 \pm 6$ měsících od druhého výkonu a 4. výkon po dalších 4 měsících. První výkon byl koncentrován na izolaci plicních žil (PŽ), strategie opakovaných výkonů se individualizovala od prosté reizolace PZ̆ po komplexní ablaci v levé síni (LS). Elektrická aktivita v PŽ se vždy snímala Laso katetrem.

Výsledky: Před 1. reablací byla přítomna PFS u 51 (71 \%), paroxyzmální LS tachykardie (LST) u 4 (6\%), perzistentní FS u $9(12 \%)$ a perzistentní LST u $8(11 \%)$ pac. Před 2. reablací byla PFS u 5 (29\%), paroxyzmální LST u 7 (41\%), perzistentní FS u 3 (18\%) a perzistentní LST u 2 (12\%) pac; před 3. reablací byla perzistentní LST. Při první reablaci byla přítomna elektrická aktivita v PŽ (PŽ Ary) u 48 (67\%), příčina $\mathrm{v}$ arytmogenním substrátu síní (Substr Ary) byla podezřívána u 21 (29\%) a obě příčiny (PŽ-Substr Ary) u 3 (4\%) pac. Při druhé reablaci byla zjevná PŽ Ary u 2 (12\%), Substr Ary u 9 (53\%) a PŽ-Substr Ary u 6 (35\%) pac. LST řešená 3. reablací byla závislá na substrátu. Po dobu sledování $20 \pm 12$ měs od poslední ablace je bez arytmie 60 (83 \%) pac, bez antiarytmik (AA) 49 (68\%) a s AA 11 (15\%) pac. Po 3, resp. 4 ablacích je bez arytmie 15/17 (88\%) pac.

Závěr: S počtem reablací narůstá zastoupení organizovaných arytmií, jejichž příčina spočívá $\mathrm{v}$ arytmogenním substrátu síní mimo PŽ. Může to být důsledkem odkrývání přirozených prríčin nebo předchozích ablačních zásahů nebo obojího. Přes složitost patofyziologie recidivující FS je indivi- dualizovaná ablační strategie klinicky účinná a zvyšuje globální účinnost metody nad 90 \%.

\section{RECIDIVUJÍCÍ ARYTMIE PO ABLACI CHRONICKÉ FIBRILACE SÍNÍ - ORGANIZOVANÉ ARYTMIE Z PR̆EDNÍ STĚNY LEVÉ SÍNĚ ODSTRANITELNÉ OPAKOVANOU KATETROVOU ABLACÍ}

FIALA M, CHOVANČÍK J, NEVŘALOVÁ R, WOJNAROVÁ D, MORAVEC R, SZYMECZEK H, NEUWIRTH R, JIRAVSKÝ O, NYKL I, BRANNY M

Kardiologické oddělení,

Nemocnice Podlesí a. s., Třinec

Cíl práce: Prezentace recidivujících arytmií po ablaci chronické fibrilace síní (CHFS) a výsledků opakované ablace.

Metodika: První ablace sestávala z obkružujících a komplexních lineárních lézí v levé síni (LS) a ablace v koronárním sinu (CS). Z 96 pacientů (pac) s CHFS podstoupilo druhou ablaci $30(31 \%)$ pac (9 $\check{Z}$, věk $52 \pm 10$ let): $2 \times$ pro paroxyzmální $\mathrm{FS}, 13 \times$ pro perzistentní $\mathrm{FS}, 1 \times$ pro paroxyzmální LS tachykardii (LST), 12× pro perzistentní LST, lx pro perzistentní flutter síní I a $1 \times$ pro paroxyzmální reentry tachykardii $z$ pravé síně (1). Třetí ablace se provedla u 6 pac; $1 \times$ pro paroxyzmální $\mathrm{FS}, 1 \times$ pro paroxyzmální LST, $3 \times$ pro perzistentní LST a $1 \times$ pro perzistentní pravosíňovou reentry tachykardii.

Výsledky: Paroxyzmální FS/LST (3 - první reablace, 2 druhá reablace) byly ukončeny bez další vyvolatelnosti. FS (3) se ukončila při lineární lézi mezi pravou dolní plicní žilou (PŽ) a posteroseptálním mitrálním prstencem, 2 LST při ablaci u septálního okraje ústí ouška LS (LSO). Všechny perzistentní LST (12 - první reablace, 3 - druhá reablace) se ukončily při ablaci na septálním okraji ústí LSO (2), horním okraji ústí LSO (3), Bachmannova svazku (BB) (3), ve stropě LS (1), v antru levých PŽ (2) a v CS (4). Z 13 perzistentních FS se sinusový rytmus (SR) obnovil přímo $z$ FS u 1 pac (antrum levých PŽ) a přes tranzitorní LST u 5 pac. Místa obnovení SR přes LST byla BB (3), septální okraj LST (1) a strop LS (1). Během sledování $14 \pm 11$ měsíců od poslední ablace má 24 (80\%) pac stabilní SR, 5 (17\%) pac má perzistentní FS a 1 (3\%) pac má perzistentní LST.

Závěr: Po komplexní ablaci v LS a CS pro CHFS: 1 . je vysoké zastoupení recidivujících monomorfních LST; 2 . tyto arytmie lze ukončit a stabilní SR obnovit $\mathrm{s}$ vysokou účinností; 3. recidivující arytmie, FS nebo LST, mají převážně makroreentry mechanismus využívající přední stěnu LS mimo oblast PŽ.

\section{POROVNÁNÍ VYBRANÝCH SKUPIN NEMOCNÝCH S PODEZR̆ENÍM NA KLINICKY VÝZNAMNOU PORUCHU INTEGRITY SINNOVEEHO SEPTA A JEJICH STR̆EDNĚDOBÉ VYYSLEDKY PO KATETRIZAČNIIM UZÁVĔRU}

FIEDLER J, BLAŠKO P, LINHARTOVÁ K, HONĚK T, VESELKA J

Kardiologické oddělení Kardiovaskulárního centra, FN Motol, Praha

Úvod: Porucha integrity síňového septa - foramen ovale patens (PFO) či defekt síňového septa (DSS) - může vést $\mathrm{k}$ paradoxní embolizaci u části nemocných s kryptogenním ischemickým iktem (iCMP). Podobně postižení v rámci dekompresní příhody (DCS) II. typu při hloubkovém potápění je podmíněno preexistujícím pravo-levým zkratem. 
Cil: Porovnat vybrané ukazatele u jedinců po uvedených příhodách, u nichž se předpokládá PFO či DSS II. typu.

Metodika: Soubor D tvořilo 10 potápěčů po dokumentované DCS II. typu. Soubor C 107 nemocných po nehemoragické iCMP (včetně TIA) neurčeného zdroje. Kontrolnî skupinu K 14 potápěčů bez DCS II. typu. Pacienti nad 66 let, s fibrilací síní, chlopenní vadou nebyli zařazeni. Po transtorakálním (TTE) vyšetření následovalo TEE s bolusem do žíly a provedení Valsalvova manévru. Dále jsme zaznamenali četnost aneuryzmatu síňového septa (ASAE). Př̀ pozitivním nálezu $\mathrm{PFO}$ či DSS II. typu $\mathrm{v}$ souboru $\mathrm{D}$ a $\mathrm{C}$ byl nabídnut katetrizační uzávěr. U nich se po výkonu za 1 a 6 měsíců zaznamenala četnost neplánovaných TEE, krvácení, recidivy DCS, resp. iCMP, stejně jako jinou změnu na TTE.

Výsledky: V souboru C byl negativní TEE nález u 63 nemocných (58,8 \%) a jeden měl ASAE. U 3 jsme nalezli DSS II. typu bez ASAE (2,8 \%). 41 pacientů (38,3 \%) mělo PFO, $z$ nich pět $\mathrm{s}$ ASAE. $\mathrm{V}$ souboru $\mathrm{D}$ byl záchyt $\mathrm{PFO}$ u 9 potápěčủ (90\%), jeden $z$ nich i s ASAE. Ve skupině K byl pozitivní nález PFO u 4 (28,5 \%) bez ASAE. DSS se zde nevyskytlo. Katetrizační uzávěr byl proveden u 20 nemocných v souboru C, u 9 pozitivních v souboru D a u jednoho ze skupiny K. Během sledování nedošlo k žádným sledovaným komplikacím.

Závěr: Mezi osobami s podezřením na PFO/DSS je při TEE častěji pozitivní záchyt u jedinců po DCS při potápění než po kryptogenní iCMP. Výskyt obou těchto patologií byl vyšší než se udává $\mathrm{v}$ populaci. Katetrizační uzávěr se hlediska střednědobého sledování jeví jako výkon bezpečný a efektivní.

\section{ELEARNINGOVÉ VZDĚLÁVACÍ SYSTÉMY PRO KARDIOLOGY NA INTERNETU VE SVĚTĚ A V ČESKÉ REPUBLICE}

\section{FINSTERLE V}

\section{Elearning, Pears Health Cyber, s. r. o., Praha}

Cílem přednášky je seznámit lékaře s alternativním způsobem vzdělávání, které jim v současné době nabízí celosvětová počítačová sít internet a představit možnosti, které internet poskytuje lékaři pro jeho každodenní praxi.

Elearning je moderní efektivní formou vzdělávání, která má své výhody i nevýhody oproti vzdělání klasickému prezenčnímu. Vyžaduje určité základní technické vybavení a minimální míru počítačové gramotnosti, které jsou předpokladem pro to, aby se lékař mohl začít vzdělávat prostřednictvím internetu.

V zahraničí již několik let funguje celá řada medicínsky zaměřených webových stránek, které jsou již poměrně dlouhou dobu využívány jako standardní forma kontinuálního vzdělávání lékařů. K těm nejznámějším určitě patří Medscape (www.medscape.com)

I když není nabídka elearningových systémů v České republice tak rozsáhlá jako na západ od našich hranic, nalezneme již i u nás portál, který tento typ vzdělávání nabízí - EUNI (www.euni.cz). EUNI není omezena pouze na jeden obor, ale nabízí vzdělávací témata $z$ různých specializací, která pro tento portál připravují přední odborníci na danou problematiku. EUNI je založena na systému dynamicky aktualizovaných lekcí doplněných řadou interaktivních prvků a kasuistických rozborů. Samozřejmě zde nechybí ani test pro ověření získaných znalostí.

Kromě vzdělávacích systémů jsou již i u nás dostupné další nástroje, které mohou lékaři pomoci v každodenní praxi. Takovým nástrojem může být například virtuální ordinace, která umožňuje nejen vzájemnou komunikaci lékaře $s$ pacientem bez nutnosti fyzického kontaktu, ale i on-line objednání pacienta $\mathrm{k}$ lékaři.

Celá přenáška bude doprovázena praktickými ukázkami.

\section{SESTERSKÁ SEKCE}

\section{ÚLOHA SESTRY VE SPECIALIZOVANÉ AMBULANCI PRO PACIENTY S ONEMOCNĚNÍM KAROTID}

\author{
FIRÝTOVÁ L, VODIČKOVÁ T, MALÁ K, \\ DULAVOVÁ D
}

\section{Interní klinika, ÚVN a 1. LF UK, Praha}

Úvod: Cévní mozkové příhody jsou tř̌etí nejčastější přičinou úmrtí u nás i ve vyspělém světě. Důležitou součástí jejich prevence je karotická endarterektomie nebo perkutánní intervence významných stenóz v karotickém řečišti. Následná péče o nemocné, kteří tyto intervence podstoupili je však rozptýlena mezi zdravotnické pracovníky rưzných odborností a sekundárně preventivní opatření u nich často není optimální. Proto jsme společně s lékaři neurochirurgické kliniky péči o tyto nemocné centralizovali do jediné ambulance.

Cíl sdèlení: Shrnout zásady sekundární prevence u nemocných po intervencích $\mathrm{v}$ karotickém řečišti. Na souboru našich pacientů ukázat na nedostatečnost léčby rizikových faktorů aterosklerózy. Klademe důraz na nezastupitelnou roli sestry v komplexní edukaci nemocného i roli sestry jako pevného pilîre organizační struktury ambulance.

\section{SROVNÁNÍ INTERVALOVÉHO TRÉNINKU S POSILOVÁNÍM S INTERVALOVÝM TRÉNINKEM BEZ POSILOVÁNÍ: VÝVOJ PARAMETRÜ TRANSPORTNIIHO SYSTÉMU A HEMODYNAMIKY*}

FRANTISOVÁ M, CHLUDILOVÁ V,

MÍFKOVÁ L, VYMAZALOVÁ L, ALFADHLI A, VÁRNAY F, SIEGELOVÁ J

Klinika funkční diagnostiky a rehabilitace, FN u sv. Anny, Brno

*Podporováno grantem MSM 0021622402.

Cíl studie: Posoudit vliv dvanáctitýdenního řízeného ambulantního rehabilitačního programu s intervalovým tréninkem s posilováním a bez posilování na funkční zdatnost, výkonnost a hemodynamiku u pacientů mužů se systolickou dysfunkcí levé komory.

Soubor: Ve skupině s intervalovým tréninkem s posilováním bylo 14 mužů průměrného věku $63 \pm 8$ let a průměrné ejekční frakce $44 \pm 13,3$ procent. Do skupiny s intervalovým tréninkem bez posilování bylo zařazeno 11 mužů průměrného věku $64 \pm 7$ let s průměrnou ejekční frakcí $44 \pm 13,4 \%$. Soubory se nelišily věkem ani ejekční frakcí.

Metody: Před zahájením a po ukončení programu bylo provedeno spiroergometrické vyšetření do symptomy limitovaného maxima. Tréninková tepová frekvence a zátěž byly stanoveny na úrovni anaerobního prahu. Délka programu 12 týdnů, frekvence $3 \times$ týdně.

Výsledky: Intervalový trénink $s$ posilováním: $\mathrm{VO}_{2} \max$ $\left(\mathrm{ml}_{\mathrm{min}}{ }^{-1}\right) 1659 \pm 43$ vs. $1907 \pm 435(p<0,01)$; Wmax (W) $101 \pm 33$ vs. $124 \pm 34(p<0,01)$

Intervalový trénink bez posilování: $\mathrm{VO}_{2} \max \left(\mathrm{ml} \mathrm{min}^{-1}\right)$ $1344 \pm 373$ vs. $1542 \pm 421$ ( $p<0,05)$; Wmax (W) $74 \pm 28$ vs. $92 \pm 29(p<0,01)$.

Závěr: Dvanáctitýdenní řízený ambulantní rehabilitační program s intervalovým tréninkem vedl u obou sledovaných skupin pacientů ke statisticky významnému zvýšení maximálního př́imu kyslíku i maximálního výkonu. Hemodynamické parametry v klidu ani při zátěži se nezměnily. 
Echokardiografie je metoda ideální nejen pro správnou a přes-

\section{PREVENTIVNÍ VYŠETR̆ENÍ SPORTOVCE. KASUISTIKA}

\section{FREIMUTHOVÁ I.}

\section{Ambulance sportovní medicíny, FN Brno-Bohunice, Brno}

Cîl: Preventivní vyšetření sportovce zahrnuje interní, laboratorní vyšetření a zátěžový test většinou spiroergometrii. Podle těchto vyšetření stanovíme výkon sportovce, vypočítáme ideální tréninkovou tepovou frekvenci a případně doporučíme další vyšetření.

Kasuistika: Na preventivní sportovní prohlídku přichází 22letá žena, hráčka 1. ligy basketbalu. Sama pozoruje nižší výkonnost a udává i v klidu ,,bušení srdce“. Při interní prohlídce zjištěna klidová tachykardie, která byla potvrzena v klidu na EKG. Proto laboratorní odběry doplněny o vyšetření hladiny hormonu štítné žlázy TSH. Zjištěna vyšší hodnota. Sportovkyně byla doporučena na vyšetření do endokrinologické ambulance. Tam na základě dalších laboratorních vyšetření diagnostikována hypotyreóza. Sportovkyně je nyní na substituční léčbě a subjektivně již bez obtíží v plném tréninkovém a závodním zatížení.

Závěr: Preventivní prohlídky sportovců slouží nejen ke stanovení výkonu sportovce, doporučení změn v tréninku, ale především by měly zavčas odhalit některá onemocnění. Zamezí tím jednak pokles výkonnosti sportovce a umožní včasnou léčbu některých diagnóz.

\section{KRÁTKODOBÉ VÝSLEDKY CHIRURGICKÉ LÉČBY CHLOPENNÍCH VAD SE SNİŽENOU FUNKCÍ LEVÉ KOMORY}

FRÉLICH M, ŠTĚTKA F, POKORNÝ P, ÚTRATA P, NEČAS J, ONDRÁŠEK J, PAVLÍK P, WAGNER R, ČERNÝ J

Centrum kardiovaskulární a transplantační chirurgie, Brno

Za období 3 roků (2003-2005) se podrobilo operaci chlopenní vady srdeční (bez současné ischemické choroby srdeční) 1092 nemocných.

Předmětem našeho sdělení je soubor 97 nemocných $(8,9$ \%), kteří měli před operací depresi systolické funkce levé komory (LK) s ejekční frakcí (EF) nižší než 40 \%. Jako end-point studie jsme hodnotili kvalitu života a EF LK s ročním odstupem od operace.

$Z$ celého souboru nemocných zemřelo během ročního sledování 8 nemocných (8,2\%). Ke kontrole se dostavilo všech 89 přežívajících: zlepšenou kvalitu života a spokojenost s operací udávalo 78 nemocných $(87,6$ \%), zbývajících 11 operovaných (12,4\%) nepocítilo změnu v kvalitě života po operaci.

EF LK po roce od operace se zcela normalizovala u 49 nemocných (55,1\%), zlepšila se u $17(19,1 \%)$ a nezměnila u 23 operovaných $(25,8 \%)$.

Protože se jedná o výrazně heterogenní soubor operovaných, rozdělili jsme celou sestavu na 6 podskupin podle dominující chlopenní léze: reoperace chlopní, operace na více chlopních, aortální stenózu, aortální regurgitaci, mitrální regurgitaci a mitrální stenózu. Každou skupinu jsme hodnotili zvlášt'. Nejlepší výsledky byly dosaženy ve skupině stenotických chlopenních vad, nejhorší ve skupině reoperací.

\section{ECHOKARDIOGRAFICKÉ MONITOROVÁNÍ CHLOPENNÍCH VAD}

FRÍDL P

Echokardiografie, Kardiologie na Bulovce s. r. o., Praha nou diagnostiku, ale je i ideální metodou pro dlouhodobé sledování nemocných. Pomáhá správně načasovat radikální řešení chlopenních vad.

Pro pravidelné sledování chlopenních vad je důležité posouzení základních parametrů vady (kvantifikace) i tolerance vady - především chování velikosti srdečních oddílů, funkce komor (EF) a příp. přítomnost plicní hypertenze. Klíčový parametr pro levostranné regurgitační asymptomatické vady je ESD levé komory.

Dnes se rozšiřuje i posuzování funkční rezervy pomocí zátěžové echokardiografie. Indikujeme ji jednak tam, kde si nejsme ze základního vyšetření jisti pokročilostí vady. Průkaz ztráty funkční rezervy představuje pak indikaci k operaci. Naopak přítomná funkční rezerva u nemocných s významnou dysfunkcí komory představuje ještě indikaci ke klasickému výkonu.

U nemocných s některými komplikacemi (infekční endokarditida, tromby) je echokardiografie metodou monitorování specifické léčby.

Po operaci dovoluje tato metoda posoudit výsledky operace, případné komplikace.

\section{SESTERSKÁ SEKCE}

\section{DOMÁCÍ MONITOROVÁNÍ PACIENTŮ SE SRDEČNIIM SELHÁNIIM}

\section{GABEROVÁ L, TRÁVNÍČKOVÁ O, KEMZOVÁ K}

Kardiologické oddělení, Nemocnice Na Homolce, Praha

Úvod: Nefarmakologická léčba srdečního selhání (SS) s použitím implantátů je v současné době standardem u nemocných s dysfunkcí levé komory srdeční a maximalizovanou farmakoterapií. Domácí monitorování těchto nemocných umožňuje navíc získávat průběžná data o vývoji základního onemocnění.

Cil práce: Srovnání počtu rehospitalizací pro srdeční selhání a jiné příčiny v období 12 měsíců u nemocných s implantáty, s možností a bez možnosti domácího monitorování, a dále sledování komplikací nefarmakologické léčby srdečního selhání.

Metodika: 17 konsekutivních pacientů s biventrikulárním ICD s možností domácího monitorování srdečního selhání (Biotronik Home Monitoring ${ }^{\circledR}$ ) bylo ambulantně sledováno po dobu 12 měsíců a srovnáno se skupinou 21 nemocných identického období implantace se standardním BIV ICD.

výsledky:

\begin{tabular}{lccc}
\hline \hline $\begin{array}{l}\text { Parametr } \\
\mathbf{1 2} \text { měsíců }\end{array}$ & $\begin{array}{c}\text { Domácí } \\
\text { monitorováni }\end{array}$ & $\begin{array}{c}\text { Domácí } \\
\text { monitorování - }\end{array}$ & $\boldsymbol{p}$ \\
\hline $\begin{array}{l}\text { Rehospitalizace } \\
\text { pro SSS }\end{array}$ & 2 & 7 & 0,01 \\
$\begin{array}{l}\text { Rehospitalizace } \\
\text { - jiné př́íciny }\end{array}$ & 3 & 4 & $\mathrm{NS}$ \\
$\begin{array}{l}\text { Úmrtí } \\
\text { Průměrná dávka } \\
\text { carvediol }\end{array}$ & 1 & 4 & $\mathrm{NS}$ \\
Neadekvátní výboje & 22,5 & 12,5 & 0,01 \\
\hline \hline
\end{tabular}

Závěr: Domácí monitorování pacientů s pokročilým srdečním selháním za aktivní účasti sester antiarytmické jednotky a ambulance srdečního selhání vede v krátkodobém sledování k signifikantnímu poklesu počtu hospitalizací pro SS a umožňuje dlouhodobě optimalizovat farmakologickou léčbu SS. 


\section{METASTÁZA MELANOMU IMITUJÍCÍ MYXOM PRAVÉ SÍNĚ. KASUISTIKA}

GAJDUŠEK L, ŠKŇOUŘIL L

Kardiologické oddělení, Nemocnice Podlesí a. s., Třinec

Úvod: $\mathrm{K}$ nejčastějším primárním srdečním tumorům patří myxom. Převážně se vyskytuje v levé síni - kolem $80 \%$, v pravé síni do $20 \%$, nitrokomorová lokalizace je vzácná. Sekundární nádory jsou přibližně $20 \times$ častější než primární. $\mathrm{K}$ nim řadíme maligní melanom, tento poměrně často hematogenně metastázuje do srdce, obvykle do myokardu nebo perikardu.

Kasuistika: 77letá pacientka, po excizi maligního melanomu zad před dvěmi lety, byla hospitalizována na spádovém interním oddělení pro tříměsíční progredující námahovou dušnost III. stupně klasifikace NYHA. Echokardiograficky zjištěn tumor pravé síně obturující trikuspidální ústí. Pacientka přeložena $\mathrm{k}$ došetření na kardiologii. Jícnovým echem potvrzen nehomogenní tumor velikosti $5 \times 7 \mathrm{~cm}$, vycházející $\mathrm{z}$ oblasti trikuspidálního anulu. Stanovena pracovní diagnóza myxomu. Na CT plic a mediastina vyjádřeno podezření na hematogenně rozsetá čtyři drobná metastatická ložiska. V pravé síni hypodenzní útvar, který je hodnocen podle CT jako myxom. Jiné postižení CT hrudníku ani sonografie břicha neprokazuje. Pacientka se zhoršuje do klidové dušnosti, proto se rozhodujeme pro urgentní operaci $z$ vitální indikace. Perioperačně nález fragilního laločnatého tumoru černé barvy, činkovitě prolabujícího do pravé komory a téměř zcela obturujícího trikuspidální chlopeň, provedena jeho excize. Současně zjištěno metastatické postižení paraaortálních uzlin. Nález hodnocen jako generalizace melanomu, toto potvrzeno následně histologicky. Další postup u pacientky konzervativní. Umírá tři týdny po operaci $\mathrm{v}$ obraze generalizace malignity.

Závěr: Uvedenou kasuistikou jsme chtěli poukázat na úskalí diferenciální diagnostiky nitrosrdečních tumorů, na raritní př́ipad metastázy maligního melanomu, imitujícího myxom podle nálezů ECHO i CT. K diskusi pak úvaha o postupu u pacientky $s$ tumorem síně, kterým je vitálně ohrožena při současném podezření na generalizaci melanomu.

\section{SESTERSKÁ SEKCE}

\section{MOŽNOSTI SLEDOVÁNÍ REAKTIVITY AUTONOMNÍHO NERVOVÉHO SYSTÉMU U PACIENTŮ S HYPERTENZÍ}

GALUSZKA J, BURIÁNKOVÁ I, VLADAŘOVÁ Š, LOKOČOVÁ E, HORANCOVÁ V

\section{I. interní klinika, FN Olomouc a LF UP, Olomouc}

Cíl práce: Předvést možnosti a význam neinvazivního hodnocení autonomního nervového systému u pacientů $\mathrm{s}$ hypertenzí.

Metodika: Vyšetření souboru 30 pacientů s nově zjištěnou hypertenzí pomocí testu leh-stoj-leh před nasazením terapie a $\mathrm{v}$ průběhu terapie.

Výsledky - demontrace nálezů:

1. Grafické znázornění variability srdeční frekvence u hypertonika pomocí 3D grafu před léčbou a zlepšení VSF po dosažení kontroly TK.

2. Grafické znázornění VSF u pacienta „non-respondera“ na nasazenou terapii.

3. Numerické znázornění parametrů VSF u neléčeného a léčeného hypertonika.
4. Znázornění výsledků VSF před léčbou

a při léčbě pomocí kř́žového grafu průsečíků komplexních indexů spektrální analýzy VSF.

Závěr: Léky užívané $\mathrm{k}$ léčbě hypertenze působí at již přímo či nepř́mo také na srdeční frekvenci. Mimo finální hodnoty krevního tlaku tak sledování VSF u těchto pacientů přináší další hodnotící parametr. Použitá metoda hodnocení ANS u pacientů s hypertenzí proto umožňuje detailnější pohled na pacienta i způsob jeho léčby.

\section{VLIV LÉC̆BY POMOCÍ KONTINUÁLNÍHO POZITIVNÍHO PR̆ETLAKU V DÝCHACÍCH CESTÁCH NA PARAMETRY VARIABILITY SRDEC̆NÍ FREKVENCE U PACIENTƯ SE SYNDROMEM SPÁNKOVÉ APNOE}

GALUSZKA J, HOBZOVÁ M, SOVOVÁ E, ZAPLETALOVÁ J, LUKL J

I. interní klinika, Klinika plicních nemocí a tuberkulózy, FN Olomouc a LF UP, Ústav biofyziky, UP, Olomouc

Cíl práce: Posouzení vlivu terapie syndromu spánkové apnoe (SSA) pomocí domácího pozitivního přetlakového dýchaní (režim CPAP - continuous positive air-way pressure) na parametry variability srdeční frekvence (VSF).

Soubor a metodika: 26 pacienti̊ se SSA (19 M, $7 \check{Z}$; průměrný věk 48 let: 29-69) indikovaných $\mathrm{k}$ domácí léčbě pomocí CPAP, aplikované během nočního spánku. Hodnocení krátkodobého záznamu VSF během testu leh-stoj-leh (5 minut v každé pozici) dvakrát u celého souboru pacientů: první měření před začátkem léčby pomocí CPAP a druhé v průběhu této léčby (o 1,5 až 4 měsíce později). Byly hodnoceny následující parametry VSF: POWER HF $\left(\mathrm{ms}^{2}\right)$, POWER LF $\left(\mathrm{ms}^{2}\right)$, LF/HF, TOTAL POWER $\left(\mathrm{ms}^{2}\right)$, MSSD $\left(\mathrm{ms}^{2}\right)$.

Výsledky: 1. měření/2. měření; stoj: HF 60,7/88,9; LF 88,7/77,2; LF/HF 2,79/2,83; TOTAL PWR 216,1/457,1; MSSD 250,1/497,8; leh: HF 197,9/210,5; LF 204,2/224,4; LF/HF 2,03/2,14; TOT PWR 609,5/666,3; MSSD 738,3/776,6.

Závěr: V průběhu uvedené terapie SSA byl zjištěn vzestupný trend hodnot u všech sledovaných parametrů VSF $\mathrm{s}$ výjimkou LF/HF v supinační poloze. Avšak statistické významnosti dosáhly pouze změny vysokofrekvenční $\mathrm{HF}$ komponenty ( $p=0,049)$ a celkového spektrálního výkonu ( $p=0,009)$ ve stoje. Nález lze vykládat jako výraz zlepšené reaktivity kardiálního ANS a zejména augmentaci vagové komponenty (HF) v důsledku terapeutického účinku CPAP.

Omezení studie: 1. 27 pacientů bylo starších 60 let (vliv stárnutí na parametry VSF), 2 . heterogenní medikace ve skupině nemocných.

\section{METABOLICKÝ SYNDROM A ROZSAH KORONÁRNÍ ATEROSKLERÓZY U PACIENTÚ PO ELEKTIVNÍ PERKUTÁNNÍ KORONÁRNÍ INTERVENCI}

GOLÁŇ L, ŠIMEK S, HORÁK J, LUBANDA J, BERAN S, SKALICKÁ L, DOSTÁL O, DOSTÁLOVÁ G, KUCHYŇKA P, LINHART A

II. interní klinika kardiologie a angiologie, VFN a 1. LF UK, Praha

Úvod: Metabolický syndrom je komplex hlavních rizikových faktorů aterosklerózy. Zajímala nás prevalence tohoto syndromu u pacientů po perkutánní elektivní koronární intervenci (PCI), jeho korelace s rozsahem aterosklerózy a úloha jednotlivých rizikových faktorů metabolického syndromu.

Metody: Analyzovali jsme 102 pacientů, kteří podstoupili elektivní PCI. Hodnotili jsme lipidový profil, glykemii 
nalačno, přítomnost obezity a krevní tlak. K posouzení rozsahu koronární aterosklerózy jsme použili modifikovaný index koronární aterosklerózy (IKA) podle Gensiniho. Rozdělili jsme pacienty do dvou skupin podle střední hodnoty IKA a porovnali jsme výskyt metabolického syndromu a jeho jednotlivých komponent $\mathrm{v}$ obou skupinách.

Výsledky: Rozsah indexu koronární aterosklerózy byl 3-53,5, střední hodnota 17,5. Metabolický syndrom se vyskytoval ve $40 \%$ ve skupině pacientů s menším rozsahem koronárního postižení a v $59,2 \%$ ve skupině $\mathrm{s}$ větším postižením $(p<0,05)$. Plazmatická hladina triglyceridů a vyšší hladiny glykemií nalačno korelovaly nejvíce se stupněm koronárního postižení.

Závěr: Podle očekávání se metabolický syndrom vyskytuje častěji u pacientů s pokročilejší aterosklerózou. $Z$ jednotlivých rizikových faktorů metabolického syndromu hrály v našem souboru největší úlohu zvýšené hodnoty glykemií a triglyceridů. $\mathrm{K}$ přesnějšímu posouzení úlohy metabolického syndromu a jeho faktorů je však potřeba posouzení většího souboru pacientů.

\section{MORFOLOGICKÉ ZMĚNY KARDIOVASKULÁRNIIHO APARÁTU U PACIENTŮ S ISCHEMICKOU CHOROBOU SRDEČNÍ - HMOTNOST LEVÉ KOMORY SRDEČNÍ A TLOUŠŤKA INTIMA A MÉDIE KRČNÍCH TEPEN U PACIENTŮ PO ELEKTIVNÍ PERKUTÁNNÍ KORONÁRNÍ INTERVENCI}

GOLÁŇ L, PALEČEK T, VÍTOVEC M,

ŠIMEK S, HLUBOCKÂ Z, KEJŘOVÁ E, POLÁČEK P, BANI HANI A, AMBROŽ D, LINHART A

II. interní klinika kardiologie a angiologie, VFN a 1. LF UK, Praha

Úvod: Morfologické změny kardiovaskulárního aparátu představované hypertrofií levé komory srdeční a zesílením komplexu intimy a medie (IMT) krčních tepen jsou známými rizikovými faktory ischemické choroby srdeční. Zajímala nás korelace hypertrofie levé komory a IMT karotid s rozsahem koronární aterosklerózy u pacientů se známou ischemickou chorobou srdeční a účinnost sekundární prevence na zpomalení těchto nepříznivých změn.

Metody: Sledovali jsme 102 pacientů po elektivní koronární intervenci. Kromě základního fyzikálního vyšetření a zhodnocení klasických rizikových faktorů jsme u všech pacientů provedli transtorakální echokardografii a ultrazvukové vyšetření karotid na začátku a konci sledování. Průměrná délka sledování byla 28 měsíců. Hmotnost levé komory jsme hodnotili podle měření $\mathrm{z}$ parasternální projekce a $\mathrm{k}$ posouzení IMT karotid jsme použili automatizované počítačové měření. Rozsah koronární aterosklerózy jsme hodnotili pomocí indexu koronární aterosklerózy podle Gensiniho.

Výsledky: Při hodnocení hmotnosti levé komory $\mathrm{v} g / \mathrm{m}^{2,7}$ jsme zjistili, že 36,2 \% pacientů mělo hypertrofii levé komory na začátku a 40,9 \% na konci sledování ( $p>0,05)$. Pacienti s hypertrofií levé komory na začátku sledování měli vyšší index koronární aterosklerózy oproti pacientům bez hypertrofie $(18,38$ vs. $23,34, p<0,05)$. Počáteční hodnota IMT karotid byla 0,62 a na konci sledování 0,66 ( $p>0,05)$. Počáteční hodnota IMT byla také vyšší u pacientů s rozsáhlejším koronárním postižením $(0,60$ vs. $0,65, p>0,05)$.

Závěr: Pacienti s rozsáhlejším koronárním postižením mají častěji hypertrofii levé komory. Přes sekundární prevenci se hmotnost levé komory $u$ našich pacientů dále zvyšovala. Podobný nepříznivý trend jsme pozorovali také u hodnot tlouštky komplexu IMT krčních tepen. Tyto nálezy mohou odrážet nedostatečnost současné sekundární prevence $\mathrm{u}$ pacientů $\mathrm{s}$ ischemickou chorobou srdeční.

\section{JE NUTNÝ KE KAŽdÉMU MINIINVAZIVNÍMU ODBĚRU ŠTĚPŮ PRO REVASKULARIZACI ENDOSKOP?*}

\author{
GRUS T, LINDNER J, VIK K, GRUSOVÁ G, TOŠOVSKÝ J
}

Kardiocentrum, II. chirurgická klinika kardiovaskulární chirurgie, IV. interní klinika, VFN a 1. LF UK, Praha

*S podporou grantu 101/05/0675 GA ČR.

Úvod: Otevřený odběr štěpů pro revaskularizaci bývá často spojen s rannými komplikacemi, bolestí v ráně, prodlouženým hojením, poruchou senzitivity, špatným kosmetickým efektem. Proto trend $\mathrm{k}$ miniinvazivním odběrům štěpů pro revaskularizaci. Jednou $z$ možností je použití endoskopického intrumentária, které však má i určité limitace. Druhou možností je odběr ze stejného počtu incizí, jako za použití endoskopie jen s pomocí harmonického skalpelu, bipolárních nůžek a retraktoru.

Metodika: Byla provedena retrospektivní analýza 200 miniinvazivních odběrů vena saphena magna a 20 odběrů arteria radialis za období 3 let.

Miniinvazivní odběry se prováděli ze 3 incizí o velikosti $3 \mathrm{~cm}$ na DK a odběr a. radialis ze dvou incizí bez použití endoskopického instrumentária. Použité instrumentárium: malý tupý retraktor, harmonický skalpel, koagulace, preparační nưžky, bipolární nůžky. Štěp po odběru uložen do heparinizované krve nebo fyziologického roztoku s heparinem.

Pro posouzení kvality štěpu při různém způsobu odběru bylo zhotoveno histologické vyšetření. Provedené neurologické vyšetření detekovalo výpadky senzitivity, hybnosti. Alenovým testem, popřípadě sonografickým vyšetřením jsme vyloučili nevhodné pacienty $\mathrm{k}$ miniodběrům.

Výsledky: Porovnali jsme skupiny pacientů s klasickým odběrem a $\mathrm{s}$ miniodběrem, kde jsme neshledali významnější prodloužení doby hospitalizace, nebyl zvýšený počet neurologických komplikací a došlo ke snížení výskytu ranných komplikací.

Histologické vyšetření prokázalo výraznou šetrnost odběru při použití harmonického skalpelu.

Závěr: Cílem miniinvazivních metod je menší operační zátěž pacienta, dobrý kosmetický efekt, zkrácení doby hospitalizace, výrazný pokles ranných komplikací.

$\mathrm{K}$ tomu všemu lze dospět také i bez použití nákladného a v některých případech limitujícího endoskopického instrumentária.

\section{ANTEROLATERÁLNÍ A INFEROLATERÁLNÍ INFARKT MYOKARDU PR̆I DIFUZNÍM SPASMU LEVÉ VĚNČITÉ TEPNY U PACIENTA S UROSEPSI}

\section{GŘIVA M, VINDIŠ D}

Interní klinika IPVZ,

Batova krajská nemocnice, Zlín,

Interní oddělení, Kroměřǐžská nemocnice, a. s., Kroměřǐž

Formou posteru je prezentován popis př́ípadu 64letého pacienta po cystektomii pro karcinom před 5 lety, po plastické operaci na močových cestách „Mainz pouch II“, s afunkční levou ledvinou a hypofunkční nefroticky změněnou pravou ledvinou s nefrolitiázou, s chronickou renální insuficiencí.

Pro ambulantně proběhlý QIM spodní stěny odeslán ke koronarografii. Provedena perkutánní koronární intervence (PCI) na ACD, výkon bez komplikací, pacient propuštěn bez další elevace kreatininu.

S odstupem 1 týdne od PCI je pacient rehospitalizován pro celkové zhoršení stavu s elevací dusíkatých látek a zá- 
nětlivých markerů. Stav je hodnocen jako urosepse (E. coli), i přes kombinační léčbu širokospektrými ATB je patrno pozvolné zhoršování stavu s počínajícím septickým šokem. O 3 dny později nově stenokardie, na EKG nově elevace segmentů ST anterolaterálně a inferolaterálně. Echokardiograficky nově těžká dysfunkce LK s výraznou poruchou kinetiky přední a boční stěny. Provedena rekoronarografie, kde zjištěn rozsáhlý difuzní spasmus RIA i RC. Po aplikaci Isoketu i. c. dochází k ústupu spasmů, perzistuje optimální efekt po PCI na ACD. Zavedena intraaortální balonková kontrapulsace (IABK), katecholaminová podpora, aplikován levosimendan, nadále ATB podle citlivosti. Pro metabolickou acidózu a oligoanurii zahájena CVVHD, parenterální nutrice. Pro progresi hydronefrózy vlevo provedena nefrostomie.

Při přechodném zlepšení hemodynamického stavu zrušena IABK, snižována dávka katecholaminů. Echokardiograficky mírné zlepšení funkce LK. V dalším průběhu však dochází i přes léčbu širokospektrými ATB k progresi urosepse, vedoucí k refrakternímu septickému šoku. Přes veškerou péči se nedaří stav zvládnout, pacient po týdnu umírá pod obrazem multiorgánového selhání.

\section{SESTERSKÁ SEKCE}

\section{SEDMIDENNÍ KONTINUÁLNÍ HOLTEROVSKÉ MONITOROVÁNÍ EKG PR̆I SLEDOVANÍ PACIENTŮ PO RADIOFREKVENČNÍ ABLACI ÚSTÍ PLICNÍCH ŽIL PRO FIBRILACI SÍNÍ}

\section{HAUSEROVÁ Z, NEČASOVÁ L, ŠTEFANOVÁ A, SVOBODOVÁ L}

\section{Klinika kardiologie, IKEM, Praha}

V období od 3/2005 do 10/2006 bylo na našem pracovišti provedeno 62 vyšetření u 57 pacientů, kteří podstoupili radiofrekvenční ablaci ústí plicních žil pro fibrilaci síní (RFA FiS). Monitorování bylo indikováno u nemocných bez záchytu fibrilace síní v časném období po výkonu. V souboru bylo 40 mužů (věk 53,73 $\pm 8,91$ ) a 17 žen (věk 59,64 $\pm 7,21$ ). Průměrná doba provedení prvního holterovského monitorování EKG od výkonu byla 4,42 $\pm 2,64$ měsíce, pět pacientů bylo podruhé monitorováno po $8 \pm 1,54$ měsících od výkonu (rozpětí 2 až 16 měsíců). U 67,7 \% nemocných byl v průběhu monitorování zachycen sinusový rytmus (SR), avšak téměř $60 \% \mathrm{z}$ nich přesto pocitovalo palpitace, př̀ kterých byl dokumentován SR. Naproti tomu celých $25 \%$ pacientů, u nichž byly zachyceny epizody FiS, bylo asymptomatických.

Závěr: Sedmidenní kontinuální holterovské monitorování EKG je nepostradatelným nástrojem při sledovaní pacientů po RFA.

\section{SESTERSKÁ SEKCE}

\section{PÉČE O PACIENTA PŘEd SRDEČNí KATETRIZACÍ A PO NÍ}

\section{HAVLÍČKOVÁ E}

Kardiologické oddělení, Krajská nemocnice Liberec, Liberec

V kardiocentru Liberec je ročně provedeno na 2500 srdečních katetrizací. Důležitou součástí katetrizace není jen vlastní výkon, ale i př́prava pacienta před katetrizací a následná péče po ní. Nedílnou součástí je i poučení pacienta o charakteru výkonu a časném režimu. Vlastní př́íprava na srdeční katetrizaci zahrnuje farmakologickou premedikaci a úpravu míst potenciálních cévních přístupů. Velmi důleži- tá je ošetřovatelská péče po výkonu, zejména u nemocných, kteří podstoupili perkutánní koronární intervenci. Je nutné monitorovat TK, P, místo cévního vstupu a celkový stav nemocného včetně neurologického statusu. Diskutována je problematika extrakce cévního zavaděče.

\section{HYPONATREMIE A AKUTNÍ INFARKT MYOKARDU}

HAVRÁNEK Š, ŠKULEC R, BĚLOHLÁVEK J, KOVÁRNÍK T, DYTRYCH V, LINHART A

\section{II. interni klinika kardiologie a angiologie,}

Všeobecná fakultní nemocnice a 1. LF UK, Praha

Úvod: Hyponatremie je marker nepříznivé prognózy u nemocných s chronickým srdečním selháváním. Velmi málo je však známo, zda má hyponatremie podobný prediktivní význam i u pacientů $\mathrm{s}$ akutním infarktem myokardu (AIM). Na minulém sjezdu České kardiologické společnosti jsme referovali pilotní výsledky na souboru 100 nemocných s AIM. Nyní prezentujeme data $u$ většího souboru pacientů.

Cíl studie: Popsat dynamiku změn sérových hodnot natria (S-Na+) v akutní fázi AIM, vztah hyponatremie k lokalizaci AIM a zhodnotit prognostický význam hyponatremie.

Metoda a výsledky: Provedli jsme retrospektivní analýzu 230 nemocných (77 žen, průměrný věk 65,1 \pm 13,8 let) s AIM s elevacemi úseků ST konsekutivně přijatých na koronární jednotku II. interní kliniky kardiologie a angiologie VFN a 1. LF UK Praha v letech 2004-2006. Hyponatremie byla definována jako hodnota $\mathrm{S}-\mathrm{Na}+<137 \mathrm{mmol} / 1$ při přijetí, 1. den, v prvních 72 hodinách a za celou dobu hospitalizace. Nejnižší hodnoty S-Na+ byly zaznamenány 1. den hospitalizace $(136,9 \pm 3,5 \mathrm{mmol} / \mathrm{l})$ a maximální 7 . den 139,6 \pm $3,6 \mathrm{mmol} / \mathrm{l})$. Při přijetí mělo hyponatremii $48,3 \%$ nemocných. U pacientů $\mathrm{s}$ AIM pravé komory jsme zjistili nižší $\mathrm{S}-\mathrm{Na}+$ při přijetí než u ostatních nemocných $(135,5 \pm 4,1$ vs. $137,1 \pm 3,4 ; p=0,023$ ), hyponatremie byla př́tomna u $75 \%$ nemocných s AIM PK. Nemocní s kardiogenním šokem (12,6 \% pacientů) měli významně nižší př́íjmové S-Na+ $(134,8 \pm 3,9$ vs. $137,2 \pm 3,4 ; p=0,0009)$ i nižší minimální S-Na+ v prvních 72 hodinách AIM $(133,7 \pm 4,4$ vs. 136,1 $\pm 2,9 ; p=0.0002)$ než stabilní pacienti.

Závěry: Nejnižší hodnoty $\mathrm{S}-\mathrm{Na}+$ jsou př́tomny v úvodní fázi. U nemocných s AIM pravé komory se hyponatremie vyskytuje častěji. Snížené vstupní hodnoty S-Na+ byly zjištěny u nemocných $\mathrm{s}$ kardiogenním šokem. Cílem dalšího výzkumu bude stanovení prediktivního významu hyponatremie pro osud nemocných.

\section{VENTRICULOPHASIC MODULATION OF INTRAATRIAL CONDUCTION IN TYPICAL ATRIAL FLUTTER}

HAVRÁNEK Š, ŠIMEK J, BULKOVÁ V, ŠT̃OVÍČEK P, WICHTERLE D, LINHART A

II. interní klinika kardiologie a angiologie,

VFN a 1. LF UK, Klinika kardiologe, IKEM, Praha

Introduction: Autonomic neural influence of ventricular contractions on sinus nodal discharge (ventriculophasic sinus arrhythmia) is present in the setting of complete atrioventricular (AV) block.

Hypothesis: We investigated whether an analogous phenomenon can be observed in the case of atrial macroreentrant arrhythmia.

Methods: Digital recordings (1 min) of surface ECG, lateral right atrium, and coronary sinus electrograms were obtained in 22 patients before radiofrequency ablation of 
typical atrial flutter (AFL; 17 clockwise, 5 counterclockwise) with $\geq 3$ : $1 \mathrm{AV}$ block. Atrial electrograms (A) from right atrium duodecapolar catheter and coronary sinus decapolar catheter were automatically identified and A-A intervals in different phases of ventricular cycle were compared (paired $t$-test)

Results: Consistent shortening of AFL cycle length was observed at $\sim 400 \mathrm{~ms}$ after QRS complex (figure, representative example). In all patients, AFL cycle length at lateral right atrium site was the longest $(239.8 \pm 33.2 \mathrm{~ms})$ in the interval 100-300 $\mathrm{ms}$ after QRS and the shortest (232.9 $\pm 33.3 \mathrm{~ms}$ ) in the interval 500-700 ms after QRS with mean difference of $6.9 \pm 4.8 \mathrm{~ms}(p<0.00001)$. Comparable modulation of intraatrial conduction was found for coronary sinus electrograms and for patients with counterclockwise and clockwise AFL.

Conclusions: Significant ventriculophasic oscillation of AFL cycle length was documented. However vagal efferent action following each ventricular contraction is plausible, more investigation is necessary for uncovering exact physiological mechanism of this phenomenon witch might be useful for investigation of atrial autonomic neural input.

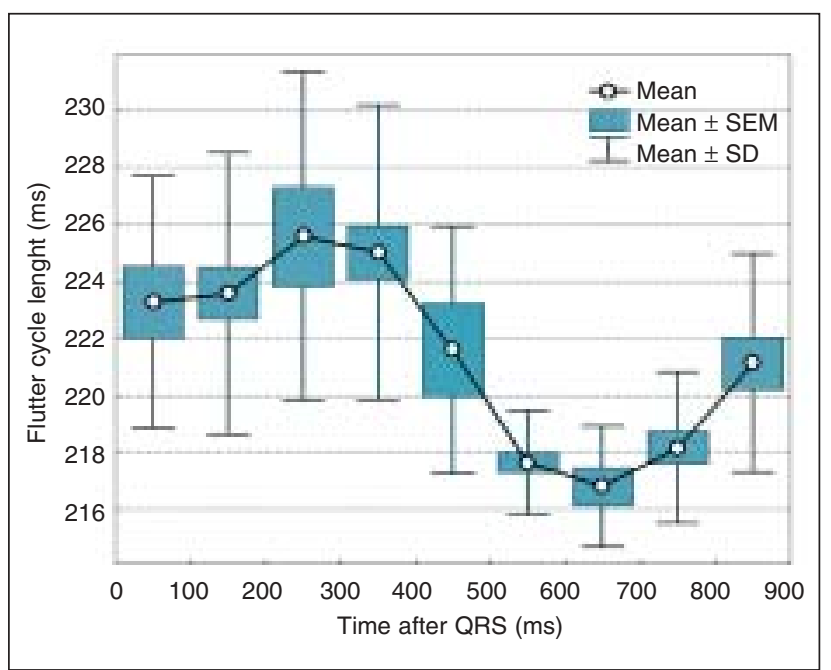

\section{VYSOKÁ HLADINA PAPP-A JE UKAZATELEM HORŠÍ PROGNÓZY NEMOCNÝCH S AKUTNÍM INFARKTEM MYOKARDU S ELEVACEMI ST}

HÁJEK P, MACEK M sr., HANSVENCLOVÁ E, HLADÍKOVÁ M, HOUBOVÁ B, MALÝ M, VESELKA J, KREBSOVÁ A

Kardiologické oddělení Kardiovaskulárního centra pro dospělé pacienty, Ústav biologie a lékařské genetiky, Ústav lékařské informatiky, FN Motol, Praha, Interní klinika/kardiologie, Virchow Klinikum, Humboldt University, Berlin, Germany

Cíl: Určit význam stanovení pregnancy-associated plasma proteinu-A (PAPP-A) z hlediska prognózy nemocných s akutním infarktem myokardu s elevacemi ST (STEMI).

Soubor pacientů a metodika: 63 konsekutivních nemocných se STEMI (51 mužů, 12 žen, medián věku 60,4 let, 41,2-83,5 let), léčených přímou koronární angioplastikou (pPCI), bylo sledováno po dobu tří let (medián 36,8 měsíců 0-49,9 měsíců). Vzorky krve byly odebrány při přijetí, vyšetřeny přístrojem Kryptor ${ }^{\mathrm{TM}}$ (Brahms-Germany), který vyhodnocuje PAPP-A spolu se svým fyziologickým inhibitorem - proform eosinophilic major basic proteinem (proMBP). U 24 (38,1 \%) pacientů byl PAPP-A/proMBP vyšetřen znovu na konci sledování.
Výsledky: Pomocí analýzy ROC jsme určili vstupní koncentraci 47,2 mIU/1, jako hodnotu s nejvyšší senzitivitou a specificitou pro rozdělení souboru na skupinu s lepším a horším přežíváním. Obě skupiny se signifikantně nelišily v klinické charakteristice. Vyšší vstupní koncentrace PAPP-A/proMBP byla významně spojena s rizikem celkové jednoroční mortality [odds ratio (OR) 11,75; 95\% CI $1,12-123,2 ; p=0,04$ ], dvouleté mortality (OR 5,46; 95\% CI 1,06-27,998; $p=0,049)$ a se zvýšeným výskytem kombinovaného ukazatele mortality a reinfarktu - na konci prvního roku (OR 4,67; 95\% CI 1,22-17,75; $p=0,028$ ) i druhého (OR 3,79; 95\% CI 1,09-13,2; $p=0,043$ ). Také Kaplanova-Meierova analýza ukázala lepší přeživání nemocných s nižší vstupní koncentrací PAPP-A/proMBP (91,7 \% vs. 73,3 \%; $p=0,05)$. Koncentrace PAPP-A/proMBP na konci sledování byly významně nižší (medián vstupních hladin -19,0 mIU/1, na konci sledování - 8,6 mIU/1; $p=0,0002$ ).

Závěr: Naše výsledky ukazují, že vysoké vstupní koncentrace PAPP-A/proMBP mají u nemocných se STEMI negativní prognostický význam s ohledem na výskyt úmrtí a reinfarktu během střednědobého sledování. Během sledování došlo $\mathrm{k}$ poklesu hladin PAPP-A/proMBP k normálním hodnotám.

\section{RHEOLYTICKÁ TROMBEKTOMIE AKUTNÍCH CÉVNÍCH UZÁVĚRI}

\author{
HELLER S, VAŘEJKA P, BERAN S,
} SKALICKÁ L, CHOCHOLA M

II. interní klinika kardiologie a angiologie, VFN a 1. LF UK, Praha

Úvod: Akutní tepenné uzávěry jsou závažným medicínským stavem, mnohdy ohrožujícím pacienta na životě. Mohou být způsobeny embolizací do nativních tepen nebo trombózou nebo uzávěrem periferní chirurgické rekonstrukce. Perkutánní prostá aspirační trombektomie a lokální trombolýza jsou běžně použivanou technikou k léčbě akutní končetinové ischemie zvláště infrainguinálně. Nově se používají efektivnější moderní mechanická trombektomická zařízení.

Metodika: Od ledna 2005 jsme léčili endovaskulárně celkem 45 pacientů pomocí mechanické rheolytické trombektomie přístrojem Angiojet (Possis Medical, Minneapolis, MN, USA) pro akutní končetinovou ischemii.

Výsledky: Ve většině případů jsme k dosažení optimálního angiografického obrazu doplnili léčbu lokálním podáním malé dávky trombolytika. Použití mechanické trombektomie zkrátilo dobu reperfuze končetiny a zkrátilo dobu podávání lokální trombolýzy. $\mathrm{V}$ jednom případě byl pro embolizační komplikaci nutný chirurgický výkon. Dvakrát jsme zaznamenali přechodnou makroskopickou hematurii bez negativního efektu na renální funkce. Výsledky a detaily použití budou podrobně diskutovány ve sdělení.

\section{HODNOCENÍ POKLESU ELEVACÍ ÚSEKU ST V POROVNÁNÍ S HODNOCENÍM PROPUSTNOSTI MIKROVASKULÁRNÍHO PROSTORU (BLUSH) METODOU DENZOGRAFIE U NEMOCNÝCH S AKUTNIIM INFARKTEM MYOKARDU R̆EŠENÝCH DPCI}

HERMAN A, BUNČEK L, ŠMORANC P, VARVAŘOVSKÝ I, MATĚJKA J, ROZSÍVAL V, STEINHART L

Pracoviště invazivní kardiologie, Kardio-Troll, Kardiologické oddělení interní kliniky,

Krajská nemocnice Pardubice, Pardubice,

Radiologická klinika, FN Králové, Hradec Králové 
Hodnocení propustnosti mikrovaskulárního prostoru (BLUSH) ACD a ACS jako celku se děje pomocí hodnocení dilučních křivek. Nositelem informace je kontrastní látka. Vlastní hodnocení je prováděno pomocí SW, vyvinutého $Z$ výpočetního prostředí MATLAB-The Math Works Inc.

K hodnocení byla zvolena základní projekční sít o rozměru $6 \times 8$ „region of interest“ (ROI), která pokrývá plochu projekce celého příslušného koronárního řečiště. Propustnost se stanoví z poměru ROI s prokazatelnými dilučními křivkami k celkovému počtu ROI přehledné projekce /(počet ROI s dilučními křivkami/48) ×100\%/. Normální distribuce kvantitativně hodnocené mikrovaskulární perfuze (BLUSH) odpovídá Gaussovu rozložení, kdy lze nemocné rozdělit do kvartil podle rozsahu počtu automaticky hodnocených ROI s hodnotitelnými dilučními křivkami.

Hodnocení poklesu elevací úseku ST u nemocných s akutním infarktem myokardu je ukazatelem další prognózy vývoje ejekční frakce a klinického stavu. Křivky EKG jsme hodnotili při přjetí, 1, 3 a 12 hod. po intervenci. Vyhodnocené údaje jsme porovnali s hodnocením BLUSH po provedení intervence.

Autoři popisují soubor 40 nemocných léčených přímou PCI pro akutní infarkt myokardu se STE (STEMI). Kvantitativní hodnota myokardiální perfuze je porovnávána s regresí elevací ST na EKG a velikostí infarktu myokardu podle biochemických markerů v intervalech při přijetí, následně po provedení intervence, za 6 a 12 hod. po intervenci. Součástí hodnocení angiografického nálezu byl počet postižených cév a hodnocení TIMI průtoku před provedením intervence a po ní, hodnocení ejekční frakce, mitrální regurgitace a vlastní hodnocení BLUSH po provedení intervence.

Závěr: Pokles elevací úseku ST je spolehlivým prognostickým ukazatelem a současně s hodnocením propustnosti mikrovaskulárního řečiště poskytuje další údaje o stavu myokardu u nemocných s AIM, řešených metodou dPCI.

\section{SESTERSKÁ SEKCE}

\section{DISEKUJÍCÍ ANEURYZMA AORTY, KOMPLIKOVANÉ SRDEČNÍ TAMPONÁDOU}

\section{HESS T}

Kardiocentrum, koronární JIP,

Krajská nemocnice Liberec, Liberec

Disekcí aorty rozumíme stav, při kterém dochází v důsledku intramurálního pronikání krve $\mathrm{k}$ rozštěpení aortální stěny. Disekující tunel proniká intimou i medií. Kanál následující za trhlinou může být segmentální, ale i kompletně postihující hrudní i břišní aortu, kdy odchlípená část intimy zužuje odstup aortálních větví s následnými ischemickými projevy. Kanál v distální části může perforovat znovu do aorty (re-entry). Většina neléčených disekcí končí šokovým stavem, který bývá podmíněn bud' náhle vzniklou hypovolemií při ruptuře aorty do pleurální dutiny, nebo srdeční tamponádou, směřuje-li krvácení do perikardiální dutiny. Tyto komplikace vedou obvykle rychle ke smrti nemocného. Referujeme kasuistiku 53letého pacienta s akutní disekcí aorty, který krátce po přijetí upadá do šokového stavu. Při echokardiografickém vyšetření byla zjištěna srdeční tamponáda a vlající intima v ascendentní aortě. Pro velké bolesti, neklid a těžkou hypotenzi byla nutná celková anestezie s umělou plicní ventilací a byla provedena život zachraňující perikardiocentéza s odsátím $600 \mathrm{ml}$ krve $\mathrm{z}$ perikardiální dutiny. Pacient byl neodkladně přeložen $\mathrm{k}$ emergentnímu operačnímu řešení na kardiochirurgii a byl úspěšně operován.

\section{PR̆IŠEL! - SLYŠEL! - VIDĚL! - Vİ? VÝSLEDKY PRÜZKUMU U LAIKŮ V OBLASTI KPR V PROGRAMU ŠŇŮRA ŽIVOTA}

\author{
HETCLOVÁ D, BRAVENCOVÁ Š
}

I. interní klinika, JIP, FN Olomouc, Olomouc

V roce 1992 byla ve Fakultní nemocnici v Olomouci založena Nadace pro Srdce Hané. $K$ aktivitám této nadace patří vznik Klubu kardiaků, zajištění nákupu moderních přístrojů pro kardiology nebo projekty pro časnou diagnostiku infarktu myokardu v terénu.

Jejím cílem je také aktivní vzdělávání populace v oblasti prevence kardiovaskulárních onemocnění.

Na tomto vzdělávání se podílí projekt „Šňůra života“, kde se formou zábavně-vzdělávacího odpoledne seznamují občané se základní podporou života (BSL) s možností praktického nácviku.

Poslední Šňůra života proběhla v říjnu 2006, kde bylo současně s výukou a přednáškami provedeno šetření o znalostech BSL a automatizovaných externích defibrilátorech u široké veřejnosti.

Bylo vyhodnoceno 85 dotazníků, kde respondenti odpovídali na 10 otázek. Výsledky nás informovaly nejen o významu primární prevence, ale budou užity i k přípravě dalšího vzdělávání veřejnosti.

\section{SESTERSKÁ SEKCE}

\section{PÉČE O PACIENTA S DG. MYXOM. KASUISTIKA}

\section{HNATOVA K, ŘEHÁKOVÁ M}

Interní kardiologická klinika, JIP, FN Brno-Bohunice, Brno

Přednáška bude obsahovat charakteristiku myxomu, jeho diagnostiku, léčbu, komplikace, nejčastější ošetřovatelské diagnózy a na závěr kasuistiku konkrétního pacienta.

\section{SLEDOVÁNÍ ÚČINNOSTI ANTIKOAGULAČNÍ LÉČBY U NEMOCNÝCH S FIBRILACÍ SÍNÍ V ZÁVISLOSTI NA VĔKU}

HNÁTEK T, ZOGALA D, KAMENÍK L, JEŘÁBEK I, ZAVORAL M

\section{Kardiologické oddělení,}

Interní klinika, Oddělení nukleární medicíny, ÚVN a 1. LF UK, Praha

Úvod: Perorální antikoagulační léčba je standardem u nemocných s fibrilací síní. Úspěšnost léčby závisí na mnoha faktorech, zejména u starších nemocných.

Cíle studie: 1 . Zjistit účinnost antikoagulační léčby u nemocných s fibrilací síní, propuštěných v průběhu let 2004 a $2005 \mathrm{z}$ našeho kardiologického oddělení (vyjma nemocných po implantaci metalické chlopenní protézy). 2. Porovnat účinnost antikoagulační léčby u skupiny mladších (< 75 let) a starších (75 let a více) nemocných.

Metodika: Zařazeno 203 pacientů, data o léčbě byla zjištěna telefonicky, zjištěny poslední 2 hodnoty INR. Dodatečně 30 nemocných vyřazeno vesměs pro nedostatek údajů, data zbylých 173 pacientů byla dále analyzována. 
Léčebný interval stanoven na INR 2,0-3,5, jako účinná antikoagulace hodnocen stav, když poslední a předposlední hodnota ležela v tomto intervalu.

Výsledky: Průměrný věk pacientů je 73,5 \pm 7,8 let (medián 74 let). Ženy tvořily 49 \%.

$Z$ celého souboru 173 nemocných zemřelo během sledování 24 pacientů (14%). Dále analyzováno 149 žijících nemocných. Průměrná doba od dimise je 15,3 $\pm 3,1$ měsíce (medián 15 měs.). Trvale je antikoagulováno 104 nemocných (70 \% žijících pacientů), z toho účinně 47 \%. Z 52 mladších nemocných je účinně antikoagulováno 25 pacientů (48 \%).

Z 52 starších nemocných je účinně antikoagulováno 24 pacientů (46\%), rozdíl není statisticky významný $p=0,98$ ( $\chi^{2}$ test). Dále byly sledovány další faktory úspěšnosti léčby a klinická data (četnosti rehospitalizací, intervalů kontrol INR, významných krvácení (5×) a cévních mozkových příhod /4× ischemická, 1× hemoragická/).

Závěr: Podíl trvale správně antikoagulovaných nemocných činí zhruba $47 \%$ napříč celým věkovým spektrem, neplatí hypotéza o horší léčbě u starších nemocných. (Práce však nezahrnuje ty nemocné, kterým $z$ důvodů polymorbidity nebyl warfarin podán vůbec!)

Procento závažných komplikací je relativně nízké.

\section{VASKULITIDY A KORONÁRNÍ POSTIŽENÍ}

HOFÍREK I, LITZMAN J, FEITOVÁ V, GROCH L, ŘEHÁK Z, ŠÁRNÍK S, ROTNÁGL J

\section{I. interní-kardioangiologická klinika, FN u sv. Anny, Brno}

Zánětlivá autoimunní onemocnění cév, vaskulitidy, mohou postihovat rưzné části cévního systému, včetně předpokládaného častějšího postižení koronárních tepen. To je specifické u Kawasakiho artritidy. Uvádí se u vaskulitid velkých tepen, Takayasu a velkobuněčné artritidy, ale může se objevit i u jiných typů. Postižení se může manifestovat jako infarkt myokardu, někdy němým, zejména u mladších jedinců s fyziologickým obrazem na koronarogramu. Podobně se předpokládá častější cévní a koronární postižení u pacientů $\mathrm{s}$ vrozenou agamaglobulinemií a chyběním ochranného působení imunoglobulinů proti ateroskleróze.

Práce předkládá klinické zkušenosti s pacienty s vaskulitidami různého typu (48 osob) a s jednotlivými př́ipady se segmentálním postižením myokardu, včetně případů s fyziologickým koronarogramem. V klinické praxi se zatím v další diagnostice uplatňovaly klinické zkušenosti, echokardiografická vyšetření, imunologie a v dalších krocích částečně angiografie MR a PET, které s vývojem nových technologií postupně nabývají na významu.

Ve skupině pacientů s vaskulitidami (48 osob) byly segmentální poruchy kinetiky myokardu nalezeny u 3 pacientů, 2 případy velkobuněčných artritid a $1 \times$ mikroskopická polyangiitida. Koronarograficky maximálně s nespecifickým změnami do $40 \%$.

Pilotně se předkládá srovnání $\mathrm{s}$ pacienty $\mathrm{s}$ dědičnou agamaglobulinemií, kde ve skupině 10 pacientů nebyly nalezeny specifické známky cévního nebo koronárního postižení

Pilotní nálezy zatím nenaznačují předpokládaný zvýšený výskyt koronárního postižení u pacientů s různými typy vaskulitid (asi s výjimkou velkobuněčných) a u pacientů $\mathrm{s}$ vrozenou agamaglobulinemií.

\section{SESTERSKÁ SEKCE}

\section{ODDĚLENÍ NEINVAZIVNÍ KARDIOLOGIE}

\section{HOFMANOVÁ G}

Oddělení ambulantních provozů,

FN Hradec Králové, Hradec Králové

V roce 2004 se Oddělení neinvazivní kardiologie FN HK nastěhovalo do nového pavilonu interních oborů. Ordinací máme sedm a součástí oddělení je i recepční pult, kde jsou registrováni a objednáváni pacienti na všechny vyšetřovací metody.

Našimi pacienty jsou ambulantní a hospitalizovaní nemocní z FN HK, z ordinací praktických lékařů z Královéhradeckého regionu i mimo něj. Oddělení neinvazivní kardiologie slouží k diagnostice kardiovaskulárních onemocnění. Provádíme zde: ultrazvukové vyšetření srdce a cév (TTE, TEE, dobutaminové ECHO), měření distálních tlaků na $\mathrm{HK}$ a DK, Holterovo monitorování EKG a TK, ergometrické vyšetření, tilt-up test.

$\mathrm{Na}$ našich ambulancích pracují 3 lékaři, 6 zdravotních sester a 1 administrativní pracovnice.

Další lékaři, kteří zde pracují, jsou z lůžkových oddělení a také ti, kteří zde absolvují odbornou stáž.

\section{POSTIŽENÍ SRDCE PR̆I PRIMÁRNÍM HYPERALDOSTERONISMU VE SROVNÁNİ S NİZKORENINOVOU A NORMORENINOVOU FORMOU ESENCIÁLNÍ HYPERTENZE*}

HOLAJ R, ZELINKA T, PETRÁK O, ŠTRAUCH B, BĚLÁČEK J, WIDIMSKÝ J

III. interní klinika, VFN a 1. LF UK, Praha

*Projekt byl podpořen grantem IGA MZČR NR/8155-5.

Cill: U nemocných s primárním hyperaldosteronismem (PHA) dochází v srdci ke zmnožení kolagenu vedoucímu k myokardiální fibróze. Pokročilejší hypertrofie a dilatace stěn či větší hmotnost levé komory (LK) ve srovnání s nemocnými s esenciální hypertenzí stejné závažnosti však nebyly echograficky prokázány. Rozdíly v hmotnosti LK byly publikovány po vyčlenění nemocných s nízkoreninovou hypertenzí (LRH) volumdependentní formou esenciální hypertenze.

Soubor a metodika: Echografickým přístrojem SONOS 5500 bylo vyšetřeno 40 nemocných s PHA, 29 nemocných s LRH a 28 nemocných s normoreninovou hypertenzí (NRH) stejné klinické závažnosti.

Tabulka k abstraktu MUDr. Holaje

\begin{tabular}{|c|c|c|c|c|}
\hline & PHA (n = 44) & LRH (n = 29) & NRH (n = 28) & ANOVA \\
\hline Věk (roky) & $58 \pm 8$ & $57 \pm 8$ & $54 \pm 6$ & NS \\
\hline Pohlaví (ženy/muži) & $15 / 29$ & $13 / 16$ & $9 / 19$ & - \\
\hline Krevní tlak (mm Hg) & $159 \pm 19 / 94 \pm 12$ & $159 \pm 11 / 100 \pm 7$ & $158 \pm 25 / 96 \pm 13$ & NS \\
\hline Trvání hypertenze (roky) & $12,0 \pm 7,5$ & $11,7 \pm 9,5$ & $15,4 \pm 10,1$ & NS \\
\hline Rozměr LK/BSA & $2,60 \pm 0,27$ & $2,60 \pm 0,28$ & $2,56 \pm 0,31$ & NS \\
\hline Relativní tlouštka stěn LK & $0,41 \pm 0,06$ & $0,42 \pm 0,07$ & $0,44 \pm 0,08$ & NS \\
\hline Hmotnost LK/BSA & $109,3 \pm 24,1$ & $110,4 \pm 27,0$ & $104,7 \pm 21,8$ & NS \\
\hline
\end{tabular}


Výsledky: Demografická data a výsledky echografických měření LK v diastole jsou shrnuty v tabulce.

Závěr: Významné rozdíly $\mathrm{v}$ echograficky měřených parametrech LK mezi nemocnými s různým mechanismem vzniku a působení arteriální hypertenze nebyly potvrzeny.

\section{ZVYŠUJÍ LÉKOVÉ STENTY DLOUHODOBOU MORTALITU? VÝSLEDKY PROSPEKTIVNÍHO REGISTRU KARDIOCENTRA LIBEREC}

HOLM F, HORÁK D, HRABOŠ V, ŠIMEK R, ŠEMBERA Z

Kardiologické oddělení, Krajská nemocnice Liberec, Liberec

Lékové stenty (DES) snižují četnost in-stent restenózy přibližně o polovinu, avšak neovlivňují následnou mortalitu ani výskyt nefatálního infarktu myokardu (IM). V posledním roce se objevily signály o vyšší incidenci pozdní trombózy DES spojené s vyšší mortalitou/IM.

Cil studie: Analýza dlouhodobých výsledků prospektivního nerandomizovaného registru pacientů $\mathrm{s}$ implantovaným sirolimovým stentem (SES).

Charakteristika souboru: 151 pacientů (66 \% mužů) s průměrným věkem 57 let bylo sledováno 22,6 (18-24) měsíců. Arteriální hypertenzi mělo $70 \%$, hyperlipidemii $48 \%$, diabetes mellitus $25 \%$, IM v anamnéze $41 \%$ a kuřáků bylo $34 \%$. Stabilní formou koronární nemoci v čase implantace trpělo $64 \%$, akutním koronárním syndromem $36 \%$ nemocných. Duální antiagregační léčba aspirinem a clopidogrelem trvala u většiny pacientů 3 měsíce, u malé části 6 měsíců.

Výsledky: Celkem bylo implantováno 184 SES, průměr implantovaných stentů na pacienta byl 1,23. Průměrný diametr stentu byl 3,06 mm s průměrnou délkou 22,2 mm. $Z$ cílových tepen byla ošetřena nejčastěji přední sestupná větev levé tepny (65\%) a pravá tepna (16 \%). Během sledovaného období byla celková mortalita $2 \%$, kardiální mortalita $\%$, avšak žádný pacient nezemřel v souvislosti s implantací DES. In-stent restenóza (ISR) se vyskytla u 2,7 \%, angiograficky ověřená in-stent trombóza (IST) u 0,7\% pacientů. Následná revaskularizace cílové léze byla provedena u 2 \% nemocných. Průměrný interval výskytu ISR/IST byl 17,3 měsíců od implantace.

Závěr: Výsledky dlouhodobého sledování pacientů s SES ukazují nízkou incidenci in-stent restenózy a trombózy.

Dlouhodobá mortalita je také velmi nízká a nebyla v žádné souvislosti s implantací lékového stentu. Omezením registru je relativně nízký počet probandů, výhodou dlouhodobé sledování neselektované populace.

\section{SESTERSKÁ SEKCE}

\section{VÝZNAM DOMÁCÍHO SLEDOVÁNÍ U IMPLATABILNÍCH KARDIOVERTERŮ-DEFIBRILÁTORŮ (ICD)}

HOLÝ F, KRÁLOVEC Š, TÁBORSKÝ M, NEUŽIL P, TREGLER M

Kardiologické oddělení, stimulační sál, Nemocnice Na Homolce, Praha

Na našem pracovišti bylo implantováno 26 ICD s možností dálkového sledování v rámci studie REFORM. Dvěma nemocným byl implantován ICD s biventrikulární stimulací, kteří jsou zařazeni ve studii HOME CARE.

Home Monitoring je systém, který přenáší na základě telemetrického přenosu získaná data $z$ ICD do pacientské jednotky. Odtud přes GSM sítě do servisního centra, kde jsou ukládána. Pokud přenesená data obsahují závažné informa- ce, například o náhlém výskytu komorových tachykardií a vydané terapii ICD (ATP nebo výboj), o vypnuté detekci přístroje ICD nebo o nepřiměřené hodnotě šokové impedance, vyrozumí neprodleně implantační centrum zprávou.

Z našich až doposud získaných výsledků vyplývá, že informační systém Home Monitoring u nemocných s ICD přináší možnost získat ihned informace o výskytu a léčbě komorových arytmií, stejně tak jako adekvátně informuje o technickém stavu přístroje.

\section{SESTERSKÁ SEKCE}

\section{DLOUHODOBÉ SLEDOVÁNÍ NEMOCNÝCH S ARYTMOGENNÍ DYSPLAZIII/KARDIOMYOPATIÍ. KASUISTIKA}

HOMOLOVÁ J, DANIŠOVÁ A

\section{Klinika kardiologie, IKEM, Praha}

Arytmogenní dysplazie/kardiomyopatie pravé komory srdeční (ARVD/C) představuje onemocnění charakterizované postižením pravé komory srdeční, které se klinicky manifestuje komorovými arytmiemi - palpitacemi, synkopou, náhlou srdeční smrtí, méně obvyklé jsou projevy pravostranného srdečního selhání.

Cílem předložené práce: Zhodnocení možností léčby nemocných sledovaných pro ARVD/C na našem pracovišti.

Soubor nemocných: Dlouhodobě sledujeme 19 nemocných (15 mužů, průměrný věk $40 \pm 12$ let) sledovaných pro diagnózu ARVD/C. Prưměrný věk při stanovení diagnózy byl 36 let (15-77 let). 23letý muž byl resuscitován pro oběhovou zástavu na podkladě fibrilace komor, u 8 nemocných se onemocnění manifestovalo synkopou, u 9 palpitacemi s dokumentovanou komorovou tachykardií, 1 nemocný byl v době stanovení diagnózy asymptomatický. Průměrná doba sledování činila 128 měsíců (12-258).

Výsledky: Ze sledovaného souboru k 1. 1. 2007 přežívá 16 nemocných. O ovlivnění arytmogenního substrátu $R F$ ablací jsme se pokusili u 13 nemocných. U 12 nemocných byl implantován kardioverter-defibrilátor pro recidivy či indukovatelnost komorových tachykardií, u 3 byly nutné opakované hospitalizace pro arytmickou bouři. Nedílnou součástí léčby našich nemocných je farmakoterapie, nejčastěji podáváme sotalol či amiodaron $\mathrm{v}$ kombinaci $\mathrm{s}$ betablokátory. Projevy pravostranné srdeční insuficience refrakterní na léčbu byly důvodem ortotopické transplantace srdce u 49letého muže.

Závěry: Diagnóza ARVD představuje pro svého nositele reálné riziko náhlé srdeční smrti, současné možnosti léčby zásadním způsobem ovlivňují kvalitu života i prognózu nemocných s nejzávažnější formou onemocnění.

\section{MONITOROVÁNÍ KARDIOTOXICITY ANTRACYKLINŮ POMOCÍ BIOCHEMICKÝCH MARKERŨ, ECHOKARDIOGRAFIE A ELEKTROKARDIOGRAFIE*}

HORÁČEK JM, PUDIL R, TICHÝ M, JEBAVÝ L, SLOVÁČEK L

II. interní klinika - Oddělení klinické hematologie, I. interní klinika, Ústav klinické biochemie a laboratorní diagnostiky, FN Hradec Králové, Hradec Králové

*Práce byla podpořena z výzkumného záměru MO OFVZ 0000503.

Cíl: Hodnocení kardiotoxicity antracyklinů (ANT) pomocí 3 diagnostických metod - biochemických markerů - N-terminálního pro brain natriuretického peptidu (NT-proBNP), 
Tabulka

Abnormální kardiální nálezy při léčbě antracykliny $(\mathrm{n}=26)$

\begin{tabular}{|c|c|c|c|c|}
\hline Abnormální kardiální nálezy & Před CHT & Po 1. CHT & Po posledni CHT & 1/2 R po CHT \\
\hline Elevace NT-proBNP & $3(11,5 \%)$ & $23(88,5 \%)$ & $23(88,5 \%)$ & $16(61,5 \%)$ \\
\hline Pozitivní cTnT & 0 & 0 & 0 & $3(11,5 \%)$ \\
\hline Porucha systolické funkce LK & 0 & $1(3,8 \%)$ & $1(3,8 \%)$ & $2(7,7 \%)$ \\
\hline Porucha diastolické funkce LK & $1(3,8 \%)$ & $5(19,2 \%)$ & $6(23,1 \%)$ & $12(46,2 \%)$ \\
\hline Prodloužení QTc intervalu & $1(3,8 \%)$ & $3(11,5 \%)$ & $7(26,9 \%)$ & $9(34,6 \%)$ \\
\hline Snížení voltáže QRS & - & $3(11,5 \%)$ & $5(19,2 \%)$ & $6(23,1 \%)$ \\
\hline
\end{tabular}

Elevace NT-proBNP - NT-proBNP nad $100 \mathrm{pg} / \mathrm{ml}$ pro muže, nad $150 \mathrm{pg} / \mathrm{ml}$ pro ženy, pozitivní cTnT - cTnT nad 0,01 ng/ml, porucha systolické funkce LK - EF pod 55 \%, porucha diastolické funkce LK - inverze E/A, DT nad 220 ms, prodloužení QTc intervalu - QTc nad 440 ms, snížení voltáže QRS - snížení úhrnné voltáže komplexu QRS v končetinových svodech o více než 1,0 mV oproti před CHT

kardiálního troponinu T (cTnT); echokardiografie (ECHO) a elektrokardiografie (EKG).

Soubor a metodika: Ve studii bylo 26 pacientů léčených pro akutní leukemii (průměrný věk 46,2 \pm 12,4 let, 15 mužů, 11 žen), kteří byli léčeni chemoterapií (CHT) s ANT. Kardiální vyšetření bylo provedeno vstupně (před CHT), po první CHT (po 1. CHT) - kumulativní dávka ANT 136,3 $\pm 28,3$ $\mathrm{mg} / \mathrm{m}^{2}$, po poslední CHT (po posl. CHT) - kumulativní dávka ANT $464,3 \pm 117,5 \mathrm{mg} / \mathrm{m}^{2}$ a s odstupem 6 měsíců po ukončení léčby (1/2 R po CHT).

Výsledky: Výsledky jsou přehledně shrnuty $\mathrm{v}$ tabulce.

Šest měsíců po léčbě koncentrace NT-proBNP korelovaly se systolickou a diastolickou dysfunkcí LK na ECHO $(\mathrm{r}=0,514 ; p<0,01)$ a $(\mathrm{r}=0,587 ; p<0,01)$. Snížená voltáž QRS na EKG korelovala se systolickou a diastolickou dysfunkcí LK na ECHO ( $\mathrm{r}=0,660 ; p<0,001)$ a $(\mathrm{r}=0,592$; $p<0,01)$.

Závěry: Naše výsledky ukazují výskyt akutní a chronické kardiotoxicity ANT. Klinická manifestace kardiotoxicity ve smyslu srdečního selhání se rozvinula u 2 (7,7\%) pacientů. U asymptomatických pacientů abnormální kardiální nálezy (elevace NT-proBNP, diastolická dysfunkce LK, prodloužení intervalu QTc) naznačují subklinickou kardiotoxicitu, což představuje riziko pro rozvoj srdečního selhání a maligních komorových arytmií $\mathrm{v}$ budoucnosti. Vzhledem $\mathrm{k}$ riziku pozdní kardiotoxicity ANT je další kardiologické sledování nezbytné $\mathrm{u}$ všech pacientů po prodělané CHT $\mathrm{s}$ ANT.

\section{TRANSPLANTACE KRVETVORNÝCH BUNĚK PRO HEMATOLOGICKÉ ONEMOCNËNÍ A JEJÍ VLIV NA KREVNÍ TLAK A TEPOVOU FREKVENCI}

HORÁČEK JM, JEBAVÝ L, JAKL M, SLOVÁČEK L, PÁSTOROVÁ J

II. interní klinika - Oddělení klinické hematologie, Klinika gerontologická a metabolická, FN Hradec Králové, Hradec Králové

Cíl: Sledování změn krevního tlaku (TK) a tepové frekvence (TF) při převodu štěpu krvetvorných buněk a posouzení vlivu kryokonzervační látky ve štěpu - dimethylsulfoxidu (DMSO).

Soubor a metodika: Do studie bylo zařazeno 153 pacientů (průměrný věk 49,1 $\pm 12,6$ let, 80 mužů, 73 žen), kteří podstoupili transplantaci krvetvorných buněk (TKB) pro hematologické onemocnění ve FN Hradec Králové v letech 2003-2005. Ve 133 prrípadech byla použita kryokonzervace štěpu pomocí DMSO, zbylých 20 převodů bylo bez kryokonzervace. Ve 115 případech se jednalo o autologní TKB, ve 38 př́ipadech o alogenní TKB. Systolický TK (STK), diastolický TK (DTK) a TF byly u obou skupin měřeny bezprostředně před podáním štěpu krvetvorných buněk a po podání.

Výsledky: Ve skupině s použitím DMSO vzrostla průměrná hodnota STK ze 122,3 $\pm 17,9$ mm Hg na $127,7 \pm 18,1$ mm Hg $(p<0,0001)$. Průměrná hodnota DTK během podávání štěpu vzrostla ze $70,9 \pm 12,3 \mathrm{~mm} \mathrm{Hg}$ na $74,1 \pm 12,6$ $\mathrm{mm} \mathrm{Hg}(p<0,01)$. Průměrná hodnota TF vzrostla pouze nesignifikantně. Ve skupině bez použití DMSO byly změny STK, DTK i TF během podávání štěpu pouze nevýznamné. Při použití DMSO vykazovaly změny STK a TF závislost na dávce DMSO, nárůst byl od dávky $0,8 \mathrm{~g} / \mathrm{kg}$ tělesné hmotnosti signifikantně vyšší oproti dávkám nižším $(p<0,01$ a $p<0,05)$. Změny ve skupině léčených hypertoniků a ostatních pacientů nebyly statisticky významně odlišné.

Závěry: Podání štěpu krvetvorných buněk obsahujícího DMSO vede ke statisticky významnému vzestupu STK a DTK. Změna TF statisticky významná není. Změny STK a TF jsou závislé na dávce podaného DMSO. Změny sledovaných parametrů bývají zpravidla přechodné a asymptomatické a nevyžadují léčebnou intervenci. Mohou však být příčinou komplikací, obzvláště u pacientů s preexistujícím kardiovaskulárním onemocněním. Těmto pacientům by měla být věnována zvýšená pozornost a jejich stav před TKB dostatečně kompenzován.

\section{VÝSKYT CÉVNÍCH KOMPLIKACÍ U PACIENTŮ TRANSPORTOVANÝCH NA VZDÁLENÉ KARDIOCHIRURGICKÉ PRACOVIŠTĚ SE ZAVEDENOU INTRAAORTÁLNÍ BALONKOVOU KONTRAPULSACÍ}

HORÁK D, HOLM F, HRABOŠ V, POLÁŠEK R, TELEKES P, ŠEMBERA $Z$

Kardiologické oddělení, Kardiocentrum, Krajská nemocnice Liberec, Liberec

Intraaortální balonková kontrapulsace (IABK) je zavedenou a efektivní metodou podpory selhávajícího oběhu. $V$ našem kardiocentru, kde nemáme $\mathrm{k}$ dispozici místní kardiochirurgické pracoviště, jsme někdy nuceni transportovat pacienty se zavedenou IABK.

Cíl: Zjistit, zda pacienti indikovaní ke kardiochirurgické intervenci transportovaní na vzdálené kardiochirurgické pracoviště se zavedenou IABK mají více cévních komplikací než pacienti s IABK bez transportu.

Metody: Retrospektivní analýza registru pacientů u kterých byla použita IABK. Porovnání specifických komplikací mezi skupinou pacientů transportovaných na kardiochirurgické pracoviště proti skupině pacientů bez transportu. Sledován byl výskyt cévních komplikací vyžadujících chirurgickou intervenci nebo vedoucích $\mathrm{k}$ ohrožení či ztrátě dolní končetiny.

Výsledky: Od 22. 12. 2004 do 13. 11. 2006 (22,7 měsíce) byla pro podporu oběhu na našem oddělení použita IABK celkem u 67 pacientů. $Z$ tohoto počtu bylo se zavedenou IABK transportováno celkem 18 (27\%) pacientů na vzdálené kardiochirurgické pracoviště. Všichni transportovaní pacienti transport přežili. Během transportu nebyla zazname- 
nána žádná akutní cévní komplikace (krvácení či akutní končetinová ischemie). Cévní komplikace byla zaznamenána u 1 pacienta transportovaného na chirurgické oddělení (6\%). Incidence cévních komplikací u pacientů bez transportu (celkem 49 pacientů, $73 \%$ z celkového počtu) byla 3 (6 \%). U všech pacientů byla cévní komplikace vyřešena uspokojivě, žádný z pacientů neutrpěl ztrátu končetiny.

Závěr: IABK je účinnou metodou podpory oběhu a perfuze myokardu, která je použitelná i během transportu pacientů na vzdálené pracoviště. Neprokazujeme vyšší počet cévních komplikací u pacientů s IABK transportovaných na vzdálené pracoviště ve srovnáních $\mathrm{s}$ pacienty bez transportu.

\section{UZÁVĔR MÍSTA PUNKCE A. SUBCLAVIA SYSTÉMEM ANGIOSEAL U NEMOCNÉHO S KOMBINOVANOU ANTIKOAGULAČNÍ A ANTIAGREGAČNÍ LÉČBOU}

HORÁK D, HRABOŠ V

\section{Kardiologické oddělení, Krajská nemocnice Liberec, Liberec}

K uzávěru místa punkce femorální arterie po koronární intervenci lze použít, kromě manuální/mechanické komprese, několik systémů (AngioSeal, VasoSeal, Perclose), které $\mathrm{v}$ randomizovaných studiích snižovaly dyskomfort nemocných a umožnily jejich rychlejší mobilizaci bez ovlivnění četnosti periferních vaskulárních komplikací.

Na našem pracovišti máme největší zkušenost s platformou AngioSeal (St. Jude Medical), založenou primárně na mechanickém principu uzávěru místa punkce mezi dvě biodegradabilní komponenty, tvořené kotvou a kolagenovou zátkou. Ačkoliv tento cévní systém je určen pro cévní uzávěr a. femoralis po koronární intervenci, demonstrujeme možnost jeho využití $\mathrm{k}$ uzávěru $\mathrm{a}$. subclavia $\mathrm{u}$ nemocného s kombinovanou antitrombotickou a antiagregační léčbou.

69letý muž byl na koronární jednotku (KJ) přijat po kardiopulmonální resuscitaci pro komorovou fibrilaci v rámci akutního infarktu myokardu s elevacemi ST. Pacientovi při kanylaci centrální žíly byl zaveden 8,5 F centrální žilní katetr do pravé arteria subclavia. Nemocný byl na kombinované antiagregační (ASA + clopidogrel) a antikoakulační léčbě heparinem. Vzhledem k nemožnosti komprese a. subclavia jsme se po dohodě $\mathrm{s}$ cévním chirurgem rozhodli uzavřít podklíčkovou tepnu $8 \mathrm{~F}$ systémem AngioSeal. Výkon i další průběh hospitalizace proběhl bez jakýchkoli krvácivých komplikací.

Uvedená kasuistika demonstruje úspěšné použití systému AngioSeal k uzávěru místa punkce a. subclavia u rizikového nemocného na kombinované antiagregační antikoagulační terapii. Podle našeho názoru představuje použití AngioSealu v této indikaci bezpečnou alternativu chirurgického řešení.

\section{KLINICKÉ POUŽITÍ KMENOVÝCH BUNĚK KOSTNÍ DR̆ENĚ PO AKUTNÍM INFARKTU MYOKARDU. PR̆EDČASNĔ UKONČENÁ STUDIE*}

HORÁK J, PĚNIČKA M, KOBYLKA P, PYTLÍK R, KOZÁK T, BĚLOHLÁVEK O, LANG O, SKALICKÁ H, LINHART A, WIDIMSKÝ P

\section{II. interní klinika, VFN a 1. LF UK,}

III. interní-kardiologická klinika, FN KV a 3. LF UK, Oddělení buněčné terapie, Ústav klinické

a experimentální hematologie,

I. interní klinika, VFN a 1. LF UK,

Oddělení klinické hematologie, FN KV a 3. LF UK,

Oddělení nukleární medicíny, Nemocnice Na Homolce,
Oddělení nukleární medicíny, III. interní-kardiologická klinika, FN KV a 3. LF UK, Praha

*Podpořeno grantem IGA MZ ČR č. 8225-3/2004.

Cíle: I přes široce rozšířené použití efektivních reperfuzních léčebných metod, pacienti s rozsáhlým akutním infarktem myokardu (AIM), kteří přicházejí k léčbě pozdě, mají špatnou prognózu. Studie sledovala bezpečnost a efektivitu intrakoronární (i. c.) aplikace kmenových buněk kostní dřeně $(\mathrm{KB}) \mathrm{u}$ této skupiny nemocných.

Metodika: 27 pacientů s velkým AIM přední stěny (věk $59 \pm 12$ let, 81 \% mužů), léčených koronární angioplastikou (PCI) s implantací stentu za 4 a více hodin po začátku symptomů a významnou následnou dysfunkcí LK (průměrná ejekční frakce $39 \pm 6$ \%) bylo randomizováno bud' k i. c. aplikaci BMC za 4-11 dní po příhodě ( $\mathrm{n}=17$, skupina /sk/ A) nebo ke standardní medikamentózní léčbě ( $\mathrm{n}=10$, sk B). Klinický stav, funkce LK echokardiograficky a velikost infarktového ložiska pomocí perfuzní scintigrafie myokardu byly zhodnoceny při propuštění a za 4 měsíce po příhodě, kdy byla provedena i kontrolní koronární angiografie.

Výsledky: U 3 nemocných ve skupině A došlo $\mathrm{k}$ závažným komplikacím, které vedly $\mathrm{k}$ jejich úmrtí, $\mathrm{z}$ toho jedna byla $\mathrm{v}$ přímé souvislosti s odběrem KB. Restenóza byla detekována u 2 nemocných v každé skupině. EF LK stoupla srovnatelně v obou skupinách $(+6 \%$ ve sk $\mathrm{A},+8 \%$ ve sk B, NS). Nebyl žádný rozdíl ve změně konečného diastolického objemu LK (+ $9 \mathrm{ml}$ ve sk $\mathrm{A},+12 \mathrm{ml}$ ve sk B, NS), konečného systolického objemu LK ( $\mathrm{z}-2 \mathrm{ml} \mathrm{v}$ obou skupinách) či indexu pohyblivosti stěny LK (pokles o $12,8 \%$ ve sk A, o 7,4 \% ve sk B, NS). Velikost infarktového ložiska poklesla v obou skupinách stejně (o 26,3 \% a 25,7\%, NS).

Závěr: U pacientů $\mathrm{s}$ velkým AIM a opožděnou reperfuzí došlo ke zlepšení funkce LK po PCI, žádný aditivní efekt i. c. aplikace KB na funkci LK či parametry její remodelace však nebyl detekován. Odběr KB u této skupiny nemocných může být navíc provázen vážnými komplikacemi. Studie byla proto předčasně ukončena.

\section{TROMBÓZA AORTÁLNÍ NÁHRADY KOMPLIKOVANÁ EMBOLIZACÍ DO CNS, DIAGNOSTIKA, TERAPIE. KASUISTIKA*}

HORÁKOVÁ L, VOJÁČEK J, PUDIL R, SOLAŘ M, MĚŠŤAN M, RAUPACH J

Kardiologické oddělení, FN Hradec Králové a LF UK, Hradec Králové

*Podpořeno granty MSMO021620817 a MZO 00179906.

Trombóza chlopenní náhrady patří mezi závažné komplikace, které mohou ohrozit pacienta na životě.

Autoři prezentují případ 55leté ženy, u které došlo 1 měsíc po implantaci aortální náhrady typu St. Jude Medical ke vzniku trombózy (v důsledku změny účinnosti antikoagulační terapie jiným onemocněním a jeho medikamentózní terapií). Diagnóza byla potvrzena echokardiograficky (TEE) a skiaskopicky. Pacientka byla léčena heparinem a následně trombolyticky. V průběhu trombolytické léčby došlo ke vzniku pravostranné hemiparézy a expresivní afázie. Bezprostředně provedené CT mozku prokázalo emboligenní uzávěr v povodí a. cerebri media 1. sin., který byl bezprostředně odstraněn použitím mechanického extrakčního zařízení za angiografické kontroly. Pacientka zůstala bez neurologického deficitu.

Uveřejněním kasuistiky autoři chtějí poukázat na: (1) velmi pečlivé sledování účinnosti antikoagulační terapie 
u pacientů s mechanickými chlopenními náhradami a všech faktorů, které ji mohou ovlivnit, (2) možnosti diagnostiky a terapie této komplikace a (3) způsob diagnostiky a terapie emboligenních komplikací do CNS.

\section{SESTERSKÁ SEKCE}

\section{OŠETŘOVÁNÍ PACIENTA S DIAGNÓZOU PLICNÍ EMBOLIE. KASUISTIKA}

\section{HORÁLKOVÁ E}

III. interní klinika, koronární jednotka, VFN a 1. LF UK, Praha

Cílem přednášky je seznámit s případem 21letého muže, přijatého na naší koronární jednotku $\mathrm{s}$ diagnózou plicní embolie, která se potvrdila pomocí CT angiografie. Vyvolávající příčinou byla fyzická zátěž, ale zdroj embolizace nebyl zjištěn. Indikováno bylo včasné podání trombolýzy, které proběhlo bez komplikací. Po překladu na standardní oddělení se plicní embolie zopakovala a opakované podání trombolýzy bylo nezbytné.

V přednášce bude popsán průběh hospitalizace i následný opakovaný překlad pacienta na standardní oddělení a následné propuštění domů.

\section{DROGY A KARDIOVASKULÁRNÍ ONEMOCNËNÍ*}

HORKÝ K

II. interní klinika kardiologie a angiologie, VFN a 1. LF UK, Praha

*Práce podpořena výzkumným záměrem MZO 000064165.

Cíl: Upozornit na negativní dopady abúzu psychotropních látek na vývoj kardiovaskulárních onemocnění.

Klinické přiznaky: Pro kardiovaskulární aparát mají nejzávažnější účinky kokain, amfetamin, metamfetamin (pervitin) nebo jejich substituované deriváty (extáze). Blokáda zpětného vychytávání katecholaminů v synaptické štěrbině zvyšuje dostupnost volných katecholaminů pro jejich vazbu na receptory. To vede $\mathrm{k}$ psychomotorickému neklidu, hypertermii, křečím až poruchám vědomí. V oblasti kardiovaskulární navozují tachykardii, vzestup krevního tlaku až těžké hypertenzní krize s možným vznikem cévních mozkových příhod. Napomáhají tomu endoteliální dysfunkce, urychlený rozvoj aterosklerózy, zvýšená pohotovost k tvorbě trombu, drogami indukovaná zánětlivá vaskulitida. Dalšími kardiovaskulárními projevy předávkování mohou být stenokardie, ischemie až infarkt myokardu, komorové tachykardie, náhlá kardiální smrt ( $2 \%)$. Známé jsou rovněž bakteriální a mykotické endokarditidy u aplikací i. v. nebo aortální disekce při prudkém vzestupu TK. Chronický abúzus bývá provázen dilatační kardiomyopatií s následným srdečním selháním.

Léčba akutních kardiovaskulárních účinků psychotropních drog spočívá ve zrušení vazokonstrikčního efektu podáním alfa agonisty fentolaminu, dále lze užít verapamil a nitroglycerin. Naopak betablokátory vazokonstrikci podporují. Labetalol s alfa- i betalytickým účinkem snižuje kokainem vyvolanou hypertenzi, ale neovlivňuje koronární vazokonstrikci.

Závěry: Na projevy kardiovaskulárních a cerebrovaskulárních komplikací abúzu psychotropních látek nutno častější pomýšlet především u mladších osob bez kardiovaskulárních rizikových faktorů a bez delší KV anamnézy. Somatické komplikace abúzu drog vyžadují specifickou terapii s navazující odvykací léčbou.

\section{RESYNCHRONIZAČNÍ LÉČBA U NEMOCNÝCH S POKROČILY̌M SRDEČNIIM SELHÁNÍM. DLOUHODOBÉ KLINICKÉ SLEDOVÁNÍ}

HOŠKOVÁ L, MÁLEK I, RIEDLBAUCHOVÁ L, MAREK T, BYTEŠNÍK J, KAUTZNER J

Klinika kardiologie, IKEM, Praha

Srdeční resynchronizační léčba (CRT) přispívá ke zlepšení symptomů a tolerance zátěže u nemocných s chronickým srdečním selháním (CHSI), u nichž obtíže trvají i při optimální farmakologické léčbě.

Cílem práce: Posoudit klinický efekt CRT v průběhu 2,7-6,5 let po implantaci.

Metodika: Hodnotili jsme soubor 94 pacientů s pokročilým CHSI (46 DKMP, 45 ICHS a 3 RCHS), kterým byl v letech 2000-2004 implantován biventrikulární kardiostimulátor.

Před implantací byli všichni nemocní ve funkční třídě NYHA III. st., s těžkou dysfunkcí LK (EF 22,5 $\pm 3,6 \%$ ), EDD LK 75,6 \pm 8,3 mm, mitrální regurgitací 3,5 \pm 0,6 st., nízkou tolerancí zátěže $\left(\mathrm{VO}_{2} \max .12,5 \pm 2,8 \mathrm{ml} / \mathrm{kg} / \mathrm{min}\right)$ a šíří komplexu QRS $180 \pm 20,1 \mathrm{msec}$. Soubor jsme rozdělili podle enddiastolického rozměru levé komory (EDD LK) na skupinu I: EDD LK < 76 mm (n = 46) a skupinu II: EDD LK $\geq 76 \mathrm{~mm}(\mathrm{n}=48)$.

Ke statistickému zpracování byla použita analýza rozptylu (ANOVA) s opakováním, párový $t$-test a dvouvýběrový $t$-test.

Výsledky: V obou skupinách došlo ke zlepšení NYHA třídy po 12 měsících $(p<0,01)$ o $0,76 \pm 0,43$ st. ve sk. I a o $0,5 \pm 0,54$ st. ve sk. II. EF LK ve sk. I vzrostla po 12 měs. o $5 \%(p<0,05)$. MiR statisticky významně poklesla po 12 měs. ve sk. I $(p<0,05)$ z $2,9 \pm 0,8$ st. na $2,5 \pm 0,6$ st. a $\mathrm{VO}_{2}$ max. vzrostla po 12 měs. ve sk. I o $2,43 \mathrm{ml} / \mathrm{kg} / \mathrm{min}$ $(p<0,05)$. Ve sk. II se sledované parametry nezlepšily. Nepříznivý průběh onemocnění se projevil u $51 \%$ nemocných, ve sk. II zemřeli 4 nemocní a 7 podstoupilo Tx srdce za 0,9-1,6 měs. po implantaci, ve sk. I zemřel 1 a 2 nemocní podstoupili Tx srdce za 0,9-1,6 let.

Závěr: Dlouhodobý klinicky příznivý efekt resynchronizační léčby jsme zaznamenali u $49 \%$ nemocných našeho souboru. Ke zlepšení tř́idy NYHA došlo u všech nemocných, avšak pouze ve skupině $\mathrm{s}$ méně výraznou dilatací LK bylo dosaženo příznivé reverzní remodelace LK. CRT umožnila u $10 \%$ pacientů překlenout období k transplantaci srdce.

\section{SESTERSKÁ SEKCE}

\section{ECHOKARDIOGRAFIE U STRUKTURÁLNÍCH KOMPLIKACÍ INFEKČNÍ ENDOKARDITIDY}

\section{HOŠKOVÁ V, MAREK T}

Klinika kardiologie, IKEM, Praha

I v éře rozvinuté antibiotické léčby zůstává infekční endokarditida onemocněním $\mathrm{s}$ vysokým rizikem závažných komplikací, včetně úmrtí. Jedním $z$ dưvodů je obtížnost či dokonce nemožnost spolehlivé časné diagnostiky s následnou cílenou antibiotickou léčbou. Neexistuje rychlý a jednoduchý diagnostický test. Infekční endokarditida je především klinická diagnóza. Echokardiografie má však důležité postavení: 1. identifikuje predisponující strukturální vady a umožňuje následnou ATB prevenci, 2. má klíčovou roli v diagnostice, 3. detekuje komplikace, 4. hodnotí hemodynamické následky, 5. posuzuje vývoj strukturálních změn při terapii, tedy hodnotí efekt léčby, 6. pomáhá při stanovení prognózy. 
V klinické praxi se stále setkáváme s řadou závažných komplikací: destrukce chlopní, vznik annulárních abscesů, vznik píštělí, purulentní perikarditidy, embolizace vegetací. Destrukce jsou typické pro stafylokokové infekce, které se vyskytují u oslabených pacientů nebo u narkomanů. Nálezy si často vynutí rozsáhlé rekonstrukční výkony annulư a okolí s náhradou chlopní. Recidivy infekcí jsou časté a mohou končit i úmrtím pacientů. V přednášce budeme prezentovat několik kasuistik rozsáhlých destrukcí kořene aorty, mitrální chlopně či srdečního křižèe.

\section{JAK SE V ČR MĚNÍ KLINICKÝ OBRAZ A LÉČBA STABILNÍ ANGINY PECTORIS}

HRADEC J, SACHOVÁ M

III. interní klinika, VFN a 1. LF UK, Praha

Úvod a metodika: V roce 2001 byl v ČR proveden průzkum ATP (Angina Treatment Patterns Survey), který přinesl informace o stavu diagnostiky a léčby nemocných se stabilní anginou pectoris (AP) v ČR. V roce 2006 byl proveden podobný průzkum ATP III. Zúčastnilo se ho 1308 ambulantních nemocných se stabilní AP. Výsledky obou průzkumů byly porovnány.

Výsledky: Co se za posledních 5 let, od roku 2001 do roku 2006 změnilo:

1. Nemocní s AP byli v průměru o 2 roky starší (69 \pm 10 vs. $67 \pm 9$ roků).

2. Zvýšily se jejich průměrné hodnoty krevního tlaku $(139 \pm 15 / 83 \pm 9$ vs. $136 \pm 15 / 81 \pm 8$ mm Hg) a přibylo hypertoniků (83 vs. $71 \%$ )

3. Zvýšil se počet nemocných s dyslipidemií (78 vs. $66 \%$ ), ale průměrné plazmatické koncentrace celkového i LDL-cholesterolu se snížily $(5,1 \pm 1,3$ vs. $5,6 \pm 0,9 \mathrm{mmol} / 1$ a $3,1 \pm 0,9$ vs. $3,4 \pm 1,0 \mathrm{mmol} / \mathrm{l})$.

4. Výrazně se zvýšil počet nemocných, kteří prodělali infarkt myokardu (49,6 vs. 33,0 \%) a také těch, kteří byli vyšetřeni koronarograficky (55,2 vs. 16,3\%).

5. Velmi dramaticky se změnila léčba. Počet nemocných, kteři byli léčeni invazivně, se více než zdvojnásobil (56,0 vs. 24,4 \%), především zásluhou PCI (39,7 vs. $13,3 \%)$.

6. Významné změny nastaly i ve farmakoterapii. Zvýšil se počet nemocných léčených betablokátory (79,7 vs. $64,4 \%$ ) a snížil počet nemocných léčených nitráty (65,9 vs. 82,8 \%). Významně se zvýšilo uživání hypolipidemik (82,4 vs. 57,0 \%), mezi nimiž naprosto převládly statiny (93,3 vs. $61,9 \%$ ). Častěji se užívají inhibitory ACE (60,7 vs. 54,8 \%), více nemocných je na perorálních antikoagulanciích (12,5 vs. 4,2\%). Dosti významně se změnilo spektrum používaných přípravků a je zřetelná tendence $\mathrm{k}$ používání vyšších denních dávek.

Závěr: Za posledních 5 let se v ČR významně zvýšil rizikový profil nemocných se stabilní AP. Zdvojnásobil se počet nemocných léčených invazivně a významně se zlepšila i medikamentózní léčba.

\section{VÝZNAM STANOVENÍ NT-prOBNP V DIFERENCIÁLNÍ DIAGNOSTICE DUŠNOSTI}

\section{HRDLIČKA M, BRABEC T, MACEK P}

Interní oddělení, FN Brno, Brno

Cíl: Posouzení významu stanovení NT-proBNP v diferenciální diagnostice dušnosti u pacientů přijímaných na interní oddělení.
Soubor a metodika: Na OKL FN Brno bylo v období od dubna do září 2006 stanoveno NT-proBNP u 425 pacientů. Následně byla provedena analýza 73 pacientů (41 mužů, 32 žen), u nichž bylo v návaznosti provedeno echokardiografické vyšetření.

Pro hodnocení jsme vybrali několik parametrů:

- hladiny NT-proBNP u systolické dysfunkce

levé komory,

- hladiny NT-proBNP u izolované diastolické dysfunkce levé komory,

- vztah hladin NT-proBNP a klasifikace NYHA,

- pokles hladin NT-proBNP při léčbě srdečního selhání,

- hladiny NT-proBNP u pacientů bez dysfunkce

levé komory.

Dále byla provedena stratifikace pacientů podle hodnot NT-proBNP a sledování jejich dalšího osudu po propuštění $z$ nemocnice.

Výsledky:

1. sledování jednoznačně prokázalo nepřímou úměrnost mezi nárůstem NT-proBNP a velikostí ejekční frakce,

2. taktéž izolovaná diastolická dysfunkce levé komory je provázena vzestupem hodnot NT-proBNP, i když zde není nárůst tak markantní, jako tomu je u poruchy funkce systolické,

3. hodnota NT-proBNP narůstá úměrně se stupněm klasifikace NYHA,

4. po nasazení účinné léčby srdečního selhání významně klesá hodnota NT-proBNP při kontrolním vyšetření,

5. velmi nízké hodnoty NT-proBNP u dušnosti bez prokázané systolické či diastolické dysfunkce levé komory (extrakardiální etiologie).

Závěr: Hlavní přínos stanovení NT-proBNP: rychlá diferenciální diagnostika dušnosti kardiální a nekardiální etiologie, monitorování účinnosti terapie srdečního selhání.

\section{BEZPEČNOST A ÚČINNOST KOMBINACE SIROLIMU A MYKOFENOLÁTU MOFETILU U PACIENTŮ V POZDĚJŠÍM OBDOBÍ PO TRANSPLANTACI SRDCE S RENÁLNÍ DYSFUNKCÍ}

HUDE P, ŠPINAROVÁ L, KREJČÍ J, PAVELČÍKOVÁ H, ČERNÝ J, SIROTKOVÁ A

I. interní-kardioangiologická klinika, FN u sv. Anny, CKTCH, Patologicko-anatomický ústav, FN u sv. Anny, Brno

Úvod: Na vzniku či progresi renální dysfunkce po transplantaci srdce (HTx) se podílí podávání kalcineurinových inhibitorů (CNI).

Cil: Zhodnotit bezpečnost a účinnost imunosupresivního režimu bez CNI (sirolimus + mykofenolát mofetil /MMF/) $\mathrm{u}$ pacientů $\mathrm{v}$ pozdějším období po HTx s chronickou renální dysfunkcí.

Soubor a metodika: Od 5/2004 do $12 / 2006$ jsme převedli 17 pacientů (15 mužů, 2 ženy) po HTx z cyklosporinu A nebo tacrolimu na sirolimus. Průměrný věk pacientů v době převodu byl 57,4 $\pm 8,0$ roku. Průměrná doba od transplantace byla $6,8 \pm 2,5$ roku a vstupním kritériem hladina sérového kreatininu > $150 \mu \mathrm{mol} / 1$. Před změnou imunosuprese, $\mathrm{v}$ průběhu a po roce jsme sledovali laboratorní testy, echokardiografické parametry, EMB. Jako startovací dávku jsme zahájili $6 \mathrm{mg}$ sirolimu, od druhého dne $2 \mathrm{mg}$ a dále podle aktuálních koncentrací sirolimu, které jsme udržovali v rozmezí 5-9 ng/ml. První den byla dávka CNI 
snížena na polovinu a druhý den byl CNI vysazen. Hladiny MMF udržovány 1,5-4,0 mg/1.

Výsledky: Provedené EMB na počátku i po 1 roce sledování byly u všech pacientů bez známek rejekce (grade 0 nebo IA). Rozdíl echokardiograficky stanovené EF LK před konverzí a po roce sledování byl statisticky nevýznamný $58,2 \pm 4,6 \%$ vs. $58,4 \pm 2,7 \%$ ( $p=$ NS).

$\mathrm{V}$ průběhu 1 roku došlo $\mathrm{k}$ významnému poklesu hladiny sérového kreatininu $\mathrm{z}$ 190,5 \pm 41,3 $\mu \mathrm{mol} / \mathrm{l}$ na $162,8 \pm 57,1 \mu \mathrm{mol} / 1(p<0,01)$. Glomerulární filtrace (GFR) neprokázala signifikantní zlepšení z $0,72 \pm 0,21 \mathrm{ml} / \mathrm{s}$ na $0,88 \pm 0,32 \mathrm{ml} / \mathrm{s}(p=0,2)$. Roční sledování nedokončilo 5 pacientů. 2 pacienti zemřeli - malignita $(\mathrm{n}=1)$ a infekce $(\mathrm{n}=1) .3$ pacienti byli pro nežádoucí účinky převedeni na původní CNI.

Závěr: Naše výsledky prokázaly bezpečnost a účinnost imunosupresivního režimu bez CNI u pacientů v pozdějším období po HTx s chronickou renální dysfunkcí. Jako každý imunosupresivní režim má i tato kombinace imunosupresiv nežádoucí účinky.

\section{TAKO-TSUBO KARDIOMYOPATIE}

\section{HUDEC M, NYKL I, ŠKŇOUŘIL L, BRANNY M}

Kardiologické oddělení,

Nemocnice Podlesí a. s., Třinec

Cíl: Kasuisticky prezentovat př́ípad nemocné s „Tako-tsubo“ kardiomyopatií.

Popis: Pacientka byla přijata na kardiologické oddělení k akutní koronarografii pod obrazem koronárního syndro$\mathrm{mu}-\mathrm{s}$ bolestmi na hrudi a s naznačenými elevacemi ST ve svodech I, aVL, V5-V6.

Tyto obtíže začaly po psychickém rozrušení, konkrétně po úmrtí matky pacientky.

Koronarograficky byl zjištěn prakticky negativní koronarogram, ventrikulograficky akineze hrotové oblasti levé komory srdeční „balonovitého charakteru“ a hyperkineze bazálních oblastí s EF kolem 40-45 \%. Laboratorně pak mírný vzestup kardiospecifických enzymů.

Echokardiograficky levá komora $\mathrm{s}$ dysfunkcí s EF kolem $30 \%$, kdy je zjevně patrná akineze dilatovaného hrotu a apikálních 1/2-2/3 stěn LK - kulovitá remodelace a hyperkineze bazálních segmentů stěn LK vyjma baze anterosepta. Kontrolní echokardiografie s odstupem asi 1 měsíce pak prokazuje normalizaci systolické funkce levé komory srdeční s lehkou poruchou relaxace, bez regionální poruchy kinetiky.

Závěr: Autoři prezentují případ „Tako-tsubo“ KMP včetně obrazové dokumentace.

\section{SESTERSKÁ SEKCE}

\section{AORTÁLNÍ DIREKCE. KASUISTIKA}

\section{HUŇÁČKOVÁ V, MACHOVÁ K}

Echokardiografické oddělení, Kardiologie na Bulovce s. r. o., Praha

Aortální disekce je závažné život ohrožující onemocnění. Velká část nemocných umírá do hodiny od objevu příznakư. Podstata onemocnění tkví v rozštěpení listů aorty. Symptomatologie a průběh pak jsou dány lokalizací a rozsahem disekce. Projevy mohou být jednak $z$ ischemie orgánů (odchlípený list v luminu uzavírá odstupy cév) nebo ztenčená stěna praská a nemocný umírá na vnitřní krvácení. Pokud se aneuryzma provalí do perikardu - dochází $\mathrm{k}$ tamponádě srdeční.
Jen malá část nemocných přeživá toto akutní období, prognózu výrazně zlepšují možnosti operačních technik. Dnes k možnostem léčby přistupuje i možnost léčby katetrizační. Malá část nemocných přechází do chronicity.

Sdělení se zabývá vzácnou kasuistikou ženy, která byla na naše pracoviště odeslána pro akutní infarkt myokardu a při katetrizaci byla disekce objevena. Vzhledem $\mathrm{k}$ akutnímu infarktu nebyla ani operována. Infarkt i direkce byly léčeny konzervativně. Provedená kontrolní vyšetření prokazují stabilizovaný nález.

\section{VIABILITA MYOKARDU - VÝZNAM JEJÍHO STANOVENÍ PR̆ED REVASKULARIZACÍ U PACIENTŮ SE SYSTOLICKOU DYSFUNKCÍ LEVÉ KOMORY SRDEČNÍ A ISCHEMICKOU KARDIOMYOPATII}

\author{
HUTYRA M, SKÁLA T

\section{I. interní klinika, FN Olomouc a LF UP, Olomouc}

Na základě dostupných literárních údajů je revaskularizace metodou volby $\mathrm{u}$ pacientů $\mathrm{s}$ ischemickou kardiomyopatî́ a středně těžkou až těžkou systolickou dysfunkcí levé komory srdeční. Nicméně do současné doby není zcela jasné, jaká je optimální terapeutická strategie u takto definované skupiny pacientů i s ohledem na vysoké periprocedurální riziko, spojené s operačním výkonem. Přehledová přednáška je koncipována jako souhrn současných možností testování viability myokardu a jejího významu v optimalizaci terapeutické strategie pacientů s ischemickou kardiomyopatií a systolickou dysfunkcí levé komory srdeční. Dále jsou zmíněny literárně dostupné údaje o efektu revaskularizace na globální funkci levé komory srdeční a prognózu takto léčených pacientů, zejména s ohledem na předoperační výsledky testování viability myokardu s cílem optimální selekce pacientů $\mathrm{z}$ hlediska indikace $\mathrm{k}$ revaskularizaci.

\section{REGISTR INFARKTŮ MYOKARDU - VÝSLEDKY Z ROKU 2006}

CHARALAMPIDI K, GRÜNFELDOVÁ H, MONHART $Z$, JANSKÝ P, RYŠAVÁ D, HUBAČ J, FALTUS V

Interní oddělení, Městská nemocnice Čáslav, Čáslav, Interní oddělení, Nemocnice Znojmo, Znojmo, Interní oddělení, Nemocnice Kutná Hora, Kutná Hora, Interní oddělení, Nemocnice Chrudim, Chrudim

Zpracovali jsme data o pacientech s diagnostikovaným IM od 1. 1. do 31. 12. 2006 ze spádové oblasti nemocnic Čáslav, Chrudim, Kutná Hora a Znojmo - spádová oblast zahrnuje celkem 300 tisíc obyvatel.

Cílem projektu je pomoci jednoduchého sběru dat zhodnotit léčebné a diagnostické postupy u všech pacientů s IM v několika regionech ČR, rizikový profil pacientů a klinický průběh onemocnění, a získat reálná data o mortalitě pacientů s IM.

Zařazovacím kritériem do registru byly klinická symptomatologie IM, elevace ST nebo pozitivita biochemických markerů nekrózy myokardu (troponin T nebo I, CKMB) u pacientů přijatých $\mathrm{k}$ hospitalizaci. Informace byly získávány $\mathrm{z}$ dokumentace pacientů a zadávány do elektronického dotazníku.

$Z$ léčebných postupů byla hodnocena farmakoterapie během 24 hodin po prrijetí, léčbu při propuštění. Byl sledován výskyt komplikací (srdeční selhání, šok, exitus, maligní artymie s nutností defibrilace, umělé ventilace) během hospitalizace.

$\mathrm{V}$ jednotlivých nemocnicích jsme sledovali reperfuzní terapie u STEMI, elektivní koronarografie NSTEMI za hospi- 
talizace, echokardiografické vyšetření za hospitalizace, průměrnou délku hospitalizace a hospitalizační mortalitu.

Statistická analýza sledovaných údajů ve výše uvedených regionech a jejich vzájemné porovnání jsou obsahem našeho sdělení.

\section{DVANÁCTITÝdENNÍ R̆İZENÝ AMBULANTNÍ REHABILITAČNÍ PROGRAM U MUŽÜ PO AORTOKORONÁRNIIM BYPASSU: VLIV NA AEROBNÍ KAPACITU A MAXIMÁLNÍ VÝKON*}

CHLUDILOVA V, FRANTISOVÁ M, MÍFKOVÁ L, POCHMONOVÁ J, POSPÍŠIL P, KONEČNÝ L, VANK P, VÁRNAY F, SIEGELOVÁ J

Klinika funkční diagnostiky a rehabilitace,

FN u su. Anny a LF MU, Brno

*Podporováno grantem MSM 0021622402.

Cíl studie: Posoudit vliv dvanáctitýdenního řízeného ambulantního rehabilitačního programu u mužů po aortokoronárním bypassu (ACB) na výkonnost funkční zdatnosti.

Soubor: Do studie bylo zařazeno 16 mužů po ACB (průměrný věk $63 \pm 8$ let, průměrná ejekční frakce $49 \pm 10,9$ ). Soubor jsme rozdělili do 2 skupin. První skupinu tvořilo 8 mužů (průměrný věk $62 \pm 8$, průměrná $\mathrm{EF} 52 \pm 10,7 \%$ ), kteří absolvovali v rámci druhé fáze kardiovaskulární rehabilitace kombinovaný trénink (KT). Druhou skupinu tvořilo rovněž 8 mužů (průměrný věk $64 \pm 8$ let, průměrná $\mathrm{EF}$ $46 \pm 11,1 \%$ ), kteří absolvovali čistě aerobní trénink (AT).

Metody: Před zahájením a po ukončení programu bylo provedeno spiroergometrické vyšetření do symptomy limitovaného maxima. Tréninková tepová frekvence a zátěž byly stanoveny na úrovni anaerobního prahu. Ambulantní rízený program probíhal $3 \times$ týdně po dobu 12 týdnů.

Výsledky: Skupina $s$ KT: $\mathrm{VO}_{2} \max 1481 \pm 268,8$ vs. $1821 \pm 499,0 \mathrm{ml} \cdot \mathrm{min}^{-1}(p<0,05)$; Wmax $95 \pm 20,0$ vs. 121 $\pm 36,7 \mathrm{~W}(p<0,05)$. Skupina $s$ AT: $\mathrm{VO}_{2} \max 1389 \pm 411,3$ vs. $595 \pm 397,6 \mathrm{ml} \cdot \mathrm{min}^{-1}(p<0,01)$; Wmax $81 \pm 29,6$ vs. 129 $\pm 29,2 \mathrm{~W}(p<0,05)$.

Závěr: Dvanáctitýdenní rehabilitační program vedl ke zvýšení aerobní kapacity i maximálního dosaženého výkonu jak u skupiny mužů s kombinovaným tréninkem, tak u skupiny mužů s aerobním tréninkem bez posilování. Nedošlo ke změně základních hemodynamických parametrů v klidu ani na vrcholu zátěže.

\section{TERAPEUTICKÁ VASKULOGENEZE U PACIENTŮ S KRITICKOU KONČETINOVOU ISCHEMIÍ DOLNÍCH KONČETIN*}

CHOCHOLA M, PYTLÍK P, KOBYLKA P, SKALICKÁ L, BERAN S, VAŘEJKA P, JIRÁT S, KŘIVÁNEK J, ASCHERMANN M, LINHART A

II. interní klinika kardiologie a angiologie, I. interní klinika, Klinika hematologie,

Ústav klinické a experimentální hematologie,

Radiodiagnostická klinika, VFN a 1. LF UK, Praha

*Podpořeno grantem IGA NR 8047-3.

Úvod: Cílem projektu bylo zjistit bezpečnost a účinnost autologní transplantace dřeňových buněk intraarteriální cestou u pacientů s chronickou kritickou ischemii dolních končetin (CHKKI).

Metodika: Od 1. 9. 2004 do 31. 12. 2007 jsme provedli autologní intravaskulární transplantaci dřeňových buněk u 28 pacientů (17 mužů a 11 žen) s CHKKI. Průměrný věk souboru byl 60 roků (26-85). 14 nemocných mělo trofický defekt. $Z$ dalších komorbidit: 15 (53,5\%) pacientů se léčí pro diabetes melitus, 12 (42,8\%) pacientů pro ICHS, $19(67,8 \%)$ pacientů pro hypertenzi, $6(21,4 \%)$ pacientů pro trombangiitis obliterans (TAO), u 14 (50,0\%) pacientů byla zjištěna hyperlipoproteinemie, u 5 (17,8 \%) pacientů byla zjištěna anamnéza embolizace do tepen dolních končetin při chronické fibrilaci síní, 5 (17,8 \%) pacientů mělo v anamnéze cévní mozkovou příhodu, 11 (39,3\%) pacientů byli bývalí kư̌áci.

Výsledky: Velkou amputaci končetiny, pro na analgetika nereagující klidové bolesti, podstoupili do 3 měsíců po implantaci 2 pacienti. Žádný nemocný nezemřel. Ke zhojení defektu došlo u 11 (80 \%) ze 14 nemocných. Podle hodnocení stupně ICHDK se podařilo převést do stadia klaudikací (IIb podle Fontaina) 22 (84,6\%) nemocných. U 2 (7,6\%) pacientů i když došlo ke zhojení defektu, přetrvávaly klidové bolesti, ale dobře reagující na analgetickou léčbu. U 2 nemocných přetrvával defekt (i když zmenšen) i po roce léčby. $\mathrm{U}$ souboru došlo $\mathrm{k}$ vzestupu průměrných hodnot AAI z 0,54 na 0,67 , stejně tak došlo $\mathrm{k}$ vzestupu průměrných hodnot tpO2 z 14,9 na $37,2 \mathrm{~mm} \mathrm{Hg}$.

Závěr: Naše výsledky ukazuji, že schopnost cévní stěny reagovat na intraarteriální aplikaci kmenových buněk se ukazuje jako nadějná terapeutická metoda $\mathrm{k}$ odstranění nebo snížení projevi̊ tkáňové ischemie u nemocných CHKKI.

\section{ZBYTKOVÉ SIIÑNOÉ TACHYKARDIE PO ABLACI FIBRILACE SIINÍ PR̆EDSTAVUJI ŠIROKÉ SPEKTRUM REENTRY OKRUHÜ A JEJICH KRITICKÝCH MÍST}

CHOVANČÍK J, FIALA M, SZYMECZEK H, WOJNAROVÁ D, MORAVEC R, NEUWIRTH R, NEVŘALOVÁ R, JIRAVSKÝ O, NYKL I, BRANNY M

Kardiologie, Kardiocentrum, Nemocnice Podlesí a. s., Třinec

Cílem práce: Prezentace klinických charakteristik a výsledků mapování a katetrové ablace pro levosíňovou tachykardii (LST) po dř́vější ablaci pro fibrilaci síní (FS).

Metodika: Soubor zahrnul 30 pacientů (pac) $(9 \check{Z}, 57 \pm$ 10 let), z nichž 14 (48\%) bylo po ablaci chronické FS, 2 (7\%) pac bylo po ablaci perzistentní FS, 12 (38\%) pac bylo po ablaci paroxyzmální FS a $2(7 \%)$ pac bylo po chirurgické MAZE ablaci.

Výsledky: Klinická LST byla před reablací perzistentní u 24 (79 \%) pac a paroxyzmální u 6 (21\%) pac (6× po ablaci paroxyzmální FS, $1 \times$ po ablaci chronické FS). Stabilní LST byla selektivně mapována (CARTO) u $20(66 \%)$ pac (10× po chronické fibrilaci síní, $2 \times$ po perzistentní $\mathrm{FS}, 6 \times$ po paroxyzmální FS a $2 \times$ MAZE), ale pro další formy LST byla ablace dokončena anatomicky u 10 pac $(6 \times$ po chronické FS, $3 \times$ po paroxyzmální FS a $1 \times$ po perzistentní FS). Pro střídání tvarů LST se mapování a ablace primárně provedly anatomicky u 10 pac ( $4 \times$ po chronické $F S, 6 \times$ po paroxyzmální FS). Selektivní mapování odhalilo fokální vznik tachykardie u 2/20 (11\%) pac $-\mathrm{Z}$ anter plicních žil (PŽ) $(1 \times$ po ablaci chronické FS a $1 \times$ po ablaci paroxyzmální FS - jediná měla vlastnosti ektopické arytmie). SR se podařilo obnovit ablací u 29 (97\%) pac. Místa ablace, po nichž se nastolil stabilní sinusový rytmus, byla: Bachmannův svazek $7 \times$, septální ústí ouška $3 \times$, horní ústí ouška $3 \times$, strop levé síně $4 \times$, antrum levých PŽ $5 \times$, koronární sinus $5 \times$ a oblast mezi pravou dolní $\mathrm{PŽ} \mathrm{a} \mathrm{mitrálním} \mathrm{prstencem} 2 \times$.

Závěr: 1. LST po předchozí katetrové nebo chirurgické ablaci FS má převážně charakter reentry. 2. Kritická místa reentry okruhů jsou často $\mathrm{v}$ různých místech levé síně. 
3. Riziko vzniku LST souvisí s rozsahem a počtem předchozích ablačních zásahů. 4. Arytmogenní substrát a reentry okruhy jsou často komplexní. 5. Tzv. nemapovatelné LST lze řšsit anatomickým př́stupem $\mathrm{k}$ ablaci.

\section{LÉČBA ROSIGLITAZONEM JE SPOJENA SE VZESTUPEM HODNOTY SMYKOVÉ RYCHLOSTI VE SPOLEČNÉ KAROTIDĔ PR̆I NEZMĚNĚNÉ KOMPENZACI DIABETES MELLITUS 2. TYPU}

CHYTILOVÁ E, MALÍK J, KASALOVÁ Z, ŠTULC T, DOLEŽALOVÁ R

\section{III. interní klinika, VFN a 1. LF UK, Praha}

Úvod: Snížené smykové napětí je lokálním rizikovým faktorem pro aterogenezi. Diabetici 2. typu mají nižší hodnotu smykové rychlosti ve společných karotidách, a to i v případě dobré kompenzace. Cílem práce bylo posoudit vliv rosiglitazonu na smykové napětí ve společných karotidách $\mathrm{u}$ diabetiků 2 . typu.

Soubor nemocných a metodika: Bylo zařazeno 26 diabetiků (DM), věk 62 let \pm 10 let, léčených metforminem, statinem a ACE-I minimálně po dobu 6 měsíců. U každého pacienta jsme před léčbou a po 5 měsících léčby rosiglitazonem $(4 \mathrm{mg}$ denně) sonograficky měřili vnitřní průměr společné karotidy, maximální (Vmax) rychlost proudění krve. Vypočítali jsme smykovou rychlost (WSR), jakožto aproximaci smykového napětí. Dále byla změřena výška komplexu intima/media (IMT). Rozdíly byly testovány párovým $t$-testem.

Výsledky: Při nezměněné kompenzaci DM došlo k vzestupu hodnoty smykové rychlosti ve společných karotidách. Pozorovaný vzestup smykové rychlosti je výsledkem nejen zmenšení průměru cévy, ale také vyšší rychlosti proudění.

\begin{tabular}{lccc}
\hline \hline & Před léčbou & Po léčbě & Hodnota $\boldsymbol{p}$ \\
\hline Glyk Hb (\%) & $5,7 \pm 1,1$ & $5,7 \pm 1,1$ & 0,756 \\
IMT (mm) & $0,74 \pm 0,11$ & $0,73 \pm 0,07$ & 0,63 \\
Vnitřní průměr & $7,50 \pm 0,81$ & $7,35 \pm 0,84$ & 0,19 \\
cévy (mm) & & & \\
Vmax $\left(\mathrm{cm} . \mathrm{s}^{-1}\right)$ & $62,6 \pm 9,9$ & $64,7 \pm 10,8$ & 0,13 \\
WSRmax $\left(\mathrm{s}^{-1}\right)$ & $34,7 \pm 6,3$ & $38,6 \pm 9,6$ & 0,03 \\
\hline \hline
\end{tabular}

Závěr: Léčba rosiglitazonem u diabetiků vede ke vzestupu WSR.

\section{TRANSRADIÁLNÍ PCI: SROVNÁNÍ 5 F A 6 F INSTRUMENTÁRIA S OHLEDEM NA POST- -PROCEDURÁLNÍ PRÚCHOdNOST RADIÁLNÍ TEPNY}

INDRÁK J, INDRÁKOVÁ D, BRANNY M, ČERNÝ J, VODZINSKÁ A, NYKL I, JANUŠKA J, KUČERA D

Kardiologické oddělení, Oddělení intervenční radiologie, Nemocnice Podlesí a. s., Třinec

Cíl práce: Ověřit předpokládanou reverzní závislost mezi kalibrem instrumentária použitého při transradiální PCI a pravděpodobností postprocedurální průchodnosti radiální tepny.

Soubor a metodika: $V$ roce 2006 bylo na katetrizačním pracovišti Kardiocentra Třinec provedeno 4757 koronárních katetrizací, z toho 1867 transradiálně (39,2 \%). Za stejné období bylo provedeno $1787 \mathrm{PCI}, \mathrm{z}$ toho 752 transradiálně $(42,1 \%)$. U $40 \%$ pacientů v různém časovém odstupu po transradiální PCI (v průměru po jednom měsíci) bylo rutinně provedeno palpační (jakožto izolované jen výjimečně) a doplerovské (ve většině případů) stanovení postprocedu- rální průchodnosti radiální tepny. Byla zkoumána závislost pravděpodobnosti postprocedurální patence/okluze na různých vstupních parametrech, mimo jiné na kalibru použitého instrumentária ( $5 \mathrm{~F}$ vs. 6 F). Nerandomizované, prospektivní hodnocení, statistická analýza.

Výsledky: K datu 15. 1. 2007 byla provedena analýza u 301 pacienta. $\mathrm{K}$ tomuto datu byl nalezen následující výskyt postprocedurální okluze radiální tepny: celkově 10,96\% (33/301), resp. pro instrumentárium 5 F 10,38 \% (22/212), resp. pro instrumentárium 6 F 12,36 \% (11/89). Všechny okluze jsou asymptomatické a kompenzované kolaterálním oběhem. Sběr dat bude i nadále pokračovat (plán do konce dubna 2007) a konečná analýza bude prezentována v květnové verzi sdělení.

Závěr: Zjistili jsme trend nepřímé závislosti mezi velikostí instrumentária a postprocedurální průchodností radiální tepny. Bylo by pravděpodobně užitečné verifikovat tento výsledek randomizovanou studií.

\section{DLOUHODOBÝ OSUD NEMOCNÝCH PO UKONČENÍ DUÁLNÍ ANTIAGREGAČNÍ LÉČBY U NEMOCNÝCH $S$ IMPLANTOVANÝM LÉKEM POTAŽENÝM KORONÁRNÍM STENTEM \\ (HOMEDES REGISTR: HEALTH OUTCOMES \\ AND MORTALITY EVALUATIONS AFTER INVASIVE CORONARY TREATMENT USING DRUG ELUTING STENTS)}

JAKABČIN J, ČERVINKA P, JÄGER J, BĚHOUNEK M, ŠPAČEK R, BYSTROŇ M, KVAŠŇÁK M

Kardiologické oddělení, Masarykova nemocnice Ústí nad Labem, Ústí nad Labem

Cíl: Cílem naší práce bylo zjistit výskyt pozdních (více než 6 měsíců od intervence) klinických příhod způsobených trombózou stentu u nemocných s implantovaným lékem potaženým stentem (DES) po ukončení duální antigregační léčby.

Soubor a metodika: V období leden 2004 až květen 2006 273 pacientů podstoupilo perkutánní koronární intervenci (PCI) s implantací lékem potaženého stentu. $Z$ této kohorty nemocných celkem 171 ukončilo 12 měsíční a 18měsíční sledování. Trombóza stentu byla definována: 1. angiografickým průkazem trombu; 2 . reinfarktem v povodí původně intervenované tepny nebo 3. náhlým, neočekávaným úmrtím.

Výsledky: V 18. měsíci jsme zaznamenali celkem 9 případů (5,2 \%) pozdní trombózy lékem potaženého stentu, které se klinicky manifestovaly jako náhlá smrt u 4 nemocných a jako nefatální IM u 5 nemocných. Převážná většina př́ihod se udála mezi 7.-12. měsícem po intervenci s průměrnou dobou vzniku od přerušení užívání clopidogrelu 121 dnů. Opakovanou intervenci na původně ošetřené tepně jsme zaznamenali u $7 \%$ nemocných. Celkový počet všech kardiovaskulárních př́ihod byl 12,2\%.

Závěr: Výskyt těchto př́ihod v našem souboru koreluje s výsledky nedávno publikované studie BASKET LATE. Naše studie prokazuje trend $\mathrm{k}$ vyššímu výskytu pozdních KV úmrtí a nefatálních IM po ukončení duální antiagregační léčby u nemocných s lékem potaženým stentem.

\section{PERKUTÁNNÍ KATETRIZAC̆Ní UZÁvĔR PERZISTUJICIHO DUCTUS ARTERIOSUS BOTALLI POMOCÍ AMPLATZOVA OKLUDERU U STARŠİHO PACIENTA. KASUISTIKA}

JAKABČIN J, ČERVINKA P, BYSTROŇ M, STERNTHAL P, DERNER M 
Kardiologické oddělení, Radiologické oddělení, Masarykova nemocnice Ústí nad Labem, Ústí nad Labem, Interní oddělení, Nemocnice Teplice, Teplice

Nechirurgický uzávěr ductus arteriosus je metodou volby této vrozené srdeční vady v dospělosti. Nejvíce zkušeností je $\mathrm{v}$ současné době s uzávěry tepenné dučeje pomocí Amplatzova okluderu.

V kasuistickém sdělení prezentujeme případ 70leté nemocné, diabetičky, hypertoničky s prodělanou cévní mozkovou př́hodou, která byla na našem pracovišti vyšetřena pro progredující námahovou dušnost a stenokardie. Transtorakální ECHO prokazuje plicní hypertenzi a vyjadřuje podezření na perzistující tepennou dučej. Nebyla zjištěna dilatace srdečních oddílů ani porucha kinetiky stěny levé komory srdeční s normální systolickou funkcí. Nemocná podstoupila srdeční katetrizaci. Selektivní koronarografie vyloučila významné stenózy na věnčitém řečišti. Angiograficky i dilučně byla potvrzena tepenná dučej s velikostí zkratu $\mathrm{Qp} / \mathrm{Gs}$ 1,5 a mírná prekapilární plicní hypertenze. Diagnostika byla doplněna o CT angiografii, která jednoznačně prokazuje perzistující tepennou dučej.

Defekt byl uzavřen pomocí Amplatzova okluderu velikosti $12 / 10 \mathrm{~mm}$ cestou pravé stehenní žíly s použitím $7 \mathrm{~F}$ instrumentária. Tepenná dučej byla sondována retrográdně $\mathrm{z}$ aorty se zavedením vodicího drátu do pravé srdeční komory a jeho vytažením kličkou přes pravou stehenní žílu. Poté byl po vytaženém zaváděcím drátu zaveden katetr, přes který jsme implantovali okluder. Angiografie prokazovala dobrou polohu okluderu. Po uvolnění zaváděcího kabelu okluder kompletně obturuje původní dučej. Finální angiografie plicnice i aortografie prokazují kompletní uzávěr dučeje. Kontrolní CT angiografie prokazuje optimální pozici okluderu. Výkon i hospitalizace proběhla bez komplikací.

Závěr: Kasuistika dokumentuje úspěšný nechirurgický uzávěr perzistující tepenné dučeje $\mathrm{s}$ využitím Amplatzova okluderu $\mathrm{s}$ využitím interdisciplinárního přístupu $\mathrm{v}$ diagnostice této $\mathrm{v}$ dospělosti nepř́liš časté vrozené vady.

SESTERSKÁ SEKCE

\section{AKUTNII INFARKT MYOKARDU, KARDIOGENNÍ ŠOK, KONTRAPULSACE}

JALČOVIKOVÁ N, DOBIÁŠOVÁ J, WOSYKOVÁ M

Klinika kardiologie, IKEM, Praha

Péče o pacienta s akutním infarktem myokardu v kardiogenním šoku s nutností zavedení IABK. Úlohy sestry na intenzivní péči.

\section{VLIV DVANÁCTITÝDENNÍHO REHABILITAČNÍHO PROGRAMU S AEROBNÍ ZÁTĚŽí, KOMBINOVANOU SE SILOVÝMI PRVKY, NA KVALITU ŽIVOTA NEMOCNÝCH S CHRONICKOU ISCHEMICKOU CHOROBOU SRDEČNÍ}

JANČÍK J, SIEGELOVÁ J, DOBŠÁK P,

PANOVSKÝ R, POCHMONOVÁ J, MÍFKOVÁ L,

VYMAZALOVÁ L, VANK P, TOMÍČKOVÁ J,

FRANTISOVÁ M

Katedra sportouní medicíny,

Fakulta sportovních studií MU,

Klinika funkční diagnostiky a rehabilitace,

1. kardio-angiologická klinika,

FN u sv. Anny a LF MU, Brno
Depresivní a anxiózní stavy jsou časté. Vedou ke zhoršení kvality života a je možné je považovat za nezávislý rizikový faktor koronární příhody.

Cíl práce: Posoudit vliv dvanáctitýdenního rehabilitačního programu s kombinovanou zátěží na kvalitu života nemocných s chronickou ischemickou chorobou srdeční verifikovanou koronarograficky (významná stenóza nejméně jedné koronární tepny) nebo enzymaticky potvrzeným infarktem myokardu v anamnéze před více než třemi měsíci.

Materiál a metody: Do studie jsme zařadili 83 mužů cvičících s aerobní zátěží kombinovanou po čtrnácti dnech se silovými prvky (průměrný věk: $62 \pm 9$ roků, EF $47 \pm 8 \%$, výška: $177 \pm 6 \mathrm{~cm}$, hmotnost: $86 \pm 11 \mathrm{~kg}$ ). Před zahájením a po absolvování rehabilitačního programu bylo provedeno spiroergometrické vyšetření a hodnocena kvalita života pomocí modifikovaného dotazníku SAQ (The Seattle Angina Questionare).

Výsledky: Kladně a statisticky významně byla ovlivněna limitace běžných denních aktivit $(79,7 \pm 19,0$ vs. 84,9 $\left.\pm 16,4^{*}\right)$, zlepšila se stabilita $\left(78,2 \pm 19,1\right.$ vs. $\left.85,6 \pm 16,1^{*}\right)$ a snížila se frekvence obtíží i nutnosti medikace $(83,5 \pm 15,6$ vs. $\left.88,2 \pm 14,5^{*}\right)$. Zlepšila se spokojenost s průběhem a kvalitou léčby $\left(87,8 \pm 14,6\right.$ vs. $\left.92,9 \pm 11,5^{*}\right)$, ustoupily obavy z úmrtí a došlo ke zlepšení vnímání prožitku života $(67,2 \pm$ 19,7 vs. $\left.73,8 \pm 19,5^{*}\right)$. Zvýšila se funkční aerobní zdatnost vyjádřená př́jmem kyslíku. $\left(\mathrm{VO}_{2}\right.$ peak. $\mathrm{kg}^{-1} 20,6 \pm 5$ vs. 22,9 $\left.\pm 6,3 \mathrm{ml} \cdot \mathrm{kg}^{-1} \cdot \mathrm{min}^{-1 *}\right) ;\left({ }^{*} p<0,05\right.$ Wilcoxonův test pro párové hodnoty).

Závěr: Dvanáctitýdenní řízený ambulantní rehabilitační program s kombinovanou zátěží vedl u nemocných s chronickou ischemickou chorobou srdeční ve stabilizovaném stavu ke zlepšení funkční aerobní zdatnosti i kvality života.

\section{SESTERSKÁ SEKCE}

\section{UPGRADE NA BIVENTRIKULÁRNÍ STIMULACI PRO ROZVOJ POKROČILÉHO SRDEČNÍHO SELHÁNÍ U DOSUD KONVENČNĔ STIMULOVANÝCH}

JANČÍKOVÁ L, TRČKOVÁ R, REHÁKOVÁ Z, PŠENIČKA M, KEJŘOVÁ E, LINHART A

II. interní klinika kardiologie a angiologie, VFN a 1. LF UK, Praha

Resynchronizační léčba je prokázanou účinnou nefarmakologickou léčebnou metodou u nemocných s pokročilou dysfunkcí levé komory, s širokým komplexem QRS a poruchou synchronizace, která je provázena pokročilým srdečním selháním.

V literatuře jsou sporadické údaje o příznivém účinku biventrikulární stimulace u nemocných s konvenční stimulací z pravé komory, u kterých došlo k rozvoji pokročilého srdečního selhání.

Na našem pracovišti byl proveden upgrade konvenční stimulace $\mathrm{z}$ pravé komory na biventrikulární stimulaci zatím u 24 pacientů.

V tomto sdělení předkládáme 2 kasuistiky pacientů, jimž byl proveden upgrade na biventrikulární stimulaci s velmi dobrým klinickým efektem i úpravou echokardiografických parametrů.

SESTERSKÁ SEKCE

\section{VÝZNAM HOLTEROVA MONITOROVÁNÍ U PACIENTŮ PO RADIOFREKVENČNÍ ABLACI FIBRILACE SÍNÍ}

JANÍČKOVÁ S, KYSELOVÁ I, VLAŠÍNOVÁ J 
Interní-kardiologická klinika,

FN Brno-Bohunice, Brno

Fibrilace síní je nejčastěji se vyskytující arytmií. Její výskyt stoupá s věkem.

Jde o arytmii s nekoordinovanou síňovou aktivací s následným zhoršením mechanické funkce síní. Fibrilace síní bývá častou prríčinou tromboembolických příhod. Formy rozlišujeme paroxyzmální, perzistující a chronické. Péče pacienty $\mathrm{s}$ fibrilací síní má dvě roviny: 1. vlastní arytmie, 2. prevence tromboembolie.

Jednou z nejmodernějších terapií fibrilace síní je katetrizační ablace, izolace plicních žil. Pacienti, kteří tuto léčbu podstoupili bývají i nadále ve sledování arytmologické ambulance a ve 3 . a 12 . měsíci po výkonu je prováděno kontrolní Holterovo monitorování.

U části těchto nemocných jsou zachyceny paroxyzmy fibrilace síni, často asymptomatické. Nález těchto arytmií je důležitý $z$ hlediska další antiarytmické medikace a rozhodování, zda ponechat antikoagulační terapii.

\section{PILOTNÍ ZKUŠENOSTI \\ S PR̆EDNEMOCNIČNÍ TROMBOLÝZOU TENEKTEPLÁZOU A NÁSLEDNOU AKUTNII INTERVENČNÍ LÉČBOU U AIM V JIHOMORAVSKÉM KRAJ*}

JANOUŠEK S, URBÁNEK P, GROCH L, NOVÁK M, HLINOMAZ O, a kolektiv

Interní-kardiologická klinika, FN Brno, Brno, Interní-kardioangiologická klinika,

FN u sv. Anny, Brno

*Podporováno $M Z$ ČR v rámci

Projektu podpory kvality zdravotni péče 13a/05 MEZ -OZF/2.

Cill práce: Ověřit příznivé zahraniční zkušenosti s přednemocniční trombolytickou léčbou (TL) akutního infarktu myokardu (AIM) s elevacemi ST a následnou intervenční léčbou (PCI) na území Jihomoravského (JM) kraje.

Soubor a metodika: Nutnou podmínkou přítomnost elevací $\mathrm{ST}>1 \mathrm{~mm}$ aspoň ve 2 svodech na EKG záznamu př̀ kontaktu s RZS, nepřítomnost kontraindikací pro TL a věk < 75 let. 2 indikační skupiny nemocných: A. kontakt s RZS do 2 hodin od vzniku obtíží, B. transport k PCI delší než 60 , resp. $90 \mathrm{~min}$. Léčba IV: $500 \mathrm{mg}$ ASA, tenektepláza (TNK) (RMetalyse) a heparin (podle váhy), PO 300 mg Plavixu, transport do intervenčního centra a následná PCI. Léčba indikována lékaři RZS na celém území JM kraje. Kontroly po 1,6 a 12 měsících.

Výsledky: Pilotně v období 4/2006-10/2006 zařazeno 11 nemocných (3 ženy) průměrného věku 61 let (42-69 let), všichni s anamnézou obtíží < 2 hod. Při zahájení TL 4 (36 \%) nemocní ve stadiu Killip III-IV. Do nemocnice přichází jeden ve stadiu Killip III, ostatní Killip I-II, vstupní koronarografie: zcela průchodná tepna (TIMI flow III) 7/11 (64\%), částečně (TIMI flow II) 1/11 (9 \%). Po PCI všichni TIMI flow III. U jedné nemocné jen minimální léze (aborted IM). Nulová hospitalizační i 30denní mortalita. U nikoho nedošlo při podání TNK a následující akutní koronarografii včetně angioplastiky k závažným krvácivým komplikacím.

Závěr: Pilotní výsledky ukazují příznivé ovlivnění klinického stavu i prognózy nemocných s AIM přednemocničně léčených IV TNK, s následnou akutní intervenční léčbou u nemocných mladších 75 let, při zahájení léčby do dvou hodin od vzniku obtíží bez vzniku závažných komplikací. Další podrobné zhodnocení následujícího rozsáhlejšího souboru nemocných takto léčených bude ovšem nezbytné.

\section{VLIV GENOVÉHO POLYMORFISMU GLU298ASP ENDOTELIÁLNÍ NO SYNTÁZY NA AKUTNII VAZOREAKTIVITU U IDIOPATICKÉ PLICNÍ ARTERIÁLNÍ HYPERTENZE}

JANSA P, JÁCHYMOVÁ M, ASCHERMANN M, HORÁK J, AMBROŽ D, LINHART A

II. interní klinika kardiologie a angiologie, Ústav klinické biochemie, VFN a 1. LF UK, Praha

Úvod: Stanovení akutní plicní vazoreaktivity u nemocných s plicní arteriální hypertenzí (PAH) je zásadní pro stanovení strategie léčby a odhad prognózy. Alelická frekvence Asp298 genového polymorfismu Glu298Asp endotheliální NO syntázy je signifikantně nižší u pacientů s PAH. Příčinou může být vyšší letalita a horší prognóza jedinců s homozygotni konstitucí.

Cíl: Určit vliv genového polymorfismu Glu298Asp endotheliální NO syntázy na akutní vazoreaktivitu u idiopatické PAH.

Soubor nemocných a metodika: Do studie bylo zařazeno 35 nemocných s idiopatickou PAH (43 \% mužů, průměrný věk $43 \pm 14$ roků) ve funkční trrídě NYHA III a IV. Polymorfismus Glu298Asp byl detekován metodou polymerázové řetězové reakce a analýzou délky restrikčních fragmentů. Test akutní plicní vazodilatace byl proveden syntetickým analogem prostacyklinu (dávka titrovaná od $2 \mathrm{ng} / \mathrm{kg} / \mathrm{min}$ do $12 \mathrm{ng} / \mathrm{kg} / \mathrm{min}$ vždy po $2 \mathrm{ng} / \mathrm{kg} / \mathrm{min}$ ).

Výsledky: Ve studované populaci bylo identifikováno 13 heterozygotů Glu/Asp a 22 nemocných s normálním genotypem Glu/Glu. Obě skupiny se významně nelišily ve vstupních hodnotách středního tlaku v plicnici (58 \pm 9 vs. $57 \pm 10 \mathrm{~mm} \mathrm{Hg})$, srdečního indexu $(2,24 \pm 0,71$ vs. $\left.2,2 \pm 0,57 \mathrm{l} / \mathrm{min} / \mathrm{m}^{2}\right)$ a plicní arteriolární rezistence $(12,74$ $\pm 3,42$ vs. $12,98 \pm 4,73$ WU). Při testu akutní plicní vazodilatace byl $\mathrm{u}$ nemocných $\mathrm{s}$ genotypem Glu/Asp zaznamenán méně významný nárůst srdečního indexu než u nemocných s genotypem Glu/Glu (+ $26 \%$ vs. + $39 \%, p=0,1$ ) a méně významný pokles plicní arteriolární rezistence ve srovnání s nemocnými s genotypem Glu/Glu (-23\% vs. $-33 \%, p=0,09$ ). Z hlediska kritérií WHO byly všechny testy negativní.

Závěr: Genový polymorfismus Glu298Asp endoteliální NO syntázy je u nemocných s PAH charakterizován horš odpovědí při testu akutní plicní vazoreaktivity a může být proto rovněž spojen s horší prognózou těchto pacientů.

\section{NAŠE ZKUŠENOSTI S CENTRALIZACÍ NEMOCNÝCH S CHRONICKOU TROMBOEMBOLICKOU PLICNÍ HYPERTENZI}

JANSA P, LINDNER J, ASCHERMANN M, ŠIMKOVÁ I, GONCALVESOVÁ E, AMBROŽ D, PALEČEK T, LINHART A

II. interní klinika kardiologie a angiologie,

II. chirurgická klinika kardiochirurgie a cévní chirurgie, VFN a 1. LF UK, Praha, Slovenský ústav srdcových a cievnych chorôb, Bratislava, SR

Úvod: Chronická tromboembolická plicní hypertenze (CTEPH) je důsledkem postupné obstrukce plicních cév intraluminálně organizovanými tromby a remodelace plicních arteriol v perfundovaných oblastech. Důsledkem je nárůst tlaků v plicnici, plicní cévní rezistence a pravostranné srdeční selhání. Dřive se odhadovalo, že k rozvoji CTEPH dojde asi u 0,1-0,5 \% pacientů, kteří přežijí akutní plicní embolii. Některé práce však ukazují na několikanásobně 
častější výskyt. Léčbou volby u nemocných s chirurgicky dostupnou trombotickou obstrukcí plicnice je endarterektomie plicnice. Alternativu u periferního postižení může představovat specifická farmakoterapie.

Soubor nemocných a metodika: V letech 2003-2006 bylo v Centru pro plicní hypertenzi na II. interní klinice VFN a 1. LF UK v Praze diagnostikováno celkem 96 nemocných se CTEPH (56 \% mužů, průměrný věk 52 let). V září 2004 byla v Kardiocentru VFN v Praze zavedena metoda endarterektomie plicnice. U operabilních nemocných je indikována endarterektomie plicnice.

Výsledky: Endarterektomie plicnice byla provedena u 39 nemocných včetně 2 nemocných ze Slovenska. Všichni pacienti byli v klinickém stadiu NYHA III a IV. Mortalita v operovaném souboru činila $10,26 \%$. Krátce po operaci došlo prakticky $\mathrm{k}$ normalizaci hemodynamických parametrů. Vzdálenost při testu šestiminutovou chưzí se prodloužila během 6 měsíců po operaci průměrně o 212 .

Závěr: Výsledky chirurgické léčby CTEPH jsou zcela srovnatelné s renomovanými zahraničními pracovišti. V ČR a SR lze očekávat několik desítek vhodných kandidátů $\mathrm{k}$ endarterektomii plicnice ročně. Jedno expertní centrum provádějící endarterektmomie a mající zkušenosti s komplexní léčbou chronické plicní hypertenze je pro tuto populaci zcela dostačující.

\section{KASUISTIKA PACIENTKY SE SYNDROMEM TAKO-TSUBO}

JARKOVSKÝ P, ŠKVAŘIL J, SEDLOŇ P, ČERNOHOUS M, JEŘÁBEK I, ZAVORAL M

Kardiologické oddělení, Interní klinika, ÚVN a 1. LF UK, Praha

Úvod: Syndrom Tako-tsubo zahrnuje typickou bolest na hrudi spojenou s přechodnou dyskinezí hrotu s případným postižením středních segmentů LK, elevace ST v prekordiálních svodech s nevýznamným nálezem na koronárních tepnách a lehkou elevaci markerů myokardiální léze. Jednoznačná etiopatogeneze zůstává nedořešena, porucha vzniká vždy v souvislosti s psychickou či fyzickou námahou. Prevalence udávaná u nemocných s AKS s elevacemi ST je 1,7-2,2 \%, převažují ženy v postmenopauzálním věku. Prognóza je dobrá, hospitalizační mortalita se pohybuje kolem $1 \%$. U 3,5 \% nemocných jsou popsány recidivy.

Popis připadu: Jednalo se o 63letou ženu s anamnézou opakovaných bolestí na hrudi ve vazbě na stres od roku 2000, byla vyšetřována na několika pracovištích v období, kdy neměla akutní obtíže včetně TTE, TEE s normálními nálezy, zátěžové testy odmítala. Chronicky užívala 2,5 mg indapamidu a 25 mg metoprololu bez výraznějšího ovlivnění obtíží. Přechodně pobývala na Ukrajině, kde byla zhruba dva roky v péči lidových léčitelů.

$\mathrm{V}$ roce 2006 byla hospitalizována pro typickou stenokardii vzniklou při rodinné hádce. RZS zjistila STE V3-4, po s. 1. aplikaci nitrátu však došlo ke zhoršení bolestí a $\mathrm{k}$ hypotenzi. Při vstupní TTE byla zjištěna EF LKS 30 \% s obrazem dyskineze hrotu a významný intraventrikulární gradient. SKG byla bez patologie, ventrikulograficky nález odpovídal TTE. Nemocná byla dimitována na kombinaci metoprolol, amlodipin, ASA a SSRI v uspokojivém stavu, echokardiografický obraz se zcela normalizoval do měsíce od přijetí. Klidový SPECT srdce prokázal normální distribuci 99mTc-MIBI. Zátěžové testy a zvažované MRI nemocná odmítá. Nemocná nadále zůstává v našem dispenzáři. Případ byl uzavřen jako syndrom Tako-tsubo.

Závěr: Kasuistika potvrzuje dobrou prognózu i úzké podskupiny nemocných s recidivami obtíží.
SESTERSKÁ SEKCE

\section{POUŽITÍ CUTTINGOVÉHO BALONU PR̆I PCI}

\section{JEČMÍNKOVÁ J}

Interní-kardioangiologická klinika, FN Brno-Bohunice, Brno

Při každé balonkové angioplastice dochází $\mathrm{k}$ mikrodisekci intimy dilatovatované tepny. Asi v $5 \%$ vznikne po dilataci velká disekce, která hrozí úplným uzávěrem tepny a rozvojem IM, jako komplikace výkonu. Problém po výkonu představuje také restenóza, tj. opětovné zúžení tepny v témže místě. Možným řešením i prevencí pro tyto 2 komplikace je cuttingový balon /CB/.

CB je speciální balon opatřený 3 nebo 4 mikrochirurgickými žiletkami uloženými podélně na balonu. Při rozvinutí balonu čepelky naříznou intimu a vytvoří tak kontrolované rozšiřrení v místě aterosklerotického plátu tepny.

Unikátní uspořádání tohoto instrumentária minimalizuje obvyklé trauma cévní stěny spojené s tradiční angioplastikou, umožňuje dilatovat tepny menším tlakem, snižuje riziko komplexních disekcí, a tím i riziko neoproloferace a restenózy tepny.

Použití tohoto instrumentária je kontraindikováno při koronárním spasmu bez významných stenóz.

Loni jsme na našem pracovišti použili $\mathrm{CB}$ u 41 pacientů. Ve svém sdělení budu prezentovat 2 kasuistiky. V 1 . případě je řešena restenóza ve stentu a ve 2 . př́ípadě je $\mathrm{CB}$ použit při prosté angioplastice.

\section{KARDIOLOGICKÝ PROFIL DOSPĚLEHO PACIENTA PO KARDIOTOXICKÉ CHEMOTERAPII*}

JEDLIČKA F, ELBL L, VÁŠOVÁ I, TOMÁŠKOVÁ I, NAVRÁTIL M, ŠMARDOVÁ L, WÁGNEROVÁ B, KRÁL Z, VORLÍČEK J, ŠPINAR J

Interní-kardiologická klinika, Interní-hematoonkologická klinika, FN Brno, Brno

*Tato práce vznikla za podpory VVZ MŠMT 0021622402.

Cíl: Autoři provedli studii za účelem vyhodnocení kardiologického profilu pacientů dlouhodobě žijících po léčbě pro maligní lymfomy.

Pacienti a metody: Bylo zařazeno 96 nemocných (47 m/49 ž) ve věku $43 \pm 15$ let žijících 5-10 let po ukončení léčby. Provedli jsme klidovou a zátěžovou echokardiografii, spiroergometrii, ambulantní monitorování TK (AMTK) a EKG (AMEKG) a vyšetření variability intervalu RR.

Výsledky: 6 nemocných (6\%) mělo $\mathrm{EF}<50 \%, 29$ (30 \%) mělo pokles $\mathrm{EF}>10 \%$ ve srovnání se vstupní hodnotou. Diastolická dysfunkce byla u 36 (38 \%) nemocných, hodnota Teiova indexu $>0,55$ byla u 30 nemocných $(31 \%)$. 15 (15\%) mělo hodnotu $\mathrm{pVO}_{2}<20 \mathrm{ml} / \mathrm{kg} / \mathrm{min}$. Hodnoty TKmean při AMTK > 130/80 byly naměřeny u 31 (30\%) nemocných. Redukovanou variabilitu intervalu RR jsme diagnostikovali u 38 nemocných (46\%). U 30 (31\%) nemocných jsme nalezli asymptomatické arytmie při AMEKG $\mathrm{s}$ převahou výskytu paroxyzmů fibrilace síní a KES IIIa podle Lowna.

U 7 (7\%) byla diagnostikována ICHS, u 4 (4\%) srdeční selhávání, 15 (16\%) hypertenze, 3 (3\%) dyslipidemie a u 5 (5\%) diabetes, 19 nemocných (20\%) bylo ve věku > 60 let. Multiregresní analýza prokázala vztah mezi patologií při $\mathrm{AM}$, věkem a doprovodným srdečním onemocněním (zvláště hypertenzí). Pokles EF a index TEI > 0,55 jsou významně 
ovlivněny přidruženým srdečním onemocněním. Diastolická dysfunkce je ovlivněna věkem, onkologickou léčbou a přidruženým srdečním onemocněním. Snížená kardiopulmonální výkonnost je ovlivněna vyšším věkem a diastolickou dysfunkcí.

Závěr: Předložené výsledky ukazují na nutnost podrobnějšího kardiologického screeningu dospělých nemocných po onkologické léčbě, časné diagnostiky a léčby rizikových faktorů vedoucích $\mathrm{k}$ poškození funkce myokardu bez ohledu na vlastní kardiotoxicitu onkologické terapie.

\section{ADMA - SENZITIVNÍ UKAZATEL ENDOTELIÁLNÍ DYSFUNKCE U DĚTÍ S FAMILIÁRNÍ HYPERCHOLESTEROLEMIÍ A DIABETES MELLITUS 1. TYPU*}

\section{JEHLIČKA P, MAYER O, RACEK J, STOŽICKÝ F}

Dětská klinika, II. interní klinika,

Ústav klinické biochemie a hematologie, FN Plzeň, Plzeň

*Podpořeno IGA NR 8455-3.

Úvod: Děti s familiární hypercholesterolemií (FH) nebo diabetes mellitus 1 . typu (DM1) mají vysoké riziko vzniku makrovaskulárních nebo mikrovaskulárních komplikací v časném věku. Jednou $z$ možností stanovení rizika je průkaz přítomnosti endoteliální dysfunkce.

Cil studie: Stanovit a porovnat sonografické a biochemické ukazatele endoteliální dysfunkce u rizikových skupin dětí pomocí různých metod.

Metody: U rizikových dětí s $\mathrm{FH}$ ( $\mathrm{n}=30$, prům. věk 15,1 $\pm 2,9$ let) a s DM1 ( $\mathrm{n}=30$, prům. věk $14,4 \pm 1,6$ let, doba od diagnózy 4,4 \pm 2 let) byly hodnoceny následující rizikové ukazatele: hsCRP, oxidované LDL (oxLDL), malondialdehyd (MDA) a asymetrický dimetylarginin (ADMA). Souběžně byla hodnocena endoteliální dysfunkce sonograficky - flow mediated dilation (FMD) a decelerační index (DI). Stejné ukazatele byly stanoveny u kontrolní skupiny zcela zdravých dětí ( $n=30$, průměrný věk 15,3 $\pm 1,7$ let). Biochemické ukazatele byly porovnány mezi jednotlivými soubory a korelovány s FMD a DI.

Výsledky: Koncentrace ADMA byly významně vyšší u dětí s FH $(0,97 \mu \mathrm{mol} / 1$, SE 0,03, $p<0,001)$ a s DM1 $(0,85 \mu \mathrm{mol} / 1$, $\mathrm{SE} 0,05, p<0,01)$ než v kontrolním souboru $(0,70 \mu \mathrm{mol} / 1, \mathrm{SE}$ 0,04). V ostatních biochemických ukazatelích se skupiny nelišily. Hodnoty DI dosahovaly ve skupině FH 18,4 \%, DM1 16,9 \% a u zdravých dětí 22,7\%. Mezi sledovanými skupinami nebyly nalezeny statisticky významné rozdíly v FMD a DI.

Závěr: Plazmatická koncentrace asymetrického dimetylargininu byla v naší studii spolehlivějším ukazatelem endoteliální dysfunkce u dětí než ostatní biochemické i sonografické parametry. Stanovení asymetrického dimetylargininu v krvi může být dobrým ukazatelem rizika cévního postižení u dětí.

\section{SPONTÁNNÍ DISEKCE KMENE LEVÉ VĚNČITÉ TEPNY JAKO VZÁCNÁ PR̆ÍČIINA AIM U MLADÉ ŽENY}

\section{JEŘÁBEK P, VYTISKA M, KALA P, BOČEK O,} NEUGEBAUER P, POLOCZEK M, PAŘENICA J

Interní-kardiologická klinika, FN Brno, Brno

Úvod: Příčinou vzniku AIM je téměř ve všech případech koronární ateroskleróza srdce s rupturou AS plátu a následnou trombózou tepny. Neaterosklerotické postižení věnčitých tepen je vzácnou prŕíčinou vzniku infarktu myokardu, vyskytuje se asi u $6 \%$ pacientů s AIM, často u mladých lidí bez rizikových faktorů ICHS.

Metodika: Autoři prezentují případ mladé ženy s AIM v důsledku spontánní disekce kmene levé věnčité tepny, zasahující významně celý proximální a část středního úseku ramus interventricularis anterior (RIA) a hraničně i proximální část ramus circumflexus (RC). Diagnóza byla stanovena na základě koronarografie a potvrzena vyšetřením intrakoronárním ultrazvukem (IVUS). Pacientka byla léčena akutní PCI kmene levé věnčité tepny, proximální a střední části RIA s implantací dvou drug eluting stentů (DES).

Výsledky: Po kontrolní koronarografii a reintervenci kmene ACS byla pacientka propuštěna do ambulantní péče s přetrvávající dysfunkcí LK (EF LK 40 \% při akinezi hrotu a části PS). V ošetřené části levé věnčité tepny byl po opakované intervenci docílen optimální výsledek, postižení RC bylo hodnoceno jako funkčně nevýznamné $(\mathrm{FFR}=0,92)$ a disekce byla bez další progrese. Rovněž vyšetření CT ascendentní aorty neprokázalo disekci.

Diskuse: Spontánní disekce věnčité tepny (SCAD) je vzácná prŕičina vzniku AIM. V literatuře je popsáno asi 250 případů SCAD, klinicky se často manifestuje jako náhlá smrt a celková mortalita je odhadována na 70 \%. Jako rizikové faktory se uvádí ženské pohlaví, těhotenství, hormonální antikoncepce, hypertenze, systémové onemocnění pojiva a ateromatóza aorty. Terapeutický postup není jednoznačně stanoven, v popisovaných případech se uplatňovala chirurgická revaskularizace i intervenční léčba - PCI s implantací stentů.

Závěr: Koronární intervence byla pravděpodobně život zachraňujícím zákrokem u mladé ženy s raritním koronárním postižením.

\section{SIGNIFIKANTNÍ ELEVACE VE SVODU AVR PR̆I HODNOCENÍ POZITIVITY ERGOMETRICKÉHO TESTU}

JIRAVSKÁ-GODULA B, JIRAVSKÝ O, BARTNICKÁ M, BRANNY M

Interni ambulance, Kardiocentrum,

Oddělení nemocí z povolání a laboratoř funkční diagnostiky, Nemocnice Podlesí a. s., Třinec

Cîl: Ověřit význam signifikantních elevací ST ve svodu aVR př̀ ergometrii s ohledem na následující koronarografický nález.

Soubor a metodika: Prospektivní sledování všech pacientů indikovaných $\mathrm{k}$ ergometrii pro suspektní ICHS. Ergometrické vyšetření je prováděno na přístroji Cardiosoft, jedná se o bicyklovou ergometrii. Zátěžové vyšetření bylo prováděno $z$ indikace suspektní ICHS. Protokol zátěžového vyšetření zahrnuje pretest, dále zátěžovou část: excercise, kde zátěž je zvyšována o 2 min o 25 W (výjimečně o $50 \mathrm{~W}$ ) z úvodních $50 \mathrm{~W}$. Důvodem ukončení testu je nález pozitivity pokud jde o ICHS. Elevace ST úseku aVR jsou hodnoceny manuálně.

Následně u každého pacienta se signifikantní elelavací ST byla provedena koronarografie a výsledek komentován s ohledem na lokalizaci postižení koronárních tepen.

Výsledky: Celkově bylo od 11. 5. 2005 do 11. 1. 2007 vyšetřeno ergometricky 1020 pacientů ve věku od 45 let do 78 let. Signifikantní elevace SR zaznamenány u 42 pacientů (15 žen a 27 mužů)

Tito pacienti byli následně koronarograficky vyšetřeni. 4 vyšetření byla negativní pokud jde o aterosklerotické postižení koronárních tepen.

Všichni ostatní měli postižení na kmeni ACS či RIA, ale izolované SVD byly zaznamenány pouze 4 , v ostatních prrí padech se jedná o 2VD či MVD.

Závěr: Signifikantní elevace ST při ergometrickém vyšetření jsou v našem souboru pacientů známkou velmi 
suspektního postižení koronárních tepen aterosklerózou. Ve shodě s literárními údaji dominuje postižení ACS či RIA, leč SVD byla pouze sporadická, dominujícím nálezem byla 2VD či MVD s postižením kmene ACS či RIA.

\section{PROGNÓZA PACIENTŮ S AKUTNÍM INFARKTEM MYOKARDU A UMĚLOU PLICNİ VENTILACÍ V ÉR̆E PRIMÁRNÍ KORONÁRNÍ INTERVENCE*}

JIRMÁR̆ R, PĚNIČKA M, DVOŘÁK J, LISA L, BUDEŠÍNSKÝ T, MOŤOVSKÁ Z, WIDIMSKÝ P

III. interní-kardiologická klinika,

FN KV a 3. LF UK, Praha

*Podporováno grantem IGA MZ ČR č. 9022-3/2006.

Cil: Zjistit časnou a dlouhodobou prognózu pacientů s AIM a nutností umělé plicní ventilace (UPV) v éře primární PCI.

Soubor a metodika: Retrospektivně byl zhodnocen průběh onemocnění v souboru 510 pacientů $z$ regionu Prahy (průměrný věk $65 \pm 12$ ) přijatých do kardiocentra FN KV pro AIM (STEMI i non-STEMI) v období leden 2003 až prosinec 2005 a indikovaných k primární PCI. Z tohoto souboru 43 pacientů (průměrný věk $67 \pm 13)$ bylo léčeno UPV $(n=22)$ či KPCR + UPV (n = 21) v akutní fázi. Indikací k UPV byl kardiogenní šok u 18 (42\%) pacientů, plicní edém u 19 (44\%) pacientů a předchozí KPCR pro primární maligní arytmie u $6(14 \%)$ pacientů. STEMI mělo $88 \%$ pacientů ze souboru pacientů s AIM na UPV. PCI byla provedena úspěšně u $86 \%$ pacientů na UPV.

Výsledky: Mezi 467 nemocnými z regionu Prahy s AIM léčenými PCI bez nutnosti UPV mělo 61 nemocných srdeční selhání Killip III, IV, tj. 13 \%. Mezi 43 nemocnými s UPV/KPCR mělo srdeční selhání Killip III nebo IV 35 nemocných, tj. $81 \%$. Mortalita týdenní, měsíční a roční ve skupině pacientů s AIM na UPV pro plicní edém byla $21,1 \%$, $36,8 \%$ a $52,5 \%$, ve skupině s UPV pro kardiogenní šok $61,1 \%, 66,6 \%, 77,8 \%$. Ve skupině pacientů indikovaných k UPV pouze pro maligní arytmie byla mortalita $\% \%, 16,6 \%$, 33,3\%. Závažné extrakardiální komplikace (závažná posthypoxická encefalopatie, aspirace, závažné infekce, krvácení do GIT) se vyskytly u 34 \% pacientů na UPV. Průměrná délka hospitalizace pacientů, kteří byli propuštěni, byla 16,7 dne.

Závěr: V současné době moderní léčby AIM pomocí primární PCI vznikne nutnost UPV/KPCR v akutní fázi zhruba v $8 \%$ př́ípadi̊. Tito nemocní mají vysokou mortalitu $z$ podstaty své choroby. Ve srovnání s literárními údaji před érou primární PCI je však mortalita i u těchto pacientů při současné léčbě podstatně nižší. Nemocní na UPV po KPCR pro primární maligní arytmie mají relativně příznivou prognózu při léčbě primární PCI.

\section{VLIV POLYMORFISMU C5266T V GENU PRO NNOS NA VARIABILITU V SRDEC̆NÍM INTERVALU}

JÍRA M, ZÁVODNÁ E, HONZÍKOVÁ N, NOVÁKOVÁ Z, VAŠKU゚ A, IZAKOVIČOVÁ-HOLLÁ L, FIŠER B

Fyziologický ústav, Ústav patologické fyziologie, LF MU, Brno

Cíl: Snížená variabilita v srdečním intervalu a snížená citlivost baroreflexu jsou spojeny s nepříznivou prognózou u pacientů po infarktu myokardu. Cílem studie bylo vyhodnotit asociaci polymorfismu C5266T v genu pro neuronální syntázu oxidu dusnatého (nNOS) $\mathrm{s}$ variabilitou $\mathrm{v}$ srdečním intervalu a citlivostí baroreflexu.
Soubor a metodika: Krevní tlak a srdeční intervaly byly zaznamenávány 5 minut (Finapres, dýchání s frekvencí $0,33 \mathrm{~Hz})$ u 145 zdravých osob (20-24 let) v klidu, třikrát v týdenních intervalech. Variabilita $\mathrm{v}$ srdečním intervalu (VSIrel v relativních jednotkách - r. u., VSIabs v absolutních jednotkách $-\mathrm{ms}^{2}$ ) a citlivost baroreflexu (BRS v ms/mm Hg) byly určeny spektrální metodou ve frekvenčním pásmu 0,05-0,15 Hz. Genotypy byly stanoveny metodou polymerázové řetězové reakce a restrikční analýzy za použití enzymu EcoI. Srovnávali jsme VSIrel, VSIabs a BRS mezi genotypy tohoto polymorfismu (Kruskal-Wallis, Mann-Whitney s Bonferroni-Holmovou korekcí).

Výsledky: Frekvence genotypů polymorfismu C5266T byla: $53,1 \%$ (CC, $\mathrm{n}=77$ ), 40,8 \% (TC, $\mathrm{n}=59$ ), 6,2 \% (TT, $\mathrm{n}=9$ ). Mezi genotypy byl nalezen signifikantní rozdíl ve VSIrel (Kruskal-Wallis - CC: 0,261 \pm 0,085, CT: 0,316 \pm 0,100, TT: 0,317 $\pm 0,102$ r. u., $p<0,01)$. Nositelé méně četné alely (homozygoti TT a heterozygoti CT) měli signifikantně větší VSIrel ve srovnání s homozygoty CC (Mann-Whitney -

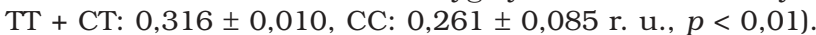
U nositelů méně četné alely byla přítomna tendence $\mathrm{k}$ vyšším hodnotám BRS, ačkoli rozdíl v BRS mezi nimi a homozygoty CC nebyl signifikantní.

Závěr: Byla nalezena signifikantní asociace polymorfismu C5266T v genu pro nNOS s variabilitou v srdečním intervalu. Méně četná alela T je spojována se zvýšenou produkcí oxidu dusnatého. Přítomnost této alely by mohla představovat protektivní faktor před zvýšenou aktivitou sympatiku.

\section{ÚLOHA DISTRIBUCE TUKU V OVLIVNĚNÍ RIZIKOVÝCH FAKTORŮ KARDIOVASKULÁRNÍCH ONEMOCNĚNİ V NÁHODNÉM POPULAČNÍM VZORKU ČR}

JOZÍFOVÁ M, CíFKOVÁ R, ŠKODOVÁ Z, LÁNSKÁ V, POLEDNE R

Pracoviště preventivní kardiologie, IKEM, Praha

Úvod: Převládající distribuce tuků v gluteofemorální oblasti má na rozdíl od centrální obezity příznivý účinek na riziko KVO.

Cíl: Zjistit vztah mezi obvody pasu, boků a KVO a jejich rizikovými faktory.

Metodika: Studie byla provedena v 1\% náhodném vzorku obyvatelstva ve věku 25-64 roků v období 2000/2001 (1 513 mužů, 1639 žen). Lipidy a glykemie byly stanoveny enzymatickými metodami. Krevní tlak a antropometrické hodnoty byly měřeny podle doporučení odborných společností. Zjištovali jsme vztah mezi rizikovými faktory KVO a obvodem pasu a s obvodem boků v populaci ČR v období $2000 / 2001$

Výsledky: Výskyt rizikových faktorů a kardiovaskulárních onemocnění u osob s vyšším obvodem boků (4. kvartil) v porovnání s osobami s obvodem boků v 1 . kvartilu $(\mathrm{OR}=1)$.

\begin{tabular}{|c|c|c|c|c|c|}
\hline Muži & $\mathbf{O} \mathbf{R}^{*}$ & 95\% CI & Ženy & $\mathbf{O} \mathbf{R}^{*}$ & 95\% CI \\
\hline Diabetes & 0,68 & $0,32-1,41$ & & 0,35 & $0,15-0,84$ \\
\hline Nízký HDL & 0,96 & $0,56-1,64$ & & 0,51 & $0,29-0,90$ \\
\hline Zvýšené TG & 0,45 & $0,27-0,74$ & & 0,69 & $0,38-1,23$ \\
\hline
\end{tabular}

* - adj. na věk, BMI a obvod pasu

Hodnoty krevního tlaku nebyly obvodem boků ovlivněny. Celkový a LDL-cholesterol se snižoval s narůstajícím obvodem boků pouze u žen.

Prevalence hypertenze a diabetu signifikantně narůstá ve kvartilech obvodu pasu u žen, u mužů tento vývoj ne- 
ní patrný. Průměrné hodnoty krevního tlaku, celkového a HDL-cholesterolu se zhoršovaly s narůstajícím obvodem pasu u obou pohlaví. Pouze u žen se zvyšovala glykemie a LDL-cholesterol s narůstajícím obvodem pasu.

Závěr: U mužů se s narůstajícím obvodem boků významně snižuje plazmatická koncentrace triglyceridů. U žen koreluje zvětšený obvod boků s nižší prevalencí diabetu a sníženého HDL-cholesterolu. Riziko kardiovaskulárních onemocnění a diabetu narůstá s obvodem pasu.

\section{CELKOVÉ KARDIOVASKULÁRNE RIZIKO SLOVENSKEJ POPULÁCIE}

JURKOVICOVÁ J, ŠTEFÁNIKOVÁ Z, ŠEVČÍKOVÁ L, ÁGHOVÁ L'

Ústav hygieny, Lekárska fakulta UK, Bratislava, SR

Ciel: Zistit výskyt rizikových faktorov (RF) kardiovaskulárnych (KV) chorôb v slovenskej populácii. Vypočítat celkový a priemerný počet $\mathrm{RF}$, celkové KV riziko podla modelu SCÓRE. Porovnat riziko podla framinghamského skórovania a podla modelu SCÓRE. Porovnat jednotlivé populačné skupiny podla veku, pohlavia, úrovne vzdelania, zamestnania a regiónu. Zistit trendy výskytu RF.

Súbor a metodika: V priebehu 6 rokov (1999-2004) vyšetrených 12959 dospelých osôb - dobrovolníkov (35,9 \% mužov) v 49 mestách SR v priemernom veku $47,2 \pm 14,6$ rokov. Zistoval sa výskyt biologických $\mathrm{RF}$ - hladina celkového cholesterolu v krvi; u 1342 osôb kompletný lipidový profil (automat Reflotron), TK (digitálne, Omron), nadhmotnost/ obezita (BMI) a fajčenie. Priemerný počet RF vypočítaný $Z$ celkového počtu $4 \mathrm{RF}$ : cholesterol $\geq 5 \mathrm{mmol} / \mathrm{l}$, TK $\geq 140 /$ $\geq 90 \mathrm{~mm} \mathrm{Hg}, \mathrm{BMI} \geq 25$ muži, $\geq 24$ ženy, fajčenie.

Výsledky: Len 13,9 \% osôb (10,1 \% mužov, 16,0 \% žien) nemalo ani jeden zo 4 RF. Najvyššie zastúpenie majú osoby s 2 RF (31,6 \%); všetky 4 RF mali 4,7 \% mužov a 2,4 \% žien. Podla SCÓRE je vo vysokom riziku ( $\geq 5 \%$ ) 30,1\% mužov a 6,0 \% žien v aktuálnom veku 40-65 rokov. Po projekcii rizika na vek 60 rokov u všetkých vyšetrených vo veku 18-65 rokov je vo vysokom riziku $62 \%$ mužov a 6,2 \% žien. $\mathrm{V}$ skupine s kompletným lipidovým profilom sa pri porovnaní celkového KV rizika, aj podla framingahmského skórovania, aj podla modelu SCÓRE, ukázalo podhodnocovanie rizika v slovenskej populácii podla framinghamského skórovania.

Záver: KV riziko významne súvisí s vekom, pohlavím, so stupňom vzdelania; zistili sa významné regionálne rozdiely (najlepšie výsledky boli u obyvatelov velkých miest - Bratislavy a Košíc, najhoršie v okresoch južného a východného Slovenska). Trendy hlavných RF sú v priebehu 6 rokov velmi mierne, klesajúce s výnimkou fajčenia, ktoré stúpa u oboch pohlaví.

\section{KOMUNITNí MODEL V PALIATIVNÍ PÉČI O NEMOCNÉ S POKROČILYYM CHRONICKÝM SRDEČNÍM SELHÁNÍM}

\section{KABELKA L, VÍTOVEC J \\ I. interní-kardioangiologická klinika, \\ FN u sv. Anny, Brno}

U neonkologicky nemocných se v zahraničí osvědčuje forma domácí paliativní péče. Zároveň zvláště ve Velké Británii je uplatňován model „komunitní péče“. Základním principem je propojení (osobní kontakt, spolupráce, předávání nemocného, snaha o sjednocení komunikace) sítě ambulantních i lůžkových poskytovatelů akutní a následné péče v regionu v úrovni komunikační a kompetenční. U pokročilého srdečního selhání se v zahraničí ukazuje pro dynamiku klinického stavu vhodná existence specializovaných koordinátorů péče - nejen v lékařské, ale i sesterské rovině. Zdravotní sestra (heart failure nurse specialist) má za úkol základní diagnostiku i uspořádání symptomů a komplikací v péči o klienta $\mathrm{v}$ jeho přirozeném prostředí - komunitě (domov či náhradní sociální prostředí) a jejím úkolem je pomoci zvýšit kvalitu života nemocného a snížit počet rehospitalizací pomocí edukace a podpory nemocného a jeho blízkých (lepší porozumění diagnóze, obtížím, dietním opatřením. možnostem života s nemocí - také tedy lepší přizpůsobení /compliance/). V případě akutních komplikací se připravují dopředu scénáře jejich řešení ve spolupráci s nemocným a jeho blízkými; při nepoměru mezi možnostmi zajištění péče $\mathrm{v}$ přirozeném prostředí a kvalitou života nemocného se řešením stává lůžková paliativní péče, ne vždy nutně specializovaného charakteru. I v zařízení například typu LDN (zhoršení mobility, nutná bazální úprava terapie, přechodná respirační infekce apod.) totiž působí dále výše uvedená zdravotní sestra a i zde je, stejně jako u praktického lékaře, kontaktní osobou pro spolupráci se specialistou. Tento model i vzhledem k demografickému vývoji a stárnoucí populaci nabízí efektní a komplexní řešení, které ve svých důsledcích negeneruje další zbytečné náklady na péči - spíše ji činí efektivnější.

\section{LÉKAR̆SKÝ A POPULAČNÍ MODEL INTERVENCE RIZIKOVYYCH FAKTORŮ KVO U ZAMĚSTNANCŮ NEMOCNICE}

KALETOVÁ M, SOVOVÁ E, NAKLÁDALOVÁ M, DOUPALOVÁ P, BENUŠOVÁ I

I. interní klinika, Klinika pracouního lékařství, FN Olomouc a LF UP, Olomouc

Cíl: Zjistit účinnost intervence rizikových faktorů (RF) kardiovaskulárních onemocnění (KVO) u zaměstnanců nemocnice. Porovnat lékařský a populační model intervence.

Soubor a metodika: U 709 zaměstnanců jsme stanovili výšku KV rizika. U vysoce rizikových (32 mužů - průměrný věk 45 let a 8 žen - průměrný věk 49 let) jsme důsledně uplatnili lékařský model intervence RF. Nerizikové zaměstnance (83 mužů - průměrný věk 37 let a 626 žen - průměrný věk 36 let) jsme poučili dopisem. $V$ odstupu 2 let jsme provedli kontrolní vyšetření. Výsledky jsme zpracovali dvouvýběrovým párovým $t$-testem.

Výsledky: U rizikových jsme nalezli statisticky významné snížení LDL z 3,56 na 2,05 u mužů ( $p=0,001)$, ostatní sledované parametry: TK, BMI, WHR, celkový cholesterol (TC), HDL, Tri a LDL u žen byly bez signifikantních změn, přesto významně pokleslo celkové riziko KVO z $20 \%$ na $16,6 \%$ u mužů $(p=0,025)$ a z $20 \%$ na $13,7 \%$ u žen $(p=0,011)$. U nerizikových mužů došlo $\mathrm{k}$ významnému zvýšení TC $(5,01 / 5,10 ; p=0,001)$, Tri $(1,16 / 2,86 ; p=0,001)$, HDL $(1,31 / 1,39 ; p=0,026)$ a snížení LDL $(2,65 / 1,12$ $p=0,001)$. U nerizikových žen došlo $\mathrm{k}$ významnému zvýšení TC $(5,01 / 5,10 ; p=0,001)$, Tri $(1,16 / 2,86 ; p=0,001)$, HDL $(1,61 / 1,69 ; p=0,001)$ a snížení LDL $(2,65 / 1,12$ $p=0,001)$. Nerizikoví neměli změnu $\mathrm{v}$ parametrech BMI, WHR a celkového kardiovaskulárního rizika.

Závěr: Lékařský model intervence měl statisticky významný vliv na pokles celkového rizika KVO u vysoce rizikových zaměstnanců nemocnice, vliv na zlepšení jednotlivých RF jsme nepozorovali. Vliv populačního modelu intervence se v odstupu 2 let od prvního vyšetření neprojevil snížením celkového kardiovaskulárního rizika. 


\section{SROVNÁNÍ STIMULACE Z VÝTOKU PRAVÉ KOMORY S KONVENČNÍ PRAVOKOMOROVOU STIMULACÍ, RETROSPEKTIVNÍ ANALÝZA U 134 PACIENTŮ}

KAMENÍK L, SEDLOŇ P, ČERNOHOUS M, ŠEVČÍKOVÁ K

\section{Kardiologické oddělení, ÚVN Praha a 1. LF UK, Praha}

Úvod: Dyssynchronie provázející dlouhodobou kardiostimulaci (KS) $z$ hrotu pravé komory je spojena s rizikem nastartování kaskády nepříznivého patofyziologického vývoje s finálním obrazem diskonduktivní kardiomyopatie. Alternativou ke snížení rizika nepříznivého působení KS je implantace elektrody do výtokového traktu pravé komory (RVOT).

Cille studie: Primární: stanovit šířku QRS ve skupině pacientů při KS ze septální části RVOT a porovnat parametr při konvenční KS. Sekundární: zhodnotit význam amplitudy intrakardiálního komorového signálu podle šíře QRS, jako parametru spoluurčujícího optimální pozici elektrody pro KS z RVOT.

Metodika: Retrospektivně bylo vyhodnoceno:

45 pacientů (průměrný věk 75,24 ) se stimulací na septu RVOT v roce 2006 (1)

44 pacientů (průměrný věk 75,25$)$ konvenčně stimulovaných $\mathrm{v}$ roce 2006 (2)

45 pacientů (průměrný věk 76,78 ) konvenčně stimulovaných do roku 2005 (3)

Skupiny se odlišovaly typem použité elektrody. Byly hodnoceny tyto parametry: šíře stimulovaného QRS při frekvenci 90/min (hodnocena zaslepeně lékařem), střední amplituda komorového signálu (SA), impedance komorové elektrody (I), stimulační práh (T). V (1) a (2) použity parametry $z$ doby implantace, šíře $\mathrm{QRS}$ měřena $\mathrm{v}$ průběhu roce 2006, ve (3) byly všechny parametry měřeny v roce 2006.

Výsledky: Průměrná šiře QRS intervalu v (1): 0,1351 s se střední odchylkou (SO) 0,0135 s, (2): 0,1482 s s SO 0,0130 s (3): 0,1487 s s SO 0,0132 s. Diference šíře QRS: (1) od (2) a (1) od (3) byly statisticky signifikantní při hladině významnosti 0,01. Korelace šíře QRS k SA nebyla nalezena, korelační koeficient $(\mathrm{KK})$ - 0,064, nebyla zjištěna korelace mezi intervalem QRS a věkem pacienta, KK: -0,104

Závěr: KS z RVOT měla kratší stimulovaný interval QRS oproti konvenční KS. Amplitudu komorového signálu během implantace nelze použít jako pomocné kritérium k optimalizaci polohy elektrody v RVOT.

\section{ROLE STANOVENÍ KaLCIOVÉHO SKÓRE POMOCİ VÝPOČETNÍ TOMOGRAFIE (CT) V KOMBINACI SE ZÁTĚŽOVÝM SPECT-ZOBRAZENIIM MYOKARDIÁLNÍ PERFUZE V DETEKCI ICHS}

KAMÍNEK M, SOVOVÁ E, BURIÁNKOVÁ E, METELKOVÁ I, VAVERKOVÁ H, STEJSKAL D, LUKL J

Klinika nukleární medicíny, I. interní klinika, III. interní klinika, FN Olomouc a LF UP, Olomouc, Oddělení laboratorní medicíny,

Nemocnice Šternberk, Šternberk

Cîl: Analyzovat postavení CT-stanovení kalciového (Ca) skóre ve vyšetřovacím algoritmu nemocných se suspektní ICHS a porovnat výsledky se zátěžovým SPECT-zobrazením myokardiální perfuze.

Metodika: Ca skóre bylo vyšetřeno u 37 pacientů (29 asymptomatických rizikových pacientů a 8 s koronarograficky prokázanou ICHS) na $\mathrm{PET} / \mathrm{CT}$ kameře Siemens
Biograph 16. Pro identifikaci kalcifikovaných lézí byla používaná hranice 130 Hounsfieldových jednotek. U pacientů s abnormálním Ca skóre bylo doplněno zátěžové gated SPECT-vyšetření (kamera Siemens e.cam, pro kvantifikaci perfuze a funkce byl použit software 4D-MSPECT).

Výsledky: V kontrolním souboru pacientů s prokázanou ICHS bylo průměrné Ca skóre $797 \pm 545 ; 6$ pacientů $\mathrm{s} \mathrm{Ca}$ skóre $>400$, 1 pacient v rozmezí 100-400 a u 1 pacienta bylo skóre nulové ( 8 dnů po akutním IM jako primomanifestaci ICHS). U asymptomatických pacientů bylo průměrné Ca skóre $78 \pm 224$; převažovalo nulové (16 pacientů), resp. minimálně zvýšené skóre (3 pacienti). Ca skóre bylo zvýšené u 10 pacientů ( 5 mírně, 3 středně a 2 měli Ca skóre > 400); z těchto pacientů mělo 7 normální SPECT a byli nadále léčeni medikamentózně, 3 pacienti s abnormálním SPECT byli odesláni ke koronarografii (u 2 pacientů s mírnou perfuzní abnormalitou byly nalezeny hraniční stenózy ke konzervativnímu řešení, 1 pacient s rozsáhlou pozátěžovou poruchou perfuze měl zjištěnu nemoc 3 tepen k operačnímu řešení).

Závěr: Z 29 rizikových asymptomatických pacientů byl identifikován 1 pacient $\mathrm{s}$ nemocí tří tepen, $\mathrm{u}$ něhož bylo indikováno kardiochirurgické řešení. Nález abnormálního Ca skóre je nutné ověřit pomocí zátěžového testu - z 10 pacientů mělo 7 normální zátěžový perfuzní SPECT. Kombinace obou metod tak umožňuje nově identifikovat podskupinu pacientů s extenzivní subklinickou aterosklerózu, u nichž je vhodná intenzivní medikamentózní léčba.

\section{SENZITIVITA A SPECIFICITA ZÁTĚŽOVÉHO GATED SPECT-ZOBRAZENÍ MYOKARDIÁLNÍ PERFUZE PRO DETEKCI ISCHEMICKÉ CHOROBY SRDEČNÍ: VALIDACE NÁLEZỦ POMOCÍ KORONAROGRAFIE}

KAMÍNEK M, OSTŘANSKÝ J, METELKOVÁ I, BUDÍKOVÁ M, RICHTER M, SLUKA M, INDRÁKOVÁ J

Klinika nukleární medicíny, I. interní klinika, FN Olomouc a LF UP, Olomouc

Cîl: Analýza senzitivity a specificity zátěžového gated SPECT-zobrazení myokardu pro detekci ICHS a kvantitativních parametrů perfuze a funkce levé komory při identifikaci pacientů s nemocí více koronárních tepen.

Soubor a metodika: V současnosti evidujeme 463 pacientů, kteří měli na KNM FN Olomouc od 6/2001 do 12/2004 zátěžové Tc99m MIBI, resp. Tl-201 gated SPECT myokardu na kameře Siemens e.cam, a nález byl následně ověřen koronarograficky. Složení souboru: 322 mužů a 141 žen, průměrný věk $62 \pm 10$ let, 134 pacientů po předchozím infarktu myokardu a 110 po revaskularizaci. Pro kvantifikaci sumačního zátěžového skóre (SSS), ejekční frakce (EF) a tranzientní ischemické dilatace (TID) levé komory byl použit software 4D-MSPECT.

Výsledky: Koronarografie byla negativní u 138 vyšetřených, zúžení > 50 \% mělo 325 nemocných. Na základě vizuálního hodnocení obrazů byla senzitivita a specificita SPECT $93 \%(301 / 325)$ a $78 \%(107 / 138)$. Senzitivita SPECT byla $89 \%, 98 \%$ a $94 \%$ u pacientů s nemocí 1,2 , resp. 3 tepen. Kvantitativní analýza perfuze ukázala narůst SSS podle počtu postižených povodí: 9 pro 1 tepnu vs. 13 a 15 při postižení 2 , resp. 3 povodí. Zatímco u pacientů s nemocí 1 tepny se průměrná pozátěžová EF (58 $\pm 11 \%)$ významně nelišila od klidové EF $(59 \pm 11 \%)$, při postižení více tepen byla pozátěžová EF (52 $\pm 10 \%)$ o $3 \%$ horší než v klidu $(55 \pm 11 \%)$. Poměr TID narůstal podle počtu postižených povodí: 1,07 pro nemoc 1 tepny a 1,09 , resp. 1,14 pro nemoc 2 , resp. 3 tepen. Známky poischemického omráčení levé komory (pozátěžové zhoršení EF > 5 \% a/nebo poměr TID > 1,17) mělo $45 \%, 52 \%$ a $69 \%$ pacientů s nemocí 1, 2, resp. 3 tepen. 
Závěr: Byla ověřena vysoká přesnost zátěžového SPECT-vyšetření pro detekci ICHS. Kvantitativní parametry funkce zjištěné pomocí gated SPECT umožňují identifikaci pacientů s poischemickým omráčením levé komory, u nichž lze předpokládat nemoc více tepen.

\section{OSUD NEMOCNÝCH PO KARDIOPULMONÁRNÍ RESUSCITACI PR̆I AKUTNIMM INFARKTU MYOKARDU, LÉČENÝCH PCI NA IKK FN BRNO}

KAŇOVSKÝ J, JANOUŠEK S, PAŘENICA J,

KALA P, NEUGEBAUER P, JEŘÁBEK P, BOČEK O,

POLOCZEK M, VYTISKA M, ŠPINAR J

Interní-kardiologická klinika, FN Brno-Bohunice, Brno

Úvod: Pacienti, u nichž vznikne jako komplikace akutního infarktu myokardu (AIM) zástava krevního oběhu, jsou skupinou, jejichž léčba patří k nejobtížnějším a jejich prognóza je vždy výrazně nejistá. Práce sleduje osud těchto pacientů přijatých na koronární jednotku naší kliniky (KJ IKK) v druhém pololetí roku 2006.

Soubor pacientů: Pacienti přijatí na KJ IKK po proběhlé oběhové zástavě $\mathrm{s}$ diagnózou AIM $\mathrm{v}$ druhém pololetí roku 2006 (10 pacientů, $z$ toho 8 mužů, průměrný věk $63 \pm 6$ let, medián 65 let).

Metoda: Prospektivní sledování pacientů kontinuálně od příjmu do propuštění i nadále, telefonické kontroly pacientů za pokračující hospitalizace i v domácí péči, běžné statistické metody.

Výsledky: Průměrná doba zahájení rozšiřrené resuscitace posádkou RLP byla $7 \pm 4$ minuty. U 9 pacientů byla při př́jezdu RLP zachycena fibrilace komor, jen $\mathrm{u}$ jednoho asystolie. Všichni však byli v průběhu resuscitace minimálně $1 \times$ defibrilováni. Jako úvodní léčba po přijetí na KJ IKK byla u všech pacientů provedena koronární angioplastika, u $8 \mathrm{z}$ nich direktní (do 12 hod. od vzniku AIM), u 2 pacientů později. $Z$ deseti prrijatých pacientů $3(30 \%)$ zemřeli ještě za hospitalizace na oddělení intenzivní péče ( 2 na naší KJ, 1 na spádovém pracovišti shodné úrovně), 1 pacientka zemřela s odstupem asi 5 měsíců v zařízení následné péče pro dekubitální sepsi. Plně se do aktivního života navrátili 2 pacienti, 3 jsou ještě hospitalizováni v nemocničních zařízeních, rehabilitující ve stabilním stavu.

Závěr: Moderní intervenční metody léčby AIM představují naději na zlepšení prognózy pacientů, u nichž je průběh komplikován oběhovou zástavou s nutností kardiopulmonární resuscitace. Definitivní zhodnocení terapie však bude možno učinit až s rozsáhlejším souborem nemocných.

\section{PROSPEKTIVNÍ REGISTR PACIENTŮ S AKUTNÍM SRDEČNIIM SELHÁNIIM HOSPITALIZOVANÝCH NA} III. INTERNÍ-KARDIOLOGICKÉ KLINICE FN KV A 3. LF UK*

KARÁSEK J, WIDIMSKÝ P, OŠT̃ÁDAL P, HESOVÁ K, HRABÁKOVÁ H, ŠPAČEK R, PĚNIČKA M

III. interní-kardiologická klinika, Kardiocentrum, FN KV a 3. LF UK, Praha

*Podpořeno VZ UK MSM OO 21620817.

Cíl: Vytvořit prospektivní registr pacientů s akutním srdečním selháním, detailně charakterizovat populaci těchto pacientů a stanovit jejich krátkodobou prognózu.

Metodika: Prospektivně vedený registr po sobě jdoucích pacientů (za 11 let, $51 \%$ mužů) s akutním srdečním selháním $(\mathrm{n}=202)$, průměrný věk 75 let, hospitalizovaných na III. interní-kardiologické klinice FN KV a 3. LF UK.
Výsledky: Průměrná ejekční frakce jedinců s akutním srdečním selháním $15 \% ; 63$ (31,2 \%) pacientů mělo zachovalou ejekční frakci ( $\geq 45 \%) \pm$ byla 38 . Troponin I při přijetí byl zvýšený u 65 (32,1 \%) nemocných. Příčina akutního srdečního selhání byla rozdělena na základní onemocnění vedoucí $\mathrm{k}$ selhání a spouštěcí mechanismus, který ved k akutnímu zhoršení (tabulka I). Základním onemocněním byla ve většině př́ikladů ischemická choroba srdeční často doprovázená mitrální insuficiencí a hypertenzí. Mezi spouštěcími mechanismy dominovaly akutní koronární syndromy spolu s hypertenzí a poruchami rytmu, zejména tachyfibrilací síní (celkem 75,8 \% případů). Průměrná doba hospitalizace 3,8 dne. Během hospitalizace zemřelo $40 \pm 6,6$ dne, $z$ toho na JIP 3,7 \pm byla 7,2 (19,8 \%) nemocných.

Závěr: Akutní srdeční selhání přestavuje různorodou skupinu onemocnění a je charakterizováno špatnou krátkodobou prognózou. Mezi nejčastější prŕičiny akutního srdečního selhání patří ischemická choroba srdeční spolu s mitrální insuficiencí, hypertenzí a tachyfibrilací síní.

Tabulka I

Základní př́ičina (onemocnění) a vyvolávající příčina (spouštěcí mechanismus) akutního srdečního selhání

\begin{tabular}{lcc}
\hline \hline & $\begin{array}{c}\text { Základní } \\
\text { přičina }\end{array}$ & $\begin{array}{c}\text { Vyvolávající } \\
\text { přičina }\end{array}$ \\
\hline ICHS, n (\%) & $143(71)$ & $\begin{array}{c}\text { Celkem: } 72(35,7) \\
\text { STEMI: } 38(18,8), \\
\text { AP/NSTEMI: 34 (16,9) }\end{array}$ \\
Mitrální insuficience, & $44(21,8)$ & $\mathrm{n} \mathrm{a}$ \\
n (\%) & $22(11)$ & $43(213)$ \\
Hypertenze, n (\%) & $\mathrm{n} \mathrm{a}$ \\
Aortální vada, n (\%) & $11(5,4)$ & $\mathrm{n} \mathrm{a}$ \\
Kardiomyopatie, n (\%) & $7(3,5)$ & $9(4,5)$ \\
Plicní embolie, n (\%) & $7(3,5)$ & $3(1,5)$ \\
Myokarditida, n (\%) & $5(2,5)$ & $38(18,8)$ \\
Arytmie, n (\%) & $1(0,5)$ & $33(16,3)$ \\
Jiné, n (\%) & $3(1,5)$ & $22(11)$ \\
Neurčitelné, n (\%) & $6(3)$ & \\
\hline \hline
\end{tabular}

\section{SRDEČNÍ SELHÁNÍ JAKO KOMPLIKACE LÉČBY PERORÁLNÍMI ANTIDIABETIKY. KASUISTIKA}

KASALOVÁ Z, KRUPIČKA J, CHYTILOVÁ E

III. interní klinika, VFN a 1. LF UK, Praha

Rosiglitazon ze skupiny thiazolinedionů patří mezi novější, zatím spíše méně použivané perorální antidiabetikum. Jedním z možných nežádoucích účinků tohoto léku je rozvoj srdečního selhání v důsledku retence tekutin. U pacientů s dobrou systolickou funkcí levé komory je riziko srdečního selhání sice minimální, ale i u nich je třeba na tuto komplikaci myslet.

Kasuistika dokumentuje případ 58leté diabetičky 2. typu po náhradě mitrální chlopně pro porevmatickou mitrální stenózu. Několik let po operaci byla pacientka zcela bez obtí ží, náhle ale začalo opakovaně - celkem třikrát v průběhu 8 měsíců - docházet k rozvoji oboustranné kardiální dekompenzace, jednou i s nutností hospitalizace. Kontrolní echokardiografické vyšetření prokázalo dobrou systolickou funkci levé komory i dobrou funkci chlopenní náhrady. Příčinou srdečního selhání bylo zřejmě přidání rosiglitazonu k dosavadní terapii diabetu metforminem a glimepiridem - časově korelovalo s první atakou srdečního selhání. Po vysazení rosiglitazonu je pacientka již 28 měsíců zcela bez známek srdečního selhání. U pacientů se strukturálním srdečním onemocněním je tedy třeba být, i přes příznivý echokardiografický nález při terapii ro-siglitazonem opatrni. 


\section{SROVNÁNÍ EFEKTU IZOLOVANÉ LEVOKOMOROVÉ A BIVENTRIKULÁRNÍ STIMULACE U NEMOGNÝCH S GHRONICKÝM SRDEČNÍM SELHÁNÍM NA PODKLADĚ IDIOPATICKÉ DILATAČNÍ KARDIOMYOPATIE*}

KAUTZNER J, RIEDLBAUCHOVÁ L, MAREK T, POPOVÁ L, MLČOCHOVÁ H, HOŠKOVÁ L, PEICHL P

Klinika kardiologie, IKEM, Praha

*Podpořeno grantem IGA MZČR 8541-3/2005.

Úvod: Předběžná data ukazují, že izolovaná levokomorová stimulace (LVP) vede ke srovnatelnému zlepšení jako stimulace biventrikulární (BV). Dlouhodobý efekt LVP a vliv na komorovou dyssynchronii však nejsou známy. $\mathrm{K}$ vyloučení vlivu jizev po infarktu myokardu na průběh aktivace komor, byl dopad LVP studován pouze u pacientů $\mathrm{s}$ idiopatickou dilatační kardiomyopatií.

Metodika: Do studie bylo zahrnuto celkem 27 pacientů, kteří splňovali konvenční indikační kriteria $\mathrm{k}$ resynchronizační terapii. Nemocní byli randomizováni k BV $(\mathrm{n}=13)$ nebo LVP $(n=14)$ a jejich dlouhodobé klinické a echokardiografické zlepšení bylo sledováno každé 3 měsíce. Za klinické „respondery“ byli označeni nemocní se zlepšením NYHA třídy o $>1$ stupeň.

Výsledky: Vstupní charakteristika byla srovnatelná u obou skupin. Ačkoliv jak BV, tak LVP vedly ke zlepšení třídy NYHA a tolerance zátěže při 6minutovém testu chůze, LVP byla spojena se signifikantně lepšími výsledky. V BV skupině bylo celkem 4/13 nonresponderů, zatímco ve skupině s LVP byli pouze $2 / 14(p=0,006)$. Významná redukce mitrální regurgitace a vzestup EF levé komory byly pozorovány pouze $\mathrm{u}$ LVP. $\mathrm{U}$ obou skupin byl patrný trend $\mathrm{k}$ redukci enddiastolického rozměru levé komory. Jak LVP, tak BV prodloužily významně preejekční periodu pravé komory $(110,9 \pm 19$ na $140,4 \pm 40$ u BV a 108,9 \pm 29 na 155,1 \pm 43 ms u LVP) bez korespondující změny tohoto intervalu u komory levé. Výsledkem byla redukce interventrikulární dyssynchronie (viz tabulka).

\begin{tabular}{lccc}
\hline \hline & NYHA & 6minutový test $(\mathbf{m})$ & $\boldsymbol{p}<\mathbf{0 , 0 5}$ \\
\hline BV bas & $3,1 \pm 0,3$ & $302 \pm 101$ & \\
BV 3 měs & $2,5 \pm 0,5^{*}$ & $332 \pm 102$ & $*$ \\
LVP bas & $3,1 \pm 0,3$ & $376 \pm 91$ & $*$ \\
LVP 3 měs & $1,8 \pm 0,7^{*}$ & $426 \pm 83^{*}$ & $*$ \\
$p=($ BV $\times$ LVP $)$ & 0,02 & 0,03 & \\
\hline \hline
\end{tabular}

Závěry: U nemocných s dilatační kardiomyopatií je izolovaná LVP v porovnání $\mathrm{s} B V$ spojena s výraznějším klinickým zlepšením, redukcí mitrální regurgitace a vzestupem $\mathrm{EF}$ levé komory.

\section{SESTERSKÁ SEKCE}

\section{PROBLEMATIKA LÉČENÍ INFEKČNÍ ENDOKARDITIDY}

KÁNSKÁ J

Kardiocentrum, jednotka intermediální péče, Krajská nemocnice Liberec, Liberec

Infekční endokarditida (dále IE) je onemocnění s incidenc 2-5/100 000, průměrná úmrtnost činí 10-30 \%. Většinou postihuje pacienty s preexistující chlopenní vadou či imunokompromitované nemocné, v poslední době přibylo IE na chlopenních náhradách a IE $\mathrm{u}$ intravenózních narkomanů. Obtížné léčbě napomáhá určení etiologického agens s prů- kazem citlivosti $\mathrm{k}$ antibiotikům a rovněž identifikace místa vstupu agens do krevního řečiště a jeho sanace. Léčbou volby je kombinovaná dlouhodobá antibiotická terapie se snahou o sterilizaci infekčního ložiska a v druhé době chirurgická korekce chlopenní vady. $\mathrm{V}$ některých př́ípadech dojde $\mathrm{k}$ relapsu IE bud' na protéze nebo na chlopni ošetřené plastikou. Referujeme kasuistiku 69letého muže s IE, jako infekční agens jsme identifikovali pseudomonádovou infekci. Po dlouhodobé antibiotické léčbě byla provedena náhrada aortální chlopně a mitrální valvuloplastika. Po operaci se však objevily subfebrilie s pozitivními hemokulturami s nutností dlouhodobé léčby antibiotiky a není vyloučena ani další chirurgická intervence.

Závěr: Naše kasuistika dokládá závažnost problematiky IE a problémy spojené $\mathrm{s}$ její léčbou jak konzeravtivní, tak operační.

\section{VIEWS ON THE ROLE OF ARTERIAL PULSE WAVE REFLECTION*}

\section{KENNER T}

Physiologisches Institut der Karl-Franzens, Universität Graz, Graz, Austria

\section{*Support: MSM0021622402.}

It seems that recently the interest in the role of pulse wave reflection in the arterial system has been amplified. In recognition of the effect of wave reflection, a new pulse-related „amplification index“ was introduced for diagnostic purpose.

Besides these historical remarks it seems interesting to discuss some special aspects of wave reflection in arteries. Any location in elastic tubes where the mechanical properties or the dimension changes gives rise to reflection of pressure and flow waves. In the periphery of the arteries the reflection usually is positive. The increase of the pressure amplitude towards the periphery is due to reflection and to the effect of tapering of the arteries. Since the pressure-flow-relation in the peripheral resistance vessels is nonlinear, the magnitude of the reflection factor depends on the pressure level. In locations where an artery is collapsed, e.g. by a pressure cuff, remarkable changes of the reflection factor from positive to negative during the time of the transient of one pulse can be observed. Reflected waves returning from a peripheral artery, e.g. from the upper extremity, are reflected negatively when arriving at the branching point from the aorta. A particular note has to be made with respect to the repercussion of reflected waves on the heart. Consequences thereof are the questions concerning optimization of heartbeat and adjustment between heart and arterial system.

We have observed that the magnitude of the reflection factor may vary from beat to beat. One attempt to interpret this phenomenon is the assumption of interference between slow variations of resistance and pressure and fast cardio-ballistic vibrations in the vicinity of arteries, particularly in extremities.

E. Wetterer and T. Kenner. Dynamik des Arterienpulses. Springer, 1968

\section{ANOMÁLIE VĔNČITÝCH TEPEN - SROVNÁNÍ LITERÁRNÍCH ÚDAJƯ S NÁLEZY U KONSEKUTIVNÍCH VYŠETR̆ENÍ V KATETRIZAČNÍ LABORATOR̆I}

KMONÍČEK P, FORMÁNEK P, ASCHERMANN O, KOPŘIVA K

Kardiologické oddělení, Nemocnice Na Homolce, Praha 
Literárně je udáván výskyt anomálií odstupů věnčitých tepen kolem $0,5 \% \mathrm{v}$ nálezech $\mathrm{z}$ katetrizační laboratoře. Nejčastější anomálií jsou popisovány separované odstupy ramus interventricularis anterior (RIA) a ramus circmflexus (RCx) (35,3\%), následované odstupem pravé věnčité tepny (ACD) z levého koronárního sinu (20,6 \%). Třetí nejčastější anomálií je odstup RCx z pravého koronárního sinu (20 \%). Solitární věnčitá tepna byla popsána v 8,8 \% všech anomálií.

Revizí nálezů konsekutivních katetrizačních vyšetření v naší katetrizační laboratoři jsme z 1138 nálezů identifikovali výskyt anomálií odstupů věnčitých tepen u 27 nemocných, což je 2,37 \% vyšetřených. Separované odstupy RIA a RCx u 9 nemocných (33,3 \%), anomální odstup ACD Z levého koronárního sinu u 11 probandů (40,7\%) a odstup RCx z pravého koronárního sinu u 4 vyšetřených (14,8 \%). U jednoho nemocného jsme nalezli solitární levou věnčitou tepnu $(3,7 \%)$ a rovněž u jednoho nemocného odstup levé věnčité tepny $z$ plicnice.

Zaměřili jsme se i na výskyt hypoplastické tepny v té formě, kdy nedosahuje mezikomorového žlábku (tento nález byl identifikován v 6,8 \%) a rovněž na výskyt hypoplazie RIA. Tento nález byl mnohem vzácnější $(0,7 \%)$, avšak přinášel často svým nositelưm obtíže ve formě bolestí na hrudi a/nebo námahovou dušnost.

Vyšší procento výskytu anomálií věnčitých tepen si vysvětlujeme vyšším počtem vyšetřených nemocných s diagnózou některé vrozené vývojové vady srdeční. U těchto nemocných je výskyt anomálií věnčitých tepen častější a v našem souboru přesahoval $10 \%$.

\section{SESTERSKÁ SEKCE}

\section{KOMPLIKOVANÝ PRŮBĚH ONEMOCNĚNÍ PR̆I INFEKČNÍ ENDOKARDITIDĔ. KASUISTIKA NEMOCNÉHO S HOMOGRAFTEM}

KNAIFLOVÁ M, TYLOVÁ I

Oddělení echokardiografie,

Kardiologie Na Bulovce s. r. o., Praha

Nemocný byl v roce 1990 hospitalizován pro embolické pří hody v mozku a ve slezině. Podrobným vyšetřením byla zjištěna infekční endokarditida aortální bikuspidální chlopně. Etiologické agens bylo St. aureus.

Chirurg provedl náhradu aortální chlopně a aortálního kořene homograftem.

V dalším období byl nemocný stabilizován, byl pravidelně klinicky a echokardiograficky sledován. Parametry náhrady byly příznivé až do roku 2005, kdy se objevily známky časné degenerace homograftu. Byla provedena nová operace s implantací konduitu, nebyla zjištěna nová ataka infekční endokarditidy.

V roce 2006 ale je opět aktivní ataka IE s mohutnou infiltrací anulu aorty, s abscesy a pseudoaneuryzmaty. Jako etiologické agens je detekován Staphylococcus aureus.

Nová ataka musela být řešena novou operací a byla skvěle zvládnuta. Nyní je opět nemocný ve velmi dobrém stavu.

\section{ISCHEMICKÁ MITRÁLNÍ REGURGITACE. CÍlE STUDIE PRAGUE 9*}

KOČKA V, WIDIMSKÝ P, LEHÁR F, VESELKA J, PEŠL L, FORMÁNEK P, ŠŤÁSEK J, HERMAN A, ČERVINKA P, HOLM F

II. interní-kardiologická klinika, FN KV a 3. LF UK, Praha, I. interní-kardioangiologická klinika, FN u sv. Anny a MU,
Brno, Kardiologická klinika, FN Motol a 2. LF UK, Praha, Kardiologické oddělení, Nemocnice České Budějovice, České Budějovice, Kardiologické oddělení, Nemocnice Na Homolce, Praha, Kardiocentrum, FN Hradec Králové a LF UK, Hradec Králové, Kardiologické oddělení, Masarykova nemocnice Ústí nad Labem, Ústí nad Labem,

Kardiologické oddělení, Krajská nemocnice Liberec, Liberec

*Podpořeno grantem VZ MSM0021620817.

Ischemická mitrální regurgitace (IMR) je definována přítomností významné koronární nemoci (nejčastěji i stavem po infarktu myokardu) a absencí strukturálních změn mitrální chlopně.

Téma ischemické mitrální regurgitace je značně komplikováno $\mathrm{z}$ důvodu:

1. obtíží při kvantifikaci hemodynamické významnosti mitrální regurgitace, která vyžaduje syntézu několika metod a zkušenosti vyšetřujícího,

2. změnou významnosti regurgitace $\mathrm{v}$ závislosti na hemodynamických parametrech či ischemii myokardu.

Optimální léčebná strategie IMR je podle Doporučení ACC kontroverzní. Existují většinou nerandomizované studie $\mathrm{z}$ jednoho centra, prokazující prospěch kompletní chirurgické revaskularizace, doplněné o plastiku mitrální chlopně. Existují však i studie popisující významné zmenšení mitrální regurgitace po chirurgické revaskularizaci bez zákroku na mitrální chlopni. Zásadním poznatkem je významně vyšší riziko kombinovaného chirurgického výkonu oproti „pouhé“ chirurgické revaskularizaci, z literatury mezi $4-21 \%$, recentně $8 \%$

$Z$ těchto skutečností vyplývá záměr multicentrické prospektivní randomizované otevřené studie PRAGUE 9. Této studie se účastní 9 kardiologických a 6 kardiochirurgických center v České republice. Subjekty studie jsou pacienti potenciálně indikovaní $\mathrm{k}$ chirurgické revaskularizaci myokardu s př́itomnou jakoukoliv IMR kromě triviální a klinicky těžké. Randomizace probíhá mezi kompletním chirurgickým výkonem $(\mathrm{CABG}$ + plastika mitrální chlopně s případně MAZE procedurou) a perkutánní koronární intervencí (na všech významných stenózách). Je povolen přesun pacienta (,cross-over“) z jedné léčebné skupiny do druhé, pokud je to v zájmu pacienta. Hypotézou studie je nižší mortalita pacientů v perkutánní větvi. Sledování je klinické a echokardiografické v období 1 roku a 5 let. Studie byla zahájena randomizací prvního pacienta dne 3. 1. 2007.

\section{DIGOXIN TOXICITY RELATED MYOCARDIAL EDEMA. CASE REPORT}

\section{KOČKOVÁ R, MC FADDEN E}

Cardiology Department, Cork University Hospital, Cork, Ireland

A 62 year old female attempted suicide taking three fistfuls of Digoxin. She presented to Emergency Department five hours later with already developed symptoms of digoxin toxicity including severe bradycardia. Her digoxin level was over $20.4 \mathrm{ng} / \mathrm{ml}$, potassium level was $5.2 \mathrm{mmol} / \mathrm{L}$. She was treated with Digoxin-Specific Fab Antibody Fragments and Atropine with prompt improvement and haemodynamic stabilisation. Echocardiography in subacute phase demonstrated significant left ventricular hypertrophy and abnormal myocardial texture. Repeat echocardiography before discharge (on day ten) showed borderline myocardial thickness and normal appearance of her myocardium. This 
phenomenon is consistent with transient myocardial edema. As there was no other explanation for this finding we believe it was related to digoxin toxicity. This has not been described before.

\section{PSYCHOLOGICAL AND PHYSICAL EFFECT AFTER TWO-WEEK CARDIAC REHABILITATION (PHASE II) IN PATIENTS WITH ACUTE MYOCARDIAL INFARCTION*}

KOHZUKI M, NAGASAKI M, MINAMI N, SIEGELOVÁ J, DOBŠÁK P

Department of Internal Medicine and Rehabilitation Science, Tohoku University of Sendai, Sendai, Japan, Klinika funkční diagnostiky a rehabilitace,

FN U sv. Anny, Brno

*Support: Grand for The Japanese Scientific.

Research (No 1371552).

Grant MSMO021622402, CZ.

Objective: Lifestyle modification should be acquired during phase II and maintained thereafter. We have designed a new 2 -week hospitalized phase II CR program. The purpose of the present study is to clarify whether quality of life (QOL), the psychological and physical status of patients with acute myocardial infarction (MI) improves after participation in the program.

Methods: Fifty-one patients with acute MI were enrolled in the program. Another 34 patients with acute MI who did not participate in the program served as a control group. The rehabilitation program consisted of exercise training, education and counseling. QOL, the physical and psychological status of the patients was evaluated before, at 1 month after the program, and at 6- and 12-month follow-up. Quality of life (QOL) was assessed using established and validated QOL scales. The psychological status was assessed by the Spielberger state-trait anxiety inventory questionnaire (STAI) and self-rating questionnaire for depression (SRQ-D).

Results: After participation in the program, the exercise tolerance, serum lipid profiles and STAI anxiety score of the patients were improved significantly. At 6-month follow-up, these parameters remained improved and regular physical activity was maintained. QOL score was also improved significantly. Even at 12-month follow-up, lipid profiles remained improved and regular physical activity was maintained.

Conclusion: Two-week hospitalized phase II CR program improved $\mathrm{QOL}$ and the management of cardiac risk factors in patients with MI. This program provides beneficial effects on QOL, psychological and physical activities in the recovery phase and may also contribute to the secondary prevention of MI.

\section{EVAKUAČní PUnKCe PeRIKaRdiálního VÝPOTKU PO KARDIOCHIRURGICKÉ OPERACI. NAŠE ZKUŠENOSTI}

\section{KOLEK M}

\section{Kardiochirurgické centrum, FNsP Ostrava, Ostrava}

Incidence perikardiálních výpotků po kardiochirurgických výkonech (revaskularizacích a chlopenní chirurgii) se udává od 58 do $64 \%$. Výskyt srdeční tamponády je přibližně 1,5 \%.

Cíl: Prezentovat zkušenosti našeho pracoviště s prováděním perikardiocentézy po srdeční operaci v období od $12 / 2004$ do $12 / 2006$.
Metodika a výsledky: Soubor je tvořen 38 nemocnými průměrného věku 62,9 let, žen bylo $42 \%$. Časový odstup perikardiocentézy od operace byl 6-80 dní, medián 13 dní. Indikací k punkci perikardu byl nejčastěji progredující velký perikardiální výpotek bez známek srdeční tamponády 15 nemocných (39,5\%), dále velký výpotek s klinickými echokardiografickými (ECHO) známkami srdeční tamponády - 11 nemocných (29 \%), velký výpotek pouze s ECHO-známkami tamponády - 10 pacientů (26,3 \%) a lokalizovaná kolekce tekutiny s útlakem některého srdečního oddílu - 2 pacienti (5,3\%). Maximální separace listů perikardu byla zjištěna nejčastěji při inferolaterální stěně levé srdeční komory. V souladu s tímto nálezem byla perikardiocentéza provedena nejčastěji $z$ apikálního přístupu, vždy za ECHO-kontroly. U 95 \% nemocných byl perikardiální drén ponechán na aktivním sání, doba drenáže činila 1-6 dní, medián 1 den. Jednorázově bylo při punkci odsáto 50-1 200 ml výpotku (medián $465 \mathrm{ml}$ ). Odpad $\mathrm{z}$ drénu na aktivním sání byl 30-2 950 ml (medián 210 ml). Specifická váha výpotku kolísala od 1015 do 1 045, medián 1 025. Třikrát došlo $\mathrm{k}$ recidivě významného výpotku s nutností opakování perikardiální punkce. Nezaznamenali jsme žádnou komplikaci v souvislosti s perikardiocentézou. S vyšší pravděpodobností provedení perikardiocentézy byla asociována chlopenní chirurgie, chirurgie ascendentní aorty a MAZE procedura - výkony spojené s nutností antikoagulační léčby v pooperačním období.

Závěr: Perikardiocentéza je efektivní a bezpečná metoda léčby perikardiálních výpotků po srdeční operaci.

\section{ANEURYZMATA ABDOMINÁLNÍ AORTY A TEPEN DKK}

KOLOŠOVÁ R, MRÓZEK V, PAVLAS I, ZEMAN K, GISTINGER T, TALAFA V

Interní oddělení, Nemocnice Frýdek-Místek, Frýdek-Místek

Aneuryzma znamená trvalé rozšíření tepny (na více než 1,5 násobek šíře obvyklé v daném segmentu). Přirozenou tendencí aneuryzmat je další dilatace a rozvoj nástěnného trombu. Z toho pramení obvyklé komplikace - útisk okolních struktur, ruptura, trombóza a uzávěr tepny, distální embolizce.

Aneuryzata jsou většinou diagnostikována některou ze zobrazovacích metod, nejvhodnější a nejdostupnější pro screening je ultrazvukové vyšetření.

$\mathrm{Na}$ interním oddělení nemocnice Frýdek je provádíme od roku 1992. Nyní na přístrojích Accuson 128 XP/10C, ALOCA 4000 a $5000 \mathrm{~s}$ použitím barevného dopplerovského mapování. V abdominální oblasti a malé pánvi používáme sektorovou sondu a frekvence 2,5-4,5 MHZ, na končetinách pak krátkou lineární sondu a frekvence 5-7,5 MHz.

V loňském roce jsme provedli 948 dopplerovských vyšetření tepen dkk a abdominální aorty. Při nich jsme diagnostikovali 26× aneuryzma abdominální aorty, 3× aneuryzma ilických tepen, $12 \times$ aneuryzma arteria poplitea, $1 \times$ aneuryzma AFS, $1 \times$ aneuryzma distální anastomózy F-P bypassu, $4 \times$ byla nalezena dilatační arteriopatie tepen dkk.

U pacientů indikovaných k operačnímu řešení doplňujeme vyšetření dalšími zobrazovacími metodami - CT, spirální CTA, popř. MRA a DSA.

Obecně je $u$ pacienta $s$ onemocněním periferních tepen riziko progrese lokálního onemocnění $25 \% \mathrm{v}$ průběhu 2-5 let, zatímco riziko KV úmrtí do 5 let je 30\%. Proto před indikací $\mathrm{k}$ operačnímu výkonu u pacienta dovyšetřujeme karotidy, provádíme ECHO srdce, v indikovaných případech dobutaminové ECHO, SPECT myokardu či koronarografii. $\mathrm{V}$ práci jsou dále rozebrána rizika aneuryzmat $\mathrm{v}$ jednotlivých lokalizacích, naše nálezy, zjištěné komplikace, možnosti a indikace $\mathrm{k}$ jejich řešení. 


\section{RENAL FUNCTION AND LIPID SPECTRUM IN PATIENTS WITH ARTERIAL HYPERTENSION: COINCIDENCE OR CORRELATION?}

KOSMÁLOVÁ V, LIETAVA J, MAKOVICKÝ T, KUBOVÁ M, DUKÁT A

\section{II. interná klinika, Fakultná nemocnica, Bratislava, SR}

Introduction: Causal relationship between blood pressure and renal function is well establish and accepted. However, lipid spectrum level and markers of renal function in normal creatine level were not investigated in details in patients with arterial hypertension.

Method: Multicentral crosssectional project screened 1061 pts (M: 38.0\%; F: 61.1\%) with essential hypertention [(SBP: $156.1 \pm 13.4$ vs. $152.2 \pm 16.3 \mathrm{mmHg}(p<0.03)$; DBP $(94.5 \pm 7.47$ vs $92.9 \pm 8.3 \mathrm{mmHg}(p<0.003)]$. All pts were analysed for lipid spectrum and creatinine (CREA) level). 36 pts were excluded due to CREA > $135 \mu \mathrm{mol} / \mathrm{L}$.

Results: After splitt of pts according to quartils [Q] of CREA, we found expected highest both SBP and DBP in the highest quartil of CREA ( $p<0.04$; resp. 0.02). Of lipid spectrum, only triacylglycerids exhibited significant increase with Q-CREA $(p<0.001)$ with correlation $\mathrm{r}=0.17(p<0.01)$. Waist circumference shown increase from $91.6 \pm 13.3$ to 96.1 $\pm 13.5 \mathrm{~cm}(p<0.03)$ in $\mathrm{Q}$-CREA and it correlated both with Q-CREA $[\mathrm{r}=0.12(p<0.001)]$ and CREA $[\mathrm{r}=0.13(p<0.01)]$. Adjustment to diabetes mellitus cancelled given correlations.

Conclusion: Significant association between serum creatine and triacylglycerids in pts with arterial hypertension could be caused by presence of diabetes mellitus and/or metabolic syndrom. Waist circumference shown significant direct relationship with increased creatinine.

\section{SESTERSKÁ SEKCE}

\section{OŠEtřovatelská PÉČe o PACIENTA PO ENDOVASKULÁRNÍM VÝKONU}

\section{KOSTKOVA I, KNEŘOVÁ H, BERAN S, LINHART A}

II. interní klinika kardiologie a angiologie, VFN a 1. LF UK, Praha

Řada srdečních a cévních onemocnění je v dnešní době spíše než chirurgicky, řešena pomocí katetrizačních metod. Pro pacienta to představuje šetrnější řešení. S endovaskulárními výkony se setkáváme hlavně $\mathrm{u}$ pacientů $\mathrm{s}$ diagnózou ischemické choroby srdeční, infarktem myokardu, ischemií končetinových tepen. Indikací $\mathrm{k}$ výkonu mohou být důvody diagnostické (flebografie, arteriografie, koronarografie) či léčebné (angiplastika, stenting, trombolytická terapie).

Naše sdělení bude rozděleno do několika částí: příprava psychická, fyzická, ošetřovatelská péče po výkonu, včetně základních ošetřovatelských diagnóz a možných komplikací.

$\mathrm{Na}$ závěr bych ráda zdůraznila nezastupitelnou úlohu sestry v péči o pacienty po endovaskulárních výkonech.

\section{ROZDÍLY V MORFOLOGII A SLOŽENÍ PLÁTŮ U NEMOCNÝCH SE STABILNÍ A NESTABILNÍ ANGINOU PECTORIS. STUDIE S INTRAVASKULÁRNÍM ULTRAZVUKEM A VIRTUÁLNÍ HISTOLOGIÍ}

KOVÁRNÍK T, HORÁK J, DOSTÁL O, ASCHERMANN M, LINHART A

II. interní klinika, FN a 1. LF UK, Praha
Cíl: Srovnat rozdíly ve velikosti a složení aterosklerotických plátů pomocí intravaskulárního ultrazvuku (IVUS) a virtuální histologie (VH).

Metody: Jedná se o retrospektivní analýzu 100 nemocných vyšetřených na II. interní klinice VFN. Indikací provedení vyšetření IVUS bylo hodnocení hemodynamické významnosti lézí, či indikace nejvhodnější strategie koronární intervence. Hodnoceno bylo 20 mm nejvýznamnější části ze zobrazeného plátu. K vyšetření byl použit přístroj a katetry (Eagle Eye) firmy Volcano (Volcano Therapeutics, Rancho Cordova, CA, USA). Velikost plátů byla hodnocena srovnáním průměrné hodnoty plaque burden $(\mathrm{PB}), \mathrm{tj}$. procentuální velikosti stenózy v prŕičném řezu tepnou. Složení plátů bylo hodnoceno podle zastoupení jednotlivých složek (\%): fibrózní - F, fibrolipidové - FL, nekrotické - NC, kalcifikace - C. Byl srovnáván výskyt tzv. thin cap fibroatheroma (TCFA), tj. plátu s tenkou fibrózní čepičkou. Pro diagnózu TCFA byla použita definice: > 10\% zastoupení nekrotické tkáně v plátu s $\mathrm{PB}>40 \% \mathrm{~s}$ přímým kontaktem NC s lumen tepny ve třech po sobě následujících řezech.

Výsledky: Ze 100 zařazených nemocných bylo 51 se stabilní anginou pectoris (SAP) a 49 s nestabilní anginou pectoris (NAP). U nemocných s NAP vs. SAP byla významně častěji nalezena ruptura aterosklerotického plátu (79 \% vs. $47 \%, p=0,001$ ), byl zjištěn větší PB (55\% vs. $50 \%$, $p=0,03)$. TCFA byla nalezena častěji u nemocných s NAP (78 \% vs. $57 \%, p=0,03$ ); NC složka plátu byla nesignifikantně více zastoupena v plátech pacientů s NAP (14,1 vs. $11,3 \%$ a F složka byla u nemocných s NAP zastoupena méně než u nemocných se SAP (58 \% vs. $63 \%, p=0,01$ ).

Závěry: Aterosklerotické pláty u nemocných s NAP jsou objemnější, častěji obsahují rupturu a TCFA a méně fibrózní tkáň ve srovnání s pacienty se SAP.

\section{ŘEŠ́ENÍ NEÚČINNÉ DEFIBRILACE ICD PO VYČERPÁNÍ OBVYKLY̌CH POSTUPŨ P̌̆ı TESTOVÁNÍ deFIBRILAČNÍHO PRAHU. KASUISTIKA}

KOŽELUHOVÁ M, BYTEŠNÍK J, ČIHÁK R, SKALSKÝ I

\section{Klinika kardiologie, IKEM, Praha}

Úvod: Implantabilní kardioverter-defibrilátory (ICD) jsou multifunkční programovatelné přístroje, které jsou určené k terminaci život ohrožující arytmie. Na konci implantační procedury se testuje funkčnost defibrilačního systému zároveň $\mathrm{s}$ ověřováním defibrilačního prahu (DFT). Ve většině center se v rámci implantace ověřuje $2 \times$ terminace vyvolané fibrilace komor (FK) výbojem energie o $10 \mathrm{~J}$ nižší než je maximální kapacita přístroje. V následující kasuistice shrnujeme řešení při neúčinné defibrilaci ICD.

42letý nemocný s dilatační kardiomyopatií, stanovení diagnózy v roce 2005.

Zavedena terapie srdečního selhání, v dalším období NYHA II. 23. 5. 2005 v terénu laická resuscitace pro oběhovou zástavu, vs. na podkladě maligní arytmie s následným záchytem nesetrvalých KT (nsKT) na spádovém pracovišti.

Došlo k progresi dysfunkce levé komory srdeční (EF pod 20 \%). Nemocný indikován k implantaci ICD.

5. 6. 2006 implantace ICD - při testování přístroj nepřerušil FK ani výbojem $21 \mathrm{~J}$ ani $31 \mathrm{~J}$, ta terminována až zevním výbojem. Test opakován se stejným výsledkem při opačné konfiguraci defibrilačních elektrod. 7. 6. 2006 systém doplněný o epikardiální elektrody s vyšší energií nezrušil FK, následně refrakterní FK nereagující na zevní výboje, nutná urgentní torakotomie, mimotělní oběh, úspěšná defibrilace až přímou aplikací DC pomocí 4 epikardiálních 
plošných elektrod. Následně inotropní podpora, intraaortální balonková kontrapulsace. Vzhledem k nespolehlivé defibrilaci i při použití všech obvyklých postupů byl pacient zařazen na čekací listinu transplantace srdce (OTS), jako urgentní kandidát. 24. 7. 2006 - OTS.

Závěr: V poslední době je ve světě patrný trend $\mathrm{k}$ implantaci ICD bez testování DFT. Naše kasuistika dokumentuje, že $\mathrm{u}$ individálních pacientů má stanovení DFT nezastupitelný význam a jeho výsledek může přispět $\mathrm{k}$ výběru jiného medicínského postupu, včetně OTS.

\section{POUŽITÍ PERKUTÁNNI MECHANICKÉ FRAGMENTACE EMBOLU V PLICNICI}

\section{KRAJINA A, LOJÍK M, RAUPACH J, CHOVANEC V}

Radiologická klinika, FN Hradec Králové,

Hradec Králové

Cíl: Retrospektivní analýza použití mechanické fragmentace a rozptýlení embolu při masivní plicní embolizaci ke zlepšení plicní hemodynamiky. Teoretickým předpokladem je, že součet průsvitu větví třetího až čtvrtého řádu arteria pulmonalis je zhruba $4 \times$ vyšší než průsvit větví prvního řádu. Uvolněním centrálně uloženého embolu směrem do periferie tak může dojít ke zvýšení prưtoku plicním řečištěm.

Soubor a metodika: Do studie bylo zahrnuto 5 nemocných (4 ženy a 1 muž) průměrného věku 67 roků (52-80 let) s masivní plicní embolizací. 3 nemocní byli 1-3 dny po rozsáhlém chirurgickém výkonu, 1 nemocná po druhostranné pneumonektomii pro karcinom plic, další po nefrektomii S extirpací smíšeného trombu $z$ dolní duté žíly a další po totální endoprotéze kyčelního kloubu. U všech byla po embolizační příhodě nutná resuscitace, došlo k významnému poklesu systémového tlaku. Zaintubovaní nemocní byli urgentně přemístěni na katetrizační sál. Do plicnice byl zaveden $9 \mathrm{~F}$ flexibilní sheath a katetr tvaru pigtail 7-8 F a provedeny pokusy o fragmentaci embolů ruční rotací katetru. Ve 3 prrípadech bylo podáno 20-40 mg tkáňového plazminového aktivátoru ve snaze zvrátit nepříznivý vývoj.

Výsledky: 2 nemocní (40 \%) přežili a byli dále léčeni a propuštěni do domácího ošetření. 3 nemocní (60\%) zemřeli následkem systémové hypotenze ( $\mathrm{z}$ toho 2 během výkonu).

Závěr: Včasná diagnóza plicní embolizace, a to i na základě klinických příznaků a okamžitá katetrizace plicnice s fragmentací embolů, může u omezeného počtu nemocných vést ke zvýšení průtoku krve plicním řečištěm a k záchraně života.

\section{SÍŇOVÉ ARYTMIE PO CHIRURGICKÉ LÉČBĔ FIBRILACE SÍNÍ POMOCÍ RADIOFREKVENČNÍ ENERGIE}

KRAUSOVÁ R, KAUTZNER J, MALÝ J, PIRK J, SKALSKÝ I

\section{Kardiocentrum, IKEM, Praha}

Perioperační radiofrekvenční (RF) ablace se stává rutinní metodou léčby fibrilace síní (FS) u pacientů indikovaných ke kardiochirurgickým zákrokům. Problémem v pooperačním sledování bývají symptomatické síňové arytmie.

Cílem studie: Analyzovat srdeční rytmus u pacientů po chirurgické ablaci FS. Zaměřili jsme se na klinickou a elektrofyziologickou charakteristiku pacientů se symptomatickými tachyarytmiemi a jejich následnou léčbu.

Soubor a metodika: Od srpna 2000 do listopadu 2006 podstoupilo 415 pacientů (163 žen, průměrný věk 67,5 let) $\mathrm{s}$ chronickou nebo paroxyzmální $\mathrm{FS}$ ablaci v levé síni pomo- cí RF energie před náhradou chlopně a/nebo aortokoronárním bypassem. Pacienti se symptomatickou recidivující síňovou arytmií byli indikováni k elektrofyziologickému vyšetření (EFV) a elektroanatomickému mapování pomocí systému CARTO. V indikovaných případech byla provedena katetrizační ablace.

Výsledky: Pravidelná síňová tachyarytmie byla během sledování alespoň jedenkrát dokumentována u 62 pacientů (15 \% celého souboru) a byla většinou pouze přechodná. U dvanácti pacientů (3 \%, 3 ženy) se symptomatickou arytmií bylo provedeno EFV. Pět pacientů mělo typický flutter síní, ve čtyřech případech byla dokumentována makroreentry tachykardie $z$ levé síně. Ve dvou případech byla potvrzena postincizionální pravostranná síňová tachykardie. Jeden pacient měl mnohočetné arytmie. Všech 12 pacientů bylo úspěšně vyřešeno pomocí katetrizační RF ablace. Během 18měsíčního sledování (rozmezí 2-48 měsíců) byli tito nemocní bez dokumentovaných arytmií.

Závěr: Pravidelné síňové arytmie jsou poměrně časté po chirurgické ablační léčbě. Většinou jsou pouze přechodné. Nejčastější arytmií vyžadující následnou katetrizační ablaci je flutter síní. Katetrizační ablace je dostupnou a efektivní metodou léčby i v př́ípadě levosíňových arytmií.

\section{PERFOROVANÉ ANEURYZMA MITRÁLNÍ CHLOPNĔ S ECHOKARDIOGRAFICKYYM OBRAZEM PROLAPSU JAKO VZÁCNÁ KOMPLIKACE INFEKČNÍ ENDOKARDITIDY}

\section{KRÁL J, HRADEC J, KÁBRTOVÁ E, ROHN V}

III. interní klinika, II. chirurgická klinika kardiovaskulární chirurgie, VFN a 1. LF UK, Praha

Úvod: Prolaps mitrální chlopně (PMCH) se dělí na primární a sekundární. Primární PMCH se vyskytuje jako familiární, nefamiliární nebo spojený s dědičnými chorobami pojivové tkáně, např́klad Marfanovým syndromem.

Sekundární PMCH je podmíněn zmenšením dutiny levé komory, ischemickou dysfunkcí papilárních svalů nebo rupturou šlašinky. Popisujeme vzácný případ prolapsu vzniklého jako komplikace infekční endokarditidy.

Popis připadu: Šedesátičtyřletý muž byl hospitalizován pro septický stav 5 měsíců po cholecystektomii a choledochojejunoanastomóze pro stenózu distálního choledochu s obstrukčním ikterem. Pooperační průběh byl komplikován akutní pankreatitidou se vznikem objemné pseudocysty. Echokardiograficky byl zjištěn prolaps zadního cípu mitrální chlopně $\mathrm{s}$ významnou mitrální regurgitací a počínající dilatací levé komory. Nemocný byl indikován k plastice mitrální chlopně. Peroperačně bylo nalezeno aneuryzma zadního cípu mitrální chlopně se dvěma perforacemi. V anamnéze nebylo nic, co by ukazovalo na př́tomnost $\mathrm{PMCH}$ v předchorobí. Pacient měl sníženou imunitu při komplikovaném průběhu pankreatitidy. Echokardiografické vyšetření, především transezofageální, zobrazilo normální morfologii cípů chlopně i šlašinek až na oblast scalopu P3. Komisurální prolaps byl tvořen lokalizovaným vyklenutím se ztenčením stěny, se závažnou mitrální regurgitací s asymetrickým proudem krve. Obraz myxomatózní degenerace cípu zcela chyběl.

Závěr: Odlišení sekundárního PMCH, který vznikne jako komplikace infekční endokarditidy, od primárního $\mathrm{PMCH}$, na který nasedne infekční endokarditida, je obtížné. Ke správné diagnóze může napomoci němá anamnéza ve smyslu prrítomnosti $\mathrm{PMCH}$, atypická lokalizace prolapsu a nález ztenčení chlopně v místě prolapsu místo obvyklého ztluštění. Přínosem by mohla být také trojrozměrná echokardiografie. 


\section{RESYNCHRONIZAC̆NÍ LÉC̆BA SRDEČNÍHO SELHÁNÍ - SROVNÁNÍ VÝSLEDKÜ PO TR̆ECH A DVANÁCTI MĚSÍCÍCH OD IMPLANTACE}

KREJČÍ J, NOVÁK M, HUDE P, PAVELČÍKOVÁ H, OZÁBALOVÁ E, MELUZÍN J, ŠPINAROVÁ L

I. interní-kardioangiologická klinika,

FN u sv. Anny, Brno

Cíl práce: Ověřit, zda časné změny některých hemodynamic kých a echokardiografických parametrů přetrvávají i po 1 roce od implantace biventrikulárního kardiostimulátoru (BiV KS).

Soubor nemocných: 50 optimálně farmakologicky léčených nemocných $\mathrm{s}$ pokročilým srdečním selháním ve třídě NYHA 3,0 $\pm 0,3 ;$ s ejekční frakcí levé komory ( $\mathrm{EF} L K)$ $20 \pm 5 \%$, se středním tlakem v plicnici (MPA) 29,3 $\pm 10,6$ mm Hg a tlakem v zaklínění (PCW) $18,9 \pm 8,9 \mathrm{~mm} \mathrm{Hg}$, bylo vyšetřeno (prováděno $\mathrm{ECHO}$ srdce, spiroergometrie, pravostranná katetrizace) před implantací BiV KS (kontrola 0), 3 měsíce (kontrola $3 \mathrm{M}$ ) a 12 měsíců (kontrola $12 \mathrm{M}$ ) po implantaci. Byly srovnávány změny sledovaných parametrů při jednotlivých kontrolách.

Výsledky:

\section{ETIOLOGIE POSTIŽENÍ MITRÁLNÍCH CHLOPNÍ VE VZTAHU KE KRÁTKODOBÉ PROGNÓZE}

KRUPIČKA J, BENEŠOVÁ M, ČERNÝ Š, POPELOVÁ J, MACHAČ M, BENEDÍK J, JIRÁSEK V, JEHLIČKA P, DOUBEK D

Kardiochirurgické oddělení, Nemocnice Na Homolce, Praha

Mitrální valvuloplastiky (MVP) představovaly 73 \% všech výkonů na mitrální chlopni provedených v NNH od dubna 2002 do ledna 2006.

Metodika: Zhodnotili jsme soubor 213 pacientů (69\% z celkového počtu MVP, průměrný věk 61 let, $67 \%$ mužů) s mitrální insuficiencí (MI) s kompletními daty. U všech pacientů bylo provedeno zhodnocení etiologie mitrální chlopně $z$ videozáznamů 2 hodnotiteli. Pooperační sledování bylo 30 dnů.

Výsledky: Viz tabulka.

$Z$ výsledků vyplývá, že nejčastější přičinou je degenerativní postižení (63\%). Druhým nejčastějším je ischemické postižení (17\%). Zatímco degenerativní postižení má příznivou krátkodobou mortalitu $(2,9 \%)$, a to i přes poměrně vysoký věk (67 let), ischemické postižení má naopak nejvyš-

Tabulka k abstraktu MUDr. Krejčího

\begin{tabular}{lccccccc}
\hline \hline & $\delta$ NYHA & $\delta$ pVO2 (ml/kg/min) & $\delta$ MPA (mm Hg) & $\delta$ PCW (mm Hg) & $\delta$ Dd (mm) & $\delta$ Ds (mm) & $\delta$ EF LK (\%) \\
\hline O vs. 3M & $0,66^{* * *}$ & $1,9^{* * *}$ & $6,7^{* * *}$ & $4,9^{* *}$ & $1,5^{*}$ & $3,3^{* * *}$ & $5,4^{* * *}$ \\
O vs. 12M & $0,70^{* * *}$ & $1,5^{*}$ & $4,4^{*}$ & $3,1^{*}$ & $4,8^{* *}$ & $5,6^{* * *}$ & $5,9^{* * *}$ \\
3M vs. 12M & 0,04 & $-0,3$ & $-2,3^{*}$ & $-1,8^{*}$ & $3,8^{*}$ & 2,2 & 0,5 \\
\hline \hline
\end{tabular}

${ }^{*} \mathrm{p}<0,05,{ }^{* *} \mathrm{p}<0,01,{ }^{* * *} \mathrm{p}<0,001, \mathrm{pVO} 2$ - vrcholová spotřeba kyslíku při spiroerometrii, Dd - diastolický rozměr levé komory, Ds - systolický rozměr levé komory

Závěr: Resynchronizační léčba vedla ke statisticky významnému zlepšení všech sledovaných parametrů při kontrolách $3 \mathrm{M}$ i $12 \mathrm{M}$ ve srovnání s kontrolou 0 . Naopak mezi 3. a 12. měsícem došlo ke zhoršení hodnot MPA i PCW. To naznačuje, že BiV KS u podobných nemocných není definitivním léčebným řešením, ale pro určitou skupinu nemocných spíše „bridgingem“ k srdeční transplantaci. ší mortalitu (8,3\%). Průměrná předoperační významnost MI byla 3,5, což zejména u degenerativních vad (skutečná významnost 3,8), které mají průměrnou mortalitu srovnatelnou s aortálními stenózami, je známkou pozdních indikací k výkonu. Všechny typy postižení je možné operovat s dobrým efektem - průměrná významnost MI na čtyřstupňové škále byla 0,3 .

Tabulka k abstraktu MUDr. Krupičky: Etiologie...

\begin{tabular}{lrcccc}
\hline \hline Etiologie & n & \% & věk & Muži (\%) & $\begin{array}{c}\text { Významnost MI } \\
\text { Pŕed výkonem/po výkonu }\end{array}$ \\
\hline Revmatická & 16 & 8 & 69 & 81 & $3,6 / 0,1$ \\
Degenerativní & 137 & 63 & 64 & 64 & $3,8 / 0,2$ \\
Ischemická & 36 & 17 & & 63 & $3,7 / 0,1$ \\
Sekundární & 13 & 6 & 3 & 43 & $3,6 / 0,0$ \\
Infekční & 7 & 1,5 & & 67 & $3,9 / 0,6$ \\
Vrozená & 3 & 0,5 & & 0 & $3,0 / 1,0$ \\
Jiná & 1 & & & & 0 \\
\hline \hline
\end{tabular}

*4stupňová škála, průměrná hodnota

SESTERSKÁ SEKCE

\section{ELEKTRICKÁ KARDIOVERZE V SOUČASNOSTI A ÚLOHA SESTRY}

KRUMPOCHOVÁ P

Interní oddělení, Nemocnice Valašské Meziřičí, a. s., Valašské Meziříčí

Autorka překládá souhrnné informace o současném postavení elektrické kardioverze v moderní kardiologii a intenzivní medicíně a úloze sester při jejím provádění.
Závěr: Nejčastější přičinou mitrálních insuficiencí je degenerativní postižení chlopně, které má zároveň nízkou 30denní mortalitu po výkonu. Nehledě na etiologii postižení jsou výsledky plastik příznivé.

\section{STÁRNOUCÍ POPULACE A RIZIKO MITRÁLNÍCH VALVULOPLASTIK}

KRUPIČKA J, BENEŠOVÁ M, ČERNÝ Š, POPELOVÁ J, MACHAČ M, BENEDÍK J, JIRÁSEK V JEHLIČKA P, DOUBEK D

Kardiochirurgické oddělení, Nemocnice Na Homolce, Praha 
Stárnoucí populace a rozvoj operačních technik přivádějí k operaci stále starší pacienty. Cílem naší práce bylo zhodnotit rizika seniorů podle etiologie postižení mitrální chlopně.

Metodika: Zhodnotili jsme soubor 213 pacientů s kompletními daty $z$ hlediska klinických dat (věk, pohlaví), echokardiografických dat (etiologie postižení mitrální chlopně) a $z$ hlediska krátkodobé prognózy (30denní mortalita). Významnost mitrální insuficience (MI) byla hodnocena 4 stupňovou škálou (1-4).

Výsledky: Seniorů ( $\geq 70$ let) bylo $46 \%$ (n = 98). Jejich průměrný věk byl 75 let (70-82). V souboru mladších pacientů ( $\leq 69$ let) byl průměrný věk 56 let $(21-69, p<0,01)$. Mužů bylo $64 \%(n=63)$ vs. 70 \% (n = 80). Významnost MI před operací byla 3,3 vs. 3,7 , po operaci 0,3 vs. 0,3 ( $p=\mathrm{NS}$ ). Nejčastějším rizikovým faktorem (RF) u seniorů bylo KV

\begin{tabular}{lccc}
\hline \hline Etiologie & $\begin{array}{c}\text { Mortalita (\%): } \\
\geq \mathbf{7 0} \text { let }\end{array}$ & $\begin{array}{c}\text { Mortalita (\%): } \\
\geq \mathbf{6 9} \text { let }\end{array}$ & $\boldsymbol{p}$ \\
\hline Porevmatická & 11,1 & 0 & $<0,01$ \\
Degenerativní & 4,2 & 1,5 & $\mathrm{NS}$ \\
Ischemická & 22,2 & 3,7 & $<0,01$ \\
Sekundární & 0 & 0 & $\mathrm{NS}$ \\
Infekční & - & 0 & \\
Vrozená & 0 & 0 & $\mathrm{NS}$ \\
Jiná (HKMP) & - & 0 & \\
\hline \hline
\end{tabular}

onemocnění, u mladších obezita. Senioři měli 1 RF v $73 \%$ (vs. $57 \%$ ), 2 ve $49 \%$ (vs. $54 \%$ ) a $\geq 3$ v $43 \%$ (vs. $41 \%$ ). Celková mortalita seniorů byla $5,4 \%$ vs. $0,8 \%(p<0,05)$. Po rozdělení podle etiologie insuficience se mortalita mezi skupinami diametrálně odlišovala.

Závěr: Provést plastiku mitrální chlopně ve věku nad 70 let je možné s přijatelným průměrným rizikem. Mortalita se ale významně liší podle etiologie postižení chlopně. Porevmatické a zejména ischemické mitrální insuficience jsou zatíženy vysokým rizikem mortality v krátkodobém horizontu.

\section{LZE R̆ÍDIT LÉČBU SRDEČNÍHO SELHÁNÍ PODLE BNP? (STUDIE OPTIMA - USPOŘÁDÁNÍ, PRVNÍ VÝSLEDKY)}

\author{
KRUPIČKA J, JANOTA T, HRADEC J
}

Kardiochirurgické oddělení, Nemocnice Na Homolce, III. interní klinika, VFN a 1. LF UK, Praha

Úvod: Kardiální dysfunkce vede k neurohormonální odpovědi, jejímž výsledkem jsou i zvýšené plazmatické hladiny natriuretických peptidů (NP). Při srdečním selhání (SS) mají NP význam diagnostický a prognostický. Objevily se také zprávy, že pomocí NP lze řídit léčbu nemocných se SS.

Cíl: Posoudit, zda léčba SS se snahou docílit normální hladinu BNP povede ke snížení výskytu kardiovaskulárních příhod.

Uspořádání: Do studie bude zařazeno 100 pacientů hospitalizovaných pro akutní srdeční selhání (primomanifestace či zhoršení chronického SS). Tito nemocní budou randomizováni na léčbu k co nejnižší hladině BNP (skupina BNP) a na léčbu podle klinického stavu (klinická skupina). Nemocní budou sledováni v 3 měsíčních intervalech po dobu 2 let. Sledovaným klinickým ukazatelem je součet všech úmrtí, hospitalizací pro SS a zhoršení SS bez nutnosti hospitalizace.

Výsledky: K datu odeslání abstraktu bylo zařazeno 25 pacientů průměrného věku 73 let, s průměrnou hodnotou vstupního BNP 669 pg/ml. Během ročního sledování (medián 9 měsíců) byl nižší výskyt epizod dekompenzace SS ve skupině BNP oproti skupině klinické ( 8 vs. 11). V prvních 6 měsících sledování postihla první KV příhoda 50 \% pa- cientů ve skupině BNP a $46 \%$ v klinické skupině. Pouze u 2/3 pacientů bylo možné při intenzifikované farmakologické léčbě dosáhnout normální hladinu BNP $(<100$ pg/ml resp. < $150 \mathrm{pg} / \mathrm{ml}$ při lehké renální insuficienci).

Závěr: Vzhledem $\mathrm{k}$ malému počtu nemocných nelze zatím předběžná data statisticky hodnotit. První výsledky však naznačují, že stanovování hladin BNP u pacientů s chronickým SS může pomoci časnému odhalení hrozící kardiální dekompenzace a umožňuje upravit léčbu jednotlivým pacientům na míru se snahou dosáhnout cílovou hodnotu BNP. Ne u každého pacienta však lze dosáhnout normalizace této hodnoty.

\section{VÝSLEDKY CHIRURGICKÉ LÉČBY EBSTEINOVY ANOMÁLIE TRIKUSPIDÁLNÍ CHLOPNË*}

KRUPIČKOVÁ S, CHALOUPECKÝ V, TLÁSKAL T, HUČÍN B, GEBAUER R, HRÁDKOVÁ G, POPELOVÁ J, ČERNÝ Š, NEČASOVÁ A, ŠKOVRÁNEK J

Dětské kardiocentrum, FN Motol, Praha, Interní-kardiologická klinika, FN Brno, Brno

*Podporováno z výzkumného záměru MZ ČR MZO-00064203.

V letech 1982 až 2005 bylo v Dětském kardiocentru operováno 31 pacientů $\mathrm{s}$ Ebsteinovou anomálií trikuspidální chlopně (TV) ve věku 2 až 58 let (medián 11 let). Plastika trikuspidální chlopně byla provedena v 18 případech. Primární náhradu TV vyžadovalo 8 nemocných, $z$ nichž u 5 byla použita biologická a u 3 mechanická chlopeň. U 5 pacientů s nevýznamnou insuficiencí TV byl uzavřen pouze defekt síňového nebo komorového septa. Bidirekční kavopulmonální anastomóza byla provedena v 7 př́ipadech. Časně po operaci zemřeli $2(6,5 \%)$ pacienti a další dva za 3 a 6 let po korekci. $Z$ evidence bylo ztraceno 6 jedinců.

Závažnou trikuspidální insuficienci, hodnocenou echokardiograficky (st. 3-4) mělo před operací 26 (84\%) pacientů. U $6(33 \%)$ z 18 pacientů po plastice trikuspidální chlopně došlo ke zlepšení její funkce alespoň o jeden stupeň. Ve 12 př́padech zůstala významnost insuficience stejná, nebo se zhoršila. V této podskupině byla trikuspidální chlopeň časně nahrazena u 2 pacientů a u dalších 2 v odstupu 6 a 11 let. Z 8 pacientů po primární náhradě TV vyžadovaly 2 děti následnou reoperaci pro blokádu mechanické chlopně trombem.

Při vyšetření 21 pacientů ve věku 7 až 40 let (medián 20 let) a v intervalu 1 až 22 let (medián 4 roky) od korekce vady bylo do I. třídy NYHA zařazeno 7 (33 \%), do II. třídy 13 (62 \%) jedinců a 1 pacient nebyl klasifikován. Nevýznamnou trikuspidální insuficienci mělo 9 (42,9 \%) pacientů, významnou insuficienci $6(28,6 \%)$ a trikuspidální chlopeň byla nahrazena v $6(28,6$ \%) případech.

Závěr: Výsledek chirurgické léčby Ebsteinovy anomálie určuje závažnost postižení trikuspidální chlopně a pravé komory. Bidirekční kavopulmonální anastomóza je vhodná při snížené funkční kapacitě pravé komory.

\section{SESTERSKÁ SEKCE}

\section{JAK RESPEKTUJÍ NEMOCNÍ S OBEZITOU PO KARDIOVASKULÁRNÍ PR̆ÍHODĔ DOPORUČENÍ OŠETR̆UJÍCÍHO TÝMU?}

\section{KŘEČKOVÁ M, BĚLOHLÁVEK J, LINHART A}

II. interní klinika kardiologie a angiologie,

VFN a 1. LF UK, Praha 
Úvod: Obezita a zvláště pak cukrovka v kombinaci s obezitou jsou velmi významnými rizikovými faktory aterosklerózy. Položili jsme si otázku, zda pacienti s již prodělanou kardiovaskulární příhodou respektují doporučení o nutnosti zhubnout a o změně dietního a životního režimu.

Metody: Ke zhodnocení jsme zvolili soubor 39 nemocných (22 mužů) s obezitou a prodělanou kardiovaskulárni př́hodou (nejčastěji po infarktu myokardu). Průměrný věk nemocných při vstupu do sledování činil 69,5 let a průměrný BMI 33,1. Nemocní byli sledováni v ambulanci po dobu 3 měsíců a vždy jim byl pečlivě vysvětlen správný dietní i pohybový režim a zdưrazněna nutnost zhubnout.

Výsledky: Nemocní jsou zatím sledovaní přes 2 roky a zhodnotili jsme dodržování režimu při půlročních kontrolách a změnu váhy po 2letém sledování. Při pravidelných kontrolách za 6 měsíců odpovídali nemocní na otázku o dodržování režimu takto: 18 (46\%) nemocných odpovědělo na všech 4 návštěvách, že režim dodržuje; 9 (23\%) nemocných odpovědělo, že režim dodržuje alespoň při $50 \%$ návštěv a $12(31 \%)$ odpovědělo že režim nedodržuje vůbec nebo jen při jedné ze 4 návštěv za celé 2leté sledování. $Z$ celkového počtu 39 nemocných zhublo 16 pacientů, přibralo 21 a stejnou váhu měli 2 nemocní. Nejvyšší váhový úbytek činil 4,4 kg a nejvyšší přírůstek 3,7 kg. Žádnému nemocnému se nepodařilo zhubnout více než $5 \mathrm{~kg}$.

Závěr: Naši obézní nemocní nedodržují doporučovaný dietní režim uspokojivě, třetina prakticky vůbec. Zhublo jen $41 \%$ nemocných, nikdo $z$ nich nedosáhl váhový úbytek více než $5 \mathrm{~kg}$. Naopak, $54 \%$ nemocných přibralo, a to přesto, že jim je nutnost změny životního stylu připomínána a vysvětlována při každé ambulantní návštěvě.

\section{SESTERSKÁ SEKCE}

\section{MIMOTĚLNÍ ELIMINAČNÍ METODY V DĔTSKÉ KARDIOCHIRURGII}

KŘIVSKÁ D, LÁTROVÁ J

FN Motol, Praha

Akutní selhání ledvin je charakterizován náhlým, obvykle reverzibilním poklesem funkce ledvin, snížením glomerulární filtrace, oligurií, anurií a patologickým složením vnitřního prostředí. Př́ičiny jsou prerenální.

Diagnostika - klinická: oligurie méně než $0,5 \mathrm{ml} / \mathrm{kg} /$ 24hod., edémy; - laboratorní: metabolická acidóza, zvýšená sérová koncentrace urey, kreatininu a kyseliny močové, snížená koncentrace kalcia, vysoká osmolalita moče a snížená koncentrace kalia v moči.

Terapie - konzervativní - substituční: CVVH, peritoneální dialýza.

CVVH - přestup vody a solutů přes dialyzační membránu, kanylace centrální žíly, heparinizace pacienta.

Peritoneální dialýza - metoda volby, přestup vody a solutů přes peritoneum, katetr zavedený do dutiny břišní, bez heparinizace.

V letech 1997-2006 jsme tuto metodu použili u 111 pacientů. Zahájení peritoneální dialýzy - příprava pomůcek; - př́íprava pacienta.

Dialyzační cyklus: zahajujeme hodinovým cyklem, $10 \mathrm{mi}-$ nut napouštění ohřátého dialyzačního roztoku do dutiny břišní, 30-35 minut ekvilibrace (přesun vody a solutů mezi krví a dialyzačním roztokem), 15-20 minut vypouštění dialyzátu.

Monitorování pacienta: kompletní invazivní monitorace + EKG, $\mathrm{SaO}_{2}$, TT, KT + diuréza v hodinových intervalech. Vnitřní prostředí kontrolujeme obvykle za jednu až 1 1/2 hodiny, biochemická vyšetření a bilanci tekutin provádíme po 6 hod.
Každých 24 hod. mikrobiologická vyšetření, vyšetření celkové bílkoviny a koncentrace iontů v moči.

Péče o pacienta: dýchací cesty, invazivní vstupy (prevence infekce), kůže (prevence dekubitů), operační rána a dialyzační katetr, prevence vysychání oční rohovky.

Zajistit tepelný komfort a zvýšenou hygienickou péči.

Komplikace: ze 111 pacientů $1 \times$ peritonitida, $1 \times$ poranění nitrobřišních orgánů.

Závěrem lze říci, že se vždy jednalo o reverzibilní poškození funkce ledvin a během několika dnů až týdnů došlo k jejímu obnovení.

SESTERSKÁ SEKCE

\section{KORONAROGRAFICKÉ NÁLEZY U MLADÝCH PACIENTŮ S AKUTNIMM INFARKTEM MYOKARDU}

KUBÍČKOVÁ M, KOŠUTOVÁ J, POPKOVÁ A

I. interní-kardiologická klinika, FN u sv. Anny, Brno

Anylýza koronarografických nálezů a rizikových faktorů $\mathrm{u}$ pacientů $\mathrm{s}$ akutním infarktem myokardu ve věku pod 50 let.

\section{ZMĚNÍ SE KREVNÍ TLAK U LÉČENÉHO HYPERTONIKA PO IMPLANTACI KARDIOSTIMULÁTORU?}

KUBKOVÁ L, ŠPINAR J, PRYMUSOVÁ K, KAŇOVSKÝ J, ŠEBO M, MIKLÍK R, TOMÁŠEK A, DVOŘÁKOVÁ E, MUSIL V, POZDÍŠEK Z

Interní-kardiologická klinika, FN Brno, Brno

Cíl: Zjistit, zda implantace trvalé kardiostimulace u léčených hypertoniků může mít vliv na hodnoty krevního tlaku u těchto pacientů.

Soubor pacientů a metody: Retrospektivní analýza skupiny 259 pacientů s léčenou hypertenzí (HT), jimž byl v letech 2004-2006 implantován trvalý kardiostimulační systém (PM) na Interní-kardiologické klinice ve FN Brno. Mezi pacienty s průměrným věkem $74 \pm 9$ let (medián 75 let) bylo 134 mužů (52 \%). Srovnávali jsme hodnotu krevního tlaku (TK) u těchto pacienti̊ před implantací a po implantaci PM a hodnotili vliv dalších faktorů na změnu TK. TK < 140/90 mm Hg byl hodnocen jako dobře kontrolovaná hypertenze, TK $\geq 140 / 90$ mm Hg jako špatně kontrolovaná hypertenze.

Výsledky: Před implantací PM byl průměrný sTK 146 $\pm 25 \mathrm{~mm} \mathrm{Hg}$ (medián $145 \mathrm{~mm} \mathrm{Hg}$ ) a průměrný dTK $82 \pm 14$ mm Hg (medián 80 mm Hg); TK < 140/90 mm Hg mělo 79 (30,5 \%) pacientů, TK $\geq 140 / 90$ mm Hg 180 (69,5\%) pacientů. Po implantaci PM byl průměrný sTK $130 \pm 16 \mathrm{~mm}$ Hg (medián $130 \mathrm{~mm} \mathrm{Hg)} \mathrm{a} \mathrm{průměrný} \mathrm{dTK} 76 \pm 11 \mathrm{~mm} \mathrm{Hg}$ (medián 80 mm Hg); TK < 140/90 mm Hg mělo 135 (52 \%) pacientů, TK $\geq 140 / 90$ mm Hg mělo 124 (48 \%) pacientů. Po implantaci PM statisticky významně poklesl počet pacientů se špatně kontrolovanou hypertenzí $(p<0,001)$. Rovněž jsme pozorovali statisticky významný nárůst $\mathrm{v}$ zastoupení betablokátorů $(\mathrm{BB}) \mathrm{v}$ medikaci u pacientů po implantaci $\mathrm{PM}$ $(p<0,001)$ - před implantací mělo BB v medikaci $128(49 \%)$ pacientů a po implantaci 177 (68 \%) pacientů.

Závěr: Po implantaci trvalé kardiostimulace dochází k poklesu krevního tlaku u hodnocených pacientů. Ke snížení krevního tlaku může vést již samotná implantace kardiostimulátoru baroreflexním mechanismem. Dobře kontrolované hypertenze však možno u těchto pacientů dosáhnout díky zavedení betablokátorů do medikace, a to zvlášt u těch z nich, kteří tuto skupinu léků dřive netolerovali pro bradykardii. 


\section{KOMBINOVANÝ CHIRURGICKO-ENDOVASKULÁRNÍ PŘÍSTUP K ONEMOCNĚNÍ HRUDNÍ AORTY}

KUČERA D, HOMZA M, VÁLKA M, ČÍŽEK V, ŠPAK L, PLEVA M, BRÁT R

\section{Centrum vaskulárních intervencí,}

Vitkovická nemocnice a. s., Ostrava, Kardiochirurgická klinika, FN Ostrava Poruba, Ostrava Poruba

Cíl práce: Zhodnocení možností hybridního (endovaskulárně-chirurgického) přístupu při řešení onemocnění hrudní aorty.

Pacienti a metodika: Na našem pracovišti jsme od roku 1999 zavedli celkem 51 hrudních stentgraftů u 50 pacientů a jako konzultanti jsme se podíleli na implantaci dalších 7 hrudních graftů na pracovištích v České republice a Polsku. U 27 pacientů se jednalo o disekci hrudní aorty typu B Stanfordské klasifikace a u 23 pacientů o aneuryzma sestupné hrudní aorty. Hybridní způsob ošetření hrudní aorty podstoupilo celkem 9 pacientů. 5 pacienti s aneuryzmatem aortálního oblouku, 3 pacienti s prodělanou disekcí hrudní aorty typu A s plněním nepravého lumen v oblasti aortálního oblouku a sestupné hrudní aorty a její dilatací, 1 pacient $\mathrm{s}$ intramurálním hematomem aorty a její dilatací.

Výsledky: Technicky úspěšná byla implantace u 8 pacientů, $\mathrm{u}$ jednoho se nám nepodařilo stentgraft zavést na místo určení. Po implantaci jsme detekovali 1 endoleak I. typu kolem proximálního konce graftu. V pooperačním období jsme zaznamenali jeden případ paraplegie dolních končetin řešený úspěšně spinální drenáží. V následném sledování zemřel pacient s neúspěšným zavedením stentgraftu na rupturu aneuryzmatu a pacient $\mathrm{s}$ přetrvávajícím endoleakem 8 měsíců po implantaci z důvodu krvácení při rozvinutí aortobronchiální píštěle.

Závěr: Vzájemná kombinace endovaskulárního a chirurgického přístupu $\mathrm{k}$ řešení problematiky aneuryzmat a disekcí hrudní aorty otvírá nové možnosti léčby dříve těžko řešitelných případů při akceptovatelném riziku periprocedurálních i následných komplikací.

\section{PTA VNITŘNÍ KRKAVICE - VYSTAČÍME JEN S JEDNÍM TYPEM STENTU ČI PROTEKCE?}

KUČERA D, HOMZA M, ČÍŽEK V, VÁLKA M, ŠPAK L, PLEVA M

Centrum vaskulárních intervencí,

Vítkovická nemocnice a. s., Ostrava

Cíl: Práce retrospektivně zpracovává indikace k výkonu, typy užitých stentů a cerebrální protekce a snaží se nalézt př́ičiny, které vedly ke komplikacím spojených s touto léčbou.

Soubor a metodika: Od vzniku Centra vaskulárních intervencí bylo na našem pracovišti provedeno celkem 308 perkutánních angioplastik vnitřní krkavice.

Protekční filtry jsou v dnešní době nejčastějším typem protekce pro svou jednoduchost zavádění a manipulaci. Taktéž na našem pracovišti byl tento typ protekce nejčastěji zastoupen - 98,4\%. V 5 případech $(1,6 \%)$ jsme užili proximální okluzivní protekci. Z 308 implantovaných stentů byly nejčastěji užívány stenty nitinolové s otevřenými buňkami - 188 (61\%), ocelové samoexpandabilní stenty byly implantovány v počtu $103(33,4 \%)$, nitinolové stenty s uzavřeným typem buněk v 13 případech (4,3\%), 3× byl implantován ocelový koronární stent (1\%) a $1 \times$ periferní stentgraft (Jo-stentgraft) - 0,3 \%.

Výsledky: Primární úspěšnost léčby byla v našem souboru $100 \%$. Na úspěšnosti se největší měrou podílely dostatečné počty prováděných výkonů a možnost volit $z$ různých typů zaváděcích katetrů a sheathů, cerebrální protekce a stentů.
U 86 \% pacientů se v různé míře závažnosti vyskytla vazovagální reakce při dodilatování karotického stentu. Periprocedurálně se $1 \times$ vyskytla lehká CMP a $2 \times$ TIA, u 4 pacientů se rozvinula TIA s odstupem více než 12 hod. a u jednoho pacienta se rozvinula hemorhagická CMP 2 dny po výkonu s následným úmrtím - celková míra komplikací 2,6 \%.

Závěr: Je zřejmé, že dostatečný počet výkonů a zkušenosti pracoviště společně s optimálně zvoleným druhem stentu a cerebrální protekce nejenom zlepšují akutní výsledek perkutánní intervence, ale taktéž omezují subakutní embolické komplikace a zaručují dlouhodobou průchodnost intervenované tepny.

\section{SESTERSKÁ SEKCE}

\section{VYUŽITÍ PRAVOSTRANNÉ SRDEČNÍ KATETRIZACE V LÉČ́BĔ AKUTNIIHO SRDEČNÍHO SELHÁNÍ NA KORONÁRNÍ JEDNOTCE}

KUČEROVÁ A, MARCINECHOVÁ K, PAŘENICA J, ŠPINAR J

\section{Koronární jednotka, FN Brno, Brno}

Ve vyšetřování centrální hemodynamiky představuje zlatý standard pravostranná srdeční katetrizace. První měření pravostranné srdeční katetrizace na koronární jednotce FN Brno za pomocí Swanova-Ganzova katetru bylo provedeno $\mathrm{v}$ roce 1993. Během následujících let počet měření postupně vzrostl. V roce 2005 jsme provedli měření Swanovým-Ganzovým katetrem u 12 pacientů, v roce 2006 u 19 pacientů s těžkým akutním srdečním selháním.

Na koronární jednotce je zavedení Swanova-Ganzova katetru indikováno $\mathrm{u}$ pacientů $\mathrm{s}$ těžkým srdečním selháním, většinou provázeným hypotenzí špatně reagující na terapii. Informace získané $\mathrm{z}$ pravostranné tonometrie slouží $\mathrm{k}$ posouzení dostatečného plnění levé komory (PCW 18-20 mm Hg), kontinuálního monitorování tlaku v plicnici, stanovení srdečního výdeje $\mathrm{v}$ čase a $\mathrm{v}$ neposlední řadě $\mathrm{k}$ posouzení periferní vaskulární rezistence.

Kasuistika: 81letý pacient, ischemik, opakovaně hospitalizovaný na naší klinice, byl referován na koronární jednotku pro těžký plicní edém. Vstupní EKG bez jasných známek ischemie. Podle bed-side ECHO EF $30 \%$. Posléze podle vysoce pozitivního troponinu I stanovena diagnóza akutního infarktu myokardu. V úvodu nutnost intubace, pro přetrvávající hypotenzi nereagující dostatečně na katecholaminovou podporu (noradrenalin a dobutamin) byl pacientovi zaveden Swanův-Ganzův katetr. Podle nižší hodnoty tlaku v zaklínění (PCW = $10 \mathrm{~mm} \mathrm{Hg}$ ) byla indikována přes vstupní plícní edém při léčbě katecholaminy pomalá volumoterapie. Minutový srdeční výdej byl 4,9 1/min. Po vzestupu systolického krevního tlaku na $100 \mathrm{~mm} \mathrm{Hg}$ byl podán levosimendan, postupně vysazen dobutamin a snižován noradrenalin. Při této terapii dochází ke zlepšení srdečního výdeje, klesá srdeční frekvence a normalizoval se krevní tlak. Swanův-Ganzův katetr je odstraněn do 24 hod bez komplikací. Do 24 hod jsou vysazeny katecholaminy a pacient je extubován.

\section{VZTAH ÚROVNĔ ENERGETICKÉHO METABOLISMU MYOKARDU K PROGRESI HMOTNOSTI LEVÉ KOMORY U NEMOCNYYCH S FABRYHO CHOROBOU}

KUCHYNKA P, BULTAS J, HÁJEK M, PALEČEK T, DOSTÁLOVÁ G, KARETOVÁ D, MAGAGE S, GOLÁŇ L, ŠIMEK S, LINHART A

II. interní klinika kardiologie a angiologie, VFN a 1. LF UK, Praha 
Úvod: Fabryho choroba $(\mathrm{FCH})$ je na chromosom $\mathrm{X}$ vázané onemocnění, charakterizované střádáním substrátu, ceramidtrihexosidu, v mnoha orgánech a tkáních těla. Hlavní manifestací kardiálního postižení $\mathrm{FCH}$ je hypertrofie levé komory (LK). Její patogeneze však není doposud uspokojivě objasněna, nebot akumulace ceramidtrihexosidu představuje pouze $1 \%$ celkové masy LK. U mnoha forem primárních i sekundárních kardiomyopatií byla pomocí spektroskopického vyšetření magnetickou rezonancí (MRI) prokázána porucha energetického metabolismu myokardu, která by mohla mít vztah $\mathrm{k}$ progresi onemocnění. Principem MRI spektroskopie myokardu je hodnocení spektra signálů makroergních fosfátů, konkrétně poměru signálu fosfokreatinu (PCr) vưči alfa a beta signálům adenozintrifosfátu (ATP). Př́itomnost energetické deprivace myokardu je spojena s nižšími hodnotami poměru PCr/ATP.

Cíl studie: Zhodnotit vztah mezi úrovní energetického metabolismu myokardu a progresí hmotnosti LK u FCH.

Metody: U 16 jedinců s FCH byla při stanovení diagnózy jednorázově provedena MRI spektroskopie srdce $s$ hodnocením poměrů $\mathrm{PCr} / \alpha \mathrm{ATP}$, resp. PCr/ßATP. Hmotnost LK byla $\mathrm{v}$ průběhu sledování (průměr 7,6 let, rozptyl 5-13 let) hodnocena pomocí opakovaných echokardiografických vyšetření a její progrese byla srovnána $\mathrm{s}$ hodnotami poměrů PCr/ $\alpha$ ATP, resp. PCr/ $\beta$ ATP.

Výsledky: Iniciální průměrná hmotnost LK činila $245 \pm$ $88 \mathrm{~g}$ a v průběhu sledování vzrostla na $371 \pm 122 \mathrm{~g}$, což představuje průměrný nárůst $17 \mathrm{~g} /$ rok. Roční progrese hmotnosti LK významně negativně korelovala s hodnotami $\mathrm{PCr} / \alpha \mathrm{ATP}$ $(\mathrm{r}=-0,63)$ a PCr/ $\beta$ ATP $(\mathrm{r}=-0,67)$.

Závěr: Výsledky studie naznačují spojitost mezi progresí hmotnosti LK a iniciální energetickou situací myokardu u nemocných s FCH v době stanovení diagnózy. Porucha energetického metabolismu myokardu je tedy jedním $\mathrm{z}$ možných patogenetických faktorů vedoucích $\mathrm{k}$ hypertrofii LK u FCH.

\section{SESTERSKÁ SEKCE}

\section{PERFUZNÍ SCINTIGRAFIE PLIC PR̆I PODEZR̆ENÍ NA PLICNÍ EMBOLII - ZPŨSOB DOPRAVY NEMOCNÝCH A FREKVENCE KONTROLNÍCH VYŠETŘENÍ}

KUNÍKOVÁ I, KAŇKOVÁ L, LANG O

\section{Klinika nukleární medicíny, FN KV a 3. LF UK, Praha}

Úvod: Perfuzní scintigrafie plic je obvykle indikována při podezření na plicní embolii $(\mathrm{PE})$, vzhledem $\mathrm{k}$ možné recidivě je vhodné kontrolní vyšetření. Součástí ošetřovatelské péče při $\mathrm{PE}$ je klid na lůžku. Pacienti často přicházejí na vyšetření pěšky a na kontrolní vyšetření nejsou odesíláni.

Cíl: Sledovat způsob dopravy pacientů na vyšetření v závislosti na odesílajícím pracovišti a stanovit frekvenci kontrolních vyšetření.

Metoda: Zahrnuli jsme nemocné vyšetřené na našem pracovišti za pět měsíců. Sledovali jsme počet pacientů, způsob dopravy, odesílající pracoviště a frekvenci kontrolních vyšetření. Výsledky jsme vyjádřili v absolutních nebo relativních číslech.

Výsledky: Vyšetřeno 716 pacientů, z toho 262 mužů a 454 žen, průměrného věku 68 let. Přibližně polovina byla odeslána $z$ klinických pracovišt fakultní nemocnice (53,9\%), dalších 36,6 \% z jiných nemocnic a $9,5 \%$ z poliklinik. Akutně vyšetřeno 651 pacientů. $Z$ nich 456 hospitalizováno, všichni prrijeli sanitkou, ale 177 šlo od sanitky do 2 . poschodí pěšky. Dalších 195 nemocných odesláno $z$ ambulancí. Sanitkou přijelo $97 \mathrm{z}$ nich (83 od sanitky pěšky), 98 prrijelo jiným způsobem (29 autem a 69 hromadnou dopravou).

Přesvědčivě pozitivní scintigrafický nález mělo 154 nemocných. $Z$ těch, kteří byli přivezeni sanitkou, jich 53 šlo na vyšetření pěšky. 11 pacientů $\mathrm{s}$ perfuzními defekty přijelo hromadnou dopravou a na základě našeho nálezu byli odesláni $\mathrm{k}$ hospitalizaci. Kontrolní vyšetření bylo doporučeno u 154 nemocných. Skutečně se dostavilo pouze 55 (35,7\%).

Závěr: $Z$ výsledků vyplývá, že ne vždy je $s$ pacienty s podezřením na akutní PE zacházeno tak, jak by bylo žádoucí. Vliv má postoj nemocného, přístup ošetřujícího personálu i pracovníků dopravy. Mezi jednotlivými pracovišti je rozdíl $\mathrm{v}$ přístupu $\mathrm{k}$ dané problematice. Rovněž frekvence kontrolních vyšetření nedosahuje požadovaných hodnot.

\section{SYSTÉMOVÁ EMBOLIZACE OKLUDERU JAKO POZDNÍ KOMPLIKACE KATETRIZAC̆NÍHO UZÁVĚRU OUŠKA LEVÉ SÍNĔ}

\section{KUPEC J, NEUŽIL P, TÁBORSKÝ M}

Kardiologické oddělení, Nemocnice Na Homolce, Praha

Úvod: Katetrizační uzávěr ouška levé síně je moderní metodou ke snížení rizika embolizačních příhod $u$ pacientů s fibrilací síní a kontraindikací antikoagulační léčby. Uvádíme kasusitiku pacienta s neobvyklou komplikací - embolizací okluderu do suprarenální aorty.

Popis připadu: 76letý pacient s permanentní fibrilací síní byl indikován ke katetrizačnímu uzávěru ouška levé síně okluderem Watchman firmy Atritech. Dlouhodobá antikoagulace byla $\mathrm{u}$ tohoto pacienta kontraindikována pro krvácivé komplikace (opakované rektorhagie s výraznou anemizací při postiradiční kolitidě, způsobené radikální aktinoteraapi karcinomu prostaty). Okluder jsme implantovali v ŕíjnu 2005 obvyklým způsobem s peroperačním transezofageálním echokardiografickým sledováním, den před výkonem jsme provedli cílené $\mathrm{CT}$ vyšetření srdce $\mathrm{s}$ měřením velikosti ouška levé síně. „Sizing“ okluderu byl tedy zvolen na základě výsledku měření ouška 1 . síně dvěma zobrazovacími metodami. Poloha okluderu v srdečním stínu byla dokumentována cíleným RTG hrudníku následující den po výkonu, bylo provedeno cílené echokardiografické vyšetření $\mathrm{k}$ vyloučení perikardiální efuze s negativním nálezem. S odstupem měsíce bylo provedeno kontrolní CT vyšetření srdce, které překvapivě prokázalo absenci okluderu v oušku 1. síně. Nativní RTG břicha zobrazil embolizovaný okluder v úrovni Th12, CT angio vyšetření prokázalo fixaci okluderu ke stěně suprarenální aorty. Vycestování okluderu bylo zcela asymptomatické. Situaci jsme řešili endovaskulárním stažením okluderu cestou a. femoralis v epidurální anestezii ve spolupráci s cévním chirurgem.

Závěr: Výše popsaný př́pad potvrzuje nutnost opakované dokumentace polohy okluderu ouška 1 . síně v časném období po implantaci výpočetní tomografií či transezofageálním echem. Tuto neobvyklou komplikaci lze elegantně řešit endovazální extrakcí okluderu.

\section{SESTERSKÁ SEKCE}

\section{INFEKČNÍ ENDOKARDITIDA U I. V. TOXIKOMANA. KASUISTIKA}

\section{KUPKOVÁ Z, SACHOVA K, FIŠEROVÁ V,} OSTRIHOŇOVÁ J, WEINZETLOVA Z

\section{Klinika kardiologie, IKEM, Praha}

26letý pacient i. v. narkoman na substituční terapii Subutexem. Septicky stav s infekční endokarditidou (Staphylococcus aureus) mechanické mitralní náhrady (9/2006) byl 21. 12. 2006 reoperován na KKCH IKEM, provedena explantace původní mechanické náhrady a implantována nová 
mechanická náhrada. Pacient od operace subfebrilní až febrilní dlouhodobě na kombinaci antibiotik. Subfebrilie až febrilie přetrvávají. Po konzultaci s mikrobiologem antibiotika $2 \times$ změněna. Hemokultury opakovaně negativní.

Pac. na terapii Fenytoinem pro epilepsii, po epileptickém záchvatu s krátkým bezvědomím 5. 1. 2007

Závěr: Infekční endokarditis je onemocnění, které se vyskytuje s roční incidencí kolem 2-5/100 000. Průměrná mortalita činí 10 až $30 \%$. Jako predispoziční faktor se stále méně uplatňují postrevmatické srdeční vady, naopak přibývá osob s jinými dispozicemi:

implantace chlopenní protézy, vrozené srdeční vady, degenerativní změny chlopní, intravenózní narkománie.

\section{GLYKOGENOFOSFORYLÁZA BB JAKO ČASNÝ UKAZATEL MYOKARDIÁLNÍ ISCHEMIE A NEKRÓZY - MĚNÍME ZAVEDENÉ STANDARDY?}

\section{LAČŇÁK B, VÁCLAVÍK J, LAZÁROVÁ M, STEJSKAL D}

Interní oddělení, Oddělení laboratorní medicíny, Nemocnice Šternberk, Šternberk

Úvod: Nedávno byly zveřejněny informace, že glykogenfosforyláza BB (GP-BB) je vysoce senzitivním a specifickým časným ukazatelem akutního koronárního syndromu, který by mohl doplnit paletu diagnostických markerů především v prvních 4 hodinách po vzniku př́íhody.

Cíl: Stanovení koncentrace GP-BB u pacientů hospitalizovaných pro podezření na akutní koronární syndrom, srovnání s diagnostickou efektivitou ostatních ukazatelů běžně užívaných v diagnostice AKS.

Metodika: Vyšetřena skupina 48 jedinců hospitalizovaných pro bolest za sternem a podezření na AKS. U všech stanovena koncentrace cTnI, myoglobinu, CRP a GP-BB při př́jmu, za 2,6 a 12 hodin.

Výsledky: $Z$ vyšetřované skupiny byl u 21 osob diagnostikován AKS ( $\mathrm{z}$ toho u 12 non-STEMI) a u 27 jedinců byly obtíže uzavřeny jako nekoronární. Hodnoty GP-BB vykazovaly nenormální rozložení a u uvedených diagnóz se lišily $(p<0,05)$. V práci jsou diskutovány možné přičiny a provedeno srovnání diagnostické efektivity pro sledované ukazatele (AUC ROC).

Závěry: Stanovení GP-BB by mohlo být slibným ukazatelem v časné diagnostice akutního koronárního syndromu, který doplňuje již zavedenou laboratorní paletu.

\section{HODNOCENÍ DIAGNOSTICKÉ EFEKTIVITY STANOVENÍ PRA A ALDOSTERONU U OSOB S REFRAKTERNÍ HYPERTENZÍ}

LAČŇÁK B, VÁCLAVÍK J, LAZÁROVÁ M, STEJSKAL D

Interní oddělení, Oddělení laboratorní medicíny, Nemocnice Šternberk, Šternberk

Úvod: Stanovení PRA a aldosteronu je řadou pracovišt doporučováno u pacientů s rezistentními formami hypertenze.

Cíl: Hodnocení diagnostické efektivity stanovení koncentrace PRA a aldosteronu u pacientů vyšetřených pro podezření na sekundární hypertenzi.

Metodika: Vyšetřena skupina 1477 jedinců sledovaných pro refrakterní hypertenzi. U všech stanovena koncentrace iontů, PRA, aldosteronu, metanefrinů a vyšetření zaměřené na vyloučení dalších příčin sekundární hypertenze.

Výsledky: Diskutována diagnostická efektivita PRA a aldosteronu a indexu PRA/aldosteron pro stanovení př́tomnosti primárního hyperaldosteronismu, jako příčiny sekundární hypertenze a využití tohoto indexu v rutinní praxi.

Závěry: Stanovení indexu PRA/aldosteron by mohlo být slibným ukazatelem v diagnostice sekundární hypertenze.

\section{VYUŽITİ STANOVENÍ CLUSTERINU A THYMIDINKINÁZY V DIFERENCIÁLNÍ DIAGNOSTICE PLEURÁLNÍCH VÝPOTKŮ}

LAČŇÁK B, VÁCLAVÍK J, LAZÁROVÁ M, STEJSKAL D

Interní oddělení, Oddělení laboratorní medicíny, Nemocnice Šternberk, Šternberk

Úvod: Stanovení clusterinu je slibným ukazatelem pro odhad postižení tkání různými noxami. Toto vyšetření se osvědčilo $\mathrm{v}$ experimentech $\mathrm{v}$ rámci diagnostiky onemocnění CNS a v urologii. I když lze předpokládat možnost využití v diferenciální diagnostice etiologie výpotků, zatím nebyla podobná práce publikována. Nedávno byla prezentována zajímavá pilotní studie, která hovoří o diagnostickém použití stanovení thymidinkinázy v hodnocení etiologie ascitu. Informace o využití v diagnostice výpotků nebyly prezentovány.

Cíl: Hodnocení diagnostické efektivity stanovení koncentrace clusterinu a thymidinkinázy ve výpotku a séru (vč. jejich indexu sérum/výpotek) v diferenciální diagnostice etiologie výpotku.

Metodika: Vyšetřena skupina 34 jedinců s pleurálním výpotkem. Typ výpotku a konečná diagnóza byly hodnoceny na základě Lightových kritérií a dalšího komplexního vyšetření. U všech pacientů byla stanovena koncentrace bílkoviny, LD, albuminu, cholesterolu, thymidikinázy, clusterinu v séru a výpotku.

Výsledky: Diskutována diagnostická efektivita clusterinu, thimidinkinázy, jejich indexů a kombinace obou vyšetření pro odhad etiologie výpotku.

Závěry: Stanovení clusterinu $\mathrm{v}$ kombinaci $\mathrm{s}$ thymidinkinázou (ve výpotku a index sérum/výpotek) by mohl být užitečným ukazatelem $\mathrm{v}$ diferenciální diagnostice pleurálního výpotku.

\section{SCINTIGRAFIE MYOKARDU - ZÁKLADNÍ PRINCIPY A KLINICKÉ POUŽITÍ}

LANG O

Klinika nukleární medicíny, FN KV a 3. LF UK, Praha

Úvod: Scintigrafie myokardu je nejčastěji používanou metodou nukleární kardiologie. Její obrazové informace jsou v současné době využivané především pro klinické rozhodování u pacientů s ICHS.

Metoda: Základním principem zobrazení v nukleární kardiologii je detekce záření radiofarmaka detektorem a následné zpracování takto získaných dat. Nejvíce se používají radiofarmaka pro zobrazování perfuze myokardu nebo jeho viability. Pro zobrazování se používají speciální detektory ionizujícího záření - gamakamery (SPECT a PET). Získaná data se zpracovávají pomocí různých programových souborů, které umožňují kvantifikaci získaných dat.

výsledky: Největší význam scintigrafie myokardu spočívá v tom, že umožňuje rutinně zobrazit rozložení krevního toku svalovinou levé komory srdeční na vrcholu zátěže a v klidu, může tedy zcela neinvazivním způsobem měřit velikost koronární rezervy. Kromě toho poskytuje při jednom vyšetření pacienta informace nejen o distribuci prokrvení srdečního svalu, ale také o jeho mechanické funkci, a to jak globální tak regionální. Její největší klinická cena je tedy $\mathrm{v}$ rizikové stratifikaci pacientů. $\mathrm{V}$ tomto směru se $\mathrm{ji}$ 
nevyrovná žádná $\mathrm{v}$ současné době rutinně používaná neinvazivní zobrazovací metoda. Rovněž informace, které scintigrafie poskytuje o viabilitě myokardu, hrají v dnešní době epidemie srdečního selhání významnou roli, zejména při racionální indikaci revaskularizace.

Závěr: Výstupy scintigrafie myokardu byly v posledních letech akceptovány jako konečná hodnocená kritéria řady klinických lékových studií a byly rovněž uznány jako vstupní kritéria výzkumných studií, které se zabývají novými léčebnými metodami kardiovaskulárních nemocí. Poslední léta prokázala vysokou spolehlivost a reprodukovatelnost této metody, jakož i její vysoký potenciál pro měření srdečního prokrvení, viability a globální i regionální funkce levé komory.

\section{DISTRIBUCE MONONUKLEÁRNÍCH BUNĔK KOSTNÍ DR̆ENĔ V CELEEM TĚLE A V MYOKARDU PO JEJICH INTRAKORONÁRNÍ APLIKACI}

LANG O, PĚNIČKA M, KOBYLKA P, KLEISNER I, TROJANOVÁ H, WIDIMSKÝ P

Klinika nukleární medicíny, III. interní kardiologická klinika, FN KV a 3. LF UK, Praha

Úvod: Jaderné buňky kostní dřeně (JBKD) mohou být potenciálně použity $\mathrm{k}$ regeneraci poškozeného myokardu.

Cílem naší práce bylo sledovat distribuci jaderných buněk jak v těle pacienta, tak v poškozeném myokardu.

Metoda: Vyšetřili jsme 8 pacientů s ICHS (4 starý IM, 4 AIM), 7 mužů, průměrný věk 57 (45-67) let. Použili jsme autologní JBKD. Pro zobrazení bylo 20 \% buněk označeno 99mTc HMPAO. Buňky byly podány do RIA v řádu $10 \mathrm{E}+8$ buněk katetrem. Jejich distribuce byla zobrazena po 2 hodinách. U 4 pacientů jsme rovněž zobrazili distribuci perfuze myokardu 99mTc MIBI a metabolismu glukózy 18F-FDG. Obrazy byly provedeny na gamakameře Helix (metabolismus a celotělová distribuce buněk) a SP4 (perfuze a distribuce buněk v myokardu). Ejekční frakce (EF) levé komory byla měřena $\mathrm{v}$ době aplikace buněk a za několik měsíců (2-18).

Výsledky: 2 pacienti se starým infarktem myokardu měli známky jizva na hrotě a viabilní myokard anteroseptálně. JBKD se hromadily přesně ve stejné lokalizaci. EF se u těchto pacientů významně zlepšila - u jednoho pacienta z $28 \%$ na $40 \%$ za 2 měsíce, u druhého z $35 \%$ na $45 \%$ za 18 měsíců. U dalších dvou pacientů jsme JBKD v myokardu nedetekovali a EF u nich se nezměnila (zůstala 35 \% po 8 a 12 měsících). Pacienti po přímé PCI pro akutní ischemii měli hypo/akinezi apikoanteroseptálně. JBKD se u 3 z nich hromadily přesně ve stejné lokalizaci, u jednoho pouze v septu. U 3 pacientů se ejekční frakce v čase zlepšila (z 35 \% na 45 \% za 4 měsíce, z $45 \%$ na $72 \%$ za 4 měsíce a z $45 \%$ na 60 \% za 11 měsíců), u jednoho zůstala stejná (50 \% za 5 měsíců).

Závěr: Na základě našich výsledků můžeme usuzovat, že ke hromadění JBKD dochází pouze tam, kde je alespoň částečně zachovaná viabilita myokardu. Rovněž se zdá, že akumulace JBKD má vztah ke zlepšení funkce levé komory v čase. Soubor je však př́liš malý na generalizaci výsledků a mnoho otázek zůstává nezodpovězeno.

\section{KATETROVÁ ABLACE TYPICKÉHO FLUTTERU SÍNÍ JAKO LÉČEBNÁ METODA PRVNÍ VOLBY}

\section{LÁBROVÁ R, TOMAN O, FIALA M, NOVOTNÝ T, ŠPINAR J}

Interní-kardiologická klinika, FN Brno, Brno

Úvod: Typický flutter síní je častou makroreentry supraventrikulární arytmií a je provázený řadou subjektivních obtíží - palpitacemi, dušností, presynkopou, u starších pacientů anginózním syndromem. Antiarytmická terapie ke snížení rekurence flutteru síní I. typu je málo účinná, proto provádíme katetrovou ablaci lineární linií v oblasti kavotrikuspidálního istmu. Cílem práce bylo vyhodnocení výsledků katetrových ablací typického flutteru síní na IKK FN Brno-Bohunice.

Metodika: Cílovým momentem u flutteru síní I. typu bylo dosažení bidirekcionálního bloku v oblasti kavotrikuspidálního můstku aplikací radiofrekvenční energie.

Soubor pacientů a výsledky: Od roku 1985 do 12/2006 bylo na IKK FN Brno-Bohunice provedeno celkem $1285 \mathrm{ka}$ tetrových ablací supraventrikulárních (SV) tachyarytmií. V roce 2003 a 2004 se indikoval k ablaci flutter síní I. typu, jako třetí nejčastější arytmie, v roce 2005 a 2006 je typický flutter již nejčastěji indikovanou SV-arytmií ke katetrové ablaci. V roce 2006 představuje flutter síní téměř jednu třetinu (32,3 \%) SV arytmií indikovaných k ablačnímu řešení. Ablaci typického flutteru síní podstoupilo 272 pacientů, z toho bylo 65 žen (24\%) a 207 mužů (76 \%), o prưměrném věku 57,1 roků (SD 9,1). Od roku 2004 je bezprostřední úspěšnost zákroku nad $95 \%$. V roce 2006 podstoupilo ablaci isthmu 76 pacientů, $z$ toho u 5 pacientů byla reablace (6,6 \%). Významné komplikace jsme neměli. $Z$ celkového počtu 272 pacientů, kteří podstoupili ablaci pro typický flutter síní, vznikla u 2 pacientů $(0,74 \%)$ arteriovenózní píštěl a u 2 pacientů $(0,74 \%)$ byl rozsáhlejší hematom.

Závěr: Radiofrekvenční katetrovou ablaci typického flutteru síní doporučujeme jako léčebnou metodou první volby pro vysokou bezprostřední i dlouhodobou úspěšnost zákroku a minimální komplikace. Po úspěšném zákroku jsou pacienti bez nutné antikoagulační a antiarytmické terapie.

\section{SESTERSKÁ SEKCE}

\section{KOMPETENCE SESTER NA JEDNOTKÁCH INTENZIVNÍ PÉČE}

\section{LÁLOVÁ I, BĚLOHLÁVEK J}

II. interní klinika, koronární jednotka, VFN a 1. LF UK, Praha

Vstup ČR do EU v roce 2004 byl klíčovým impulsem k velmi dlouho diskutovaným změnám, které se týkaly nelékařských zdravotnických pracovníků. Dnem 1. 4. 2004 vstoupil v platnost zákon č. 96/2004 Sb. - o podmínkách získávání a uznávání způsobilosti $\mathrm{k}$ výkonu nelékařských zdravotnických povolání a k výkonu činnosti, jež souvisí s poskytováním zdravotní péče a o změně některých souvisejících zákonů. Tento zákon a s ním související předpisy vytvářejí poprvé v historii českého ošetřovatelství komplexní právní rámec pro poskytování ošetřovatelské péče, která je aktivní a obor jako takový staví na místo, které odpovídá vývoji a postavení oboru ošetřovatelství ve vyspělých zemích.

Přijetím nových právních předpisů, které upravují obsah studia všeobecných sester, systém specializačního i celoživotního vzdělávání s povinností registrace pro výkon povolání bez odborného dohledu, ale i změny v oblasti kompetencí sester, to vše je v současné době velmi diskutovaným tématem. Kromě toho, že zákon 98/2004 Sb. přinesl mnohé pozitivní a konečně nasměroval další vývoj oboru ošetřovatelství tak, aby zohledňoval celosvětový trend a byl v souladu se strategií Evropské unie, vyvstaly s jeho přijetím i mnohé otázky a problémy.

V období od prosince 2005 do února 2006 byl proveden výzkum pomocí dotazníku, kterého se zúčastnilo celkem 220 sester $z$ interně zaměřených JIP. Cílem bylo zmapovat skutečně vykonávané činnosti sester, zjistit postoj sester 
k novým kompetencím, zjistit ochotu sester kontinuálně se vzdělávat a učit se novým výkonům. Po vyhodnocení byly zjištěny zajímavé skutečnosti, jež podle mého názoru vystihují současnou praxi na jednotkách intenzivní péče. Sestry projevily ochotu učit se novým výkonům a rozšíření kompetencí vnímají převážně kladně. Většina sester je také ochotna se kontinuálně vzdělávat a uvítala by užší specializaci sester na JIP.

\section{JAKÁ MŮŽE BÝT SOUVISLOST MEZI SYNKOPOU, AKUTNIIM INFARKTEM MYOKARDU A TIA? KASUISTIKA}

LEBR J, KALA P, PAŘENICA J, BRYCHTA T, POLOCZEK M

Interní oddělení, Oblastní nemocnice Př́ibram, a. s., Př́bram, Interní-kardiologická klinika, FN Brno, Brno

Úvod: Ruptura aterosklerotického plátu s nasedající trombózou je hlavní příčinou akutního koronárního syndromu. Asi 6 \% všech nemocných nemá prokazatelnou přitomnost koronární aterosklerózy při časné angiografii.

Cíl: Na předložené kasuistice dokumentovat diagnostický algoritmus a možné způsoby ošetření infarktové tepny u AKS kardioembolizační etiologie.

Kasuistika: Autoři popisují případ pacientky s akutním inferolaterálním infarktem myokardu způsobeným embolizací do povodí ramus circumflexus a ramus marginalis sinister levé věnčité tepny. 79letá nemocná byla hospitalizována pro náhle vzniklou dušnost provázenou krátkou poruchou vědomí a tranzitorním fokálním neurologickým deficitem $\mathrm{v}$ podobě centrální parézy $\mathrm{n}$. facialis vlevo. Na vstupním EKG byla zjištěna fibrilace síní a vývoj STEMI inferolaterálně. SKG ukázala okluzi periferní části RC a RMS2 při jinak minimálních okrajových aterosklerotických změnách v proximální RIA. Postižené věnčité tepny byly ošetřeny víceetáŽovou prostou primární PCI s dobrým efektem. TEE-vyšetření provedené po stabilizací stavu odhalilo přítomnost trombů v oušku levé síně a potvrdilo úvodní podezření na kardioembolizační původ IM. Ke kontrole frekvence komor byl nasazen betablokátor a jako profylaxe rekurence tepenné embolizace zavedena perorální antikoagulační léčba adjustovanými dávkami warfarinu.

Závěr: Koincidence infarktu myokardu s fibrilací síní a TIA/CMP nebo jinou formou tepenné embolizace by vždy měla vést $\mathrm{k}$ úvahám o možné embolizační etiologii. SKG a echokardiografie $\mathrm{s}$ transezofageální studií představují zásadní vyšetření pro odhalení kardioembolizační př́ičiny AKS. Jako možné způsoby léčby jsou v literatuře nejčastěji uváděny: aspirace embolu s mechanickou protekcí chránící před jeho distálním posunem, doplněná případně prostou primární PCI nebo PCI s implantací stentu v případě reziduální stenózy.

\section{SROVNÁNÍ AKUTNIIHO VLIVU STIMULACE SEPTA A HROTU NA ECHOKARDIOGRAFICKÉ PARAMETRY KOMOROVÉ DYSSYNCHRONIE*}

LEFFLEROVÁ K, LUPÍNEK P, KAUTZNER J, BYTEŠNÍK J, ČIHÁK R, KRAUSOVÁ R, VANČURA V
Klinika kardiologie, IKEM, Praha

*Studie byla podpořena IGA MZ ČR č. 8553-3/2005.

Úvod: Stimulace hrotu pravé komory srdeční představuje již téměř 50 let rutinní místo pro trvalou kardiostimulaci $z$ bradyarytmické indikace. Řada experimentálních i klinických studií však naznačuje, že stimulace hrotu pravé komory (PK) srdeční vede $\mathrm{k}$ výrazné asynchronii aktivace komor. Řešením je stimulace $z$ alternativních míst PK. Cílem předložené studie je srovnání akutního dopadu stimulace septa a hrotu na echokardiograficky hodnocené parametry komorové dyssynchronie.

Metodika: 40 pacientů (30 mužů, průměrný věk $73 \pm 10$ let) s pokročilou blokádou AV a zachovanou ejekční frakcí LK (EF > $45 \%)$ bylo zařazeno do studie. Pts byli randomizováni v poměru 2: $1 \mathrm{k}$ septální stimulaci (26 pts, průměrný věk $73 \pm 10$ let) nebo hrotové stimulaci (14 pts, průměrný věk $72 \pm 8$ let). Elektroda s aktivní fixací byla umístěna bud na septum či do hrotu PK. Echokardiografické vyšetření včetně hodnocení tkáňového „Dopplera“ (TDI) bylo provedeno do týdne po implantaci. Hodnotili jsme parametry intera intraventrikulární dyssynchronie. Interventrikulární mechanický delay (IVMD) byl hodnocen jako rozdíl mezi preejekčním časem levé a pravé kontroly. Intraventrikulární dyssynchronie LK byla analyzována $z$ výsledků TDI, hodnotili jsem rozdíl rychlosti počátku, resp. vrcholu kontrakce septa a laterální stěny LK.

Výsledky: viz tabulka.

Závěr: V předložené studii stimulace septa, ani hrotu pravé komory nevedla akutně $\mathrm{k}$ signikantní inter- a intraventrikulární dyssynchronii. V obou skupinách jsme však zaznamenali velký individuální rozptyl ve všech sledovaných parametrech.

\section{ČASNÉ VÝSLEDKY PLICNÍ ENDARTEREKTOMIE PACIENTŨ S PLICNÍ HYPERTENZI A ANTIFOSFOLIPIDOVÝM SYNDROMEM}

LINDNER J, JANSA P, PALEČEK T, GRUS T, VÍTKOVÁ I, KUNSTÝR̆ J, RUBEŠ D, KVASNIČKA J, ASCHERMANN M, LINHART A

II. chirurgická klinika, Kardiocentrum, II. interní klinika kardiologie a angiologie, Oddělení patologie,

Klinika anesteziologie, resuscitace a intenzivní medicíny, Oddělení hematologie, VFN a 1. LF UK, Praha

Úvod a cíl práce: Antifosfolipidový syndrom (AFS) je autoimunitní onemocnění s hyperkoagulačním stavem a vyskytuje se asi u $2 \%$ populace. U pacientů a chronickou tromboembolickou plicní hypertenzí (CTEPH) patří mezi nejčastější získané trombofilní stavy. Zprávy o úspěšné chirurgické léčbě $\mathrm{CTECH}$ u tohoto velmi závažného postižení plicní cirkulace jsou sporadické. Při AFS dochází jak k postižení centrálních, tak i periferních plicních tepen. Centrální postižení je $\mathrm{v}$ indikovaných případech řešitelné endarterektomií plicních tepen (PEA). Cílem naší práce bylo shrnout časné výsledky a upozornit na některá úskalí léčby těchto vysoce rizikových nemocných.

Tabulka k abstraktu MUDr. Lefflerové

\begin{tabular}{lccccc}
\hline \hline & $\begin{array}{c}\text { Preejekční čas LK } \\
(\mathbf{m s})\end{array}$ & $\begin{array}{c}\text { Preejekční čas PK } \\
\text { (ms) }\end{array}$ & IVMD (ms) & $\begin{array}{c}\text { Septal-lateral delay } \\
\text { - počátek (ms) }\end{array}$ & $\begin{array}{c}\text { Septal-lateral delay } \\
\text { - vrchol (ms) }\end{array}$ \\
\hline Stimulace septa & $140 \pm 22$ & $114 \pm 22$ & $19 \pm 23$ & $6 \pm 30$ & $32 \pm 52$ \\
Stimulace hrotu & $147 \pm 23$ & $121 \pm 24$ & $21 \pm 18$ & $17 \pm 42$ & $21 \pm 56$ \\
P-value & $\mathrm{NS}$ & $\mathrm{NS}$ & $\mathrm{NS}$ & $\mathrm{NS}$ & $\mathrm{NS}$ \\
\hline \hline
\end{tabular}


Materiál a metody: Od září 2004 do prosince 2006 jsme odoperovali 39 nemocných s CHTEPH, u 4 jsem zjistili AFS, tj. 10,25 \% (3 ženy a 1 muž). Průměrný věk byl 31,8 $\pm 8,6$, mPA $55 \pm 2,24$, CI 2,12 $\pm 0,83$ a PVR 777,4 $\pm 207,6$. Klinicky se jednalo o nemocné těžce symptomatické s NYHA III $\mathrm{u}$ třech a NYHA IV u jedné nemocné. Pro statistickou analýzu byl použit $t$-test, $\chi^{2}$ a ANOVA test.

výsledky: Porovnáním výsledků hemodynamiky po PEA a srovnáním u pacientů s AFS, jinou trombofilií a bez zjištěné trombofilie jsme nezjistili statisticky významný rozdíl u mPA, CI ani PVR časně po operaci (24 hodin). Porovnali jsme také histologické nálezy a u trombofilních stavu stejně jako u AFS. Při dalším sledování (2 roky od operace) jsou 3 nemocní NYHA I a jedna NYHA II, testem šestiminutové chůze dosahují všichni nemocní zlepšení (6 WMT). Ze specifických komplikací jsme zaznamenali jednou sukcesivní embolii a jednou migraci kavárního filtru.

Závěr: Časné výsledky plicní endarterektomie i u nemocných s CHTEP a AFS jsou velmi dobré a vyžadují trvalou a velmi úzkou multidisciplinární spolupráci.

Průběh je často komplikovaný, ale časný hemodynamický efekt i následné klinické zlepšení je stejně příznivé jako u nemocných po PEA bez trombofilie.

\section{PARATHORMON A KALCIFIKOVANÁ AORTÁLNÍ STENÓZA}

LINHARTOVÁ K, ŠTĚRBÁKOVÁ G,

ČERBÁK R, RACEK J, TREFIL L, BERNAT I, VESELKA J

Kardiovaskulární centrum, FN Motol, Praha,

I. interní klinika, Ústav klinické biochemie

a hematologie, FN Plzeň, Plzeň

Úvod: Časná léze aortální stenózy (AS) se stavbou podobá aterosklerotickému plátu, hlavním rysem progrese vady je však kalcifikace. Parathormon (PTH) je jedním $z$ hlavních regulátorů metabolismu kalcia. Cílem naší práce bylo zjistit, zda existuje asociace PTH a metabolismu kalcia s AS u pacientů s významnou koronární nemocí.

Metody: Do studie jsme prospektivně zařazovali konsekutivní pacienty $\mathrm{s}$ angiograficky významnou koronární nemocí spojenou $\mathrm{s}$ AS (střední transvalvulární aortální gradient $\geq 30 \mathrm{~mm} \mathrm{Hg}$ ) nebo aortální sklerózou (střední gradient $\leq 10 \mathrm{~mm} \mathrm{Hg}$ ). Porovnali jsme sérové hladiny PTH a parametry metabolismu kalcia mezi oběma skupinami a identifikovali nezávislé rizikové faktory AS pomocí logistické regrese.

Výsledky: Zařadili jsme 122 pacientů s AS (85 mužů) a 101 pacientů s aortální sklerózou (76 mužů). Pacienti s AS byli starší (71 \pm 7 vs. $66 \pm 7$ let; $p<0,001)$, měli vyšší hladinu sérového PTH (57 \pm 26 vs. $40 \pm 18 \mathrm{pg} / \mathrm{ml} ; p<0,001)$, vyšší 24 hodinovou exkreci fosforu (P) do moči $(21 \pm 12$ vs. $17 \pm 10 \mathrm{mmol} / 24$ hod.; $p=0,01)$ a nižší clearance kreatininu $(1,14 \pm 0,4$ vs. $1,25 \pm 0,3 \mathrm{ml} / \mathrm{sec} ; p=0,04)$ než ti s aortální sklerózou. Mezi oběma skupinami nebyly statisticky významné rozdíly $\mathrm{v}$ hladině sérového $\mathrm{P}$ a ionizovaného kalcia, 24hodinové exkreci kalcia do moči a výskytu rizikových faktorů: hypertenze, kouření, diabetu, dyslipidemie, hladin LDL- a HDL-cholesterolu, indexu tělesné hmotnosti a vysoce senzitivního C-reaktivního proteinu. Zjistili jsme nezávislou asociaci AS s hladinou PTH (OR 1,04, 95\% CI 1,02-1,05; $p<0,001$ ) a věkem (OR 1,09, 95\% CI 1,03-1,14; $p<0,001$ ).

Závěr: U pacientů $\mathrm{s}$ významnou koronární nemocí jsme zjistili nezávislou pozitivní asociaci hladiny sérového PTH s kalcifikovanou AS. Zvýšená exkrece fosforu také svědčí pro možnou asociaci změn metabolismu kalcia s kalcifikací aortální chlopně u této skupiny pacientů.

\section{KLINICKÉ VYUŽITÍ DÁLKOVÉHO MONITOROVÁNÍ (HOME MONITORING) IMPLANTABILNICH PACEMAKERŮ A DEFIBRILÁTORŮ*}

LIPOLDOVÁ-MÜLLEROVÁ J, NOVÁK M, DVOŘÁK I, VYKYPĚL T, KAMARÝT P

I. interní-kardioangiologická klinika,

FN u sv. Anny, Brno

\section{*MŠMT-MSM 0021622402}

Úvod: Biotronik Home Monitoring (HM) je v ČR nejrozšířenějším systémem dálkového monitorování nositelů pacemakerů (PM) a defibrilátorů (ICD). Implantovaný PM či ICD vybavený anténou vysílá signál, který je zachycen pacientskou jednotkou CardioMessenger (CM). Po digitální transformaci je signál formou SMS odeslán do centra v Berlíně. Přenesené informace jsou automaticky analyzovány a výsledek zpřístupněn lékaři na zabezpečeném serveru. Odesílání probíhá každý den $\mathrm{v}$ naprogramovanou hodinu a v případě závažného nálezu či záchytu arytmie. Podmínkou úspěšného přenosu je nepřekročení vzdálenosti 3-5 m mezi pacientem a CM a pokrytí signálem mobilní sítě.

Metody: První aktivace HM v našem centru byla provedena 23. 4. 2005. Pacienti ambulantně vyšetřeni $1,3,6$ a 12 měsíců po aktivaci, či dříve, $\mathrm{v}$ případě hlášené události. Ambulantní kontrola zahrnovala standardní přeměření parametrů PM/ICD a dokumentaci všech zaznamenaných epizod. Nálezy byly porovnány s hlášením HM. Do 31. 12. 2006 jsme použili HM u 29 pac (ICD 25×, PM 4×).

Výsledky: Nejčastější důvody neodeslání zprávy: nedodržení vzdálenosti od CM či vybitý $\mathrm{CM}$, nedostatečné pokrytí mobilní sítí, mechanické poškození $\mathrm{CM}$, úmrtí. Zaznamenané důvody deaktivace: úmrtí, OTS. Zaznamenané arytmie: komorová tachykardie/fibrilace (KT/FK) řešená antitachykardickou stimulací/výboji ( $31 \times$ u 5 pac), KT/FK bez terapie ( $3 \times$ u 2 pac), detekce v zóně KT/FK při supraventrikulární arytmii (19× u 3 pac), nesetrvalé KT u PM ( $80 \times$ u 2 pac).

Další hlášení: pokles \% komorové stimulace u resynchronizační terapie (32× u 2 pac), vysoká impedance některé $z$ elektrod ( $17 \times$ u 4 pac).

Závěr: $Z$ použití HM nejvíce profitují pacienti s biventrikulárními PM a ICD. HM umožňuje časnou detekci dysfunkce elektrod, arytmické bouře, přidružených arytmií, poruch $\mathrm{PM} / \mathrm{ICD}$, deplece baterie. Přenos IKEG rozšiřuje možnosti péče o pacienty s ICD.

\section{SESTERSKÁ SEKCE}

\section{MÁ ANTIBIOTICKÁ PROFYLAXE OPODSTATNĚNİ U IMPLANTACÍ KARDIOSTIMULÁTORÚ A ICD?}

\section{LIVOROVÁ J, MASLÁKOVÁ M, KEMZOVA K}

Kardiologické oddělení, Nemocnice Na Homolce, Praha

Úvod: Význam antibiotické profylaxe - indikace, délka trvání a typ použitého antibiotika není stále jednoznačně objasněn. Rada prací zpochybňuje úlohu preventivního podávání antibiotik, existuje ale i řada studií, které tuto teorii podporují.

Cíl práce: Srovnání počtu infekčních komplikací ve střednědobém sledování u nemocných s primo a reimplatací kardiostimulátorů (KS) a implantabilních kardioverterůdefibrilátorů (ICD).

Metodika: 121 konsekutivních pacientů s provedenou primo (82) a reimplantací KS a ICD (39) v lednu až březnu 


\section{Seznam firem inzerujících v tomto čísle}

Servier s. r. 0

2. strana obálky, strana 1,69

sanofi-aventis

.......... 3. a 4. strana obálky

Krka zastoupení pro ČR

strana 15 a mezi stranami 48 a 49

Cardion s. r. 0. . strana 19 a 121

BTL zdravotnická technika, s. r. 0 . strana 62

Medtronic Czechia s. r. 0 strana 77

MedProGo, s. r. 0.

strana 93 a 117

Johnson \& Johnson S. r. 0 .

strana 113

\section{KOMPLEXNÍ VYBAVENÍ PRO KARDIOLOGIE}

DVANÁCTIKANÁLOVÁ EKG

BTLOBLC

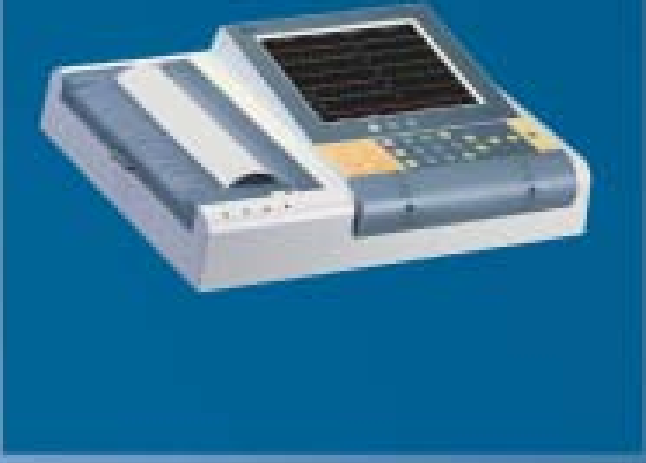

\section{EKG HOLTERY}

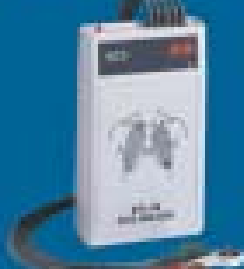

\section{ERGOMETRICKÉ SYSTÉMY}

BTLOB EAGO
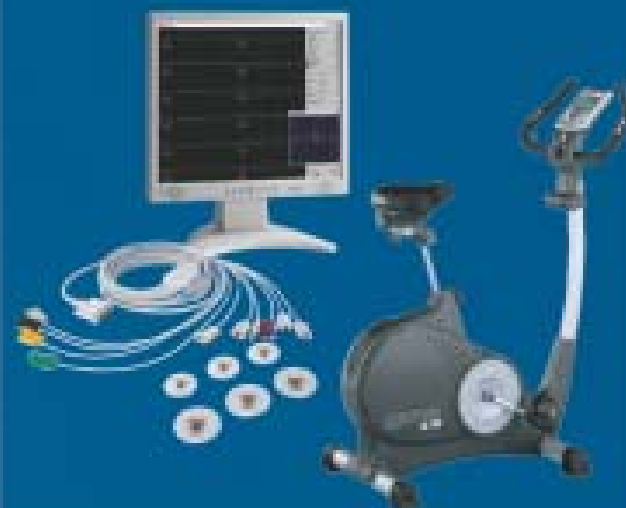

AMBULANTNI MONITORY TLAKU BTL-O8 ABPM

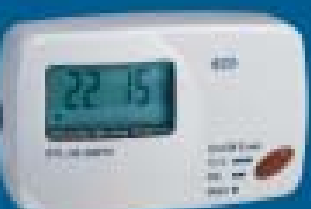

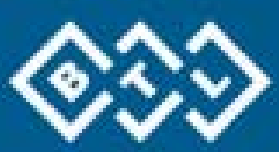

VERTIKALIZAĆNI STOLY

BTL-1800 TILT

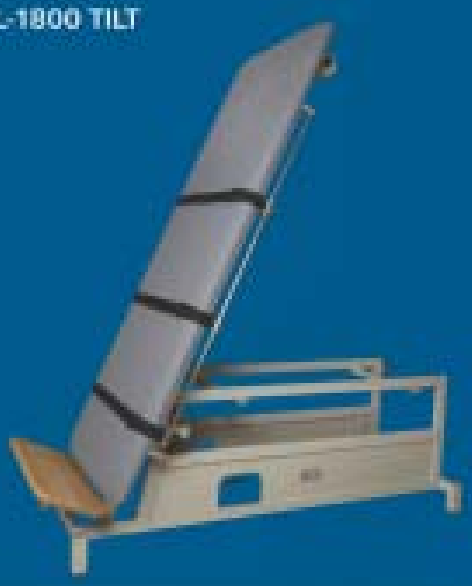

BTL zdravotnická technika, a.s. Ŝantrochova 16, 16200 Praha 6 TEL/FAX 235363606,235361392 GSM 777920272 - 4 obchodebtl.cz, www.btl.cz 
2003 bylo sledováno ambulantně po dobu 3 let (průměr $32 \pm 8$ měs.) Tyto nemocní byli randomizováni $1: 1 \mathrm{k}$ preventivní ATB-terapii (cefalosporin 1-3 g i. v. podle hmotnosti - 1 hodinu před výkonem a dále 2 . dávka 8 hod. po výkonu). Byl hodnocen výskyt infekčních komplikací v kapse KS, výskyt infekční endokarditidy a komplikace léčby infekcí.

Výsledky:

\begin{tabular}{lccccc}
\hline \hline Komplikace & $\begin{array}{c}\text { Primo } \\
\text { ATB + }\end{array}$ & $\begin{array}{c}\text { Reimplan- } \\
\text { tace ATB + }\end{array}$ & $\begin{array}{c}\text { Primo } \\
\text { ATB - }\end{array}$ & $\begin{array}{c}\text { Reimplan- } \\
\text { tace ATB - }\end{array}$ & $\boldsymbol{p}$ \\
\hline Infekční kapsy & 0 & 1 & 3 & 4 & 0,01 \\
Endokarditis & 0 & 1 & 2 & 4 & 0,01 \\
Úmrtí & 0 & 1 & 1 & 2 & NS \\
\hline \hline
\end{tabular}

Závěr: Jako rizikové se jeví z pohledu infekčních komplikací zejména reimplantace jak KS tak ICD. Méně infekčních komplikací se ve střednědobém sledování vyskytlo u nemocných s podáním profylaktického antibiotika parenterálně. ATB prevence tak mưže dlouhodobě přispět ke snížení nutnosti kompletních extrakcí systémů jak endovazální, tak kardiochirurgickou cestou $z$ důvodů závažných infekčních komplikací u implantátů.

\section{VYUŽITÍ KOMBINACE NEINVAZIVNÍCH VYŠETR̆OVACÍCH METOd PRO STRATIFIKACI RIZIKA NÁHLÉ SRDEČNÍ SMRTI U PACIENTŮ PO INFARKTU MYOKARDU}

LOKAJ P, KŘIVAN L, KOZÁK M, SEPŠI M, VLAŠÍNOVÁ J, ŠPINAR J

\section{I. interní-kardiologická klinika, FN Brno, Brno}

Cíl: Existuje několik neinvazivních metod pro rizikovou stratifikaci pacientů po infarktu myokardu (IM) léčených koronární angioplastikou. Cílem bylo vytvořit neinvazivní stratifikaci kombinací rizikových znaků a stanovit rizika náhlé srdeční smrti (NSS) a jejich využití $\mathrm{k}$ cílené implantaci implantabilního kardioverteru-defibrilátoru (ICD) u pacientů po IM.

Soubor a metodika: Do studie byli zařazeni pacienti léčeni optimální farmakoterapií a maximální možnou revaskularizací. Vyšetřili jsme celkem 171 pacientů průměrného věku 62,7 let $(\mathrm{SD}=12,4)$. Pacienti po IM byli vyšetřeni neinvazivními metodami: echokardiografie pro určení ejekční frakce levé komory (EF LK); Holterovo EKG ke stanovení variability $\mathrm{v}$ tepových intervalech (HRV), turbulence srdečního rytmu (HRT), vyšetření citlivosti baroreflexu (BRS) a př́tomnosti pozdních potenciálů (LP). U pacientů zařazených do studie jsme sledovali mortalitu dotazníkovou metodou.

Výsledky: Pacienti byli rozděleni do 5 kategorií podle počtu rizikových markerů:

BRS $<3 \mathrm{~ms} / \mathrm{mm} \mathrm{Hg}$, SDNN $<70 \mathrm{~ms} ;$ TO $>0 \%$, TS $<2,5$ ms/interval RR. $Z$ počtu 79 pacientů (známá hodnota 4 rizikových znaků), byly u 30 (38,0 \%) pacientů všechny hodnoty fyziologické, u $28(35,4 \%)$ byla patologie v jednom parametru, u $13(16,5 \%)$ pacientů byly patologické 2 parametry, u 5 (6,3 \%) pacientů parametry 3 a u 3 (3,8 \%) pacientů 4 rizikové faktory. Průměr EF LK u pacientů s vysokým počtem rizikových faktorů ( 3 nebo 4 ) byl $36,5 \%$ vs. $48,4 \%$ $\mathrm{u}$ pacientů bez rizikového faktoru $(p=0,066)$. Abnormální hodnoty neinvazivních markerů nekorelují s počtem postižených koronárních tepen, rozsahem revaskularizace, výskytem LP nebo EF LK. V průběhu sledování $(27,9$ měsíců) zemřelo $11(6,4 \%)$ pacientů, $z$ toho $2(1,6 \%)$ na NSS.

Závěr: Důležitost neinvazivních rizikových znaků bude pravděpodobně klesat $\mathrm{s}$ použitím invazivních metod $\mathrm{v}$ léčbě akutního infarktu myokardu.

\section{VLIV POUŽITÍ CENTRIFUGÁLNÍ PUMPY, LEUKOCYTÁRNÍHO FILTRU A HEMOKOMPATIBILNİHO POVRCHU NA POOPERAČNÍ PRŮBĚH U KARDIOCHIRURGICKÝCH NEMOCNÝCH STARŠÍCH 70 LET. PRVNİ VÝSLEDKY*}

LONSKÝ V, MANĎÁK J, KUBÍČEK J, VÁLEK R, KUNEŠ P, VOLT M, BÍMOVÁ J, VALENTOVÁ P, NOVÁKOVÁ D

Kardiochirurgické oddělení,

FN Hradec Králové a LF UK, Hradec Králové

*Studie je podporována výzkumným záměrem FN Hradec Králové MZO 00179906.

Cíl: Počet nemocných starších 70 let operovaných v mimotělním oběhu $(\mathrm{MO})$ vzrůstá. Tito nemocní mají vyšší mortalitu i pooperační morbiditu. V současnosti jsou $\mathrm{k}$ dispozici nové technologie, které umožňují zlepšit systém MO. Jejich cena však nedovoluje standardní využití a jejich pozitivní účinek není v klinice zcela jasně prokázán. Cílem studie je ověrit jejich vliv na pooperační průběh.

Metoda: Sledovali jsme 18 po sobě jdoucích nemocných starších 70 let, operovaných pro ICHS. 9 (S) bylo operováno za použití systému potaženého heparinem, centrifugální pumpy a leukodeplečního filtru. $9(\mathrm{~N})$ bylo operováno za použití standardního MO. Analyzovali jsme různé demografické, předoperační, peroperační a pooperační údaje.

Výsledky: Skupiny se nelišily ve věku, tělesném povrchu, $\mathrm{EF}$, trvání $\mathrm{MO}$, uzávěru aorty svorkou, počtech bypassů, v pooperačních krevních ztrátách a potřebě transfuzí. Významně byla zkrácena délka pooperační ventilace $6 \pm 2$ vs. $14 \pm 10$ hod.; $p<0,05)$ ve skupině S. Vzestup počtu leukocytů po operaci byl významně nižší ve skupině $S(6,6 \pm 0,7$ na $8,5 \pm 2,1$ vs. $6,6 \pm 1,6$ na $11,05 \pm 3,1 ; p<0,05$ ). Nebyl rozdíl v pooperačním poklesu počtu trombocytů. Žádný nemocný nezemřel.

Závěr: Naše výsledky zatím nepodporují předpoklad absolutní výhody zlepšených nad standardně použivanými systémy MO. Pozorovali jsme významné zkrácení doby pooperační ventilace (důsledek snížení počtu aktivovaných leukocytů)? Nepotvrdili jsme ochranný efekt systému na trombocyty. Nebyl rozdíl $\mathrm{v}$ krevních ztrátách ani $\mathrm{v}$ potřebě pooperačních transfuzí. $\mathrm{K}$ definitivnímu rozhodnutí o možných výhodách nových systémů jsou nutná data od většího počtu nemocných.

\section{KONCENTRACE HSCRP U PACIENTŮ S INFARKTEM MYOKARDU - VLIV PROSTR̆EDÍ A POLYMORFISMUS V GENU CD14}

\section{LORENZOVÁ A, STANĚK V, STÁVEK P,} HUBÁČEK J, LÁNSKÁ V, POLEDNE R

III. interní-kardiologická klinika, FN KV a 3. LF UK, Klinika kardiologie, Laborator pro výzkum aterosklerózy, Oddělení statistiky, IKEM, Praha

Cíl: Zvýšená koncentrace ultrasenzitivně měřeného CRP (hsCRP) souvisí s rizikem vzniku infarktu myokardu, avšak mechanismy regulující koncentraci hsCRP nejsou ještě zcela objasněny. V naší studii byl studován vliv polymorfismu CD14 a faktorů prostředí na koncentraci hsCRP u pacientů s infarktem myokardu a kontrolní skupiny.

Soubor a metodika: Sledovanou skupinu tvořilo 284 pacientů (muži, věk do 65 let) přijatých na koronární jednotku IKEM pro akutní infarkt myokardu v období 6/2001-5/2003.

Kontrolní soubor $(n=568)$ tvořili věkově odpovídající jedinci z 1 \% reprezentativního populačního vzorku (náhodný výběr podle věkového kritéria). U každého pacienta byly 
změřeny antropometrické parametry a stanoven lipidogram po přijetí na koronární jednotku, koncentrace hsCRP byla stanovena při roční kontrole po infarktu myokardu (klidová hodnota hsCRP).

Výsledky: Pacienti a kontrolní soubor se nelišili v BMI, avšak pacienti měli převažující abdominální typ obezity. Koncentrace hsCRP byla vyšší $(1,56 \mathrm{mg} / 1, p=0,001 ; \pm 2,31$ mg/l) než u kontrol (1,40 \pm u pacientů 2,12$)$, přestože většina pacientů byla $\mathrm{v}$ době odběru léčena statiny. V koncentracích lipoproteinů nebyl nalezen významný rozdíl. Distribuce jednotlivých genotypů CD14 se mezi pacienty a kontrolami nelišila. U pacientů kuřáků nesoucích C alelu CD14 byla koncentrace hsCRP signifikantně vyšší $(2,04 \pm 2,38$ $\mathrm{mg} / \mathrm{l})$ než u nekuřáků $\mathrm{s}$ touto alelou $(1,70 \pm 1,97 \mathrm{mg} / \mathrm{l})$, $p=0,0012$. U kontrolního souboru nebyl rozdíl $\mathrm{v}$ koncentraci hsCRP u jednotlivých genotypů mezi kuřáky a nekuřáky. Podle lineární regrese byla hodnota hsCRP u pacientů statisticky významně ovlivněna statiny, zatímco u kontrolní skupiny měl vliv věk, kouření, úroveň vzdělání a BMI.

Závěr: Vyšší koncentrace hsCRP u pacientů s C alelou CD14 svědčí pro významnou interakci genotyp - prostředí. Alela $\mathrm{C}$ je pravděpodobně rizikovým faktorem pro infarkt myokardu pouze u kuřáků.

\section{PATŘí AMIOdARON DO LÉČBY SRDEČNÍHO SELHÁNÍ? NE}

\section{LUPINNEK P}

\section{Klinika kardiologie, IKEM, Praha}

Amiodaron je antiarytmikum vysoce účinné v léčbě supraventrikulárních i komorových arytmií a je přitom poměrně bezpečný, co se týče proarytmogenního účinku. Kromě betablokátorů je jediným antiarytmikem, jehož podávání lze akceptovat $\mathrm{u}$ nemocných se srdečním selháním. Tyto jeho vynikající vlastnosti však často vedou $\mathrm{k}$ jeho velkorysému podávání i tam, kde není indikován. Přitom nežádoucí účinky amiodaronu zdaleka nejsou nevýznamné. Hypertyreóza nebo „amiodaronová plíce“ v některých případech závažným způsobem zkomplikují průběh srdečního selhání, případně jsou překážkou provedení srdeční transplantace. Stává se tak mnohdy $\mathrm{v}$ př́padech, kde antiarytmická farmakoterapie neměla být správně vưbec podána. Nesprávné je především paušální podávání amiodaronu, jako prevence náhlé srdeční smrti nemocným se srdečním selháním a asymptomatickou zvýšenou komorovou ektopickou aktivitou, včetně krátkých běhů komorové tachykardie. Ve studii SCD-HeFT u nemocných se systolickým srdečním selháním amiodaron neovlivnil mortalitu ve srovnání s placebem, účinný byl pouze implantabilní defibrilátor. Ten je v současné době terapií volby u rizikových nemocných. Nefarmakologická léčba arytmií je alternativou i v řadě dalších situací, zejména v léčbě supraventrikulárních, ale i některých komorových tachyarytmií.

U nemocných se srdečním selháním by indikace $\mathrm{k}$ léčbě amiodaronem měla být zvlášt pečlivě zvažována a měl by být podáván jen tehdy, je-li pro něj jasná a podložená indikace a není-li výhodnější alternativa v podobě nefarmakologické léčby.

\section{MASIVNÍ PLICNÍ EMBOLIZACE U GRAVIDNÍ PACIENTKY. KASUISTIKA}

\section{MADĚROVÁ E, VLAŠÍNOVÁ J, KAŇOVSKÝ J, ŠPINAR J}

Interní-kardiologická klinika, FN Brno, Brno

Popis: Představujeme případ úspěšné léčby masivní plicní embolizace u gravidní nemocné. 27letá pacientka přichází v 25. týdnu gravidity pro masivní plicní embolizaci (klinický obraz, echokardiograficky nález dilatace pravostranných oddílů, nepřímé známky plicní hypertenze), podle CT vyšetření nález trombu ve větvení pravé i levé pulmonální arterie. Léčba započata nízkomolekulárním heparinem (LMWH) v kontinuální infuzi, pro oběhovou nestabilitu krátce po přijetí podána $\mathrm{z}$ vitální indikace trombolýza $\mathrm{v}$ celkovém podání - t-PA v dávce $100 \mathrm{mg}$ ve 2 hodinové infuzi, léčba proběhla bez komplikací. Následně pokračováno v léčbě LMWH v plné antikoagulační dávce za sledování anti-Xa až do porodu - ten je plánovaný ve 40. týdnu gravidity, bez komplikací.

Diskuse: V diskusi se zabýváme možnostmi léčby plicní embolizace $\mathrm{v}$ graviditě.

\section{GENETICKÝ SCREENING MUTACÍ GENŮ ZODPOVËDNÝCH ZA HYPERTROFICKOU KARDIOMYOPATII: PILOTNÍ ZKUŠENOSTI*}

MAGAGE S, JÁCHYMOVÁ M, DOSTÁLOVÁ G, KUCHYNKA P, HAVRÁNEK Š, PALEČEK T, LINHART A

ll. interní klinika, Laboratoř molekulární kardiologie, VFN a 1. LF UK, Praha

*Výzkumný záměr MZO 00064165.

Hypertrofická kardiomyopatie (HKMP) je morfologicky definována jako hypertrofie levé komory při absenci jiného systémového nebo srdečního onemocnění, které by bylo schopno vést $\mathrm{k}$ takovému stupni zbytnění myokardu, jako je např. arteriální hypertenze nebo aortální stenóza. Familiární HKMP je pravděpodobně nejčastěji se vyskytující formou kardiomyopatie s odhadovanou prevalencí 1 : 500. Z klinického pohledu je dominantní skutečností, že HKMP je nejčastější příčinou náhlé srdeční smrti u mladých jedinců, především sportovců.

HKMP je autosomálně dominantně dědičným onemocněním s variabilní penetrací a expresí. Podstatou genetického defektu jsou mutace $\mathrm{v}$ genech kódujících sarkomerické proteiny. Do současnosti bylo popsáno více než 400 mutací v 11 genech, což činí genetickou diagnostiku HKMP velmi obtížnou.

Recentní výsledky rozsáhlého projektu EUROGENE však ukazují, že 80 \% detekovatelných mutací u nemocných s HKMP představují mutace ve dvou genech, a to pro těžké řetězce $\beta$-myozinu a protein $\mathrm{C}$ vázající myozin. $\mathrm{V}$ současnosti je proto doporučováno zahájit v centrech zabývajících se diagnostikou genetický screening testováním těchto dvou genů a následně se případně zaměřit na analýzu genů pro troponiny I a T, jejichž prevalence činila v registru EUROGENE v souhrnu $11 \%$ a také proto, že mutace troponinu $\mathrm{T}$ byly $\mathrm{v}$ minulosti dány do souvislosti s výrazně maligním arytmogenním potenciálem.

V Kardiocentru 1. lékařské fakulty Univerzity Karlovy bylo v roce 2005 zahájeno systematické genetické vyšetřování jedinců postižených HKMP a jejich příbuzných. Pilotní výsledky tohoto programu a nástin koncepce jeho činnosti do budoucna jsou vlastním předmětem sdělení.

\section{VLIV ZaLOŽENÍ CÉVNÍHO dIALYZAČNİHO ZKRATU NA HLADINU NATRIURETICKÉHO PEPTIDU}

\section{MALÍK J, TUKA V, KASALOVÁ Z, SLAVÍKOVÁ M}

III. interní klinika, Klinika kardiovaskulární chirurgie, VFN a 1. LF UK, Praha

Úvod: Vysoký průtok dialyzačním cévním zkratem může vést $\mathrm{k}$ rozvoji/dekompenzaci chronického srdečního selhání. Za hemodynamicky významný je považován zkrat, kterým 
protéká více než 1/3 srdečního výdeje. Předpokládali jsme, že již zkraty s nižším průtokem mohou vést $\mathrm{k}$ ovlivnění hladiny natriuretického peptidu (BNP).

Soubor a metody: Vyšetřili jsme pacienty s chronickou renální insuficiencí před založením cévního zkratu a 6 týdnů poté. 50 \% byli diabetici. Hladiny BNP byly porovnány párovým $t$-testem.

Výsledky: Bylo zařazeno 30 pacientů ve věku 63,6 \pm 13,5 let. Průtok zkratem po 6 týdnech od založení byl $709 \pm 311$ $\mathrm{ml} / \mathrm{min}$. Hodnota BNP stoupla po založení zkratu z 231 $\pm 144 \mathrm{ng} / 1$ na $428 \pm 438 \mathrm{ng} / 1, p=0,018$.

Závěr: Také cévní zkraty s obvyklým průtokem vedou $\mathrm{k}$ přetížení oběhu, měřeného hladinou BNP.

\section{AKUTNII PSEUDOANEURYZMA LEVÉ KOMORY SRDEČNÍ JAKO KOMPLIKACE AKUTNIHO INFARKTU MYOKARDU. KASUISTIKA}

MALÝ J, TELEKES P, HRABOŠ V, HOLM F, URBAN T, KOTULÁK T, LIPŠ M

Kardiocentrum, Nemocnice Liberec, Liberec,

Klinika kardiovaskulární chirurgie, VFN a 1. LF UK, Praha

Naše sdělení popisuje případ pacientky s nálezem rozsáhlého pseudoaneuryzmatu zadní stěny levé komory srdeční při ruptuře volné stěny myokardu v náhodné koincidenci s rozsáhlým aneuryzmatem aorty. 76letá pacienka byla přijata primárním transportem $\mathrm{z}$ terénu pro akutní koronární syndrom. Stenokardie měla intermitentně 48 hodin, při př́ijezdu na EKG STEMI posterolaterálně. Diagnóza byla stanovena na základně urgentní SKG s levografií, kde byl nález uzávěru RIVP s heterokolaterálním plněním, difuzní postižení RPLD a RMS bez jasné culprit léze. Podle levografie velké, laločnaté pseudoaneuryzma zadní stěny levé komory srdeční. Echokardiograficky globální EF LK 35 \%, oběhově nevýznamná separace perikardu bez známek tamponády. Kardiomarkery svědčily o vzniku infarktu myokardu před více než 24 hodinami. Nález konzultován s kardiochirurgem a pro riziko vzniku ruptury a tamponády srdeční byla pacientka chirurgicky intervenována. Logistické EUROSCORE $91 \%$. Nemocná byla operována s nálezem srdce kompletně uloženého ve srůstech, deviované doleva rozsáhlým aneuryzmatem aorty $(8 \mathrm{~cm})$. Na zadní stěně levé komory srdeční defekt ve velkém infarktovém prokrváceném ložisku asi $2 \mathrm{~cm}$, ten byl uzavřen.

Závěr: Ruptura volné stěny srdeční není vzácnou, avšak téměř vždy fatální komplikací akutních koronárních syndromů. Z dostupných dat vyplývá, že rizikovými faktory této komplikace jsou ženské pohlaví, primomanifestace ischemické choroby srdeční a anamnéza bolestí na hrudi starší 24 hodin. V tomto konkrétním případě pacientka kritický stav přežila, včetně transportu na vzdálené kardiochirurgické pracoviště a operace zatížené extrémně vysokým rizikem. Život pacientky zachránil excesivní jizevnatý proces v perikardu.

\section{NEOBVYKLÝ NÁLEZ IMITUJÍCÍ VÝZNAMNOU TRIKUSPIDÁLNÍ STENÓZU}

MANDYSOVÁ E, NIEDERLE P, FORMÁNEK P, SUTHERLAND G

Kardiologické oddělení, Nemocnice Na Homolce, Praha, Cardiology, St. Georges Hospital, Londýn, UK

Hypereozinofilní syndrom představuje klinickou jednotku, charakterizovanou eozinofilií (>1 500 eozinofilů $/ \mathrm{mm}^{3}$ ), trvající nejméně šest měsíců a manifestující se orgánovým postiže- ním (srdce, plíce, kostní dřeň, mozek). Příčina onemocnění je nejasná, jedná se o zánětlivý proces, vyvolaný pravděpodobně toxickým působením eozinofilů nebo jejich působků ve tkáních.

Onemocnění srdce bývá pravidlem, vyskytuje se u více než tří čtvrtin nemocných. Nejčastěji bývají postiženy srdeční komory, kde dochází k výraznému ztluštění endokardu vtokové části i hrotu obou komor. Klinické příznaky bývají rưzně vyjádřeny, od zpočátku asymptomatického průběhu až po známky těžkého postižení pravé a/nebo levé srdeční komory. Onemocnění se nejčastěji manifestuje srdečním selháním a systémovou embolizací a vede zpravidla do několika let k smrti (kardiální, ledvinové, jaterní nebo respirační selhání).

Kardiální postižení, známé pod názvem Lőfflerova endokarditida, představuje typické restriktivní srdeční onemocnění.

Uvádíme případ 52leté ženy, u které bylo onemocnění diagnostikováno před 6 lety. Manifestovalo se projevy pravostranného srdečního selhání s excesivní recidivující trombózou pravostranných srdečních oddílů a projevy trikuspidální stenózy, které byly řešeny náhradou trikuspidální chlopně bioprotézou s její následnou operací pro stenózu. Rok a půl po druhé operaci byla nemocná přijata na naše oddělení se známkami těžkého pravostranného srdečního selhávání. Při echokardiografickém vyšetření byl zjištěn neobvyklý nález: výrazná obstrukce vtokové části pravé srdeční komory rozsáhlým trombem, imitujícím restenózu bioprotézy. Po trombolytické léčbě byla obstrukce zčásti redukována a došlo k výraznému klinickému zlepšení pacientky, která dále zůstává v našem ambulantním sledování.

\section{SLEDOVÁNÍ NEMOCNÝCH SE SRDEC̆NÍ INSUFICIENCİ A BIVENTRIKULÁRNÍ STIMULACÍ}

MANDYSOVÁ E, TÁBORSKÝ M, NIEDERLE P, MRÁZ T

Kardiologické oddělení, Nemocnice Na Homolce, Praha

Transtorakální echokardiografie představuje široce dostupnou neinvazivní metodu pro hodnocení srdeční funkce. Umožňuje hodnotit morfologii i funkci srdečního svalu (systolickou i diastolickou), morfologii srdečních chlopní, semikvantifikovat srdeční vady a posuzovat morfologii i funkci perikardu. S její pomocí je tak velice pravděpodobně možné usuzovat příčinu srdečního selhání a spolu s dalšími vyšetřovacími metodami stanovit další postup v jeho léčbě.

U menší části nemocných ustoupí srdeční selhání po konzervativní léčbě (myokarditidy, alkoholová kardiomyopatie), u části po invazivní (koronární angioplastika) a operační léčbě (chlopenní a zkratové vady, aj.). Srdeční selhání však může progredovat i navzdory komplexní léčbě a stává se na ni refrakterním.

Je-li př́ičinou refrakterního srdečního selhání myogenní postižení levé srdeční komory (nejčastěji při ICHS nebo KMP) a jsou-li splněna příslušná kritéria, je indikována resynchronizační léčba $(\mathrm{CRT}$ = cardiac resynchronization therapy).

Echokardiografie má roli nejen při výběru nemocných k CRT, ale i v jejich dalším sledování. Bezprostředně po výkonu pomáhá nastavit správné stimulační parametry (atrioventrikulární i interventrikulární zpoždění). Na základě střednědobého a delšího echokardiografického sledování je možné stále přesněji určovat, kteří nemocní nejvíce profitují z tohoto typu léčby a kteří představují skupinu non-responderů. Spolu s tím je možné posuzovat podíl přidružených srdečních onemocnění i komplikací, vzniklých v souvislosti s CRT (vegetace na elektrodách, apod.).

Současným úkolem echokardiografie je nalézt obecně uznávaná neinvazivní kritéria pro diagnostiku asynchronie 
srdečních kontrakcí, k čemuž přispívá i sledování nemocných s pomocí nových echokardiografických přístupů.

\section{EMBOLIZACE VĔTVÍ ARTERIA MESENTERICA SUPERIOR JAKO KOMPLIKACE PR̆ÍMÉ KORONÁRNÍ ANGIOPLASTIKY R̆EŠENÁ LOKÁLNÍ TROMBOLÝZOU}

MAŇOUŠEK J, POLOCZEK M, PǍ̌ENICA J, SEDMÍK J, ŠPINAR J

Interní-kardiologická klinika, FN Brno, Brno

Úvod: Možnou komplikací akutní koronarografie a přímé koronární angioplastiky (PCI) jsou embolizace do systémového řečiště včetně splanchnických tepen. Mortalita poznané a včas léčené příhody (tj. bez infarzace tkáně) je nízká; v opačném případě se bliží 70-90 \%

Kasuistika: 59letý muž (diabetik II. typu s těžkou smíšenou hyperlipoproteinemií a artropatií v anamnéze) byl přijat na koronární jednotku pro akutní STE AIM inferolaterálně (delay 10 hodin), Killip I. Stav byl řešen přímou PCI ACD $\mathrm{s}$ implantací stentu. Po ukončení výkonu se u pacienta rozvíjí úporná bolest $\mathrm{v}$ epigastriu a pravém mezogastriu s další progresí, sugerující vaskulární břišní komplikaci. Při urgentním $\mathrm{CT}$ vyšetření břicha $\mathrm{s}$ kontrastem byl prokázán nástěnný trombus abdominální aorty pod odstupem renálních tepen a defekty náplně arteria mesenterica superior (AMS) pro pravý tračník a terminální ileum. Po konzultaci s chirurgem a invazivním radiologem bylo jako nejlepší alternativa zvoleno provedení lokální trombolýzy - katetrem podána Actilysa $30 \mathrm{mg}$ frakcionovaně do větví AMS s promptním ústupem bolesti (při suboptimálním angiografickém nálezu). Následně bylo pokračováno v infuzi Fragminu. Další průběh hospitalizace byl příznivý - pacient bez známek infarzace střeva, postupně zatěžován stravou, rehabilituje chưzí. Kontrolní duplexní vyšetření detekuje normální arteriální tok v lumen AMS. Devátý den je pacient propuštěn do domácí péče.

Závěr, diskuse: Při náhlé bolesti břicha vzniklé v návaznosti na katetrizační výkon je nutné myslet na nekardiální cévní př́íhodu (trombóza, embolizace, disekce) a neodkladně zajistit další došetření - duplexní sonografii, kontrastní CT angiografii či přímo angiografické vyšetření. Některé příhody je pak možné dále řešit invazivními radiologickými technikami včetně podání selektivní trombolýzy (redukovaná dávka trombolytika) s dobrým efektem.

\section{BNP JE LEPŠÍ NEŽ ZÁTĚŽovÁ ECHOKARDIOGRAFIE V KRÁTKODOBÉ PREDIKCI VZNIKU SYMPTOMÜ U MUŽU S ASYMPTOMATICKOU CHRONICKOU VÝZNAMNOU AORTÁLNÍ REGURGITACÍ}

MAREK T, KAUTZNER J, LÁNSKÁ V, KARASOVÁ L

Klinika kardiologie, Oddělení lékařské statistiky, Izotopové servisní středisko, IKEM, Praha

Cíl: Zhodnocení významu zátěžové echokardiografie a hladin BNP v predikci krátkodobého vývoje onemocnění = vznik symptomů, v průběhu 18měsíčního sledování u asymptomatických mužů s významnou chronickou aortální regurgitací (AoR) a dilatací levé komory, kteří dosud splňují kritéria konzervativní léčby.

Soubor a metoda: 49 mužů s asymptomatickou významnou chronickou AoR a dilatací levé komory, bez jiných kardiálních či závažnějších extrakardiálních onemocnění, pod- stoupilo kontrastní zátěžovou echokardiografii na sklopném bicyklu Ergoline $800 \mathrm{~L}$ (stupňovaná zátěž po $25 \mathrm{~W}$ po 3 min), „symptom - limited“ test. Před zátěží po 20 min klidu odebrána venózní krev na BNP, které stanoveno pomocí RIA-kitů. Získané údaje vztaženy $\mathrm{k}$ vývoji onemocnění v následujících 18 měsících a statisticky zhodnoceny.

Výsledky: U 6 mužů došlo ke vzniku symptomů během 18měsíčního sledování (skupina I), zbývajících 43 mužů (skupina II) bylo nadále bez obtíží. Nebylo statistického rozdílu mezi oběma skupinami v následujících parametrech: věk, BMI, klidová ejekční frakce, enddiastolický a endsystolický objem levé komory, mitrální regurgitace. Zátěžová ejekční frakce levé komory poklesla ve skupině I proti skupině II (delta $\mathrm{EF}-7 \pm 5,2 \%$ vs. $2 \pm 10,3 \%, p<0,045$ ). U pacientů s poklesem zátěžové ejekční frakce levé komory o více než $6 \%$ lze predikovat s $83 \%$ senzitivitou a $76 \%$ specificitou vznik symptomů v následujících 18 měsících. Klidové hladiny BNP byly statisticky významně vyšší ve skupině I proti skupině II $(93,9 \pm 22,1$ vs. $29,9 \pm 23,8 \mathrm{pg} / \mathrm{ml}$, $p<0,0001)$. Hladina BNP $95 \mathrm{pg} / \mathrm{ml}$ a vyšší predikovala vznik symptomů v následujících 18 měsících s $83 \%$ senzitivitou a $100 \%$ specificitou.

Závěr: Klidové hladiny BNP mají lepší potenciál než zátěžová echokardiografie $\mathrm{v}$ identifikaci rizikových pacientů ve skupině mužů $\mathrm{s}$ asymptomatickou chronickou významnou AoR, kteří dosud splňují kritéria konzervativní léčby.

\section{NEKARDIÁLNÍ OPERACE U PACIENTŨ S PLICNÍ HYPERTENZI}

MAREŠOVÁ J, JANSA P, AMBROŽ D, ASCHERMANN M, LINHART A, STŘIITESKÝ M, BLÁHA J

II. interní klinika kardiologie a angiologie, VFN a 1. LF UK, Praha

Úvod: Plicní hypertenze (PH) je syndrom sdružující onemocnění s vážnou prognózou. Kurativní chirurgická léčba PH má svá indikační omezení, zejména u chronické tromboembolické PH (CTEPH), farmakologická léčba plicní arteriální hypertenze (PAH) má své nežádoucí účinky a individuálně variabilní léčebný efekt. Péče o pacienty je ještě náročnější $\mathrm{v}$ případě dalších přidružených onemocnění. Pacienti s PH mají obecně přiznávanou vysokou rizikovost všech operačních zákroků.

Cíl práce: Shrnout zkušenosti s perioperační péčí o pacienty s PH, kteří podstoupili nekardiální operaci ve specializovaném centru.

Soubor pacientů a metodika: V Centru pro PH VFN v Praze bylo v letech 2004 až 2006 indikováno sedm nemocných s prekapilární $\mathrm{PH}$ k nekardiochirurgickým výkonům. Muž s PAH podstoupil nefrektomii pro adenokarcinom ledviny. Nemocný s těžkou PAH byl akutně operován pro krvácení do zaživacího traktu. U muže s těžkou PAH na kontinuální léčbě subkutánním treprostinilem byla provedena pro tumor močového měchýře cystektomie.

Žena s těžkou idiopatickou PAH na kontinuální léčbě intravenózním epoprostenolem byla operována pro perianální píštěl. Nemocné s komplexní cyanotickou vadou s univentrikulárním srdcem, na kontinuální léčbě intravenózním epoprostenolem, byla provedena hysterektomie. Žena s CTEPH po endarterektomii plicnice byla operována pro karcinom těla děložního a další nemocná s CTEPH po endarterektomii plicnice podstoupila hysterektomii pro myomatózní uterus.

Všechny výkony byly prováděny $\mathrm{v}$ zázemí kardioanestezie v celkové nebo spinální anestezii.

Výsledky: Časná i pozdní mortalita byla nulová. Ve třech případech byl pooperačně použit inhalační iloprost $\mathrm{k}$ ovlivnění $\mathrm{PH}$. 
Závěr: Centralizace nemocných s PH vede k získání maxima zkušeností a tak umožňuje indikovat tyto pacienty i k takovým výkonům, které by byly jinak v důsledku základního onemocnění kontraindikovány.

\section{VIABILITA MYOKARDU A SRDEČNÍ DYSSYNCHRONIE JSOU VÝZNAMNÝMI PREDIKTORY PERIOPERAČNÍ MORTALITY U VYSOCE RIZIKOVÝCH PACIENTŮ (EUROSCORE > $10 \%$ ) S ISCHEMICKOU KARDIOMYOPATIÍ PODSTUPUJÍCÍCH CHIRURGICKOU REVASKULARIZACI MYOKARDU}

MARUŠKOVÁ M, GREGOR P, PĚNIČKA M

III. interní-kardiologická klinika, FN KV a 3. LF UK, Praha

Cíl: Testovat zda posouzení viability myokardu a srdeční dyssynchronie kontrakcí zpřesní předpověd’ perioperačního rizika u vysoce rizikových pacientů (EuroSCORE > $10 \%$ ) $\mathrm{s}$ ischemickou dysfunkcí levé komory srdeční (LKS) podstupujících aortokoronární bypass (AKB).

Soubor pacientů a metodika: Soubor pacientů se skládal z 79 jedinců (průměrný věk $65 \pm 9$ let; $84 \%$ mužů; ejekční frakce LKS $30 \pm 6 \%$ s logistickým EuroSCORE > $10 \%$ podstupujících AKB. Viabilita myokardu byla vyšetřena magnetickou rezonancí s použitím kontrastní látky na bázi Gadolinia. Srdeční dyssynchronie byla stanovena tkáňovou dopplerovskou echokardiografií v 6 bazálních segmentech LKS.

Výsledky: Dvacet (25,3 \%) pacientů zemřelo do 30 dnů po AKB (úmrtí v nemocnici). Pacienti, kteří operaci přežili ( $n=59$ ), měli signifikantně větší množství viabilního myokardu $(6,9 \pm 3,6$ viabilních segmentů vs. $3,4 \pm 3,3$, $p<0,001)$ a menší dyssynchronii LKS $(75 \pm 55$ ms vs. 179 $\pm 83 \mathrm{~ms}, p<0,001)$ než pacienti, kteří zemřeli. Př́itomnost dyssynchronie LKS $\geq 105$ ms a $<5$ dysfunkčních viabilních segmentů byly nezávislými prediktory perioperačního úmrtí pro odhad perioperačního rizika jeví kombinace zavedeného EuroSCORE modelu $\mathrm{s}$ vyšetřením viability myokardu a srdeční dyssynchronie. Nemocní s vysokým EuroSCORE a neviabilním myokardem mají př́iliš vysoké perioperační riziko a neměli by proto podstupovat AKB.

\section{TEOFYLIN V PREVENCI KONTRASTEM INDUKOVANÉ NEFROPATIE U PACIENTŮ PODSTUPUJICICCH KORONAROGRAFII. RANDOMIZOVANÁ STUDIE*}

MATĚJKA J, VARVAŘOVSKÝ I, KVASNIČKA J, HERMAN A, VOJTÍŠEK P, ROZSÍVAL V

Kardiologické oddělení, Kardio-Troll, Krajská Nemocnice Pardubice, Pardubice

*Podporováno grantem IGA MZD ČR č. 1A8652-3/2005.

Úvod: Zhoršení renálních funkcí funkcí po podání kontrastní látky - kontrastem indukovaná nefropatie (CIN) představuje závažnou komplikaci koronarografie a koronární intervence.

Cíl: Zjistit účinnost teofylinu v prevenci CIN v rizikové populaci za současné adekvátní protokolem stanovené parenterální hydratace.

Metodika: Byla zahájena prospektivní dvojitě zaslepená randomizovaná studie, do které jsou zařazováni pacienti podstupující koronarografii a/nebo PCI se vstupním kreatininem vyšším než $130 \mu \mathrm{mo} / 1$. Minimálně 90 minut před koronarografií je podána infuze FR $500 \mathrm{ml}+240 \mathrm{mg}$ teofylinu (aktivní větev) nebo infuze FR $500 \mathrm{ml}$ (placebo). Je použito izoosmolární kontrastní látky (iodixanol). Po invazivním vyšetření pokračuje parenterální hydratace pomocí FR po dobu 24 hodin. Je stanovena hodnota sérového kreatininu den před invazivním vyšetřením, dále $\mathrm{v}$ den 1,2 a 3 . Pro hodnocení renálního postižení je rozhodující kontrolní odběr kreatininu v den 3 .

Tabulka k abstraktu MUDr. Matějky

\begin{tabular}{lccc}
\hline \hline & Placebo & Aktivni větev & Celý soubor \\
\hline Diabetes mellitus & $68 \%$ & $56 \%$ & $61 \%$ \\
Renální insuficience & $74 \%$ & $68 \%$ & $73 \%$ \\
PCI & $42 \%$ & $26 \%$ & $34 \%$ \\
Množství kontrastní látky & $89 \pm 29 \mathrm{ml}$ & $90 \pm 31 \mathrm{ml}$ & $89 \pm 30 \mathrm{ml}$ \\
Př́jem tekutin v den výkonu & $3182 \pm 621 \mathrm{ml}$ & $3091 \pm 575 \mathrm{ml}$ & $316 \pm 589 \mathrm{ml}$ \\
Vstupní S - kreatinin & $182 \pm 35 \mu \mathrm{mol} / 1$ & $184 \pm 35 \mu \mathrm{mol} / 1$ & $183 \pm 35 \mu \mathrm{mol} / 1$ \\
Kontrolní S - kreatinin & $183 \pm 44 \mu \mathrm{mol} / 1$ & $188 \pm 44 \mu \mathrm{mol} / 1$ & $185 \pm 45 \mu \mathrm{mol} / 1$ \\
\hline \hline
\end{tabular}

( $p<0,001)$. Tabulka I ukazuje riziko stanovené EuroSCORE a porovnání skutečné perioperační mortality. Přítomnost viabilního myokardu ustálila mortalitu na hodnotách předpovězených EuroSCORE. Přítomnost viabilního myokardu se současnou absencí dyssynchronie (VIAB-DYS) snížila predikovanou mortalitu na polovinu. Nepřitomnost viability (NVIAB) trojnásobně zvýšila riziko perioperačního úmrtí v porovnání $\mathrm{s}$ odhadem podle EuroSCORE.

Závěr: U vysoce rizikových pacientů $\mathrm{s}$ ischemickou dysfunkcí LKS plánovaných na AKB se optimálním postupem

\begin{tabular}{lccc}
\hline \hline & $\begin{array}{c}\text { VIAB } \\
(\mathbf{n}=\mathbf{4 8})\end{array}$ & $\begin{array}{c}\text { NVIAB } \\
(\mathbf{n}=\mathbf{3 1})\end{array}$ & $\begin{array}{c}\text { VIAB-DYS } \\
(\mathbf{n}=\mathbf{3 4})\end{array}$ \\
\hline EuroScore (\%) & 14,5 & 14,3 & 14,4 \\
Mortalita (\%) & 14,6 & 41,9 & 5,9 \\
Změna operačního rizika & Beze & $\uparrow 293 \%$ & $\downarrow 59 \%$ \\
VIAB a/nebo DYS & změny & & \\
\hline \hline
\end{tabular}

Výsledky: Analýza zahrnuje 51 doposud zařazených pacientů (viz tabulka).

Závěr: Ve studované rizikové populaci nedošlo po koronarografii a/nebo PCI $\mathrm{k}$ významnému vzestupu sérového kreatininu. Tento fakt lze přisoudit minimálnímu nutnému množství použité kontrastní izoosmolární látky a důsledné hydrataci. Renoprotektivní efekt antagonisty adenozinu teofylinu nebyl jednoznačně vyjádřen. Autoři předkládají předběžné výsledky projektu, ty budou aktualizovány v průběhu další randomizace pacientů.

\section{SESTERSKÁ SEKCE}

\section{ZÁTĚŽOVÉ TESTY V DETEKCI A DIAGNOSTICE ICHS}

MATUROVÁ P, VYMĚTAL P

Kardiologická ambulance, Uničov 
Cíl: Detekce a diagnostika ICHS zátěžovými testy.

Soubor: 496 pacientů vyšetřených ergometrickým zátěžovým testem.

Metodika: Po dobu 22 měsíců probíhal sběr dat pacientů, vyšetřovaných zátěžovým testem, $\mathrm{k}$ posouzení rizika ICHS.

Výsledky: Negativní test: 355 pacientů (71,5 \%); pozitivní test: 86 pacientů (17,5 \%); nediagnostický test: 28 pacientů (5,6 \%); hraniční test: 27 pacientů (5,4\%).

Závěr: Analýza následného postupu při pozitivním výsledku ergometrického vyšetření.

\section{PREDIKTIVNÍ POTENCIÁL NT-prOBNP U PACIENTŮ SE STABILIZOVANOU ISCHEMICKOU CHOROBOU SRDEČNİ*}

\section{MAYER O jr., ŠIMON J, PLÁŠKOVÁ M, MARKETA G}

Centrum preventivní kardiologie,

II. interní klinika-Univerzita Karlova, FN Plzeň a LF, Plzeň, Pracoviště preventivní kardiologie, IKEM, Praha

\section{*Podpořeno grantem IGA MZ.}

Východisko: Koncentrace N-terminálního fragmentu B - typu natriuretického peptide (NT-proBNP) významně předpovídá mortalitu pacientů se srdečním selháním či akutním koronárním syndromem. Cílem naší studie bylo stanovit prediktivní potenciál NT-proBNP na celkovou mortalitu pacientů se stabilizovanou chronickou ischemickou chorobou srdeční, ale bez klinických známek selhávání levé komory srdeční.

Metoda: Ve studii bylo vyšetřeno celkem 385 pacientů 6-24 měsíců po akutním koronárním syndromu či revaskularizaci (český vzorek studie EuroAspire II, vyšetřený v letech 1999-2000), avšak bez klinických známek manifestního srdečního selhání (tj. NYHA I, s negativní anamnézou hospitalizace pro srdečního selhání či známou dysfunkcí LKS, aktuálně bez objektivních známek srdečního selhání či chronické terapie kličkovými diuretiky). Celková mortalita byla stanovena k 1. 1. 2006, tj. medián sledování činil 6,46 let. Hladiny NT-proBNP byly stanoveny metodikou ELISA.

Výsledky: Celkem ve sledovaném souboru zemřelo 36 pacientů (tj. 9,35 \%). Pacienti s iniciální hodnotou NT-proBNP $>862$ pmol/1 (tj. v nejvyšším kvintilu) vykazovali asi $3 \times$ vyšší celkovou mortalitu než pacienti $\mathrm{s}$ nižšími hodnotami $(p<0,001)$ a jejich průměrná délka života byla zhruba o 194 dní kratší. Po adjustaci na možné spolupodílející se faktory mnohočetnou logistickou regresí činilo relativní riziko úmrtí $z$ jakékoliv přičiny (odds ratio (95\% conf. intervaly) pro pacienty s NT-proBNP > 862 pmol/1 3,26 $(1,40-7,62)$.

Závěr: Asymptomatická elevace NT-proBNP představuje významný prognostický faktor i u pacientů se stabilizovanou ischemickou chorobou srdeční, ještě bez klinických projevů srdečního selhávání.

\section{ROZSÁHLÝ INTRAKARDIÁLNÍ ÚTVAR V PRAVÉ SRDEC̆NÍ KOMOR̆E - METASTÁZA MELANOMU. KASUISTIKA}

\section{MÁCHA J, STANĚK L, TALACKOVÁ P, NIEDERLE P}

Kardiologické oddělení, Nemocnice Na Homolce, Praha, Interní oddělení, Bioptická laborator̆,

Nemocnice Chomutov, Chomutov

Úvod: Prezentujeme případ nemocného u kterého jsme prokázali objemnou metastázu melanomu v pravé srdeční komoře (PK).
Popis připadu: 81letý nemocný 7 měsíců před přjetím operovaný pro melanom na hrudníku, byl hospitalizován pro zhoršení dušnosti. Při echokardiografickém vyšetření (TTE) byl $\mathrm{u}$ něho zjištěn útvar vyplňující celou PK, trikuspidální regurgitace a známky těžké plicní hypertenze (PH). Útvar byl považován za trombus a proto byla podána intravenózní trombolýza (IVT), po které došlo ke zlepšení dušnosti nemocného, ale velikost útvaru se při kontrole TTE po IVT nezměnila. Nemocný byl přeložen na naše oddělení se suspekcí na nádorový původ útvaru. Námi provedené TTE potvrdilo předchozí nálezy. PK byla vyplněna solidní útvarem o rozměrech $70 \times 30 \times 40$ mm prolabujícím přes trikuspidální chlopeň, byla přítomna masivní trikuspidální regurgitace i těžká $\mathrm{PH}$. Nález potvrdila i magnetická rezonance srdce. Doplnili jsme intrakardiální biopsii útvaru. $Z$ histologického rozboru vzorků byl potvrzen melanom. Kardiochirurg vzhledem k rozsahu nádoru vyloučil možnost operačního řešení. Nemocný byl léčen antikoagulační léčbou a předán do péče onkologického oddělení. Bylo rozhodnuto o provedení paliativní radioterapie (RT). V průběhu aplikace RT se stav nemocného zhoršil, RT byla přerušena, ale nemocný záhy umírá pod obrazem nezvratného srdečního selhání. Sekčně byl potvrzen tumor v PK. Histologie odebraných vzorků i zde potvrdila nádorovou tkáň melanomu.

Závěr: U 50 \% nemocných s melanomem bývá sekčně diagnostikováno srdeční postižení. Nález takto objemného intrakardiálního tumoru je vzácný. V našem případě vzhledem $\mathrm{k}$ pokročilosti nádorového onemocnění a stavu pacienta nebyla možná operační léčba a nemocný byl léčen pouze paliativně. Zajímavé je zlepšení stavu po podání IVT, kdy zřejmě došlo k rozpuštění přidružené sukcesivní plicní embolizace.

\section{HODNOCENÍ KARDIOVASKULÁRNÍHO RIZIKA V PRIMÁRNÍ PREVENCI - RŮZNÁ DOPORUČENÍ VS. KLINICKÁ PRAXE}

\section{MÁLEK F, FROHLICH J}

\section{I. interní klinika, FN KV a 3. LF UK, Praha, Healthy Heart Lipid Clinic, St. Paul's Hospital, Vancouver, Canada}

Úvod: Na základě všech doporučení jsou pacienti s vysokým rizikem koronární příhody léčeni s cílem dosažení co nejnižších koncentrací LDL-cholesterolu. U asymptomatických jedinců se předchozí doporučení lišila jak př̀ hodnocení rizika, tak př̀i definování cílových koncentrací lipidů.

Cíle studie: Zjistit, zda se u souboru jedincủ bez manifestní aterosklerózy liší odhad 10letého koronárního rizika podle různých doporučení a zda má případný rozdíl v odhadu vliv na definované cílové koncentrace pro LDL-cholesterol.

Soubor nemocných a metodika: Analýza dat $\mathrm{z}$ ambulantních karet 100 jedinců bez klinické aterosklerózy, kteří byli postupně odeslaní $\mathrm{k}$ iniciálnímu vyšetření $\mathrm{v}$ Lipid Clinic, Healthy Heart, St. Paul's Hospital od 1. 11. 2002 do 31. 3. 2002. Soubor 59 žen a 41 mužů s průměrným věkem $51 \pm 10$ let. Kardiovaskulární riziko vypočteno a cílové koncentrace lipidů definovány podle: starších kanadských doporučení 2000 (I), posledních doporučení 2003 /ve shodě s NCEP ATP III-(II)/, procamových tabulek (III) a „procam“ algoritmu (IV). Kalkulované riziko a cílové koncentrace lipidư byly porovnány s odhadem rizika získaným $\mathrm{z}$ lékařských zpráv specialistů z Lipid Clinic (V).

Výsledky: Byl nalezen významný rozdíl v odhadu 10letého rizika podle doporučení (II) a obou kalkulací Procam (III a IV). Byl nalezen rozdíl $\mathrm{v}$ definovaných cílových koncentracích pro LDL-cholesterol podle doporučení (I) a podle doporučení (II, III, IV a výpočtu V). U 29 pacientů změnili specialisté z Lipid Clinic kalkulované riziko, v 27 př́padech byl odhad rizika zvýšen. 


\section{Významná inovace ve farmakoterapil anginy pectoris}
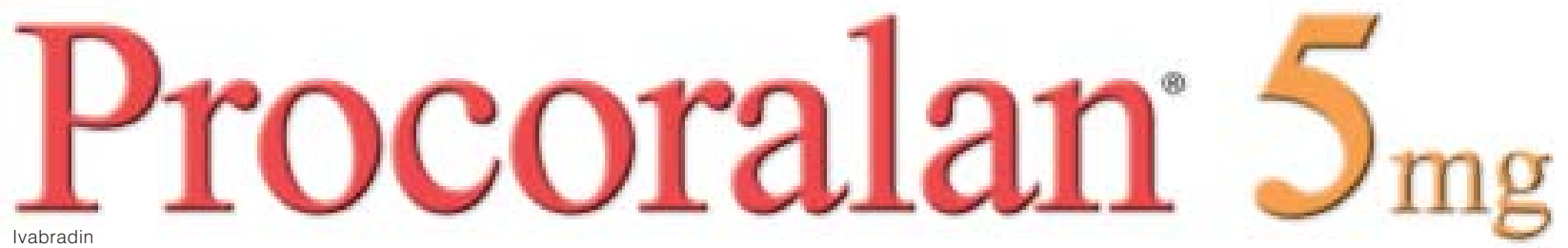

\section{První selektivní a specifický inhibitor I kanálu pưsobící v sinoatriálním uzlư ${ }^{1,2}$}

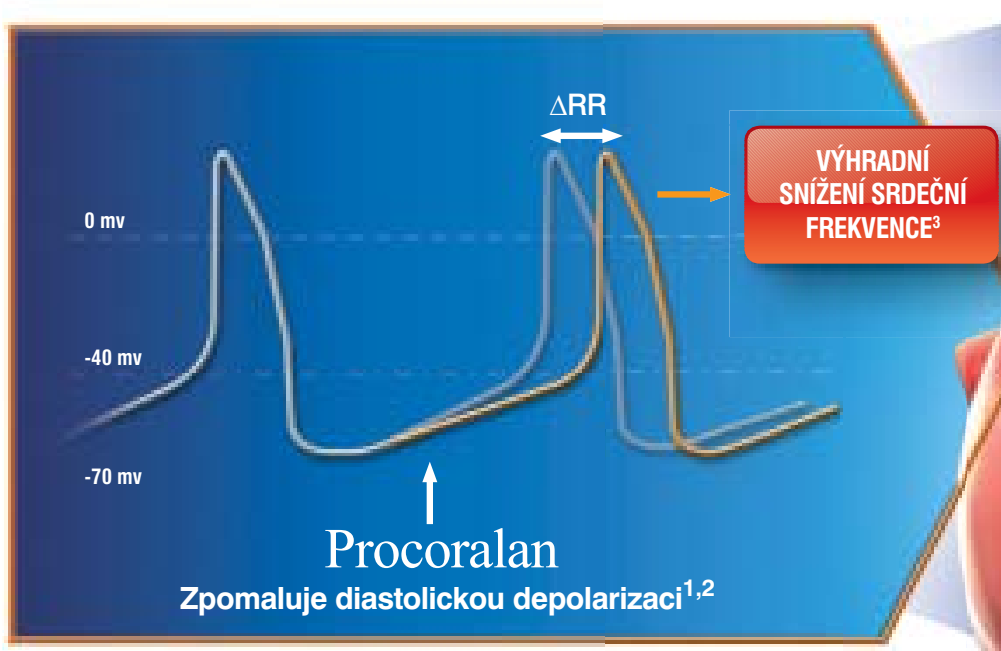

Výhradní snížení srdeční frekvence 0 10-14 tepů/min. ${ }^{3}$

Významná antianginózní a antiischemická účinnost srovnatelná s referenční léčbou ${ }^{3,4}$

Zachovává kontraktilitu myokardu, vedení vzruchu a repolarizaci komor ${ }^{5}$

Vynikající tolerance pacienty3,4

\section{1 tableta $2 \times$ denně}

Zkrácená informace o př́pravku Procoralan ${ }^{\circledR} 5 \mathrm{mg}$ : Složení a balení: Jedna potahovaná tableta obsahuje $5 \mathrm{mg}$ ivabradinum (odpovídajicí $5,390 \mathrm{mg}$ ivabradinum hydrochloridum). 56 tablet v 1 balení. Indikace: Symptomatická léčba chronické stabilní anginy pectoris u pacientů s normálním sinusovým rytmem, u kterých jsou kontraindikovány nebo nejsou tolerovány beta-blokátory. Dávkování a zpưsob podání: Doporučená úvodní dávka ivabradinu je $5 \mathrm{mg}$ dvakrát denně (ráno a večer, během jídla). Po třech až čtyřech týdnech léčby může být na základě terapeutické odpovědi dávka zvýšena na 7,5mg dvakrát denně. Pokud se během léčby tepová frekvence v klidu trvale snízí pod 50 tepů za minutu nebo se u pacienta objeví symptomy vztahující se k bradykardii jako závratě, únava nebo hypotenze, dávka musí být titrována směrem dolủ až na možnou dávku 2,5mg dvakrát denně (půl $5 \mathrm{mg}$ tablety dvakrát denně). Kontraindikace: Přecitlivělost na složky prípravku, klidová tepová frekvence před léčbou pod 60 tepů/min., kardiogenní šok, akutní infarkt myokardu, těžká hypotenze, sick sinus syndrom, sino-atriální blokáda, těžká hypotenze (< 90/50 mmHg), těžká jaterní insuficience, sinoatriální blokáda, srdeční selhání NYHA III-IV, závislost na kardiostimulátoru, nestabilní angina pectoris, AV blokáda III. stupně, kombinace se silnými inhibitory CYP3A4, těhotenství, kojení. Interakce: Kombinace s léky snižujícími srdeční frekvenci (nedoporučuje se současné podávání s verapamilem a diltiazemem). Současné uživání prípravků prodlužujících QT interval se nedoporučuje. Inhibitory a induktory CYP3A4 mohou ovlivňovat metabolismus a farmakokinetiku. Varování a zvláštní opatření pro použití: Procoralan není účinný v léčbě arytmií. Jeho uživání se nedoporučuje u pacientů s AV blokádou II. stupně a u pacientů s vrozeným syndromem dlouhého QT. Opatrnosti je třeba u pacientů s asymptomatickou dysfunkcí levé komory, srdečním selháním NYHA II a s retinitis pigmentosa. Procoralan ovlivňuje retinální funkci. Při neočekávaném zhoršení vizu by mělo být zváženo ukončení léčby. Nežádoucí účinky: Nejčastějši: zrakové vjemy (přechodné zvýšení jasu v periferii zorného pole), rozmazané vidění, bradykardie, AV blokáda I. stupně, komorové extrasystoly, bolest hlavy, závratě. Méně časté: palpitace, supraventrikulární extrasystoly, nauzea, zácpa, průjem, vertigo, dušnost, svalové křeče, hyperurikemie, eozinofilie, zvýšení kreatininu v krvi. Uchovávání: Žádné zvláštní podmínky uchovávání. Držitel rozhodnutí o registraci: Les Laboratoires Servier, 22 rue Garnier, 92200, Neuilly-sur-Seine, Francie. Registrační číslo: EU/1/05/316/003. Datum poslední revize textu: 25. 10. 2005. Před předepsáním prípravku si přečtěte Souhrn údajư o prípravku. Výdej prípravku je vázán na lékařský předpis. Př́pravek je částečně hrazen z prostředků veřejného zdravotního pojištění. Servier s.r.0., Klimentská 46, 11002 Praha 1. Tel.: +420 222118 307; fax: +420 222118 300, www.servier.cz 
Hlavním důvodem zvýšení odhadu rizika byla pozitivní rodinná anamnéza pacientů.

Závěr: Použití různých algoritmů vede $\mathrm{k}$ odlišnému odha$\mathrm{du}$ úrovně rizika a $\mathrm{k}$ definování odlišných cílových koncentrací lipidů. Výpočet rizika u jedinců v primární prevenci je pouze prvním krokem při celkovém hodnocení kardiovaskulárního rizika.

\section{STRUKTUROVANÁ PÉČE O NEMOCNÉ S CHRONICKÝM SRDEČNÍM SELHÁNÍM}

MÁLEK I, HEGAROVÁ M

Klinika kardiologie, IKEM, Praha

Chronické srdeční selhání (CHSS) představuje jeden ze závažných problémů současné medicíny. Léčení těchto nemocných vyžaduje komplexní přístup a strukturu zajištující, aby u každého jednotlivého pacienta byly využity všechny léčebné možnosti.

Základním pilířem ambulantní péče je kardiolog, který spolupracuje s praktickým lékařem. Hlavním úkolem je zde včasná diagnóza, u prokázaného onemocnění pak edukace pacienta a správné vedení farmakoterapie. Kardiolog obvykle též rozhoduje o potřebnosti hospitalizace. Důvodem přijetí na interní-kardiologické oddělení nemocnice je nejčastěji srdeční dekompenzace, která se u těchto pacientů často opakuje. Existuje též řada důvodů, proč je žádoucí konzultovat kardiocentrum; nejlépe to, které má zaveden komplexní program péče o nemocné se srdečním selháním. Ǩada nemocných má prospěch $\mathrm{z}$ revaskularizace myokardu, resynchronizační léčby či ošetření flutteru a fibrilace síní. Jednoznačná je indikace $\mathrm{k}$ vyšetření nemocného, který prodělal synkopu, epizodu komorové tachykardie či oběhovou zástavu.

U nemocných s pokročilým srdečním selháním, u nichž lze uvažovat o srdeční transplantaci, má být rovnou kontaktováno kardiocentrum s programem transplantace srdce (TXS) (IKEM Praha a CKTCH Brno), která nabízejí všechny dostupné možnosti léčby. $\mathrm{V}$ naléhavých situacích je nutno zvážit indikaci $\mathrm{k}$ mechanické podpoře srdce, tato metoda je zavedena v IKEM jako „bridging“ $\mathrm{k}$ TxS.

Praxe léčení nemocných s pokročilým selháním a nemocných s implantovanými stimulátory a ICD si vynutila koncipování specializovaných ambulancí, které se v kardiocentrech stávají důležitou složkou péče.

\section{PR̆EKVAPIVĔ NEGATIVNÍ VZTAH TĚLESNÉ VÝŠKY K STIMULOVANÉ HLADINĚ INZULINU U NEDIABETIKŮ S RIZIKEM PRO KARDIOVASKULÁRNÍ CHOROBY}

MÁLKOVÁ J, KRAML P, ANDĚL M

Kardiocentrum, II. interní klinika, FN KV a 3. LFUK, Praha

Cílem práce bylo studovat vztah parametrů tělesného habitu $\mathrm{k}$ hladině inzulinu nalačno a stimulované $\mathrm{v}$ orálním glukózovém tolerančním testu.

Vyšetřili jsme 173 osob, 80 žen a 93 mužů ve věku 26-86 let, nediabetiků, sledovaných jako skupina s vysokým rizikem v Programu prevence kardiovaskulárních chorob.

Vztahy mezi parametry tělesného habitu a hladin inzulinu byly hodnoceny pomocí Spearmannových korelačních koeficientů. Zjistili jsme statisticky významnou korelaci mezi hladinou inzulinu a body mass indexem (BMI), waist to hip ratio (WHR). Překvapivě silný vztah byl nalezen mezi stimulovanou hladinou inzulinu a tělesnou výškou, a to vztah negativní $(\mathrm{r}=-0,22 ; p \leq 0,0001)$. Tento vztah je možné vyjádřit i matematicky.
Závěr: Pravděpodobně osoby s menší postavou a menším objemem kosterního svalstva mají větší sklon $\mathrm{k}$ abdominálnímu typu obezity, který se sdružuje s inzulinovou rezistencí a metabolickým syndromem. Může být také jednou z přičin již známého negativního vztahu mezi výškou a kardiovaskulární mortalitou a morbiditou.

\section{SESTERSKÁ SEKCE}

\section{HYGIENICKÁ PRAVIDLA \\ PR̆ı TRANSEZOFAGEÁLNIIM VYŠETR̆ENÍ. JAK PR̆EDCHÁZET NOZOKOMIÁLNÍM NÁKAZÁM}

MEJTSKÁ I, NOVÁKOVÁ V, SOVOVÁ E, HRACHOVINOVÁ Š

\section{1. interní klinika, FN Olomouc a LF UP, Olomouc}

Snížení výskytu nozokomiálních nákaz (NN) patří k základním pravidlům kvalitní zdravotní péče. Na našem pracovišti provádíme vyšší stupeň dezinfekce jícnové sondy, která zabrání přenosu infekce na vyšetřovanou osobu a zároveň chrání zdravotní personál.

Cíle studie: Po zavedení vyššího stupně desinfekce zjistit výskyt NN u pacientů, kteří podstoupili vyšetření jícnovou sondou.

Soubor, metodika: Po zavedení vyššího stupně desinfekce jícnové sondy jsme hodnotili výskyt NN u pacientů, kteři podstoupili vyšetření jícnovou sondou. Soubor tvoří 1675 pacientů (973 mužů a 702 žen) vyšetřených od začátku roku 2003 do zář́i 2006.

Výsledky: U žádného pacienta nebyla prokázána NN v souvislosti s vyšetřením jícnovou sondou. Na základě výsledků byl vytvořen ošetřovatelský standard, který obsahuje základní pravidla pro tento ošetřovatelský proces.

Závěr: Vyšší stupeň dezinfekce je účinná prevence NN u pacientů vyšetřovaných jícnovou sondou.

\section{DISSEKUJÍCÍ AORTÁLNÍ ANEURYZMA U PACIENTA S EXCESIVNÍMI ARTERIÁLNÍMI TORTUOZITAMI - NOVÝ SYNDROM SPOJENÝ S MUTACEMI TGF-BETA RECEPTORU}

MELENOVSKÝ V, ADAMÍRA M, KAUTZNEROVÁ D, WEICHET J, LOEYS B

Klinika kardiologie, Klinika kardiochirurgie, Radiodiagnostické oddělení, IKEM, Radiodiagnostické oddělení, Nemocnice Na Homolce, Praha, Center for Medical Genetics, Gent University Hospital, Gent, Belgie

20letý dosud zdravý muž normální tělesné konstituce se dostavil na urgentní př́jem pro tupou retrosternální bolest, která začala předchozí den při sportu. Objektivní nález u pacienta byl bez pozoruhodností, mimo hrudní kyfózy pacient nejevil žádné známky Marfanova syndromu či jiného onemocnění pojiva. Na cílený dotaz však pacient uvedl, že jeho matka a babička zemřely na rupturu aorty. Ihned provedené echo a CT angio (obrázek A) potvrdilo disekci aneuryzmaticky dilatovaného kořene aorty sahající od sinotubulární junkce po odstupy cév oblouku. Urgentně podstoupil náhradu chlopně a kořene aorty podle Benthala. Histologie prokázala cystickou medionekrózu s fokálními defekty elastinu. Pooperační průběh byl nekomplikovaný. K prevenci progrese cévních změn byla zahájena terapie betablokátorem a losartanem. Pooperační MR-angio prokázalo normální kalibr hrudní a břišní aorty. Pozoruhodným nálezem byly difuzní elongace a extrémní tortuozity tepen středního 


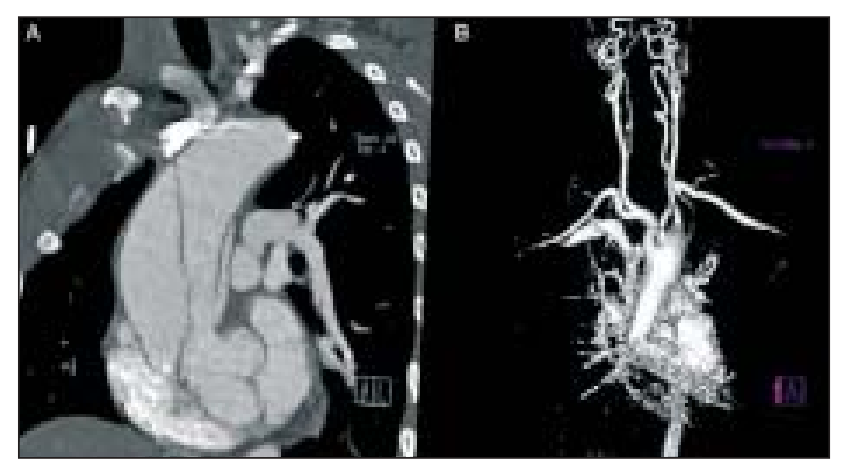

kalibru, vyjádřené především v karotickém a vertebrálním řečišti (obrázek B). Nálezy u tohoto pacienta (non-marfanoidní disekce, arteriální tortuosity, $\mathrm{AD}$ dědičnost) svědčily pro to, že by se mohlo jednat o nedávno popsaný Loeysův-Dietzův syndrom (LDS, OMIM 609192, New Engl J Med 2006; 355(8):788-98), který je kauzálně spojen s mutacemi v genu kódující TGF- $\beta$ receptor I či II. Sekvenace probandovy DNA kódující TGFBR1/2 identifikovala dinstinktní Arg487Gln mutaci v 9. exonu TGFBR1, která nebyla př́tomna ani $\mathrm{u}$ jednoho $\mathrm{z}$ genotypovaných nepostižených př́ibuzných, potvrzující tak tuto diagnózu. Kasuistika ilustruje, že s proximální aortální disekcí se lze setkat i u mladých pacientů bez rysů Marfanova syndromu a klinický obraz při prezentaci může být netypicky chudý. Genetické vyšetření rodiny může odhalit další postižené jedince, u kterých sledování a elektivní náhrada kořene aorty může zlepšit dlouhodobou prognózu.

\section{METABOLIC SYNDROME IS CHARACTERIZED BY INCREASED VENTRICULAR SYSTOLIC STIFFENING AND VENTRICULO-ARTERIAL MISMATCH}

MELENOVSKÝ V, MAJIDI F, KASS D, LAKATTA E, NAJJAR S

Klinika kardiologie, IKEM, Praha,

NIA, National Institutes of Health, Division of Cardiology, Johns Hopkins Hospital, Laboratory

of Cardiovascular Sciences, Baltimore, USA

Background: Left ventricular (LV) end-systolic stiffness (Ees) reflects LV contractility, geometry and mass. With aging, Ees maintains constant ratio to total arterial load (arterial elastance, Ea), so that ventriculo-vascular coupling is preserved and cardiac performance is optimized. We tested

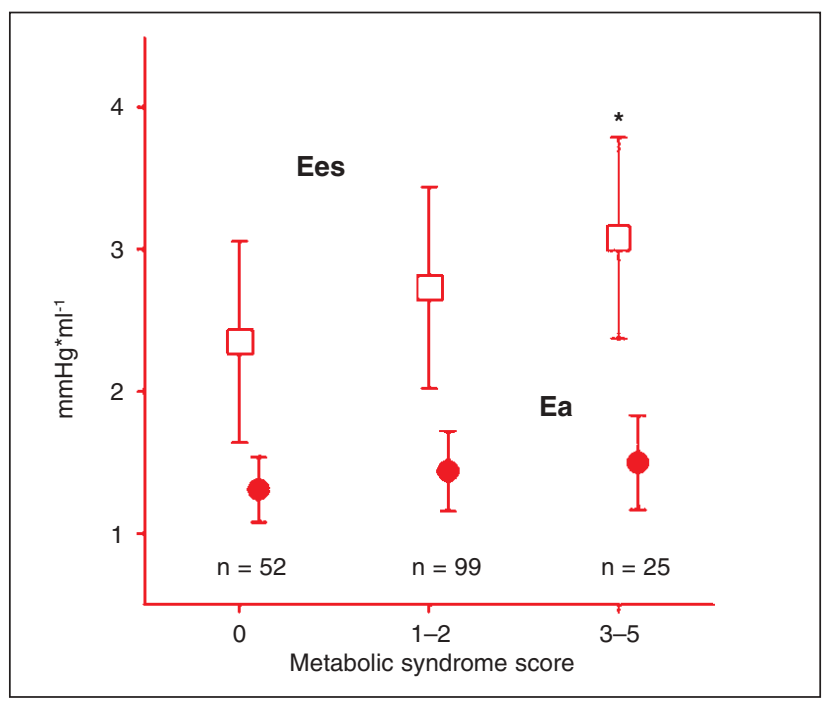

the hypothesis that metabolic syndrome (MS) adversely impacts this coupling relationship.

Methods: Ea and Ees were estimated by single-beat methods (Chen CH, JACC 2001;38(7):2028-34) based on resting $\mathrm{BP}$ and echocardiograms from 176 ambulatory participants (age $64 \pm 13 \mathrm{y}, 51 \%$ females) in the Baltimore Longitudinal Study of Aging. MS status and score were determined according to ATP III-NCEP.

Results: MS+ subjects had higher Ees (3.1 vs. 2.6 $\mathrm{mmHg} / \mathrm{mL}, p=0.002$ ) and Ees/Ea ratio (2.1 vs. $1.9, p=0.02$ ) than MS-, while Ea was similar in both groups (1.5 vs. $1.4 \mathrm{mmHg} / \mathrm{mL}, p=0.07)$. MS score correlated with Ees ( $\mathrm{r}=0.27, p<0.001$, Figure). Pulse pressure and relative LV wall thickness were higher in MS+, while systemic resistance, LV mass, age and gender were similar $(p>0.1)$ in both groups. Ees and Ees/Ea ratio correlated with peak $\mathrm{VO}_{2}$ ( $r=-0.33$ and $-0.29, p<0.001$ ), which was lower in MS+ subjects (19 vs. $25 \mathrm{~mL} / \mathrm{kg} / \mathrm{min}, p<0.001$ ).

Conclusions: In MS, ventricular stiffening rises beyond that predicted by arterial load. This implies less systolic reserve, and the corresponding ventricular-arterial mismatch likely contributes to exercise intolerance. Neurohumoral and metabolic factors promoting disproportionate higher Ees in MS need to be identified.

\section{3, 6, A 12 MĚSÍČNÍ VÝSLEDKY AUTOLOGNÍ TRANSPLANTACE MONONUKLEÁRNÍCH BUNĚKK KOSTNII DR̆ENĚ U NEMOCNÝCH S AKUTNIM INFARKTEM MYOKARDU*}

MELUZÍN J, JANOUŠEK S, GROCH L, MAYER J, HLINOMAZ O, PANOVSKÝ R, KALA P, KOŘÍSTEK Z, KLABUSAY M, KAMIINEK M

I. interní-kardioangiologická klinika, FN u sv. Anny, Interní-kardiologická klinika, Interní-hematoonkologická klinika, FN Brno, Brno, Oddělení nukleární medicíny, FN Olomouc a LF UP, Olomouc

*Práce byla podpořena grantem IGA č. 1A/8676-3.

Úvod: V současné době existuje velmi málo údajů o dlouhodobé účinnosti buněčné transplantace. Proto bylo cílem této práce zhodnotit změny regionální a globální funkce levé komory (LK) během ročního sledování u nemocných s akutním infarktem myokardu (IM), léčených autologní transplantací mononukleárních buněk kostní dřeně (MBKD).

Soubor nemocných a metodika: Do studie bylo zařazeno 60 nemocných s poprvé vzniklým akutním IM léčeným koronární angioplastikou s implantací stentu, kteří dokončili jednoroční sledování. Nemocní byli randomizováni do 3 skupin po 20 nemocných. Skupina A byla léčena vyšší dávkou MBKD (100 000000 buněk), skupina B pak nižší dávkou MBKD (10 000000 buněk). Nemocní neléčení buněčnou transplantací tvořili kontrolní skupinu C. Byly srovnány výsledky tkáňové dopplerovské echokardiografie a SPECT, získané před buněčnou transplantací a za 3,6 , a 12 měsíců po ní.

Výsledky: Systolické rychlosti pohybu stěny LK postižené infarktem (Sa) $5,2 \mathrm{~cm} / \mathrm{s}, 4,6 \mathrm{~cm} / \mathrm{s}$, a $4,4 \mathrm{~cm} / \mathrm{s}$ ve skupinách $\mathrm{C}, \mathrm{B}$, a A narostly ve 3 . měsíci sledování o $0,0 \mathrm{~cm} / \mathrm{s}$, $0,3 \mathrm{~cm} / \mathrm{s}$ ( $p=\mathrm{NS}$ vs. C) a o $0,7 \mathrm{~cm} / \mathrm{s}$ ( $p<0,05$ vs. C). Ve 12 . měsíci se však odpovídající změny Sa oproti bazálním hodnotám v jednotlivých skupinách navzájem nelišily $(0,1 \mathrm{~cm} / \mathrm{s}$, $0,2 \mathrm{~cm} / \mathrm{s}$, a $0,6 \mathrm{~cm} / \mathrm{s}, p=\mathrm{NS}$ ). Naproti tomu potransplantační zlepšení globálních parametrů funkce LK (ejekční frakce a průměrná systolická rychlost pohybu 6 stěn LK) zůstalo zachováno během celého ročního sledování a bylo významně lepší u skupiny A ve srovnání s kontrolním souborem. 
Závěr: Autologní transplantace vyšší dávky MBKD vedla u nemocných s akutním IM ke zlepšení globální funkce LK, které přetrvávalo během ročního sledování. Zlepšení regionální funkce LK po buněčné transplantaci však mělo u těchto nemocných klesající tendenci a v 1 . roce sledování již nebylo statisticky významné.

\section{INTRACORONARY DELIVERY OF MONONUCLEAR BONE MARROW CELLS IN EXPERIMENTAL MYOCARDIAL INFARCTION. THE OPTIMALIZATION OF DELIVERY TECHNIQUE}

MELUZÍN J, VLAŠÍN M, GROCH L, MAYER J, KŘEN L, RAUŠER P, TICHÝ B, HORŇÁČEK I, SITAR J, PALŠA S

1st Dept. of Internal Medicine/Cardioangiology, St. Anna Hospital, Dogs and Cat Clinic,

University of Veterinary and Pharmaceutical Science, Dept. of Internal Medicine/Hematooncology,

Dept of Pathology, FH Brno, Brno

Aim: Intracoronary mononuclear bone marrow (MBM) cel transplantation using repeat catheter balloon inflation-deflation technique may be associated with serious complications. The aim of this project is to compare the effectiveness of 2 techniques of cell transport into the acutely infarcted myocardium: 1 . the standard repeat intracoronary short-term, low-volume injections during angioplasty balloon inflations (technique A) and 2. a new technique - intracoronary continuous slow cell infusion in a higher volume without balloon inflations (technique B).

Methods: The study consists of pilot experiments and of the main randomized protocol comparing techniques $A$ and B. In the initial pilot study, the feasibility of individual procedures and the optimal methodology for the main protocol were tested in 27 pigs. In 24 of them, the experimental myocardial infarction (MI) was created by a 90-min occlusion of the LAD coronary artery using angioplasty balloon inflation. Allogeneic MBM cell transplantation into the infarcted myocardium was performed at various time intervals following MI. In addition, different cell doses and both cell delivery techniques were tested. Implanted cells were stained with green CMFDA fluorescent dye. Pigs were euthanized 1 or 24 hours after the transplantation and the numbers of implanted MBM cells were quantified by fluorescent microscopy in the area of MI.

Results: Based on pilot experiments, the MBM cell dose of 20,000,000 and the 3-day interval from the induction of MI to the time of cell transplantation were selected for the main randomized protocol. The results of the main randomized protocol comparing both cell transplantation techniques are not available yet and will be presented at the congress.

Conclusion: Pilot experiments demonstrated the feasibility of the study. The final results will be presented at the congress.

\section{NAŠE PRVNÍ ZKUŠENOSTI S CT-KORONAROGRAFIÍ}

\section{MIFKOVA A, NOVOTNÝ J}

Interní oddělení, Radiologické oddělení, Vojenská nemocnice Olomouc, Olomouc

CT-koronarografie je neinvazivní způsob zobrazení kardiovaskulární soustavy. Součástí hodnocení je zhotovení trojrozměrné rekonstrukce cévních struktur podobné klasické angiografii. Vysoká negativní prediktivní hodnota (98-99 \%) téměř s jistotou vyloučí významnou stenózu. V naší práci jsme se soustředili na pacienty zařazené podle indikačních kritérií ke koronarografii do třídy II. Vyšetřili jsme 31 pacientů (18 mužů, 13 žen) s některou $\mathrm{z}$ těchto diagnóz - stp. aortokoronárním bypassu, bolest na hrudi, stp. PCI/PTCA, námahová dušnost, NSKT v úvodu do anestezie. 15 pacientů mělo CT koronarografický nález bez významnější patologie, 16 pacientů mělo nález pozitivní. Tyto pacienty jsme indikovali k elektivní koronarografii (3 pacienti vyšetření odmítli) a výsledky jsme potom porovnali s výsledkem CT-vyšetření. U všech pacientů se stenózou či zaniklým aortokoronárním bypassem se diagnóza potvrdila a pacienti byli indikováni $\mathrm{k}$ revaskularizaci nebo byla stenóza řešena PTCA se zavedením stentu. U ostatních pacientů (3) se diagnóza nepotvrdila. Při zpětném hodnocení se jednalo o pacienty, $u$ kterých byla přítomna některá $z$ arytmií.

Závěr: CT-koronarografie s EKG synchronizací je metoda vhodná pro zobrazení koronárního řečiště, zejména neníli klinický nález takový, že jednoznačně splňuje kritéria pro rekoronarografii. Výhodou je menší stupeň intervence a radiační a časové zátěže pacienta.

Podmínkou kvalitního vyšetření je pravidelný srdeční rytmus, při nepravidelném rytmu dochází $\mathrm{k}$ rozfázování obrazu se sníženou kvalitou zobrazení.

\section{LETÁ MORTALITA PACIENTŮ S CHRONICKY̌M SRDEČNÍM SELHÁNÍM (CHSS)}

MIKLÍK R, TOMÁŠEK A, ŠEBO M, DVOŘÁKOVÁ E, LUDKA O, ŠPINAR J

Interní-kardiologická klinika, FN Brno, Brno

Cíl: Stratifikace faktorů 2leté mortality pacientů s CHSS.

Metodika: Retrospektivní analýza chorobopisů nemocných propuštěných $z$ Interní-kardiologické kliniky v období 10-12/2004, běžné statistické testy.

Soubor: 839 primohospitalizací (466 mužů, 373 žen). Diagnózu CHSS splňovalo 144 (17,2 \%) nemocných, 94 mužů, 50 žen. 62,5 \% bylo NYHA < III, 37,5 \% NYHA $\geq$ III.

Výsledky: Pacienti s CHSS byli v průměru o 5,5 let starší než ostatní - 68,2 $\pm 12,1$ let $(p<0,01)$. 2letá mortalita pacientů bez CHSS byla 8,9 \%, s CHSS 27,1 \% $(p<0,001)$, u nemocných NYHA < III 22,2 \% a NYHA > III 35,2\% ( $p=0,09)$. Průměrný věk zemřelých s CHSS byl 73,0 let oproti žijícím 66,5 let ( $p<0,01)$.

Mezi přežívajícími a zemřelými pacienty mělo ICHS $74,3 \%$ vs. $79,5 \%$, stav po IM $61,0 \%$ vs. $59,0 \%$, HT $65,7 \%$ vs. $64,1 \%$, FiSi v anamnéze $41,9 \%$ vs. 46,2 \%, DKMP 20,0 \% vs. $12,8 \%$, DM $33,3 \%$ vs. $46,2 \%$, CMP $17,1 \%$ vs. $20,5 \%$ (vše NS). Z hemodynamických parametrů byl průměrný TKs 124,8 vs. $119,5 \mathrm{~mm} \mathrm{Hg}$, TF 73,0 vs. $75,3 / \mathrm{min}$, pulsní TK 50,2 vs. $51,3 \mathrm{~mm} \mathrm{Hg}$ (vše NS), TKd 74,7 vs. $68,2 \mathrm{~mm} \mathrm{Hg}$ $(p<0,01)$, mortalita byla vyšší u pacientů s EF LK $<25 \%$ ( $p<0,05)$. Z laboratorních hodnot byl cholesterol 4,85 vs. 4,20 mmol/1, LDL 2,93 vs. 2,23 mmol/1 (obojí $p<0,05$ ), HDL a TG byly sníženy u zemřelých (NS), urea 7,7 vs. 11,3 mmol/1, kreatinin 110,7 vs. $141,2 \mu \mathrm{mol} / 1$, KM 395,8 vs. $488,5 \mu \mathrm{mol} / 1$, HGB 138,7 vs. $123,9 \mathrm{~g} / 1$ (vše $p<0,01$ ). $\mathrm{V}$ medikaci mělo $\mathrm{BB} 82 \%$ vs. $72 \%$ pacientů, diuretika $84 \%$ vs. $87 \%$, digitalis $32 \%$ vs. $36 \%$, spirolonakton $54 \%$ vs. $56 \%$,warfarin $18 \%$ vs. $8 \%$ (vše NS), ACE-I/ARB $90 \%$ vs. $72 \%(p<0,01)$, kombinaci $\mathrm{BB}+\mathrm{ACE}-\mathrm{I} / \mathrm{ARB} 76 \%$ vs. $59 \%(p<0,05)$.

Závěr: 2letá mortalita pacientů s CHSS je 3,5× vyšší než jiných pacientů. Významně negativní vliv měly zvýšené dusíkaté látky a KM, snížený celkový a LDL-chol., nižší diastola, výrazně snížená EF LK, anemie. Jednotlivé komorbidity neměly na mortalitu významný vliv. V medikaci významně snížily mortalitu ACE-I/ARB a jejich kombinace s BB, výrazný preventivní trend vykazuje antikoagulace. 


\section{PR̆İNOS VYŠETR̆OVÁNÍ INR V KARDIOLOGICKÉ AMBULANCI PR̆ÍSTROJEM COAGUCHEK XS A S}

MLÁDKOVÁ M, LORENCOVÁ D, BERKA L

Kardiologická ambulance, Jindřichův Hradec

V období od záríi až prosinec 2006 jsme vyšetřovali INR u 180 pacientů kardio-angiologické ordinace, současně laboratorní metodou podle Quicka a systémem CoaguChek XS a S. Jednalo se o nemocné indikované $\mathrm{k}$ antikoagulační terapii $\mathrm{v}$ širokém spektru diagnóz. Opakované vyšetření nemocných oběma metodami prokázalo prakticky nevýznamné rozdíly výsledků vyšetření INR (Quick) v širokém pásmu hodnot. Možnost vyšetřování systémem CoaguChek XS a S je přínosem pro řízení antikolagulační léčby nemocných v kardiologické i angiologické praxi, nejen v místech geograficky vzdálených od laboratoři vyšetřujících INR klasickým způsobem nebo při pobytu $\mathrm{v}$ cizině. Je také př́nosem pro vyšetřování nemocných $\mathrm{v}$ relativní blízkosti těchto laboratoří $\mathrm{v}$ případech, kdy pro korekci terapie hraje důležitou roli obtížnost odběru venózní krve, požadavek bezprostředního získání výsledku nebo neobvyklá denní doba vyšetřování.

\section{VÝSKYT FIBRILACE SİNİ U NEMOCNÝCH S CHRONICKÝM SRDEČNÍM SELHÁNÍM INDIKOVANÝCH K IMPLANTACI BIVENTRIKULÁRNÍ STIMULACE}

MLČOCHOVÁ H, RIEDLBAUCHOVÁ L, ČIHÁK R, BYTEŠNÍK J, VANČURA V, POPOVÁ L, PEICHL P, KAUTZNER J

Klinika kardiologie, IKEM, Praha

Úvod: Biventrikulární stimulace (BiV) je indikována u pacientů (pts) s pokročilým srdečním selháním s cílem upravit interventrikulární dyssynchronii, a tím zlepšit klinický stav nemocných. Uplatnění BiV stimulace však může být potlačeno fibrilací síní (FS) či síňovou tachykardií s rychlejší ko- jednalo o síňovou tachykardii ( 3 chronické a 1 paroxyzmální). Pacienti s paroxyzmální formou FS byli léčeni pouze konzervativně.

Závěr: Fibrilace síní se vyskytovala v jedné čtvrtině nemocných se srdečním selháním indikovaných $\mathrm{k}$ resynchronizační terapii. Ve $14 \%$ z celého souboru bylo nutno provést neselektivní ablaci AV junkce. Většina pacientů indikovaných $\mathrm{k}$ této ablaci měla chronickou formu supraventrikulární tachyarytmie.

\section{INHIBITOR IIB/IIIA ABCIXIMAB A JEHO VLIV NA VZNIK LOKÁLNÍCH KOMPLIKACÍ V TR̆ÍSLE PO PERKUTÁNNÍCH KORONÁRNÍCH INTERVENCÍCH}

MOKOŠOVÁ S, ŠTIIPAL R, KÁÑA A, MINAŘÍK T, RUBÁČEK M, PLEVA L, ŠTVERÁK P, MATOŠKA P

Interní klinika, Oddělení invazivní kardiologie,

FNsP Ostrava, Ostrava

Cíl: Zjištění celkového výskytu lokálních komplikací v třísle u pacientů po perkutánních koronárních intervencích (PCI) a současně posouzení výskytu těchto komplikací v závislosti na podání inhibitoru IIb/IIIa abciximabu.

Soubor: Na našem oddělení invazivní kardiologie bylo za období od 1. 1. 2005 do 31. 12. 2006 provedeno celkem 1482 PCI, z toho 1349 (91\%) pacientům byl implantován alespoň jeden stent. 223 pacientům byl během výkonu podán inhibitor IIb/IIIa abciximab (15\%). Lokální komplikace $\mathrm{s}$ nutností dalšího řešení se vyskytly u 30 pacientů (2,02 \%). Z těchto komplikací bylo 21 pseudoaneuryzmat (PSA) $(1,4 \%), 7$ hematomů a krvácení $(0,5 \%)$ a 2 disekce a. illiaca (AI) $(0,13 \%) .5$ případů z 30 si vyžádalo chirurgické řešení $(16,7 \%)$.

$\mathrm{Z}$ celkového počtu 30 pacientů $\mathrm{s}$ komplikací 8 dostalo abciximab (26,7\%).

Výsledky: Pravděpodobnost výskytu komplikací u pacientů, kteří nedostali inhibitor IIb/IIIa je 1,8\%, u pacientů, kteři medikaci dostali je tato pravděpodobnost 3,6\%. Výsledky jsou uvedeny $\mathrm{v}$ tabulce.

Tabulka k abstraktu MUDr. Mokošové

\begin{tabular}{lccc}
\hline \hline Charakteristika komplikací & Bez abciximabu (n=1 259) & S abciximabem (n = 223) & $\boldsymbol{p}$ value (n = 1 482) \\
\hline PSA & $15(1,2 \%)$ & $6(2,7 \%)$ & 0,081 \\
Hematom (krvácení) & $5(0,4 \%)$ & $2(0,9 \%)$ & 0,285 \\
Disekce AI & $2(0,2 \%)$ & $0(0 \%)$ & $\mathrm{NS}$ \\
Celkem & $22(1,8 \%)$ & $8(3,6 \%)$ & 0,072 \\
\hline \hline
\end{tabular}

morovou odpovědí. Tento stav často vede k progresi srdeční insuficience.

Cíl: Cílem studie bylo zaznamenat výskyt fibrilace síní a četnost provedení neselektivní ablace AV junkce u nemocných po implantaci BiV stimulačního systému.

Metodika: Do studie jsme zařadili celkem 205 pacientů s pokročilým srdečním selháním (181 mužů, průměrný věk $62 \pm 10$ let), kteří od ledna 2003 do června 2005 podstoupili na naší klinice implantaci BiV kardiostimulátoru (PM), BiV defibrilátoru (ICD) či rozšíření již stávajícího systému na BiV PM či BiV ICD. U těchto pacientů jsme sledovali výskyt a charakter FS či síňové tachykardie a nutnost provedení neselektivní katetrizační ablace AV junkce.

Výsledky: Fibrilaci síní jsme zjistili u $26 \%$ nemocných z celého souboru (53 pts). Chronická FS byla zaznamenána u 43 pts (21\%), paroxyzmální u 10 pts (5\%) a síñové tachykardie u 5 pts $(2 \%)$ z celého souboru nemocných. Neselektivní ablaci AV junkce podstoupilo celkem 29 nemocných, $z$ toho mělo 25 pts chronickou formu FS a ve 4 případech se
Závěr: Dosažené procento výskytu komplikací k celkovému počtu zákroků je 2,02\%, což je na dolní hranici publikovaných dat. Na základě statistické analýzy není $\mathrm{z}$ hlediska výskytu lokálních komplikací v tř́sle na hladině významnosti 0,05 rozdíl mezi soubory pacientů, u nichž byl či nebyl podán inhibitor IIb/IIIa.

\section{VÝSKYT RIZIKOVÝCH FAKTORŮ ISCHEMICKÉ CHOROBY SRDEČNÍ U PACIENTŨ S AKUTNÍM INFARKTEM MYOKARDU A JEJICH VÝZNAM PRO KRÁTKODOBOU PROGNÓZU*}

MONHART Z, FALTUS V, GRÜNFELDOVÁ H, RYŠAVÁ D, HUBAČ J, VELIMSKÝ T, BALLEK J, JANSKÝ P

Interní oddělení, Nemocnice Znojmo, Znojmo,

EuroMISE centrum, Ústav informatiky AV ČR, v. v. i. Praha, Interní oddělení, Městská nemocnice Čáslav, Čáslav, 
Interní oddělení, Nemocnice Kutná Hora, Kutná Hora, Interni oddělení, Nemocnice Chrudim, Chrudim, Interní oddělení, Nemocnice Písek, Písek, Interní oddělení, Nemocnice Jindřichův Hradec, Jindřichův Hradec, Kardiovaskulární centrum, FN Motol, Praha

*Práce vznikla za podpory výzkumného záměru AVOZ10300504 Ústavu informatiky AV ČR, v. v. i.

Cil: Posoudit prognostický význam přítomnosti některých rizikových faktorů (RF) ischemické choroby srdeční (ICHS) $\mathrm{u}$ pacientů s infarktem myokardu (IM).

Soubor a metodika: Hodnocen byl výskyt hypertenze, hyperlipidemie a diabetes mellitus $\mathrm{v}$ neselektované populaci pacientů s IM. Do pilotního registru bylo v letech 2003-2005 zařazeno 2076 pacientů (jedná se o všechny pacienty s diagnostikovaným IM v nemocnicích, podílejících se v průběhu jednotlivých let na projektu).

Výsledky: Nejčastějším sledovaným RF byla hypertenze (1 539/2 053; 75,0 \%), dále hyperlipidemie (1 031/2 014; $51,2 \%)$, nejméně často byl zaznamenán výskyt diabetu (863/2 044; 42,2 \%). Všechny sledované RF byly přítomny u 23,6 \% pacientů (474/2006), dva RF u 33,7 \% (677/2006), jeden RF u 29,4 \% (590/2006), žádný RF nebyl přítomen u 13,2 \% pacientů (265/2006). Hodnotili jsme hospitalizační mortalitu v závislosti na přítomnosti jednotlivých $\mathrm{RF}$ a jejich kumulace - $\mathrm{u}$ pacientů $\mathrm{s}$ hypertenzí byla mortalita (156/1 527; 10,2 \%), u diabetiků (114/856; 13,3 \%), u pacientů s hyperlipidemií (73/1026; 7,1\%). Hospitalizační mortalita se ve skupinách bez RF, s jedním, dvěma a se tř̌emi RF významně nelišila - $u$ pacientů bez RF byla mortalita $14,6 \%(38 / 260)$, u pacientů s jedním RF byla mortalita 9,3\% (54/580), u pacientů se dvěma RF 8,9\% (60/673), se třemi RF byla mortalita 10,4\% (49/472).

Závěr: Nejčastějším rizikovým faktorem v neselektované populaci pacientů s IM je hypertenze, dále hyperlipidemie a diabetes mellitus. Nejvyšší šance úmrtí je ve skupině pacientů s diabetes mellitus. Neprokázali jsme závislost hospitalizační mortality na kumulaci rizikových faktorů.

\section{ÚSPĚŠNOST EXTERNII ELEKTRICKÉ KARDIOVERZE MONOFÁZICKÝM VS. BIFÁZICKÝM REKTILINEÁRNİM VÝBOJEM U PACIENTỦ S FIBRILACİ SIINII. ZKUŠENOSTI PRACOVIŠTĔ}

\section{MYSLIVEC O, POKORNÝ M, PAĎOUR F}

I. interní oddělení, jednotka intenzivní péče, FN Bulovka, Praha

Cil: Naše sdělení se zaměřuje na srovnání monofázické vs. bifázické elektrické kardioverze (EKV) u pacientů s fibrilací síní (FS), hospitalizovaných na JIP I. int. odd. FNB. Současně byl zkoumán výskyt rizikových faktorů pro vznik FS i výskyt komplikací v souvislostí s EKV.

Metodika: K EKV byli indikováni pacienti s FS s délkou trvání do 1 roku.

V období I/2000 do XI/2006 jsme provedli EKV u celkového počtu 173 pacientů, $z$ toho u 67 pacientů monofázickým výbojem, u 106 pacientů bifázickým výbojem. K provedení EKV bylo $\mathrm{v}$ případě monofázického výboje použito přístroje 43120A Defibrillator Hewlett-Packard (max. výboj $360 \mathrm{~J})$, k aplikaci bifázických výbojů sloužil defibrilátor Lifepak 20 Medtronic (max. energie $360 \mathrm{~J}$ ).

Výsledky: Aplikováno bylo celkem 292 výbojů (148 monofázických) s úspěšností verze na sinusový rytmus $84,3 \%$ vs. 95,3 \% u bifázického výboje. V prezentovaném souboru pacientů se nevyskytly žádné závažné komplikace. Mezi lehkými komplikacemi dominovala křečová aktivita v sou- vislosti s aplikovanou nitrožilní anestezií (etomidatem) - celkově u $4 \%$ pacientů. Indikace trvalé kardiostimulace pro závažnou převodní poruchu srdečního rytmu demaskovanou nastoleným sinusovým rytmem byla učiněna ve 2 případech $(1,2 \%)$. Studované rizikové faktory vzniku FS se vyskytly v souboru s následující frekvencí: ICHS (67,6\%), arteriální hypertenze (76,3\%), abúzus alkoholu $(2,9 \%)$, revmatická horečka v anamnéze (6,9 \%), mitrální vada (54,3\%), trikuspidální vada (29,5\%).

Závěr: EKV představuje vysoce účinnou a bezpečnou metodu k verzi FS na sinusový rytmus. Efektivita verze bifázickým oproti monofázickým výbojem byla ve shodě s literárními údaji i v našem souboru pacientů vyšší (95,3 vs. $84,3 \%)$ při významně nižším prưměrném počtu výbojů aplikovaných $\mathrm{s}$ cílem nastolit sinusový rytmus (2,0 vs. 1,5 výboje) a významně nižším průměrném kumulativním výboji (372,2 vs. 175,3 J).

\section{SESTERSKÁ SEKCE}

\section{ISCHEMICKÁ CHOROBA SRDEČNÍ (ICHS) JAKO ŽIVOTNÍ ÚDĚL?}

NAJMANOVA J, ŽÁČKOVÁ I

Klinika kardiologie, IKEM, Praha

V našem sdělení uvádíme kasuistiku pacienta, ročník 1950, který prodělal v červnu 1999 rozsáhlý infarkt myokardu (IM) s komplikovaným průběhem.

Pro recidivy komorových tachykardií byl pacientovi naimplantován automatický implantabilní kardioverter-defibrilátor (AICD) - na jiném pracovišti.

Pacient přichází na naše pracoviště v září 1999 ke zvážení dalšího postupu. Vzhledem k dysfunkci levé komory srdeční, významné mitrální insuficienci, hemodynamicky těžké postkapilární plicní hypertenzi je indikován k ortotopické transplantaci srdce (OTS). Ta byla provedena v prosinci 1999.

V lednu 2004 je pacient hospitalizován pro náhle vzniklou dušnost při infektu. Zjištěn anteroextenzivní IM, jako projev ischemické choroby srdečního štěpu.

Stav byl dále komplikován maligními arytmiemi, pro které byl i resuscitován. Na základě elektrofyziologického vyšetření (EFV) byl pacientovi naimplantován AICD s biventrikulární funkcí.

V odstupu šesti měsíců došlo ke zhoršení stavu. Pacient opakovaně hospitalizován pro série výbojů AICD. Byly dokumentovány komorové tachykardie (KT), které trvají i přes intenzivní medikamentózní léčbu. Je nutná umělá plicní ventilace (UPV). Provedena radiofrekvenční ablace (RFA) s částečným efektem. V ř́́jnu 2004 je pacient indikován $\mathrm{k}$ retransplantaci srdce, která proběhla bez chirurgických komplikací 23. 10. 2004. Pacient v prosinci 2004 prodělal akutní onemocnění toxoplazmózou, dobře reagující na terapii. Důsledkem léčby byl útlum kostní dřeně. Nyní je zdravotní stav uspokojivý, funkce srdečního štěpu je dobrá.

Závěr: S pokrokem transplantační medicíny stoupají nároky na další péči o tyto nemocné, $\mathrm{s}$ cílem jednak prodloužit přežívání, jednak zlepšit kvalitu života.

Retransplantace srdce je prozatím jedinou definitivní léčbou selhání srdečního štěpu, jehož příčinou je koronární nemoc.

\section{AKUTNÍ INFARKT MYOKARDU SPODNÍ STĚNY U MLADÉHO PACIENTA S KORONÁRNÍ ANOMÁLIII}

NÁPLAVA R, SLABÁK M, COUFAL Z, ČÍHALÍK Č, HORÁK D

Interní klinika IPVZ, Batova krajská nemocnice, Zlín,

Radiologická klinika, FN Olomouc, Olomouc 
Prezentujeme dokumentovaný případ mladého pacienta, kuřáka, který byl přijat na naše oddělení pro akutní IM spodní stěny při uzávěru proximální části a. coronaria dextra. Případ byl zajímavý především přítomností vzácné koronární anomálie. Jednalo se o atypicky odstupující a. coronaria dextra $z$ levého koronárního sinu a abnormálním průběhem mezi kmenem aorty a plicnice, jak bylo následně potvrzeno vyšetřením magnetickou rezonancí. Samotný katetrizační výkon byl v důsledku anomálie technicky obtížný. Intervenčním zásahem se však i přes obtížnost výkonu podařilo zprůchodnit uzavřenou cévu s velmi dobrým výsledným efektem. Pacient je již více než rok sledován v naší kardiologické ambulanci. Jeho stav je při negativním nálezu trombofilních markerů klinicky dlouhodobě stabilizován, bez projevů ischemické choroby srdeční.

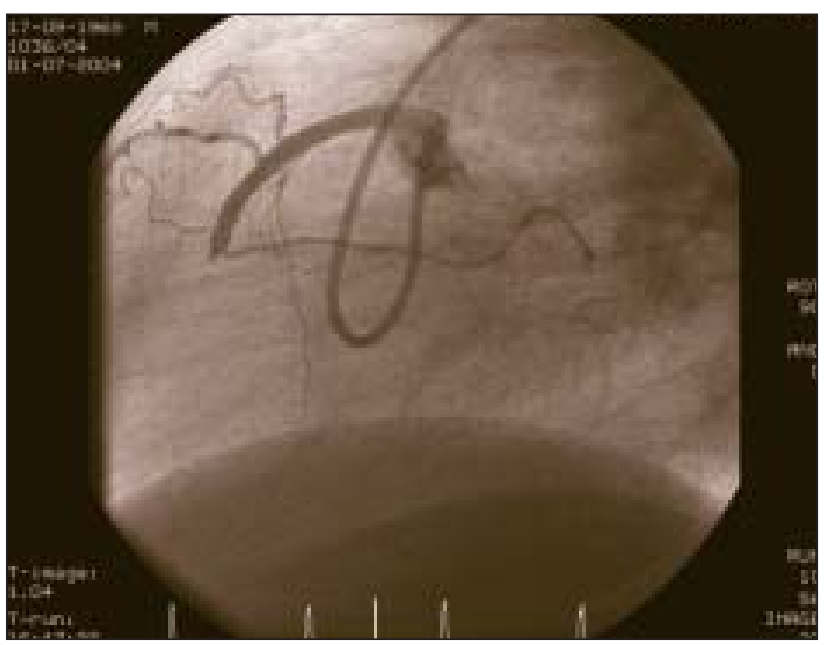

\section{AKUTNÍ BOLEST NA HRUDNÍKU JAKO PROJEV AKUTNÍ MYOKARDITIDY PR̆I SALMONELOVÉ INFEKCI. NAŠE KLINICKÉ ZKUŠENOSTI}

NÁPLAVA R, GŘIVA M, COUFAL Z, ČÍHALÍK Č, BAR̆INKA A

Interní klinika IPVZ, Krajská nemocnice T. Bati, Zlín, Infekčni oddělení, Kroměřǐž

Klinické projevy myokarditidy jsou velmi rozmanité a zahrnují širokou škálu klinických příznaků od asymptomatického průběhu až po fulminantní srdeční selhání. Bolesti na hrudníku patří mezi iniciálně relativně častější projevy myokarditid (10-30 \%) a jsou klinicky velmi obtížně odlišitelné od bolestí koronární etiologie. Podobně jako klinické projevy onemocnění je i etiologie myokarditid velmi široká. Myokarditida u salmonelové systémové infekce patří mezi vzácnější projevy tohoto onemocnění a literárně jsou uváděny ojedinělé kasuistiky tohoto postižení. Předkládáme tři kasuistiky pacientů, kteří byli akutně přijati na naši kliniku pod obrazem akutní bolesti na hrudníku. Všichni pacienti byli akutně koronarografováni pro podezření na akutní koronární syndrom, další klinické sledování a diferenciální diagnostika však potvrdila přítomnost salmonelové myokarditidy. Všichni pacienti byli následně léčeni antibiotiky s kompletní klinickou úpravou a restitucí.

\section{KVANTIFIKACE MITRÁLNÍ REGURGITACE U PROMËNLIVÉHO REGURGITAČNIIHO ÚSTİ*}

NEČAS J, KOVALOVÁ S, POKORNÝ P, ÚTRATA P, BEDÁŇOVÁ H, PETRIKOVITS E, RŮŽIČKA P, VESPALEC J

CKTCH, Brno
Úvod: Kvantifikace mitrální regurgitace je jedním z neoblíbených úkolů echokardiografistů. Kromě problémů s tvarem konvergenční zóny je třeba se často vypořádat s proměnlivostí regurgitačního ústí. Metodické zvládnutí kvantifikace těchto regurgitací patří $\mathrm{k}$ nejnáročnějším echokardiografickým vyšetřením.

Cíl práce: Představit námi vyvinutou metodiku a porovnat výsledky kvantifikace u ústí konstantních a proměnlivých ve $2 \mathrm{D}$ i $3 \mathrm{D}$ provedení.

Materiál a metodika: Pomocí 2D a 3D echokardiografie jsme vyšetřili 41 nemocných s mitrální regurgitací. Určovali jsme tvar a chování regurgitačního ústí, prováděli volumetrii levé komory, měřili systolický objem a pomocí vlastního algoritmu a programu jsme vypočítávali standardní parametry mitrální regurgitace. Nemocné jsme rozdělili na skupiny s ústím konstantním a s ústím proměnlivým. Získané hodnoty jsme podrobili regresní analýze v obou skupinách u 2D i 3D vyšetření. Korelovali jsme celkový systolický objem se součtem efektivního systolického a regurgitačního objemu a výsledky statistické analýzy pro jednotlivé skupiny jsme porovnali.

Výsledky: Podle 2D ECHO mělo 27 nemocných regurgitační ústí konstantní a 14 nemocných proměnlivé. Korelace totálního systolického objemu se součtem efektivního systolického a regurgitačního objemu vykazovala u konstantního ústí hodnotu $\mathrm{r}=0,89 \mathrm{~s} p<0,0005 \mathrm{a} u$ proměnlivého hodnotu $\mathrm{r}=0,94 \mathrm{~s} p<0,0005$. 3D ECHO vykazovalo 16 konstantních a 22 proměnlivých regurgitačních ústí. Analogická regresní analýza vykázala pro ústí konstantní $\mathrm{r}=0,799$ $\mathrm{s} p<0,0005$ a pro ústí proměnlivé $\mathrm{r}=0,77 \mathrm{~s} p<0,0005$.

Závěry: Proměnlivé regurgitační ústí se vyskytuje $u$ více než 1/3 nemocných s mitrální regurgitací. Kvantifikaci mitrální regurgitace u proměnlivého regurgitačního ústí lze provést $\mathrm{s}$ přesností srovnatelnou $\mathrm{s}$ ústím konstantním. Verze 2D kvantifikace je zatím přesnější než verze 3D.

\section{VÝSLEDKY POHYBOVÉ LÉČBY OBÉZNÍCH V ZÁVISLOSTI NA VĚKU A PR̆IDRUŽENÝCH CHOROB ÁCH*}

NEČASOVÁ J, ROSENBERGOVÁ B, SVAČINOVÁ H, TARASOVÁ M, SVOBODA L, SIEGELOVÁ J

Klinika funkční diagnostiky a rehabilitace, FN u sv. Anny a LF MU, Brno

*Podporováno grantem: MSMO021622402.

Cíl práce: Zhodnocení vlivu pohybové léčby na antropometrické parametry obézních v závislosti na věku a přidružených chorobách.

Soubor pacientů a metodika: Bylo vyšetřeno 16 obézních žen (věk $56 \pm 9$ let, hmotnost $91 \pm 12 \mathrm{~kg}$, BMI $36 \pm 5$ ), které $\mathrm{v}$ rámci terapie obezity absolvovaly skupinové cvičení na Klinice funkční diagnostiky a rehabilitace FN u sv. Anny v Brně. Sledované přidružené choroby: hypertenze ( 9 ž), DM 2. typu (3 ž), kombinace DM a hypertenze (1 1 z), hypertenze a dyslipidemie $(4$ ž). Pět žen bylo bez sledovaných přidružených chorob. Před zahájením a po ukončení 12týdenní pohybové léčby byly stanoveny antropometrické hodnoty (hmotnost, obvod pasu, výpočet BMI, \% tuku a hmotnost tuku) a spiroergometrií intenzita zátěže - na úrovni anaerobního prahu. V rámci celkové terapie obezity bylo doporučeno pokračovat $\mathrm{v}$ redukci energetického prŕjmu o 2000 $\mathrm{kJ} /$ den $\mathrm{v}$ průběhu sledovaného období.

Výsledky: U všech antropometrických parametrů klesala velikost poklesu hodnot $\mathrm{s}$ narůstajícím počtem přidružených 
chorob; signifikantní změny jsme prokázali u hmotnosti a \% tuku. K výraznější redukci hmotnosti a \% tuku došlo u žen bez přidružené choroby oproti ženám se dvěma a více přidruženými chorobami. Nejmladší věková kategorie (věk do 54 let včetně) dosáhla s výjimkou hodnot obvodu pasu vždy nejvýraznějšího zlepšení u hmotnosti, BMI a \% tuku.

Závěr: Nižší věk lze na základě našich výsledků považovat za významný faktor ovlivňující úspěšnost nefarmakologické intervence u obézních. Obézní ženy bez přidružených chorob dosáhly nejvýraznějšího zlepšení všech antropometrických parametrů. Tyto výsledky naznačují, že počet přidružených chorob může významně určovat vliv pohybové léčby na hodnoty antropometrických parametrů.

\section{TUPÉ PORANĚNÍ SRDCE}

NEDBAL P, POLÁŠEK R, HOLM F, ŠVANCAR P, ZÝKOVÁ I, LUKÁŠ R, ŠRÁM J

Kardiologické oddělení, ARO, Traumacentrum,

Krajská nemocnice Liberec, Liberec

Tupé poranění srdce při poraněních hrudníku v rámci polytraumatu bývá častým nediagnostikovaným poraněním, které může mít i fatální následky. Skutečná incidence není přesně známa, literární údaje se pohybují v širokém rozpětí od 7 do $81 \%$ pacientů s tupým poraněním hrudníku. Toto rozpětí je dáno absencí diagnostického standardu a nepřesnou terminologií. $Z$ praktického hlediska je řešena problematika tupého poranění srdce následovně: 1 . identifikace rizikového nemocného, 2. stanovení diagnostických algoritmů a 3. způsob léčby. Cílem terapie je zabránit dlouhodobým nepříznivým následkům v důsledku srdeční kontuze. Doporučený postup se opírá o dosud publikovaná data.

V našem sdělení prezentujeme kasuistiku pacienta s polytraumatem, který utrpěl tupé poranění srdce s rupturou závěsného aparátu trikuspidální chlopně s akutním selháním pravé srdeční komory a následným multiorgánovým selháním. Pro náhle vzniklou těžkou srdeční dekompenzaci 3. den hospitalizace byla diagnóza stanovena echokardiografickým vyšetřením. Pacient byl úspěšně konzervativně léčen a v druhé době byla provedena trikuspidální náhrada mechanickou protézou s dosud 2letým přežíváním s dobrou kvalitou života.

\section{LATE THROMBOSIS IN DRUG ELUTING STENTS}

NEGAHBAN Q, HLINOMAZ O, GROCH L, HORŇÁČEK I, FISCHEROVÁ B, REZEK M

\section{I. interní-kardiologická klinika,}

FN u sv. Anny, Brno

Background: Late thrombosis in drug eluting stents (DES) seems to be a more serious problem than expected. There is a lot of controversy among the experts worldwide and the data published are often incomplete and uncertain.

Methods: We have followed up 146 consecutive patients to whom DES were implanted in our institution since 2002 till 2005. With these patients we have paired 146 patients, who received bare metal stents (BMS) always immediately after the patient with DES implantation. The aim of our retrospective study has been to show what is the mortality rate difference between both groups. We have found out the main cause of death and the section report by contacting the physicians taking care of the patients before they died.

Results: The all cause mortality was $10.3 \%(n=15)$ in DES vs $10.9 \%(n=16)$ in BMS patients. There were $33.3 \%$
(5/15) sudden deaths in DES group compared to the $50.0 \%$ $(8 / 16)$ in BMS group. The average follow up was 42 months. The time from the stent implantation to death was 17.2 months in DES vs 10.0 months in BMS group.

Conclusion: The all cause mortality and sudden death in patients receiving BMS was nonsignificantly higher than in DES group.

\section{ŘízENÁ AMBULANTNÍ REHABILITACE U NEMOCNÝCH PO OPERACI CHLOPENNÍCH SRDEC̆NÍCH VAD}

\section{NEHYBA S, CHALOUPKA V, SOUČEK R}

Interní kardiologická klinika,
FN Brno-Bohunice, Brno

Úvod: Náhrada srdeční chlopně upravuje hemodynamiku, zlepšuje funkční stav a prodlužuje život u nemocných s chlopenní vadou. Zlepšení zátěžové tolerance umožňuje vyšší pohybovou aktivitu a spolurozhoduje o kvalitě života. Jedná se o jednu z prvních prací hodnotících vliv fyzického tréninku u nemocných po operaci chlopenních vad.

Cíl práce: Efekt 8týdenního komplexního rehabilitačního programu na oběhové parametry, funkci LK a funkční kapacitu pacientů po operaci aortální i mitrální srdeční vady.

Soubor nemocných a metodika: Zařazeno 21 nemocných, 18 mužů, 3 ženy, věk 27-86 let (56 \pm 16), 15 operováno pro ao stenózu, 4 pro kombinovanou ao vadu a 2 pro mi regurgitaci. Provedena $14 \times$ náhrada mechanickou protézou, $5 \times$ bioprotézou, $2 \times$ plastika chlopně, u 6 pacientů současně CABG pro koronární postižení. Rehabilitace zahájena za 4-6 týdnů po propuštění. Nemocní vyšetřeni klinicky, zátěžovou echokg a spiroergometrií před rehabilitací a po rehabilitaci. Program byl odvozen od standardního typu pro pacienty s ICHS. Aerobní trénink na úrovni $50-80 \%$ maxima. Od 4. týdne zařazení resistenčních cviků do $50 \%$ 1-RM ke zvýšení svalové síly.

Výsledky: Nedošlo k významným změnám klidových hodnot SF, sTK a dTK před rehabilitací a po skončení rehabilitace (SF $77 \pm 12$, resp. $75 \pm 8$; sTK $127 \pm 13$, resp. 128 \pm 11 a dTK $80 \pm 8$, resp. $82 \pm 2$ ). Parametry systolické funkce LK se nezměnily, parametry diastolické a globální funkce se měnily nevýznamně. Došlo $\mathrm{k}$ významnému zlepšení zátěžové tolerance $(p<0,005)$ a ke zvýšení aerobní kapacity.

Závěr: Pravidelný trénink u pacientů po operaci chlopenních srdečních vad vede ke zlepšení aerobní kapacity a zátěžové tolerance. Funkce LK nebyla ovlivněna. Cvičení nevyvolalo nežádoucí oběhové reakce a lze je doporučit jako součást léčby po operaci srdečních chlopní. Řizený rehabilitační program umožňuje adjustaci antikoagulační léčby.

\section{SESTERSKÁ SEKCE}

\section{UŽITÍ AMPLATZOVA OKLUDERU K UZÁVĚRU DUCTUS BOTTALI}

\section{NETUŠILOVÁ M, HANZLÍKOVÁ D}

Kardiologické oddělení,

Masarykova nemocnice Ústí nad Labem,

Ústí nad Labem

Cílem sdělení je seznámit vás $\mathrm{s}$ našimi zkušenosti $\mathrm{s}$ užitím Amplatzova okluderu k uzávěru ductus Bottali. Naše poznatky ukazují, že tato metoda je pro pacienta méně zatěžující, a proto ji lze využít i u pacientů s vysokým operačním rizikem. 


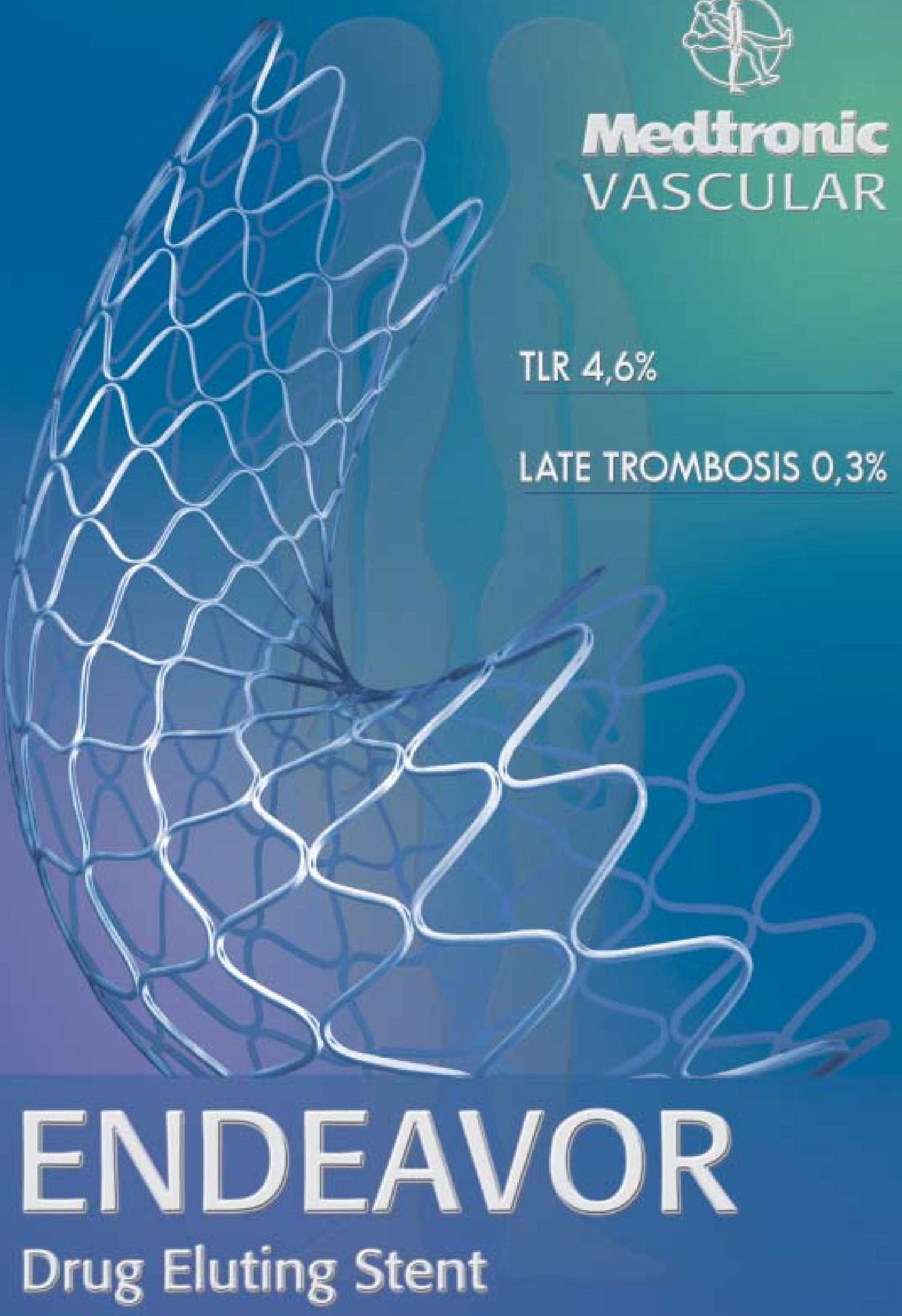




\section{POLYMORFISMY V GENECH PRO NUKLEÁRNÍ RECEPTORY PPAR A RXR NEJSOU ASOCIOVÁNY S VÝZNAMNOU ANGIOGRAFICKOU RESTENÓZOU V KORONÁRNİM STENTU}

NEUGEBAUER P, PÁVKOVÁ-GOLDBERGOVÁ M, KALA P, JEŘÁBEK P, BOČEK O, POLOCZEK M, VYTISKA M, PAŘENICA J, ŠPINAR J, VAŠKU゚ A

Interní-kardiologická klinika, Oddělení angiologie, FN Brno, Ústav patologické fyziologie, Ústav patologické fyziologie, LF MU Brno, Brno

Úvod: Kromě zvyklých klinických a periprocedurálních faktorů ovlivňuje vznik restenózy ve stentu i hereditární složka. Nukleární receptory PPAR a RXR regulují kromě metabolismu glukózy, lipidů a homeostázy i buněčnou diferenciaci, mohly by tedy ovlivňovat i proliferaci neointimy, jež je hlavním mechanismem restenózy ve stentu.

Cil: Zjistit možnou asociaci polymorfismů v genech pro výše uvedené receptory s angiografickou restenózou ve stentu.

Metodika: Prospektivní angiografická, klinická a genetická analýza nemocných s implantovaným stentem pro denovo lézi nativní koronární tepny. Genotypy polymorfismu PPAR- $\alpha$ L162V, PPAR- $\gamma$ C161T a A (39526)AA RXR- $\alpha$ byly detekovány pomocí metod PCR (polymerase chain reaction) a RFLP (restriction fragment length polymorphism).

Soubor: Bylo zařazeno 576 pacientů, kontrolní angiografie byla provedena u $485 \mathrm{z}$ nich (84,2 \%). Průměrný věk byl 69,5 roku, $\mathrm{z}$ rizikových faktorů dominovala hypertenze (73,6 \%), diabetiků vyžadujících léčbu bylo 25,1 \%. Z diagnóz převažovaly stabilní AP (43,2 \%) a akutní koronární syndrom (41,4\%), 30,9 \% nemocných bylo po infarktu. Bylo implantováno 1,5 stentu na pacienta, u 16,2\% byl zaveden stent vylučující léky (DES). 18,3\% mělo délku stentovaného úseku nad $30 \mathrm{~mm}, 26,1 \%$ mělo ošetřenu tepnu o průměru 2,75 mm a menší, u 23,9 \% byl proveden stenting více tepen.

Výsledky: Výskyt angiografické restenózy nad $50 \%$ byl 25,5\%, klinický korelát mělo 10,1 \% pacientů, opakovaná revaskularizace léze (TLR) byla nutná v 13,6 \%. Reinfarkt prodělalo $1,2 \%$. 6měsíční mortalita celého souboru 576 pacientů byla $1,2 \%$. Výskyt angiografické restenózy u jednotlivých alel RXR- $\alpha$ byl $24,8 \%$ vs. $35,1 \%$ ( $p=$ NS), u PPAR- $\alpha$ $27,1 \%$ vs. $18,7 \%$ ( $p=$ NS), u PPAR- $\gamma 27,7 \%$ vs. $23,9 \%$ ( $p=$ NS).

Závěr: I přes možnou patofyziologickou souvislost jsme neprokázali asociaci polymorfismů v genech pro nukleární receptory $\mathrm{s}$ angiografickou restenózou ve stentu.

\section{HOME-MONITORING U NEMOCNÝCH PO PRODĚLANÉM INFARKTU MYOKARDU A IMPLANTACÍ ICD}

\section{NEUŽIL P, TÁBORSKÝ M, ŠEDIVÁ L, HOLÝ F}

Kardiologické oddělení, Nemocnice Na Homolce, Praha

Cil: Ověřit efektivitu funkce Home-Monitoring u nemocných s implantovaným ICD přístrojem.

Soubor a metodika: $\mathrm{V}$ rámci studie REFORM (zařazeno 155 nemocných) jsme v našem centru zařadili 24 nemocných (19 mužů a 5 žen, prưměrného věku 65,5 let). ICD přístroj byl indikován v rámci sekundární prevence po detekované epizodě KTA. Všichni nemocní prodělali v minulosti infarkt myokardu. Po implantaci ICD byli vybaveni komunikačním zařízením Messenger $\mathrm{k}$ přidávání informací $\mathrm{z}$ paměti ICD do řídicího centra, odkud byly zpracované informace předávány našemu implantačnímu centru pomocí internetového přenosu dat. Nemocní byli sledováni pravidelně v KS ambulanci po dobu
24 měsíců. Byla porovnávána data předaná zařízením Messenger a data získaná při kontrole ICD přístroje.

Výsledky: Během sledování $\mathrm{v}$ našem souboru zemřeli 3 nemocní ( 1 muž a 2 ženy). 1 nemocný ukončil předčasně sledování (ICD doplněno o biventrikulární stimulaci), 1 muž nedokončil sledování.

Komorové tachyarytmie byly detekovány u 9 nemocných, tj. 15 nemocných bylo bez komorových arytmií. Celkem bylo detekováno 229 epizod KT a 78 epizod KF, v zóně detekce KT bylo všech 229 epizod detekováno u jediného nemocného! Zbývajících 8 nemocných mělo všechny epizody detekovány $\mathrm{v}$ rámci zóny pro KF. Všechna data byla vždy adekvátně avizována informačním centrem a potvrdili jsme shodu detekce tachyarytmií během kontrol nemocných v KS ambulanci.

Závěr: Funkce Homo-Monitoring umožňuje přesné a především velmi rychlé předávání dat $z$ paměti přístroje implantujícímu centru, umožňuje významně urychlit léčbu nemocných s ICD a předejít i kritickým situacím, jako jsou např. arytmické bouře.

\section{HYBRIDNÍ TERAPIE - ABLACE A PREVENTIVNÍ STIMULACE U NEMOCNÝCH S CHRONICKOU FORMOU FIBRILACE SÍNÍ. STUDIE HAPPI-AF}

NEUŽIL P

Kardiologické oddělení, Nemocnice Na Homolce, Praha

Cíl: $\mathrm{V}$ randomizované studii $\mathrm{z}$ jednoho centra ověrit efekt hybridní terapie - katetrizační ablace s použitím algoritmů preventivní stimulace, jako kombinované léčby nemocných s chronickou formou fibrilace síní.

Soubor a metoda: Do studie jsme zařadili celkem 150 nemocných a randomizovali je do celkem tři skupin terapie: A. preventivní stimulace, B. katetrizační ablace, C. katetrizační ablace a preventivní stimulace, $\mathrm{v}$ rámci studie jsme nemocné sledovali 15 měsíců. Průměrný věk 64 let, trvání arytmie v průměru 85 měsíců, EF LK $63 \%$. Na konci studie bylo studováno ve skupině $\mathrm{A} / 34, \mathrm{~B} / 38$ a C/38 nemocných. $\mathrm{K}$ analýze detekovaných arytmií $\mathrm{v}$ rámci sledování bylo použito algoritmu KS Selection 9000. Katetrizační ablaci jsme prováděli jako extraostiální izolaci plicních žil s použitím mapování CARTO.

Výsledky: Signifikantně významné redukce výskytu fibrilace síní bylo dosaženo jak ve skupině $\mathrm{B}$ a $\mathrm{C}(p<0,001)$. Pouze minimální efekt byl dosažen ve skupině preventivní stimulace, i když i zde došlo k redukci výskytu FiS (vliv bradykardické stimulace). Ke kompletní eliminaci výskytu FiS došlo ve skupině C (hybridní léčba) u více než $60 \%$ nemocných, ve skupině B (ablační léčba) zhruba u $40 \%$ nemocných a ve skupině A (preventivní stimulace) u necelých $30 \%$ nemocných.

Závěr: Jedná se o první studii s kontinuálním monitorováním síňového rytmu po provedení katetrizační ablace pro chronickou formu FiS. Prokazujeme výrazně vyšší účinnost kombinované ablační a stimulační terapie.

\section{KARDIOCHIRURGICKÁ ELIMINACE KOMOROVÝCH TACHYARYTMIÍ NAVIGOVANÁ ELEKTROANATOMICKÝM MAPOVÁNIIM}

NEUŽIL P, TÁBORSKY M, ŠEDIVÁ L, ČERNÝ Š, BENEDÍK J, KRÁLOVEC Š

Kardiologické oddělení, Kardiochirurgické oddělení, Nemocnice Na Homolce, Praha

Cíl: Zjistit efektivitu CARTO mapování substrátu před provedením kardiochirurgického zákroku s cílem odstranit arytmogenní substrát komorových tachyarytmií. 
Soubor a metodika: Elektroanatomické mapování provedeno u 15 nemocných po IM (9 mužů, 6 žen, průměrného věku 63,8 \pm 7,6 let). Indukce komorových tachykardií a označení specifických potenciálů aplikací RF energie. Následný komplexní KCH zákrok s provedením aneuryzmektomie a kryodestrukce označených zón a nebo bez provedení. Následné kontrolní testování inducibility KTA a případně implantace ICD.

výsledky: Výkon dokončen u všech 15 nemocných s provedením aneuryzmektomie u 11 a identifikací RF lézí u 7 nemocných. Během výkonu nezemřel žádný pacient. Po výkonu došlo ke zlepšení funkce LK (EF LK z 32,2 \pm 5,3 \% před výkonem na $42,7 \pm 5,6 \%$ po $\mathrm{KCH}$ výkonu). Během kontrolní EFV nebyla indukována žádná KT. 16 měsíců po výkonu zemřel 1 nemocný (nekardiální př́ičina), 8 měsíců po výkonu recidivovala KT opakovaně u 1 nemocného.

Závěr: Naše výsledku ukazují na vysokou efektivitu komplexního KCH zákroku navigovaného substrátovým mapováním, je nutné ověřit efekt této metodiky s výrazně vyšším počtem nemocných.

\section{SROVNÁNÍ POUŽITÍ RADIOFREKVENČNÍ A STANDARDNÍ TECHNIKY PR̆I TRANSVENÓZNÍ EXTRAKCI STIMULAC̆NÍCH ELEKTROD}

NEUŽIL P, TÁBORSKÝ M, ŠEDIVÁ L, PETRŮ J, KRÁLOVEC Š, HOLÝ F, VOPÁLKA R

Kardiologické oddělení, Oddělení zdravotnické techniky, Nemocnice Na Homolce, Praha

Cíl: $\mathrm{V}$ rámci prospektivní randomizované studie $\mathrm{z}$ jednoho centra srovnat účinnost provedení extrakce stiomulačních elektrod s podporou radiofrekvenční $(\mathrm{RF})$ energie oproti standardní technice s použitím prosté kontratrakce.

Soubor a metoda: V rámci 627 nemocných, u kterých jsme provedli v posledních 10 letech transvenózní extrakci stimulačních elektrod, jsme provedli u 120 nemocných randomizovaně extrakci 161 elektrod bud's využitím standardní techniky prosté kontratrakce $\mathrm{a} /$ nebo $\mathrm{s}$ použitím zavaděčů $\mathrm{s}$ možností aplikace RF energie. V každé skupině bylo po 60 nemocných, 96 mužů a 24 žen, střední věk $62,7 \pm 9,6$ let. U 16 nemocných byla provedena explantace 17 ICD elektrod. Průměrná doba od implantace elektrod byla 73,4 $\pm 15,7$ měsíců.

Výsledky: Kompletní extrakce bylo dosaženo u 78 elektrod $(93 \%)$ v RF skupině a 56 elektrod $(73 \%)$ ve standardní skupině $(p<0,01)$. V RF skupině jsme extrahovali 9 z 10 ICD elektrod a pouze 4 ze 7 ICD elektrod ve skupině standardní techniky kontratrakce tj. $90 \%$ vs. $57 \%$. Ve skupině RF extrakcí bylo dosaženo signifikantního zkrácení času extrakce $(9,6 \pm 6,2$ min vs. $21 \pm 9$ min, $p<0,01)$. Femorální přístup extrakce jsme použili u dvou nemocných, $1 \times$ u PM a $1 \times$ u ICD elektrody. Závažné komplikace byly spojeny pouze s použitím standardního systému: septické embolizace do plic u obou nemocných.

Závěr: Na základě této randomizované studie se 120 nemocnými jsme prokázali výrazně vyšší efektivitu výkonu s použitím RF energie. Nepozorovali jsme žádnou život ohrožující komplikaci v obou skupinách.

\section{VZTAH HODNOT KREVNÍHO TLAKU PR̆ı AMBULANTNÍM MONITOROVÁNÍ K NËKTERÝM MORFOLOGICKY̌M A BIOCHEMICKÝM PARAMETRÜM HYPERTONIKŮ S METABOLICKÝM SYNDROMEM}

NĚMCOVÁ H, ŠPÁC J, SOUČEK M, ČIŽMÁROVÁ H

II. interní klinika, FN u sv. Anny, Brno
Soubor 57 hypertoniků (45 mužů, 15 žen), průměrného věku 49,7 roků s BMI $29,7 \mathrm{~kg} / \mathrm{m}^{2}$, u nichž jsme diagnostikovali metabolický syndrom, jsme vyšetřili TK pomocí 24hodinového monitorování. Morfologii levé komory jsme hodnotili 2D echokardiografickým vyšetřením, diastolické parametry pomocí dopplerovského vyšetření transmitrálního toku a tkáňového dopplerovského hodnocení pohybu mitrálního prstence. Vedle základních biochemických parametrů jsme zjištovali některé biochemické markery aterosklerózy. Sledovali jsme také funkci ledvin stanovením glomerulární filtrace a mikroalbuminurii.

Nalezli jsme závislost mezi hmotností levé komory, vyjádřené indexem hmotnosti levé komory, diastolickou funkcí levé komory a krevním tlakem. Respondenti se zvýšenou masou levé komory měli podstatně vyšší průměrný noční TK ve srovnání s jedinci bez hypertrofie $(122,2 / 73,6 \mathrm{~mm} \mathrm{Hg}$ proti $126,1 / 76,4 \mathrm{~mm} \mathrm{Hg})$. Rozdíly v průměrných denních tlacích byly nesignifikantní.

Osoby s dopplerovsky stanovenou diastolickou dysfunkcí (43\% souboru) měli, oproti respondentům s normální diastolickou funkcí, jasně vyšší prưměrný 24hodinový i denní TK. Rozdíly ve spánkovém krevním tlaku nebyly významné. Obdobné rozdíly průměrného 24 hodinového tlaku jsme zjistili mezi jedinci se sníženou a normální glomerulární filtrací (138/88 vs. $134 / 83,2 \mathrm{~mm} \mathrm{Hg).}$

Již u osob s mírnou hypertenzí s průměrným kazuálním krevním tlakem 140,3/91,2 mm Hg jsme nalezli známky orgánového postižení.

Naše nálezy podporují názory a doporučení, že je vhodné u rizikových osob ovlivňovat krevní tlak již při nižších hodnotách než je horní hranice normy 140/90 mm Hg.

\section{POROVNÁNÍ PRŮTOKŮ AORTOKORONÁRNIIMI BYPASSY S LOKÁLNÍ MYOKARDIÁLNÍ PERFUZI HODNOCENOU ZÁTĚŽOVÝM SPECT ZOBRAZENÍM*}

NĚMEC P, KAMÍNEK M, BRUK V,

GWOZDZIEWICZ M, STERIOVSKÝ A, ŠIMEK M, ŠANTAVÝ P, METELKOVÁ I

\section{Kardiochirurugická klinika, FN Olomouc, Olomouc}

*Práce byla podporována grantem IGA MZ NR 7791-3/2004.

Cílem práce bylo oveřrit, zda velikost peroperačně měřeného průtoku aortokoronárními bypassy má vliv na pooperační perfuzi myokardu v oblastech jednotlivých věnčitých tepen.

Soubor nemocných a metodika: Do studie bylo zařazeno 51 nemocných, kteří byli rozděleni do dvou skupin. Ve skupině A byla provedena revaskularizace povodí levé věnčité tepny tepenným $Y$ graftem a ve skupině $B$ byla revaskularizace provedena konvenční technikou /levá a. thoracica interna (ATI) do povodí r. interventricularis anterior (RIA) a žilní štěpy do povodí r. circumflexus (RC)/. Průtok bypassy byl měřen na konci operace. SPECT vyšetření bylo provedeno těsně před operací a 1-3 měsíce po operaci.

Výsledky: Průtok levou ATI se v obou skupinách nelišil $(26,6 \pm 19,5 \mathrm{ml} / \mathrm{min}$ a $28,0 \pm 21,4 \mathrm{ml} / \mathrm{min})$. Průtok pravým raménkem $Y$ graftu do povodí $r$. circumflexus byl statisticky významně nižší ve srovnání s průtokem žilními štěpy do stejné oblasti $(32,7 \pm 17,8 \mathrm{ml} / \mathrm{min}$ a $56,3 \pm 30,8 \mathrm{ml} / \mathrm{min}$, $p<0,05)$. Pooperační SPECT odhalil významné snížení perfuzního defektu levé komory po operaci. Ve skupině A to bylo o $13,7 \pm 13,8 \%$ a ve skupině B o $13,6 \pm 12,7 \%$. Rozdíl mezi oběma skupinami nebyl statisticky významný. Snížení velikosti perfuzního defektu v povodí RIA ani v povodí RC se také $\mathrm{v}$ obou skupinách nelišilo (povodí RIA ve skupině $\mathrm{A}$ o $9,5 \pm 19,6 \%$ a ve skupině B o $11,9 \pm 16,7 \%$, povodí RC ve skupině A o $14,9 \pm 19,3$ a ve skupině $B$ o $16,4 \pm 25,3 \%$ ). 
Závěr: U pacientů s kompletní revaskularizací myokardu přináší revaskularizace povodí levé věnčité tepny tepenným Y graftem stejné zlepšení perfuzního defektu, hodnocené SPECT-vyšetřením jako revaskularizace klasickou technikou přesto, že peroperační průtoky do oblasti RC jsou u klasické techniky signifikantně vyšší.

\section{SESTERSKÁ SEKCE}

\section{OŠETR̆OVÁNÍ OPERAČNÍCH RAN PO OPERACI NA SRDCI A PR̆EDCHÁZENÍ KOMPLIKACÍM}

\section{NIEWELTOVÁ M}

Kardiocentrum, jednotka intermediální péče, Krajská Nemocnice Liberec, Liberec

Srdce jako orgán nezbytný pro život zastává funkci oběhového čerpadla pro malý a velký oběh krevní. Získané chlopňové vady srdeční levého srdce dělíme na stenotické, regurgitační a kombinované. Farmakologická léčba není kauzální, pouze symptomatická a slouží ke zmírnění symptomů. Kauzální léčbou je chirurgická korekce vady, v některých indikacích může být vada korigována perkutánně (např́iklad mitrální balonková valvuloplastika). Chirurgický způsob léčby spočívá bud' v náhradě chlopně protézou nebo v záchovné operaci pomocí plastiky. Podle způsobu chirurgického ošetření pacient musí být krátkodobě nebo doživotně antikoagulačně léčen. $Z$ ošetřovatelského hlediska je mimo jiné důležitá prevence komplikací při hojení operačních ran a jsou diskutovány hlavní zásady jejich ošetřování.

\section{DVOULETÉ ZKUŠENOSTI S HODNOCENÍM ZÁVAŽNOSTI AORTÁLNÍ STENÓZY, VČETNĚ POUŽÍVÁNÍ ECHOKONTRASTNÍCH LÁTEK PRO LEVOSTRANNÉ ODDÍLY}

NOVÁK A, PETROVÁ I, DRAŽKA J, KUBÍČKOVÁ M, BĚHOUNEK M, BYSTROŇ M, KVAŠŇÁK M, ČERVINKA P

Kardiologické oddělení, Masarykova nemocnice Ústí nad Labem, Ústí nad Labem

Cílem naší práce bylo zhodnotit přínos použití echokontrastních látek pro levostranné oddíly v hodnocení závažnosti aortální stenózy.

Při špatné vyšetřitelnosti $z$ prekordia může být přínosné použití kontrastních látek pro levostranné oddíly (Optison, Sonovue). Tyto kontrastní látky umožní přesné změření středního gradientu $\mathrm{z}$ optimální dopplerovské křivky, přesnější změření ejekční frakce. Při jícnovém vyšetření je často nevhodný úhel pro měření gradientu dopplerovským vyšetřením, pak echokontrastní látka umožní optimalizovat kvalitu dopplerovské křivky $z$ transtorakálního vyšetření $z$ hrotu.

$\mathrm{V}$ práci prezentujeme zkušenosti $z$ provozu dvou echolaboratoří, v kterých jsme za dva roky vyšetřili celkem přes 11000 tisíc pacientů. U 12 \% pacientů s aortální stenózou jsme použili echokontrastní látku pro levostranné oddíly. Byli to hưře vyšetřitelní pacienti $z$ prekordia a pacienti s ne- optimálním úhlem pro dopplerovské vyšetření gradientu aortální chlopně v prủběhu jícnové echokardiografie. Dále pacienti v průběhu dobutaminové zátěžové echokardiografie $\mathrm{k}$ opacifikaci dutiny levé komory a měření gradientu na aortální chlopni a v LVOT echokontrastní látkou.

Až na jednoho obézního pacienta $\mathrm{s}$ emfyzémem jsme u všech pacientů získali optimální dopplerovskou křivku z prekordia, často i po malém množství echokontrastní látky (0,5 ml Sonovue). Výhodou této látky je i snadná příprava a možnost okamžitého použití. Cena operace jedné náhrady aortální chlopně se odhaduje na 300000 korun, pokud je pozitivní přínos echokontrastní látky ve výtěžnosti echokardiografického vyšetření pro správné zhodnocení závažnosti aortální stenózy, nehraje její cena zásadní roli.

\section{PŘÍSPĚVEK KE STANOVENÍ „OPTIMÁLNÍHO“ DYNAMICKÉHO ATRIOVENTRIKULÁRNİHO INTERVALU POMOCÍ TRANSTORAKÁLNİ IMPEDANČNİ KARDIOGRAFIE U PACIENTŮ S POKROČILOU ATRIOVENTRIKULÁRNÍ BLOKÁDOU KORIGOVANOU PM DDD*}

\section{NOVÁK M, KAMARÝT P, LIPOLDOVÁ J, HOMOLKA P,} VYKYPĚL T, BUCHTOVÁ K, SIEGLOVÁ J

I. interní-kardioangiologická klinika, Klinika funkční diagnostiky a rehabilitace, FN u sv. Anny, Brno

*Podpořeno grantem MŠMT-MSM 0021622402.

Cil: Pomocí impedanční kardiografie (IKG) zjistit atrioventrikulární intervaly (AVI) s největším srdečním výdejem cardiac output (max $\mathrm{CO}$ ) při sekvenční stimulaci 80 a $100 . \mathrm{min}^{-1}$. Posoudit, zda lze IKG použít k optimalizaci programování dynamického AVI.

Pacienti a metody: 19 pacientům (pac), 15 mužům a 4 ženám, průměrného věku 75,0 \pm 7,6 roků, s PM DDD implantovaným pro pokročilou AVB (10× ischemická, 9× neischemická etiologie, ejekční frakce levé komory 50-65 \%, diastolická dysfunkce u 14 pac) v poloze vleže stanoven CO pomocí IKG (Task Force Monitor CNSystems, Rakousko). PM programován: DDD, 80. $\mathrm{min}^{-1}$ a $100 . \mathrm{min}^{-1}$ (aby byla zajištěna konstantní frekvence stimulace), AVI 100, 120, 140, 160, 180 ms (AVI u obou frekvencí programován randomizovaně). Vyrovnávací fáze $2 \mathrm{~min}$, fáze měření 2 min.

Výsledky: Optimální AVI (definovaný jako AVI při max CO) při stimulaci DO0 80. $\mathrm{min}^{-1}$ byl $100-160 \mathrm{~ms}$ a při 100. min $^{-1} 100-180 \mathrm{~ms}$.

Optimální AVI [ms] u jednotlivých pac při stimulaci D00 viz tabulka.

Diskuse: Při stimulaci $100 . \mathrm{min}^{-1}$ proti $80 . \mathrm{min}^{-1}$, předpokládaný kratší optimální AVI prokázán jen u 4 z 19 pac. U 9 pac byl stejný, u 4 delší a u 2 neurčitelný.

Limitace: Max CO stanoven jen při dvou stimulačních frekvencích a jen v rozmezí AVI 100-180 ms.

Závěr: „Optimální“ AVI definovaný jako AVI při max. CO $\mathrm{u}$ pac s pokročilou AVB vykazoval zřetelné interindividuální rozdíly. Při DO0 $100 . \mathrm{min}^{-1}$ proti $80 . \mathrm{min}^{-1}$ bylo zkrácení optimálního AVI prokázáno jen u 4 z 19 pac. IKG může pomoci při programování základního a dynamického AVI u pacientů s pokročilou AVB.

Tabulka k abstraktu MUDr. M. Nováka

\begin{tabular}{|c|c|c|c|c|c|c|c|c|c|c|c|c|c|c|c|c|c|c|c|}
\hline Pac. č. & 1 & 2 & 3 & 4 & 5 & 6 & 7 & 8 & 9 & 10 & 11 & 12 & 13 & 14 & 15 & 16 & 17 & 18 & 19 \\
\hline 80 ppm & 120 & 160 & 100 & 100 & 120 & 140 & $*$ & 140 & 160 & 140 & 160 & 100 & 160 & 100 & 100 & 100 & 100 & 160 & 140 \\
\hline 100 ppm & 120 & 160 & 100 & 140 & 100 & 120 & $*$ & 140 & 160 & 120 & 140 & 100 & 160 & 120 & $*$ & 100 & 100 & 180 & 180 \\
\hline
\end{tabular}

*Neurčitelná hodnota pro kolísání a minimální rozdíly 


\section{KVALITA ŽIVOTA VELMI STARÝCH NEMOCNÝCH PO NÁHRADĚ AORTÁLNÍ CHLOPNĔ}

NOVÁK V

I. interní klinika, FN Hradec Králové, Hořice v Podkrkonoší

Staří nemocní představují ve vyspělých zemích rostoucí segment konzumentů zdravotní péče v oblasti chronických a degenerativních onemocnění, mezi kterými v kardiologii dominují aortální valvulopatie a ischemická choroba srdeční $\mathrm{K}$ nejčastěji prováděným kardiochirurgickým výkonům patří náhrada aortální chlopně, aortokoronární bypass nebo kombinovaný výkon. Pro nepříznivé demografické rozložení obyvatel dochází $\mathrm{k}$ posunu věku, kdy nemocní podstupují náhradu aortální chlopně, do 8. až 9. dekády života. V práci se zabýváme retrospektivním studiem kvality života souboru přes 100 osob starších 78 let, kterým byla provedena náhrada aortální chlopně na Kardiochirurgické klinice ve Fakultní nemocnici v Hradci Králové v intervalu let 2000-2005, žijících v době zpracování výsledků studie. Základním cílem šetření bylo modifikovaným dotazníkem kvality života získat od těchto nemocných informace o jejich stescích před operací a po operaci (s rozborem četnosti výskytu typických symptomů), jejich spokojenosti se zdravotním stavem po operaci, informace o nutnosti rehospitalizace pro kardiální obtíže, o spokojenosti s pooperační ambulantní péčí a v neposlední řadě data o spektru chronické medikace. Vedlejším cílem bylo sledování typu implantované náhrady do aortální pozice, četnosti a druhu komplikací operace, četnosti a druhu eventuálně současně provedeného jiného výkonu (např. koronární revaskularizace, implantace kardiostimulátoru) a Euro Score rizika. Jak je $z$ literatury doloženo, náhrada aortální chlopně je výkon, který při respektování indikací prodlužuje život pacientům s hemodynamicky významnou valvulopatií, což platí i pro staré nemocné (s vyšší udávanou morbiditou a mortalitou než u mladších). Naše práce dokazuje, že i z hlediska kvality života, jakožto subjektivního hodnotícího parametru, jde o výkon, který má své místo u starých nemocných.

\section{HODINOVÉ AMBULANTNÍ MONITOROVÁNÍ KREVNÍHO TLAKU U PACIENTŮ PO TERAPII NÁDOROVÉHO ONEMOCNĚNÍ*}

NOVÁKOVÁ Z, ZÁVODNÁ E, HONZÍKOVÁ N, HRSTKOVÁ H, FIŠER B, ŠT̃ASTNÁ J, KRONTORÁDOVÁ K

Lékařská fakulta, Fyziologický ústav, MU, 1. dětská interní klinika, FN Brno, pracoviště Dětská nemocnice, 1. dětská interní klinika FDN, FN Brno, Brno

*Podpořeno granty: IGA MZ č. NR 8006-3 a VVZ MŠMT č.0021622402.

Úvod: Antracyklinová antibiotika jsou běžně užívanými léky volby pro léčbu dětských hematologických malignit i přes svoje vedlejší účinky - kardiotoxicitu a interakce s autonomním nervovým systémem.

Cíl studie: Porovnání 24hodinových profilů krevního tlaku (ABPM) pacientů 4-16 let po léčbě antracykliny a zdravých stejně starých kontrol.

Soubor a metodika: Vyšetřili jsme 110 dětí, dospívajících a mladých dospělých. Hodnoty ABPM pacientů s diagnózou akutní lymfoblastická leukémie (skupina A, počet vyšetřených, $\mathrm{n}=45$ ), kteří prodělali léčbu antracykliny (prưměrná doba od konce terapie po provedení $\mathrm{ABPM}=9,7 \pm 3,1$ let, kumulativní dávka antracyklinů $=227 \pm 42 \mathrm{mg} / \mathrm{m}^{2}$ ) byly srovnány s hodnotami zdravých dětských dobrovolníků z řad studentů brněnských gymnázií a vysokých škol (skupina $Z$, $\mathrm{n}=65$ ). Soubor byl rozdělen do tř́ podskupin podle věku:13-15 let ( $A: n=10 ; Z: n=9$ ), $16-18$ let $(A: n=20$; $Z: \mathrm{n}=33$ ) a $19-21$ let (A: $\mathrm{n}=15 ; Z: \mathrm{n}=23$ ). ABPM bylo provedeno př́ístrojem firmy Space Lab International standardní metodikou. Měření probíhala v $15 \mathrm{~min}$ intervalech $\mathrm{v}$ denních a ve $20 \mathrm{~min}$ intervalech $\mathrm{v}$ nočních hodinách. Byly hodnoceny průměrné hodnoty a směrodatné odchylky $z$ každé hodiny.

Výsledky: Našli jsme statisticky významný rozdíl mezi skupinami $A$ a $Z$ ve večerních a nočních hodinách (mezi 20:00 až 2:00 hod.) ve věkové podskupině 19-21 let, a to jak v systolickém (STK), tak diastolickém (DTK) krevním tlaku. Průměrná hodnota za těchto 7 hodin byla: STK - A: 104,6 $\pm 9,3 \mathrm{~mm} \mathrm{Hg}, Z: 117,8 \pm 12,3 \mathrm{~mm} \mathrm{Hg}, p<0,01$; DTK - A: $58,2 \pm 7,2 \mathrm{~mm} \mathrm{Hg}, \mathrm{H}: 67,7 \pm 10,4 \mathrm{~mm} \mathrm{Hg}, p<0,01$.

Závěr: I několik let po léčbě antracykliny převažují v nočních hodinách u mladých dospělých nižší hodnoty krevního tlaku než u stejně starých zdravých jedinců. Tato okolnost naznačuje narušení sympatické nervové aktivity antracyklinovou léčbou.

\section{ZÁTĚŽOVÉ VYŠETŘENÍ DĚTÍ A ADOLESCENTŮ PO PRODĚLANÉ PROTINÁdOROVÉ TERAPII ANTRACYKLINY*}

NOVÁKOVÁ Z, KRONTORÁDOVÁ K, HRSTKOVÁ H, ŠŤASTNÁ J, ELBL L, TOMÁŠKOVÁ I, HONZİKOVÁ N, FIŠER B, ZÁVODNÁ E

Lékařská fakulta, Fyziologický ústav, MU,

1. dětská interní klinika, FN Brno, pracoviště FDN, 1. dětská interní klinika, FN Brno, pracoviště Dětská nemocnice, Oddělení funkčního vyšetřování, FN Brno, Brno

*Podpořeno MSM 0021622402.

Úvod: Cílem studie byla analýza kardiovaskulárních parametrů během bicyklové ergometrie $u$ bývalých onkologických pacientů a zdravých dětí a adolescentů.

Soubor a metodika: Vyšetřili jsme 19 pacientů ve věku $16,2 \pm 2,2$ let léčených v minulosti protinádorovou léčbou antracykliny (akutní lymfoblastická leukémie, 8,3 \pm 3,2 let po ukončení léčby) a 19 zdravých dětí. Kontroly byly náhodně vybrány ze souboru 60 zdravých dobrovolníků vyšetřených ve školách $\mathrm{v}$ Brně párovaně podle věku, $\mathrm{v}$ poměru $1: 1$. Při testování na ergometru jsme použili stupňovanou zátěž v krocích po $25 \mathrm{~W} / 2$ min do vyčerpání. Analyzovali jsme klidové hodnoty ejekční frakce, systolického a diastolického krevního tlaku a tepové frekvence a tytéž parametry bezprostředně po ukončení testu současně $\mathrm{s}$ ukazateli zátěže (pVO2 $\mathrm{v} \mathrm{ml} / \mathrm{min}$ a $\mathrm{pVO} 2 \mathrm{v} \mathrm{ml} / \mathrm{min} / \mathrm{kg}$; maximální tolerovanou zátěž ve $\mathrm{W}$ a maximální tolerovanou zátěž ve $\mathrm{W} / \mathrm{kg}$ ). Dále byly stanoveny klidové hodnoty citlivosti baroreflexu dané spektrální metodou z pětiminutového záznamu krevního tlaku (Finapres) jako indexu autonomní regulace krevního tlaku (BRS, ms/mm Hg; BRSf $\mathrm{Hz} / \mathrm{mm} \mathrm{Hg}$ ).

Výsledky: Skupiny pacientů a kontrol se nelišily ani v klidových hodnotách základních oběhových parametrů ani během zátěžového testu. Signifikantně se lišil rozptyl hodnot maximální tolerované zátěže a maximální tolerované zátěže na $\mathrm{kg}$ tělesné hmotnosti ( $p<0,05, F$-test).

Závěr: Ačkoliv jsme nalezli rozdíl v rozptylu hodnot tolerované zátěže mezi pacienty a kontrolami, nenašli jsme rozdíly mezi průměry sledovaných hodnot. To ukazuje na skutečnost, že u většiny pacientů po prodělané léčbě antracykliny není ovlivněna fyzická výkonnost. 


\section{DIAGNOSTIKA PLICNI EMBOLIE NA PODKLADĚ SPIRÁLNÍ CT ANGIOGRAFIE PLIC}

\section{NOVOTNÁ M}

Interní oddělení, Karlovarská krajská nemocnice a. s., Karlovy Vary

Cílem práce je posoudit vyloučení nebo potvrzení konečné diagnózy akutní plicní embolie provedením spirální CT-angiografie plic u pacientů se suspektní plicní embolií na podkladě rizikových faktorů, klinických přínaků plicní embolie a paraklinických vyšetření v období 1. 1. 200331. 12. 2006 na interním oddělení Karlovarské nemocnice, kde bylo 3. 12. 2002 instalováno spirální CT (CT Philips Mx $8000 q$ s čtyřřadým detektorem).

Soubor a metodika: V období 1. 1. 2003-31. 12. 2006 bylo u 630 pacientů ( 384 žen, 246 mužů) provedeno CTA plicní vyšetření. U 95 pac. (15 \%) - 58 žen a 37 mužů byla diagnostikována plicní embolie. Údaje byly statisticky vyhodnoceny a srovnány s údaji uvedenými v literatuře.

Výsledky: V souboru 95 pac. s diagnostikovanou PE byly $z$ rizikových faktorů přitomny - osobní anamnéza TEN u 9 pac. $(9,5 \%)$, žilní insuficience u 7 pac. $(7,4 \%)$, operace u 14 pac. $(14,8 \%)$, malignita u 11 pac. $(11,6 \%)$, trauma u 7 pac. (7,4\%), imobilita u 1 pac. (1,1\%), hormonální ATC u 4 pac. (4,2 \%). $Z$ klinických příznaků PE byly prrítomny - dušnost u 65 pac. (68,4 \%), bolesti na hrudi u 29 pac. (30,5 \%), kašel u 11 pac. (11,6\%), synkopa u 7 pac. $(7,4 \%)$, slabost u 13 pac. (13,7\%), hemoptýza u 2 pac. $(2,1 \%)$. Z objemových příznaků PE byly př́tomny - tachykardie u 26 pac. (27,4 \%), hypotenze u 14 pac. $(14,7 \%)$, otoky DK u 13 pac. $(13,7 \%)$. Z paraklinických vyšetření EKG provedeno u $100 \%$ pac. - EKG-známky PE u 44 pac. (46,3 \%), RTG snímek plic proveden u 66 pac. (70 \%), známky PE př́tomny u 58 pac. (87\%). TTE provedeno u 72 pac. $(75 \%)$ - u 34 pac. (47\%) dilatace PK, systolická dysfunkce PK u 17 pac. (23,6 \%), Tři insuficience u 22 pac. $(30,6 \%)$, známky plicni hypertenze u 27 pac. (37,5\%). Duplexní sono žil DK provedeno u 19 pac. (20\%), z toho diagnostikováno FT u 13 pac. $(68,4 \%)$. D-dimery odebrané u 70 pac. $(73,7 \%)$, zvýšené hodnoty ve $100 \%$, cTpT odebraný u 50 pac. $(52,6 \%$ ), zvýšené hodnoty u 23 pac. $(24,2 \%)$, vyšetření $A B R$ u 20 pac. (21\%), známky hypoxemie u 10 pac. (50 \%).

Závěr: Spirální CT v naší nemocnici umožňuje 24hodinovou dostupnost na rozdíl od scintigrafického vyšetření, navíc je lokalizováno ve stejné budově, ve které se nachází interní oddělení.

\section{MUTAČNÍ ANALÝZA KANDIDÁTNÍCH GENŨ SCN1B, KCND3 A ANK2 U PACIENTÜ S KLINICKOU DIAGNÓZOU SYNDROMU DLOUHÉHO INTERVALU QT*}

NOVOTNÝ T, RAUDENSKÁ M, BITTNEROVÁ A, FLORIÁNOVÁ A, CHROUST K, GAILLYOVÁ R, SEMRÁD B, KADLECOVÁ J, ŠIŠÁKOVÁ M, ŠPINAR J

Interní-kardiologická klinika, FN Brno, Katedra genetiky a molekulární biologie, Př́rodovědecká fakulta MU, Oddělení lékařské genetiky, FN Brno, Katedra genetiky a molekulární biologie, MU, Brno

*Výzkum byl podpořen grantem IGA MZ č. 8063-3.

Úvod: Příčinou syndromu dlouhého intervalu QT (LQTS) jsou zhruba u 50-60\% pacientů mutace genů pro srdeční iontové kanály (KCNQ1, KCNH2, SCN5A, KCNE1, KCNE2). U ostatních zůstává etiologie nejasná.

Cíl studie: Ověření hypotézy o účasti jiných kandidátních genů $\mathrm{v}$ patofyziologii LQTS: geny SCN1B a KCND3 kódují proteiny iontových kanálů, gen ANK2 kóduje cytoskeletární protein interagující s iontovými kanály.

Metody: Soubor byl tvořen 12 pacienty s klinickou diagnózou LQTS bez nálezu mutace $\mathrm{v}$ základním souboru genů (KCNQ1, KCNH2, SCN5A, KCNE1, KCNE2). Proto u nich byla provedena mutační analýza kandidátních genů SCN1B, KCND3 a 10 exonů genu ANK2. Mutační analýza byla prováděna standardními metodami: PCR, SSCP a DNA sekvenování.

Výsledky: Celkem bylo nalezeno 5 polymorfismů, $2 \mathrm{v}$ genu KCND3 a 3 v genu SCN1B. Žádná z těchto změn sekvence DNA nevedla ke změně sekvence aminokyselin ani se nenacházela $\mathrm{v}$ blízkosti míst sestřihu. Polymorfismus G246T v genu SCN1B dosud nebyl v literatuře popsán.

Závěry: Nebyla nalezena žádná mutace s možným kauzálním vlivem na rozvoj obrazu LQTS. Molekulární mechanismus syndromu zůstává u těchto pacientů nejasný.

\section{MÉNĚ OBVYKLÉ PŘíčINY KORONÁRNÍ NEMOCI ANEB NEMYSLEME JEN NA ATEROSKLERÓZU}

NYKL I, BRANNY M, ČERNÝ J, INDRÁK J, JANUŠKA J, VODZINSKÁ A

Kardiologické oddělení, Kardiocentrum, Podlesí a. s., Třinec

Úvod: Koronární nemoc je obecně až příliš vnímána jako jen projev aterosklerózy (AS). Proto nás někdy až překvapí pacienti (pt) s koronárními syndromy a patologií způsobenou neaterosklerotickými (non-AS) příčinami koronární nemoci. Koronární intervence $\mathrm{v}$ těchto situacích mohou být oproti klasické příčině AS komplikovanější.

Cíl: V souboru pt vyšetřených koronarograficky (SKG) a v kontextu s literárními údaji upozornit na výskyt a základní klinickou problematiku non-AS koronárních patologií.

Soubor a metodika: Retrospektivní analýza souboru 9629 pt vyšetřených elektivně či akutně SKG v období 1/2005-12/2006 v Kardiocentru Třinec Podlesí.

Výsledky: Koronární nemoc či patologie zjištěna při SKG je minimálně v $95 \%$ AS původu. Non-AS př́činy se vyskytují u zhruba $5 \%$ pt a lze je rozdělit na 1 . vrozené koronární anomálie, 2. získané příčiny koronární nemoci. Vrozené koronární anomálie s výskytem u 0,5\% pt odeslaných $\mathrm{k}$ SKG můžeme dále dělit na ischemizující (klinicky nejzávažnější je anomální odstup ACS z ACD - výskyt u 0,08 \%o SKG), potenciálně ischemizující (nejběžnější je myokardiální svalový můstek - u 8,5 \% SKG), neischemizující (nejběžnější je anomální ústí RCX z ACD či pravého sinu - u 0,67 \% SKG). Mezi získanými non-AS příčinami se vyskytují například vaskulitidy (Takayasu), koronární disekce (spontánní, posttraumatické), iatrogenní poškození RCX po implantaci mitrálního ringu, embolizace do koronárních arterií, koronární aneuryzma. Zcela specifickou jednotkou je Tako-tsu-bo kardiomyopatie.

Závěr: Non-aterosklerotické příčiny koronární nemoci či koronárních syndromů se vyskytují až u $5 \%$ pt vyšetřených SKG. Některé mají závažný klinický význam. I velmi mladý člověk bez AS může být proto závažně koronárně nemocný. Přítomnost i prosté neischemizující vrozené koronární anomálie může komplikovat provádění intervencí PCI.

\section{SESTERSKÁ SEKCE}

\section{DETEKCE DEPRESE V KATETRIZAČNÍ LABORATOR̆I POMOCÍ BECKOVY STUPNICE PRO HODNOCENÍ DEPRESE}

ONDRÁČKOVÁ M, ŠKVAŘILOVÁ M, VLKOVÁ M, KVAPILOVÁ V, DRTINOVÁ E, KLESLOVÁ L, ZEMANOVÁ J 
Katetrizační laboratoř, Karlovarská krajská nemocnice a. s., Karlovy Vary

Úvod: Tato přednáška navazuje na přednášku o detekci depresivní a úzkostné nebo depresivní symptomatiky u nemocných podstupujících diagnostickou selektivní koronarografii pomocí krátké verze dotazníku PHQ.

Cíl studie: Detekce úzkostní nebo depresivní symptomatiky nemocných přijatých ke koronarografii pomocí Beckovy stupnice deprese. Zjistit srozumitelnost otázek, příp. potřebu spolupráce při vyplňování se sestrou nebo lékařem. Vyhodnotit časovou náročnost pro sestru nebo lékaře.

Výsledky: Tento typ dotazníku vyžadoval spolupráci se sestrou nebo lékařem jen malého procenta nemocných. Většina položených otázek i jejich hodnocení byla pro nemocné srozumitelná. Po vysvětlení smyslu dotazníku nám žádný nemocný neodmítl jeho vyplnění. Hodnocení dotazníku je velmi jednoduché a trvá méně než 1 minutu. Tímto dotazníkem jsme detekovali $7 \%$ těžkých forem deprese s úvahou o sebevraždě. Těmto nemocným byla nabídnuta psychiatrická léčba.

Závěr: Vyplnění tohoto jednoduchého dotazníku považujeme za časově nenáročný a vhodný k aktivnímu vyhledávání depresí ohrožených kardiaků, zejména na pracovištích s vysokým počtem nemocných. Další léčba a sledování vyžaduje spolupráci s psychiatrem.

\section{OBĚHOVÁ KOMPENZACE A HODNOTA BNP KARDIAKA PR̆I PR̆IJETÍ A PR̆I UKONČENÍ HOSPITALIZACE}

\section{ORAL I, MISTRÍK J, NÁPLAVA R}

Oddělení intenziuní péče, Nemocnice Hranice a. s., Hranice, Interní klinika IPVZ, Krajská nemocnice T. Bati, Zlín

Úvod: Hodnota BNP je užívána jako diagnostický i prognostický marker pro pacienty se srdečním selháním. Zvažuje se řízení léčby srdečního selhávání podle hodnot BNP.
Výsledky: U všech nemocných došlo k normalizaci fyzikálního nálezu. Ostatní výsledky v tabulkách.

Závěr: V průběhu léčby dochází ke statisticky významnému poklesu BNP. I přes úpravu klinického obrazu a subjektivních pocitů však zůstává hodnota BNP při propuštění jednoznačně patologická. „Normalizace fyzikálního nálezu“ zřejmě neznamená jednoznačnou „oběhovou kompenzaci“ pacienta. Pacienti s první atakou dekompenzace mají ve srovnání s pacienty s opakovanou dekompenzací při přijetí nižší hodnotu BNP při výraznějších subjektivních obtížích jak při přijetí, tak při propuštění. K posouzení prognózy bude zřejmě vhodný odběr BNP v době subjektivního optima pacienta podle dotazníku.

\section{VZTAH MEZI PATOLOGICKOU HODNOTOU BNP PR̆I AKUTNÍ SRDEČNÍ DEKOMPENZACI A RIZIKEM DALŠÍHO SRDEČNÍHO SELHÁNÍ A ÚMRTÍ NA SRDEČNÍ SELHÁNÍ V PRŨBĚHU NÁSLEDUJÍCÍCH 2 LET}

\section{ORAL I, MISTRÍK J, NÁPLAVA R}

Oddělení intenzivní péče, Nemocnice Hranice a. s., Hranice, Interní klinika IPVZ, Krajská nemocnice T. Bati, Zlín

Úvod: Hodnota BNP je již standardně užívána jako diagnostický marker pro průkaz srdečního selhávání. Užití hodnoty BNP jako dlouhodobého prognostického markeru pro recidivu srdečního selhání a pro úmrtí $z$ důvodu srdečního selhání, je zatím ve stadiu prospektivního sledování souborů.

Soubor a metodika: 146 pacientů hospitalizovaných v první polovině roku 2004 pro akutní srdeční selhání (ICHS, hypertenze, chlopenní vada), sledováno prospektivně po dobu 2 let (do konce roku 2006). Vstupní diagnóza stanovena za základě klinického obrazu a zvýšené hodnoty BNP při přijetí (BNP > $100 \mathrm{pg} / \mathrm{ml}$ ). Posuzován vztah mezi hodnotou BNP při přijetí, echokardiografickým nálezem a další hospitalizací nebo úmrtím v průběhu následujících 2 let.

Tabulka I k abstraktu MUDr. Orala: Oběhová...

\begin{tabular}{|c|c|c|c|c|c|c|c|}
\hline Všichni & BNP & Kondice & Dušnost & LKd mm & EF \% & LS mm & TO ml \\
\hline Vstup & 1066 & $45 \%$ & $43 \%$ & 55,1 & 47 & 45 & 70,5 \\
\hline Propuštění & 601 & $77 \%$ & $80 \%$ & 55,0 & 49 & 44 & 71,2 \\
\hline$t$-test & $p<0,002$ & $p<0,000004$ & $p<0,000002$ & NS & NS & NS & NS \\
\hline
\end{tabular}

Tabulka II k abstraktu MUDr. Orala: Oběhová...

\begin{tabular}{|c|c|c|c|c|c|c|}
\hline Ataka & BNP vstup & BNP propuštěni & Kondice vstup & Kondice propuštěni & Dušnost vstup & $\begin{array}{c}\text { Dušnost } \\
\text { propuštěn }\end{array}$ \\
\hline První (32) & 930 & 610 & $27,5 \%$ & $57,5 \%$ & $13 \%$ & $77 \%$ \\
\hline Opakovaná (76) & 1279 & 599 & $50,0 \%$ & $80,0 \%$ & $45 \%$ & $80 \%$ \\
\hline
\end{tabular}

Soubor a metodika: 108 pacientů s akutním srdečním selháním (ICHS, hypertenze, chlopenní vada). Vyšetřen BNP, ECHO a fyzikální nález při vstupu a při propuštění, graficky znázorněn v \% pocit kondice a dušnosti.
Výsledky: V průběhu sledování zemřelo celkem 42 nemocných, 104 pacientů přežilo. Rehospitalizováno bylo celkem 94 nemocných, z toho do 1 roku 58 nemocných, do 2 let 36 nemocných. 52 nemocných bylo bez rehospitalizace.

Tabulka k abstraktu MUDr. Orala: Vztah...

\begin{tabular}{|c|c|c|c|c|}
\hline Skupina & BNP (pg/ml) & Skupina & BNP (pg/ml) & T-TEST \\
\hline Rehospitalizováno & 1083 & Nerehospitalizováno & 740 & $p<0,043$ \\
\hline Rehospitalizováno do 1 roku & 1295 & Rehospitalizováno po 1 roku & 612 & $p<0,014$ \\
\hline Nerehospitalizováno & 740 & Rehospitalizováno po 1 roku & 612 & $p<0,62$ \\
\hline Žijící & 927 & Zemřelí & 1045 & $p<0,46$ \\
\hline Rehospitalizováno, žijící & 1113 & Rehospitalizovano, zemřelí & 1045 & $p<0,73$ \\
\hline
\end{tabular}


Průměrné hodnoty BNP s porovnáním jednotlivých skupin přináší tabulka.

Závěr: BNP u pacientů, rehospitalizovaných do 1 roku, bylo statisticky významně vyšší než BNP rehospitalizovaných po 1 roce a nerehospitalizovaných. Překvapivě nebyl významný rozdíl $\mathrm{v}$ hodnotách BNP mezi přeživajícími a zemřelými.

Z echokardiografických parametrů byl prokázán statisticky významný rozdíl mezi diastolickým rozměrem levé komory a ejekční frakcí levé komory u nemocných s rehospitaizaací a bez ní $(p<0,005)$, resp. $(p<0,075)$.

\section{VYŠŠÍ AKTIVITA KREVNÍCH DESTIČEK JE PR̆ÍTOMNA U PACIENTU゚ S ISCHEMICKÝMI KOMPLIKACEMI PO PCI VE SROVNÁNÍ S PACIENTY S ISCHEMICKÝMI KOMPLIKACEMI PO CABG*}

OSMANČÍK P, BEDNÁŘ F, ŠTROS P, MÓCIKOVÁ H, JIRÁSEK K, WIDIMSKÝ P

III. interní-kardiologická klinika, FN KV a 3. LF UK Oddělení klinické hematologie, FN KV, Praha

*Podpořeno grantem VZ č. MSMO021620817.

Cíl: Krevní destičky hrají významnou roli jak v patogenezi akutních koronárních syndromů, tak v progresi aterosklerózy. Jejich role $\mathrm{v}$ patogenezi ischemických komplikací je téměř automaticky předpokládána, přesná data o jejich roli v této oblasti jsou ř́dká. Cílem práce proto bylo porovnat aktivitu krevních destiček u pacientů s ischemickými komplikacemi po dvou typech revaskularizačních procedur: $\mathrm{u}$ pacientů $\mathrm{s}$ uzávěrem bypassu po kardiochirurgické operaci a s restenózou po perkutánní koronární intervenci.

Soubor a metodika: Bylo vyšetřeno celkem 45 pacientů. Jednalo se o 15 pacientů $\mathrm{s}$ nejhorší průchodností bypassů ze studie PRAGUE-4 (našito 47 aortokoronárních štěpů, 72,3 \% štěpů uzavřených při roční koronarografické kontrole), 15 pacientů $s$ nejlepší průchodností štěpů ze studie PRAGUE-4 (51 štěpů, $100 \%$ průchodných) a 15 pacientů s restenózou ve stentu. Krevní odběry byly provedeny alespoň 4 týdny po kontrolní koronarografii, $v$ prrípadě prováděné PCI nejméně 4 týdny po ní. Žádný $\mathrm{z}$ pacientů nebyl v době krevních odběrů na duální protidestičkové léčbě. Destičková aktivita byla stanovena membránovou expresí CD62P antigenu průtokovou cytometrií (\% CD62P pozitivních destiček), agregace pomocí ADP-aggregometrie.

Výsledky: Všechny tři skupiny byly srovnatelné věkem, přítomností diabetu, ejekční frakcí levé komory. Membránová exprese $\mathrm{CD} 62 \mathrm{P}$ byla vyšší ve skupině pacientů $\mathrm{s}$ restenózou ve srovnání s ostatními dvěma skupinami $(1,96+0,07$ vs. $0,77+0,03$ vs. $0,57+0,03$ ). Membránová exprese CD62P se ovšem již nelišila mezi pacienty s uzavřenými a průchodnými bypassy. ADP-aggregometrie nebyla rozdílná mezi třemi skupinami.

Závěr: Destičková aktivita je vyšší u pacientů s restenózou po PCI ve srovnání s pacienty s uzávěry bypassu. Krevní destičky hrají významnější roli v patogenezi ischemických komplikací po PCI než po CABG.

SESTERSKÁ SEKCE

\section{ARYTMICKÉ BOUR̆E SPOUŠTĔNÉ BIVENTRIKULÁRNÍ STIMULACÍ U PACIENTA S IDIOPATICKOU DILATAČNÍ KARDIOMYOPATIÍ. KASUISTIKA}

OSTRIHOŇOVÁ J, FIŠEROVÁ V, ŠACHOVÁ K, WEINZETTLOVÁ $Z$

Klinika kardiologie, IKEM, Praha
Kasuistika: 62letý nemocný s idiopatickou dilatační kardiomyopatií (DKMP) a chronickou fibrilací síní po neselektivní ablaci AV junkce a implantaci kardiostimulátoru v roce 1998 , byl vyšetřován v 2/2004 pro symptomatické běhy monomorfní komorové tachykardie (KT) s frekvencí 165/min. Při elektrofyziologickém vyšetření byly vyvolány dvě KT. Jedna pocházející z výtokového traktu levé komory (LVOT) a druhá charakteru reentry o fr. 180/min. Pacient byl zajištěn ICD. Po implantaci přístroje byly problémem recidivy pomalé KT pod detekční hranicí ICD a progrese srdeční insuficience. V 6/2004 bylo provedeno rozšíření stimulace na biventrikulární systém (BiV), kdy byla levokomorová elektroda umístěna v anterolaterální žíle. BiV stimulace spouštěla běhy nesetrvalé KT z LVOT. Po přechodném vypnutí došlo ke stabilizaci stavu po zvýšení dávky betablokátorů a zvýšení frekvence stimulace na $75 / \mathrm{min}$. V odstupu 14 dnů byl pacient přijat pro sérii výbojů z ICD (22 během 24 hod.) pro běhy KT o fr. 180/min, které byly spouštěny při BiV stimulaci. Při elektroanatomickém mapování byl lokalizován fokální zdroj pomalé KT, pocházející z LVOT a následně při programované stimulaci komor ještě vyvolána KT o fr. 182/min odlišné morfologie. Oba arytmogenní zdroje byly odstraněny radiofrekvenční ablací. Následně již nebyla žádná monomorfní KT při BiV stimulaci.

Závěr: U nemocných s DKMP se vyskytují KT jak fokálního původu, tak reentry typu. Jde o důsledek anisotropního vedení při fibróze myokardu. Případ dokumentuje proarytmický efekt BiV stimulace a možnosti řešení katetrizační ablací.

\section{SESTERSKÁ SEKCE}

\section{KLINICKÉ VYUŽITÍ ZÁTĚŽOVÉ ECHOKARDIOGRAFIE U NEMOCNÝCH BEZ ISCHEMICKÉ CHOROBY SRDEČNI**}

\section{OURODOVÁ R, VRBOVÁ M}

Interní kardiologická klinika, FN Bohunice, Brno

*Tato práce vznikla za podpory VVZ MŠMT 0021622402.

Cíl: Zátěžová echokardiografie (ZE) patří mezi specializované echokardiografické vyšetření, které je v první řadě indikováno v diagnostice ischemické choroby srdeční (ICHS). Autorky podávají přehled využití této metody $\mathrm{v}$ méně častých indikacích u pacientů bez diagnózy ICHS.

Problematika: Mezi neischemická poškození srdce, kdy využiváme ZE, patří stanovení závažnosti chlopenních vad, funkce umělých chlopní, posouzení funkce transplantovaného srdce, funkce srdce u myokarditid a kardiomyopatií. Samostatnou kapitolu tvoří testování funkce srdce u onkologických nemocných po kardiotoxické chemoterapii. K vyšetřování použiváme testy dynamickou i farmakologickou zátěží.

Závěr: Autorky vycházejí ze zkušeností vlastního pracoviště, kde je tato metoda $\mathrm{v}$ řadě indikací dlouhodobě prováděna. $Z E$ může $\mathrm{u}$ neischemického poškození myokardu významně ovlivnit př́istup lékařu $\mathrm{k}$ zahájení časné léčby srdečního selhání a $\mathrm{k}$ celému způsobu léčby nemocného. Navíc pracoviště rozšírilo indikační kritéria pro ZE na pediatrické pacienty, především s onkologickým onemocněním.

\section{EFEKT PLICNÍ ENDARTEREKTOMIE NA TÍŽI SEKUNDÁRNII TRIKUSPIDÁLNÍ REGURGITACE U JEDINCŮ S CHRONICKOU TROMBOEMBOLICKOU PLICNÍ HYPERTENZİ}

PALEČEK T, JANSA P, LINDNER J, HLUBOCKÁ $Z$, AMBROŽ D, ASCHERMANN M, LINHART A

II. interní klinika kardiologie a angiologie, II. chirurgická klinika kardiovaskulární chirurgie, VFN a 1. LF UK, Praha 
Úvod a cíl práce: Plicní endarterektomie (PEA) vede u operabilních jedinců $\mathrm{s}$ chronickou tromboembolickou plicní hypertenzí (CTEPH) k výraznému poklesu až normalizaci tlaku v plicnici a plicní vaskulární rezistence. Redukce tlakového přetížení vede časně po výkonu ke zmenšení pravé komory (PK) a zlepšení její systolické funkce. Změny morfologie PK navozené PEA mají vliv na významnost sekundární trikuspidální regurgitace (TR), která je u jedinců s CTEPH charakteristicky př́tomna.

Cíl práce: Zhodnotit velikost změny TR časně po provedení PEA.

Metody: 15 jedinců se symptomatickou CTEPH ( $48 \pm 14$ let, 11 mužů) bylo kompletně echokardiograficky vyšetřeno před provedením PEA a 2 týdny po provedení PEA. Systolický tlak v plicnici (PASP) byl odhadován $\mathrm{z}$ vrcholového gradientu TR. Velikost a funkce PK byly hodnoceny podle enddiastolického rozměru PK (PKEDD) a frakční změny plochy PK (PKFAC). Významnost TR byla posuzována kvalitativně na základě měření plochy barevného jetu TR a kvantitativně pomocí metody PISA $\mathrm{s}$ hodnocením efektivního regurgitačního ústí (ERO) a regurgitačního objemu (RV).

Výsledky: Dva týdny po PEA došlo k významnému poklesu PASP z $94 \pm 31 \mathrm{~mm} \mathrm{Hg}$ na $35 \pm 18 \mathrm{~mm} \mathrm{Hg}(p<0,001)$. PKEDD se výrazně zmenšil ze $47 \pm 6 \mathrm{~mm}$ na $31 \pm 5 \mathrm{~mm}$ a PKFAC signifikantně narostla $z \quad 0,22 \pm 0,08$ na $0,33 \pm 0,10$ (vše $p<0,001$ ). Plocha TR se významně zmenšila $z 13 \pm 4 \mathrm{~cm}^{2}$ na $5 \pm 4 \mathrm{~cm}^{2}(p<0,001)$. Rovněž byla zjištěna významná redukce $\operatorname{ERO}\left(0,38 \pm 0,12 \mathrm{~cm}^{2}\right.$ vs. $\left.0,16 \pm 0,08 \mathrm{~cm}^{2}\right)$ a $\mathrm{RV}$ $(60 \pm 22 \mathrm{ml}$ vs. $14 \pm 10 \mathrm{ml})$ (vše $p<0,001)$.

Závěry: K výraznému poklesu pravostranného tlakového přetížení se současným zlepšením funkce a morfologie PK dochází již časně po PEA. Tyto změny mají za následek významnou redukci tíže sekundární TR. Chirurgický výkon na trikuspidální chlopni není proto u nemocných se CTEPH podstupujících PEA, indikován.

\section{VLIV TĚLESNÉHO TRÉNINKU NA DIASTOLICKOU FUNKCI LEVÉ KOMORY U NEMOCNÝCH S ISCHEMICKOU CHOROBOU SRDEČNÍ}

PANOVSKÝ R, JURÁNEK P, MELUZÍN J, JANČÁR R, KINCL V, MÍFKOVÁ L, VÁRNAY F, CHLUDILOVÁ V, SIEGELOVÁ J, JANČÍK J

I. interní-kardioangiologická klinika, Klinika funkční diagnostiky a rehabilitace, FN u sv. Anny, Brno

Cíl: Zhodnotit změny diastolické funkce LK (levé komory srdeční) u pacientů s ICHS a řízeným tréninkovým programem.

Soubor pacientů a metodika: 25 nemocných s chronickou ICHS a absolvovaným 3měsíčním tréninkovým programem bylo retrospektivně po 1 roce sledování rozděleno do 2 skupin podle jejich fyzické aktivity po ukončení řízeného programu: skupina A - pacienti, kteří navázali intenzivní individuální aktivitou a skupina B - pacienti, kteří v tréninku nepokračovali.

Diastolická funkce LK byla hodnocena pomocí pulsní tkáňové dopplerovské echokardiografie. Byly stanoveny hodnoty časných diastolických rychlostí mitrálního anulu na septu (Ea sept), laterální (Ea lat), přední (Ea ant) a dolní stěně (Ea inf) levé komory. Celková diastolická funkce LK (Ea celk) byla hodnocena jako průměr časných diastolických rychlostí (Ea) všech hodnocených stěn u daného pacienta. Změny regionální a celkové diastolické funkce LK byly srovnávány v klidu a při maximální zátěži dobutaminem.

Výsledky: U 12 pacientů skupiny A došlo v klidu ke zvýšení rychlosti vlny Ea sept o $0,13 \mathrm{~cm} / \mathrm{s}$, Ea ant o $0,05 \mathrm{~cm} / \mathrm{s}$ a Ea inf o $0,34 \mathrm{~cm} / \mathrm{s}$, ke snížení rychlosti vlny Ea lat o $0,58 \mathrm{~cm} / \mathrm{s}$ a Ea celkové o $0,02 \mathrm{~cm} / \mathrm{s}$ (vše $p=$ NS). Př́i zátě- ži došlo ke snížení rychlosti vlny Ea sept o $0,03 \mathrm{~cm} / \mathrm{s}$ ( $p=\mathrm{NS}$ ), zvýšení rychlosti vlny Ea lat o $2,97 \mathrm{~cm} / \mathrm{s}(p<0,05)$, Ea inf o $1,84 \mathrm{~cm} / \mathrm{s}(p=\mathrm{NS})$, Ea ant o $2,65 \mathrm{~cm} / \mathrm{s}(p<0,05)$ a Ea celk o 1,86 cm/s $(p<0,05)$.

Ve skupině B došlo u 13 pacientů v klidu ke snížení rychlosti vlny Ea lat o $1,11 \mathrm{~cm} / \mathrm{s}$, Ea ant o $1,04 \mathrm{~cm} / \mathrm{s}$, Ea inf o $1,63 \mathrm{~cm} / \mathrm{s}$ (vše $p=\mathrm{NS}$ ) a Ea sept o $1,27(p<0,05)$, Ea celk o $1,26 \mathrm{~cm} / \mathrm{s}(p<0,05)$. Při zátěži došlo ke snížení rychlosti vlny Ea lat o 0,41 cm/s, Ea sept o $1,14 \mathrm{~cm} / \mathrm{s}$, Ea inf o 0,78 $\mathrm{cm} / \mathrm{s}$, Ea celk o $0,78 \mathrm{~cm} / \mathrm{s}$ (vše $p=\mathrm{NS}$ ) a Ea ant o 0,79 $\mathrm{cm} / \mathrm{s}(p<0,05)$.

Závěr: Byl zjištěn trend k příznivému ovlivnění parametrů diastolické funkce LK pravidelnou tělesnou aktivitou.

\section{REMODELACE LEVÉ KOMORY PO AKUTNÍM INFARKTU MYOKARDU JE OVLIVNËNA POLYMORFISMEM GENU PRO MMP-2*}

PAŘENICA J, GOLDBERGOVÁ-PÁVKOVÁ M, POLOCZEK M, ELBL L, KALA P, TOMAN O, NEUGEBAUER P, VYTISKA M, VAŠKŮ A, ŠPINAR J

Interní-kardiologická klinika, FN Brno, Brno

*Podpořeno grantem ČKS a VVZ MŠMT 0021622402.

Úvod: Remodelace LK po akutním IM je hlavní příčinou vedoucí ke srdečnímu selhání. Extracelulární matrix je tvořena prostorovou sítí makromolekulárních vláken. Matrix metaloproteinázy jsou enzymy, které ve fázi reparace infarktového ložiska odbourávají extracelulární matrix. Rozsáhlé odbourání ECM může vést $\mathrm{k}$ dilataci a remodelaci LK po AIM. Jednou $z$ cest ovlivňující aktivitu MMP jsou polymorfismy v promotorové oblasti genu pro MMP2.

Cíl: Prokázat vztah mezi čtyřmi polymorfismy v promotorové oblasti genu pro MMP2 (-1575 G/A, -1306C/T, -790T/G a $-735 \mathrm{C} / \mathrm{T})$ a remodelací LK po STEMI řešeném primární PCI.

Metodika: Do studie byli zařazení pacienti se STEMI léčení primární PCI. Všem pacientům bylo provedeno 3.-5. den echo srdce. Pacienti byli rozděleni podle EF LK $(<>50 \%), \operatorname{EDV}\left(<>125 \mathrm{~cm}^{3}\right), \mathrm{ESV}\left(<>55 \mathrm{~cm}^{3}\right), \mathrm{SV}\left(<>65 \mathrm{~cm}^{3}\right)$ vždy na 2 skupiny. Genotypy čtyř polymorfismů v promotorové oblasti genu pro MMP2 byly detekovány pomocí metod PCR a RFLP.

Výsledky: Dosud bylo vyhodnoceno 101 pacientů. Byly nalezeny rozdíly $\mathrm{v}$ zastoupení genotypu TT polymorfismu -790G/T v promotorové oblasti genu pro MMP2 mezi skupinami při rozdělení podle $\mathrm{EF}$. Ve skupině $\mathrm{s} \mathrm{EF}<50 \%$ bylo častější zastoupení genotypu TT $(p=0,05)$. Při rozdělení pacientů podle SV byly nalezeny rozdíly $\mathrm{v}$ zastoupení genotypu GT polymorfismu -790T/G v genu pro MMP2. Vyšší zastoupení této genetické varianty GT bylo ve skupině $\mathrm{s}$ nižší $\mathrm{SV}<65 \mathrm{~cm}^{3}(p=0,04)$. Mezi skupinami rozdělenými podle EDV a ESV nebyl zjištěn rozdíl v zastoupení polymorfismu $-790 \mathrm{~T} / \mathrm{G}$ v genu pro MMP2. Ani v př́padě ostatních polymorfismů v promotoru genu pro MMP2 nebyly nalezeny signifikantní odlišnosti mezi takto definovanými skupinami.

Závěr: Tato práce vůbec jako první naznačuje, že remodelace LK po AIM je mimo jiné ovlivněna polymorfismem -790T/G promotorové oblasti genu pro MMP2. Výsledky vyžadují další studium.

\section{INVAZIVNÍ ELEKTROFYZIOLOGIE U GERIATRICKÝCH NEMOCNÝCH}

\section{PAŘIIEEK P, HAMAN L, DUDA J, DOSTÁLOVÁ H}

I. interní klinika, FN Hradec Králové a LF UK, Hradec Králové 
Elektrofyziologické vyšetření srdce (EFV) a katetrizační ablace (KA) jsou v současné době standardními diagnostickými a terapeutickými metodami u nemocných s poruchami srdečního rytmu.

Cílem práce byla retrospektivní analýza výsledků u všech nemocných indikovaných $\mathrm{k}$ EFV a/nebo KA na pracovišti autorů v letech 1998-2006 s přihlédnutím na věk nemocných.

Soubor, který tvořilo celkem 2008 nemocných, byl rozdělen na skupinu A (nemocní $\leq 65$ let, $\mathrm{n}=1$ 429) a na skupinu B (nemocní > 65 let, $\mathrm{n}=579$ ). Ve skupině $\mathrm{B}$ byla KA provedena u 275 nemocných (126 žen a 149 mužů, průměrný věk 71 let). Trvání symptomů a počet užívaných antiarytmik se mezi skupinou A a B statisticky nelišil. Statisticky významný rozdíl mezi skupinami A a B byl v indikacích, a to $\mathrm{v}$ př́tomnosti akcesorní dráhy (23 vs. $4 \%$ ) a flutteru síní (19 vs. 36 \%). U ostatních tachyarytmií nebyly významné rozdíly př́tomny. Významný rozdíl mezi skupinou A a B nebyl nalezen ani v úspěšnosti KA (96,4 vs. $96,3 \%)$, v rekurenci arytmií po KA (2,8 vs. $3,2 \%)$ a ve výskytu komplikací (2,8 vs. $2,0 \%)$.

Geriatričtí nemocní představovali 29 \% všech nemocných indikovaných $\mathrm{k} \mathrm{EFV/KA,} \mathrm{přičemž} \mathrm{KA} \mathrm{byla} \mathrm{provedena} \mathrm{u} 48 \%$ z nich. Nejčastější indikací ke KA byla atrioventrikulární nodální reentry tachykardie a flutter síní, naopak přítomnost akcesorní spojky byla prokázána vzácně. Výsledky KA (úspěšnost, recidivy, komplikace) u nemocných ve věku nad 65 let se nelišily od výsledků KA u nemocných mladších.

\section{X-VÁZANÁ DILATAČNÍ KARDIOMYOPATIE $\checkmark$ DÚSLEDKU MUTACE GENU PRO DYSTROFIN (XP21)}

PAVELČÍKOVÁ H, TOMAN J, ŠPINAROVÁ L, HUDE P, KREJČÍ J, FAJKUSOVÁ L, VYTOPIL M

I. interní-kardiologická klinika, FN u sv. Anny, Neurologická klinika, FN Brno, Brno

Cíl: V souboru pacientů s idiopatickou dilatační kardiomyopatií (DKMP) vyhledat nemocné s mutací dystrofinového genu a současně pátrat po poškození kosterního svalstva těchto nemocných.

Metodika: Vyšetřeno bylo 50 pacientů (10 žen a $40 \mathrm{mu}$ žů), průměrný věk v době diagnózy DKMP byl 39,49 \pm 8,78 let, funkční klasifikace NYHA II-IV, EF LK 26, $12 \pm 8,41 \%$. Nemocní byli vyšetřeni kardiologicky (klinické vyšetření, laboratoř, EKG, RTG, ECHO, pravostranná katetrizace), neurologicky (klinické vyšetření, EMG) a byla provedena analýza promotoru Pm, prvního exonu a části prvního intronu metodou sekvenční analýzy DNA z leukocytů periferní krve. 35 pacientů podstoupilo biopsii $z \mathrm{~m}$. vastus lateralis, vzorky byly hodnoceny histologicky, histochemicky, imunohistochemicky a byla provedena analýza mRNA dystrofinového genu.

Výsledky: U 10 pacientů byla pozitivní rodinná anamnéza pokud jde o výskyt DKMP. Abnormní svalový nález byl u 24 pacientů, u 18 nemocných byl abnormní nález při hodnocení svalových biopsií. U 1 pacienta byl zjištěn deficit $\beta$-sarkoglykanu. Genetická analýza genu pro dystrofin odhalila patologický nález u 3 pacientů - delece exonu 2 transkriptu mRNA $z$ promotoru Pm, inzerce části 1. intronu transkriptu mRNA $z$ promotoru Pc a delece exonu 3 a části exonů 2 a 4 transkriptu mRNA $z$ promotoru Pm.

Závěr: Ve sledovaném souboru byli zachyceni 3 nemocní (6\%) s patologiemi v dystrofinovém genu, jehož mutace jsou zodpovědné za X-vázanou DKMP a svalové dystrofie. Pozitivní rodinná anamnéza výskytu DKMP byla zjištěna u 10 nemocných (20\%), což odpovídá literárním údajům o výskytu fami- liární DKMP (20-30 \%). V těchto případech se může jednat o mutace některých dalších genů vedoucích $\mathrm{k}$ rozvoji DKMP (gen pro laminA/C, actin, emerin, sarkoglykany a další).

\section{AMBULANTNÍ LÉČBA HLUBOKÉ ŽILNÍ TROMBÓZY}

PAVLAS I, KOLOŠOVÁ R, ZEMAN K, GISTINGER T, TALAFA V, MRÓZEK V

Interní oddělení, Nemocnice Frýdek-Místek p. o., Frýdek-Mistek

Hluboká žilní trombóza je časté onemocnění, jehož incidence stále narůstá. Ambulantní léčba akutní žilní trombózy představuje moderní způsob léčby, jehož zavedení do praxe umožnily nízkomolekulární hepariny. Má své nesporné výhody, ale i rizika. Předpokladem je přesná klinická, dopplerovská a laboratorní diagnostika, snadná možnost ambulantních kontrol, spolupráce nemocného a jeho zájem o tuto léčbu. Je indikována u trombózy bércových žil a při podezření na ni. Ambulantní léčba je možná, není-li důvod $\mathrm{k}$ nemocniční léčbě pro jiné onemocnění nebo celkový stav nemocného.

Za období 2004-2006 jsme dopplerovsky diagnostikovali 139 bércových žilních trombóz a $z$ nich zhruba polovina byla léčena ambulantně. $\mathrm{V}$ naší práci porovnáváme obě skupiny bércových trombóz - léčených ambulantně a za hospitalizace. Všímáme si rozdílností, počtů komplikací (například incidence krvácení, recidiv trombóz, vznik plicní embolie).

\section{HYPOPLAZIE KOMOR A JEJICH PRENATÁLNÍ DIAgNOSTIKA}

PAVLÍČEK J, GRUSZKA T

Dětské oddělení,

Městská nemocnice Ostrava, Ostrava

Cil: Zjistit výskyt významných srdečních vad (VSV) - hypoplazie levé a pravé komory v Moravskoslezském (MS) kraji, zhodnotit úspěšnost jejich prenatální detekce, posoudit rozhodování rodičů při prenatálně poznané vadě.

Soubor a metodika: VSV detekované prenatálně ve vlastní ambulanci a výsledky prenatálního screeningu VSV regionu MS kraje. Studie výskytu VSV a prenatální záchytnosti $z$ let 1999-2006.

Výsledky: V letech 1999-2006 se v regionu MS kraje vyskytlo prenatálně a postnatálně celkem 55 VSV s hypoplazií pravé nebo levé komory. U hypoplazie levé komory (syndrom hypoplastického levého srdce nebo komplexní vady $\mathrm{s}$ hypoplastickou levou komorou) bylo z celkového počtu 32 prenatálně poznáno 21 (65,6 \%). Hypoplazie pravé komory byla $z$ celkového počtu 23 prenatálně diagnostikována 16× (69,6 \%). Na grafech jsou uvedeny počty a procento poznaných vad v jednotlivých letech a ve srovnání s ostatními VSV a jejich prenatální záchytností. Souhrnně obě uvedené diagnózy tvoří $1 / 3$ všech prenatálních patologických nálezů. V našich podmínkách se rodiče u těchto VSV téměř vždy rozhodují pro ukončení gravidity (výjimky tvoří pozdní diagnostika po 24. týdnu, vícečetné těhotenství a některé hypoplazie pravé komory).

Závěry: Hypoplazie komor patři k prenatálně dobře diagnostikovatelným vadám ve druhém trimestru těhotenství a většina by měla být prenatálně poznána. V regionu MS kraje jsou prenatálně odhaleny $2 / 3$ těchto vad a je možné screening dále zlepšovat. Rodiče se téměř vždy u těchto typů vad rozhodují těhotenství ukončit. 


\section{AKUTNÍ A SUBAKUTNÍ INFEKČNÍ ENDOKARDITIDA. KASUISTIKA}

\author{
PAVLÍČKOVÁ I, NERADOVÁ R
}

Interní oddělení, Nemocnice Znojmo p. o., Znojmo

66letá pacientka přijata na chirurgické oddělení pro poranění kohoutem na pravé dolní končetině. Pro febrilie a narůstající CRP přeložena na interní oddělení. Bylo provedeno jícnové ECHO a stanovena diagnóza infekční endokarditis. $Z$ tohoto důvodu byla pacientka přeložena na interní JIP $\mathrm{k}$ monitoraci $\mathrm{FF}$.

Při přijetí pacientka febrilní, ležící, měla silné bolesti PDK, byl zaveden centrální žilní katetr a permanentní močový katetr. Během hospitalizace se opakovaně odebíraly hemokultury, byla nasazena nová ATB léčba, analgetika, podpora nutriční výživy - Nutridrink, následně parenterální výživa. Obden prováděny převazy PDK chirurgem. $\mathrm{V}$ počáteční fázi byla pacientka celkově upoutána na lůžko, neklidná. Sedmý den hospitalizace na interní JIP si pacientka s pomocí sedá na lůžku, sama jí. V průběhu další hospitalizace se př́jem potravy výrazně zlepšuje, pacientka vysazována do křesla, postupně snížena dávka analgetik i paranterální výživy, klesá hladina CRP. Asi po měsíci pacientka přeložena na standardní interní oddělení, kde je prováděna intenzivnější RHB. Převaz PDK prováděn denně zdravotní sestrou na oddělení. Přibližně po měsíci a půl pacientka propuštěna do domácího léčení.

Podrobný průběh hospitalizace a léčba na JIP jsou obsahem sdělení.

\section{KUMULATIVNÍ INCIDENCE TERAPIE IMPLANTABILNÍM KARDIOVERTEREM-DEFIBRILÁTOREM - DLOUHODOBÉ VÝSLEDKY Z JEDNOHO IMPLANTAČNÍHO CENTRA}

PAVLÍKOVÁ K, WICHTERLE D, ANGER Z, PŠENIČKA M, LINHART A

II. interní klinika kardiologie a angliologie,

Kardiostimulační oddělení, VFN a 1. LF UK, Praha

Cíl: Cílem práce bylo retrospektivně zhodnotit incidenci terapie implantabilním kardioverterem-defibrilátorem (ICD) $\mathrm{u}$ pacientů sledovaných $\mathrm{v}$ našem centru.

Metodika: Vyhodnocované údaje byly čerpány $z$ databáze ambulantních kontrol $\mathrm{s}$ pravidelně aktualizovaným časovým záznamem o proběhlých ICD terapiích (adekvátní/neadekvátní ATP - antitachykardický pacing a adekvátní/neadekvátní DEF - defibrilační výboj). Kumulativní incidence prvního adekvátního DEF a první adekvátní ICD terapie (ATP/DEF) byla hodnocena Kaplanovou-Meierovou analýzou a pomocí univariačního Coxova regresního modelu byl sledován vliv věku ( $>60$ let), šíře QRS (>120 ms) a EF LK (< 40 \%) na výskyt ICD terapie.

Výsledky: Celkem bylo zpracováno 220 pacientů s ICD (181 mužů) ve věku $63 \pm 13$ let. Indikace implantace byla u $96 \%$ pacientů sekundárně preventivní s následující distribucí základních diagnóz: ICHS (71,8\%), DKMP (13,2\%), jiná (15,0 \%). Průměrná EF LK byla $38,5 \pm 12,6 \%$ a šíře QRS komplexu $110 \pm 37$ ms. Medián doby sledování byl 23,7 měsíců (interkvartilové rozpětí 10,4-44,3 měsíců). Celkem bylo zaznamenáno 853 úspěšných a 42 neúspěšných adekvátních ATP, 230 úspěšných a 1 neúspěšný adekvátní DEF, 237 neadekvátních ATP a 39 neadekvátních DEF.
Kumulativní incidence adekvátního DEF po 2 a 4 letech sledování byla 30 a $39 \%$. Kumulativní incidence adekvátní ICD terapie (ATP/DEF) po 2 a 4 letech byla 45 a $58 \%$ (viz obrázek). Jediným multivariačním prediktorem první adekvátní ICD terapie byl věk > 60 let spojený s relativním rizikem 1,65 oproti věku $<60$ let $(\log$ rank $p=0,02)$. Signifikantně snížená EF LK ani rozšířený komplex QRS nebyly univariačními prediktory ICD terapie.

Závěr: Nárůst kumulativní incidence adekvátní ICD terapie se s časovým odstupem po implantaci progresivně zpomaluje, ale je stále patrný i po více než 4 letech. Jediným prediktorem časné adekvátní ICD terapie je věk nad 60 let.

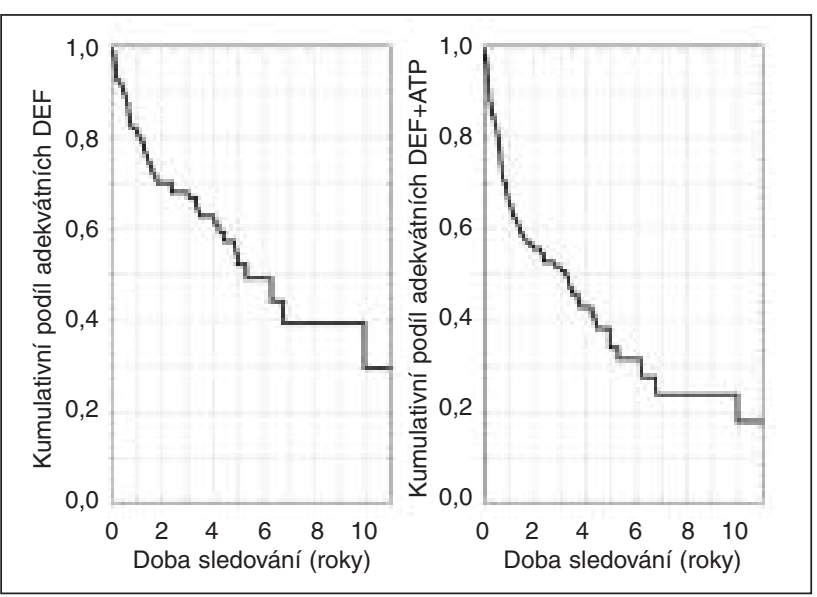

\section{LÉČBA PACIENTŮ PO KARDIOPULMONÁLNÍ RESUSCITACI NA KARDIOLOGICKÉ JIP*}

PECHMAN V, ROKYTA R, GAJDOŠ P, JÁGROVÁ L

1. interní klinika, kardiologická jednotka intenzivní péče, FN Plzeň, Plzeň

*Podpořeno Kardiovaskulárním VZ UK č. MSM 0021620817 „Invazivní př́stupy k záchraně a regeneraci myokardu“.

Úvod: Náhlá zástava oběhu má nejčastěji přičinu kardiální. Nemocní po kardiopulmonální resuscitaci (KPR) mají velmi nepř́iznivou prognózu s častým neurologickým deficitem a do domácího ošetř̌ování je jich propuštěno v uspokojivém stavu pouze $2-30 \%$.

Soubor pacientů: V období let 2005-2006 bylo na kardiologické JIP hospitalizováno 57 pacientů po protrahované KPR $\mathrm{s}$ přetrvávající poruchou vědomí při př́jimu na JIP.

Metodika: Retrospektivní analýza souboru pacientů se zaměřením na etiologii zástavy oběhu, anamnestické údaje (vstupní srdeční rytmus při zahájení KPR, nemocniční/mimonemocniční KPR), vyšetření (koronarografie), způsob léčby (aplikace léčebné hypotermie) a klinický výsledek nemocných.

Výsledky: Ze sledovaného souboru 57 pacientů (věk $67 \pm$ 12 let) bylo 47 (82\%) resuscitováno mimo nemocnici a 10 (18\%) v nemocnici. U 33 (58\%) pacientů byla vstupním srdečním rytmem komorová fibrilace, u 24 (42\%) pak asystolie/bezpulsová elektrická aktivita. Urgentní koronarografické vyšetření bylo indikováno u 36 pacientů. PCI byla provedena u 26 pacientů. Léčebnou hypotermii jsme aplikovali u všech pacientů, cílové teploty $32-34{ }^{\circ} \mathrm{C}$ bylo dosaženo u 37 pacientů. Do domácího ošetřování bylo v dobrém stavu bez významného neurologického či somatického deficitu (Glasgow outcome score 4-5) propuštěno 27 (47\%) nemocných.

Závěr: Komplexní poresuscitační péčí lze významně ovlivnit jinak velmi nepř́żnivou prognózu pacientů po KPR. Nemocní léčeni na KJIP dosahovali lepšího klinického výsledku 
při porovnání s literárními údaji i proto, že se jednalo o selektovanou skupinu pacientů.

\section{KATETRIZAC̆NÍ ABLACE KOMOROVÝCH TACHYKARDIÍ U PACIENTŮ S ICHS A DOBROU FUNKCÍ LEVÉ KOMORY: DLOUHODOBÉ VÝSLEDKY}

\section{PEICHL P, ČIHÁK R, BYTEŠNÍK J, KAUTZNER J}

Klinika kardiologie, IKEM, Praha

Úvod: Pacienti s ischemickou chorobou srdeční (ICHS), hemodynamicky tolerovatelnými monomorfními komorovými tachykardiemi (KT) a zachovalou systolickou funkcí levé komory (EF LK > 40 \%) mohou profitovat $\mathrm{z}$ katetrizační ablace KT bez nutnosti implantace kardioverteru-defibrilátoru (ICD). Cílem práce bylo retrospektivně analyzovat dlouhodobé výsledky katetrizační ablace KT u této skupiny pacientů.

Metody: Z celkového počtu 265 katetrizačních ablací KT, které byly provedeny na našem pracovišti od ledna 2001 do června 2006, bylo nalezeno 10 pacientů s ICHS, EF LK > $40 \%$ a dokumentovaným paroxyzmem tolerované KT (všichni muži, průměrný věk $71 \pm 7$ let). Průměrná EF LK byla $47 \pm 8 \%$, průměrná frekvence komorové tachykardie byla $175 \pm 30 / \mathrm{min}$. Ablace byla provedena ve všech př́i padech pomocí elektroanatomického mapovacího systému (CARTO, Biosense-Webster, Izrael).

Výsledky: Katetrizační ablací byla klinická KT odstraněna ve všech případech $\mathrm{s}$ výjimkou jednoho pacienta. Po výkonu byl u 2 pacientů implantován ICD vzhledem k vyvolatelnosti dalších morfologií netolerovaných KT. Během sledování $26 \pm 17$ měsíců nebylo zaznamenáno žádné náhlé úmrtí, jeden pacient zemřel z nekardiální příčiny. U jednoho pacienta došlo $\mathrm{k}$ recidivě klinické $\mathrm{KT}$, která byla úspěšně odstraněna reablací. U pacientů s implantovaným ICD nebyly v paměti přístroje zaznamenány žádné epizody KT.

Závěr: Výskyt setrvalých monomorfních komorových tachykardií u pacientů s ICHS a dobrou funkcí levé komory srdeční je nízký. U většiny těchto pacientů však lze komorové tachykardie úspěšně odstranit katetrizační ablací bez nutnosti následné implantace kardioverteru-defibrilátoru.

\section{ACTINOBACILLUS ACTINOMYCETEMCOMITANS - TYPICKÝ, ALE MÁLO ČASTÝ PŨVODCE INFEKČNÍ ENDOKARDITIDY. KASUISTIKA}

PELOUCH R, LONSKÝ V, SOLAŘ M, VOJÁČEK J, PLESKOT M, HRUBÁ I

I. interní klinika, Kardiochirurgická klinika, FN-UK Hradec Králové, Hradec Králové

Bakterie ze skupiny HACEK patři mezi typické původce infekční endokarditidy (IE) a způsobují přibližně $3 \%$ všech případů tohoto onemocnění. Actinobacillus actinomycetemcomitans je nejčastějším pưvodcem IE $z$ této skupiny. Jde o malou gramnegativní bakterii, která je součástí normální flóry dutiny ústní a orofaryngu. Kromě periodontitidy (často u mladých jedinců) může působit i některá závažná onemocnění (IE, bakteremie s postižením jiných orgánů, ranné infekce). Infekční endokarditida způsobená tímto mikrobem nejčastěji postihuje mladší muže. Typický je subakutní až chronický průběh s četnými komplikacemi, především emboligenními. I přes četné komplikace je prognóza těchto pacientů poměrně příznivá. Actinobacillus actinomycetemcomitans je dobře citlivý na betalaktámová antibiotika a léčbou volby je kombinace ampicilin + gentamicin; alternativou je léčba cefalosporinovým antibiotikem 3. generace, nejčastěji ceftriaxonem.
Autoři prezentují případ 33letého muže, který byl hospitalizován ve Fakultní nemocnici v Hradci Králové pro infekční endokarditidu bikuspidální aortální chlopně, způsobenou Actinobacillem actinomycetemcomitans. Průběh onemocnění byl komplikován glomerulonefritidou, hepatopatií, perforací cípu aortální chlopně se vznikem významné insuficience. Poslední závažnou komplikací byla embolizace do koronární tepny. Po této př́ihodě byl pacient indikován k urgentní náhradě aortální chlopně. Operační výkon i další léčba již proběhly bez komplikací a pacient byl propuštěn domů.

\section{SESTERSKÁ SEKCE}

\section{TROMBOEMBOLICKÉ KOMPLIKACE PO RADIOFREKVENČNÍ ABLACI}

\section{PERHÁČOVÁ I}

III. interní-kardiologická klinika, koronární jednotka, FN KV a 3. LF UK, Praha

Úvod: Přes veškeré snahy v kardiologii a v kardiovaskulární chirurgii ve světě i u nás patři choroby srdce a cév ve všech rozvinutých zemích, včetně ČR, k nejčastějším příčinám nemocnosti a mají na svědomí přes 50 \% všech umírajících.

$\mathrm{K}$ významnému zlepšení péče o takto nemocné přispívají i moderní postupy invazivní kardiologie. Jednou $z$ nich je i léčba poruch srdečního rytmu pomocí katetrizační ablace.

Metodika: Kasuistikou u mladé pacientky chci přibližit málo se vyskytující komplikace po radiofrekvenční ablaci, a to tromboembolické komplikace, která vznikla bezprostředně po výkonu a prodloužila tím hospitalizaci pacientky na klinice a zároveň nepříznivě ovlivnila její další život.

Cíl: Zhodnocení průběhu hospitalizace, prozkoumání všech potencionálních rizik na další život pacientky.

Závěr: V současné době, kdy patří RFA k moderní a přínosné léčbě pro pacienta s tachyarytmií, nesmíme zapomenout, že i přes veškerou snahu všech zúčastněných se komplikace vyskytují a i když v minimu př́padech, musíme se zabývat otázkou, jak nejlíp zmírnit potencionální riziko jejich vzniku.

\section{IMPLANTACE SIROLIMUS-ELUTING STENTU DO ANOMÁLNĔ ODSTUPUJÍCÍHO KMENE LEVÉ VĔNČITÉ TEPNY}

\author{
PEŠEK J, KOLLROS R, FERDA J \\ I. interní klinika, Radiodiagnostická klinika, \\ FN Plzeñ a LF UK Praha, Plzeň
}

Popis případu: 76letá pacientka, hypertonička s fibrilací síní, byla hospitalizována na spádovém interním oddělení pro akutní non-Q-infarkt myokardu přední stěny. Pro recidivu stenokardií druhý den přeložena na naše pracoviště. Při přijetí na koronární jednotku byla pacientka hypotenzní, v počínajícím kardiogenním šoku. Bezprostředně po stabilizaci oběhu provedeno echokardiografické vyšetření s nálezem systolické dysfunkce levé komory srdeční s EF 35 \% při akinezi volné přední stěny a anterosepta. Při koronarografii diagnostikována vlasová stenóza kmene levé věnčité tepny anomálně odstupujícího $\mathrm{z}$ pravého koronárního sinu, kraniálně od odstupu pravé věnčité tepny. Ad hoc byla provedena katetrizační revaskularizace $\mathrm{s}$ implantací sirolimus-eluting stentu. Po revaskularizaci došlo k ústupu levostranné kardiální insuficience, byla ukončena katecholaminová podpora, kontrolní echokardiografické vyšetření prokázalo vzestup EF levé komory. Na CT-angiografii koronárních tepen byl diagnostikován anomální odstup kmene z pravého koro- 
nárního sinu s průběhem ventrálně od arteria pulmonalis. Pacientka byla propuštěna $\mathrm{v}$ dobrém stavu do domácího ošetřování, při kontrolní koronarografii za 6 měsíců nebyla přítomna restenóza, při ambulantní kontrole za 11 měsíců pacientka neudávala obtíže, byla v dobrém stavu, bez známek srdečního selhání.

Závěr: Příznivý dlouhodobý výsledek katetrizační revaskularizace opravňuje použití sirolimus-eluting stentu při léčbě stenózy anomálně odstupujícího kmene levé věnčité tepny.

\section{KOMPLEXNİ INTERVENCE RIZIKOVÝCH FAKTORŮ ATEROSKLERÓZY U DIABETIKŮ 2. TYPU V SEKUNDÁRNÍ PREVENCI KARDIOVASKULÁRNÍCH ONEMOCNĚNİ*}

PETRLOVÁ B, ROSOLOVÁ H, ŠIMON J, ŠÍPOVÁ I, ŠIFALDA P

II. interní klinika, FN Plzeň, Plzeň

*Podpořeno grantem IGA MZČR 82 79-3 (2005-2007).

Úvod: Diabetici 2. typu, kteří již trpí kardiovaskulárními chorobami (CVD), jsou nejrizikovější nemocní pro novou aterotrombotickou př́hodu v celé populaci. Sledovali a analyzovali jsme rizikový profil těchto nemocných a jeho změnu po zařazení do Komplexního intervenčního programu (CIP).

Metodika: Anamnéza, antropometrické a laboratorní parametry a současná léčba byly získány $z$ lékařské dokumentace ošetřujících ambulantních kardiologů, diabetologů a praktických lékařů v Plzni. CIP se skládá z osobní konzultace životního stylu (doporučení diety, nekouření, možnosti pravidelného vedeného cvičení jedenkrát týdně) a zahájení léčby fenofibrátem v dávce $267 \mathrm{mg}$ přidáním $\mathrm{k}$ současné léčbě. Po šesti měsících byl zkoumán efekt provedené intervence.

Výsledky: $Z 420$ vybraných diabetiků 2 . typu bylo zařazeno 227 nemocných (54\%), kteří již prodělali kardiovaskulární př́íhodu - 105 mužů (70 \pm 8 let) a 122 žen $(71 \pm 9$ let). Asi $10 \%$ mužů a $5 \%$ žen byli současnými kuřáky, bývalými kuřáky bylo $60 \%$, resp. $35 \%$ probandů. Kontrola krevního tlaku se zlepšila - cílových hodnot pod 130/80 mm Hg dosáhlo před intervencí $6 \%$ mužů a $9 \%$ žen, poté $18 \%$ mužů a 20 \% žen, ačkoliv nebyla měněna zavedená antihypertenzní léčba. Zlepšila se i lačná glykemie a snížil se obvod pasu. Cílových hodnot lipidogramu - celkový cholesterol $<4,5 \mathrm{mmol} / \mathrm{l}$, LDL-chol $<2,5 \mathrm{mmol} / 1$ TG $<1,7 \mathrm{mmol} / 1$ a HDL-chol $>1,0$ u mužů a > 1,3 mmol/1 u žen dosahovalo před CIP jen $14 \%$ mužů a 17 \% žen, po CIP 60 \% nemocných.

Závěr: Intervence životního stylu podle protokolu CIP byla u kardiovaskulárně vysokorizikových nemocných velmi úspěšná. Nefarmakologická léčba spolu s medikací fenofibrátem přidanou $\mathrm{k}$ současné léčbě a individuální př́istup k nemocným zlepšily jejich rizikový profil a také compliance sledovaných nemocných.

\section{TEPENNÁ EMBOLIZACE JAKO KOMPLIKACE PERKUTÁNNÍ TROMBOTIZACE POSTKATETRIZAČNÍHO PSEUDOANEURYZMATU ARTERIA FEMORALIS}

PETRŮ J, VITÁSEK P, PŘINDIŠOVÁ H, NEUŽIL P, BÁRTÍK K

Kardiologické oddělení, Cévní chirurgie, Radiodiagnostické oddělení, Nemocnice Na Homolce, Praha

Úvod: $\mathrm{S}$ narůstajícím množstvím prováděných srdečních katetrizací se zvyšuje i počet komplikací punkce femorálních cév. $V$ naší práci jsme se zaměřili na postkatetrizačně vzniklé falešné výdutě arteria femoralis, jejich léčbu a popisujeme neobvyklou komplikaci této léčby $\mathrm{v}$ podobě embolizace tkáňového lepidla do arteria poplitea.

Soubor: Za období dvou let (2005-2006) jsme postkatetrizačně vzniklou falešnou výdut diagnostikovali u 39 pacientů. 27 nemocných bylo indikováno k perkutánní trombotizaci aplikací tkáňového lepidla (Tissucol $\left.{ }^{\circledR}\right)$ do výdutě se $100 \%$ úspěšností. U devíti nemocných stačila $\mathrm{k}$ trombotizaci výdutě cílená komprese, ve třech případech byla nutná chirurgická korekce.

Kasuistika: U 57letého nemocného byla po provedení izolace plicních žil pro paroxyzmální formu fibrilace síní diagnostikována falešná výdut levé arteria femoralis communis velikosti $2,5 \times 2 \mathrm{~cm}$. S odstupem dvou dnů byla výdut trombotizována aplikací $2 \mathrm{ml}$ Tissucol Kit ${ }^{\circledR}$ (Baxter AG, Wien). Kontrolní vyšetření ultrazvukem další den dokumentovalo příznivý nález $\mathrm{v}$ tř́sle $\mathrm{s}$ průchodným tepenným řečištěm až do úrovně a. poplitea a pacient byl propuštěn. Následující den se pacient dostavil pro nově vzniklé klaudikace levé dolní končetiny (LDK). Angiografie potvrdila embolický uzávěr - částečně obtékaný embolus v distální a. poplitea a proximální a. fibularis. V epidurální anestezii byla provedena urgentní embolektomie, lehce se podařilo vybavit celistvý odlitkový embolus tvořený tkáňovým lepidlem. Další průběh byl již nekomplikovaný. Při kontrolách za 1 a 3 měsíce již pacient neudával klaudikace a měl dobře hmatné pulsace až do periferie LDK.

Závěr: V současné době je perkutánní trombotizace postkatetrizační falešné výdutě metodou volby. Tento postup má vysokou efektivitu a komplikace jsou raritní, přesto je třeba s nimi počítat a před propuštěním pacienta vyloučit jejich možnost.

\section{ZKUŠENOSTI S EXTRAKCÍ LEVOKOMORÝCH STIMULAC̆NICH ELEKTROD}

PETRŮ J, TÁBORSKÝ M, NEUŽIL P, ŠEDIVÁ L, KUPEC J, VOPÁLKA R, KRÁLOVEC Š, HOLÝ F, BRADA J

Kardiologické oddělení, Nemocnice Na Homolce, Praha

Úvod: Biventrikulární stimulace je standardní léčbou v indikovaných případech srdečního selhání. Máme bohaté zkušenosti s endovazálním zaváděním levokomorových (LV) elektrod cestou koronárního sinu (CS). Relativně málo dat a zkušeností je ale $\mathrm{s}$ jejich příp. extrakcí.

Soubor: Od roku 2002 do konce roku 2006 bylo v naší nemocnici implantováno 545 biventrikulárních stimulátorů-defibrilátorů. U 24 pacientů byla $\mathrm{v}$ průběhu sledování nutná extrakce LV elektrod. Indikací k extrakci byly většinou infekční komplikace (76 \%), dále dislokace či infrakce elektrody LV (24\%). K extrakci byla použita prostá trakce, v případě problematické extrakce či uvíznutí elektrody v ústí CS jsme používali extrakční systém využívající radiofrekvenční (RF) energii (Perfecta $\left.{ }^{\mathrm{TM}}\right)$.

Výsledky: Celkově bylo extrahováno 25 elektrod LV. Průměrná doba od primoimplantace byla 12,3 měsíců. Ve většině případů stačila $\mathrm{k}$ extrakci $\mathrm{LV}$ elektrody prostá trakce (21), RF extrakční systém Perfecta ${ }^{\mathrm{TM}}$ byl použit u čtyřech elektrod LV. Nepozorovali jsme žádné závažnější komplikace přímo související s extrakčním výkonem, žádný pacient nezemřel. Kompletně bylo extrahováno $\mathrm{z}$ koronárního sinu 22 elektrod LV. Třrikrát byla extrakce inkompletní s ponecháním fragmentu elektrody LV. V jednom př́ipadě jsme se snažili o extrakci fragmentu LV elektrody femorálním přístupem. Ve druhé době byla indikována reimplantace biventrikulárního stimulačního systému ve 22 př́ípadech s úspěšností zavedení elektrody LV 77,3 \%. 
Závěr: Extrakci LV elektrody docílíme většinou prostou trakcí, to je ale jistě ovlivněno relativně krátkodobým uložením elektrod ve větvích CS. V komplikovaných případech se dá použít technika RF extrakčního systému či alternativní femorální přístup. Problémy s extrakcí elektrod LV můžeme očekávat v budoucnu v souvislosti s delší dobou od implantace a vývojem alternativních technik fixace elektrod LV.

\section{SRDEČNÍ DYSSYNCHRONIE U PACIENTŮ S ISCHEMICKOU KARDIOMYOPATIÍ PODSTUPUJICICH CHIRURGICKOU REVASKULARIZACI MYOKARDU*}

\section{PĚNIČKA M}

III. interní-kardiologická klinika, Kardiocentrum, FN KV a 3. LF UK, Praha

*Podpořeno grantem IGA č. 8524-5 S.

Přednáška shrnuje význam srdeční dyssynchronie kontrakcí u pacientů $\mathrm{s}$ ischemickou dysfunkcí levé komory srdeční podstupujících aortokoronární bypass. Po stručné přehledné části budou prezentovány pưvodní výsledky ze 3 multicentrických studií koordinovaných III. interní-kardiologickou klinikou FN KV a 3. LF UK v Praze.

\section{BUNĚC̆NÁ LÉČBA POŠKOZENÉHO MYOKARDU: ÚVOD DO PROBLEMATIKY*}

\section{PĚNIČKA M, SIMINIAK T}

III. interní-kardiologická klinika,

Kardiocentrum, FN KV a 3. LF UK, Praha,

Dept. of Cardiology, University School of Medical Sciences Poznaň, Poznaň, Poland

\section{*Supported by the EU LSSM-CT-2004-511992 S.}

Akutní infarkt myokardu s následnou remodelací levé komory srdeční (LKS) je hlavní příčinou městnavého srdečního selhání a úmrtí v rozvinutých zemích. Souvisí to jednak se stárnutím populace, a jednak se zlepšenou péčí o pacienty $\mathrm{s}$ akutními koronárními syndromy. Mechanismy, které spojují infarkt myokardu se špatnou prognózou, jsou všeobecně známé a dobře popsané: akutní ischemie myokardu $\rightarrow$ infarkt $\rightarrow$ ztráta kontraktilní masy LKS $\rightarrow$ dilatace LKS $\rightarrow$ srdeční selhání $\rightarrow$ špatná dlouhodobá prognóza. Nepříznivá remodelace LKS je v současné době nalézána až u 30 \% pacientů léčených primární perkutánní koronární intervencí (PCI), přestože infarktová tepna zůstane trvale průchodná. Tyto výsledky naznačují, že samotná revaskularizace často nezabrání rozvoji dilatace LKS se všemi jejími následky. Kauzální léčba infarktu myokardu by rovněž měla nahradit ztrátu kardiomyocytů.

V současnosti je velice intenzivně studována možnost záchrany ohroženého myokardu pomocí transplantace různých typů autologních buněk $\mathrm{u}$ akutních nebo chronických forem ischemické choroby srdeční. Tato metoda sleduje 3 hlavní cíle: neovaskularizaci, náhradu zaniklých kardiomyocytů a navození reverzní remodelace LKS. Preklinické studie prokázaly u několika typů buněk potenciál „opravit” akutně nebo chronicky postižený myokard. Jedná se o embryonální kmenové buňky, kosterní myoblasty, kmenové buňky kostní dřeně a rezidentní srdeční kmenové buňky. Na základě nadějných výsledků experimentálních studií byly provedeny pilotní klinické studie. Jedná se vždy o autologní buňky, takže není třeba imunosuprese. Nejvíce dostupných údajů je pro kosterní myoblasty a kmenové buňky (KB) kostní dřeně. Cílem přehledné přednášky je uvést posluchače do problematicky buněčné léčby poškozeného myokardu se zaměřením na kosterní myoblasty a KB kostní dřeně.

\section{SRDEČNÍ DYSSYNCHRONIE ZHORŠUJE PROGNÓZU NEMOCNÝCH SE STR̆EDNĔ TĚŽKÝM SYSTOLICKÝM SRDEČNÍM SELHÁNÍM PODSTUPUJÍCÍCH AORTOKORONÁRNÍ BYPASS*}

PĚNIČKA M, MĚDÍLEK K, LINKOVÁ H, TOUŠEK P, HAVLÍKOVÁ M, TRAKALOVÁ H, WIDIMSKÝ P, BARTU゚NĚK J

III. interní-kardiologická klinika, Kardiocentrum, FN KV a 3. LF UK, Praha, Kardiochirurgická klinika, FN Hradec Králové, Hradec Králové,

Cardiovascular Center, OLV Ziekenhuis, Aalst, Belgium

*Podpořeno grantem IGA č. 8524-5.

Přítomnost srdeční dyssynchronie zhoršuje prognózu pacientů $\mathrm{s}$ ischemickou dysfunkcí levé komory (LK). Cílem naší práce bylo studovat vztah mezi srdeční dyssynchroniî́ a prognózou pacientů s ischemickou kardiomyopatií podstupujících aortokoronární bypas (AKB).

Metodika: Do studie bylo zařazeno 215 pacientů s ischemickou kardiomyopatií a dušností (věk $65 \pm 9$ let, $81 \%$ mužů, ejekční frakce LK $30 \pm 6 \%$ ) postupujících AKB. Dyssynchronie byla hodnocena v bazálních segmentech LK pomocí tkáňového dopplerovského vyšetření před AKB (pre-AKB) a 1 měsíc po AKB (post-AKB).

Výsledky: 25 (11,6 \%) pacientů zemřelo do 30 dnů po AKB (nemocniční mortalita). Přítomnost těžké pre-AKB dyssynchronie $\geq 119$ ms měla nejvyšší prediktivní přesnost ze všech testovaných parametrů pro předpověd' nemocniční mortality se senzitivitou $84 \%$ a specificitou $71 \%$. Během dalšího sledování (medián 359 dní; IQQR 219-561) zemřelo dalších 19 (10,3 \%) pacientů a 34 (18,5 \%) bylo hospitalizováno pro dekompenzaci srdečního selhání. Perzistence významné post-AKB dyssynchronie $\geq 72$ ms a přítomnost $\geq 5$ viabilních segmentů byly jediné dva parametry, které nezávisle předpovídaly celkovou mortalitu a hospitalizace pro srdeční selhání s HR 5,23; 95\% CI 2,64-10,33 ( $p<0,001)$ a HR 0,61; 95\% CI 0,53-0,70 $(p<0,001)$. Pacienti bez post-AKB dyssynchronie a s viabilním myokardem měli výbornou prognózu ve srovnání s jedinci $\mathrm{s}$ těžkou dyssynchronií a neviabilním myokardem (mortalita a hospitalizace $3 \%$ vs. $64 \%, p<0,001)$.

Závěr: Přítomnost těžké dyssynchronie zhoršuje prognózu pacientů přes provedenou revaskularizaci. Tyto výsledky volají po prospektivní randomizované studii testující použití resynchronizační léčby $\mathrm{u}$ pacientů $\mathrm{s}$ ischemickou dysfunkcí LK a těžkou dyssynchronií postupujících AKB.

\section{DETEKCE ASYMPTOMATICKÉ DYSFUNKCE LEVÉ KOMORY SRDEČNII U NEMOCNÝCH S METABOLICKÝM SYNDROMEM A DIABETES MELLITUS 2. TYPU}

\section{PLACHÝ M, ŠPÁC J, SOUČEK M}

\section{II. interní klinika, FN u sv. Anny, Brno}

Pacienti s diabetes mellitus (DM) představují vysoce rizikovou skupinu pacientů pokud jde o kardiovaskulární (KV) morbidity a mortality, a to nejen $z$ důvodů aterosklerotického postižení koronárního řečiště, ale i pro hypertrofii levé komory (LK) a srdeční dysfunkci. V naší práci jsme sledovali korelaci hladin BNP a NT-proBNP v séru s echokardiografickým nálezem asymptomatické dysfunkce LK. 
Hodnotili jsme BNP a NT-proBNP u 44 nemocných s metabolickým syndromem (MS) - průměrný věk 45 let, BMI 32,4 a 42 nemocných s hypertenzí a diabetes mellitus 2. typu (HT + DM) - průměrného věku 64 let, BMI 29,6 s nepoškozenou ledvinnou funkcí.

Žádný nemocný neměl anamnézu ischemické choroby srdeční ani příznaky svědčící pro toto onemocnění. U 2 nemocných tj. 5 \% souboru jsme zjistili hladinu BNP, resp. NT-proBNP větší než 100 pg/1, resp. 125 pg/l a u 11 nemocných (tj. $13 \%$ ) byla hladina BNP mezi 50-100 pg/1. Echokardiografické hodnocení funkce levé komory srdeční prokázalo hypertrofii stěn LK u 46 \%, mírně sníženou systolickou funkci u $15 \%$, u 40 \% nemocných diastolickou dysfunkci LK a u 10 \% restrikční poruchu plnění levé komory.

Hladiny BNP a NT-proBNP jsou u diabetiků zvýšeny již v počátečních stadiích dysfunkce LK, a to jak systolické, tak i diastolické. BNP je lehce dostupný a spolehlivý parametr ke stratifikaci KV rizika a celkové mortality. Intenzivní léčbou již v klinicky asymptomatickém období při zvýšené hladině BNP mưže být dosaženo lepší prognózy a kvality života.

\section{LOŽISKOVÁ AKUTNÍ REJEKCE MODERATE, LÉČIT ČI NELÉČIT?}

\section{PODZIMKOVÁ M, MÁLEK I, HOŠKOVÁ L}

Klinika kardiologie, IKEM, Praha

Otázce, zda léčit nebo ponechat bez léčby akutní celulární rejekci moderate se věnovala řada pracovišt. Celulární rejekce moderate je podle International Society for Heart and Lung Transplantation (ISHLT) charakterizovaná výskytem lymfocytárních infiltrátů a poškozením myocytů. Stupňování definuje Banffská klasifikace: stupeň 2 znamená výskyt 1 nebo 2 izolovaných ložisek, je-li výskyt multifokální, pak jde o stupeň $3 \mathrm{~A}$ při difuzním postižení st. 3B.

Na naší klinice bylo v období leden-květen 2006 provedeno celkem 241 endomyokardiálních biopsií (EMB) u 143 pacientů. $8 \times$ byla zaznamenána rejekce $3 \mathrm{~A}$ u 8 nemocných, léčeni byli všichni. $12 \times$ byla př́tomna ložisková rejekce moderate st. 2 u 12 pacientů. $Z$ toho 6 nemocných dostalo antirejekční léčbu, 5 bylo bez léčby, $1 \times$ byl změněn imunosupresivní protokol; cyklosporin byl nahrazen tacrolimem. Důvodem podání antirejekční léčby byla ve 2 případech krátká doba od transplantace, 2 nemocní měli komplikovaný předchozí průběh, vč. výskytu rejekce a 2 pacienti byli léčeni bez jednoznačné indikace.

Žádný z pacientů s rejekcí st. 2 neměl klinické potíže ani echokardiografické známky dysfunkce štěpu. U 1 pacienta byla i přes podanou léčbu $\mathrm{v}$ následující EMB zaznamenána rejekce 3A. Ostatní nemocní, léčení i neléčení měli následující EMB bez známek rejekce.

Fokální rejekce moderate st. 2 Banffské klasifikace není vždy důvodem k podání antirejekční léčby. Záleží na době od transplantace, klinickém stavu pacienta, echokardiografickém nálezu a zkušenosti lékaře. Je-li pacient $\mathrm{v}$ pořádku a uplynuly-li 3 měsíce od transplantace, pak není nutné fokální rejekci moderate léčit. Nicméně jako ve všem platí individuální př́istup $\mathrm{k}$ problému a každému pacientovi.

\section{PR̆ÍNOS A ÚSKALÍ SRDEČNÍ RESYNCHRONIZAČNÍ TERAPIE U PACIENTA V CHRONICKÉM DIALYZAČNIM PROGRAMU. KASUISTIKA}

POLÁŠEK R, KUČERA P, RYBA M, HOLM F

Kardiologické oddělení, Interní oddělení,

Krajská nemocnice Liberec, Liberec
U pacientů $\mathrm{s}$ terminálním renálním selháním je prokázán vyšší výskyt ICHS a jejich komplikací, především srdečního selhání. Systolická dysfunkce levé komory představuje jeden $\mathrm{z}$ nejsilnějších prediktorů mortality $\mathrm{u}$ nemocných v dialyzačním programu. Je proto překvapující, jak málo máme spolehlivých informací $z$ randomizovaných klinických studií týkajících se léčby chronického srdečního selhání u této populace. Týká se to nejen farmakoterapie, ale i moderní srdeční resynchronizační terapie (SRT). V naší kasuistice sledujeme 73letého muže, který prodělal v roce 2004 Q-IM. V lednu 2005 byl léčen CABG pro nemoc 3 tepen. V únoru byl rehospitalizován pro akutní srdeční selhání s EF 28 \%, s mitrální insuficiencí 4/4. Došlo k progresi do té doby mírné renální insuficience s nutností trvalé hemodialýzy. Do května byl opakovaně rehospitalizován pro akutní srdeční selhání refrakterní k farmakoterapii se zhoršením EF na 17 \%. Proto jsme v červenci 2005 provedli implantaci biventrikulárního kardiostimulátoru. Zvolili jsme přístup z levé v. subclavia pro okluzi pravé v. subclavia. V ř́jinu 2005 došlo k závažné komplikaci - trombotickému uzávěru levé brachiocefalické žíly ohrožující průchodnost AV fistule. Pacient byl úspěšně léčen lokální trombolýzou a PTA, se zprůchodněním brachiocefalické žíly a zachováním AV fistule přes komplikující katetrovou sepsi z AG katetru. SRT vedla k výraznému zlepšení symptomů $z$ funkční třídy NYHA IV na II, které přetrvává již 18 měsíců. V naší kasuistice dokazujeme, že i u pacienta $\mathrm{v}$ hemodiylzačním programu můžeme SRT dosáhnout výrazného symptomatického zlepšení. Musíme však počítat s určitými technickými obtížemi (konkurence o žilní přístup s AV fistulí, časté stenózy větví horní duté žíly po opakovaných kanylacích) a větší četností komplikací - krvácení do kapsy, trombotické komplikace a patrně i větší riziko infekce.

\section{TROMBOASPIRACE U PACIENTŮ S AKUTNÍM INFARKTEM MYOKARDU LÉČENÝCH PR̆ÍMOU PERKUTÁNNÍ KORONÁRNÍ INTERVENCİ*}

POLOCZEK M, KALA P, BOČEK O, NEUGEBAUER P, PAŘENICA J, JEŘÁBEK P, VYTISKA M, TOMAN O, ŠPINAR J

\section{Interní-kardiologická klinika, FN Brno, Brno}

*Podpořeno grantem VVZ 0021622402.

Cíl: Sledování pacientů léčených primární koronární intervencí (PPCI) s použitím tromboaspiračních katetrů (TA) a jejich srovnání s kontrolní skupinou.

Metodika: V období 6/2006-12/2006 jsme u 58 pacientů s akutním infarktem myokardu s elevací ST (STEMI) během PPCI použili $\mathrm{k}$ odstranění trombu nového tromboaspiračního instrumentária. U 54 pacientů byla získána validní EKG data k určení ústupu elevací ST po STEMI. Jako kontrolní skupinu jsme použili soubor 118 pacientů léčených pouze PPCI. Podle ústupu elevací ST jsme pacienty rozdělili do 2 skupin (ústup do $50 \%$ a $50 \%$ a více).

Výsledky: Průměrný věk pacientů byl shodný v obou skupinách $(63,6$ let u TA vs. 63,1 bez TA $(p=0,8)$. Skupiny se nelišily v zastoupení pohlaví (muži $74,1 \%$ u TA vs. 74,6 \% $(p=0,95)$. Průtok krve koronární tepnou nebyl na začátku PPCI př́tomen (TIMI flow 0-1) u 45 (77,8 \%) pacientů s TA a $91(77,1 \%)$ pacientů ve skupině bez TA $(p=0,94)$. Obnovení průtoku (TIMI flow 2,3 ) na konci intervenčního výkonu bylo podobné v obou skupinách $(98,2 \%$ s TA vs. $98,3 \%$ bez TA). Pozorovali jsme trend $\mathrm{k}$ častějšímu normálnímu průtoku (TIMI 3) u pacientů bez tromboaspirace $(95,7 \%$ vs. $87,9 \%, p=0,053)$. Alespoň polovičního ústupu elevací ST na konci intervence bylo dosaženo u $22(40,7 \%)$ pacientů 
s tromboaspirací proti $62(52,5 \%)$ pouze s primární PCI bez tromboaspirace $p=0,15$ ).

Závěr: Parametry průtoku a ústupu elevací jsme hodnotili u konsekutivně prvních pacientů léčených tromboaspirací, použití tromboaspiračních metod bylo v našem souboru spojeno s trendem $\mathrm{k}$ méně častému dosažení normálního průtoku koronární tepnou.

\section{SROVNÁNÍ ÚSTUPU ELEVACÍ ST S ČASNÝMI ZMĚNAMI NATRIURETICKÝCH PEPTIDŮ A BIG-ENDOTELINU*}

POLOCZEK M, PAŘENICA J,

KALA P, TOMAN O, BOČEK O, NEUGEBAUER P,

JEŘÁBEK P, VYTISKA M, ČERMÁKOVÁ Z,

\section{ŠPINAR J}

Interní-kardiologická klinika,

Oddělení klinické biochemie, FN Brno, Brno

*Podpořeno grantem VVZ 0021622402.

Cíl: Srovnání změn hladin natriuretických peptidů a big-endotelinu a jejich korelace s ústupem elevací ST u pacientů s akutním infarktem myokardu (STEMI).

Metodika: V období 10/2005-5/2006 bylo zařazeno 73 pacientů se STEMI s iniciálně uzavřenou koronární tepnou (TIMI flow 0-1), u kterých byla provedena úspěšná primární perkutánní koronární intervence (PPCI). Pacienti byli rozděleni podle ústupu elevací ST po skončení PPCI do skupiny $\mathrm{A}(\mathrm{n}=33) \mathrm{s}$ ústupem elevací ST pod $50 \%$ a skupiny B $(n=40)$ s ústupem elevací ST $50 \%$ a více. Byla provedena analýza BNP, NT-proBNP a hladin big-endotelinu (BE) při přijetí a za 24 hodin od vzniku STEMI. Statisticky jsme porovnali změnu těchto faktorů ve 2 skupinách pacientů rozdělených podle ústupu elevací ST.

Výsledky: Změna BNP ve skupině A byla nevýznamně vyšší $(70,7 \mathrm{pg} / \mathrm{ml})$ než ve skupině $B(59,5 \mathrm{pg} / \mathrm{ml}, p=0,49)$. Změna hladiny BE se téměř nelišila (A snížení o 0,94 pmol/1, B snížení o $0,84 \mathrm{pmol} / 1, p=0,79$ ). Hladina NT-proBNP měla trend $\mathrm{k}$ vyšší hodnotě $\mathrm{u}$ skupiny $\mathrm{A}$ (průměrný nárůst o $2526 \mathrm{pg} / \mathrm{ml}$ proti $1734 \mathrm{pg} / \mathrm{ml}$ ve skupině $\mathrm{B}, p=0,195)$.

Závěr: Pacienti $\mathrm{s}$ kompletnějším ústupem elevací ST po úspěšné primární koronární intervenci měli trend $\mathrm{k}$ nižším hodnotám NT-proBNP během 24 hodin od vzniku STEMI, změny hladiny BNP a big-endotelinu se výrazněji nelišily.

\section{SESTERSKÁ SEKCE}

\section{KATETRIZAC̆NÍ ABLACE FIBRILACE SÍNÍ. OŠETR̆OVATELSKÁ PÉČE O PACIENTY PR̆Ed VYŠETR̆ENÍM A PO VYŠETR̆ENÍ}

\author{
POSPÍŠILOVÁ M, NOVÁKOVÁ M
}

\section{Klinika kardiologie, IKEM, Praha}

Fibrilace síní /FS/ je nejčastější arytmie, která se u člověka vyskytuje. Jednou $\mathrm{Z}$ metod léčby FS je katetrizační ablace, která spočívá v izolaci ústí plicních žil pomocí radiofrekvenční energie. Na našem pracovišti tato metoda přešla $z$ klinických zkoušek do praxe již před třemi lety. V současné době se stala rutinním výkonem a i sestry mají dobře zvládnutou péči o tyto pacienty. $V$ přednášce vás chceme $s$ touto metodou seznámit a poukázat i na ošetřovatelskou péči.

Úkolem sestry je pacienta připravit na výkon a pečlivě sledovat a ošetřovat po výkonu.

Den před vyšetřením sestra pacientovi vyholí obě třísla a hrudník, pacient se vykoupe a sestra kanyluje periferní žílu. Důležitá je psychická př́íprava.
Po vlastní ablaci přivážíme pacienta ze sálu po 3 až 5 hodinách. Má 3 až 4 sheaty v obou tříslech, někdy i v krku. Na oddělení sestra pacientovi vysvětlí další postup.

Natočíme EKG, připojíme monitorování EKG, změříme TK a dále ho sledujeme po 1 hod. Protože se při výkonu aplikoval Heparin, provedeme vyšetření ACT, kdy hodnotíme účinnost heparinizace. Pokud hodnota klesne pod 170 s, mohou se sheaty odstranit. Vzhledem k většímu počtu sheatů často dochází $\mathrm{k}$ vagové reakci, kterou musím rozpoznat a začít řešit. Po vytažení sheatů se provede bandáž obou třísel. Sestra se snaží ulevit od bolesti způsobené dlouhým ležením namazáním zad, aplikací analgetik s. c., polohováním lưžka apod. Pacientovi dáme najíst, podáváme dostatek tekutin a sledujeme vyprazdňování.

Důležitá je neustálá kontrola pacienta, protože sestra je první, kdo může rozpoznat první příznaky komplikací. Jakékoliv změny jako dušnost a kašel, bolest při dýchání, pokles TK apod. hlásí lékaři.

Po uplynutí 1 hod. od vytažení sheatů se nasazuje infuze s Heparinem, jako prevence tromboembolických komplikací. Infuze kape za kontroly aPTT do druhého dne.

Pacient opouští lůžko následující den po kontrole lékařem.

\section{SESTERSKÁ SEKCE}

\section{EKG - OPAKOVÁNÍ JE MATKA MOUdROSTI}

\section{POVOLNÁ P}

Koronární jednotka, FN KV a 3. LF UK, Praha

I při současných možnostech moderní medicíny platí, že nejlepším monitorem pacienta je sestra. Autorka ve sdělení připomíná zlatý standard kardiologického vyšetření: záznam EKG a jeho hodnocení. Pro kardiologickou sestru dnešních dnů nestačí vědět pouze ŽE, ale dưležité je i PROČ a Co $\mathrm{s}$ tím dál. Nový pohled na staré věci může zesvětlit šed’ všednodenní rutiny.

Závěr: Prezentace několika animovaných audio/vizuálních záznamů EKG (EKG videoklip).

\section{DLOUHODOBÉ KOMPLIKACE PO OPERACI AKUTNÍ DISEKCE AORTY TYPU A. KASUISTIKA}

POVOLNÝ P, RIEGEL K, POVOLNÁ P, PODPĚROVÁ M, POVOLNÝ J

\section{Koronární jednotka, Nemocnice Kladno, Kladno}

Kasuistika popisuje pacienta s akutní disekcí typu A diagnostikovanou v Oblastní nemocnici Kladno v květnu 2004. Pacient úspěšně akutně operován na Kardiochirurgickém oddělení Nemocnice Na Homolce. Provedena náhrada ascendentní aorty a oblouku (hemiarch), resuspenze aortální chlopně a remodelace ST-junkce. V květnu 2005 byl přijat $\mathrm{k}$ plánovanému kardiochirurgickému výkonu - aortobikarotickému bypassu, stentingu oblouku a descendentní aorty. Během výkonu nalezen suspektní periaortální absces a falešné aneuryzma, proto výkon konvertován na náhradu aortálního oblouku. V časném pooperačním období dochází $\mathrm{k}$ rozvoji ischemické cévní mozkové přihody $\mathrm{s}$ pravostrannou hemiplegií a afázií. $V$ následujících měsících přes intenzivní rehabilitaci stav jen minimálně regreduje $\mathrm{s}$ reziduálním významným neurologickým deficitem. Daná kasuistika dokládá, že aortální desekce, zvládnutá v akutní fázi úspěšnou operací, představuje pro pacienta trvalé riziko vzniku, popř. progrese závažných komplikací jak základního onemocnění, tak vlastního operačního výkonu. 


\section{Kvalita, prestiž, aktuálnost, tradice}

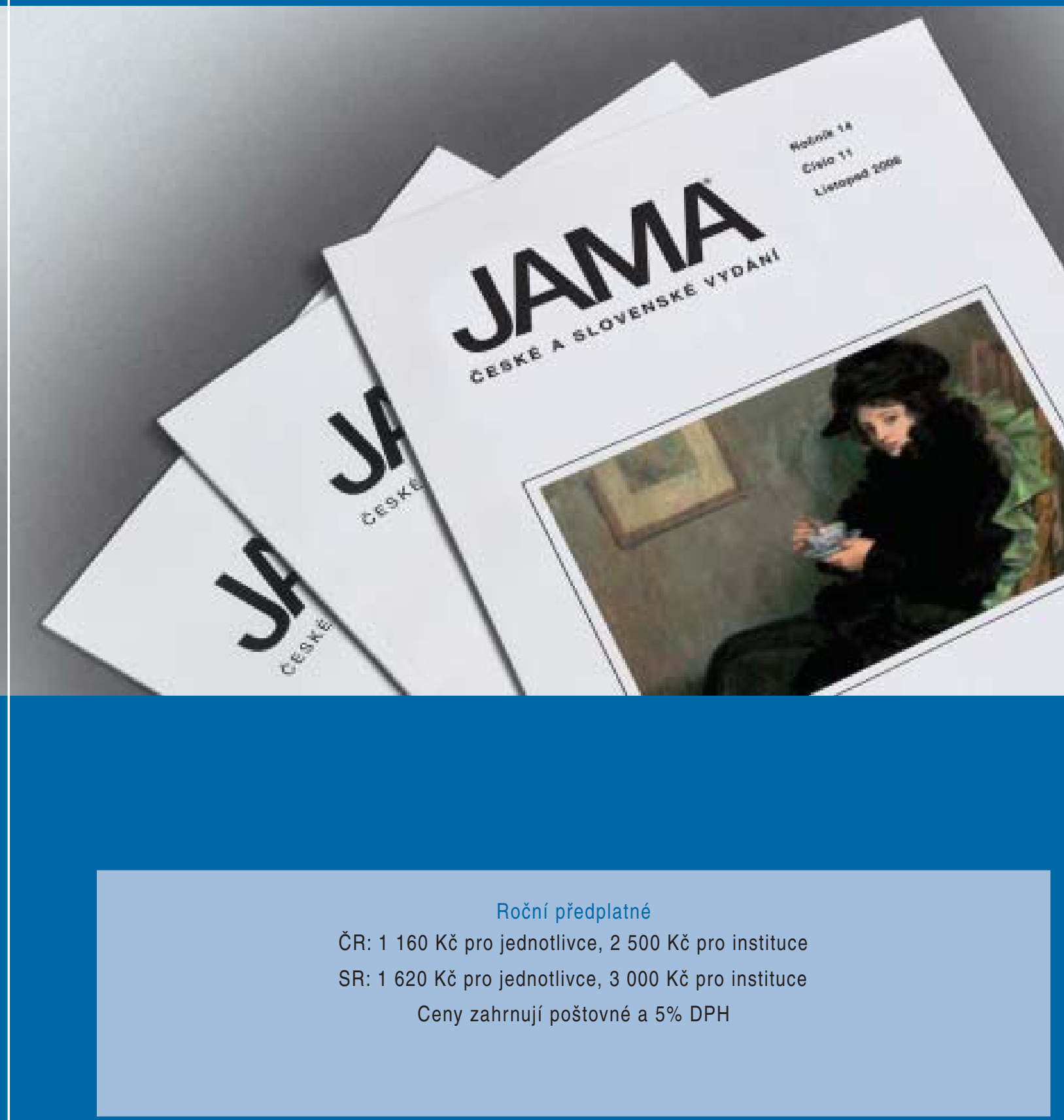

MedProGo, s. r. o. • Anglická 17, 12000 Praha 2 • tel.: +420 222512649 • fax: +420 222520160 e-mail: predplatne@medprogo.com 
Závěr: Ve skupině 21 pacientů splňujících kritéria pro implantaci BiV PM došlo po 3 měsících ke statisticky vý-

ORGANIZACE PÉČE O PACIENTY INDIKOVANÉ K BIVENTRIKULÁRNÍ STIMULACI

PRACHAŘOVÁ I, VLAŠÍNOVÁ J, NOVÁČKOVÁ J, CETLOVÁ I

Interní-kardiologická klinika, FN Brno-Bohunice, Brno

Na naší klinice bylo provedeno 123 implantací PM a ICD $\mathrm{v}$ biventrikulárnním režimu. U pacientů indikovaných k implantaci máme stanovený následující protokol:

Před implantací pacient přichází na kardiostimulační ambulanci, kde se objedná na echokardiografické vyšetření s tkáňovým dopplerovským vyšetřením, spiroergometrii a koronarografii.

Po absolvování těchto vyšetření je pacient přijat na lůžko, provedou se základní odběry včetně BNP.

Po implantaci se provádí EKG, kontrola funkce přístroje s odstupem 2 dnů, RTG na postavení elektrod a ECHO srdce.

Další kontrola je plánovaná po měsíci, kde mimo běžných vyšetření pacienty objednáváme i do rehabilitačního programu. V prvním roce po implantaci pacienty kontrolujeme po třech měsících. V dalších letech jednou za půl roku.

U pacientů implantovaných pro srdeční selhání, sledujeme změny $\mathrm{BNP}, \mathrm{ECHO} \mathrm{k}$ posouzení $\mathrm{EF}$, funkční skupinu, změnu kvality života, opakované hospitalizace pro srdeční selhání, úmrtí a komplikace spojené s implantací

\section{RESYNCHRONIZAC̆NÍ TERAPIE - HODNOCENÍ ČASNÉHO KLINICKÉHO A HEMODYNAMICKËHO EFEKTU}

PRAUS R, PAŘÍZEK P, TAUCHMAN M, HAMAN L, FRIDRICH J, MAŠÍN V

I. interní klinika, FN Hradec Králové a LF UK,

Ústav lékařské biofyziky, LF UK, Hradec Králové

Cíl: V prospektivním sledování posoudit časný efekt srdeční resynchronizační terapie (SRT).

Soubor a metody: 21 pacientům průměrného věku 67 let (44-77), se srdeční insuficiencí NYHA II-III/IV, šírí komplexu QRS 160 ms a více, diagnózou DKMP 6×, ICHS $13 \times$, koincidencí obojího $2 \times$, byl v období od 9. 8. 2005 do 9. 10. 2006 implantován biventrikulární systém (13× ICD $+\mathrm{BiV}, 4 \times \mathrm{BiV}$ a $4 \times$ upgrade stávajícího PM na BiV). Před implantací a za 3 měsíce po implantaci byly hodnoceny: tř́ida NYHA, kvalita života vyjádřená podle skóre Minnesotského dotazníku, 6minutový test chůze. Dále bylo provedeno echokardiografické vyšetření včetně posouzení komorové dyssynchronie, $\mathrm{dP} / \mathrm{dt}$ a VTI průtoku v LVOT.

Výsledky: Po 3 měsících SRT došlo: k poklesu průměrné tř́ídy NYHA ze 3 na 2, zlepšení průměrné kvality života ze 44,8 na 30,8 bodů, prodloužení průměrné vzdálenosti při 6 minutovém testu chůze z $363 \mathrm{~m}$ na $423 \mathrm{~m}$, zvětšení průměrné hodnoty $\mathrm{dP} / \mathrm{dt}$ z $386 \mathrm{~mm} \mathrm{Hg} / \mathrm{s}$ na $914 \mathrm{~mm} \mathrm{Hg} / \mathrm{s}$ $(p<0,001)$, zvětšení průměrné hodnoty VTI průtoku v LVOT z $12,2 \mathrm{~cm}$ na $14,5 \mathrm{~cm}(p<0,001)$, vzestupu průměrné $\mathrm{EF}$ LK z $21,1 \%$ na $23,9 \% .13$ pacientů (sk. A) vykazovalo současný pokles třídy NYHA, zlepšení průměrné kvality života i prodloužení vzdálenosti při 6minutovém testu chưze (průměrné prodloužení z $352 \mathrm{~m}$ na $447 \mathrm{~m})(p=0,019)$. U dalších 8 pacientů (sk. B) došlo pouze $\mathrm{k}$ poklesu třídy NYHA a/nebo zlepšení kvality života. Při srovnání skupin A a B byly u skupiny A zjištěny větší průměrné hodnoty šiřre komplexu QRS, preejekčního času levé komory a interventrikulárního zpoždění. znamnému zvětšení průměrných hodnot $\mathrm{dP} / \mathrm{dt}$ a VTI průtoku v LVOT. 13 pacientů vykazovalo současný pokles třídy NYHA, prodloužení vzdálenosti při 6minutovém testu chůze a zlepšení kvality života.

\section{SESTERSKÁ SEKCE}

\section{ASPEKTY DIETNÍCH OPATR̆ENÍ PR̆I TERAPII WARFARINEM Z POHLEDU SESTRY}

\author{
PROSECKÁ P, THURAYA A
}

Kardiologické oddělení, Kardiologická ambulance, Brno

Léčba warfarinem se týká neustále se zvětšujícího množství pacientů. Kolísání této terapie je v některých situacích i život ohrožující. Dietní opatření mohou s léčbou warfarinem výrazně interferovat. Informovanost pacienta má značný dopad na účinnost terapie. Dotazníkovou akcí pak byla míra informovanosti ověřena.

\section{SESTERSKÁ SEKCE}

\section{VYUŽITÍ HEMODYNAMICKÉHO MONITOROVÁNÍ NA KARDIOLOGICKÉ JEDNOTCE INTENZIVNÍ PÉČE}

PRUDKÁ R, TRAXMANDLOVÁ M, ČERNÁ M, ROKYTA R

Kardiologická jednotka intenzivní péče, FN Plzeň, Plzeň

Zavedení hemodynamického monitorování do klinické praxe znamená otevření nových možností v péči o kriticky nemocné. Přímé měření parametrů hemodynamiky s následným výpočtem odvozených veličin umožňuje sestavení tzv. hemodynamického profilu, který významným způsobem přispívá $\mathrm{k}$ přesnějšímu určení příčin oběhové nestability a ke kontrole účinnosti zvoleného terapeutického postupu.

Na našem pracovišti je hemodynamické monitorování součástí komplexní péče o kriticky nemocné v šokových stavech.

V následné kasuistice prezentujeme přínos hemodynamického monitorování u 71letého muže, obézního hypertonika, diabetika, v minulosti již s proběhlým $\mathrm{Q}$-infarktem myokardu spodní a zadní stěny levé komory srdeční (LKS), který byl přijat na KJIP s 5hodinovou anamnézou stenokardií, na registrovaném EKG s elevacemi ST nad spodní stěnou LKS. Byla provedena urgentní PTCA (bez implantace stentu pro extrémně vinutou tepnu). Výkon komplikován plicním edémem, plně se rozvinul kardiogenní šok. Byla zavedena intraaortální balonková kontrapulsace a podán levosimendan. Při komplexní péči včetně hemodynamického monitorování a katecholaminové podpory dochází postupně ke stabilizaci stavu nemocného, který je 12. den pobytu překládán $\mathrm{v}$ dobrém stavu na standardní lůžko. 10 měsíců po dimisi dochází na pravidelné kontroly na naší ambulanci a kvalita jeho života je dobrá.

\section{RESYNCHRONIZAČNÍ TERAPIE CHRONICKÉHO SRDEČNÍHO SELHÁNİ - JEDNOROČNÍ MORTALITA A KVALITA ŽIVOTA PR̆I SINUSOVÉM RYTMU A FIBRILACI SÍNÍ}

\section{PRYMUSOVÁ K, VLAŠÍNOVÁ J, ŠPINAR J}

Interní-kardiologická klinika, FN Brno, Brno

Cíl: Srovnání mortality a kvality života u pacientů (pac.) s chronickým srdečním selháním (CHSS) po zavedení 
resynchronizační terapie biventrikulárním kardiostimulátorem (CRT). Srovnávali jsme pacienty se sinusovým rytmem (SR), permanentní fibrilací síní (fisi) a s nově vzniklou fisi po implantaci CRT.

Metodika: Retrospektivní follow-up kvality života pacientů v 1., 3., 6., 12. měsíci a mortalita ve 12. měsíci po zavedení CRT u pacientů hospitalizovaných na IKK FN Brno v letech 2002-2005.

Byla sledována skupina 62 pac. s CHSS průměrného věku $67 \pm 8$ let, průměrné $\mathrm{EF}$ LK $23,5 \%$, z toho mužů 46 (71 \%). Průměrná doba sledování byla $23 \pm 14$ měsíců. Permanentní fibrilaci síní mělo 7 pac. (11,3\%), sinusový rytmus trvale udrželo 50 pac. $(80,6 \%)$ a nově po zavedení CRT se vyvinula fibrilace síní u 5 pac. $(8,1 \%)$.

Výsledky: Jednoroční mortalita $u$ pacientů $s$ trvajícím SR byla $14 \%$, u pac. s permanentní fisi $14,3 \%$, u pac. s nově vzniklou fisi po zavedení CRT byla $20 \%$. Nebyl signifikantní rozdíl v mortalitě mezi pac. se SR a pac. s permanentní fisi či nově vzniklou fisi. Kvalita života ve 12 . měsíci, posuzovaná podle klasifikace NYHA, hodnocení tolerance námahy a subjektivního stavu pacientem, vykazovala signifikantní rozdíl ve prospěch pacientů se SR ve srovnání s pac. s permanentní fisi $(p<0,05)$ i s pac. $\mathrm{s}$ fisi nově vzniklou po zavedení CRT $(p<0,05)$.

Závěr: Jednoroční follow-up potvrdil benefit ze zavedení CRT u CHSS pacientů. Není statisticky významný rozdíl v mortalitě mezi pacienty s trvajícím SR a pacienty s permanentí fisi či s nově vzniklou fisi. Pacienti léčení CRT se SR mají lepší kvalitu života ve srovnání s pacienty, u kterých se po implantaci biventrikulárního kardiostimulátoru vyvinula fisi či pacienty s permanentní fisi již před implantací.

\section{UPGRADE NA BIVENTRIKULÁRNÍ KARDIOSTIMULACI U PACIENTŮ SE SRDEČNÍM SELHÁNÍM NAVOZENÝM STIMULACÍ PRAVÉ KOMORY}

\section{PŠENIČKA M, KEJŘOVÁ E, GANDALOVIČOVÁ J,} MAGAGE S, LINHART A

II. interní klinika kardiologie a angiologie, VFN a 1. LF UK, Praha

Úvod: Resynchronizační léčba (SRL) představuje v současné době účinnou nefarmakologickou metodu léčby srdečního selhání u nemocných s pokročilou dysfunkcí levé komory, širokým QRS a prokázanou poruchou synchronizace. Je relativně málo dat o účinku SRL u pacientů, u kterých se vyvinulo srdeční selhání po zavedení trvalé kardiostimulace $\mathrm{z}$ pravé komory.

Metody a výsledky: Zhodnotili jsme klinické a echokardiografické parametry u pacientů s trvalou kardiostimulací pravé komory, u kterých byl indikován upgrade na biventrikulární stimulaci pro rozvoj srdečního selhání, a jejich následný vývoj během ročního sledování. Soubor tvořilo 34 nemocných trvale stimulovaných z pravé komory (30 DDDR pro síňokomorovou blokádu nebo sick sinus syndrom a 4 VVIR pro fibrilaci síní s pomalou odpovědí komor). Střední délka stimulace pravé komory byla 42 měsíců (6-108 měsíců). Nemocní byli před upgradem ve funkční třídě NYHA III-IV při optimální farmakologické léčbě. Všichni splňovali echokardiografická kritéria srdeční dyssynchronie. Průměrná ejekční frakce levé komory (EF LK) byla $28 \%$. Po 3 měsících došlo ke klinickému zlepšení u 90 \% nemocných (u 80 \% zlepšení třídy NYHA alespoň o jeden stupeň), u 55 \% nemocných bylo možno vysadit zcela diuretika. $85 \%$ nemocných mělo zlepšení EF LK o více než 10 \%. Klinický efekt přetrvával u $90 \%$ nemocných i po jednom roce, zlepšení EF LK o více než $10 \%$ mělo dokonce $90 \%$. Pouze tř̆i nemocní neměli klinické zlepšení, u dvou došlo ke zhoršení EF LK. Je- den pacient zemřel po devíti měsících na progresi srdečního selhání.

Závěr: Naše výsledky ukazují, že pacienti se srdečním selháním a trvalou kardiostimulací pravé komory zásadně profitují z upgrade na biventrikulární stimulaci. Dochází ke zlepšení globální funkce levé komory, parametrů dyssynchronie a symptomů srdečního selhání.

\section{PROGNOSTICKÝ VÝZNAM PRŮMĚRU DOLNÍ DUTÉ ŽÍLY U PACIENTƯ S AKUTNÍM SRDEČNÍM SELHÁNÍM*}

\author{
PUDIL R, TICHÝ M, BLÁHA V, VOJÁČEK J, PRAUS R
}

\section{1. interní klinika, FN Hradec Králové-UK, Praha, LF, Hradec Králové}

*Finančně podpořeno granty MSMO021620817 a MZO 00179906

Úvod: Měření velikosti a změn dolní duté žíly (DDŽ) se uplatňuje především při stanovení tlakových poměrů pravé síně srdeční. Méně je známo o vztahu šíře dolní duté žíly a mortality pacientů s akutním srdečním selháním.

Cíl práce: Cílem práce bylo určení vztahu průměru dolní duté žíly a mortality u pacientů s akutním srdečním selháním.

Metodika a výsledky: Studie byla provedena na souboru 96 pacientů přijatých pro akutní srdeční selhání na jednotku intenzivní péče ( $68 \pm 11$ let, 45 žen). Během jednoročního sledování 32 pacientů zemřelo. Echokardiografické vyšetření a odběr plazmatické hladiny NT-proBNP byly provedeny $\mathrm{v}$ den přijetí.

Prưměrná hladina NT-proBNP nemocných byla $8000 \pm$ $9000 \mathrm{pg} / \mathrm{ml}$ vs. kontrolní soubor $90 \pm 80 \mathrm{pg} / \mathrm{ml}, p<0,01$, medián $6277 \mathrm{pg} / \mathrm{ml}$. Průměr DDŽ byl 22,2 $\pm 3,4 \mathrm{~mm}$ vs. $15,4 \pm 1,9 \mathrm{~mm}, p<0,01)$. Byla nalezena korelace mezi hladinou NT-proBNP a průměrem dolní duté žíly $(\mathrm{r}=0,51$, $p<0,01)$. Při analýze těchto dat jsme prokázali významný vztah průměru DDŽ a hladiny kreatininu $(p<0,01)$, dále vztah $\mathrm{k}$ pohlaví $(p<0,05)$. Vícerozměrná analýza neprokázala vliv některých faktorů (vliv diabetu, hyperlipidemie, přítomnosti fibrilace síní, ICHS v anamnéze apod.).

Analýza mortalitních dat ukázala větší průměr dolní duté žily u zemřelých $(20,5 \pm 1,7 \mathrm{~mm}$ vs. $24,4 \pm 2,1 \mathrm{~mm}, p<0,05)$. Hazard ratio pro úmrtí ze všech u pacientů s průměrem dolní duté žíly nad medián bylo $2,0(1,0-7,5)$ pro 7 denní mortalitu, $1,8(1,1-6,1)$ pro 28denní a $4,1(1,3-12,6)$ pro jednoroční mortalitu. Podobně HR pro NT-proBNP nad medián bylo $2,9(0,8-10,1)$ pro $7 d e n n i ́, 3,6(1,2-11,1)$ pro 28denní a $3,8(1,5-9,6)$ pro jednoroční mortalitu.

Závěr: Měření dolního průměru dolní duté žíly je velmi jednoduchou součástí echokardiografického vyšetření a u pacientů s akutním srdečním selháním je prostý průměr dolní duté žíly významným ukazatelem krátkodobé a dlouhodobé prognózy.

\section{ENDOVASKULÁRNÍ LÉČBA KOMPLIKOVANÉ AKUTNÍ DISEKCE AORTY TYPU B}

RAUPACH J, LOJÍK M, TUNA M, HARRER J, BRTKO M, MĚDÍLEK K, ŽÁČEK P

Radiologická klinika, Kardiochirurgická klinika, FN Hradec Králové, Hradec Králové

Cíl: Optimální léčba disekce sestupné hrudní aorty typu B zůstává předmětem diskusí.

U nekomplikované disekce aorty typu B obvykle využiváme konzervativní léčbu. I přes optimální korekci tlaku dosa- 
huje tato léčba nemocniční a 3leté letality $11 \%$ a 22,4\%. U komplikovaných disekcí (např. ruptura aorty, ischemie) dosahuje nemocniční letalita při chirurgické léčbě 30-50 \%. Alternativním řešením komplikované disekce typu $\mathrm{B}$ je léčba pomocí stentgraftů a stentů. Principem je zavedení hrudního stentgraftu přes místo primárního entry. Zabrání se tak plnění nepravého kanálu krví a navodí se jeho trombóza a remodelace stěny aorty. Výkon se provádí $z$ pouhé femorální arteriotomie.

Soubor a metodika: V období května 2001 až října 2006 jsme léčili 9 pacientů (1 ženu, 8 mužů, věk: 27-81 let, průměrně 59 let) pro komplikovanou disekci aorty typu B. Indikace k endovaskulární léčbě byly akutní ruptura či prosakování $3 \times$, ischemické komplikace $1 \times$, časná expanze aorty $3 \times$, krutá bolest nereagující na léčbu $2 \times$. V 8 př́ipadech se jednalo o disekci aorty typu B s primárním entry za odstupem levé podklíčkové tepny. Jednou jsme léčili ischemické komplikace při disekci břišní aorty a pánevních tepen. Celkem bylo zavedeno 8 hrudních stentgraftů, 1 aortální a 2 pánevní stenty.

Výsledky: Jeden pacient s rupturou aorty zemřel na následky CMP, která vznikla 3. den po léčbě. 30denní a celková letalita našeho souboru je tedy 10\%. Celková doba sledování byla (2-67 měsíců, průměrně 19,6 měsíců). $Z$ perioperačních komplikací se u jedné 55leté nemocné vyvinula retrográdní disekce části ascendentní aorty. Pacientka přežívá na konzervativní terapii po dobu 67 měsíců.

Závěr: Naše výsledky potvrdily účinnost a efektivitu endovaskulární léčby. Pro svoji miniinvazivitu a rychlou dostupnost se endovaskulární léčba v našem centru stala metodou volby pro komplikované aortální disekce typu B.

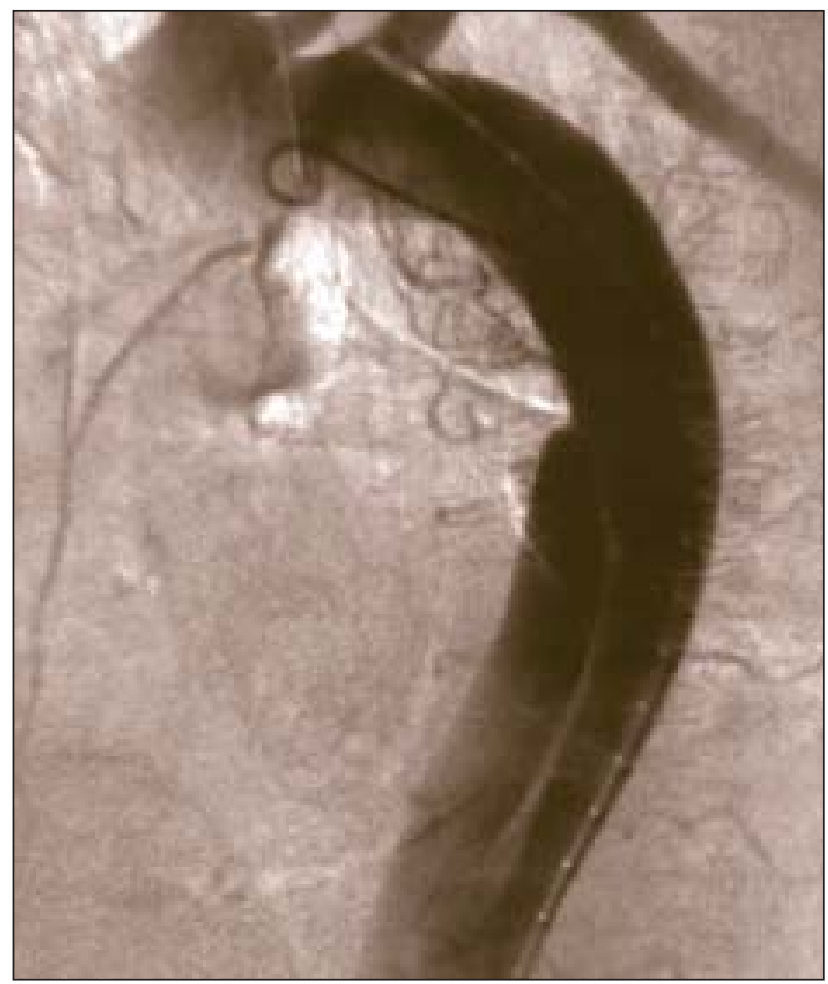

SESTERSKÁ SEKCE

\section{KONTRASTEM INDUKOVANÁ NEFROPATIE}

\section{REJNARTOVÁ P}

Kardiocentrum - katetrizační laborator̆,

Krajská nemocnice Liberec, Liberec
Kontrastem indukovaná nefropatie (CIN) je častým a závažným klinickým problémem, který významně negativně ovlivňuje prognózu nemocných.

CIN je definována jako nově vzniklá renální insuficience nebo její zhoršení v souvislosti s podáním kontrastní látky (vzestup kreatininu o $44 \mu \mathrm{mol} / 1$ nebo o 25 \% výchozí hodnoty).

Mechanismus vzniku CIN u predisponovaného nemocného je komplexní (kombinace prrímého toxického účinku kontraktní látky a ischemie dřeně ledvin).

Nejzávažnější rizikové faktory vzniku CIN jsou chronická renální insuficience, anemie diabetes mellitus, věk > 75 let, deplece intravaskulárního objemu, srdeční selhání a užívání nefrotoxických léků.

Zhoršení renálních funkcí po podání kontrastní látky je spojeno s prodlouženou dobou hospitalizace, zvýšením MACE a mortality nemocných podstupujících vyšetření s použitím kontrastní látky.

Pro klinickou praxi je zásadně důležité, že pečlivou rizikovou stratifikací můžeme vznik CIN předjímat a indikovat nemocné, kteří profitují z preventivních opatření (i. v. hydratace, NAC, vysazení nefrotoxických léků, hemofiltrace, použití izoosmolárních kontrastních látek v co nejnižší dávce, vyhnout se opakovanému podání kontrastní látky), případně indikovat alternativní zobrazovací metodu bez použití kontrastní látky.

\section{KOMPLIKACE LOKÁLNÍ TROMBOLÝZY PR̆I LÉČBĔ AKUTNÍ ISCHEMIE DOLNÍCH KONČETIN}

RIEGEL K, POVOLNÝ P, PODPĚROVÁ M, LUZUM P, POVOLNÝ J

Koronární jednotka, Oblastní nemocnice Kladno, Kladno

Lokální krvácivé komplikace se při protrahované trombolytické léčbě arteriálních uzávěrů na dolních končetinách vyskytují opakovaně. Problematika je uvedena kasuistikou pacientky se závažnou hemoragií po ukončení léčby.

75letá pacientka s akutní ischemií pravé dolní končetiny na podkladě tromboembolického uzávěru podkolenní tepny byla léčena lokální trombolýzou alteplázou. V průběhu aplikace pacientka chvílemi nedodržuje klidový režim, dochází $\mathrm{k}$ rozvoji hematomu v okolí vpichu do femorální tepny. Aplikace trombolytika ukončena asi po 20 hodinách vzhledem $\mathrm{k}$ progresi hematomu. Kontrolní angiografie prokazuje parciální zlepšení nálezu. Po normalizaci koagulačních parametrů odstraněn sheath. I přes manuální kompresi vpichu dochází k rychlému rozvoji rozsáhlého hematomu s hemodynamicky významnou krevní ztrátou, s nutností intenzivní léčby počínajícího hemoragického šoku. Současně progreduje ischemie bérce s rozvojem compartment syndromu s následnou trvalou peroneální parézou.

Léčba tromboembolických arteriálních uzávěrů lokální trombolýzou má i při dodržení kontraindikací riziko závažných komplikací, které významně stoupá úměrně době podávání trombolytika. Př́i rozhodování o této léčbě je nutno zohlednit kromě klinického nálezu i spolupráci pacienta při dodržování režimu.

\section{DVOJNÁSOBNÝ AKUTNÍ INFARKT \\ MYOKARDU A AKUTNÍ CÉVNÍ MOZKOVÁ PR̆íHODA KARDIOEMBOLIZAČNÍ ETIOLOGIE}

ROHÁČ F, WIDIMSKÝ P, LISA L

III. interní-kardiologická klinika, FN KV a 3. LF UK, Praha

53letý muž byl přijat na kardiologickou kliniku poté co byl nalezen ležící před obchodem. Objektivně somnolentní 
až soporózní, s pravostrannou hemiplegií, afázií, dysartrií, předcházely křeče končetin. Na EKG byly elevace úseku ST. Neurologické symptomy se rychle upravovaly během převozu do nemocnice. Při přjetí pacient již plně při vědomí, orientován, přetrvávala lehká expresivní afázie. Echokardiografie při přijetí prokazuje těžkou systolickou dysfunkci levé komory srdeční (akineze téměř celé přední stěny, septa, aneuryzma hrotu) a nález dvou mobilních kulovitých trombů $(12 \times 12 \mathrm{~mm}) \mathrm{v}$ hrotě levé komory (obrázek). Vzhledem ke známkám akutního infarktu myokardu byl pacient akutně katetrizován s nálezem nezužující koronární aterosklerózy na RIA, významné (70\%) stenózy levé septální větve a 80\% stenózy sekundární větve r. diagonalis (obrázek), nebyla prováděna žádná intervence na koronárních cévách. Do katetrizace byl pacient léčen Heparinem (celkem 150 j/kg), Aspégic 0,5 g, Plavix 600 mg. Po katetrizaci podáván nízkomolekulární heparin (Clexane $1 \mathrm{mg} / \mathrm{kg} / \mathrm{den}$ ) a Anopyrin $200 \mathrm{mg} /$ den. Další echokardiografie provedena následující den po prrijetí, kde přetrvávala stejná porucha kinetiky, patrný byl jen jeden mobilní kulovitý trombus $(6 \times 10 \mathrm{~mm})$ a druhý přisedlý pláštový útvar velikosti $5 \times 10 \mathrm{~mm}$. V dalším průběhu hospitalizace příznivý stav. Čtvrtý den od přijetí však náhlý vznik stenokardií a na EKG obraz akutního infarktu s elevacemi na spodní stěně. Provedená koronarografie prokázala shodný nález na levé koronární tepně, na pravé koronární tepně byl patrný uzávěr r. interventricularis posterior patrným trombem (obrázek), intervence neprováděna. Do medikace přidán Plavix. Echokardiografie provedená 12. den od přijetí již neprokazuje tromby v levé komoře, došlo k úpravě systolické funkce (55 \%).

\section{NÁHRADA AORTÁLNİ CHLOPNĔ U RIZIKOVÝCH PACIENTŨ. JSOU CHIRURGICKÉ VÝSLEDKY SKUTEČNĚ TAK ŠPATNÉ JAKO PREDIKCE EUROSCORE?}

ROHN V, TOŠOVSKÝ J, SEMRÁD M, URBAN T, LINDNER J, FICHTL J

Klinika kardiovaskulární chirurgie, VFN a 1. LF UK, Praha

Cíl: V současné době probíhají klinické studie perkutánní implantace protézy aortální chlopně, která by v brzké době měla být alternativou operace $\mathrm{u}$ pacientů $\mathrm{s}$ vysokým operačním rizikem hodnoceným podle EuroScore. Na druhé straně také chirurgická technika, vedení mimotělního oběhu, anestezie a pooperační péče prodělaly značný vývoj v posledních letech. Tato studie má za cíl ozřejmit, jaké jsou skutečné výsledky chirurgické náhrady aortální chlopně (AVR) a do jaké míry je model predikce EuroScore přesný u této podskupiny pacientů. září 2006 jsme provedli náhradu aortální chlopně 383 pacientům. $160 \mathrm{z}$ nich mělo aditivní EuroScore vyšší nebo rovno 6. Průměrný věk těchto pacientů byl 75 (34-86) let.

Výsledky: Průměrné EuroScore bylo 7,01 (6-11), což odpovídá v této skupině predikované perioperační mortalitě podle logistického EuroScore 19,43\%. Skutečná 30denní mortalita byla $8,75 \%(p<0,001)$. Průměrná délka intubace byla 48,5 hodiny, délka pobytu na JIP byla 5 dní. Pro pooperační krvácení byl revidován jeden pacient $(0,6 \%)$, jeden nemocný měl mediastinitidu. Průměrná velikost chlopenní náhrady byla $22,9 \mathrm{~mm}$.

Závěr: Náhradu aortální chlopně lze provést s nízkým operačním rizikem i u rizikových pacientů. Predikovaná mortalita pomocí EuroScore v tomto př́ípadě do značné míry nadhodnocuje. Dobré dlouhodobé výsledky pacientů po náhradě aortální chlopně jsou dostatečně dokumentovány.

\section{VLIV ENTERÁLNÍ NUTRICE NA GLOBÁLNÍ HEMODYNAMIKU A FUNKCI LEVÉ KOMORY SRDEČNÍ U PACIENTŮ PO AKUTNÍM INFARKTU MYOKARDU*}

ROKYTA R, KROPÁČEK J, LINHARTOVÁ K, ŠIMANOVÁ A, PECHMAN V, GAJDOŠ P

I. interní klinika, kardiologická jednotka intenzivní péče, FN Plzeř a LF UK, Oddělení kardiologie, Kardiovaskulární centrum, FN Motol, Praha

*Podpořeno Kardiovaskulárním grantem VZ UK č. MSM 0021620817

„Invazivní př́stupy $k$ záchraně a regeneraci myokardu“.

Úvod: Fyziologická hyperemická odpověd’ po podání enterální nutrice (EN) je zachována u pacientů po kardiochirurgických výkonech vyžadujících katecholaminy i u pacientů v těžké sepsi. Cílem této studie je zhodnotit parametry globální hemodynamiky a vybrané echokardiografické parametry před EN a po podání EN u pacientů po prodělaném infarktu myokardu (IM) se systolickou dysfunkcí levé komory srdeční (LKS).

Soubor a metodika: Do studie bylo zatím zařazeno 8 pacientů (věk 34-74 let) po IM léčeném primární PCI. Studie byla provedena 3.-7. den po IM, žádný pacient neměl v době studie katecholaminy. První série dat (0) byla získána po celonočním lačnění, 2. a 3 . série dat 60 , resp. 120 min po perorálním podání Nutridrinku (10 kcal/kg). Hemodynamika byla sledována monitorem VIGILEO ${ }^{\circledR}$ (Edwards). V čase 0 a 60 min byla prováděna transtorakální echokardiografie, $\mathrm{EF}$ LKS byla hodnocena modifikovanou Simpsonovou metodou.

Výsledky: viz tabulka.

Tabulka k abstraktu MUDr. Rokyty

\begin{tabular}{|c|c|c|c|c|}
\hline & $\mathbf{0}$ & $60 \mathrm{~min}$ & $120 \mathrm{~min}$ & $\boldsymbol{p}$ \\
\hline Tepová frekvence/min & $76(70 ; 86)$ & $87(80 ; 98)^{*}$ & $81(77 ; 92)$ & $<0,05$ \\
\hline Střední arteriální tlak (mm Hg) & $90(86 ; 98)$ & $89(85 ; 95)$ & $87(82 ; 91)$ & NS \\
\hline Tepový objem $\left(\mathrm{ml} / \mathrm{m}^{2}\right)$ & $34(31 ; 35)$ & $38(34 ; 42)$ & $35(32 ; 44)$ & NS \\
\hline Srdeční index $\left(1 / \mathrm{min} / \mathrm{m}^{2}\right)$ & $2,8(2,5 ; 3,0)$ & $3,5(3,1 ; 3,7)^{*}$ & $3,2(2,9 ; 3,4)$ & $<0,01$ \\
\hline EF LKS (\%) & $41(33 ; 45)$ & $45(38 ; 47)$ & & NS \\
\hline Enddiastolický objem $\left(\mathrm{ml} / \mathrm{m}^{2}\right)$ & $60(53 ; 64)$ & $60(52 ; 67)$ & & NS \\
\hline E/E'med & $16(11 ; 17)$ & $11(10 ; 15)$ & & NS \\
\hline
\end{tabular}

Data jsou medián, 25. a 75. percentil; NS - nesignifikatní, *60 min vs. 0 (Friedman RM-ANOVA)

Soubor a metodika: V retrospektivní studii $z$ našeho pracoviště jsme zhodnotili výsledky AVR u vysoce rizikových pacientů (aditivní EuroScore > 6) a srovnali jejich perioperační průběh s predikovanou mortalitou. Od ledna 2004 do
Závěr: Naše předběžné výsledky naznačují, že fyziologická hyperemická odpověd’ je zachována i u pacientů po recentně prodělaném infarktu myokardu se systolickou dysfunkcí levé komory srdeční. 


\section{ČASNÁ ANGIOGRAFICKÁ KONTROLA AKUTNÍ PERIOPERAČNÍ ISCHEMIE MYOKARDU (APIM) PO CHIRURGICKÉ REVASKULARIZACI}

ROMANIV S, DOBIÁŠ M, STŘÍTESKÝ M, VONDRÁČEK V, TOŠOVSKÝ J, HORÁK J

Klinika anesteziologie, resuscitace a intenzivní medicíny, Klinika kardiovaskulární chirurgie,

VFN a 1. LF UK, Praha

Úvod: Akutní infarkt myokardu (AIM) během chirurgické revaskularizace myokardu (CABG) se vyskytuje ve 3-10\% a je významným faktorem morbidity a mortality. 30denní mortalita pacientů reoperovaných pro APIM za hemodynamické (HD) stability je udávána mezi 11-16 \% a ve stavu těžké HD nestability až 39-50 \%. Dosud nebyla publikována žádná studie hodnocení vlivu SKG a příp. perkutánní koronární intervence (PCI) na „outcome“ pacientů s APIM. Pouze jednotlivé „case“ - série dokládají bezpečnost PTCA distálních anastomóz koronárních bypassů.

Soubor nemocných: Od 1. 1. do 31. 12. 2005 na KKVCH VFN a 1. LF UK bylo provedeno 699 CABG. Provedli jsme retrospektivní analýzu selektivních koronarografií (SKG), provedených urgentně po CABG $\mathrm{z}$ indikace APIM.

Metodika: Pro diagnostiku APIM byla nutná přitomnost aspoň dvou $z$ následujících nálezů: patologický nález EKG, maligní komorové arytmie, HD nestabilita navzdory adekvátní inotropní podpoře, patologický ECHO nález.

Indikací k SKG byla APIM a obtížnost určení culprit lesion a/nebo neschůdnost další chirurgické intervence. Významnost ischemie byla stanovována echokardiograficky (nově vzniklá nebo zhoršená lokalizovaná porucha kinetiky 3 a více segmentů).

Kontraindikací SKG byla těžká HD nestabilita, znemožňující transport do katetrizační laboratoře nebo velké krevní ztráty.

Výsledky: SKG byla provedena u 11 pacientů. Patologický SKG nález byl př́tomen u 9 (82\%) pacientů, z toho úspěšná ad hoc PCI byla provedena u $8(73 \%)$ a reoperace u pouhých 4 (36 \%) nemocných. Reoperace bylo ušetřeno 7 (64\%) pacientů. SKG/PCI nebyla spojena s žádnými komplikacemi.

Závěry: Správně indikovaná urgentní SKG pro APIM významně přispěla $\mathrm{k}$ určení culprit lesion, $\mathrm{k}$ redukci počtu reoperací a nebyla spojena s periprocedurálními komplikacemi.

\section{ÚROVEŇ KONTROLY HYPERTENZE U NEMOCNÝCH S METABOLICKÝM SYNDROMEM A PR̆IDRUŽENÝMI CHOROBAMI}

\section{ROSOLOVÁ H}

Centrum preventivní kardiologie,

II. interní klinika, FN Plzeň, Plzeň

Úvod: Hypertenze je jedním ze základních rizikových faktorů metabolického syndromu (MS) a její úspěšná léčba snižuje kardiovaskulární riziko.

Metodika: Studie byla iniciovaná Institutem metabolického syndromu v ČR a provedená ambulantními lékaři (praktickými i specialisty). Sledovala 3479 nemocných s MS diagnostikovaným podle přijatých kritérií NCEP III. Lékaři promluvili se všemi zařazenými nemocnými o konkrétní změně životního stylu a zdưraznili nutnost uživání všech již zavedených léků. Zavedená antihypertenzní léčba se v průběhu půlročního sledování neměnila. Lékaři měřili kazuální klidový krevní tlak (TK) vsedě standardním způsobem 2 krát před zahájením intervence a při návštěvě závěrečné (po půl roce); vždy 2. měření bylo zaneseno do protokolu.
Výsledky: Ze souboru 3479 nemocných (1 710 mužů a 1744 žen) průměrného věku $59 \pm 11$ let užívalo antihypertenzní terapii $68 \%$ nemocných (tj. 2349 osob). Téměř polovina nemocných měla současně diabetes. Hypertonici bez diabetu měli TK pod 140/90 mm Hg pouze ve $38 \%$ a hypertonici s diabetem měli TK pod $130 / 80 \mathrm{~mm} \mathrm{Hg}$ dokonce pouze v $6 \%$. V průběhu studie došlo $\mathrm{k}$ významnému snížení TK u obou skupin hypertoniků v průměru o $7 \%$ (o 10/6 mm Hg). Dosažení cílových TK se zlepšilo o $12 \%$ u hypertoniků bez diabetu (tj. $50 \%$ dosáhlo hodnot TK pod $140 / 90 \mathrm{~mm} \mathrm{Hg}$ ) a o $6 \%$ u hypertoniků s diabetem (tj. $12 \%$ dosáhlo TK pod 130/80 mm Hg).

Závěr: Na mírném zlepšení kontroly hypertenze se zřejmě podílela významná redukce hmotnosti nemocných a větší pozornost lékaře, individuální intervence zaměřená na Životní styl i užívání všech léků a následně lepší adherence nemocných $\mathrm{k}$ antihypertenzní terapii. Stále je však třeba zlepšovat terapii hypertenze $\mathrm{v}$ ambulantní praxi.

\section{SESTERSKÁ SEKCE}

\section{TRANSSEPTÁLNÍ METODA JE VÝHODNĚJŠÍ OPROTI TRANSAORTÁLNIIMU PR̆ÍSTUPU PR̆I ABLACI LEVOSTRANNÝCH PR̆İDATNÝCH DRAH}

ROTTER N, SIKOROVÁ M, WOJNAROVÁ D, RUSNOKOVÁ R, ZOUBKOVÁ R, KOTASOVÁ R, WOJNAROVÁ D, MORAVEC R, SZYMECZEK H, CHOVANČÍK J

\section{Kardiologické oddělení, Nemocnice Podlesí a. s., Třinec}

Cíl práce: Srovnání retrográdního transaortálního (Retro) a transseptálního (TS) př́ístupu při katetrové ablaci levostranných př́idatných drah (LPD)

Metodika: V souboru bylo 36 pacientů (pac) s LPD, u kterých byla od I/2005 do X/2006 provedena katetrová ablace. U 21 pac $(8 \check{Z}, 42 \pm 12$ let) byla ablace primárně Retro, u 15 pac ( $7 \check{Z}, 45 \pm 8$ let) byla ablace primárně TS.

Výsledky: Jiná arytmie se současně řešila ve skupině Retro $2 \times$ (AVNRT a flutter) a ve skupině TS 1x (AVNRT). Skiaskopický čas ve skupině Retro byl $19 \pm 13$ (3-45, medián 15) a ve skupině TS byl $12 \pm 8$ (3-26, medián 10); $p=0,02$. Celkový čas výkonu byl ve skupině Retro $114 \pm 53$ (60-200, medián 120) a ve skupině TS $120 \pm 60$ (60-240, medián 120); $p=$ NS. Počet RF aplikací byl ve skupině Retro $10 \pm 8(2-30$, medián 6) a ve skupině TS $11 \pm 10$ (1-38, medián 8); $p=$ NS. Ve skupině Retro byla nakonec ablace $3 \times$ úspěšně dokončena $z$ TS přístupu. Ve skupině TS byly charakteristiky výkonu ovlivněny 4 složitými epikardiálními drahami, kdy 3x byla ablace započata uvnitř koronárního sinu (CS) a dokončena TS a naopak $1 \times$ byla primárně TS ablace dokončena epikardiálně v CS. Výkony byly bez komplikací.

Závěr: 1. Transseptální př́istup je oproti transaortálnímu přístupu spojen s kratším skiaskopickým časem, nebot umožňuje snazší mapování mitrálního prstence. 2. Další výhodou transseptálního přístupu je pouze žilní přístup spojený potenciálně s menším rizikem cévních komplikací, kratší rekonvalescencí po výkonu a kratší hospitalizací.

\section{OPERACE DEKOMPENZOVANÉ KOMBINOVANÉ AORTÁLNÍ VADY S TĚŽKOU DYSFUNKCÍ OBOU KOMOR. KASUISTIKA*}

ROUČKA P, ŠMIID M, HÁJEK T, ZÁRYBNICKÁ M

Kardiochirurgické oddělení, FN Plzeñ, Plzeñ 
*Práce byla podpořena grantem VZ UK

v Praze č. MSM 0021620817, uděleným MŠMT ČR.

Kasuistika: 40letý muž, aktivní sportovec M. N. s anamnesticky udávanou, blíže nespecifikovanou srdeční vadou, bez dalšího sledování v dospělosti, byl přijat 12. 10. 2005 na naše oddělení pro recidivující oboustranné srdeční selhání s anasarkou (NYHA IV).

Echokardiograficky potvrzena významná dysfunkce obou komor (EF LKS 20-25 \% a PKS 20-30\%) při trikuspidalizované kombinované významné aortální vadě $\mathrm{s}$ převahou aortální insuficience na podkladě vrozené bikuspidální chlopně. Současně diagnostikována plicní hypertenze se systolickým tlakem v plicnici $70 \mathrm{~mm}$ Hg a trombus v hrotu LKS. Diagnóza potvrzena oboustrannou srdeční katetrizací s vyloučením koronárního postižení. Zátěžovým vyšetřením prokázána hraniční funkční rezerva LKS se vzestupem EF LKS o 5-10 \%. Po kompletaci vyšetření indikován ke kardiochirurgické operaci, která byla odložena pro komplikující bronchopneumonii.

13. 10. 2005 provedena mechanická náhrada aortální chlopně a plastika trikuspidální chlopně anuloplastickým ringem. Po 9denním nekomplikovaném hospitalizačním pobytu $\mathrm{s}$ účinnou warfarinizací propuštěn do domácího ošetřování.

Během ročního sledování došlo $\mathrm{k}$ úplnému vymizení kardiální symptomatologie, echokardiograficky popsána postupná normalizace systolické funkce obou komor, regrese jejich koncentrické hypertrofie a normalizace tlaku v plicním řečišti.

Závěr: Těžká systolická dysfunkce obou komor u kombinované aortální vady a převahou aortální insuficience představuje vysoké peri- i postoperační riziko. U části pacientů přetrvává i po úspěšné kardiochirurgické operaci ireverzibilní dysfunkce obou komor. V našem případě přinesla operace pacientovi jednoznačný profit a odvrátila transplantaci srdce, která by též mohla být zvažována jako první metoda volby.

\section{VROZENÉ ANOMÁLIE VĚNČITÝCH TEPEN V DOSPĚLOSTI}

ROZSÍVAL V

Pracoviště invazivní kardiologie, Kardio-Troll, Pardubice

Sdělení se týká abnormalit počátku, průběhu a distribuce koronární arteriální cirkulace. $Z$ některou anomálií se setkáme u $1 \%$ koronarografovaných. Zjištěné abnormality jsou většinou benigní (81 \%), ale jsou i potenciálně závažné a jsou druhou nejčastější př́ičinou náhlé smrti sportovců. Diagnózu stanovíme koronarografií, ale i pomocí ECHO-vyšetření (s výhodou TEE) MRI nebo CT vyšetřením. TEE vyšetření by mohlo sloužit jako screening závažných nálezů. $Z$ praktického hlediska rozdělíme anomálie na ty, které ovlivňují myokardiální perfuzi a ty, které ji neovlivňují. Mezi závažnější formy patří koronární fistule, anomální odstup věnčité tepny $\mathrm{z}$ plicnice ( $\mathrm{v}$ práci rozvedeno), anomální odstup RIA zprava s průběhem mezi aortou a plicnicí, kongenitální stenózy či atrézie. Podrobněji jsou rozvedeny typy koronárních fistulí, jejich symptomaologie a možnosti řešení. Uvedena kasuistika $z$ vlastní praxe. Uvedeny jsou jednotlivé typy anomálních odstupů věnčitých cév z plicnice, klinický obraz a možnosti řešení. Dokumentováno vlastními nemocnými. V práci je poukázáno i na možnost nově vzniklých cév, odstupujících z koronární cirkulace, zásobujících nádor v myokardu nebo mediastinu (dokumentováno vlastní kasuistikou).

Závěr: a) s vrozenými anomáliemi věnčitých tepen se setkáváme i v dospělosti, b) je třeba detekovat a odlišit potenciálně nebezpečné nálezy, c) otázka screeningu u vrcholových sportovců - TEE?, c) v terapii se rozhodujeme mezi operačním řešením nebo katetrizační intervencí.

\section{ÚROVEŇ SEKUNDÁRNÍ PREVENCE U NEMOCNÝCH PO INTERVENCI V KAROTICKÉM ŘEČIŠTI}

\section{RUČKA D, KAČÍRKOVÁ K, ČERNOHOUS M,} NETUKA D, OSTRÝ S

Interní klinika, Nerochirurgická klinika, ÚVN a 1. LF UK, Praha

Úvod: Přibývá nemocných, $\mathrm{u}$ nichž byla $\mathrm{v}$ rámci prevence CMP provedena chirurgická nebo perkutánní intervence významných stenóz v karotickém řečišti. Péče o tyto nemocné je však rozptýlena mezi lékaře různých odborností a není vzácností, že po úspěšném intervenčním zákroku často uniká pozornosti následná medikamentózní terapie a korekce rizikových faktorů. Přitom je evidentní, že právě tato léčba zásadně ovlivňuje jejich další prognózu.

Cíl práce: Zhodnotit úroveň léčby a kompenzace rizikových faktorů u nemocných po chirurgické nebo perkutánní intervenci v karotickém řečišti.

Metodika: Všechny nemocné po karotické intervenci jsme společně s lékaři neurochirurgické kliniky sdružili do společné ambulance. Kardiologické a neurologické vyšetření bylo $\mathrm{v}$ jedné době doplněno ultrasonografií karotid. Při stanovení rizik i úpravě farmakoterapie jsme vycházeli $z$ platných guidelines ČKS pro prevenci kardiovaskulárních onemocnění.

Výsledky: Od listopadu 2005 jsme vyšetřili 107 nemocných průměrného věku $67 \pm 10$ let. $72 \%$ nemocných bylo po CMP nebo TIA, $28 \%$ po koronární př́íhodě a $12 \%$ po CABG. $76 \%$ nemocných splňovalo kritéria metabolického syndromu, $39 \%$ bylo diabetiků. Průměrný sTK byl $147 \pm 18$ mm Hg, BMI: $26 \pm 4$. Průměrné hladiny lipidů $\mathrm{v}$ mmol/1 byly následující: Chol: 5,9 \pm 1,1, LDL: 3,4 \pm 0,8, HDL: $1,2 \pm 0,2$, TAG: $2,1 \pm 0,7$. Cílových hodnot TK nedosáhlo $67 \%$, cholesterolu a LDL $49 \%$, resp. $58 \%$ nemocných. Antiagregancii bylo léčeno $92 \%$, statiny $60 \%$ a ACE-I $51 \%$ nemocných. Nadváhu mělo $65 \%$ a obezitu $16 \%$ nemocných.

Závěr: Pacienti po karotické intervenci jsou skupinou s vysokým rizikem následné kardiovaskulární příhody. Naše práce ukázala na nedostatky v sekundární prevenci. Spokojeni můžeme být pouze s úrovní antiagregační léčby. Specializované ambulance by mohly být cestou $\mathrm{k}$ zlepšení následné farmakoterapie, zvláště v centrech, které karotické intervence provádějí.

\section{SESTERSKÁ SEKCE}

\section{KATETROVÁ ABLACE KOMOROVÉ TACHYARYTMIE U PACIENTŮ SE ZDRAVÝM SRDCEM I STRUKTURÁLNĚ POSTIŽENÝM SRDCEM}

RUSNOKOVÁ R, ZOUBKOVÁ R, WOJNAROVÁ D, SIKOROVÁ M, ROTTER N, KOTASOVÁ R, MORAVEC R, SZYMECZEK H, CHOVANČÍK J

\section{Kardiologické oddělení, Nemocnice Podlesí a. s., Třinec}

Cíl práce: Prezentace indikace a výsledků ablace pro různé typy komorové tachyarytmie.

Metodika: Do souboru bylo zařazeno 34 pacientů (pac.) (15 žen, $49 \pm 13$ let). U pacientů s tzv. idiopatickou komorovou tachykardií (KT) nebo četnou komorovou extrasystolií (KES) byla ablace provedena jako kurativní výkon, u pacientů se strukturálním postižením srdce většinou jako výkon paliativní, redukující výboje ICD a prodlužující kvalitu života pacientů a životnost ICD.

Výsledky: Ablace idiopatické nesetrvalé nebo setrvalé KT byla provedena u 11 pac. (20-72 let); ve výtokovém traktu pravé komory (VTPK) u 8 pac., v jiných lokalizacích u 3 pac. Ablace četné idiopatické KES byla provedena u 23 pacientů (33-71 
let); ve VTPK u 18 pac., v jiných lokalizacích u 5 pac. Čas výkonu byl $106 \pm 48$ minut, skiaskopický čas $8 \pm 5$ minut a počet $\mathrm{RF}$ aplikací $11 \pm 8$ minut. Ablace byla úspěšná u 32 (94\%) pacientů, u 26 (100 \%) pacientů ve VTPK a u 2 (25\%) pacientů v jiných lokalizacích. Ablace KT u strukturálního postižení srdce (SPS) byla provedena u 40 pac. (37-81 let) (po IM - 32 pac., DKMP - 3 pac., arytmogenní kardiopatie PK - 4 pac., jiné - 1 pac). Cílené mapování a ablace byla provedena u 7 pac., substrátová ablace u 24 pac. a kombinace obou strategií u 9 pac. Čas výkonu byl $218 \pm 56$ minut, skiaskopický čas $20 \pm 10$ minut a počet $\mathrm{RF}$ aplikací $24 \pm 13$ minut. Ablace eliminovala klinickou KT u 38 (95\%) pacientů (u 2 pacientů po IM).

Závěr: 1. Katetrová ablace idiopatické KT/KES z VTPK je vysoce úspěšná, úspěšnost ablace v idiopatické KT/KES jiných lokalizacích je nižší zejména $z$ anatomických příčin. 2. Účinnost paliativní ablace klinické KT u pacientů s SPS je velmi dobrá a vede k významnému zlepšení kvality života.

\section{SESTERSKÁ SEKCE}

\section{ALTERNATIVNÍ HODNOCENÍ ANGIOGRAFICKY HRANIČNÍCH KORONÁRNÍCH LÉZİ METODAMI MĚR̆ENÍ FRAKČNÍ PRŮTOKOVÉ REZERVY (FFR) A INTRAVASKULÁRNİHO ULTRAZVUKU (IVUS)}

\section{RYCHETSKA D}

Kardiocentrum - katetrizační laborator̆,

Krajská nemocnice Liberec, Liberec

Metoda měření FFR a IVUS jsou komplementární metody koronární angiografie, které nám umožňují objektivnější rozhodování v katetrizační laboratoři, zejména u tzv. angiograficky hraničních lézí 40-70 \% LD.

IVUS je invazivní zobrazovací metoda, která umožňuje přímé zobrazení cévní stěny, měření lumina, velikost, distribuci a kvalitu aterosklerotických plátů. V současnosti je na našem pracovišti ke zpřesnění složení plátu dostupná technologie virtuální histologie. Měření frakční průtokové rezervy je vyšetření funkční a hodnota FFR myo je spolehlivým a specifickým indexem hemodynamické významnosti určité koronární léze, který lze opět využít na všech úrovních rozhodování během koronární intervence: zda angioplastiku provést, hodnocení reziduálního zúžení po intervenci a zvolení dalšího postupu (stent a jeho optimální implantace). Běžné využívání výše zmíněných technik na katetrizačním sále vede ke zkvalitnění rozhodovacího procesu a tím i péče o naše pacienty.

\section{AKUTNÍ PERIKARDITIDA JAKO ORGÁNOVÁ MANIFESTACE AKUTNII CHLAMYDIOVÉ INFEKCE. KASUISTIKA}

RYZLOVA M, GREGOR P, KARÁSEK J,
MOT̃OVSKÁ Z, WIDIMSKÝ P

III. interní-kardiologická klinika, FN KV a 3. LF UK, Praha

Prezentujeme případ 52letého pacienta, který byl odeslán na naší kliniku pro protrahovaný febrilní stav nejasné etiologie a velký perikardiální výpotek. Klinicky od přijetí dominovaly již několik týdnů trvající febrílie (až $39^{\circ} \mathrm{C}$ ) se schváceností, suchým kašlem a bolestí v prekordiu. Laboratorně od přijetí byla výrazná elevace zánětlivých parametrů, na CT hrudníku prokázán pleurální a perikardiální výpotek. ECHO-vyšetření potvrzuje velký perikardiální výpotek bez známek tamponády, na EKG nález sinusové tachykardie s naznačenými elevacemi úseků ST ve II, III, aVF, V5-V6, kardiospecifické enzymy negativní. Kombinovaná ATB terapie (Amoksiklav + Gentamicin a dále Aug- mentin + Ciphin) byla bez zjevného klinického efektu, provedené kultivace opakovaně negativní. V rámci dif. dg. byla vyloučena hematologická malignita, pomýšleno na systémové autoimunitní onemocnění, pro které svědčil nález hraničně pozitivních výsledků autoprotilátek (ANA 1: 160, anti Jo-1), mikroalbuminurie, hepatosplenomegalie a nález tepelných autoprotilátek v krvi (pozitivní Coombs). Proto ATB-terapie ukončena, nasazena kortikoterapie. Klinicky u pacienta dále přetrvávaly subfebrilie, laboratorně pokles zánětlivých parametrů, normalizace plicního nálezu, perikardiální výpotek přetrvává. Poté zjištěna serologická pozitivita akutní chlamydiové infekce (Chlamydia pneumoniae). Nasazena terapie makrolidy, po které dochází k ústupu subfebrilit a úplné regresi perikardiálního výpotku. Taktéž dochází $\mathrm{k}$ vymizení tepelných autoprotilátek $\mathrm{z}$ krve (negativní Coombs).

Kontrolní serologické odběry s odstupem potvrzují proběhlou akutní chlamydiovou infekci (prokázána serokonverze protilátek). Pacient je klinicky nadále bez větších obtíží, afebrilní.

Popisujeme př́ipad velmi vzácné chlamydiové perikarditidy s obrovským perikardiálním výpotkem, která klinicky imponovala zpočátku jako systémové onemocnění.

\section{SESTERSKÁ SEKCE}

\section{ZÁTĚŽOVÁ ECHOKARDIOGRAFIE - NAŠE PRAXE}

\section{SAMKOVÁ D}

I. interní klinika, Oddělení neinvazivní kardiologie, FN Hradec Králové, Hradec Králové

Úvod: Základy techniky zátěžové echokardiografie byly vyvinuty již koncem sedmdesátých let. Principem této metody je využití dvourozměrné echokardiografie $\mathrm{k}$ detekci myokardiální ischemie, která se projevuje abnormalitami pohybu stěn levé komory srdeční.

Indikace $\mathbf{k}$ zátěžové echokardiografii:

a) diagnostika ischemické choroby srdeční,

b) zhodnocení efektu revaskularizace,

c) rozlišení mezi ischemickým myokardem, jizvou a viabilním myokardem.

Metodika:

Formy zátěže - 1. dynamická zátěž, 2. farmakologická zátěž, 3. jícnová stimulace.

Možnosti zobrazení - 1. transtorakální ultrazvuk, 2 . transezofageální ultrazvuk. Standardní dávkovací protokol - a) diagnostika ischemické choroby srdeční, b) posouzení viability.

Průběh vyšetření - úloha sestry: dokumentace, pomůcky, příprava pacienta, průběh vyšetření.

Závěr: Zátěžová echokardiografie je neinvazivní, opakovatelná, ekonomicky dostupná a bezpečná metoda. Pro svou vysokou diagnostickou přesnost $v$ současné době patři mezi metody vysoce účinné.

\section{SPIROERGOMETRIE V AMBULANCI PRO CHRONICKÉ SRDEČNÍ SELHÁNÍ - „NAPOVÍ“ NÁM VÍCE O PACIENTOVI?}

\section{SCHEJBALOVÁ M}

Kardiologické oddělení, Nemocnice Na Homolce, Praha

Účelem zakládání ambulancí nebo jednotek pro chronické srdeční selhání je zlepšit ambulantní péči o tyto nemocné, je- 
jichž počet celosvětově, a tedy i v naší republice výrazně narůstá. Pravidelnou kontrolou nemocných, uptitrací medikace a cílenou edukací nemocných se dosahuje zlepšení jejich klinického i subjektivního stavu, zvyšuje se kvalita života a prodlužuje jeho délka. Zároveň se tím předchází opakovaným hospitalizacím pro progresi kardiální nedostatečnosti.

Spiroergometrie je v současnosti uživána $z$ prognostického hlediska k odhadu závažnosti onemocnění, hlavně jako jedno Z indikačních kritérií před ortotopickou transplantací srdce.

$\mathrm{V}$ rámci komplexní péče o nemocné s chronickým srdečním selháním jsme $\mathrm{v}$ ambulanci srdečního selhání $\mathrm{v} \mathrm{Ne}$ mocnici Na Homolce testovali v průběhu roku 2006 skupinu 77 nemocných (68 mužů a 9 žen), u kterých jsme vždy v jednom dni provedli kompletní fyzikální vyšetření - včetně měření TK, Tf, EKG, odebrali jsme vzorek laboratoře včetně NT-proBNP.

Zároveň bylo provedeno echokardiografické vyšetření se zhodnocením funkce levé srdeční komory a následně byla provedena spiroergometrie. Nemocní současně vyplnili i dotazník kvality života. Skupinu nemocných jsme poté rozdělili podle klasifikace NYHA, ke které jsme přiřadili velikost ejekční frakce LK, dobu trvání zátěže, hladinu NT-proBNP a parametry jsme porovnávali se subjektivním hodnocením nemocného či jeho hodnocením v dotazníku kvality života. Zohlednili jsme i užívanou medikaci, délku sledování $\mathrm{v}$ ambulanci a další parametry. Vzhledem $\mathrm{k}$ tomu, že sběr dat byl ukončen na konci prosince 2006, budeme se výslednou analýzou našich výsledků zabývat v ústním sdělení v rámci bloku Srdečního selhání na XV. výročním sjezdu ČKS.

\section{SESTERSKÁ SEKCE}

\section{VYUŽITÍ ECHOKARDIOGRAFICKÉHO VYŠETŘENÍ V INTENZIVNÍ PÉČI}

SEDLÁKOVÁ H, KRÁL J, KÁBRTOVÁ E

III. interní klinika - echokardiografie,

VFN a 1. LF UK, Praha

Echokardiografie je neinvazivní vyšetřovací metoda využívající ultrazvuk k zobrazení srdečních struktur a velkých cév. Jedná se o velmi rozšířenou a přínosnou zobrazovací metodu, oblíbenou pro její neinvazivnost, snadnou dostupnost a opakovatelnost. Vyšetření můžeme provést bud' klasicky, přes hrudník, transtorakální echokardiografie (TTE) nebo pomocí jícnové sondy, transezofageální echokardiografie (TEE). Při transezofagiální echokardiografii je možné detailně zobrazit aortu, srdeční chlopně a vzadu v srdci umístěné části - přednostně levou síň a ouško levé síně. Echogardiografie je velmi cennou diagnostickou metodou $\mathrm{u}$ akutních stavi̊ v intenzivní péči. Na naší klinice máme proto jeden přístroj trvale umístěn přímo na koronární jednotce. To umožňuje lékaři jeho okamžité využití $\mathrm{k}$ určení správné diagnózy $\mathrm{u}$ akutních stavů a následně ke stanovení správných léčebných postupů. Echokardiografické vyšetření je př́nosné pro hodnocení srdeční funkce, přítomnosti a rozsahu poruchy srdeční kontrakce (např. u AIM) a včasné poznání komplikací ICHS (porucha systolické a diastolické funkce levé komory, porucha funkce a ruptura papilárního svalu, závažnost mitrální regurgitace, ruptura mezikomorové přepážky, př́tomnost trombu v levé komoře, perikardiální a pleurální výpotek). Kromě vyloučení jiných chorob umožňuje posoudit i dilataci pravé komory, nepř́mé známky plicní hypertenze u nemocných s podezřením na embolizaci do plic. Důležitá je i jícnová echokardiogarfie (TEE) u nemocných s podezřením na dilataci a disekci aorty, před plánovanou elektrickou kardioverzí u nemocných s fibrilací síní, za účelem vyloučení př́tomnosti nitrosrdečních trombů v dutině, zejména v oušku levé síně.

\section{ARYTMIE JAKO KOMPLIKACE AKUTNÍHO KORONÁRNIIHO SYNDROMU BEZ ELEVACÍ ÚSEKŮ ST}

SEDLOŇ P, ŠEVČÍKOVÁ K, KAMENÍK L, KOTIIK I, ČERNOHOUS M

Kardiologické oddělení, Oddělení všeobecných interních lůžek, ÚVN Praha a 1. LF UK, Praha

Akutní koronární syndromy jsou spojeny s řadou komplikací. Poruchy rytmu se vyskytují u téměř $90 \%$ nemocných s manifestním akutním koronárním syndromem, převodni poruchy se vyskytují u zhruba $25 \%$ nemocných. Akutní koronární syndromy bez elevací úseků ST jsou obvykle považovány za stav spojený s menším rizikem vzniku závažných, především komorových arytmií v akutní fázi, přesto je jejich výskyt klinicky významný a relativně častý a může znamenat zhoršení krátkodobé i dlouhodobé prognózy. Riziko vzniku závažných arytmií stoupá s př́itomnou systolickou dysfunkcí levé komory srdeční a obvykle souvisí se závažnějším postižením věnčitých tepen. Výskyt supraventrikulárních arytmií, zejména fibrilace síní, je často spojen s klinicky manifestním srdečním selháváním. Protože arytmogenní substrát $\mathrm{u}$ nemocných $\mathrm{s}$ ACS bez elevací úseků ST je obvykle různorodý a často komplexní, terapie musí být zaměřena nejen na potlačení vlastní arytmie, ale především na řešení přidružených vyvolávajících faktorů.

\section{VLIV PR̆ÍTOMNOSTI STIMULAČNÍ ELEKTRODY NA ENDOVAZÁLNII A ENDOMYOKARDIÁLNI SRDEČNÍ STRUKTURY*}

SEPŠI M, ŠINDLER M, MÚČKOVÁ K, KOZÁK M, KŘIVAN L

Interní-kardiologická klinika,

Ústav soudního lékařství, FN u sv. Anny,

Ústav patologie, FN Brno, Brno

*Výzkum je podporován grantem 1A/8598-3.

Úvod: Elektrody implantabilních systému jsou potaženy materiálem s cílem minimalizovat reakce tkáně. V experimentu (Higashi, 2003) je možno dokázat vliv stimulace na zánětlivou reakci a degeneraci myocytů.

Cílem práce: Bylo zhodnotit reakci organismu na elektrodu kardiostimulačního systému.

Soubor a metody: Pacienti s implantovaným přístrojem, kteří zemřeli v letech 2005 a 2006, a byli pitváni na Ústavu soudního lékařství FN u sv. Anny anebo v Ústavu Patologie FN Brno. Bylo zhodnoceno - počet míst fixace elektrody a histologické zhodnocení inzerce.

Statistické metody: Použita neparametrická obdoba ANOVA testu - Kruskalův-Wallisův test a Pearsonův $\chi^{2}$ test.

Výsledky: Od 1. 1. 2005 do 31. 1. 2006 byly získány údaje od 172 pacientů, 72,1 \% mužů, 27,9 \% žen, věk 76,26 $\pm 11,13$ let. Počty míst fixace byly od 0 po 4 (v. subclavia + HDŽ, srdeční síň, trikuspidální chlopeň, papilární svaly). Hodnotili jsme vliv věku pacienta v čase implantace, výrobce elektrody, typu stimulátoru (VVI/DDD), pohlaví a doby od implantace: signifikantní rozdíl byl pouze $\mathrm{v}$ době od implanatace (do smrti) mezi skupinami s různým stupněm fixace $(p=0,004)$. Histologické nálezy jsme rozdělili do skupin: normální nález, fibrotické změny, hyalinní jizva, lipomatóza a ostatní, hodnocen byl vliv: doby od implantace, procenta stimulace, typu stimulace (unipolární vs. bipolární), typu elektrody (aktivní vs. pasivní). Statisticky významný je pouze vliv délky od implantace $(p=0,025)$, ostatní parametry nejsou signifikanní. 
Závěr: Počet míst uchycení elektrod v žilním systému a histologický obraz místa inzerce elektrody jsou statisticky významně ovlivněny pouze časem od implantace, ostatní faktory nemají statisticky prokazatelný vliv.

\section{CIRKADIÁNNÍ VARIABILITA TURBULENCE SRDEČNIIHO RYTMU U PACIENTŮ PO INFARKTU MYOKARDU*}

SEPŠI M, TRČKA P, KOZÁK M, KŘIVAN L, VLAŠÍNOVÁ J, KÝR M

Interní-kardiologická klinika, FN Brno,

Centrum biostatistiky a analýz, LF MU Brno, Brno

*Výzkum je podporován grantem č. 8478-3.

Cílem práce: Stanovit cirkadiánní variabilitu HRT u pacientů po prodělaném infarktu myokardu (IM) a porovnat tuto variabilitu s HRT u skupiny pacientů bez strukturálního onemocnění srdce.

Soubor: Analýza dat pacientů, kteří v letech 2004-2006 absolvovali 24hod. EKG po infarktu myokardu (IM). Kontrolní skupina: Pacienti bez zjištěného strukturálního onemocnění srdce.

Výsledky: Ve skupině pacientů po IM byla HRT stanovena u 120 pacientů, průměrného věku 62,7 (SD 12,4), v rozmezí od 26 do 87 let - 45,0 $(12,1)$. Kontrolní skupina: 48 pacientů. Průměrný věk: 48,4 let $( \pm 15,3$ ) v rozmezí od 18,6 do 74,8 let, Výsledky srovnání po 2 hod.: signifikantní rozdíl v hodnotách jednotlivých parametrů ve skupině pacientů po IM je pouze u parametru TS $(p=0,044)$. U ostatních sledovaných parametrů (počet KES $p=0,928$, TO $p=0,598$, TT $p=0,298$ ) rozdíl nedosáhl statistické významnosti. Výsledky srovnání po 4 hod.: ve všech sledovaných parametrech rozdíl nedosáh statistické významnosti (počet KES: $p=0,350$, TO: $p=0,631$, TS $p=0,224$, TT $p=0,672$ ). Porovnání obou skupin: v kolísání parametru TO není rozdíl v žádné ze skupin. V parametru TS je prokazatelné kolísání v průběhu dne u obou skupin. U zdravých je tento důkaz vysoce signifikantní $(p<0,001)$, zatímco ve skupině po IM dosahuje pouze hraniční signifikance $(p=0,044)$. Počet KES se mezi skupinami signifikantně nelišil. Signifikantní variabilita parametru TT v průběhu dne byla prokázána pouze ve skupině zdravých ( $p=0,034)$, zatímco kolísání tohoto parametru v průběhu dne ve skupině po IM nedosahuje signifikance ( $p=0,298)$.

Závěr: Signifikatnní cirkadiánní variaci parametrů HRT nacházíme zejména $u$ pacientů bez strukturálního onemocnění srdce $u$ parametru TS, u ostatních parametrů není cirkadiánní variace.

\section{SHORT-TERM BLOOD PRESSURE CONTROL IN PATIENTS WITH CARDIAC TRANSPLANTATION*}

SIEGELOVÁ J, FIŠER B, HOMOLKA P, SVAČINOVÁ H, VÁRNAY F, VANK P, ŠPINAROVÁ L, VÍTOVEC J

Klinika funkční diagnostiky a rehabilitace, FN u sv. Anny a LF MU, Fyziologický ústav, LF MU, I. interní-kardioangiologická klinika, FN u sv. Anny a LF MU, Brno

*Support: MSM0021622402.

Background: Cardiac component of the baroreflex is responsible for attenuation of blood pressure fluctuations in the range of frequencies $0.04-0.15 \mathrm{~Hz}$ (low frequency, LF). Deinervation of the heart in patients after orthotopic cardiac transplantation (OTC) eliminates this mechanism.
Aim: The aim of the study was to compare low frequency - blood pressure variability in patients after OTC with healthy controls.

Methods: We examined 7 patients (age $55.7 \pm 9.7$ years) after 2-8 years after cardiac transplantation. ECG, blood pressure (BP) and thoracic impedance were recorded beat-by-beat during 20 minutes (Task Force Monitor, CNSystem, Austria) in supine position during spontaneous breathing and breathing controlled by metronome (5 $\mathrm{min}, 0.33 \mathrm{~Hz}$ ). The results were compared with the examination of the group of 7 healthy subjects (C) of similar age (50.0 \pm 2.8 years).

Results: Both groups did not differ (OCT versus C, mean $\pm \mathrm{SD})$ in heart rate $(80.4 \pm 10.8$ versus $72.2 \pm 6.9$ beats $/ \mathrm{min})$, in systolic $(119.4 \pm 11.8$ vs $124.9 \pm 11.0 \mathrm{mmHg})$ and diastolic BP (80.6 \pm 10.3 vs $85.7 \pm 8.3 \mathrm{mmHg})$, in stroke volume index $\left(32.6 \pm 8.9\right.$ vs $\left.39.9 \pm 6.6 \mathrm{ml} / \mathrm{m}^{2}\right)$, in cardiac index $/\left(2.54 \pm 0.55\right.$ vs $2.90 \pm 0.581 /\left(\mathrm{min}^{2} \mathrm{~m}^{2}\right) /$ and in total peripheral resistance index $(2863 \pm 552$ vs $2754 \pm 845$ dyn.s. $\mathrm{m}^{2} / \mathrm{cm}^{5}$ ). On the other hand, heart rate variability spectra $\left(\mathrm{ms}^{2}\right)$ was decreased in OTC (LF heart rate variability: $8.43 \pm 12.09$ vs $164.29 \pm 171, p<0.01)$. No difference was seen in diastolic BP variability spectra $\left(\mathrm{mmHg}^{2}\right)$ : LF $\mathrm{dBP}$ $(5.00 \pm 8.82$ vs $3.10 \pm 1.94$, NS).

Conclusion: It is concluded that LF dBP variability is unchanged in patients after OTC despite of the deinervation of the heart.

\section{JE ECHOKARDIOGRAFICKÉ VYŠETR̆ENÍ PROVÁdĔNÉ V RÁMCI PR̆EDOPERAC̆NÍ PR̆ÍPRAVY NEMOCNÝCH K NEKARDIÁLNÍM VÝKONÜM RUTINNÍM STEREOTYPEM NEBO SKUTEČNĚ NUTNY̌M VÝKONEM?}

\section{SKALICKÁ H}

\section{Kardiologie, Interní oddělení, Praha}

Úvod: V předoperační přípravě má echokardiografie své nezastupitelné místo, diagnostika kardiálních onemocnění, zejména klinicky němých, s možností upřesnit aktuální závažnost chronického kardiální postižení.

Předkládáme dvě kasuistiky náhodně zachycených závažných onemocnění v rámci předoperačně provedeného ECHA, které podtrhují význam vyšetření před plánovanou operací.

1. Kasuistika: myxom v levé síni u 28leté gravidní nemocné, s nutností přerušit těhotenství a podstoupit kardiochirurgický výkon.

2. Kasuistika: náhodně zastižená dilatační kardiomyopatie $\mathrm{u}$ nemocného před celkovou anestezií $\mathrm{k}$ provedení diagnostické tracheobronchoskopie. Echokardiografická diagnóza vedla ke změně léčby upravující klinické obtíže a od původně zamýšlené bronchoskopie bylo možné ustoupit a další léčba již pokračuje v rukou kadiologů.

$\mathrm{V}$ obou předložených př́ipadech je přínos echokardiografického vyšetření jednoznačný, vyšetření pro nemocné zásadně ovlivnilo léčebnou taktiku.

Echokardiografie má $z$ hlediska ovlivnění mortality operačních výkonů spíš funkci podpůrnou. Hodnocení celkové systolické funkce levé komory nemá prrímý vztah k ovlivnění operačního výsledku. Nález lokální poruchy kinetiky podporuje přítomnost koronárního postižení, vyžaduje však další diagnostické kroky - většinou se nelze obejít bez koronární angiografie.

Závěr: Prioritou předoperační přípravy je odhalit nemocné s postižením koronárního řečiště, infarkt myokardu v peri- i pooperačním období nejvíce ovlivňující mortalitu nemocných (60-70\%), podstupujících chirurgický výkon. Výše uvedené kasuistiky dokládají širší klinický význam echokardiografických vyšetření prováděných před plánovanými výkony s přímým ovlivněním léčby. 


\section{MINIMÁLNĔ INVAZIVNÍ TORAKOTOMICKÉ A TORAKOSKOPICKÉ VÝKONY PRO EPIKARDIÁLNÍ IMPLANTACI STIMULAČNÍCH ELEKTROD}

SKALSKÝ I, MARTINČA T, KAUTZNER J, ČIHÁK R, BYTEŠNÍK J, PIRK J, ŘIHA H, BURIAN F

Kardiocentrum, Klinika kardiologie, IKEM, Praha

Úvod: Epikardiální implantace elektrod je jedinou možností pro zajištění stimulace LK při neúspěchu endokardiálního přístupu. Jedná se např́iklad o selhání kanylace koronáního sinu, absenci, nevhodný průběh či velikost laterálních žil koronárního sinu, uzávěr žilního řečiště, endokarditidu a vegetace endovazálních elektrod. Epikardiální implantace elektrod je výhodnější pro CRT ve smyslu kratšího, relativně bezpečného výkonu, často dovoluje pod př́mou kontrolou zraku najít nejvhodnější místo pro umístění elektrody, eventuálně zajistit multiplicitu tohoto místa podle zjištěných parametrů elektrod.

Metodika: Na kardiochirurgické klinice v IKEM Praha jsme provedli $\mathrm{v}$ posledních 5 letech 14 implantací epikardiálních elektrod. 12 elektrod jsme implantovali $z$ levostranné minitorakotomie a 2 pomocí torakoskopu. Elektrody byly tunelovány $\mathrm{k}$ místu implantace PM, popř. ICD v pravé, levé podklíčkové krajině. 12 (86 \%) pacientů bylo mužů, 6 (43 \%) bylo po předchozí $\mathrm{KCH}$ intervenci, 5 (36\%) pacientů mělo ischemickou KMP, 9 (64 \%) dilatační KMP, 10 (71 \%) bylo v klasifikaci NYHA, a 8 (57 \%) pacientů mělo implantovaný ICD. Elektrody pro pravé srdeční oddíly byly implantovány endovazální cestou před chirurgickým výkonem nebo po chirurgickém výkonu. Jako stimulační elektrody elektrody jsme použili - šroubovací unipolární či bipolární a bipolární s nutností fixace stehem.

Výsledky: Všechny chirurgické implantace byly úspěšné s prahem elektrod $1,5+2 \mathrm{~V}$, R wave amplituda byla $20 \pm 12 \mathrm{mV}$. Délka operace - medián 110 min. Celková doba hospitalizace byla 3 dny. Pooperační komplikace krvácivé 1 (7\%), renální 0 , neurologické 0 , infekční 0 .

Závěr: Minimálně invazivní technika implantace epikardiálních elektrod je bezpečná a efektivní metoda nabízející výběr nejvhodnějšího místa pro stimulaci.

\section{VLIV KARDIOCHIRURGICKÉ REVASKULARIZACE MYOKARDU NA GLOBÁLNÍ SYSTOLICKOU A DIASTOLICKOU FUNKCI LEVÉ KOMORY SRDEC̆NÍ U PACIENTŮ SE SYSTOLICKOU DYSFUNKCÍ LEVÉ KOMORY SRDEČNÍ A ISCHEMICKOU KARDIOMYOPATIII A VIABILNÍM MYOKARDEM - PR̆EDBĚŽNÉ VÝSLEDKY}

SKÁLA T, HUTYRA M, KAMÍNEK M, HORÁK D, NĚMEC P, LUKL J

\section{I. interní klinika, Klinika nukleární medicíny, Radiologická klinika, Kardiochirurgická klinika, FN Olomouc a LF UP, Olomouc}

$\mathrm{V}$ přednášce jsou uvedeny dílčí výsledky změn parametrů globální systolické a diastolické funkce levé komory srdeční $\mathrm{u}$ pacientů $\mathrm{s}$ ischemickou kardiomyopatií a systolickou dysfunkcí levé komory srdeční, kteří byli indikováni k revaskularizační operaci na základě předoperačního průkazu viability myokardu. Jako zobrazovací metody použité $\mathrm{k}$ průkazu viability myokardu a zhodnocení globální funkce levé komory srdeční, provedené vstupně a po 1 roce od revaskularizace, byly použity jednotlivé modality konvenční a tkáňové dopplerovské echokardiografie, nativní a kontrastní magnetická rezonance srdce a gated SPECT myokardu.

\section{PRŮBĚH EXPERIMENTÁLNÍHO INFARKTU MYOKARDU NA ZVÍŘECİM MODELU}

\author{
SKŘIVÁNKOVÁ J, KOŠUTOVÁ J, POPKOVÁ A, NEČOVÁ I
}

I. interní-kardiologická klinika, FN u sv. Anny, Brno

Naše zkušenosti s experimentálním infarktem myokardu na zvířecím modelu s následnou aplikací kmenových buněk.

\section{SESTERSKÁ SEKCE}

\section{THORATEC - MECHANICKÁ SRDEČNÍ PODPORA}

SLAVÍKOVÁ L, AMBROŽOVÁ M, TOULOVÁ D

Kardiochirurgická klinika, IKEM, Praha

Autoři předkládají prezentaci systému mechanické srdeční podpory Thoratec. Seznamují s principem činnosti systému a jeho použití, zejména s důrazem na chirurgické aspekty implantace systému na operačním sále.

Zároveň prezentují dosavadní dosažené zkušenosti s touto metodou na vlastním pracovišti.

\section{PFO - VÝZNAMNÝ PATOGENETICKÝ FAKTOR RECIDIVUJÍCÍHO STEMI}

SLUKA M, OSTŘANSKÝ J, RICHTER M, LUKL J

I. interní klinika, FN Olomouc a LF UP, Olomouc

Výskyt embolizace do koronárních tepen s následným vznikem STEMI je relativně nízký - kolem 0,5 \%. Ze zkušeností víme, že angiografická úspěšnost řešení těchto prrípadů pomocí direktní PCI je výrazně nižšíi než u ostatních pacientů se STEMI. Dlouhodobá prognóza těchto nemocných je ovlivněna především možností terapeutického ovlivnění zdroje embolizace samotné.

Kasuistika popisuje př́pad pacienta - 34letého muže, který byl na I. interní klinice poprvé hospitalizován v I/2002 pro STEMI posterolaterální lokalizace, s koronarografickám nálezem uzávěru periferie RIA - dlouhá tepna s průběhem za hrot LK. Vzhledem ke kalibru tepny do $1,5 \mathrm{~mm}$ byl léčen trombolýzou, kontrolní SKG ukázalou dobrou průchodnost RIA, pacient stabilizovaný s EF $60 \%$ propuštěn domů. Poté dlouhodobě stabilizovaný, postupně vysazena ve spádu veškerá medikace. V I/2006 opět při sportu stenokardie s elevacemi ST na spodní stěně, koronarograficky verifikován uzávěr periferie ACD RPLD, při kalibru kolem $2 \mathrm{~mm}$ použita pouze balonková dilatace $\mathrm{s}$ posunutím uzávěru distálněji, výkon ukončen - kalibr 1,0 mm. Pacient zcela stabilní, s EF 50-55 \% a reziduální hypokinezí hrotu, propuštěn domů. Odebrány trombofilní markery, s nálezem APC rezistence, při TEE průkaz pravo-levého zkratu na úrovni septa síní při Valsalvově manévru. Na základě těchto nálezů indikován $\mathrm{k}$ uzávěru $\mathrm{PFO}$, který úspěšně proveden Amplatzovým okluderem s následnou antikoagulační terapií. Kasuistika dokumentována obrazovou a video dokumentací.

SESTERSKÁ SEKCE

\section{SPOLUPRÁCE KATETRIZAČNÍ LABORATOR̆E A KARDIOCHIRURGIE Z POHLEDU SESTRY}

SMOLÍKOVÁ K, VLASÁKOVÁ M, FORMÁNEK P, BENEDÍK J, ČERNÝ Š 
Kardiologické oddělení - katetrizační laboratoř, Kardiochirurgické oddělení, Nemocnice Na Homolce, Praha

Úvod: Pro správnou funkci kardiocentra má hlavní prioritu bezchybná komunikace katetrizační laboratoře a kardiochirurgie. Pro vlastní péči má význam nejenom provedení výkonů na obou úsecích, ale rovněž spolupráce středního zdravotnického personálu. Tato minimalizuje možné chyby především u přesunů akutních pacientů oběma směry.

Metodika: Elektivní pacienti jsou předáváni na standardní oddělení a na operaci jsou zváni podle pořadníku. Akutního pacienta zajištujeme maximální monitorací, se kterou je transportován bud' přímo na operační sál nebo na kardiochirurgickou jednotku intenzivní péče. $\mathrm{V}$ případě pooperačních komplikací je nemocný transportován do katetrizační laboratoře opět plně monitorován, případně i na ventilátoru.

Výsledky: Číselné hodnoty udávají počty za sledované období leden-červen 2006, údaje v závorce pak srovnávany s obdobím leden-červen 2005. V Nemocnici Na Homolce bylo za sledované pololetí provedeno celkem 1468 (1 569) katetrizačních vyšetření. Z tohoto počtu se jednalo o 1297 (1 378) selektivních koronarografií, 171 (191) pravostranných katetrizací. Z těchto vyšetřených bylo nabídnuto ke kardiochirurgickému výkonu celkem 327 (360) nemocných. $Z$ celkového počtu předaných pacientů byli po provedené operaci znovu vyšetřováni 2 (1) nemocní; bylo provedena reSKG a 1 (0) pooperační implantace stentu. Z uvedených čísel jasně vyplývá klesající trend jak vyšetřování nemocných, tak pacientů předaných na kardiochirurgické pracoviště.

Závěr: Za jednu $\mathrm{Z}$ nejdůležitějších složek považujeme bezchybnou ošetřovatelskou dokumentaci, kvalitní předoperační přípravu pacienta a v neposlední řadě jeho edukaci. Prezentovaná data ukazují na klesající trend počtu pacientů předávaných na kardiochirurgii. Tento stav koresponduje s celosvětovým trendem poklesu nemocných nabízených ke $\mathrm{KCH}$ výkonům.

\section{VÝSKYT PLICNÍ HYPERTENZE U PACIENTŮ SE SYNDROMEM OBSTRUKČNÍ SPÁNKOVÉ APNOE}

SOVOVÁ E, LUKL J, HOBZOVÁ M, KOLEK V, BENUŠOVẤ I, MEJTSKÁ I, NOVÁKOVÁ V, HRACHOVINOVÁ Š

I. interní klinika, Klinika plicních nemocí a tuberkulózy, FN Olomouc a LF UP, Olomouc

Cíl studie: Stanovit výskyt plicní hypertenze u pacientů s diagnózou obstruční spánkové apnoe.

Soubor a metodika: 61 pacientů (48 mužů) průměrného věku 52,32 \pm 9,68 let (muži 50,83 \pm 9,88 a ženy 57,84 \pm 6,64 let) s diagnózou středního až těžkého stupně obstrukční spánkové apnoe bylo vyšetřeno na echokardiografickém př́stroji GE VIVID 7. Do souboru nebyli zařazeni pacienti s jiným plicním onemocněním, poruchou funkce levé komory a pacienti s onemocněním, které může být příčinou postkapilární plicní hypertenze. U všech pacientů byly stanoveny základní echokardiografické parametry pro stanovení plicní hypertenze: rozměr pravé komory, akcelerační čas na plicnici (ACT), př́tomnost regurgitace na plicnici, regurgitace na trikuspidální chlopni a její gradient, př́ípadně rozměr vena cava inferior.

Výsledky: Rozměr pravé komory byl průměrně 28,60 \pm 4,80(18-42), muži (M) 29,37 \pm 4,72 (18-42), ženy (Ž) 25,76 $\pm 4,06$ (18-35). ACT bylo celkově $136,24 \pm 24,92$ (74-188), M 136,02 \pm 24,10 (74-188), Ž 137,07 \pm 24,53 (92-173). Průměrná hodnota indexu apnoe-hypopnoe byla 54,26 $\pm 21,15$

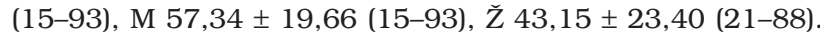
Hypertenze byla diagnostikována u 41 pacientů, 34 M a $7 \check{Z}$.
Dva pacienti (1M, 1Ž) měli stopovou regurgitaci na plicnici, 11 pacientů $(10 \mathrm{M}, 1$ Z) měli regurgitaci na trikuspidální chlopni (stopa - $32 \mathrm{~mm} \mathrm{Hg).} \mathrm{U} \mathrm{dvou} \mathrm{pacientů} \mathrm{byla} \mathrm{stanove-}$ na lehká plicní hypertenze $(3,27 \%$ souboru). Oba pacienti měli vysoký AHI $(47,77)$.

Závěr: Po vyloučení jiných příčin plicní hypertenze se plicní hypertenze vyskytuje pouze u minima pacientů s obstrukčním spánkovým apnoe. Je třeba dalších studií, které by hodnotily komplexní echokardiografické parametry $\mathrm{u}$ těchto pacientů.

\section{DYNAMIKA KONCENTRACÍ A-FABP \\ JAKO UKAZATEL ZMĚN HMOTNOSTI U OSOB VE VYSOKÉM KARDIOVASKULÁRNİM RIZIKU}

\section{STEJSKAL D, LAČŇÁK B, SOLICHOVÁ P, KARPÍŠEK M}

Oddělení laboratorní medicíny,

Interní oddělení, Nemocnice Šternberk, Šternberk

Úvod: Adipocyte-fatty acid binding protein (A-FABP) je považován za ukazatel metabolického syndromu (MS), jehož zvýšení je spojeno s kardiovaskulární mortalitou. Nejsou známy informace o dynamice A-FABP vzhledem $\mathrm{k}$ redukci hmotnosti.

Cíl: Ověřit vliv redukce hmotnosti na dynamiku sérových koncentrací A-FABP.

Metodika: 189 osob s vysokým kardiovaskulárním rizikem; vyšetření před 3měsíční agresivní dietní a režimové intervenci, po ní a po dalších 3 měsících. Stanoven v séru A -FABP, inzulin, glukóza, cholesterol, HDL, LDL, triglyceridy, vypočten Quick a BMI a WC. Ze skupiny osob, u kterých došlo $\mathrm{k}$ poklesu BMI, byly následně vybrány podskupiny podle toho, zda-li udržely pokles BMI po 6 měsících (A) nebo zda-li u nich došlo $\mathrm{k}$ vzestupu hmotnosti (B).

Výsledky: Vstupní ukazatele byly typické pro MS (Quick 0,21; triglyceridy 4,2 mmol/1; BMI 37,6; WC $129 \mathrm{~cm}$ ); hodnoty A-FABP souvisely s Quick a BMI $(p<0,01)$. Po 3 měsících došlo u 145 osob k redukci BMI. U skupiny A jsme nalezli vzestup A-FABP (42,3 vs $68,3 \mu \mathrm{g} / 1 ; p<0,01) \mathrm{s}$ následným poklesem po dalších 3 měsících $(37,1 \mu \mathrm{g} / 1 ; p<0,01)$. Hodnoty A-FABP korelovaly po 6 měs. s markery MS $(p<0,05)$. Skupina $B$ vykazovala vzestup A-FABP (ve srovnání s A méně významný; $p<0,01$ ); hodnoty A-FABP přetrvávaly zvýšené i po 6 měs. (41,9 vs. 53,6 vs. $50,7 \mu \mathrm{g} / 1$ ). U skup. B nebyly zjištěny souvislosti mezi A-FABP a MS. Rozdíly v dynamice A-FABP u pacientů s trvalou redukcí hmotnosti oproti osobám, které ji neudrží, diskutujeme. Současně se nabízí otázka o indikaci léčby statiny u osob, které podstupují razantní redukci hmotnosti. Existují důkazy o účincích statinů na snížení A-FABP nezávisle na lipoproteinech.

Závěr: Dynamika sérových koncentrací A-FABP by mohla být novým ukazatelem predikujícím změny tělesné hmotnosti. Otázkou v tomto kontextu zůstává případná terapeutická intervence statiny $\mathrm{v}$ období razantní redukce tělesné hmotnosti.

\section{SESTERSKÁ SEKCE}

\section{EDUKACE PACIENTŮ O PR̆EDOPERAČNÍM VYŠETR̆ENÍ PR̆ED CHLOPENNÍ NÁHRADOU}

\section{STRAKAYOVÁ L, SOUČKOVÁ M}

II. interní klinika kardiologie a angiologie, VFN a 1. LF UK, Praha

Naše sdělení je zaměřeno na problematiku edukace pacientů v průběhu předoperačních vyšetření. Tímto způsobem se 
snažíme zmírnit strach $z$ těchto vyšetření a následného operačního výkonu a zvýšit informovanost pacientů.

Práce je rozdělena na několik částí, které zahrnují: anatomii - stručný popis chlopní a jejich funkce, patofyziologii - příčiny postižení a jejich následky, terapii chlopenních vad - druhy chlopenních náhrad, jejich výhody a nevýhody, předoperační vyšetření - vyšetření krve, moče, rentgenová vyšetření, sonografická vyšetření, kultivační vyšetření, zubní vyšetření, gynekologické, operační riziko, možné komplikace, vlastní edukaci pacientů, ošetřovatelské diagnózy spojené s předoperačním vyšetřením.

\section{SESTERSKÁ SEKCE}

\section{KARDIOCHIRUGICKÁ IMPLANTACE LEVOKOMOROVÉ ELEKTRODY U BIVENTRIKULÁRNÍ STIMULACE JAKO ALTERNATIVA ENDOVAZÁLNÍHO PR̆ÍSTUPU}

\section{STRÁNSKÁ M, HOLÁ E, VOPÁLKA R, KRÁLOVEC S}

Kardiologické oddělení, Nemocnice Na Homolce, Praha

Úvod: Biventrikulární stimulace představuje dnes standardní léčbu pokročilého srdečního selhání u nemocných s průkazem komorové dyssynchronie. Problémem však zůstávají technické limitace endovazální implantace levokomorové elektrody (LK EL) cestou koronárního sinu a žilního systému myokardu.

Cíl práce: Srovnání efektivity a bezpečnosti endovazální a kardiochirurgické implantace levokomorové elektrody $\mathrm{u}$ nemocných indikovaných $\mathrm{k}$ srdeční resynchronizační léčbě (SRL).

Metodika: Ze 115 nemocných, kterým byl implantován v roce 2005 biventrikulární kardiostimulátor, resp. ICD, se podařilo zavést LK EL endovazálně - 103 nemocným (89,1%). Kardiochirurgická implantace cestou levostranné laterální torakotomie s použitím bipolární epikardiální elektrody Medtronic Capsure Epi ${ }^{\mathrm{TM}}$ byla provedena celkem u 37 nemocných (10 vlastní centrum + 27 ostatní centra).

Výsledky:

\begin{tabular}{lccc}
\hline \hline Parametr & $\begin{array}{c}\text { Endovazálni } \\
\text { LK EL }\end{array}$ & $\begin{array}{c}\text { KCH } \\
\text { LK EL }\end{array}$ & $\boldsymbol{p}$ \\
\hline Časné úmrtí (30 dnů) & 2 & 1 & NS \\
Tamponáda & 1 & 0 & NS \\
Fluidotorax & 1 & 8 & 0,01 \\
EF LK - 12 M (\%) & $32 \pm 12$ & $29 \pm 9$ & NS \\
\hline \hline
\end{tabular}

Závěr: Kardiochirurgická implantace levokomorové elektrody cestou limitované laterální torakotomie je po pečlivé přípravě $\mathrm{s}$ dobře vedenou anestezií bezpečnou alternativou dosažení plně efektivní resynchronizační léčby, a to i u rizikových nemocných s významnou dysfunkcí LK. V souvislosti s prováděnou chirurgickou technikou je možno pozorovat větší výkyt fluidotoraxů, které vyžadují opakovanou punkci.

\section{CHARAKTERISTIKA NEMOCNÝCH S AKUTNIMM SRDEČNÍM SELHÁNÍM A ZVYYŠENOU HLADINOU TROPONINU I}

\section{SUKOVÁ J, OŠŤÁDAL P, WIDIMSKÝ P}

III. interní-kardiologická klinika, FN KV a 3. LF UK, Praha

Úvod: Zvýšení hladiny troponinu I (TnI) bylo opakovaně popsáno u části nemocných s kompenzovaným či akutně dekompenzovaným chronickým srdečním selháním. Zastoupení a charakteristika nemocných se vzestupem TnI v neselektovaném souboru pacientů, přjatých pro akutní srdeční selhání, však dosud popsány nebyly.

Soubor a metody: Analyzovali jsme zpětně údaje od všech nemocných, hospitalizovaných na našem oddělení pro akutní srdeční selhání v období leden-ř́ijen 2006. TnI byl rutině vyšetřován při přijetí a s odstupem 12-24 hodin. Porovnávali jsme základní demografické a klinické charakteristiky u nemocných $\mathrm{s}$ TnI $\geq 0,5 \mu \mathrm{g} / 1$ (skupina TnI+) a s TnI < 0,5 $\mu \mathrm{g} / 1$ (skupina TnI-).

Výsledky: Do souboru bylo zařazeno 105 pacientů, Z nichž 28 (26,7 \%) mělo alespoň v jednom vzorku zvýšenou hladinu TnI. Ve skupině TnI+ jsme zjistili významně vyšší stupeň selhání podle Killipovy klasifikace $(p<0,0001)$, kratší dobu trvání symptomů ( $p=0,002)$, vyšší vstupní srdeční frekvenci ( $p=0,003)$, vyšší vstupní hladinu kreatininu $(p=0,002)$ a nižší body mass index $(p=0,03)$. Naproti tomu jsme mezi skupinami nenalezli rozdíl $\mathrm{v}$ dalších významných sledovaných vlastnostech, jako jsou průměrný věk, zastoupení žen, anamnéza ischemické choroby srdeční nebo základní EKG a echokardiografické parametry (ejekční frakce levé komory).

Závěr: Vzestup TnI jsme pozorovali u významné části nemocných, hospitalizovaných pro akutní srdeční selhání. Tito pacienti se odlišovali od nemocných s normální hladinou TnI v několika významných klinických charakteristikách.

\section{VLIV KARDIOVASKULÁRNÍ REHABILITACE NA TĚLESNOU ZDATNOST U DIABETIKŮ 2. TYPU S ISCHEMICKOU CHOROBOU SRDEČNI*}

SVAČINOVÁ H, MÍFKOVÁ L, ROSENBERGOVÁ B, VYMAZALOVÁ L, CHLUDILOVÁ V, VANK P, SIEGELOVÁ J

Klinika funkční diagnostiky a rehabilitace,

FN $u$ sv. Anny a LF MU, Brno

*Podporováno grantem: MSM0021622402.

Cíl práce: Zhodnotit účinek kardiovaskulární rehabilitace $\mathrm{u}$ diabetiků 2 . typu a pacientů bez diabetu s ischemickou chorobou srdeční na tělesnou zdatnost.

Soubor a metody: Vyšetřili jsme 55 mužů, $z$ toho 25 s diabetem 2. typu (DM - věk $64 \pm 6$ roků, hmotnost $88 \pm 14$ kg, BMI $29 \pm 5$, EF $45 \pm 12 \%$ ) a 30 pacientů bez diabetu (NDM - věk $60 \pm 9$ roků, hmotnost $85 \pm 10 \mathrm{~kg}$, BMI $28 \pm 3$, EF $50 \pm 8 \%$ ) Oba soubory se v uvedených parametrech signifikantně nelišily. Všichni byli 3-4 týdny po prodělaném infarktu myokardu nebo intervenčním výkonu pro ICHS zařazeni do 3měsíčního kardiovaskulárního kombinovaného tréninku. Parametry tělesné zdatnosti byly získány z výsledků spiroergometrie, kterou všichni podstoupili před 3měsíčním tréninkem a po něm. Srovnali jsme vstupní i výstupní hodnoty WSL, WSL/kg, VO2SL, VO2SL/kg, RPPSL mezi soubory DM a NDM a v rámci obou souborů jsme tyto parametry hodnotili před rehabilitací a po ní.

\begin{tabular}{lcc}
\hline \hline & DM (před) & DM (po) \\
\hline WSL & $95,6 \pm 34,8$ & $115,0 \pm 38,9^{* *}$ \\
WSL/kg & $1,1 \pm 0,4$ & $1,3 \pm 0,5^{* *}$ \\
VO2SL & $1513 \pm 411$ & $1726 \pm 470^{* *}$ \\
VO2SL/kg & $17,5 \pm 5$ & $20,1 \pm 6,5^{* *}$ \\
RPPSL & $206,7 \pm 52,4$ & $236,3 \pm 83,2^{*}$ \\
\hline \hline & NDM (před) & NDM (po) \\
\hline WSL & $114,0 \pm 29,7+$ & $126,0 \pm 29,8^{*}$ \\
WSL/kg & $1,4 \pm 0,4+$ & $1,5 \pm 0,4^{* *}$ \\
VO2SL & $1720 \pm 368+$ & $1859 \pm 410^{*}$ \\
VO2SL/kg & $20,6 \pm 4,8+$ & $22,6 \pm 5,5^{* *}$ \\
RPPSL & $208,7 \pm 52,5+$ & $244,1 \pm 58,5$ \\
\hline \hline
\end{tabular}

Před vs. po: ${ }^{*} p<0,05,{ }^{* *} p<0,01$; DM vs. NDM $:+p<0,05$ 
Výsledky: Vstupní hodnoty tělesné zdatnosti a RPPSL byly u DM signifikantně nižší než u NDM. V obou souborech došlo po 3 měsících kombinovaného tréninku ke statisticky významnému zlepšení všech sledovaných parametrů - kromě hmotnosti a BMI u DM a hodnoty RPPSL u NDM.

Závěr: Hodnoty tělesné zdatnosti byly před tréninkem u souboru DM významně nižší než u souboru NDM, po absolvování tréninku již rozdíl nebyl statisticky významný. 3měsíční kombinovaný trénink vedl u obou souborů k významnému zlepšení sledovaných hodnot i přes nezměněnou tělesnou hmotnost a BMI u diabetiků.

\section{AKUTNÍ SRDEČNÍ SELHÁNÍ V JIHOMORAVSKÉM REGIONU V ROCE 2006 Z POHLEDU PR̆EDNEMOCNIČNÍ PÉC̆E}

\section{SVOBODA $J$}

Zdravotnická záchranná služba, Předklášteři

Cíl: Analýza pacientů s akutním srdečním selháním ošetřených ZS, jejich prehospitalizační terapie, distribuce do jednotlivých nemocnic, procentuální zastoupení podle klinických projevů a příčin.

Soubor: ZZS JmK poskytuje služby pro více než 1 milion zcela neselektované populace. Z 33 tisíc výjezdů posádek s lékařem a zásahů letecké záchranné služby bylo vybráno 1 824, týkajících se akutní dušnosti kardiální etiologie nebo známek kardiálního selhávání.

Metodika: Jde o observační retrospektivní analýzu. Databáze pacientů byla získána $z$ informačního systému Zdravotnické záchranné služby JmK a kontrolou záznamů o výjezdu. Statistické vyhodnocení bylo provedeno metodou software Statistica for windows.

Výsledky: Pacienti s akutním srdečním selháním byli ošetřeni více než 100 různými lékaři a odvezeni do 14 různých nemocnic Jm kraje. Sdělení obsahuje věk pacientů, jejich rozdělení podle pohlaví, průměrný TK, $\mathrm{P}$, stav vědomí, $\mathrm{SpO}_{2}$, doby dojezdů, délky transportů. Dále jsou uvedena data týkající se léčby pacientů (diuretika, vazodilatancia, inotropika, UPV) a počet úmrtí během transportu.

Závěr: Hodnotí stávající stav z různých aspektů a obsahuje návrh organizačních opatření.

\section{ATEROGENNÍ INDEX PLAZMY ODRÁŽí MORFOLOGICKÉ ZMĚNY NA KAROTICKÝCH TEPNÁCH JEŠTĔ V ASYMPTOMATICKÉM OBDOBÍ ATEROSKLERÓZY*}

\section{SYROVÁTKA P, KRAML P, POTOČKOVÁ J}

Klinika kardiologie, IKEM, II. interní klinika, FN KV a 3. LF UK, Praha

*Práce byla podpořena grantem IGA MZČR 8529-3.
Cîl: Aterogenní index plasmy (AIP) měřený jako log (TG/ HDL-cholesterol) je ukazatelem kardiovaskulárního rizika. Cílem bylo zjistit, zda u zdravých jedinců s vyšším AIP lze detekovat morfologické, funkční či laboratorní známky aterosklerotického postižení v asymptomatickém období.

Soubor a metodika: Vyšetřili jsme 76 zdravých mužů (doposud zcela bez farmakologické léčby) ve věku od 35-60 let bez klinické manifestace aterosklerotického onemocnění. Soubor jsme rozdělili do quartilů podle AIP po 19 mužích. V prvním quartilu byli muži s normální hodnotou AIP, zatímco ve čtvrtém quartilu měli hodnotou AIP $>0,15$. Přítomnost aterosklerotických změn byla hodnocena pomocí IACC (šířky intimy společné karotické tepny), známek endotelové dysfunkce (VCAM, ICAM, von Willebrandův f., endotel dependentní vazodilatace na a. brachialis - EDV). Markery oxidačního stresu zahrnovaly oxLDL, AOPP (produkty pokročilé oxidace proteinů), hladiny retinolu, tokoferolu a celkovou antioxidační kapacitu plasmy (TAP) a ukazatele endogenních zásob železa (EFe - poměr hladiny cirkulujících transferinových receptorů a feritinu v plasmě). Inzulinová rezistence byla stanovena pomocí indexu HOMA-IR (z hodnot lačné inzulinemie a glykemie).

Výsledky: Jedinci $\mathrm{v}$ nejvyšším quartilu podle AIP vykazovali oproti kontrolní skupině významně vyšší IACC $(p<0,05)$. Nebyl však zjištěn rozdíl v ukazatelech endotelové dysfunkce. Jedinci s nejvyšším AIP měli dále signifikantně vyšší hodnoty HOMA-IR ( $p<0,001)$, celkového cholesterolu $(p<0,01)$, lipoproteinu Lp(a) $(p<0,001)$, oxLDL $(p<0,001)$, AOPP $(p<0,001)$, feritinu $(p<0,05)$ a Efe $(p<0,05)$.

Závěr: Jedinci s nejvyššími hodnotami AIP vykazují již morfologické změny na karotických tepnách. Současně jsme u nich zaznamenali vyšší ukazatele oxidačního stresu, inzulinové rezistence a endogenních zásob železa.

\section{OVLIVNĚNÍ RIZIKOVÝCH FAKTORŮ \\ KARDIOVASKULÁRNÍCH CHOROB OBÉZNICH DIABETIKU゚ 2. TYPU VYSAZENÍM INZULINU A JEHO NÁHRADOU PERORÁLNÍMI ANTIDIABETIKY*}

\section{SZABÓ M, PELÍŠKOVÁ P, MATOUŠ M, KVAPIL M}

Interní klinika, Klinika tělovýchovného lékařství, FN Motol, Praha

*Práce vznikla za podpory grantu č. /8975-3/2006 IGA MZ ČR.

Cíl: Prokázat snížení KV rizika u obézních diabetiků 2. typu po vysazení inzulinu a jeho náhradě perorálními antidiabetiky (PAD).

Soubor a metodika: Skupině 28 obézních diabetiků 2. typu s dostatečnou sekrecí endogenního inzulinu, stanovenou pomocí lačného a stimulovaného C-peptidu, byl vysazen inzulin a nahrazen PAD (metformin, rosiglitazon, glime-

Tabulka k abstraktu MUDr. Szabó

\begin{tabular}{lcccc}
\hline \hline & BMI & Pas (cm) & SAD (cm) & TF (tep/min) \\
\hline Baseline & $36,41 \pm 3,96$ & $119,07 \pm 9,77$ & $29,19 \pm 2,87$ \\
3 měsíce PAD & $34,11 \pm 3,72$ & $114,11 \pm 9,31$ & $27,22 \pm 2,60$ \\
Difference & $-2,31(p<0,001)$ & $-4,96(p<0,001)$ & $-1,96(p<0,001)$ \\
Difference $\%$ & $-6,34$ & $-4,17$ & $-6,73$ & $72,19 \pm 11,56$ \\
\hline \hline & HbA1c (\%) & CRP (mg/1) & TK-S (mm Hg) \\
\hline Baseline & $7,83 \pm 1,36$ & $2,60 \pm 2,51$ & $-4,97$ \\
3 měsíce PAD & $6,62 \pm 1,50$ & $1,46 \pm 1,65$ & $129,81 \pm 16,64$ \\
Difference & $-1,21(p<0,01)$ & $-1,15(p<0,5)$ & $125,37 \pm 16,61$ \\
Difference $\%$ & $-15,46$ & $-44,09$ & $-4,44(p<0,5)$ \\
\hline \hline
\end{tabular}


pirid) v monoterapii nebo kombinační léčbě. Pacienti byli edukováni o dietě a cvičení. 1 pacientka sledování neukončila, výsledky jsou ze souboru 27 pacientů (18 žen a 9 mužů) věku 56,96 \ 7,79 let. Sledované parametry: BMI, obvod pasu, výška břicha $\mathrm{v}$ pase (sagittal abdominal diameter $\mathrm{SAD}$ ) měřen vleže (indikátor množství viscerálního tuku a inzulinové rezistence, významný rizikový faktor KV chorob a KV mortality), HbAlc (kalibrace IFCC), CRP, tepová frekvence, krevní tlak a řada dalších.

Výsledky: Po 3 měsících léčby PAD.

Závěr: Výsledky ukazují na možnost ukončit inzulinoterapii obézním diabetikům 2. typu s dostatečnou sekrecí endogenního inzulinu a nahradit ji PAD. Po 3 měsících pacienti zlepšili kompenzaci diabetu, snížili hmotnost, CRP, tepovou frekvenci, systolický i diastolický tlak krve, což vede ke snížení rizika vaskulárních komplikací diabetu.

\section{BIOPROTÉZA V AORTÁLNÍ POZICI A JEJÍ HEMODYNAMICKÉ PARAMETRY}

ŠANTAVÝ P, BENČAT M, TROUBIL M, MARCIÁN P, BRUK V, NĚMEC P

\section{Kardiochirurgická klinika, FN Olomouc, Olomouc}

Úvod: Biologické chlopně jsou v současné době díky stárnoucí populaci implantovány stále častěji. Přes technický pokrok nejsou jejich pooperační parametry zcela optimální. Účelem prezentace je poukázat na faktory, které se uplatní na in-vivo hemodynamice implantované protézy.

Metodika: Od března 2002 do září 2006 bylo implantováno celkem 396 chlopní do aortální pozice, z toho 282 bioprotéz. Soubor nemocných tvoří 126 žen a 156 mužů, průměrný věk byl $74 \pm 6$ let, EF $50 \pm 12 \%$. Byly použity chlopně Edwards 2650, Edwards 2900, Edwards 3000, Medtronic Hall Mosaic, SJM Epic, Sorin More a Sorin Soprano. Peroperačně byl změřen prưměr aktivního ústí a průměr implantačního prstence bioprotézy. U všech nemocných byly po operaci v rámci hospitalizace echokardiograficky změřeny střední a vrcholové gradienty a efektivní plocha ústí implantované chlopně (podle rovnice kontinuity).

Výsledky: Bioprotéz Edwars (2650) bylo implantováno 21, Edwards (2900) 47, Edwards (3000) 45, bioprotéz Medtronic Hall Mosaic 31, SJM Epic 23, Sorin More 58 a Sorin Soprano 52. Nejčastěji implantovanou chlopní byla výrobcem udávaná velikost 23. Peroperačně změřené velikosti aktivního ústí i implantačních prstenců bioprotéz se od výrobcem udávané velikosti liší. Pooperační střední a maximální gradienty na všech bioprotézách byly vyšší než fyziologické. Efektivní plocha ústí bioprotéz, indexovaná na tělesný povrch pacienta, byla u všech pacientů menší než $0,85 \mathrm{~cm}^{2} / \mathrm{m}^{2}$, což je hranice pro vznik „patient-prosthesis mismatch“.

Závěr: I přes ne zcela optimální hemodynamické parametry jsou bioprotézy v dnešní době vhodnou volbou náhrady u starších nemocných s onemocněním aortální chlopně.

\section{VPLYV BLOKÁDY RENÍN-ANGIOTENZINOVÉHO SYSTÉMU NA PROGNÓZU PACIENTOV S FIBRILÁCIOU PREDSIENÍ}

ŠEBO M, TOMÁŠEK A, MIKLÍK R, DVOŘÁKOVÁ E, ŠPINAR J

Interní-kardiologická klinika, FN Brno, Brno

Ciel: Viacero štúdií preukázalo pozitívny vplyv blokády renín-angiotenzínového systému (RAS) na vznik a udržiava- nie fibrilácie predsiení. V našej práci sme sa snažili zistit vplyv užívania inhibítorov angiotenzin konvertujúceho enzýmu (ACE-I) a/alebo blokátorov receptoru 1 pre angiotenzin II (ARB) na prežívanie pacientov s touto arytmiou.

Súbor a metóda: Retrospektívna štúdia chorobopisov pacientov prepustených $\mathrm{z}$ Internej-kardiologickej kliniky FN Brno v období 10/2004-12/2005, doplnená o 1-ročnú mortalitu. Celkom 827 pacientov (451 mužov, 377 žien) s priemerným vekom 70 rokov a akoukolvek formou fibrilácie predsiení. Pacientov sme rozdelili do dvoch skupín, v prvej skupine (užívajúcej ACE-I/ARB) bolo 559 pacientov, v druhej (bez týchto liekov) ich bolo 268.

Výsledky: Pacienti užívajúci ACE-I/ARB boli starší (priemerný vek 71,5 vs. 66,5 rokov, $p<0,0001$ ), vo vyššej funkčnej triede NYHA (priemer 2,0 vs. $1,6, p<0,0001$ ), častejšie trpeli na chronické srdcové zlyhanie $(32,2 \%$ vs. $12,7 \%$, $p<0,0001)$, ICHS (61,5\% vs. $35 \%, p<0,0001)$, diabetes mellitus (29,7 \% vs. $17,5 \%, p<0,0002)$, hypertenziu (83 \% vs. $51 \%, p<0,0001)$, viac ich prekonalo cievnu mozgovú príhodu $(20,6 \%$ vs. $13 \%, p<0,01)$, mali nižšiu priemernú ejekčnú frakciu LK (49,4 vs. 56,2, $p<0,0001)$. Neboli významné rozdiely vo výskyte diastolickej dysfunkcie LK, v priemerných sérových hodnotách kreatininu, kyseliny močovej, cholesterolu, triglyceridov a hemoglobínu.

1-ročná mortalita v prvej skupine bola 10,7\%(60 pacientov $z$ 559), v skupine druhej $16 \%$ (43 z 268), $p=0,0304$

Záver: V rizikovejšej skupine pacientov liečenej ACE-I/ARB bola 1-ročná mortalita štatisticky významne nižšia ako u pacientov s menším množstvom komorbidít, avšak bez blokády RAS.

\section{EFEKTIVITA NESELEKTIVNÍ RF ABLACE AV UZLU U NEMOCNÝCH INDIKOVANÝCH K RESYNCHRONIZAC̆NI TERAPII PRO POKROČILÉ SRDEČNÍ SELHÁNÍ}

ŠEDIVÁ L, TÁBORSKÝ M, NEUŽIL P, VOPÁLKA R, PETRŮ J, ŠKODA J, KUPEC J, KRÁLOVEC Š, HOLÝ F, NIEDERLE P

Kardiologické oddělení, Nemocnice Na Homolce, Praha

Úvod: Resynchronizační stimulace (RS) je v současné době považována za nejvýznamnější pokrok $\mathrm{v}$ nefarmakologické terapii pokročilého srdečního selhání. Prevalence fibrilace síní u populace nemocných se srdečním selháním dosahuje 10-30 \%. Efektivita resynchronizace u nemocných se sinusovým rytmem byla opakovaně potvrzena řadou randomizovaných prospektivních studií, u nemocných s fibrilací síní nejsou výsledky RS zcela jednoznačné.

Cíl: Určit efektivitu RF ablace AV uzlu u nemocných s FS a zavedenou biventrikulární stimulací.

Soubor nemocných a metoda: Vyšetřeno bylo 223 nemocných (142 BiV KS, 81 BiV ICD), kterým byl v letech 2002-2003 implantován synchronizační systém. Průměrná doba sledování byla $35 \pm 12$ měsíců. $Z$ celkového počtu nemocných jsme u 37 nemocných detekovali permanentní fibrilaci síní. Fibrilace síní byla častější u nemocných se základní diagnózou DKMP (62\%). U 21 nemocných jsme provedli neselektivní RF ablaci AV uzlu s dosažením úplného bloku AV vedení a 100\% komorové biventrikulární stimulace. U 16 nemocných jsme RFA AVJ neprováděli pro holterovsky ověřenou pomalou komorovou odpověd' FS. U všech nemocných jsme za 12 měsíců po výkonu hodnotili EF LK, vzdálenost v 6minutového testu chůze, funkční klasifikaci NYHA a kvalitu života.

Výsledky: Nemocní, kteří podstoupili neselektivní RF ablaci AV uzlu vykazovali za $12 \mathrm{~m}$ po výkonu signifikantní zlepšení EF LK $(30,1 \pm 7$ vs. $23 \pm 9)$, prodloužení vzdálenosti dosažené během 6 minutového testu chůze (374 vs. $255 \mathrm{~m}$ ), a kvality života (37 vs. 49). 
Závěr: Našimi výsledky jsme dokumentovali prospěch neselektivní RF ablace u nemocných s chronickou fibrilací síní a zavedenou biventrikulární stimulací. K prokázání širší platnosti těchto výsledků by bylo třeba zhodnotit větší počet nemocných a v budoucnu uplatnit také selektivní ablaci fibrilace síní u nemocných s pokročilým srdečním selháním.

\section{NEADEKVÁTNÍ TERAPIE ICD - SROVNÁNÍ NEMOCNÝCH S PRIMÁRNÍ A SEKUNDÁRNÍ INDIKACÍ}

ŠEDIVÁ L, TÁBORSKÝ M, NEUŽIL P, VOPÁLKA R, PETRŮ J, ŠKODA J, KUPEC J, KRÁLOVEC Š, HOLÝ F, NIEDERLE P

\section{Kardiologické oddělení, Nemocnice Na Homolce, Praha}

Úvod: Populace nemocných s implantovaným kardioverterem-defibrilátorem $\mathrm{v}$ souvislosti se zlepšením diagnostiky a rozšíření indikačních kritérií stoupá. Ačkoli se stále zlepšují technické vlastnosti implantovaných přístrojů, zpřesňují se diskriminační kritéria $\mathrm{k}$ odlišení komorových a supraventrikulárních arytmií, dochází u určité části nemocných $\mathrm{k}$ neadekvátním výbojům, resp. dalším terapiím automaticky vykonávaným přístrojem.

Cill práce: Zhodnotit možnou souvislost mezi základním onemocněním a četností neadekvátních terapií. Posuzovali jsme také četnost těchto terapií u nemocných indikovaných z primární a sekundární prevence.

Soubor nemocných a metoda: Zhodnotili jsme záznamy celkem 656 nemocných, kteři byli implantováni v naší nemocnici v letech 2004-2006. Převaha nemocných měla základní onemocnění ICHS (48\%), dále DKMP (36 \%), ostatní $16 \%$. V sekundární prevenci bylo implantováno 420 nemocných, u ostatních byl implantabilní kardioverter-defibrilátor implantován $\mathrm{v}$ rámci primární prevence. Průměrná EF LK celého souboru byla 0,32 , signifikantně horší ve skupině primární prevence $(\mathrm{EF}$ LK 0,25$)$. Průměrná doba sledování našeho celého souboru souboru byla $21 \pm 9$ měsíců.

Výsledky: V celém souboru nemocných jsme zhodnocením záznamů $z$ implantovaných přístrojů zaznamenali celkem 928 epizod, u 452 nemocných, 67 \% z těchto epizod bylo léčeno výbojem kardioverteru-defibrilátoru. $Z$ těchto terapií bylo celkem 14 \% neadekvátních.

U části nemocných byly neadekvátní terapie aplikovány opakovaně, a to přes cílenou programaci a využití diskriminačních algoritmů. Počet neadekvátních terapií u nemocných implantovaných v rámci primární prevence byl vyššî (18,3\% vs. $7,4 \%)$ ve skupině sekundární prevence. Hlavní příčinou neadekvátní detekce byla fibrilace síní (78 \%), dále infrakce/fraktura ICD EL (11\%), neadekvátní programace $(11 \%)$.

\section{SESTERSKÁ SEKCE}

\section{PÉČE O PACIENTA S dG. FLEBOTROMBÓZA}

\section{ŠENKYŘÍKOVÁ M, JISKROVÁ N}

Interní kardiologická klinika, jednotka intenzivní péče, FN Brno-Bohunice, Brno

Přednáška pojednává o úloze sestry v péči o pacienta s dg. flebotrombóza.

V přednášce bude zahrnuta charakteristika onemocnění, diagnostika, léčba, možné komplikace a nejčastější ošetřovatelské diagnózy.

Pro ilustraci bude přednáška doplněna kasuistikou s fotodokumentací.

\section{JE TĚŽKÁ SYSTOLICKÁ DYSFUNKCE LEVÉ KOMORY U NEMOCNÝCH S MITRÁLNÍ REGURGITACI STÁLE KONTRAINDIKACÍ OPERACE? ANALÝZA HOSPITALIZAČNÍCH A STR̆EDNĚ̃OBÝCH VÝSLEDKŮ}

\section{ŠETINA M, PAZDERKOVÁ P, POSPÍŠILOVÁ H, ŠULDA M, MOKRÁČEK A}

Oddělení kardiovaskulární chirurgie,

Kardiovaskulární centrum, FN Motol, Praha,

Kardiocentrum, Nemocnice České Budějovice, a. s.,

České Budejjovice

Úvod: Systolická funkce levé komory je důležitým prognostickým faktorem pro operace mitrální regurgitace (MR). V literatuře se objevují sdělení o operacích pacientů $\mathrm{s} M R$ a ejekční frakcí levé komory (EF LK) pod $30 \%$. Doporučení jsou ale kontroverzní, dlouhodobé výsledky neuspokojivé a tvrzení nejsou dostatečně podložena.

Cíl: Zhodnotit krátkodobé a střednědobé výsledky operací pacientů $\mathrm{s}$ MR a těžkou dysfunkcí levé komory (EF LK $\leq 30 \%)$.

Materiál a metodika: Od ledna 2002 do března 2006 jsme provedli výkon na mitrální chlopni u 601 pacientů. $Z$ tohoto souboru 40 pacientů (30 mužů, 10 žen, průměrný věk $65,7 \pm 9,4$ let) splňovalo kritéria přítomnosti významné MR (průměr 2,9 $\pm 0,5) \mathrm{s}$ EF LK $\leq 30 \%(27,9 \pm 2,3 \%)$. Pacienti byli klinicky a echokardiograficky vyšetřeni bezprostředně po operaci, za 30 dní a za 1 rok. Hodnoceno bylo přežívání pacientů v období jednoho a dvou let po operaci.

Výsledky: Logistic euroSCORE bylo $20,6 \pm 11$,6. Ischemická etiologie byla př́činou MR u 32 pacientů (80\%). Rekonstrukce chlopně byla provedena u $37(92,5 \%)$ a náhrada u 3 pacientů. Trricet osm (95\%) pacientů podstoupilo kombinovaný výkon. Pooperačně vyžadovalo inotropní podporu 39 (97,5\%), intraaortální balonkovou kontrapulsaci 8 (20\%) a biventrikulární stimulaci 7 (17,5\%) pacientů. Hospitalizační mortalita byla $10 \%$. Jednoroční přežívání bylo $87,5 \%$ a dvouleté $85 \%$. Došlo ke zvýšení EF LK před operací, 1 měsíc a 1 rok od operace $(27,9 \% \pm 2,3 \%$ vs. $30,6 \% \pm 6,8 \%$ vs. $37,6 \% \pm 12,5 \% ; p<0,01)$. Při jednoroční kontrole měli $2(5 \%)$ pacienti MR 3 . stupně, jeden $z$ nich byl reoperován. U jednoho pacienta $(2,5 \%)$ přetrvává dušnost NYHA III.

Závěr: Uvedená studie naznačuje, že střednědobé výsledky operovaných pacientů s významnou MR a těžkou dysfunkcí levé komory mohou být uspokojivé. Názor, že těžká dysfunkce levé komory je kontraindikací operace by měl být podroben dalšímu zkoumání a případné revizi.

\section{SESTERSKÁ SEKCE}

\section{IABK INTRAAORTÁLNÍ BALONKOVÁ KONTRAPULSACE, MECHANICKÁ PODPORA LEVÉ SRDEČNÍ KOMORY}

\section{ŠEVČÍKOVÁ P, ARNOŠTOVÁ L, MÁCHA J}

Kardiologické oddělení, koronární jednotka, Nemocnice Na Homolce, Praha

Princip IABK, jak ji známe dnes, se poprvé v klinické praxi použil již v 60. letech minulého století. Přesto má tato metoda nezastupitelné místo v intenzivní léčbě akutního srdečního selhání a patř́ $\mathrm{k}$ úspěšným metodám podpory selhávajícího oběhu. Nejčastější indikace IABK, role sestry při jejím zavádění a samotná péče o pacienta na mechanické podpoře levé srdeční komory. 


\section{ANALÝZA PULSOVÉ VLNY U NEMOCNÝCH S VAZOVAGÁLNÍ SYNKOPOU*}

ŠIMEK J, CHYTILOVÁ E, TUKA V, KRUPIČKA J, NEČASOVÁ L, WICHTERLE D, KAUTZNER J

II. interní klinika kardiologie a angiologie, III. interní klinika, VFN a 1. LF UK, Klinika kardiologe, IKEM, Praha

*Podpořeno grantem IGA NR 8344-4.

Prevalence vazovagální synkopy v populaci je vysoká a její diagnostika není snadná. Rutinně prováděný tilt test má omezenou výpovědní hodnotu a je časově značně zatěžující. Recentní výzkum naznačuje, že jedinci s vazovagální synkopou se liší od zdravých kontrol v morfologii periferní tlakové vlny, pořízené za klidových podmínek vleže. Není známo, zda toto pozorování může predikovat výsledek tilt testu.

Metody: Do studie bylo konsekutivně zařazeno 131 osob (86 žen, $39 \pm 16$ let) s recidivujícími synkopami nejasné etiologie, bez přidružených onemocnění. U všech jedinců byla na základě anamnézy stanovena klinická pravděpodobnost vazovagální synkopy a poté proveden tilt test, během kterého byly pořízeny záznamy kontinuálního krevního tlaku z prstu ruky (Finometer) za klidových podmínek vleže. Jedinci s jednoznačným rozporem mezi výsledkem tilt testu a klinickou pravděpodobností vazovagální synkopy $(\mathrm{n}=33)$ byli vyloučeni ze studie. Ze získaných záznamů bylo stanoveno zpoždění mezi systolickým a diastolickým vrcholem pulsové vlny (DT) a jeho věkově korigovaná hodnota $(\mathrm{cDT}=350$-věk-DT). Jedinci s pozitivním $(\mathrm{T}+)$ a negativním (T-) výsledkem tilt testu byli porovnáni nepárovým $t$-testem.

Výsledky: Soubory (57 T+ a 41 T-) se nelišily ve věku, pohlaví, krevním tlaku a srdeční frekvenci. T+, jedinci měli významně vyšší cDT než T- jedinci $(7,12 \pm 26,1$ vs. $-9,17$ $\pm 26,0, p<0,01)$ a trend $\mathrm{k}$ nižšímu DT $(310 \pm 26 \mathrm{vs}$. $321 \pm 31, p=0,056)$. Indexy DT a cDT neumožňovaly uspokojivou predikci výsledku tilt testu.

Závěr: Studie potvrzuje hypotézu, že jedinci s pozitivním a negativním výsledkem tilt testu mají odlišnou morfologii pulsové vlny i za klidových podmínek vleže. Pozorované odlišnosti však nemají dostatečnou diagnostickou sílu.

\section{IDIOPATICKÁ KOMOROVÁ TACHYKARDIE REZISTENTNÍ NA FARMAKOLOGICKOU LÉC̆BU I ELEKTRICKOU KARDIOVERZI}

\section{ŠIMEK J, GANDALOVIČOVÁ J,} PŠENIČKA M, WICHTERLE D

II. interní klinika kardiologie a angiologie, VFN a 1. LF UK, Klinika kardiologie, IKEM, Praha

Kasuistika: 33letý muž bez strukturálního srdečního onemocnění byl přijat pro incesantní tachykardii se širokými komplexy QRS morfologie blokády pravého Tawarova raménka a sklonem osy doleva. Nemocný přiznával abúzus anabolik (nandrolon) v poslední době a v minulosti byl též dokumentován abúzus efedrinu. Př́ijmu předcházely 5denní palpitace, pro které opakovaně s krátkodobým efektem užil $80 \mathrm{mg}$ verapamilu. Masáž karotických sinů a adenozin v bolusech do dávky $24 \mathrm{mg}$ byly zcela bez efektu. Po postupném podání $140 \mathrm{mg}$ propafenonu i. v. došlo pouze ke zpomalení tachykardie ze 170/min na 150/min. Ani dva bifázické výboje $150 \mathrm{~J}$ a $200 \mathrm{~J}$ nevedly k obnovení sinusového rytmu. Následné podání $300 \mathrm{mg}$ amiodaronu i. v. vedlo ke zpomalení tachykardie na 130/min a odkrylo disociaci AV na EKG křivce. Urgentní elektrofyziologické vyšetření potvrdilo fascikulární komorovou tachykardii. Arytmie byla snadno terminovatelná a indukovatelná komorovou stimulací. Exit incesantní arytmie byl za pomoci elektroanatomického navigačního systému CARTO (Biosense Webster) lokalizován do oblasti zadního fasciklu levého Tawarova raménka, kde několik aplikací RF energie tachykardii ukončilo a způsobilo její neinducibilitu.

Závěr: Idiopatická fascikulární komorová tachykardie může být rezistentní na farmaka a elektrickou kardioverzi. Kauzální léčba radiofrekvenčních ablací dosahuje vysoké úspěšnosti. Arytmie může být indukována abúzem efedrinu. Možný vliv anabolik na arytmogenní substrát, zvažovaný v naší kasuistice, nebyl doposud publikován.

\section{SESTERSKÁ SEKCE}

\section{HEMODIALÝZA NA KORONÁRNÍ JEDNOTCE (PR̆EDNÁšKA)}

\section{ŠIPKOVÁ A}

\section{II. interní klinika, VFN a 1. LF UK, Praha}

Hemodialýza nahrazuje základní funkci ledvin, čistí a filtruje krev. Zbavuje tělo odpadových látek, nadbytečných solí a vody. Podílí se na regulaci krevního tlaku a pomáhá tělu udržet správnou rovnováhu iontů.

Akutní selhání ledvin má rưzné přičiny: dehydratace, krvácení, sepse, poškození ledvin. Z příznaků jsou dominantní otoky, hypertenze, nauzea, zvracení, oligurie-anurie a postupně se rozvíjí městnavé selhávání srdce, dochází k poruchám srdečního rytmu, křečím a bezvědomí.

Hemodialýza na koronární jednotce má své místo. Nejčastějším důvodem $\mathrm{k}$ dialyzování pacienta je hyperkalemie, hyperhydratace bez reakce na podávané diuretika nebo selhávaní srdce kombinované se selhávaním ledvin.

K dispozici je více variant režimů: kontinuální veno-venózní hemodialýza, kontinuální veno-venózní hemofiltrace, kontinuální veno-venózní hemodiafiltrace. O použití vhodného režimu rozhoduje lékař na základě zjištěných výsledků.

$\mathrm{V}$ přednášce bude popsána práce sestry před hemodialýzou, počas a po skončení hemodialýzy.

\section{STANOVENÍ QT DYNAMICITY V AKUTNÍ A CHRONICKÉ FÁZI INFARKTU MYOKARDU*}

ŠIŠÁKOVÁ M, NOVOTNÝ T, FLORIÁNOVÁ A, TOMAN O, VÍT P, KALA P, DOSTÁLOVÁ L, ŠPINAR J

\section{Kardiologická klinika, FN Brno, Brno}

*Výzkum je podporován grantem č. 8374-3.

Úvod: Poruchy repolarizace myokardu u pacientů po prodělaném myokardiálním infarktu jsou spojeny s vyšším rizikem vzniku život ohrožujících komorových arytmií a náhlé srdeční smrti. Nový způsob posouzení repolarizace představuje metoda hodnocení dynamicity intervalu QT (vztah QT/RR). Porovnávali jsme hodnoty dynamicity QT v závislosti na době uplynulé od akutního infarktu myokardu.

Soubor a metody: Vyšetřili jsme celkem 42 nemocných po prodělaném myokardiálním infarktu. Dynamicita QT byla u každého pacienta automaticky hodnocena $z$ 24hodinových záznamů EKG (MARS, QT Guard, GE), v akutní fázi po infarktu do 48 hodin od jeho vzniku a následně s odstupem 4-6 týdnů od infarktu myokardu. 
Výsledky: Strmost regresních křivek QT/RR se v obou záznamech statisticky významně neodlišovala.

Závěry: Automatické hodnocení dynamicity QT z dlouhodobých EKG záznamů má konstantní výpovědní hodnotu bez ohledu na to, zda je záznam pořízen v akutní či chronické fázi myokardiálního infarktu.

\section{NEČEKANÉ NÁLEZY NA KORONÁRNÍCH TEPNÁCH U PACIENTŮ S VROZENOU SRDEČNÍ VADOU V DOSPĚLOSTI*}

ŠÍDOVÁ M, POPELOVÁ J, ČERNÝ Š, GEBAUER R, KMONÍČEK P, NIEDERLE P

Kardiologické oddělení, Kardiochirurgické oddělení, Nemocnice Na Homolce, Dětské kardiocentrum, FN Motol, Praha

*Podpořeno grantem VZ MZO 64203-6306.

Ze 121 pacientů, kteří byli v dospělosti operováni nebo reoperováni pro vrozenou srdeční vadu na kardiochirurgii Nemocnice Na Homolce v období 1/2005-12/2006 měly dvě pacientky (tj. 1,65 \%) nečekaný a dříve nediagnostikovaný nález velkého aneuryzmatu věnčité tepny.

Kasuistika 1: 37letá pacientka po paliativní a následně radikální korekci vrozené atrézie plicnice a levé větve plicnice s defektem komorového septa, po sutuře aortokoronární píštěle, byla indikována $\mathrm{k}$ reoperaci pro významnou obstrukci pulmonální bioprotézy a středně významnou aortální regurgitaci s dilatací ascendentní aorty. Při koronarografii a CT angiografii bylo zjištěno obrovské aneuryzma kmene levé věnčité tepny velikosti $8 \times 4 \mathrm{~cm}$. Nemocná podstoupila náhradu zdegenerované pulmonální bioprotézy homograftem, náhradu aortální chlopně a kořene aorty konduitem s mechanickou aortální protézou, resekci aneuryzmatu kmene levé věnčité tepny, žilní bypass na RIA, bypass na RCX s rekonstrukcí podle Cabrolla a ablaci kavotrikuspidálního istmu. Po operaci je pacientka bez větších obtíží.

Kasuistika 2: 29letá pacientka po radikální korekci Fallotovy tetralogie se suturou koronárních píštělí a po katetrizačním uzávěru koronární píštěle $z$ RIA do pravé srdeční komory byla indikována $\mathrm{k}$ reoperaci pro významnou pulmonální regurgitaci a aneuryzma výtokového traktu pravé komory. Při předoperačních vyšetřeních bylo zjištěno $3 \mathrm{~cm}$ velké aneuryzma kmene levé věnčité tepny. Vada byla korigována náhradou pulmonální chlopně homograftem, resekcí aneuryzmatu výtokového traktu pravé komory a resekcí aneuryzmatu kmene levé věnčité tepny s implantací odstupů RIA a RCx do levého aortálního sinu. Pooperační průběh byl bez komplikací.

Závěr: U dospělých $\mathrm{s}$ vrozenou srdeční vadou je třeba myslet na dřive nediagnostikované anomálie věnčitých tepen, zvláště po uzávěru koronárních píštělí.

\section{DLOUHODOBÉ VÝSLEDKY UNIPROCEDURÁLNÍ ENDOSKOPICKÉ LASER-BALONKOVÉ KATETROVÉ ABLACE V LÉČBĚ PACIENTŮ S PAROXYZMÁLNÍ FIBRILACÍ SÍNÍ}

ŠKODA J, NEUŽIL P, REDDY V, RAVIELE A, NATALE A, KUCK K

Kardiologické oddělení,

Nemocnice Na Homolce, Praha

Úvod: Během katetrizační ablace fibrilace síní je obvykle technicky obtížné aplikovat kontinuální ablační lezi k dosažení elektrické izolace plicních žil. Nový balonový katetr
(Endoscopic Ablation System - EAS; Cardiofocus, Inc.) využivá miniaturní endoskop k reálné vizualizaci během ablace.

Systém vyzařuje nízkoenergetický nastavitelný (rotace, posun vpřed a vzad) laserový oblouk nezávisle na pozici balonu k směrování energie do oblasti plicních žil a přilehlé části levé síně. Tématem sdělení jsou dlouhodobé výsledky této prospektivní, multicentrické studie.

Metoda: Do studie byla zahrnuta 3 centra, 30 pacientů s anamnézou symptomatické farmakorezistentní paroxyzmální fibrilace síní. 26 mužů, ve věku $53 \pm 11$ let (28-73); trvání fibrilace síní: $6,2 \pm 5,1$ roky $(0,4-24,1)$; průměr levé

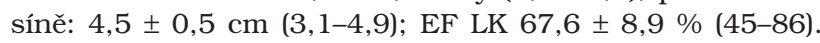
S využitím EAS byla izolována plicní ostia během jediné procedury. Ve vztahu k počtu a morfologii plicních žil nebyla uplatněna žádná vylučovací kritéria.

Výsledky: Elektrická izolace byla docílena u $91 \%$ (105/116) plicních žil. Průměrně bylo dodáno 13,9 aplikací energie na jednotlivou plicní žílu (2-40). Perikardiální tamponáda se vyskytla u 1 pacienta (bez souvislosti s EAS), u dalšího pacienta byl zaznamenán reverzibilní ischemický deficit a $\mathrm{u}$ jednoho pacienta se objevila reverzibilní paréza bráničního nervu. Zcela bez fibrilace síní za 6 měsíců bylo $70 \%$ pacientů s 30denní slepou periodou, $75 \%$ pacientů s 60denní slepou periodou, a $80 \%$ pacientů s 90denní slepou periodou. 6 měsíční a 12 měsíční úspěšnost s 90denní slepou periodou byla $80 \%$, resp. $75 \%$. Při 6 měsíční kontrole 9/70 (12,9 \%) žil mělo jen lehkou stenózu (20-50\% zúžení). Při 12měsíční kontrole, 1/8 žil (12,5 \%) měla lehkou stenózu.

Závěr: Tato pilotní studie ozřejmila bezpečnost a efektivitu uniprocedurální katetrizační ablace paroxyzmální fibrilace síní s využitím EAS.

\section{NEADEKVÁTNÍ SINUSOVÁ TACHYKARDIE: RADIOFREKVENČNÍ ABLACE EPIKARDIÁLNÍM PŘÍSTUPEM}

ŠKODA J, NEUŽIL P, REDDY V, TÁBORSKÝ M, ŠEDIVÁ L, NIEDERLE P

\section{Kardiologické oddělení, Nemocnice Na Homolce, Praha}

Úvod: Výsledky katetrizační radiofrekvenční ablace „neadekvátní" sinusové tachykardie (IST) jsou suboptimální s dlouhodobou úspěšností 23-66 \%. V našem centru jsme provedli u 5 pacientů epikardiální RF ablaci s využitím 3D elektroanatomického mapování.

Cíl: Posoudit dlouhodobou efektivitu a bezpečnost výkonu.

Metoda: 5 pacientů (1 muž, průměrného věku $39 \pm 10$ let) s normálním echokardiografickým nálezem a limitujícími symptomy farmakorezistentní IST. V epidurální anestezii bylo provedeno endokardiální a epikardiální 3D mapování. Cílem ablace byla epikardiální oblast nejčasnější sinusové aktivace s využitím izoprenalinového testu. Epikardiální aktivace jednoznačně předcházela endokardiální aktivaci.

Výsledky: Srdeční frekvence byla v klidu před ablací 103-150/min (průměr $122 \pm 14$ ) a v klidu po ablaci 63-100 (průměr $84 \pm 12$ ). Počet epikardiálních aplikací byl 2-4 (průměr 3) a průměrný čas procedury 96-155 min (průměr $134 \pm 13 \mathrm{~min})$. V dlouhodobém horizontu bylo dosaženo u 3 pacientů uspokojivého stavu (bez přítomnosti paroxyzmálních palpitací, průměrná klidová TF 53-85, průměr $68 \pm 11 / \mathrm{min}), \mathrm{z}$ nichž u jednoho pacienta byl 4 měsíce po výkonu pro chronotropní inkompetenci (max. TF $75 / \mathrm{min}$ na vrcholu zátěže 150 W) implantován dvoudutinový kardiostimulátor. Zbývající 2 pacienti měli v dlouhodobém horizontu jen parciálně uspokojivý efekt epikardiální ablace, kdy průměrná klidová TF klesla ze 103 na 85/min, resp. 117 na 85/min, nicméně perzistují limitující palpitace s nárůsty $\mathrm{TF}$ nad $140 / \mathrm{min}$. 
U Žádného pacienta nebyl poškozen brániční nerv ani stenozována horní dutá žíla.

Závěr: Epikardiální ablace neadekvátní sinusové tachykardie je relativně bezpečná. K docílení požadovaného poklesu tepové frekvence postačovalo překvapivě nízké množství aplikací RF ve srovnání s konvenční endokardiální ablací. Výsledky našeho souboru se jeví slibné $\mathrm{s}$ přihlédnutím $\mathrm{k}$ učební křivce a malému počtu pacientů

\section{ÚC̆INNOST RŮZNÝCH OCHLAZOVACÍCH REŽIMŮ PR̆I INDUKCI MÍRNÉ HYPOTERMIE U NEMOCNÝCH PO SRDEČNÍ ZÁSTAVĔ}

ŠKULEC R, BĚLOHLÁVEK J, DYTRYCH V, KOVÁRNÍK T, HORÁK J, PŠENIČKA M, ŠIMEK S, POLÁČEK P, ASCHERMANN M, LINHART A

II. interní klinika kardiologie a angiologie, VFN a 1. LF UK, Praha

Navození mírné terapeutické hypotermie (MH) je součástí poresuscitační péče. Zásadní význam má zahájit $\mathrm{MH}$ co nejdříve po obnovení spontánní cirkulace, a zároveň co nejrychleji dosáhnout terapeutickou tělesnou teplotu (tt) $<34{ }^{\circ} \mathrm{C}$.

Cíl: Porovnat účinnost kombinace ochlazovacích postupů (povrchové chlazení ledovými obklady a podání rychlé nitrožilní infuze ledového fyziologického roztoku /LFR/) s běžným prostým povrchovým ochlazováním ledovými obklady.

Soubor a metodika: Provedli jsme retrospektivní analýzu všech nemocných po srdeční zástavě (SZ) ošetřených metodou MH na naší koronární jednotce od listopadu 2003 do listopadu 2006. Pacienti byli ochlazováni bud' jednou metodou (povrchové chlazení ledovými obklady, skupina A) anebo kombinací povrchového ochlazování a velmi rychlého nitrožilního podání LFR o teplotě $4{ }^{\circ} \mathrm{C}$ v dávce $10-30 \mathrm{ml} / \mathrm{kg}$ (skupina B). Všichni nemocní byli v hluboké analgosedaci a relaxováni. Ochlazováni byli na cílovou tt $33^{\circ} \mathrm{C}$.

Výsledky: Do skupiny A bylo retrospektivně zařazeno 34 nemocných, do skupiny B 22. Tt před zahájením MH byla srovnatelná v obou skupinách $\left(35,8 \pm 1,0^{\circ} \mathrm{C}\right.$ ve skupině A a 36,1 $\pm 1,3^{\circ} \mathrm{C}$ ve skupině $\left.\mathrm{B}, p=0,476\right)$. Průměrná dávka LFR byla ve skupině B $16 \mathrm{ml} / \mathrm{kg}$. Kombinací ochlazovacích postupů bylo ve skupině B podstatně rychleji dosaženo tt $34{ }^{\circ} \mathrm{C}$ (96 \pm 78 vs. 196 $\pm 149 \mathrm{~min}, p=0,007)$ i cílové tt $33{ }^{\circ} \mathrm{C}(152 \pm 101$ vs. $276 \pm$ $189 \min , p=0,008$ ) než ve skupině A. Doba potřebná na ochlazení o $1{ }^{\circ} \mathrm{C}$ byla ve skupině $\mathrm{B}$ výrazně kratší než ve skupině A (54 \pm 40 vs. $102 \pm 63 \mathrm{~min}, p=0,003$ ). Korelaci dávky LFR a rychosti ochlazování jsme neprokázali. Rychlé podání velkého objemu LFR bylo bezpečné a jednoduché.

Závěr: Kombinace povrchového chlazení a rychlé aplikace LFR v dávce asi $16 \mathrm{ml} / \mathrm{kg}$ vede u nemocných po $\mathrm{SZ}$ léčených indukcí MH k dosažení cílové teploty podstatně rychleji než prosté povrchové ochlazování. Kombinační metoda je jednoduchá a bezpečná.

\section{PRŨZKUM POUŽíVÁNÍ TERAPEUTICKÉ MÍRNÉ HYPOTERMIE PO SRDEČNÍ ZÁSTAVĔ V ČR}

ŠKULEC R, BĚLOHLÁVEK J, KOVÁRNÍK T, DYTRYCH V, HORÁK J, PŠENIČKA M, ŠIMEK S, ASCHERMANN M, LINHART A

II. interní klinika kardiologie a angiologie, VFN a 1. LF UK, Praha

Navození terapeutické mírné hypotermie $(\mathrm{MH})$ u nemocných po srdeční zástavě co nejdřive po obnovení spontánní cirkulace (ROSC) je jediný známý postup, který snižuje riziko vážného poškození mozku a pravděpodobně redukuje i mortalitu. Přestože je tato metoda od roku 2003 součástí doporučení pro kardiopulmonální resuscitaci, literární údaje a naše praktické zkušenosti svědčí o tom, že jde o metodu nadále velmi málo použivanou. V západní Evropě a USA ji používá pouze 13-28 \% jednotek intenzivní péče. Rozhodli jsme se prozkoumat, jak často a jakým zpo̊sobem je terapeutická mírná hypotermie u nemocných po srdeční zástavě použivána v České republice. Poštou jsme obeslali 667 jednotek intenzivní péče a anesteziologicko-resuscitačních oddělení strukturovaným dotazníkem obsahujícím 23 dotazů na uvedené téma. V současné době sbíráme data a konkrétní výsledky budeme prezentovat na XV. výročním sjezdu České kardiologické společnosti.

\section{MECHANICKÁ SRDEČNÍ PODPORA IMPELLA RECOVER U „HIGH RISK“ PCI}

ŠKVǍ̌IL J, ČERNOHOUS M, SEDLOŇ P, ZAVORAL M

\section{Kardiologické oddělení, ÚVN a 1. LF UK, Praha}

Ưvod: Zatímco koronární intervence je v současnosti jednoznačně přijímána jako léčba volby u akutního koronárního syndromu (AKS), pro zavedení rutinního použití mechanické srdeční podpory u rizikových intervencí, včetně AKS, jsou údaje zatím omezenější, byṫ velmi slibné.

Popis připadu: 64letá nemocná, diabetička, hypertonička, byla přijata pro 2 hodiny s vyvíjejícími se STEMI spodní stěny. Klinicky hypotenze, Killip II. Urgentně provedená koronarografie prokazuje uzávěr dominantní ACD a kritickou stenózu distálního kmene ACS, která se dále plní TIMI III. Provedená rekanalizace $\mathrm{ACD}$ vedla $\mathrm{k}$ rychlému obnovení průtoku tepnou a k hemodynamické stabilizaci. Byla zahájena duální antiagregační léčba. Nemocná byla v dalším období oběhově stabilní, EF LK 30 \% při rozsáhlé akinezi spodní stěny. 7. den byla provedena nekomplikovaná intervence kmene ACS se současně zavedenou podporou Impella RECOVER. Při jejím použití srdeční index vzrostl z 1,3 na $1,9 \mathrm{l} / \mathrm{min} / \mathrm{m}^{2}$ a plnicí tlak LK klesl z 28 na $14 \mathrm{~mm} \mathrm{Hg}$. Po 6 měsících (pacientka byla od propuštění asymptomatická) byla provedena kontrolní katetrizace bez známek restenózy. Při ventrikulografii je patrna nevelká akineze spodní stěny, EF LK 45 \%, srdeční index 2,6 1/min/m².

Závěr: Použití mechanické podpory srdeční u rizikové koronární intervence (PCI nechráněného kmene ACS u nemocné krátce po direktní PCI ACD) bylo v našem případě jednoduché, bezpečné, nekomplikované s dobrým okamžitým efektem. Další klinický vývoj nemocné je i nadále příznivý.

\section{EMBOLIZAČNÍ LÉČBA KORONARO-ATRIÁLNIIHO ZKRATU}

\section{ŠKVǍ̌IL J, ČERNOHOUS M, JARKOVSKÝ P,} CHARVÁT F, ZAVORAL M

Kardiologické oddělení, Klinika radiologie, ÚVN a 1. LF UK, Praha

Úvod: Koronární fistule přestavují relativně vzácnou anomálii. Jejich incidence v dospělé populaci je udávána 0,1\%-1\%. Léčba je zpravidla indikována pouze u symptomatických nemocných. Jednou z možností je terapie embolizační (coiling).

Popis připadu: 55letý pacient, v mládí aktivní sportovec, byl 10 let sledován pro dysfunkci LK (veden jako DKMP). Přijat pro progresi dušnosti do stadia NYHA III a oprese na hrudi. Katetrizace srdeční prokazuje dilataci a dysfunkci LK (EF LK 18 \%, EDVi 239 ml/m², srdeční index 1,7 1/min/m²). 
Při koronarografii byla zjištěna silná vinutá malformace mezi proximálním RCx a pravou síní. Qp/Qs = 1,5. Nález byl dokumentován rovněž pomocí TEE a MR.

U nemocného byl ve 2 . době proveden úspěšný embolizační uzávěr zkratu s použitím 5 coilů. V následujícím období došlo ke zlepšení symptomů (NYHA II). Funkce LK se podstatně nelepšila. Po 6 měsících došlo opět k progresi. TEE prokazuje rekanalizaci zkratu a opakovaný pokus o embolizační uzávěr již nebyl technicky úspěšný. S ohledem na pravděpodobnou koincidenci zkratu a DKMP byl nemocný předán na vyššî pracoviště s úvahou ve smyslu resynchronizační léčby, popř. zařazení do transplantačního programu.

Závěr: Embolizační léčba koronární fistule je raritní, technicky schůdný výkon. V našem případě však došlo $\mathrm{k}$ rekanalizaci zkratu a s ohledem na pravděpodobnou koincidenci s DKMP byl další léčebný postup změněn.

\section{DETEKCE DEPRESE U NEMOCNÝCH S ICHS PODSTUPUJICICH KATETRIZACI}

\section{ŠKVAŘILOVÁ M, BERNAT I, PAĎOUR M, ONDREJČÁK R}

Intervenční kardiologie, Karlovarská krajská nemocnice a. s., Karlovy Vary

Úvod: Řada studií nemocných s depresí prokázala vyšší než dvojnásobnou mortalitu u nemocných s úzkostně depresivní symptomatikou (v jakémkoliv věku bez závislosti na sebevraždách). Některé práce prokazují, že deprese je pro kardiaka podobným rizikem jako například kouření. Přesto se soustavným aktivním vyhledáváním depresivních pacientů s prokázanou ICHS žádné pracoviště v ČR dlouhodobě nezabývá.

Cíl studie: Detekce úzkostně depresivní symptomatiky u nemocných přijatých ke koronarografii pomocí krátké verze dotazníku PHQ 10 a porovnat tuto verzi s dotazníkem Beckovy stupnice hodnocení deprese. Srovnání výsledků obou dotazníků. Posouzení srozumitelnosti otázek pro nemocné (schopnost vyplnit samostatně dotazník). Zjistit, zda nemocní s průkazem depresivní nebo úzkostně depresivní symptomatiky mají rozsáhlejší postižení koronárních tepen.

Výsledky: Beckova stupnice hodnocení deprese byla pro nemocné srozumitelnější než krátká verze dotazníku PHQ. Pomocí dotazníků jsme detekovali $9 \%$ těžkých forem deprese u krátké verze PHQ dotazníku a $7 \%$ u Beckovy stupnice deprese. Těmto nemocným byla nabídnuta psychiatrická léčba. Třetina nemocných se závažnou formou deprese neměla významné postižení věnčitých tepen, dvě třetiny měly zjištěno významné postižení aspoň jedné věnčité tepny. Vyplnění jednoduchého dotazníku považujeme za vhodný způsob aktivního vyhledávání deprese kardiaků, zejména na pracovištích, které ročně vyšetří vysoký počet nemocných. Bez aktivního přístupu zůstane $u$ většiny $z$ nich deprese nediagnostikována, a tedy i neléčena.

\section{SUBAKUTNI A POZDNÍ TROMBÓZY KORONÁRNIICH STENTŮ}

\section{ŠKVAŘILOVÁ M, BERNAT I, PAD̆OUR M, ONDREJČÁK R}

Intervenční kardiologie, Karlovarská krajská nemocnice a. s., Karlovy Vary

Vznik trombózy v implantovaném stentu významně ohrožuje další osud nemocného. Proto jsme provedli podrobnou analýzu všech 15 trombóz, které jsme řešili na našem pracovišti od 1. 11. 2005-31. 12. 2006. Jednalo se o 13 mužů a dvě ženy, průměrný věk 67 let. U 2 nemocných byl stent implantován na jiném pracovišti, 13× byl původní výkon proveden u nás. Akutní trombózu stentu (do 24 hod.) jsme nezaznamenali ani jednou, $8 \times$ se jednalo o subakutní trombózu ( 24 hod.-30 dní), 6× o pozdní (30 dní-1 rok) a jednou o velmi pozdní trombózu stentu (více než 1 rok po implantaci). 5x vznikla trombóza $\mathrm{v}$ drug eluting stentu (DES) tj. ve $2 \% \mathrm{z}$ celkově ošetřených nemocných tímto stentem a $10 \times$ u nemocných s implantovaným bare-metalovým stentem $(\mathrm{BM})$ - tj. u 1,8 \% z takto ošetřených. Původní intervence byla u $9 \mathrm{z}$ našich 13 nemocných pro STEMI s př́tomnosti trombu v lézi, $z$ toho $2 \times$ byla primární PCI provedena po 12 hodinách od vzniku STEMI s neoptimálním výsledkem. V době vzniku trombózy 6 nemocných již neuživalo duální antiagregační terapii a u 3 nemocných se tuto informaci nepodařilo spolehlivě zjistit. Jeden nemocný zemřel náhlou srdeční smrtí, 2 byli přijati v kardiogenním šoku $(1 \mathrm{z}$ nich zemřel), 2 nemocné v edému plic. Současně jsme ambulantně vyšetřili nebo telefonicky kontaktovali 3 měsíce po implantaci DES stentu 170 nemocných. Zjistili jsme, že celých $13 \%$ nemocných neuživalo doporučenou duální antiagregaci ani 6 měsíců. Jednou $z$ důležitých přičin bylo nedořešené hrazení Plavixu VZP u DES. Z našeho sledování vyplývá, že vysoké procento subakutních a pozdních trombóz koronárních stentů vzniká v souvislosti s nedodržením duální antiagregační léčby.

\section{FUNKČNÍ TRIKUSPIDÁLNÍ REGURGITACE PR̆I CHRONICKÉ MITRÁLNÍ REGURGITACI*}

\author{
ŠMÍD M, ROUČKA P, HÁJEK T, \\ ZÁRYBNICKÁ M, ČECH J
}

\section{Kardiochirurgické oddělení, FN Plzeň, Plzeň}

*Tato práce byla podpořena granty VZ UK v Praze č. MSM 0021620817, uděleným MŠMT ČR.

Úvod: Podle recentních prací nekorigovaná funkční trikuspidální regurgitace po náhradě či plastice mitrální chlopně může vést $\mathrm{k}$ další dilataci pravé komory a jejímu selhávání.

Metodika: Na kardiochirurgickém oddělení FN Plzeň bylo v letech 2002-2006 provedeno 408 výkonů na mitrální chlopni (náhrada či plastika), z nich u 155 pacientů (38\%) byla provedena plastika trikuspidální chlopně. Při pravidelných kontrolách byla sledována symptomatologie nemocných $(n=45)$, vývoj ejekční frakce levé a pravé komory srdeční, rozměry obou komor, výsledky srovnány s kontrolní skupinou pacientů $(\mathrm{n}=22)$, u kterých nebyla provedena korekce funkční trikuspidální regurgitace.

Výsledky: Podle střednědobých výsledků dochází u pacientů, kterým byla korigována funkční trikuspidální regurgitace $\mathrm{v}$ jedné době s plastikou či náhradou mitrální chlopně k signifikantnímu zlepšení dušnosti podle klasifikace NYHA, zmenšení diametru pravé komory, významnému zvýšení ejekční frakce levé komory a nevýznamnému zvýšení ejekční frakce pravé komory. U kontrolní skupiny pacientů, kterým nebyla funkční trikuspidální regurgitace korigována, došlo v dalším sledování $\mathrm{k}$ signifikantní dilataci pravé komory a u $1 / 3$ nemocných došlo $\mathrm{k}$ progresi neoperované Tri regurgitace o 1 st. a více, statisticky významné dilataci PKS a poklesu její ejekční frakce.

Závěr: Nekorigovaná funkční trikuspidální regurgitace při onemocnění mitrální chlopně může vést $\mathrm{k}$ progresi systolické dysfunkce pravé komory. Současná korekce trikuspidální regurgitace u chronické mitrální regurgitace zabraňuje další dilataci pravé komory a jejímu následnému selhávání. Současný výkon na obou chlopních nemá vliv na operační a celkovou mortalitu. 


\section{Cordis}

a fohuson affohuson company

Ground breaking, Life changing ${ }^{\mathrm{T}}$

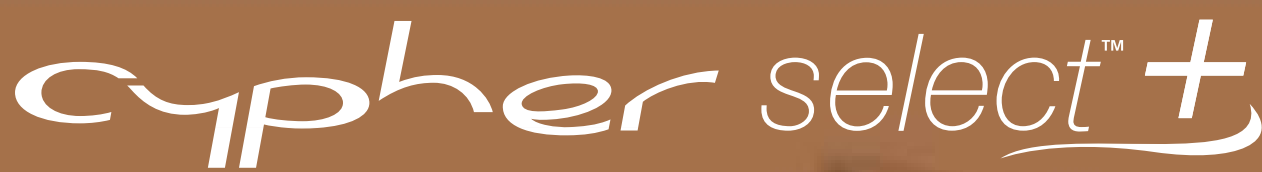

Sirolimus-eluting Coronary Stent

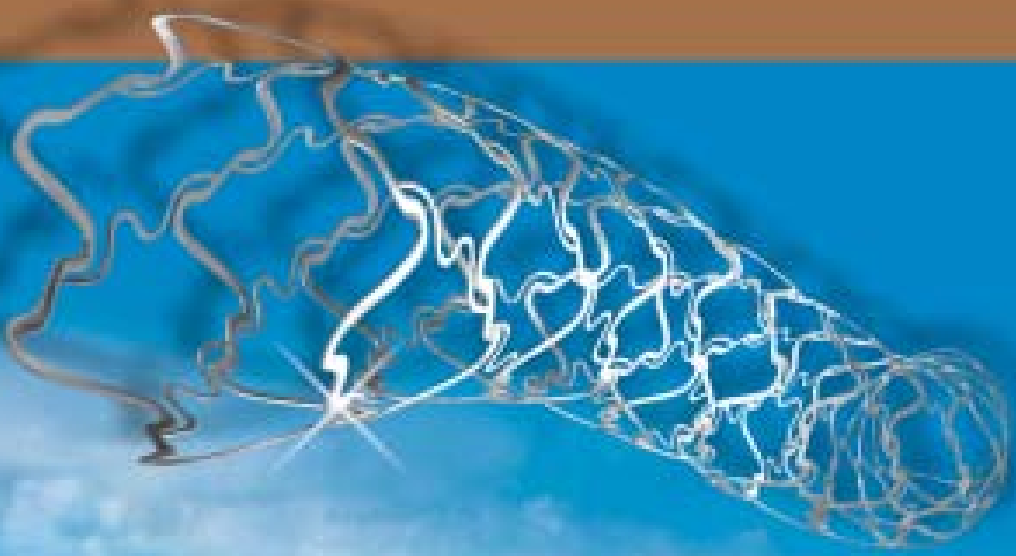

Snadná a bezpečná cesta $k$ cili

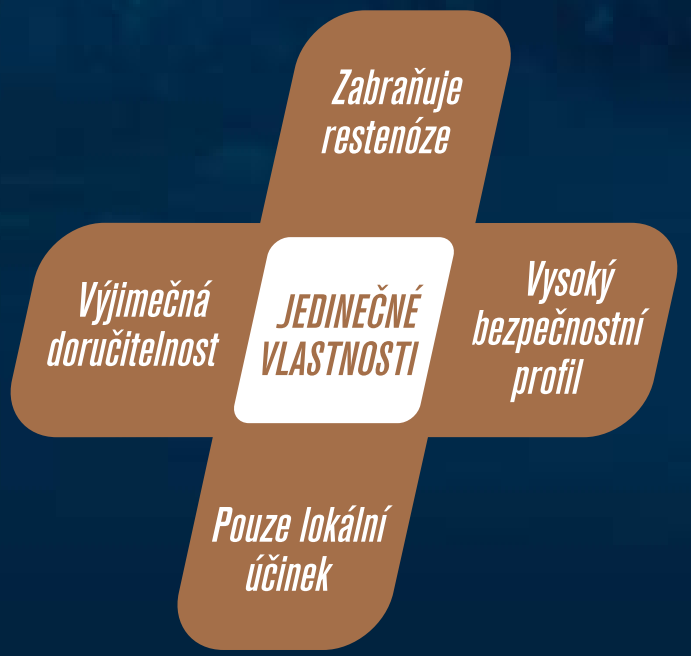




\section{POŠKOZENÍ MYOKARDU A VELKÝCH TEPEN U HYPERTONIKƯ JE SOUBĚŽNÉ. SROVNÁNÍ VÝSLEDKŮ VYŠETR̆ENÍ MYOKARDU PULSNÍM TKÁŇOVÝM DOPPLEREM A VELKỶCH CÉV MĔR̆ENÍM RYCHLOSTI PULSNİ VLNY}

\section{ŠOLC D, ŠTRAUCH B, PETRÁK O, KRÁL J, HRADEC J}

\section{III. interní klinika, VFN a 1. LF UK, Praha}

Úvod: U nemocných s arteriální hypertenzí se často rozvíjí diastolická dysfunkce levé komory (LK). Často se u nich mění také mechanické vlastnosti cévní stěny, která se stává tužší. Cílem této práce bylo zjistit, zda je u hypertoniků nějaký vztah mezi diastolickou (dys)funkcí LK a tuhostí stěny velkých cév.

Metodika: Hodnoceno bylo 40 nemocných s arteriálnî hypertenzí, kteří byli vyšetřeni echokardiograficky včetně posouzení diastolické funkce LK parametry transmitrální dopplerovské křivky a pulsním tkáňovým Dopplerem (TDI), a současně u nich byly zhodnoceny mechanické vlastnosti stěny velkých cév měřením rychlosti pulsní vlny (PWV).

Výsledky: Jsou shrnuty v tabulce. Zjistili jsme statisticky významné korelace mezi parametry diastolické funkce z TDI (časná rychlost E'), transmitrální dopplerovské křivky (decelerační čas vlny E - Mi-DT), velikostí levé síně (LS) a parametrem tuhosti cévní stěny (PWV). Průměrná PWV je významně vyšší $u$ pacientů $s$ diastolickou dysfunkcí LK hodnocenou pomocí TDI (E'/A') než u nemocných s normální diastolickou funkcí $(8,69 \pm 1,88$ vs. $6,78 \pm 1,42 \mathrm{~m} / \mathrm{s}$; $p=0,011)$

\begin{tabular}{cccc}
\hline \hline & E' $^{\prime}[\mathbf{c m} / \mathbf{s}]$ & Mi-DT [ms] & LS (M-mode) [cm] \\
\hline PWV [m/s] & $-0,5194$ & $-0,4772$ & 0,4344 \\
& $\mathrm{n}=39$ & $\mathrm{n}=32$ & $\mathrm{n}=37$ \\
& $p=0,001$ & $p=0,006$ & $p=0,007$ \\
\hline \hline
\end{tabular}

Závěr: Prokázali jsme vztah mezi diastolickými vlastnostmi LK a tuhostí cévní stěny u nemocných s arteriální hypertenzí.

\section{MINIINVAZIVNÍ MYOKARDIÁLNÍ REVASKULARIZACE U SENIORÜ. ANALÝZA ČASNÝCH VÝSLEDKŨ}

\section{ŠORM Z, HARRER J, ŽÁČEK P}

Kardiochirurgická klinika, FN Hradec Králové a LF UK, Hradec Králové

Cíl: Retrospektivní analýza časných výsledků po myokardiální revaskularizaci minimálně invazivní metodou u seniorů od 70 let rozdělených do dvou věkových skupin.

Soubor a metodika: V naší studii je zahrnuto 197 pacientů s ICHS rozdělených do dvou věkových skupin. Skupina A: $70-75$ let $(n=130)$ a skupina B: 76 let a výše ( $\mathrm{n}=67)$. U nemocných byl proveden elektivní monobypass LIMA-RIA z levostranné krátké přední minitorakotomie (MID-CAB) na Kardiochirurgické klinice v Hradci Králové v letech 1998-2005. Předoperační charakteristika nemocných $\mathrm{v}$ souborech zahrnuje kinetiku LK (popř. prodělaný IM a následné perkutánní intervence), ledvinné funkce (kreatinin v séru) a přidružená onemocnění (DM, CHOPN, CMP). Pooperačně je sledována 30denní mortalita, peri- nebo pooperační ischemie (Q- a non-Q-IM), nově vznik fibrilace nebo flutteru siní, výskyt závažných plicních, renálních, neurologických nebo ranných komplikací.

Výsledky: Studované skupiny nemocných se mezi sebou statisticky významně nelišily v žádném $z$ dat týkajících se pře- doperační charakteristiky souboru. Jediným rozdílem byl věk nemocných, který vyplývá ze zadání studie. Analýza časných pooperačních výsledků neprokázala statisticky významný rozdíl mezi studovanými skupinami ve sledovaných parametrech. Skutečná mortalita (30denní: skupina $\mathrm{A}=2,31 \% / \mathrm{B}=4,48 \%$ ) byla $\mathrm{u}$ našich souborů výrazně nižší než predikovaná (podle EUROSCORE: skupina A = 7,41 \%/B = 12,4\%).

Závěr: Preference myokardiální revaskularizace bez mimotělního oběhu a s minimální chirurgickou přístupovou cestou je u seniorů výrazem filozofie usilující o zmenšení operační zátěže u těchto rizikových nemocných.

\section{VLASTNOSTI PERIFERNÍCH TEPEN A FUNKCE LEVÉ KOMORY SRDEČNÍ U HYPERTONIKŮ $S$ METABOLICKÝM SYNDROMEM A DIABETES MELLITUS 2. TYPU}

\section{ŠPÁC J, NĚMCOVÁ H, SOUČEK M, HANUŠ J}

\section{II. interní klinika, FN u sv. Anny, Brno}

Cílem práce je hodnocení vlastností periferních tepen u nemocných s metabolickým syndromem (MS) a diabetiků 2. typu s hypertenzí (HT + DM) a vztah k funkčním vlastnostem levé komory srdeční. U 44 nemocných s MS - průměrný věk 45 let, BMI 32,4 a 42 nemocných s HT + DM - průměrného věku 64 let, BMI 29,6, s nepoškozenou ledvinnou funkcí, jsme hodnotili vlastnosti periferních tepen pomocí měření rychlosti pulsové vlny mezi aortou a stehenní tepnou, diastolické vlastnosti levé komory srdeční pomocí echokardiografie $\mathrm{s}$ dopplerovským znázorněním mitrálního průtoku a tkáňového dopplerovského zobrazení pohybu mitrálního prstence. U všech nemocných byla vyšetřena hladina natriuretických peptidů BNP a NTpro-BNP. Průměrné hodnoty rychlosti pulsové vlny aorta - stehenní tepna byly u skupiny s MS nižší než u skupiny HT a DM $(11,41 \mathrm{~m} / \mathrm{s}$ oproti $12,81 \mathrm{~m} / \mathrm{s})$, stejně jako hodnota BNP byla zvýšena u nemocných s HT a DM více než u skupiny s MS (44,2 oproti 15,0 pmol/1). Všichni nemocní měli normální systolickou funkci levé komory srdeční, nemocní s DM + HT měli vyšší hodnotu masy levé komory oproti skupině s MS (111,9 oproti 93,05 $\mathrm{g} / \mathrm{m}^{2}$ ). Dopplerovská kritéria diastolické dysfunkce levé komory mělo $42 \%$ nemocných s MS a $50 \%$ nemocných s HT a DM. U nemocných s MS a HT a DM jsme nalezli korelaci mezi vlastnostmi periferních tepen charakterizované rychlostí pulsové vlny a nálezem diastolické dysfunkce levé komory a hodnotami natriuretických peptidů. Hodnocení rychlosti pulsové vlny může být použito k rizikové stratifikaci kardiovaskulárního systému u nemocných s metabolickým syndromem, inzulinorezistencí a hypertenzí. Porušená poddajnost tepenného systému se může podílet na vzniku diastolické dysfunkce levé komory srdeční.

\section{AHEAD - ACUTE HEART FAILURE DATABASE}

ŠPINAR J, VÍTOVEC J, KETTNER J, LINHART A, PAŘENICA J, HLINOMAZ O, AL-HITI H, BĚLOHLÁVEK J, MIKLÍK R, DUŠEK L

Interní-kardiologická klinika, FN Brno, Brno, II. interní klinika kardiologie a angiologie, VFN, Praha, I. interní-kardioangiologická klinika, FN u sv. Anny, Brno

Databáze AHEAD (Acute HEArt Failure Database) je registrem nemocných $\mathrm{s}$ akutním srdečním selháním hospitalizovaných na pracovištích s 24hodinovou službou katetrizační laboratoře. ČR je země, kde je 100\% pokrytí pro direkt- 
ní angioplastiky u AIM a dojezdová doba (telefon-dveře) jen výjimečně přesahuje 60 minut.

$\mathrm{V}$ registru jsou informace o nemocných ze 4 velkých nemocnic $(2 \times$ Praha, $2 \times$ Brno) se spádovou oblastí asi 2000000 obyvatel. Registr je prospektivní, vedený na internetových stránkách (https://trials.cba.muni.cz) a spravovaný nezávislou statistickou institucí Masarykovy univerzity.

Registr byl zahájen v červenci 2006 a do 31. 12. 2006 jsou uvedena data o 382 nemocných. Srdeční selhání de novo mělo 59,3 \%, 38,9 \% dekompenzaci chronického srdečního selhání (1,8 \% neznámo), ve 42,1 \% byl průkaz ischemie, $68,1 \%$ tvořili muži. Ženy mají častěji de novo srdeční selhání (72,4 \%) než muži (52,9 \%). Průměrný věk je 71,1 let (nejvíce nemocných - 37,1 \% je ve věku 70-79 let), průměrný BMI $27,9 \mathrm{~kg} / \mathrm{m}^{2}$. Ženy mají vyšší věk i BMI než muži. 58,5 \% má anamnesticky hypertenzi a 37,7 \% diabetes mellitus. Průměrná tepová frekvence je 86 tepů za minutu a průměrný tlak 135/79 mm Hg. Ženy mají statisticky nevýznamně vyšší TK. Průměrná ejekční frakce je 36,1 \%, ženy mají statisticky významně vyšší ejekční frakci (42,1 \% vs. 32,4 \%,p<0,001).

Levosimendan byl podán u 5,7 \% nemocných, v 63,7 \% se jednalo u dekompenzaci srdečního selhání, 71,2 \% nemocných léčených levosimendanem bylo mladších něž průměr všech nemocných a nikdo neměl ejekční frakci > $40 \%$.

Závěr: Na specializovaných pracovištích s katetrizační laboratoří jsou s akutním srdečním selháním hospitalizováni častěji nemocní $\mathrm{s}$ ischemickou etiologii de novo srdečního selhání, převažují muži mladšího věku. Nemocniční mortalita bude známa v průběhu kongresu. Šest okresních nemocnic by se mělo připojit k registru začátkem roku 2007.

\section{CORD - COMPARISON OF RECOMMENDED DOSES*}

\section{ŠPINAR J, VÍTOVEC J, SOUČEK M}

Interní-kardiologická klinika, FN Brno, I. interní-kardioangiologická klinika, II. interní klinika, FN u sv. Anny, Brno

*Studie je podporována VVZ MŠMT 0021622402

Studie CORD je multicentrická, jednoduše slepá studie, která $\mathrm{u}$ pacientů s hypertenzí testuje antihypertenzní a metabolický efekt doporučovaných dávek ramiprilu a losaratanu.

Zařazeni jsou nemocní již léčeni > 3 měsíce ACE inhibitorem (který se v den zařazení vysadí) s TK < 160/90 mm Hg (skupina A). Těmto nemocným je zahájena léčba losartanem 50 mg. Nemocní neléčení ani ACE inhibitorem ani AII antagonistou, ale s TK > 140/90 mm Hg (skupina B) jsou randomizováni na léčbu losartanem 50 mg nebo ramiprilem 5 mg. Veškerá další antihypertenziva jsou povolena.

Při nedostatečné kontrole krevního tlaku je dávka zvyšována na $100 \mathrm{mg}$ losartanu, resp. $10 \mathrm{mg}$ ramiprilu, další krok je přidání hydrochlorothiazidu. Titrace je prováděna po měsíci (zvyšování dávky ramiprilu či losartanu), resp. po 3 měsících (přidání další medikace).

Nábor je „competitive,“ dokud počet nemocných léčených losartanem nedosáhne 9193 (LIFE populace).

Sledovány jsou hodnoty TK a TF, metabolické parametry, renální funkce, krevní obraz a hypertrofie levé komory. Délka studie je 12 měsíců, rizikový stupeń nemocného je při každé kontrole hodnocen tabulkou SCORE.

Primární cíl u skupiny A je prokázat že přechod z ACE-I na losartan je bezpečný a účinný, u skupiny B, že losartan v doporučované dávce je stejně účinný jako ramipril na hodnoty krevního tlaku s menším výskytem nežádoucích účinků (kašel, renální funkce, anemie). Sekundární cíle jsou ovlivnění inzulinové rezistence a hypertrofie levé komory. Studie byla zahájena v červnu 2006, do konce roku 2006 bylo zařazeno 11093 nemocných, průměrného věku 61,5 let, 5248 (47,7 \%) jsou muži, 5739 (52,2 \%) ženy, 16 $(0,1 \%)$ pohlaví neuvedeno. Nejčastější další antihypertenzivum je diuretikum 44,6 \% a betablokátor $43,4 \%$. Statin má 40,1 \%, ICHS má 30,9 \% a diabetes mellitus 32,1\%. Ukončení náboru se předpokládá v únoru 2007.

\section{CYTOKINY PO AUTOLOGNÍ TRANSPLANTACI MONONUKLEÁRNÍCH BUNĚK KOSTNÍ DR̆ENĔ U NEMOCNÝCH S AKUTNÍM INFARKTEM MYOKARDU PR̆I APLIKACI RŮZNÝCH DÁVEK*}

ŠPINAROVÁ L, MELUZÍN J, GROCH L, MAYER J, KLABUSAY M, TOMANDL J, PANOVSKÝ R, HORŇÁČEK I, KOŘÍSTEK Z

I. interní-kardioangiologická klinika, FN u sv. Anny, Interní-hematoonkologická klinika, FN Brno, Ústav lékařské chemie a biochemie, LF MU, Brno

*Práce byla podpořena výzkumným záměrem MSMT-MSM 0021622402.

Cíl práce: Posoudit vliv různých dávek mononukleárních buněk kostní dřeně (MBKD) na reakci cytokinů interleukinu 6 a tumor necrosis faktoru (TNF) alfa $u$ pacientů po infarktu myokardu (IM) s nevratně poškozeným myokardem.

Soubor nemocných a metodika: Do studie bylo zařazeno 34 nemocných s poprvé vzniklým akutním IM úspěšně léčených koronární angioplastikou s implantací stentu, u nichž byl dobutaminovou echokardiografií prokázán neviabilní myokard v infarktovém ložisku. Nemocní byli randomizováni do 3 skupin: Skupina A (15 pac) byla léčena vysokou dávkou MBKD (100 000000 buněk), skupina B (11 pac) nižší dávkou (10 000000 buněk), skupina C (8 pac) byla kontrolní. Buněčná transplantace byla provedena intrakoronárně 3.-5. den po vzniku IM intrakoronární aplikací MBKD. Byly sledovány plazmatické koncentrace IL6 a TNF alfa před aplikací, 3 a 6 měsíců po ní. IL 6 a TNF alfa byly stanoveny metodou ELISA.

Výsledky: Plazmatická koncentrace IL6 před implantací buněk byla $\mathrm{u}$ skupiny A 2,00 $\pm 1,12$, u B 1,61 $\pm 1,00$, u C $3,14 \pm 2,26 \mathrm{ng} / 1$ (NS). Po 3 měsících nebyly rozdíly mezi skupinami: u A $1,25 \pm 0,85$, u B 2,28 $\pm 3,01$, u C $1,35 \pm$ 0,88 ng/1 (vše NS) a rovněž tak po 6 měsících se skupiny mezi sebou nelišily: $1,75 \pm 1,66$ vs. $1,25 \pm 0,89$ vs. 1,64 $\pm 1,02 \mathrm{ng} / 1$ (vše NS).

Plazmatická koncentrace TNF alfa byla před implantací u skupiny A 2,20 $\pm 2,13$, u B 3,38 $\pm 2,01$ a u C 4,23 $\pm 1,84$ ng/1 (A vs. C $p<0,03$, vše ostatní NS). Po 3 měsících nebyly rozdíly mezi skupinami: u A 2,56 $\pm 2,1$, u B 3,7 $\pm 2,1$, u C $3,3 \pm 1,9 \mathrm{ng} / 1$ (vše NS) a rovněž tak po 6 měsících se skupiny mezi sebou nelišily: $2,72 \pm 2,13$ vs. $3,89 \pm 1,59$ vs. $3,83 \pm 2,00 \mathrm{ng} / 1$ (vše NS).

Závěr: Implantace MBKD ve vysoké či nízké dávce u nemocných po akutním IM nevede ke změnám v celkové aktivaci cytokinů IL6 či TNF alfa v organismu.

\section{JAKÝ JE OPTIMÁLNÍ KREVNÍ TLAK U PACIENTƯ SE SRDEČNÍM SELHÁNÍM?*}

\section{ŠPINAROVÁ L}

I. interní-kardioangiologická klinika, FN u sv. Anny, Brno

*Podpořeno VZ MSMT-MSM 0021622402.

Srdeční selhání je onemocnění starší populace. Průměrný věk při první manifestaci je 76 let. U nemocných > 75 let je etiologie ICHS > $90 \%$. Hospitalizace tvoří $5 \%$ akutních 
př́ijmů a 10 \% obložnosti. Doporučovaný krevní TK podle guidelines ČSH je < 140/90 mm Hg, jako vysoký normální je hodnocen TK 130-139/85-89 mm Hg, jako normální 120-129/80-85 mm Hg a jako optimální dokonce < 120/80 mm Hg. Je však toto optimální pro pacienty se srdečním selháním? Rozdělení poznatků: A. Studie u chronického srdečního selhání. B. Studie u akutního srdečního selhání. A. Studie COPERNICUS sledovala podání carvedilolu oproti placebu u nemocných $\mathrm{s}$ těžkým srdečním selháním a průměrnou ejekční frakcí $20 \%$. Po podání carvedilolu došlo za 24 měsíců ke snížení mortality $(p<0,00014)$. Při rozdělení rizika úmrtí pacientů, či rizika úmrtí nebo hospitalizace v závislosti na výšce systolického krevního tlaku (TKs), bylo obojí lepší u pacientů s vyšším TKs: > $125 \mathrm{~mm} \mathrm{Hg}$ vs. TKs 85-95 mm Hg (obojí $p<0,0001$ ). Rovněž ve studii Ghaliho měli pacienti se systolickou dysfunkcí, kteří přežili 4 roky, vyšší TKs 158 mm Hg než pacienti zemřelí: TKs 128 mm Hg $(p<0,05)$ a diastolický TK 102 vs. 80 mm Hg $(p<0,05)$. Studie DIG, která sledovala podání digoxinu u pacientů se systolickou dysfunkcí, kteří ještě nebyli léčeni betablokátory, zahrnula 5747 pacientů. Byla selektována skupina ve třídě NYHA II a III. Nejlepší 36měsíční přeživání měli pacienti s TKs 140-149 a nejhorší s TKs < 100 mm Hg. U TKd měli nejlepší přeživání pacienti s TKd > 89 a nejhorší s TKd $<60 \mathrm{~mm} \mathrm{Hg.} \mathrm{B.}$

$Z$ registrů pacientů $\mathrm{s}$ akutním srdečním selháním ADHERE a ESC měli nejnižší hospitalizační mortalitu pacienti s TKs $>160$ a nejhorší s TKs $<120 \mathrm{~mm} \mathrm{Hg}(p<0,001)$. Ve studii EFICA byl TKs $>160$ mm Hg spojený s nižším rizikem úmrtí RR/0,4 $(p<0,05)$. Znamená tedy hodnota TK 140/90 tu optimální pro pacienty se srdečním selháním?

SESTERSKÁ SEKCE

\section{SEDMIDENNÍ KONTINUÁLNÍ HOLTEROVO MONITOROVÁNÍ V DIFERENCIÁLNÍ DIAGNOSTICE PORUCH FUNKCE IMPLANTABILNÍCH KARDIOVERTERŮ-DEFIBRILÁTORŮ}

ŠTEFANOVÁ A, NEČASOVÁ L, HAUSEROVÁ Z

Klinika kardiologie,

antiarytmická jednotka, IKEM, Praha

V následující kasuistice chceme demonstrovat 25letou pacientku po implantaci implantabilního kardioverteru-defibrilátoru (ICD) $\mathrm{v}$ roce 1997 pro recidivující synkopy s indukovatelností fibrilace komor při elektrofyziologickém vyšetření. $\mathrm{V}$ roce 2002 byla přijata $\mathrm{k}$ výměně přístroje pro vyčerpání bateriového zdroje (kritérium ERI). Výboj od reimplantace př́stroje nepozorovala, byla asymptomatická. V prosinci 2005 byly př̀i kontrole přístroje zjištěny falešné epizody nesetrvalé komorové tachykardie (nsKT), byla upravena programace přístroje (senzing a počet detekovaných cyklů). Při kontrole v lednu 2006 přetrvávala detekce nsKT - jednalo se t. č. o technický problém a nemocná zůstávala zcela asymptomatická. Počet detekovaných cyklů výrazněji nestoupal, proto byl zvolen konzervativní postup při častějších kontrolách přístroje. Od poslední kontroly v únoru 2006 nadále asymptomatická. Byla provedeno týdenní Holterovo monitorování EKG k ověření rytmu - během tohoto monitorování nebyly zachyceny žádné komorové ektopické aktivity, ačkoliv přístroj detekoval epizody nsKT.

Sedmidenní kontinuální Holterovo monitorování může $\mathrm{v}$ individuálních prrípadech sloužit $\mathrm{k}$ ověření uvažovaného technického původu detekce arytmií v diferenciální diagnostice poruch funkce implantabilních kardioverterů-defibrilátorů a kardiostimulátorů.

\section{SESTERSKÁ SEKCE}

\section{EFEKTIVITA ENDOVAZÁLNÍ EXTRAKCE STIMULAČNÍCH ELEKTROD - SROVNÁNí STANDARDNÍHO PR̆ÍSTUPU A POUŽITÍ RADIOFREKVEČNÍ ENERGIE}

ŠTĚPNIČKOVÁ I, HOLÁ E, KRÁLOVEC Š

Kardiologické oddělení,

Nemocnice Na Homolce, Praha

Úvod: Endovazální extrakce elektrod jak pro infekční, tak pro neinfekční komplikace u implantátů představuje výkon, jehož riziko a úspěšnost jsou dány celou řadou faktorů (délka od implantace, typ použité elektrody (EL), kardiostimulační $\times$ ICD EL, známky penetrace/perforace myokardu aj.

Cíl práce: Srovnání efektivity endovazálních extrakcí s použitím standardní trakce a systému Perfekta s radiofrekvenční energií.

Metodika: 67 pacientů indikovaných ke kompletní extrakci elektrodového systému pro infekci (celkem 92 elektrod, $z$ toho $21 \mathrm{ICD}$, průměrná doba od implantace $51 \pm 21$ měsíců) bylo randomizováno na techniku extrakce $s$ použitím trakce s fixací EL speciálním styletem v tipu EL a kombinací fixačního styletu a uvolnění EL, resp. srůstů v jejím průběhu za aplikace radiofrekvenční energie (Perfekta ${ }^{\mathrm{TM}}$, Cook).

Výsledky:

\begin{tabular}{lccc}
\hline \hline Výsledky & $\begin{array}{c}\text { Trakce } \\
\text { (48 EL) }\end{array}$ & $\begin{array}{c}\text { RF energie } \\
\text { (44 EL) }\end{array}$ & $\boldsymbol{p}$ \\
\hline Komplikovaná extrakce & 37 & 43 & 0,01 \\
Ponechání typu EL & 10 & 2 & 0,01 \\
Tamponáda & 2 & 1 & NS \\
Poškození Tri chlopně & 3 & 0 & NS \\
\hline \hline
\end{tabular}

Závěr: Použití radiofrekvenční energie během endovazální extrakce KS a ICD elektrod vede k větší efektivitě a bezpečnosti výkonu, má však být prováděno ve specializovaných centrech s dostatečnými zkušenostmi, kardiochirurgickým zázemím a možností peroperačního monitorování intrakardiální echokardiografií.

\section{KALCIFIKACE AORTÁLNÍ CHLOPNĔ JE U PACIENTÚ S VÝZNAMNOU KORONÁRNÍ NEMOCÍ NEZÁVISLE SPOJENA S VYŠŠÍ HLADINOU V-CAM1 A HEMOGLOBINU A1C*}

ŠTĚRBÁKOVÁ G, LINHARTOVÁ K, FERDA J, BERNAT I, ČERBÁK R

I. interní klinika, Radiodiagnostická klinika, FN Plzeň, Plzeñ, Kardiovaskulární centrum, FN Motol, Praha, CKTCH, Brno

*Podpořeno grantem IGA MZ NR/8306-5 a VZ UK v Praze MSM0021620817.

Úvod: Aortální skleróza je ukazatelem vyšší kardiovaskulární morbidity a mortality. Je definována echokardiograficky jako ztluštění a kalcifikace aortální chlopně nezpůsobující obstrukci ústí. Hmotnost kalcia v aortální chlopni (AVC) lze stanovit multidetektorovým CT.

Cíl: Naším cílem bylo zhodnotit rizikové faktory kalcifikace aortální chlopně u pacientů s aortální sklerózou a významnou koronární nemocí. 


\section{Všechny informace pro Vaši praxi}

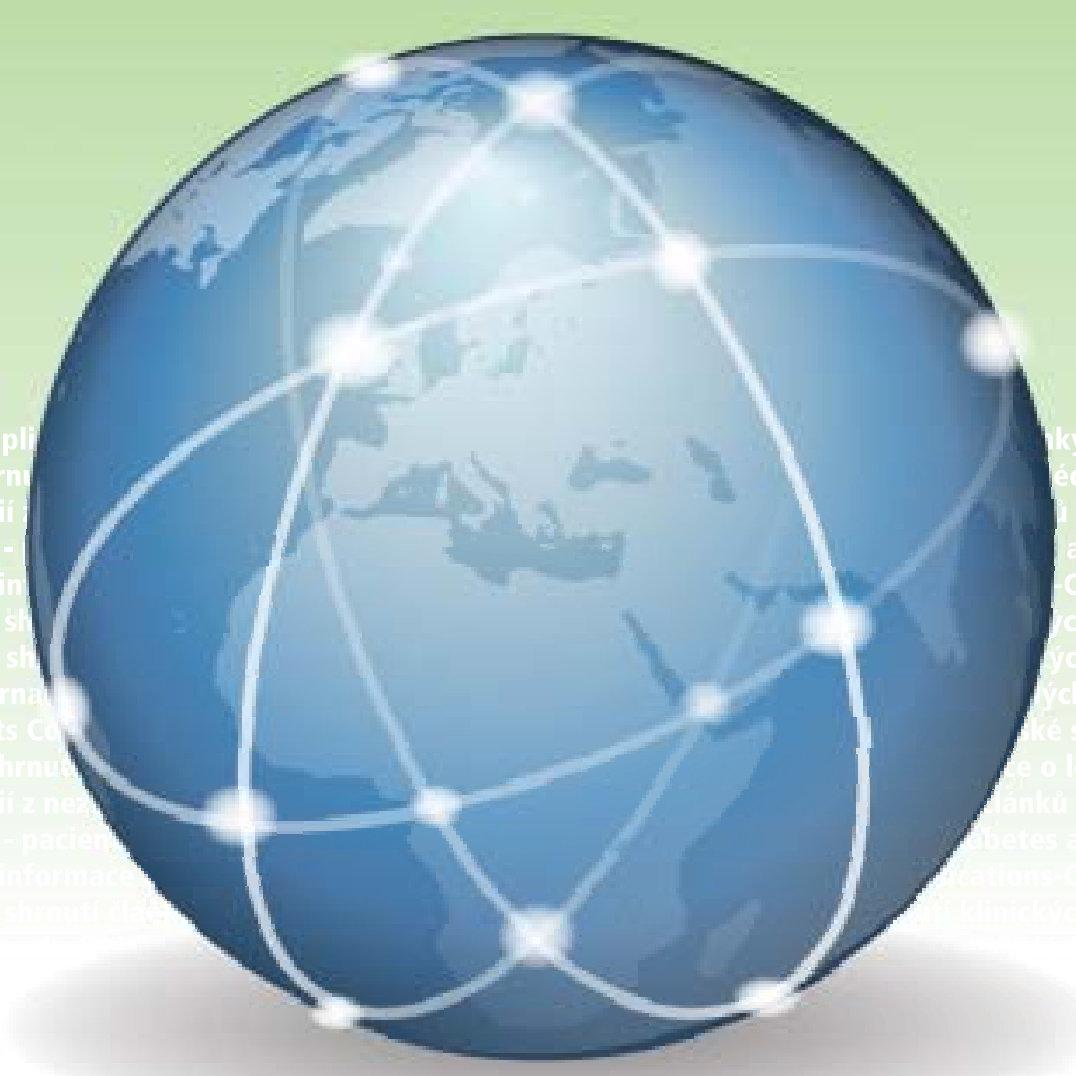

\section{...na jednom místě!}

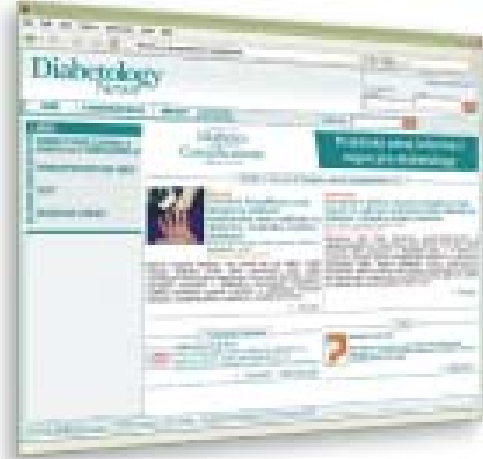

- shrnutí článků z Journal of Diabetes and Its Complications-CZ

- shrnutí klinických studií z nezávislých zdrojů

- pacientské stránky

- informace o lécích

Registrujte se na www.diabetologynews.cz

\section{Diabetology}


Metody: Do souboru jsme prospektivně zařazovali konsekutivní pacienty přijímané k elektivní koronarografii s angiograficky významnou koronární nemocí a echokardiograficky potvrzenou sklerózou aortální chlopně. Ke zhodnocení AVC byla provedena multidetektorová CT. Hodnotili jsme asociaci mezi AVC a ukazateli glukózového, kalcium-fosfátového, lipidového metabolismu a endoteliální dysfunkce univariantní analýzou a v multivariantním modelu.

Výsledky: Zařazeno bylo celkem 101 pacientů (76 můžu, věk $66 \pm 7$ let), 59 \% diabetici 2. typu. Množství kalcia v aortální chlopni se pohybovalo v rozmezí 0-824 mg (medián $=22 \mathrm{mg}$, 25. percentil $=2 \mathrm{mg}$ a 75 . percentil = $129 \mathrm{mg})$. AVC byla pozitivně spojena s glykemií ( $p=0,04)$, hladinou HbAlc ( $p=0,0007)$, hs CRP $(p=0,04)$ a V-CAM1 ( $p=0,002)$. Kalcium-fosfátový produkt vykazoval pozitivní trend, nedosáhl však statistické významnosti $(p=0,06)$. Nezávislá asociace s AVC byla zjištěna pro hladinu V-CAM1 a HbA1c $(p=0,02)$.

Neprokázali jsme asociaci AVC se závažností koronární nemoci definované počtem postižených koronárních tepen.

Závèr: U pacientů s významnou koronární nemocí a aortální sklerózou je AVC nezávislým ukazatelem dlouhodobě špatné metabolické kompenzace a endoteliální dysfunkce.

\section{VÝSLEDKY JEDNOROČNÍHO SLEDOVÁNÍ NEMOCNÝCH S INTRAKORONÁRNÍM PODÁNIM INHIBITORU IIB/IIIA ABCIXIMAB BĔHEM DIREKTNÍ PCI}

ŠTÍPAL R, MATOŠKA P, MINAŘİK T, KÁŇA A, PLEVA L, RUBÁČEK M

\section{Interní klinika, FNsP, Ostrava}

Cíl: V pilotní studii byly zhodnoceny výsledky jednoročního sledování nemocných $\mathrm{s}$ intrakoronárním (i. c.) podáním abciximabu během direktní perkutánní koronární angioplastiky (PCI) u 326 nemocných s infarktem myokardu s elevací ST.

Soubor a metodika: Pro perzistenci trombů omezujících průtok po balonkové dilataci byl podle rozhodnutí katetrizujícího u 74 (23\%) nemocných podán i. c. abciximab (ReoPro+), u zbylých 252 (77 \%) s obnoveným průtokem abciximab podán nebyl (ReoPro-). Nemocní ve skupině ReoPro+ měli ve srovnání s ReoPro- nižší věk $59,7 \pm 11,8$ vs. $63,2 \pm 11,6$ let $(p=0,025)$, ale $\mathrm{v}$ podskupinách $\mathrm{v}$ jednotlivých decéniích byl věkový rozdíl nevýznamný, stejné zastoupení mužů $68 \%$ vs. $69 \%$ ( $p=0,72)$, v obou skupinách bylo shodně implantováno 90 \% stentů. Byly hodnoceny základní charakteristiky souboru, závažné komplikace (MACE) a mortalita.

Výsledky: Ve srovnání skupiny ReoPro+ a ReoPro- byly hodnoty CK-MB 3,9 $\pm 5,0$ vs. $2,9 \pm 4,2 \mu \mathrm{kat} / 1(p=0,12)$. Ve 30denním follow-up byl výskyt MACE 8/74 (11\%) vs. $40 / 251(16 \%)(p=0,28)$ a mortalita $4 / 74(5,4 \%)$ vs. $18 / 251(7,2 \%)(p=0,60)$. V jednoročním follow-up byl výskyt MACE $18 / 74(24 \%)$ vs. 65/251 (26\%) $(p=0,70)$ a mortalita $4 / 74(5,4 \%)$ vs. $27 / 251(10,8 \%)(p=0,17)$. Mezi 30 dny a 1 rokem nezemřel žádný nemocný ve skupině ReoPro+ vs. 9/233 (3,9\%) ve skupině ReoPro- $(p=0,09)$. Dále byly soubory srovnávány $\mathrm{z}$ hlediska velikosti a lokalizace infarktu, charakteristiky intervence a anamnestických údajů. Definitivní závěry budou uvedeny po zhodnocení celého souboru více než 600 nemocných.

Závěr: Nemocní s direktní PCI a i. c. podáním abciximabu během intervence vykazovali trend $k$ většímu rozsahu infarktu podle CK-MB, nižšímu počtu MACE a mortalitě za 30 dní a nižší mortalitě za 1 rok. Definitivní závěry budou prezentovány po zhodnocení většího souboru nemocných.

\section{LUNG FUNCTION LONG-TERM AFTER ARTERIAL SWITCH OPERATION OF TRANSPOSITION OF THE GREAT ARTERIES*}

\author{
ŠULC J, CHALOUPECKÝ V, SVOBODOVÁ T, \\ TLÁSKAL T
}

Pediatrická klinika, Dětské kardiocentrum, FN Motol, Praha

*Supported by the Research Project No. MZO

00064203/6404 of the Czech Ministry of Health.

Objectives: Cardiopulmonary condition and quality of life of patients after successful arterial switch (anatomical) operation (SWT) for transposition of the great arteries (TGA) could be influenced by possibly disturbed lung function. Study on pulmonary function (PFT) using a wide spectrum of methods long-term after SWT is lacking.

Patients and methods: Fifty eight patients with TGA were operated on by SWT operation at the age of $24.4 \pm 51.8$ (median 10.0) days; small VSD was closed simultaneously in $15 / 58,26 \%$. Static lung volumes (by body plethysmography), lung elasticity (in 16/58, 28\% pts indicated) and central/peripheral airway patency measurements were performed at the age of $9.7 \pm 2.0$ (median 9.7) years after SWT. Results:

\begin{tabular}{lrl}
\hline \hline (Mean value of \% predicted \pm SD): & & \\
\hline Vital capacity (VC) & $93.2 \pm 15.9$ & NS \\
Total lung capacity (TLC) & $101.6 \pm 24.2$ & NS \\
Residual volume to TLC (RV/TLC) & $108.2 \pm 30.3$ & $p<0.04$ \\
Lung recoil at 100\% TLC (Pst100) & $128.0 \pm 36.7$ & $p<0.002$ \\
Specific lung compliance (Cst/TLC) & $83.1 \pm 23.4$ & $p<0.01$ \\
Peak expiratory flow (PEF) & $91.0 \pm 15.5$ & $p<0.04$ \\
Maximum expiratory flow at 25\% & & \\
VC/TLC & $98.2 \pm 31.4$ & NS \\
\hline \hline
\end{tabular}

Conclusions: Neither lung volume restriction nor peripheral airway obstruction was found long-term after successful SWT operation for TGA. Mild central airway obstruction, lung hyperinflation and stiff lungs were detected. Next measurements could validate present data.

\section{„REAL-TIME“" MYOKARDIÁLNÍ KONTRASTNÍ ECHOKARDIOGRAFIE JAKO NOVÝ NÁSTROJ V DIFERENCIÁLNÍ DIAGNOSTICE SRDEČNÍCH NÁDORỦ}

\section{ŠVÁB P, RATAJ O, CAMPR V}

Kardiologické oddělení, Kardiovaskulární centrum pro dospělé, Ústav patologie a molekulární medicíny, FN Motol, Praha

Dvojrozměrná echokardiografie je běžně užívanou diagnostickou metodou při detekci srdečních nádorů a trombů s vysokou senzitivitou (TTE 93 \% a TEE $97 \%$ ). V klinické praxi je však někdy velmi obtížné pomocí 2D-echokardiografie určit povahu nitrosrdeční masy, tj. rozlišení mezi trombem, benigním a maligním nádorem. Takové rozlišení přitom poskytuje důležitou diagnostickou informaci a má léčebné a prognostické důsledky pro pacienta.

Ve sdělení prezentujeme na vlastních nálezech přínos užití moderní metody „real-time“ kontrastní echokardiografie (RT-MCE). Po nitrožilním podání echokontrastní látky II. generace hodnotíme vaskularizaci patologických nitrodutinových hmot. Echokardiografické nálezy porovnáváme s výsledky histologických vyšetření. Maligní nádory jsou 
charakteristické neovaskularizací, tudíž pomocí RT-MCE detekujeme zvýšenou perfuzi. Benigní stromální nádory (nejčastější je myxom) mají sníženou mikrocirkulaci v porovnání $\mathrm{s}$ myokardem a $\mathrm{v}$ př́ipadě trombů (vaskularizace zcela chybí) nezobrazíme žádnou perfuzi.

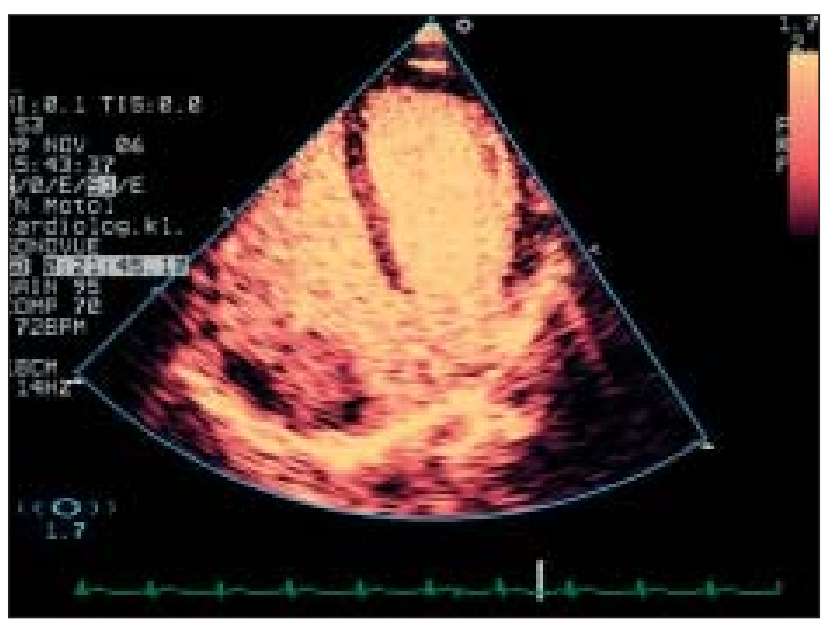

- SESTERSKÁ SEKCE

\section{PUNKCE PERIKARDU - PARACENTÉZA. KASUISTIKA}

ŠVEIDLEROVÁ V, ČERMÁKOVÁ M, KOLOUŠKOVÁ I

1. interní oddělení, jednotka intenzivní péče, FN Olomouc a LF UP, Olomouc

Východiska: Perikard je vazivová blána, která kryje srdce zvnějšku. Představuje bariéru proti infekci a umožňuje hladký pohyb srdce ve vztahu k ostatním orgánům. U zdravého člověka obsahuje 15 až 50 ml tekutiny. Pokud dojde ke zvýšení množství tekutiny v perikardiální dutině (tzv. perikardiální výpotek), dochází $\mathrm{k}$ útlaku srdce. Tento útlak vede ke zhoršení diastolického plnění, a tím k poklesu srdečního výdeje. Tento stav se nazývá tamponáda srdeční.

Obsah prezentace: Kasuistika pacienta s tamponádou srdeční. Perikardiální punkce, perikardiální drenáž do pleurální dutiny při recidivách perikardiálního výpotku - odstranění tekutiny.

\section{UZÁVĚR DEFEKTU SEPTA SÍNÍ TYPU OSTIUM SECUNDUM AMPLATZOVÝM OKLUDEREM. PRVNÍ ZKUŠENOSTI}

\section{ŠVEJDA J, VESELKA J}

Interní oddělení, Nemocnice Milosrdnúch sester sv. Karla Boromejského, Kardiologické oddělení Kardovaskulárního centra, FN Motol, Praha

Cíl: Analýza výsledků intervencí, provedených v první polovině roku 2006 na našem pracovišti.

Soubor a metodika: V období leden až červen 2006 bylo intervenováno 5 pacientů s defektem síňového septa (DSS) typu ostium secundum. Sledovali jsme průběh výkonu, výskyt periprocedurálních komplikací během výkonu, výskyt tromboembolických příhod v období dalších šesti měsíců po výkonu, př́tomnost reziduálního zkratu.

Výsledky: V období duben až červen 2006 byl proveden katetrizační uzávěr DSS u 5 pacientů ( 3 ženy) průměrného věku 55 let (45-66 let). Echokardiografické známky plicní hy- pertenze měli 3 pacienti, jejich systolický tlak v plicnici byl $55 \mathrm{~mm}$ Hg (48-60). Samotný výkon byl proveden pod TEE kontrolou. Průměrná velikost defektu (.,stretch diameter“) byla 13,6 mm (8,5-20,5 mm). Přední (aortální) okraj defektu byl zachován u 3 pacientů, u 2 pacientů nebyl prítomen. Byl použit Amplatzův okluder s průměrnou velikostí 15,2 mm (10-22 mm). Průměrný skiaskopický čas dosáhl 3,47 minuty $(2,8-4,4$ minuty). Nevyskytly se žádné periprocedurální komplikace.

Při kontrolním TTE druhý den po výkonu nebyl přitomen reziduální zkrat, plicní hypertenze se vyskytla pouze u 1 pacienta s maximálním systolickým tlakem v plicnici $45 \mathrm{~mm} \mathrm{Hg}$ Po dobu následujících 6 měsíců byli pacienti standardně léčeni duální antiagregační terapií Anopyrin 100 mg + Plavix 75 mg denně. Prevence infekční endokarditidy probíhala rovněž po dobu 6 měsíců. Klinické a echokardiografické kontroly za 1 měsíc a za 6 měsíců od výkonu neprokázaly žádné manifestní tromboembolické př́ihody, nebyl přítomen reziduální zkrat.

Závěr: Katetrizační metoda vzhledem $\mathrm{k}$ dobrým výsledkům a malému množství komplikací stále častěji nahrazuje chirurgický uzávěr hemodynamicky významných DSS typu ostium secundum ve všech případech, pokud je to technicky proveditelné. Naše zkušenosti považujeme za uspokojivé.

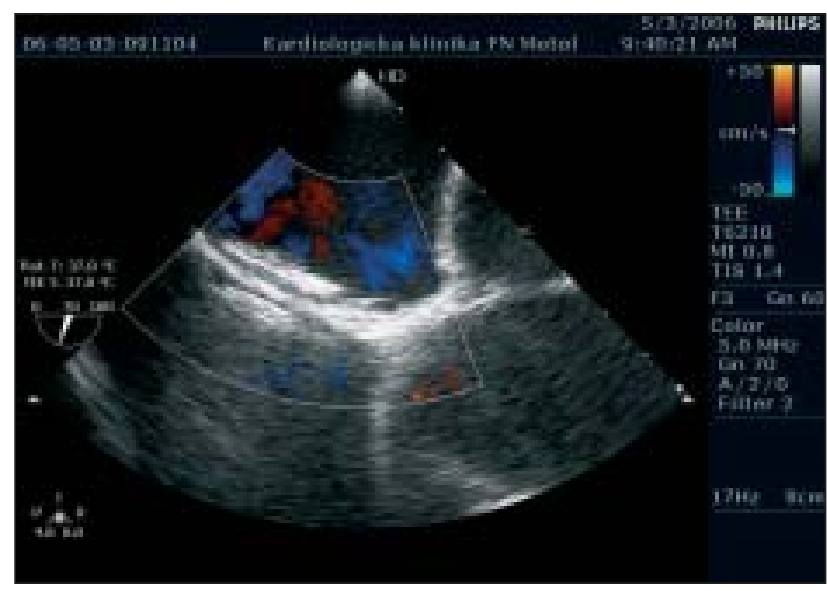

\section{KARCINOIDY A JEJICH PESTRÝ KARCINOIDNÍ SYNDROM. KARDIÁLNÍ MANIFESTACE KARCINOIDU. KASUISTIKA}

\section{TALAFA V, ZEMAN K, MRÓZEK V}

Interní oddělení, Okresní Nemocnice Frýdek-Místek, Frýdek-Místek

A. Úvod: Karcinoidy jsou poměrně vzácně se vyskytující nádory, postihující převážně zažívací trakt a bronchy. Zdaleka však nejsou vzácné a jejich incidence stoupá vzhledem $\mathrm{k}$ lepším diagnostickým možnostem.

Karcinoidy vycházejí z neuroendokrinních buňek a dávají pozitivní reakci na některé neuroendokrinní markery. Jsou obvykle dobře diferencované tzv. „low grade malignity“. Asi 1/3 bronchiálních karcinoidů však patři $\mathrm{k}$ tzv. atypickým méně diferencovaným s „high grade malignity“, považované za přechodovou variantu do malobuněčného karcinomu plic.

B. Klinický obraz: Manifestují se typickým, takzvaným karcinoidním syndromem, který vychází $z$ jejich bohaté paraendokrinní aktivity. Tento syndrom sestává $z$ rrady pestrých příznaků, $z$ těch nejtypičtějších je „flush“ obličeje (84 \%), nebo chronická cyanóza v obličeji, průjmy (70 \%), borborygmy a bolesti břicha (33\%). Méně častými příznaky je proximální myopatie (7\%), bronchospasmus (6\%), dermatóza (6\%). Asi u 2/3 nemocných s karcinoidem, pocházejícím ze střední části tenkého střeva vznikne postižení srdce, obvykle endo- 
kardu pravostranných oddílů. Jde o plaky z buněk hladkých svalů, kde jsou obsaženy kyselé polysacharidy a kolagen. Tyto změny postihují trikuspidální chlopeň, dochází k rozšiření pravé komory a pravé síně, což se projeví ve formě takzvané „carcinoid cardiopathy“, neboli Hedingerova syndromu s následnou pravostrannou kardiální insuficiencí.

Podle některých autorů je př́ičinou postižení srdce většinou karcinoid ze střední části tenkého střeva, který metastazuje do jater, protože při vzniku jaterních metastáz nejsou serotonin a bradykinin metabolizovány a působí na endokardu pravostranných oddílů fibroelastické změny.

C. Kazuistika pacienta s kardiální manifestací karcinoidu.

\section{MOTORICKÉ A KOGNITIVNÍ FUNKCE PACIENTŮ PO CÉVNÍ MOZKOVÉ PR̆İHODĔ V AKUTNII FÁZI - EFEKT REHABILITACE*}

TARASOVÁ M, NEČASOVÁ J, HOMOLKA P, VANK P, SOSIKOVÁ M, FRANTISOVÁ M, SIEGELOVÁ J

Klinika funkční diagnostiky a rehabilitace, FN u sv. Anny, Brno

*Podporováno grantem MSM 0021622402.

Cíl: Cílem práce byla analýza hodnot testovacích škál v souboru nemocných po akutní cévní mozkové příhodě (CMP) se středně těžkým a lehkým postižením v průběhu hospitalizace na I. neurologické klinice LF MU s intenzivní rehabilitační léčbou a ověření vztahu mezi věkem a přítomností kognitivního deficitu na celkový výsledek léčby.

Metodika: V souboru pacientů po CMP (96 pacientů průměrného věku $62,1 \pm 12,0$ let), jsme hodnotili výsledky testovaní míry disability za použití: testu měření funkční nezávislosti (functional independence measure - FIM), testu soběstačnosti (Barthel test - BI); a výsledky hodnocení „impairmentu“ za pomocí testu kognitivních funkcí (minimental state examination - MMSE), hodnocení celkového stavu a chůze (podle pracoviště Chedok McMaster rehabilitation centre - $\mathrm{CH}$ ). Pacienti absolvovali po dobu hospitalizace (průměrná délka 14,2 \pm 7,5 dne dní) individuální trénink minimálně 5 dní v týdnu, $2 \times$ denně.

Výsledky: (průměr $\pm \mathrm{SD}$, před versus po); FIM $(98,2$ $\pm 15,7$ vs. $\left.110,9 \pm 13,5^{* *}\right)$, BI $\left(78,2 \pm 16,7\right.$ vs. $\left.94,5 \pm 8,6^{* *}\right)$, MMSE $\left(25,2 \pm 4,7\right.$ vs. $\left.28,0 \pm 2,6^{* *}\right), \mathrm{CH}(79,8 \pm 16,2$ vs. $\left.92,0 \pm 11,6^{* *}\right)$. Korelační analýzou při srovnání souboru pacientů s věkem $\geq 70$ let s celým souborem jsme určili statistickou nezávislost ( $p>0,05)$ dosáhnutého zlepšení na vyšším věku. V případě sledování vlivu kognitivního deficitu na výsledek léčby v našem souboru pacientů jsme zjistili statisticky významnou lineární závislost s hodnotou $p<0,05$.

Závěry: Výsledky ukázaly, že komplexní léčba spolu s intenzivní rehabilitací vedla $\mathrm{u}$ pacientů po CMP v akutním stadiu ke zlepšení motorických a kognitivních funkcí hodnocením pomocí testů, které bylo statisticky významné.

\section{IDENTIFIKACE PREDIKTORŮ DLOUHODOBÉHO PR̆EŽíVÁNÍ NEMOCNÝCH SE SRDEČNÍ RESYNCHRONIZAČNÍ LÉČBOU}

TÁBORSKÝ M, NEUŽIL P, MANDYSOVÁ E, SCHEJBALOVÁ M, PETRU゚ J, KUPEC J

\section{Kardiologické oddělení, Nemocnice Na Homolce, Praha}

Úvod: Srdeční resynchronizační léčba (SRL) u nemocných s pokročilým srdečním selháním a průkazem komorové dys- synchronie prokazatelně zlepšuje funkční klasifikaci, kvalitu života, zátěžovou kapacitu a snižuje celkovou i kardiovaskulární mortalitu. Nicméně faktory predikující dlouhodobé přežívání nebyly dosud jednoznačně identifikovány.

Cíl práce: Identifikace parametrů zlepšujících dlouhodobé přežívání nemocných se SRL.

Soubor nemocných a metodika: Do studie bylo zařazeno 272 konsekutivních pacientů (179 M a 93 Ž, průměrného věku $67 \pm 12$ let, 169 ICHS a 103 DKMP), kterým byl v letech 2000-2003 implantován biventrikulární systém (181 KS a 91 ICD). Nemocní byli sledováni v kardiostimulační ambulanci pravidelně $3 \times$ ročně a část $z$ nich (117) také v ambulanci srdečního selhání. Pravidelně bylo prováděno klinické a laboratorní vyšetření, echokardiografické vyšetření se stanovením EF LK a EDD LK jednou ročně. Jako responder SRL byl definován nemocný se zlepšením funkční klasifikace NYHA minimálně o jednu třídu v kombinaci se zlepšením EF LK o > 10 \% proti vstupnímu vyšetření (12 M po výkonu).

Výsledky: Průměrná doba sledování byla $52 \pm 21$ měsíců, zemřelo celkem 47 nemocných (průměrná doba úmrtí po výkonu - 14 + 11 měs.). Univariantní analýza prokázala, že rizikovými faktory úmrtí nemocných se SRL jsou:

\begin{tabular}{lccc}
\hline \hline Parametr & $\begin{array}{c}\text { Zemřeli } \\
(\mathbf{n = 4 7 )}\end{array}$ & $\begin{array}{c}\text { Přeživajicí } \\
(\mathbf{n}=\mathbf{2 2 5})\end{array}$ & $\boldsymbol{p}$ \\
\hline Mužské pohlaví (\%) & 87 & 61 & 0,02 \\
Fibrilace síní (\%) & 49 & 21 & 0,03 \\
Mitrální regurgitace (st.) & $2,2 \pm 1,0$ & $1,4 \pm 0,9$ & 0,01 \\
Carvediol (mg) & 13,5 & 31,2 & 0,001 \\
Amiodaron (\%) & 78 & 21 & 0,01 \\
Ambulance SS (\%) & 34 & 58 & 0,01 \\
\hline \hline
\end{tabular}

Závěr: Jedinými parametry, spojenými s prodlouženým přežíváním nemocných se SRL, jsou zlepšení funkční klasifikace NYHA a EF LK během sledování po výkonu a dále pravidelné kontroly nemocných v ambulanci srdečního selhání s optimalizací farmakologické léčby.

\section{REDUKCE KOMOROVÉ STIMULACE U NEMOCNÝCH SE SICK SINUS SYNDROMEM A INTERMITENTNÍ AV BLOKÁDOU ZA POUŽITİ NOVÉHO STIMULAC̆NÍHO ALGORITMU}

\section{TÁBORSKÝ M, NEUŽIL P, KUPEC J, ŠEDIVÁ L,} VOPÁLKA R

\section{Kardiologické oddělení, Nemocnice Na Homolce, Praha}

Úvod: Řada velkých studií prokázala nepříznivý efekt komorové apikální stimulace u nemocných se sick sinus syndromem (SSS), kteří jsou indikováni k trvalé kardiostimulaci.

Cíl práce: Ověření efektivity a bezpečnosti nového stimulačního algoritmu s preferencí AAI.

Soubor nemocných a metodika: 27 nemocných $(21 \mathrm{M}$, $6 \check{Z}$, průměrný věk $58 \pm 12$ let, sekundárně preventivní indikace ICD, EF LK $27 \pm 12 \%$, holterovsky dokumentovaný SSS /1/ nebo AVB /16/ před implantací). Průměrná doba sledování $15 \pm 7$ měsíců.

Práce analyzuje procento komorové stimulace $\mathrm{u}$ nemocných indikovaných $\mathrm{k}$ ICD se současnou bradykardickou indikací s použitím holterovkých dat ICD a standardního 24hodinového holterovského vyšetření (HV) 12 měsíců po implantaci. Byl použit dvoudutinový ICD s aktivací algoritmu Manager Ventricular Pacing ${ }^{\mathrm{TM}}$ (MVP), který umožňuje automatickou změnu stimulačního režimu z AAI na DDD.

Výsledky: U 27 nemocných bylo během sledování dokumentováno celkem 621 změn režimu AAI na DDDR. Nemoc- 
ní se SSS byli stimulováni v režimu AAI v 91 \% sledovaného období, u nemocných s intermitentní AVB se síňová stimulace uplatnila ve $42 \%$ kontinuálního monitorování. Během 24hod. HV byla dokumentována AV blokáda u 5 pacientů, ve všech případech s adekvátní změnou režimu na DDD a vynecháním 1 komplexu QRS. Změna stimulačního režimu nebyla $u$ žádného $z$ nemocných označena $v$ záznamníku jako subjektivní problém.

Závěr: Komorová stimulace může být při použití algoritmu MVP významně redukována u nemocných se sick sinus syndromem se současnou možností back-up DDD režimu při výskytu blokády AV. Snížení komorové stimulace u nemocných s intermitentní blokádou AV může výrazně eliminovat další negativní remodelaci levé komory navozené pravokomorovou apikální stimulací, a to zejména u nemocných s ICD s preexistující dysfunkcí LK.

\section{SRDEČNÍ RESYNCHRONIZAČNÍ LÉČBA - SROVNÁNÍ STR̆EDNĚDOBY̌CH VÝSLEDKŮ NEMOCNÝCH SE SINUSOVÝM RYTMEM A FIBRILACÍ SÍNÍ}

TÁBORSKÝ M, NEUŽIL P, MANDYSOVÁ E, PETRŮ J, MRÁZ T

Kardiologické oddělení, Nemocnice Na Homolce, Praha

Úvod: Výsledky stávajících randomizovaných studií s výjimkou MUSTIC AF přinášejí zatím velmi málo dat o nemocných s pokročilým srdečním selháním a chronickou fibrilací síní (FiS), kteří jsou indikováni k srdeční resynchronizační léčbě (SRL).

Cill studie: Detekovat klinickou odpověd' SRL a monitorovat dlouhodobé přežívání nemocných s FiS a SRL ve srovnání s nemocnými se sinusovým rytmem (SR) a SRL.

Metoda: 115 konsekutivních pacientů roku 2004 indikovaných podle platných doporučení $\mathrm{k}$ SRL bylo sledováno po dobu $21 \pm 16$ měsíců: v době implantace mělo 84 nemocných SR, 31 mělo evidenci chronické FiS v délce trvání $32 \pm 18$ měsíců, u $27 \mathrm{z}$ nich byla provedena radiofrekvenční ablace AV uzlu s cílem kontroly komorové odpovědi a 100\% biventrikulární stimulace. Všem nemocných byl implantován kardiostimulátor s možností SRL, u 11 z nich byla levokomorová elektroda zavedena kardiochirurgickou cestou.

Výsledky: Uvádí tabulka.
Kardiologické oddělení, Nemocnice Na Homolce, Praha

Introduction: Cardiac Magnetic Resonance Imaging (CMRI) can identify myocardial infarction (MI) scars. Detection of unrecognized substrate has significant clinical implications as a most common substrate for reentrant ventricular arrhythmias. In the absence of coronary artery disease (CAD), MI is rare.

Hypothesis: The use of MRI in patients without CAD after cardiopulmonary resuscitacion (CPR) could identify the substrate dependent VT/VF mechanism.

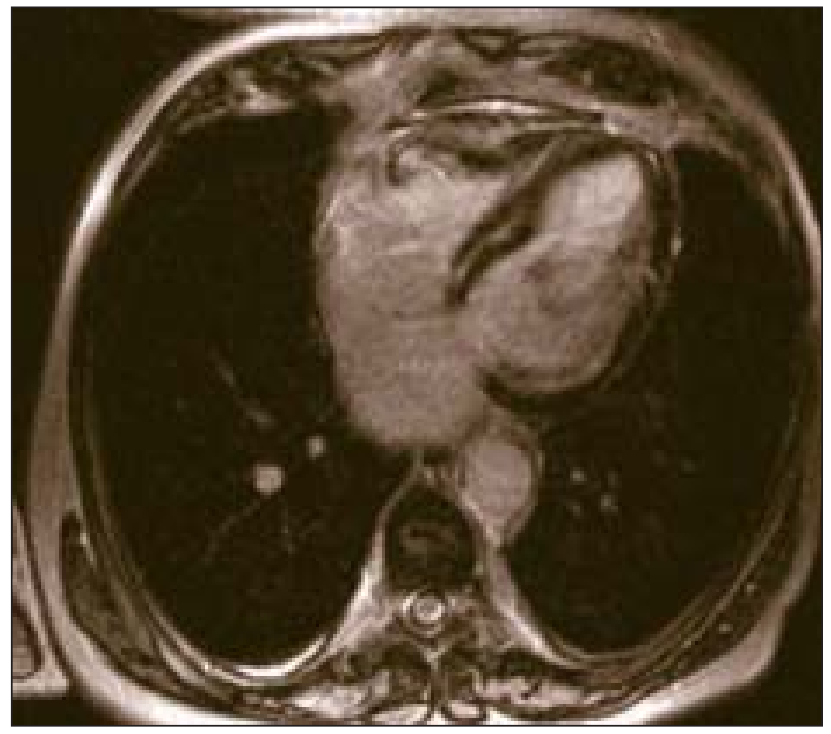

Methods: Planimetry of gadolinium late enhacement images obtained from CMRI was used to measure scar mass and surface area by two readers blinded to electrophysiological study (EPS) resuls. The mean scar size was defined as a percentage of left ventricular mass.

Resuts: 32 patients without CAD (24 had dilated cardiomyopathy, 6 hypertrophic obstructive cardiomyopathy and 2 normal hearts), mean age $49 \pm 17$ years, $73 \%$ male, mean EF $0.39 \pm 13$, underwent CMRI and EPS because of documented ventricular arrhythmias.

Tabulka k abstraktu MUDr. Táborského: Srdeční...

\begin{tabular}{|c|c|c|c|c|c|c|}
\hline & $\begin{array}{l}\text { Baseline } \\
\text { SR }\end{array}$ & FiS & $\boldsymbol{p}$ & $\begin{array}{l}\text { FU } \\
\text { SR }\end{array}$ & FiS & $\boldsymbol{p}$ \\
\hline Věk & $66 \pm 10$ & $69 \pm 8$ & NS & & & \\
\hline NYHA & $2,9 \pm 0,6$ & $3,1 \pm 0,6$ & NS & 2,1 & 2,3 & NS \\
\hline QRS (ms) & $160 \pm 31$ & $177 \pm 41$ & $<0,05$ & $140 \pm 28$ & $145 \pm 32$ & NS \\
\hline EF LK (\%) & $31 \pm 8$ & $23 \pm 9$ & $<0,05$ & $34 \pm 11$ & $32 \pm 9$ & NS \\
\hline EDD LK (mm) & $62 \pm 9$ & $69 \pm 10$ & $<0,05$ & $60 \pm 11$ & $63 \pm 10$ & NS \\
\hline
\end{tabular}

Během střednědobého sledování zemřelo 11 nemocných, $z$ toho 6 se SR $(7,1 \%)$ a 5 s FiS (16,1\%). Celková mortalita vztaženo na 100 pacientů a rok byla u SR 10,2 a u FiS 14,1 (NS).

Závěr: Fibrilace síní při správně technicky provedené a indikované SRL s kontrolovanou antikoagulační léčbou a komorovou frekvencí má srovnatelné výsledky jako u nemocných se sinusovým rytmem.

\section{THE ROLE OF CARDIAC MAGNETIC RESONANCE IMAGING IN PATIENTS WITH VENTRICULAR TACHYCARDIA AND ABSENCE OF CAD}

TÁBORSKÝ M, NEUŽIL P, BALÁK J, PETRU゚ J, KUPEC J
Tabulka k abstraktu MUDr. Táborského: The role...

\begin{tabular}{lccc}
\hline \hline Parameters & $\begin{array}{c}\text { VT/VF } \\
\text { non inducible } \\
(\mathbf{n}=\mathbf{1 8})\end{array}$ & $\begin{array}{c}\text { VT/VF } \\
\text { inducible } \\
(\mathbf{n}=\mathbf{1 4})\end{array}$ & $\boldsymbol{p}$ \\
\hline $\begin{array}{l}\text { LV EF (\%) } \\
\text { Mean scar size }\end{array}$ & $39 \pm 13$ & $37 \pm 11$ & $\mathrm{NS}$ \\
\% LV mass) & $5 \pm 3$ & $11 \pm 10$ & $<0,01$ \\
\hline \hline
\end{tabular}

Conclusions: In patients without $\mathrm{CAD}$ undergoing $\mathrm{EP}$ testing because of documented ventricular arrhythmias, the prevalence of scars is higher in pts with inducible VT/VF than in non-inducible population. Cardiac MRI should be 
considered in patients with no evidence of CAD presenting with unexplained spontaneous or inducible ventricular arrhythmias.

\section{ENDOKARDITIDA PULMONÁLNÍ CHLOPNĔ VZNIKLÁ V SOUVISLOSTI S PRAVOSTRANNOU KATETRIZACÍ}

\section{TELEKES P, PAVEL P, HOLM F, HOLÝ Z}

Kardiologické oddělení, Krajská Nemocnice Liberec, Liberec, Kardiochirurgické oddělení, Nemocnice Na Homolce, Praha, Interní oddělení, Nemocnice Česká Lípa, Česká Lípa

Infekční endokarditidy (IE) pravostranných chlopní představují méně než $5 \%$ všech infekčních endokarditid. Zpravidla postihují trikuspidální chlopeň, IE pulmonální chlopně (PV) je extrémně vzácná. Vyskytují se převážně u i. v. narkomanů nebo $\mathrm{v}$ souvislosti $\mathrm{s}$ instrumentací $\mathrm{v}$ pravostranných oddílech. Pravidlem je přitomnost mnohočetných plicních infiltrací embolizační etiologie.

Autoři popisují případ 64letého muže, který byl reoperován 4 roky po plastice mitrální chlopně (MV) pro významnou reziduální regurgitaci. Pro př́tomnou dysfunkci levé komory byl srdeční výdej monitorován plicnicovým katetrem S-G. Reoperace - replastika MV byla úspěšná, MV bez reziduální regurgitace, S-G katetr odstraněn 3. pooperační den, z konce katetru vykultivován Staphylococcus epidermidis. Tento nález byl považován za kontaminaci. Nemocný byl propuštěn v dobrém stavu, afebrilní 10. pooperační den.

Pro rozvoj subfebrilií po dimisi byl nemocný opakovaně léčen rưznými perorálními antibiotiky (ATB). Vždy došlo $\mathrm{k}$ recidivě subfebrilií po dobrání př́íslušného ATB. Po 6 týdnech léčby v hemokulturách opakovaně vykultivován Staphylococcus epidermidis. Jícnová echokardiografie odhalila vegetaci na předním cípu PV o velikosti $10 \mathrm{~mm}$. Plíce na skiagramu hrudníku byla bez infiltrátů. Následná i. v. ATB léčba podle citlivosti teicoplanin + ofloxacin nevedla $\mathrm{k}$ úspěchu, po vysazení došlo opět k recidivě subfebrilií s pozitivními hemokulturami. Nemocný podstoupil 2. reoperaci - náhradu PV homograftem. Pooperační průběh byl bez komplikací, nemocný je v dobrém klinickém stavu 24 měsíců po 2. reoperaci.

V našem případě diagnostika IE PV byla obtížnější vzhledem $\mathrm{k}$ nepř́itomnosti plicních embolizačních lézí.

\section{PARAMETRY TKÁŇOVÉHO DOPPLEROVSKÉHO ZOBRAZENİ V HODNOCENİ SYSTOLICKÉ FUNKCE LEVÉ KOMORY A JEJICH VZTAH K VĚKU}

TESÁK M, MAŇOUŠEK J, ŠPINAR J

Interní-kardiologická klinika, FN Brno, Brno

Cíl: Srovnat vztah vybraných parametrů tkáňového dopplerovského vyšetření (TDI) $\mathrm{k}$ systolické funkci levé komory hodnocené ejekční frakcí a posoudit závislost těchto parametrů na věku.

Metody: U 45 konsekutivních pacientů, kteří byli vyšetřeni $\mathrm{v}$ echokardiografické laboratoři Interní-kardiologické kliniky FN Brno v červenci 2006, byla stanovena ejekční frakce podle Simpsona a provedeno dvourozměrné barevné tkáňové dopplerovské echokardiografické vyšetření s následným off-line změřením těchto parametrů: myokardiální akcelerace ve fázi izovolumické kontrakce (izovolumická akcelerace, IVA), maximální rychlost izovolumické kontrakce (IVV) a maximální systolická ejekční rychlost (Sa) septálního okraje mitrálního anulu. Byl hodnocen vztah těchto para- metrů k ejekční frakci (EF) a závislost na věku nemocných. Vyloučeni byli pacienti s významnou chlopenní vadou, s perikardiální patologií a po kardiochirurgickém výkonu.

Výsledky: Bylo vyšetřeno 45 pacientů (21 mužů, 24 žen), průměrný věk $65,51( \pm 15,10)$ let, průměrná EF LK činila $48,07 \%( \pm 17,07 \%)$. Hodnoty IVA dobře korelovaly s velikostí ejekční frakce levé komory $(\mathrm{r}=0,64, p<0,001)$, statisticky významná byla i korelace $\mathrm{EF}$ a Sa $(\mathrm{r}=0,57, p<0,01)$ a $\mathrm{EF}$ a IVV $(\mathrm{r}=0,51, p<0,01)$. U podskupiny pacientů s echokardiograficky normální systolickou funkcí levé komory (EF > $60 \%$ ) hodnoty IVA ani IVV nekorelovaly s věkem, oproti tomu hodnota Sa s věkem klesala $(r=-0,56, p<0,05)$.

Závěr: Hodnota izovolumické akcelerace, maximální izovolumické rychlosti a maximální systolické ejekční rychlosti septálního okraje mitrálního anulu odrážejí kontraktilitu levé komory posuzovanou ejekční frakcí. Věk neovlivňuje vyjádření systolické funkce levé komory pomocí IVA a IVV.

\section{OPERACE VROZENÝCH SRDEČNÍCH VAD V DËTSKÉM KARDIOCENTRU*}

\section{TLÁSKAL T}

\section{Dětské kardiocentrum, FN Motol, Praha}

\section{*Podpořeno grantem VZ FNM MZO 00064203.}

V letošním roce slavíme 30. výročí založení Dětského kardiocentra. Cílem tohoto sdělení je podat přehled vývoje dětské kardiochirurgie v letech 1977-2007 a nastínit další perspektivy chirurgické léčby vrozených srdečních vad. Od roku 1977 bylo na našem pracovišti provedeno více než 11000 operací srdce, $\mathrm{z}$ toho $7674 \mathrm{v}$ mimotělním oběhu. Zpočátku byly prováděny převážně jednodušší operace (resekce koarktace aorty, uzávěr ASD a VSD, korekce Fallotovy tetralogie). Složité vady byly zpravidla řešeny dvoufázově. Operační úmrtnost se v prvních letech pohybovala mezi 10-12\%. Postupně byly zaváděny nové operační metody, byly zdokonalovány vyšetřovací metody, metody mimotělního oběhu a metody pooperační intenzivní péče. Propracování celého protokolu péče o novorozence a kojence $s$ vrozenou srdeční vadou umožnilo postupné snižování věku, kdy byly operace indikovány a současně zlepšování operačních výsledků. Mustardova operace TGA byla poprvé provedena v roce 1978, Rastelliho operace $\mathrm{v}$ roce 1979, Senningova operace $\mathrm{v}$ roce 1983 a anatomická korekce TGA v roce 1988. Primární korekci interrupce aortálního oblouku jsme poprvé úspěšně provedli v roce 1993, korekci transpozice s obstrukcí aortálního oblouku v roce 1995, Norwoodovu operaci v roce 1999 a primární korekci atrézie plicnice $\mathrm{s}$ aortopulmonálními kolaterálami v roce 2001. Počty operací se v posledních letech udržují mezi 450-500 a operační úmrtnost klesla na $1 \%$, a to i u komplexní TGA nebo úplné formy defektu AV septa. U Norwoodovy operace je operační mortalita 4\%. Dnes je nutné analyzovat dlouhodobé výsledky, srovnat výsledky operací a intervenčních kardiologických výkonů, zavést metodu krevní kardioplegie a zdokonalit metodu izolované perfuze hlavy při výkonech na aortálním oblouku. Do budoucna plánujeme zavést hybridní výkony u komplexních srdečních vad a transplantaci srdce $u$ kojenců.

\section{SESTERSKÁ SEKCE}

\section{ROBOTEM R̆ízENÁ NAVIGACE KATETRU}

TOLASZOVÁ H, MOLDOVÁ K, BOHÁČOVÁ J, BLÁHOVÁ M, SVOBODOVÁ L

Klinika kardiologie, IKEM, Praha 
Shrnutí: Řídicí systém pro ovládání katetrů pomocí robotu byl navržen za účelem zjednodušení manipulace $s$ katetrem a přesného umístění katetrů v oblasti kardiovaskulárního systému. Jeho schopností se využívá při mapování srdečního oddílu před zahájením radiofrekvenční ablace a do budoucnosti se počítá $\mathrm{s}$ jeho používáním během ablace. Součástí systému je elektromechanické rameno, které manipuluje s řídicím katetrem a sheatem, do kterého je vložen diagnostický katetr. Lékař sedí u vzdálené pracovní stanice, odkud ovládá pohyb katetru. Umístění pracovní stanice rozhoduje o lékařem absorbované dávce RTG záření, kterou je možno používáním robotem řízené navigace katetru redukovat.

Manipulace katetru $\mathrm{z}$ pracovní stanice je díky vhodně navrženému řídicímu zařízení zcela intuitivní.

Závěr: Robotem řízená navigace katetru představuje nový trend v antiarytmologii. Důvodem je jednodušší a pohodlnější manipulace při řízení katetru a možnost docílení pevné polohy katetru v požadované lokalitě srdečního oddílu. Vhodné umístění ovládací stanice umožňuje lékaři pracovat mimo prostor s RTG zářením.

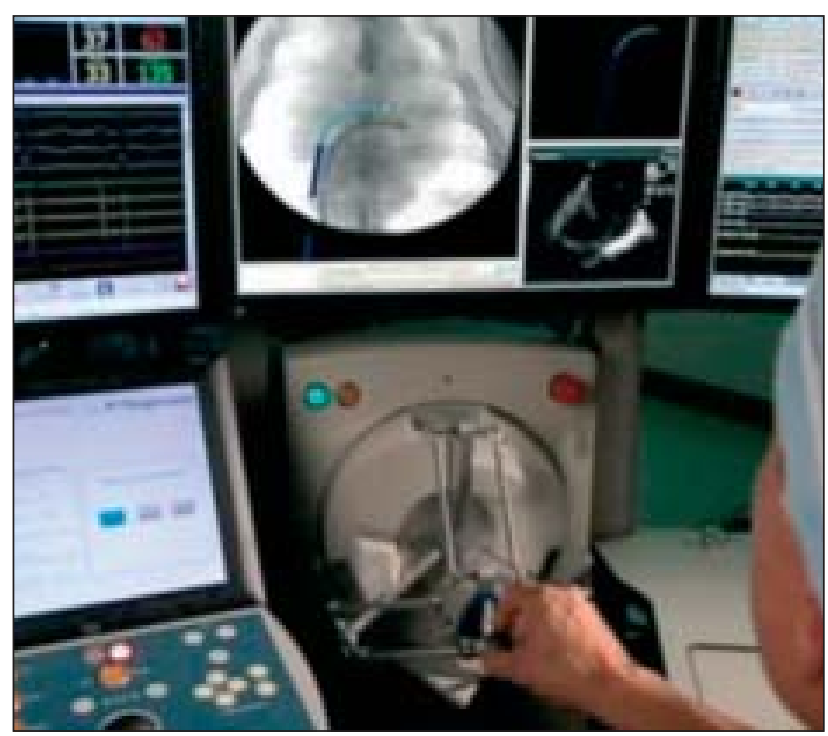

\section{ANEMIE U PACIENTŮ S AKUTNIIM KORONÁRNÍM SYNDROMEM}

TOMÁŠEK A, JANOUŠEK S, MIKLÍK R, ŠEBO M, DVOŘÁKOVÁ E, ŠPINAR J

Interní-kardiologická klinika, FN Brno, Brno

Úvod: Pozorování z poslední doby ukazují, že anemie je pravděpodobně jedním $z$ faktorů negativně ovlivňující průběh některých kardiovaskulárních onemocnění.

Cíl: Zjistit incidenci anemie u pacientů s akutními koronárními syndromy (AKS), posoudit její korelaci s některými klinickými parametry a jednoroční mortalitou nemocných.

Soubor a metodika: 453 pacientů po sobě léčených na IKK FN Brno v roce 2005 s diagnózou AKS. Anemie byla definována jako hladina hemoglobinu $(\mathrm{Hb})<120 \mathrm{~g} / 1 \mathrm{u}$ žen a $<130 \mathrm{~g} / 1 \mathrm{u}$ mužů. Pacienti byli rozděleni do 3 skupin podle vstupní hladiny $\mathrm{Hb}$. Skupina A - 347 pacientů s normální hladinou $\mathrm{Hb}(76,6 \%$ pacientů), skupina B - 85 anemických pacientů s hladinou $\mathrm{Hb}>100$ g/1 (18,7 \% pacientı̊), skupina $\mathrm{C}-21$ pacientů s $\mathrm{Hb}<100 \mathrm{~g} / 1$ (4,7 \% pacientů). Skupiny byly srovnány podle hodnot kreatininu a hypertenze $\mathrm{v}$ anamnéze a dále byla sledována jejich jednoroční mortalita.
Výsledky: Pacienti s anemií byli starší - $66 \pm 11$ let (A) vs. $72 \pm 10$ (B) vs. $74 \pm 10$ (C), $p<0,01$, anemie byla častěji spojena se zvýšením kreatininu - $98 \pm 41 \mu \mathrm{mol} / 1$ (A) vs. $117 \pm$ 64 (B) vs. $148 \pm 103$ (C), $p<0,01$. Oproti předpokladům nebyla $v$ našem souboru anemie spojena $\mathrm{s}$ vyšším výskytem hypertenze v anamnéze $-62,0 \%$ pacientů (A) vs. 71,8 \% (B) vs. $66,7 \%$ (C). Během jednoho roku od vzniku AKS zemřelo $29(8,4 \%)$ pacientů ve skupině A, $21(24,7 \%)$ pacientů ve skupině B a $10(47,6 \%)$ pacientů ve skupině $\mathrm{C}, p<0,01$.

Závěr: Anemie je spojena s horší jednoroční prognózou pacientů $\mathrm{s} A K S$, která je př́mo úměrná tíži anemie. $Z$ našeho souboru nemocných však nelze rozhodnout, zda je anemie nezávislým rizikovým faktorem nebo jen důsledkem vyššího věku, renální insuficience či dalších závažných onemocnění pacientů s AKS.

\section{LIPIDY A RIZIKO ATEROSKLERÓZY V ČESKÉ POPULACI*}

TOMEČKOVÁ M, GRÜNFELDOVÁ H, PELEŠKA J, HANUŠ P, MARUŠIAKOVÁ M, SIMERSKÁ O

\section{EuroMISE Centrum, Ústav informatiky AV ČR, Praha \\ *Č́stečně podpořeno projektem 1ET200300413.}

Vysoká prevalence rizikových faktorů $(\mathrm{RF})$ včetně lipidů v populaci České republiky je bezpochyby příčinou vysoké nemocnosti a úmrtnosti na kardiovaskulární onemocnění v ČR.

$\mathrm{V}$ populaci 980 osob (428 mužů, průměrný věk - 48,01 let a 552 žen, průměrný věk - 49,35 let) bez manifestního kardiovaskulárního onemocnění jsme zjistili vysoké průměrné hodnoty základních lipidů, které významně překračují hodnoty uvedené v Doporučení ČKS pro Prevenci kardiovaskulárních onemocnění $\mathrm{v}$ dospělém věku - tabulka $I$.

Tabulka I

Průměrné hodnoty základních lipidů - v mmol/1

\begin{tabular}{ccccc}
\hline \hline & $\begin{array}{c}\text { Celkový } \\
\text { chol. }\end{array}$ & LDL-chol. & Triglyceridy & $\begin{array}{c}\text { Non- } \\
\text { HDL-chol }\end{array}$ \\
\hline Ženy - Praha & 5,66 & 3,39 & 1,37 & 3,93 \\
- Čáslav & 5,78 & 3,43 & 1,43 & 4,02 \\
Muži - Praha & 5,35 & 3,14 & 1,74 & 3,88 \\
- Čáslav & 5,90 & 3,60 & 1,96 & 4,47 \\
\hline \hline
\end{tabular}

Současně byl v dané populaci vysoký podíl osob s rizikovými lipidovými indexy (rizikový index cholesterolu - RIC $>4$, aterogenní index plazmy - AIP > 0) a s tzv. hypertriglyceridemickým pasem (HTglPas) - tabulka II.

Tabulka II

Podíl žen a mužů s rizikovými lipidovými indexy, hypertriglyceridemickým pasem a metabolickým syndromem $-\mathrm{v} \%$

\begin{tabular}{lccccc}
\hline \hline & RIC > 4 & AIP > 0 & HTglPas & MS - 2001 & MS - 2005 \\
\hline Muži & 51,33 & 54,24 & 39,05 & 14,86 & 33,88 \\
Ženy & 27,66 & 26,40 & 32,13 & 14,94 & 31,03 \\
\hline \hline
\end{tabular}

Přísnější hodnocení metabolického syndromu (IDF - 2005 proti NCEP/ATP - 2001) zdvojnásobilo podíl vysoce rizikových osob - viz též tabulka II.

Prezentované výsledky rizikových hodnot lipidových parametrů svědčí pro velmi nepříznivou situaci v české populaci s ohledem na vznik, rozvoj a manifestaci aterosklerózy. 


\section{CIRKADIÁNNÍ VLIVY NA TURBULENCI SRDEČNÍHO RYTMU*}

TRČKA P, SEPŠI M, KOZÁK M, KřIVAN L, KÝR M, VLAŠÍNOVÁ J

IKK, FN Brno, Brno, Centrum biostatistiky a analýz, LF MU Brno, Brno

*Výzkum je podporován grantem č. 8478-3.

Cílem práce: Ověřit cirkadiánní variabilitu HRT u pacientů bez organického postižení srdce.

Soubor: Analýza dat pacientů, kteří v letech 2005-2006 absolvovali 24 Holterovo EKG. U každého byla stanovena: celková HRT, počet KES, a i HRT po 2 a 4 hodinách. Statistické vyhodnocení: Kruskalův-Wallisův test (neparametrická ANOVA).

Výsledky: HRT byla stanovena u 48 pacientů, mužů: 23, žen: 25, Průměrný věk: 48,4 let ( $\pm 15,3$ ). Výsledky po 2 hodinách: Počet KES: není signifikantní rozdíl ( $p=0,917)$. Parametr TO: není signifikantní rozdíl ( $p=0,253)$. Existuje určitá variabilita parametru TO v průběhu dne, ale statisticky nevýznamná. TS: signifikantní rozdíl v parametru TS $(p<0,001)$. V denních hodinách dosahuje parametr TS nižších hodnot. Parametr TT: signifikantní rozdíl $(p=0,034)$.

Výsledky srovnání po 4 hodinách: Signifikantní rozdíl parametru TS v jednotlivých časových pásmech $(p=0,001)$, ostatní parametry nesignifikantní: počet $\operatorname{KES}(p=0,609)$, parametr TO $(p=0,133)$, TT $(p=0,304)$.

Závěr: Parametr TS vykazuje statisticky významnou variabilitu v průběhu dne. V nočních hodinách jsou hodnoty TS vyšší. Parametr TO vykazuje určitou variabilitu v průběhu dne (s trendem podobně jako parametr TS) jak při hodnocení po 2 , tak i po 4 hodinových intervalech, ale tato variabilita nedosahuje statistické významnosti. Parametr TT má obecně menší informační hodnotu (vzhledem $\mathrm{k}$ tomu, že nabývá pouze několika diskrétních hodnot). Prokazatelnost variability $\mathrm{v}$ průběhu dne je při hodnocení po 2 hodinách zřejmá, jde ale spíše o variabilitu časových pásem jako takových, bez jasného zřetelného trendu, který by byl v souladu s ostatními parametry, a při hodnocení po 4 hodinách prokazatelnost této variability vymizí a potvrdí absenci trendu. Jako optimální časový interval pro snímání HRT se jeví čas mezi 10. a 12. hodinou ranní.

\section{K PR̆ÍNOSU NOVÉ SEISMOKARDIOGRAFICKÉ TECHNIKY NEJEN V OBLASTI LETECKÉ A KOSMICKÉ MEDICINYY, ALE I V DËTSKÉ KARDIOLOGII}

TREFNÝ Z

Kardiologická laboratoř, Praha

Srdce je senzitivním indikátorem funkčních procesů v organismu. Rytmus a síla srdečních kontrakcí kontrolovaných sympatickou a parasympatickou částí autonomního nervového systému reaguje velice citlivě na jakýkoli podnět.

Při hodnocení variability srdečního rytmu (HRV) existují specifické indikátory pro hodnocení aktivity sympatiku a parasympatiku, které umožňují popis změn tenze obou oddílů autonomního nervového systému.

V práci je popsána použitá metodika společná jak pro studium kosmonautů ve stavu beztíže, tak dětí v pozemských podmínkách. Jsou demonstrovány některé výsledky v oblasti kosmické medicíny při dlouhodobém pobytu ve vesmíru a rovněž změny u dětí za různých situací. Výsledky u obou skupin byly získány stejnou měřicí metodikou.

\section{OD WILLIAMA HARVEYE KE KOSMICKÉ KARDIOLOGII A K AMBULANTNÍ KARDIOLOGII}

TREFNÝ Z, SVAČINKA J, BAYEVSKI R, TROJAN S, SLAVÍČEK J, KITTNAR O, TREFNÝ M, SMRČKA P

Kardiologická laboratoř, Praha

Pohyb srdce a krve se manifestuje silou působící na tělo a to jak v zemské gravitaci, tak i ve stavu beztíže.

Tělo představuje mechanický vibrační systém přenášející sílu na přístroj, který je druhou částí mechanického přenosového systému. Tato systémová koncepce nám umožnila odstranit vady, kterými byla zatížena dřivější balistokardiografie. Dřívější přístroje měly vlastnosti, které invalidizovaly využití balistokardiografických metod. Po kritickém zhodnocení těchto skutečností jsme v roce 1956 zkonstruovali a zavedli přenosný kvantitativní balistokardiograf s vlastní frekvencí vyšší než $1000 \mathrm{~Hz}$. Síla působící na snímač je registrována věrně, a proto bylo možno náš přístroj kalibrovat, přičemž amplituda křivky je vyjadřována numericky v jednotkách síly (N).

Při měření těchto veličin jsme $\mathrm{u}$ ambulantních pacientů sledovali jejich vývoj ve vztahu k věku a stárnutí, k měnící se tenzi kyslíku, dále v klidu a při tělesné zátěži. Zjistili jsme rovněž lineární vztah mezi silou kosterního svalstva a systolickou silou srdeční. Tyto poznatky vedly $\mathrm{k}$ rozvoji spolupráce $\mathrm{s}$ americkým a ruským pracovištěm, zabývajícími se výzkumem v oblasti letecké a kosmické medicíny.

Kromě amplitudy křivek je možno vyhodnocovat také časové řady srdeční kontrakce, tj. variabilitu srdečního rytmu (HRV), a tak hodnotit stav a změny autonomního nervového systému a zavést indikátory pro hodnocení aktivity sympatiku a parasympatiku. Tato nová metoda kvantitativní seismokardiografie umožňuje komplexní pohled jak na inotropní, tak na chronotropní srdeční funkci, a to jak u kosmonautů ve stavu beztíže, tak $\mathrm{u}$ pacientů $\mathrm{v}$ pozemských podmínkách. V naší práci jsou demonstrovány výsledky vyšetření obou těchto sledovaných skupin stejnou přístrojovou technikou.

\section{LOKALIZOVANÁ (REGIONÁLNÍ) PERIKARDIÁLNÍ TAMPONÁDA U PACIENTŮ PO SRDEČNÍ OPERACI}

TROUBIL M, BENČAT M, NĚMEC P, HÁJEK R

Kardiochirurgická klinika, FN Olomouc a LF UP, Olomouc

Úvod: Lokalizovaná tamponáda (LT) je způsobená perikardiálním hematomem, což je regionální kolekce krevní sraženiny způsobující selektivní útlak postižených srdečních dutin.

Soubor pacientů: Během 3 let jsme diagnostikovali LT u 9 pacientů $(0,3 \%$ z celkově operovaných ) - u 3 pacientů v oblasti pravé síně, u 2 v oblasti pravé síně a pravé komory, u 2 v levé i pravé síni a pouze v levé síni ve 2 případech.

Výsledky: Diagnóza byla stanovena v rozpětí 0 . až 6 . pooperačního dne (medián 2. den), v 5 př́ípadech se stále zavedenými drény. Klinické známky tamponády byly zastoupeny následovně: hypotenze v 9 případech, sinusová tachykardie v 6 a elevace CVP v 8 případech (medián 17 mm Hg). Invazivně monitorováni byli 4 pacienti, u všech byl zjištěn nízký srdeční výdej (LCO), ale u žádného nebyla přítomna ekvalizace diastolických tlaků.

Při echokardiografickém vyšetření byly u všech známky typické pro LT - dekonfigurace kontury některého srdečního oddílu echogenní kolekcí v perikardu. V 5 případech bylo kromě TTE nutné provést TEE vyšetření. Jen ve 4 případech byla respirační variabilita transatrioventrikulárního toku 
$\geq 25 \%$. Ve 2 případech bylo iniciálně zvažováno systolické srdeční selhání, v 1 případě sepse jako příčina LCO syndromu. 8 pacientů podstoupilo operační revizi, jeden byl léčen konzervativně s dobrou reakcí na volumoterapii a analeptika s dobrým průběhem. 2 pacienti zemřeli na rozvoj MOFS.

Závěr: Obraz LT po srdeční operaci bývá díky selektivnímu útlaku postižených srdečních oddílů zpravidla rozdílný od tamponády s cirkulární efuzí a může být zaměněn s jinými klinickými stavy. Proto by LT měla být vždy zvažována v případě oběhové deteriorace a LCO syndromu. Také echokardiografická diagnóza je obtížnější a obraz perikardiálního hematomu specifický. Senzitivita TTE bývá nižší a ke stanovení diagnózy je často nutné provést TEE.

\section{JE ČAS ZMĚNIT STÁVAJÍCÍ PROTOKOL NEINVAZIVNÍHO KARDIOLOGICKÉHO TESTOVÁNÍ POTENCIÁLNÍCH KANDIDÁTŮ TRANSPLANTACE LEDVINY NA ZÁKLADĚ PËTILETÝCH ZKUŠNOSTÍ?}

\section{ULMAN J, MAREK T, VIKLICKÝ O}

\section{Klinika kardiologie, Klinika nefrologie, IKEM, Praha}

Úvod: Kardiovaskulární morbidita nemocných s chronickým selhání ledvin je značná a zhruba polovina příčin úmrtí těchto nemocných je kardiovaskulární. Transplantace ledviny velmi zásadně zlepšuje prognózu těchto nemocných i když ji zcela nevyrovná s běžnou, zdravou populací. Ve screeningu kandidátů transplantace ledviny je věnována velká pozornost kardiovaskulárním onemocněním. Podle stávajícího protokolu našeho pracoviště je ve skupině nejrizikovější nemocných, zejména s manifestní ICHS a po revaskularizaci myokardu, prováděna koronární angiografie, nemocní ve středním riziku podstupují zátěžovou echokardiografii a nemocní s nízkým kardiovaskulárním rizikem nejsou zátěžově restováni, pokud mají normální klidové EKG a klidový echokardiografický nález.

Metody: Kritický pohled na stávající protokol kardiologického testování na základě pětileté klinické zkušenosti s neinvazivním testováním kandidátů zařazených na čekací listinu transplantace ledviny u 341 konsekventních nemocných na pozadí přibývají evidence based medicine, i u nemocných s chronickou renální insuficiencí.

Závěr: Vzhledem k výsledkům v našem souboru a novým literárním poznatkům navrhujeme několik procedurálních změn: 1. Netestovat fyzickou zátěží (bicykl) pro malou výtěžnost a velkou časovou náročnost. 2. SKG i u nemocných s ICHDK. 3. Testovat i nemocné s klidovou poruchou kinetiky. 4. Zvážit zavedení pojmu urgentní či přednostní kandidát pro nemocné s dysfunkcí levé komory srdeční a normálním či minimálním nálezem na věnčitých tepnách a po vyloučení vlivu snížení suché váhy u nemocného. 5. Riziko vlastního výkonu (transplantace ledviny) odhadovat komplexně (EUROSCORE).

\section{SESTERSKÁ SEKCE}

\section{PRAVOSTRANNÁ A TRANSSEPTÁLNÍ SRDEČNÍ KATETRIZACE}

\section{URBANOVÁ V, BENEŠOVÁ V}

Katetrizační laborator̆, Kardiologie na Bulovce s. r. o., Praha

První zavedení katetru do srdce (rok 1929) bylo vlastně pravostrannou katetrizací. Objevením rentgen-kontrastní látky a jejím užitím v klinické praxi se rozvinula dnes zcela dominantní levostranná katetrizace a následná angiografická vyšetření.
V období 50.-70. let byly pravostranné a transseptální katetrizace významnou dg. metodou, jedinou indikací ke kardiochirurgickým výkonům. Od 80. let s rozvojem a dostupností UZ-vyšetření její význam pomalu klesá. Při pravostranné srdeční katetrizaci se zavádí katetr do pravé síně, pravé komory, plicnice a plicních kapilár. Katetrizací zjištujeme systolické, diastolické a střední tlaky v jednotlivých srdečních oddílech. Při katetrizaci nejen měříme tlaky, ale též odebíráme vzorky krve $z$ jednotlivých pasáží a tyto pak analyzujeme v laboratoři. $Z$ výsledků těchto údajů jsme pak schopni velmi přesně určit, o jakou vadu se jedná a zároveň tuto vadu i kvantifikovat. Při potřebě zvláště přesných výsledků měření se na našem pracovišti pak provádějí tzv. transseptální katetrizace, kdy se katetrem dostaneme $z$ pravé do levé síně propíchnutím mezisín̆ového septa. V roce 2006 bylo na našem pracovišti provedeno celkem 2263 srdečních katetrizací, z toho bylo 238 katetrizací pravostranných a 77 transseptálních.

\section{SESTERSKÁ SEKCE}

\section{OŠETR̆OVÁNí PACIENTA S TRVALOU TRACHEOSTOMIÍ. KASUISTIKA}

\section{VACHALCOVÁ M}

III. interní klinika, koronární jednotka, VFN a 1. LF UK, Praha

Chronická obstrukční plicní nemoc (CHOPN) patří celosvětově mezi nejčastější př́ičiny morbidity a mortality. Postihuje více než $5 \%$ dospělé populace. Ročně této nemoci podlehne až 4,7 milionu obyvatel. Diagnóza CHOPN je založena na anamnéze rizikových faktorů a průkazu průduškové obstrukce, příznacích - chronický kašel, tvorba sputa a dušnost. Na naší Koronární jednotce jsou často hospitalizováni pacienti s různými stadii CHOPN. Trvalá tracheostomie představuje variantu k zajištění kvalitní léčby. Při zhoršení stavu je možné v krátkém čase podat účinnou oxygenoterapii přes kyslíkový nos, nebo napojit pacienta na umělou plicní ventilaci (UPV). K závažným problémům patří psychické problémy i závislost na dýchacím přístroji.

Kasuistika: 67letá pacientka s dlouholetou diagnózou CHOPN měla od roku 2002 zavedenou trvalou tracheostomii. Zhoršujíci se respirační insuficience byla důvodem opakovaných hospitalizací s nutností napojení na UPV. Spolu s nebulizováním bronchodilatancií došlo ke zlepšení ventilace a stabilizaci celkového zdravotního stavu. Stabilizace stavu po kardiologické a plicní stránce umožnila odpojení pacientky od UPV a přeložení na spádovou plicní JIP.

\section{JE PRÍTOMNÁ SPOJITOSǏ MEDZI HODNOTAMI TLAKU KRVI A ANXIETOU A DEPRESIOU U HOSPITALIZOVANÝCH PACIENTOV S DIABETES MELLITUS TYP 2?}

VACHULOVÁ A, BUKOVINOVÁ P, GORTHA Š, RUŽEK J, VOHNOUT B

I. neurologická klinika, II. interná klinika FNsP a LF UK, Bratislava, SR, Laboratory of Genetic and Environmental Epidemiology, Center for High Technology Research, Catholic University, Campobasso, Italy

Depresívne poruchy majú vysokú prevalenciu a často sú diagnostikované $u$ pacientov $s$ diabetes mellitus (DM), ischemickou chorobou srdca a artériovou hypertenziou. Psychosociálny stres má negatívny dopad na kardiovaskulárne zdravie.

Ciel štúdie: Sledovat vztah medzi tlakom krvi, depresiou a anxietou u hospitalizovaných pacientov s diabetes mellitus 2. typu. 
Metódy: Do štúdie bolo zaradených 55 pacientov (24 mužov a 31 žien), hospitalizovaných na II. internej klinike FN a LF, vo veku 47-88 rokov s diagnózou diabetes mellitus a artériová hypertenzia. Stupeň anxiety a depresie bol posudzovaný pomocou Hamilton Anxiety Rating Scale (HAM-A) a Hamilton Rating Scale for Depression (HAM-D). Priemerné hodnoty sme porovnali použitím párového $t$-testu. Na posúdenie vztahu medzi ukazovatelmi metabolickej kompenzácie a HAM-A a HAM-D skóre sme použili Pearsonovu koreláciu.

Výsledky: Základná charakteristika súboru je v tabul'ke. Potvrdili sme vysokú frekvenciu symptómov anxiety a depresie u pacientov s DM $(36,4 \%$ s miernymi až stredne tažkými symptómami anxiety a 67,3 \% s miernymi až stredne tažkými depresívnymi symptómami). Avšak nezaznamenali sme štatisticky signifikantnú koreláciu medzi systolickým a diastolickým tlakom krvi a HAM-A ( $r=-0,09, r=-0,11)$ a HAM-D ( $\mathrm{r}=0,02, \mathrm{r}=-0,01)$. Lineárna regresná analýza použitím BMI, veku, pohlavia, HAM-A a HAM-D nedokázala, že HAM-A lebo HAM-D sú signifikantnými determinantami systolického alebo diastolického tlaku krvi v našom súbore.

Muži/ženy (\%) 24/31

Vek (roky)

BMI

Systolický TK (mm Hg)

Diastolický TK (mm Hg)

HAM-A škála

HAM-D škála

Záver: Nepotvdili sme vztah medzi anxietou a/alebo depresiou a tlakom krvi v našom súbore hospitalizovaných pacientov s diabetes mellitus.

\section{SESTERSKÁ SEKCE}

\section{ÚLOHA ECHOKARDIOGRAFIE V DIAGNOSTICE A LÉČBĚ PERIKARDIÁLNÍHO VÝPOTKU PO KARDIOCHIRURGICKÉM VÝKONU}

VAJSAROVÁ L, MAREK T

Klinika kardiologie, IKEM, Praha

Echokardiografie je základní vyšetřovací metodou v diagnostice a léčbě perikardiálního výpotku. Perikardiální vak obsahuje za normálních okolností malé množství tekutiny. Pokud je přítomno větší množství tekutiny, zobrazí se při echokardiografii jako tzv. ECHO-prázdný prostor mezi oběma listy perikardu. U malých výpotků nám pomůže M-mode v enddiastole. Při větších postačuje 2-D echokardiografie. Pro hemodynamickou významnost výpotku (až tamponádu) svědčí tyto echokardiografické známky: 1. diastolický kolaps pravé komory, 2. systolický kolaps pravé síně, 3. reciproční změny velikosti či objemů levé a pravé komory během respirace, 4. respirační kolísání průtoků AV o více než $25 \%$ - v inspiriu zvýšení průtoku Tri ústím a zmenšení průtoku v Mi ústí, 5. dilatace dolní duté žíly s chyběním respiračního kolísání, 6. známky pulsus paradoxus - kolísání VTI ve výtokovém traktu LK př̀ respiraci. Pro klinickou závažnost výpotku není rozhodující jen množství, ale i rychlost vzniku, protože rychle vzniklý výpotek může vést $\mathrm{k}$ tamponádě i při separaci do $10 \mathrm{~mm}$. Po kardiochirurgickém výkonu se perikardiální výpotek vyskytuje relativně často až u $64 \%$ pacientů s maximem okolo 5.-10. dne od operace. Avšak jen $2 \%$ jsou závažná, vyžadující léčbu. Typické je, že více než 55 \% jsou výpotky lokalizované, což vede často $\mathrm{k}$ atypické klinické manifestaci a obtížné echokardiografické diagnostice. Část těchto výpotků, zvláště pokud jsou lokalizovány jen okolo síní či jsou s četnými koaguly (hema- tomy), musí být řešena kardiochirurgicky, revizí. Pokud jsou výpotky perkutánně přístupné, je metodou volby punkce za echokardiografické kontroly (nalezení optimálního místa punkce a směru vedení jehly, monitorace odsávání).

\section{SESTERSKÁ SEKCE}

\section{SROVNÁNÍ TRVALÉ STIMULACE HROTU A SEPTA PRAVÉ SRDEČNÍ KOMORY*}

\section{VALTROVÁ I, LUDVÍKOVÁ J}

Klinika kardiologie, IKEM, Praha

*Studie byla podpořena IGA MZ ČR č. 8553-3/2005.

Úvod: Téměř 50 let je komorová elektroda trvalé kardiostimulace umistována do hrotu pravé komory srdeční. Řada experimentálních i klinických studií z poslední doby však ukazuje, že stimulace hrotu pravé komory (PK) srdeční se širokým komplexem QRS vede $\mathrm{k}$ nevýhodné aktivaci komor, která může být spojena s poruchou systolické i diastolické funkce levé komory (LK) srdeční. Řešením je stimulace $\mathrm{z}$ alternativních míst $\mathrm{PK}, \mathrm{v}$ klinické praxi nejčastěji ze středního septa PK. Na našem pracovišti je prováděna studie, která řeší srovnání stimulace septa a hrotu, vyšetřujeme echokardiografické parametry komorové dyssynchronie.

Cíl sdělení: Hodnocení akutního vlivu těchto dvou míst trvalé stimulace.

Metodika: 40 pacientů (30 mužů, průměrný věk 73 s pokročilou blokádou AV a zachovanou funkcí LK (EF > $45 \%$ ) bylo zařazeno do studie. Pts byli randomizováni $\mathrm{v}$ poměru $2: 1$ k septální stimulaci (26 pts, 10 let) nebo hrotové stimulaci (14 pts, průměrný věk $72 \pm 10$ let). Elektroda s aktivní fixací byla umístěna bud' na septum či do hrotu PK.

Závěr: $\mathrm{V}$ předložené studii bylo sice prokázáno výrazné zúžení šíře komplexu QRS při stimulaci septa pravé komory než při stimulaci hrotu, nicméně echokardiografické ukazatele komorové dyssynchronie se bezprostředně po implantaci významně nelišily. Pacienti jsou nadále ambulantně sledováni.

\section{ZUŽUJE VĚTŠÍ STIMULAČNÍ ENERGIE U NEMOCNÝCH S IMPLANTOVANÝM KARDIOSTIMULÁTOREM Ší̆I KOMPLEXU QRS? PILOTNÍ STUDIE*}

VANČURA V, WICHTERLE D, LEFFLEROVÁ K, BYTEŠNÍK J, KAUTZNER J

Klinika kardiologie, IKEM, Praha

*Studie byla podpořena grantem IGA MZČR č. 8553-3/2005.

Cíl: Vliv stimulační energie na šiři komplexu QRS u nositelů trvalého kardiostimulátoru dosud nebyl detailněji zkoumán. Cílem této studie bylo nalézt metodu, kterou by byl tento efekt měřitelný a zjistit v pilotní části studie, zda skutečně ke zúžení komplexu QRS vlivem větší stimulační energie dochází.

Soubor a metodika: Do studie bylo náhodně vybráno 5 nemocných s implantovaným kardiostimulátorem a elektrodou v pravé komoře srdeční, kteří byli dependentní na stimulaci, či měli vyšší stupeň blokády AV. Všichni nemocní měli práh stimulace pod 1,5 V/0,4 ms. Měření bylo prováděno při unipolární stimulaci o frekvenci 100/min, křivka EKG byla registrována na zařízení CardioLab ${ }^{\circledR}$ firmy GE Medical Systems. K analýze byly použity vektokardiografické svody zaznamenávané s vzorkovací frekvencí $3906 \mathrm{~Hz}$ při filtraci 0,05-1 $000 \mathrm{~Hz}$. Z nich byl vytvořen sumární vektor QRS pro jednotlivé energie stimulace. Šíře komplexu 
QRS byla hodnocena relativně vzhledem $\mathrm{k}$ šíri komplexu QRS při stimulaci o prahové energii (prahové QRS). Zúžení či rozšíření komplexu QRS oproti prahovému QRS se detekovalo pomocí maxima cross-korelační funkce, použité na oblast 201 - hodnot kolem konce komplexu QRS. Pro účely tohoto sdělení byl hodnocen rozdíl šíře prahového QRS a QRS při stimulačním napětí $4 \mathrm{~V}$, prričemž šíře stimulu zůstala beze změn na hodnotě $0,4 \mathrm{~ms}$.

Výsledky: Všichni nemocní byli muži, průměrný věk byl $72,2 \pm 7,5$ roků. Od implantace elektrody do doby tohoto měření uplynulo $4,04 \pm 3,2$ roků. U všech pacientů v této pilotní části studie byl komplex QRS použitím vyšší stimulační energie zkrácen. Šíře komplexu QRS se při použití stimulační energie $4 \mathrm{~V}$ zmenšila oproti prahové stimulační energii průměrně o $5,4 \pm 1 \mathrm{~ms}(p<0,001)$.

Závěr: Větší stimulační energie při stimulaci $z$ pravé komory srdeční zkracuje komplex QRS.

\section{LÉČBA ANEURYZMAT BR̆IŠNÍ AORTY (AAA) POMOCI IMPLANTACE STENTGRAFTU AORFIX. NOVÁ MOŽNOST PRO NEMOCNÉ S NEPR̆İZNIVÝM ANATOMICKÝM NÁLEZEM NA AORTĚ?}

VAR̆EJKA P, SKALICKÁ L, CHOCHOLA M, HELLER S, BERAN S, JIRÁT S, LINHART A

II. interní klinika kardiologie a angiologie, VFN a 1. LF UK, Praha

AAA je nejčastějším pravým aneuryzmatem s vysokým rizikem ruptury, pokud není včas léčeno. Endovaskulární léčba pomocí implantace stentgraftu zaznamenává od roku 1991, kdy byla uvedena do praxe, dynamický rozvoj. Nevhodné anatomické poměry na břišní aortě a pánevních tepnách patři k nejvýznamnějším limitům pro širší využití této metody.

Na II. interní klinice VFN, Praha jsme od 12/2005 začali používat nový stentgraft AORFIX fy. Lombard Medical, který svojí unikátní konstrukcí umožňuje provádět tyto výkony i u nemocných s nepřiznivou konfigurací aorty zejména s angulovaným krčkem. Do 12/2006 jsme provedli 12 implantací a minimálně 6měsíční sledování proběhlo u 10 nemocných.

U všech nemocných se podařilo stentgraft správně implantovat, $v$ jednom př́padě jsme pro proximální endoleak I. typu použili proximální extenzi. Kontrolní CT-vyšetření při dimisi prokázalo u všech nemocných velmi příznivý nález s kompletní trombotizací vaku AAA, bez přítomnosti patologického zatékání kontrastní látky. Během minimálně 6měsíčního sledování jsme nezaznamenali žádné úmrtí ani rupturu AAA, kontrolní CT provedené s odstupem 6 měsíců prokázalo zastavení růstu vaku AAA a u dvou nemocných, kteří absolvovali $C T$ vyšetření s odstupem 12 měsíců, bylo prokázáno zmenšování vaku AAA.

Naše zkušennosti s tímto typem stentgraftu jsou velmi dobré, zejména zjištění zmenšování vaku AAA po výkonu je velmi nadějným nálezem. Představuje účinnou a bezpečnou alternativu i u nemocných, kteři se zdáli být nevhodní k endovaskulární léčbě pro nepříznivé anatomické poměry na aortě nebo pánevních tepnách.

\section{BEZPEČNOST AMBULANTNĔ PROVEDENÉ PCI TRANSRADIÁLNÍM PR̆íSTUPEM. PILOTNÍ STUdIE}

VEČEŘA J, VARVAŘOVSKÝ I,

MATĚJKA J, KŘížOVÁ A, BOŘKOVÁ V

Kardiologické oddělení,

Krajská nemocnice Pardubice, Kardio-Troll, Pardubice
Cill: Přípravnou fází k zahájení ambulantního provozu koronárních angioplastik je pilotní studie, hodnotící bezpečnost takového postupu.

Soubor a metodika: Hodnoceno 69 nemocných, u kterých na diagnostický výkon provedený transradiálním přístupem navazovala ad hoc provedená koronární angioplastika (PCI). Kromě 8 nemocných byli všichni pacienti nejméně 24 hodin před výkonem léčeni nasycovací dávkou $300 \mathrm{mg}$ clopidogrelu spolu s kyselinou acetylsalicylovou v dávce 100 mg denně. Zavaděč $z$ radiální tepny byl odstraněn ihned po výkonu a mechanická komprese (Radstat) ponechána poté 7 hodin. Modelovou situací je tedy „virtuální dimise“ nemocného za 7 hodin po ukončení PCI, kdy sledujeme četnost: 1. pokračujícího krvácení $z$ radiální tepny, 2. vzestupu myokardiálních enzymů po PCI, 3. přítomnosti pulsace radiální tepny.

Bylo ošetřeno 48 mužů $(\varnothing$ věk 64 let) a 21 žen ( $\varnothing$ věk 70 let). PCI bylo ošetřeno celkem 84 koronárních lézí, implantováno 82 stentů, angiografická charakteristika lézí odpovídala obvyklé distribuci (léze typ A-12, B1-28, B2-30, C-14). Bifurkační léze byla ošetřena „kissing technikou“ v 18 případech.

Výsledky: 1. Doba komprese 7 hodin byla postačující u 53 nemocných (77\%). Doba komprese 8 hodin byla nutná $9 \times$, 9 hodin $3 \times, 10$ hodin $3 \times$ a v jednom př́ipadě byla 13 hodin.

2. Vzestup troponinu I nad horní hranici normálního rozmezí (cTnI $\geq 1,0 \mu \mathrm{mol} / 1$ ) byl v 7 . hodině př́itomen u 3 nemocných (4\%) bez doprovodné klinické symptomatologie a bez EKG změn specifických pro ischemii myokardu.

3. Pulsace radiální tepny nebyla $v 7$. hodině hmatná u jedné nemocné.

Závěr: Transradiální přístup je bezpečným postupem a umožňuje ambulantní provedení PCI s propuštěním většiny nemocných 7 hodin od výkonu. Prodloužení nutné doby komprese $\mathrm{u}$ čtvrtiny pacientů je hlavním omezením takového postupu a může souviset s podáním nasycovací dávky clopidogrelu 24 hodin před elektivní PCI.

\section{PURULENTNÍ PERIKARDITIDA S TAMPONÁdOU. KASUISTIKA}

\section{VINDIŠ D, TŘEŠTÍK P, NĚMEC P, ŠTUDENTOVÁ H}

Interní oddělení, Kroměřǐžská nemocnice, a. s., Kroměřǐž, Kardiochirurgická klinika, Fakultní nemocnice, Olomouc

Ưvod: Purulentní perikarditida je vzácné onemocnění s vysokou mortalitou. V převážné většině případů následuje po proběhlé bakteriemii, nejčastějším vyvolávajícím agens jsou koky G+. Průběh nemoci je velmi variabilní, většinou fulminantní. Příznaky jsou často překryty symptomatologií základní infekce a může se manifestovat až tamponádou.

$\mathrm{V}$ naší kasuistice popisujeme průběh purulentní perikarditidy u 73letého muže přijatého na naše oddělení pro centrální bronchopneumonii vlevo, tachyfibrilaci síní. Vstupní ECHO bez separace v perikardu, se střední významnou mitrální regurgitací, jinak bez významné patologie. Šestý den hospitalizace provedeno pro hemodynamickou nestabilitu kontrolní ECHO s průkazem cirkulárního perikardiálního výpotku s echokardiografickými známkami tamponády. Provedena urgentně perikardiocentéza s evakuací purulentního exsudátu. Pro velkou hustotu výpotku s ucpáváním drenáže a neustávající sekreci provedeno postupně zavedení dalšího drénu $z$ jiného punkčního místa a výměna původního. Etiologicky Staphylococcus aureus, zavedena ATB terapie podle citlivosti. Pro přetrvávající známky výpotku a trvající hemodynamické nestabilitě provedena na Kardiochirurgické klinice FN Olomouc fenestrace perikardu s rozrušením sept a drenáží. Další hospitalizace na ARO a pak na JIP vede postupně $\mathrm{k}$ úpravě stavu, dimise do domácí péče 36 . den. 
V dalším sledování ještě opakované hospitalizace pro kardiální dekompenzaci při středně významné mitrální regurgitaci, LK bez známek konstrikce perikardu.

Závěr: Suverénní metodou v diagnostice tohoto onemocnění je echokardiografie, základem léčby je cílená antibiotická terapie a perikardiocentéza. Při její neúčinnosti pak fenestrace perikardu s drenáží, dále intenzivní pooperační péče a rehabilitace. I přes vysokou mortalitu je při včasné diagnostice a terapii purulentní perikarditidy s tamponádou možno dosáhnout plného uzdravení.

\section{ANALÝZA PODSKUPIN V KLINICKÝCH STUDIÍCH*}

\section{VÍTOVEC J}

Interní-kardioangiologická klinika, FN u sv. Anny, Brno

*Vypracováno v rámci VZ MŠMT-MSM0021622402.

Rozsáhlé randomizované klinické studie poskytují nejspolehlivější údaje o účincích léčby, ale měly by být vytvořeny, analyzovány, zpracovány a vyhodnoceny tak, aby umožnily co nejefektivnější využití léčebných postupů v každodenní praxi. Analyzované podskupiny jsou významné, pokud se vyskytují velké rozdíly mezi skupinami $s$ rizikem nedostatečného výsledku léčby nebo bez ní a pokud je zde možnost různého léčebného účinku s ohledem na patofyziologii. Dále analýza je vhodná tam, kde existují praktické otázky $\mathrm{k}$ tomu, jak léčit nebo existují pochybnosti o př́nosu léčby pro specifické skupiny, jako jsou např́iklad starší lidé. Analýzy podskupin je třeba předem definovat, pečlivě zdůvodnit a omezit na několik klinicky významných problémů a následná pozorování je třeba brát $\mathrm{s}$ určitou klinickou skepsí bez ohledu na jejich statistickou významnost. Pokud u podskupin očekáváme významné účinky, měly by se klinické studie směrovat bud' na zjištění jejich spolehlivosti nebo na provedení společných analýz několika klinických studií. Jsou rozebrána pravidla pro plánování, zpracování a vyhodnocení analýz podskupin.

\section{SROVNÁNÍ AMERICKÝCH, EVROPSKÝCH A ČESKÝCH DOPORUČENÍ PRO FARMAKOLOGICKOU LÉČBU CHRONICKÉHO SRDEČNİHO SELHÁNİ*}

\section{VÍTOVEC $J$}

Interní-kardioangiologická klinika, FN u sv. Anny, Brno

*Vypracováno v rámci VZ MŠMT-MSM0021622402.

Cíl: Přehled a srovnání farmakologické léčby chronického srdečního selhání v doporučeních ACC/AHA 2005, EHS 2005 a ČKS 2006

Zdroj dat: viz literatura.

Výsledky: Základem léčby ve všech doporučeních je inhibice systému renin-angiotenzin-aldosteron, poté podání betablokátorů, diuretika jsou doporučována při retenci tekutin, digoxin v případě symptomů při maximální předchozí doporučené léčby, či fibrilaci síní s rychlou odpovědí komor. Americká i evropská doporučení mají navíc kombinační léčbu nitráty a hydralazinu (NT + HZ) u nemocných netolerujících inhibitory ACE či sartany nebo u Afroameričanů. Ostatní léčba je léčbou doprovodných onemocnění, která je v českých doporučeních zmíněna jen pro antiagregaci, antikoagulaci a hyperlipidemii.

Závěr: Všechna doporučení se shodují v lékových skupinách, liší se pouze v jednotlivých genericích a dávkách, naše doporučení nezmiňují vůbec léčbu kombinací NT + HZ.

\section{LITERATURA}

1. ACC/AHA 2005 Guideline Update for the Diagnosis and
Management of Chronic Heart Failure in the Adultsummary article. J Am Coll Cardiol 2005;46:1116-43.

2. Guidelines for the diagnosis and treatment of chronic heart failure: executive summary (update 2005): the Task Force for the Diagnosis and Treatment of Chronic Heart Failure of the European Society of Cardiology. Eur Heart J 2005;26:1115-40.

3. Doporučení pro diagnostiku a léčbu chronického srdečního selhání ČKS 2006. Cor Vasa 2007;49:K5-K34.

\section{ECHOKARDIOGRAFICKÉ DETERMINANTY VÝZNAMNOSTI MITRÁLNÍ REGURGITACE V BĚŽNÉ KLINICKÉ PRAXI}

VÍTOVEC M, PALEČEK T, HLUBOCKÁ $Z$, GOLÁŇ L, LINHART A

II. interní klinika kardiologie a angiologie, VFN a 1. LF UK, Praha

Cíl práce: Posoudit, jakým způsobem se odlišují běžně stanovované echokardiografické ukazatele nemocné s významnou neischemickou mitrální regurgitací od pacientů s méně významnou vadou.

Soubor nemocných a metodika: 147 nemocných referovaných do echokardiografické laboratoře II. interní kliniky VFN a 1. LF UK pro mitrální regurgitaci bylo po podrobné kvantifikaci vady rozděleno na pacienty s významnou vadou (skupina $\mathrm{V}, \mathrm{n}=71$ ) a nemocné $\mathrm{s}$ méně významnou vadou (skupina $\mathrm{M}, \mathrm{n}=76$ ). Pomocí analýzy ROC byly hodnoceny parametry velikosti a funkce levé komory a velikosti levé síně a posouzen jejich prediktivní význam pro odlišení méně významné a významné regurgitační vady, jako hraniční hodnota byla zvolena ta $\mathrm{s}$ nejlepším poměrem mezi senzitivitou a specificitou.

Výsledky: Mezi funkčními a morfologickými parametry jsme identifikovali jako nejvýznamnější velikost levé komory (AUC 0,72 $\pm 0,047$, cut-off $55 \mathrm{~mm}$ ) amplitudu vlny $\mathrm{E}$ transmitrálního průtoku (AUC 0,71 $\pm 0,046$, cut-off $1,0 \mathrm{~m} / \mathrm{s}$ ) a plochu levé síně počítanou $z$ měření přičného a longitudinálního rozměru v apikální projekci (AUC 0,69 \pm 0,044, cut-off $27 \mathrm{~cm}^{2}$ ). V multivariační logistické analýze predikovaly tyto parametry významnou regurgitaci následovně: velikost levé komory s OR 5,94 [95\% CI 2,29-16,45, $p<0,001]$, amplituda vlny E s OR 3,32 [1,24-9,27, $p<0,05]$ a plocha levé síně s OR 3,44 [1,26-9,69, $p<0,05]$.

Závěr: Pro hodnocení velikosti mitrální regurgitace se v klinické praxi i nadále významně uplatňují známé diskriminanty odrážející její hemodnamický dopad na levou komoru a levou síň. Hraniční hodnoty odvozené $z$ analýzy ROC jsou však $\mathrm{v}$ případě velikosti levé komory a amplitudy vlny E na mitrálním ústí podstatně menší než hodnoty uváděné v literatuře, zatímco plocha levé síně se uplatňuje až od hodnot vyšších než literárně referovaných.

\section{SESTERSKÁ SEKCE}

\section{DETEKCE DEPRESE V KATETRIZAČNÍ LABORATOR̆I POMOCÍ KRÁTKÉ VERZE DOTAZNÍKU PHQ}

VLKOVÁ M, ŠKVAŘILOVÁ M, ONDRÁČKOVÁ M, KVAPILOVÁ V, KLESLOVÁ L, ZEMANOVÁ J, DRTINOVÁ E

Katetrizační laborator̆, Karlovarská krajská nemocnice a. s., Karlovy Vary

Úvod: Aktivní vyhledávání pacientů $\mathrm{s}$ úzkostně depresivní symptomatikou zůstává stále Popelkou v primární i sekun- 
dární prevenci ICHS, přestože řada studií nemocných s depresí prokázala jejich více než dvojnásobnou mortalitu (v jakémkoliv věku bez závislosti na sebevraždách). Deprese je provázena řadou neuroendokrinních změn, které predisponují nemocné ke vzniku koronární nemoci, jako je vysoká hladina kortizolu, snížení sekrece růstového hormonu, deficit pohlavních hormonů a zvýšení hladiny noradrenalinu, jejichž důsledkem je vznik inzulinové rezistence. Ta souvisí se vznikem arteriální hypertenze, cukrovky, zvýšené aktivity sympatiku, retencí sodíku a ukládáním vysoce metabolicky aktivního viscerálního tuku, a tudíž i s předčasným vznikem ischemické choroby srdeční (ICHS).

Cil studie: Detekce úzkostně depresivní symptomatiky u nemocných přijatých ke koronarografii pomocí krátké verze dotazníku PHQ 10. Zjistit, zda jsou otázky položené v dotazníku pro nemocné srozumitelné nebo je potřeba spolupráce se sestrou nebo lékařem. Zjistit ochotu nemocných vyplnit dotazník.

Výsledky: Krátká verze dotazníku PHQ vyžadovala zejména u starších nemocných spolupráci se sestrou nebo lékařem (vysvětlení některých otázek). Po vysvětlení smyslu dotazníku nám žádný nemocný neodmítl jeho vyplnění. Tímto dotazníkem jsme detekovali 9 \% těžkých forem deprese s úvahou o sebevraždě. Těmto nemocným byla nabídnuta psychiatrická léčba. Vyplnění jednoduchého dotazníku považujeme za velmi vhodný k aktivnímu vyhledávání depresí ohrožených kardiaků zejména na pracovištích $\mathrm{s}$ katetrizační laboratoří, které ročně ošetřî vysoké procento nemocných. Bez dotazníků zůstane u naprosté většiny deprese nediagnostikována, a tedy i neléčena.

\section{ODLOŽENÝ UZÁVĔR HRUDNÍKU PO OPERACI VROZENÉ SRDEČNÍ VADY U NOVOROZENCŨ*}

VOJTOVIČ P, TLÁSKAL T, SELKO M, GEBAUER R, HUČÍN B, HOSTAŠA J, CHALOUPECKÝ V

Dětské kardiocentrum, FN Motol, Praha

*Práce podpořena grantem IGA MZ NR 9046-3 a VZ FNM 00064203.

Bezprostředně po operaci v mimotělním oběhu však často dochází ke zhoršení funkce srdce a plic pod klinickým obrazem nízkého srdečního výdeje a kapilárního úniku. Nejvíce ohroženou skupinou pacientů jsou novorozenci u nichž indikujeme odložený (sekundární) uzávěr hrudníku, jako jednu z metod prevence nebo léčby těchto kritických stavů. V letech 1991-2006 jsme operovali 506 novorozenců (nov.) s použitím mimotělního oběhu. Metodu odloženého uzávěru hrudníku jsme použili u 205 (40 \%) nov. s váhou - medián 3230 g (1 450-4 650 g) ve věku - medián 7 dní (0-28 dní). Bezprostředně po operaci nebyl hrudník uzavřen u 195 nov. Indikací byla prevence nízkého srdečního výdeje při nestabilní cirkulaci u 75 nov., krvácení z jiných než chirurgických přičin u 47 nov., otok srdce a měkkých tkání (kardiomediastinální disproporce) u 53 nov., dilatace srdce u 15 nov. a plicní edém nebo problematická ventilace u 5 nov. Metodu odloženého uzávěru hrudníku jsme použili u 10 nov., kteří měli hrudník primárně zavřený, ale u nichž bylo nutné urgentně hrudník otevřít pro tamponádu srdeční při krvácení u 6 nov., stav nízkého srdečního výdeje 2 nov., při resuscitaci 2 nov.

$\mathrm{V}$ našem souboru pacientů byl hrudník ponechán otevřený průměrně 3,5 dne (1-52 dní).

Nejčastější komplikací související s odloženým uzávěrem hrudníku byla porucha hojení rány s nutností resutury 11 nov. (6\%). Mediastinitidu jsme zaznamenali u 1 nov. $(0,05 \%)$. Mortalita našeho retrospektivního souboru pacientů byla 15 \% (31 nov.). Nebyla zaznamenána prŕičinná souvislost úmrtí pacienta s uvedenou metodou.
Metoda odloženého uzávěru hrudníku je na našem pracovišti efektivní, bezpečný a technicky nenáročný zákrok. Odložený (sekundární) uzávěru hrudníku je v kardiochirurgii novorozenců život zachraňujícím zákrokem, kterým předcházíme kritickým pooperačním stavưm.

\section{SESTERSKÁ SEKCE}

\section{LÉČEBNÁ HYPOTERMIE U NEMOCNÝCH PO SRDEČNÍ ZÁSTAVĔ}

\section{VOLEJNÍKOVÁ L, ŠVECOVÁ M}

Kardiocentrum - kardioloická jednotka

intenzivní péče, Krajská Nemocnice Liberec, Liberec

Jedním ze způsobů, jak snížit rozsah mozkového postižení u nemocných po oběhové zástavě, je léčebná hypotermie, kdy pokles tělesné teploty na $32-34^{\circ} \mathrm{C}$ po dobu $12-24$ hodin příznivě ovlivní rozsah neurologického poškození.

V kardiologii podle poznatků léčebná „chtěná“ hypotermie v mnoha případech zachránila lidský život. Použití a účinnost na koronární jednotce KNL.

\section{ALTERNATIVNÍ PR̆ÍSTUPY IMPLANTACE KARDIOSTIMULAČNICCH ELEKTROD PRO BIV STIMULACI}

VOPÁLKA R, TÁBORSKÝ M, ČERNÝ Š, TICHÁČEK L

Kardiologické oddělení,

Nemocnice Na Homolce, Praha

Úvod: V současné době se stává BiV stimulace stále více uživanou metodou léčby srdečního selhání a přesto, že instrumentárium pro implantace elektrod se stále zdokonaluje, existují případy, kdy není možno stimulační elektrody umístit klasickou transvenózní technikou. Lze použít bud' některou endoskopickou techniku nebo využít některé alternativy kardiochirurgického prrístupu.

Metoda: Na našem kardiochirurgickém pracovišti používáme dva základní př́istupy. Pro implantaci pouze levokomorové epikardiální elektrody používáme parciální torakotomii a při implantaci kompletního systému epikardiálních elektrod pro BiV stimulaci uživáme sternotomii, která však bývá vždy spojena s dalším kardiochirurgickým výkonem. Cílem námi zpracované studie je porovnání implantačních parametrů (napětový a proudový stimulační práh, přechodová impedance a amplituda vlny $\mathrm{R}$ a P) u stimulačních elektrod epikardiálních a transvenózních. Pro uvedenou studii jsme použili aktivní elektrodu SJM 1688T (umístěnou do pravé síně a komory) a jako levokomorovou elektrodu Medtronic Attain LV nebo SJM QuickSite. Epikardiální bipolární elektrody pak Medtronic CapSure Epi v délkách $60 \mathrm{~cm}$ a $35 \mathrm{~cm}$.

Výsledky: Pro tuto studii jsme transvenózním přístupem implantovali celkem 20 elektrod u osmi pacientů a epikardiálně také 20 elektrod u 12 pacientů. Měření implantačních parametrů jsme prováděli př́istrojem ERA 3000. Střední hodnoty a směrodatné odchylky naměřených hodnot byly zpracovány tabelárně i graficky jak pro transvenózní typ, tak i pro epikardiální modely elektrod.

Závěr: $Z$ uvedených výsledků lze učinit závěr, že obě alternativy implantace stimulačních elektrod pro BiV stimulaci jsou vhodné a sledované implantační parametry nevykazují statisticky významných rozdílů. Ty jsme sledovali pouze u parametru impedance, která byla statisticky významně vyšší u epikardiálních elektrod. 
OPTIMALIZACE EFEKTIVITY SRDEČNÍ HEMODYNAMIKY

\section{VOPÁLKA R, TÁBORSKÝ M}

Kardiologické oddělení, Nemocnice Na Homolce, Praha

Ve svém sdělení představuji novou metodu vedoucí $\mathrm{k}$ otimalizaci hemodynamického efektu práce srdce. Jedná se o technologii modulace srdeční kontraktility - CCM. Tato modulace se provádí pomocí přesně definovaného signálu, který se vytváří ve speciálním generátoru. Signál je aplikován v období absolutní refrakterní periody. Tento signál není aplikován v př́ipadě srdečních tachyarytmií.

Elektrodový systém je tvořen jednou RA elektrodou a dvěmi komorovými elektrodami. Ty jsou umístěny tak, že jedna je umístěna na septu RV a druhá na laterální stěně RV. Tyto elektrody jsou od sebe vzdáleny minimálně $2 \mathrm{~cm}$ $z$ důvodu lepší efektivity terapie a dále $z$ důvodu lepší funkce bezpečnostního algoritmu. Efektivní umístění elektrod je verifikováno pomocí Millarova tlakového katetru, který snímá hodnoty $\mathrm{dP} / \mathrm{dt}$. Katetr je umístěn v levé komoře cestou femorální tepny. Generátor CCM signálu necháme funkční po dobu 5-10 min a v př́padě zlepšení hodnot $\mathrm{dP} / \mathrm{dt}$ alespoň o $5 \%$, považujeme polohu elektrod za vhodnou. Vzhledem $\mathrm{k}$ tomu, že CCM signál je energeticky poměrně náročný, je generátor možno dobíjet $\mathrm{v}$ průběhu doby života baterie bez nutnosti explantace. K transportu dobíjecí energie slouží speciální cívka, která je umístěna po obvodu generátoru. Tato cívka komunikuje s druhou, která se umístí nad generátor CCM signálu. Implantovaný generátor je možno programovat pomocí speciálního programovacího systému, který je tvořen přenosným počítačem a dále analyzační jednotkou, která slouží pro vyhodnocování jak vysílaného signálu, tak i intrakardiálního elektrogramu ze všech naimplantovaných elektrod.

Závěr: V závěru sdělení uvádím kasuistiku jednoho pacienta ze třech, které byli v rámci výzkumného úkolu implantováni na našem pracovišti. Na základě našich zkušeností i výsledků ze zahraničních studií lze říci, že metoda je efektiní a pacientům významným zpo̊sobem zvyšuje kvalitu života.

\section{KLINICKÁ MANIFESTACE RECIDIVY MYXOMU LEVÉ SÍNĚ SRDEČNÍ ČASNĔ PO KARDIOLOGICKÉ KONTROLE S NEGATIVNÍM NÁLEZEM ECHO}

\section{VOPELKOVÁ $J$}

Karlovarská krajská nemocnice a. s., Karlovy Vary

Ưvod: Myxom je udáván jako nejčastější srdeční nádor. Incidence je ovlivněná věkem i pohlavím, jsou známé i dědičné formy myxomu. Myxom je tumor vyrůstající $z$ endokardu, řadí se mezi benigní nádory. Topicky postihuje myxom nejčastěji levou síň srdeční, méně častěji pravou a asi jen v $5 \%$ levou či pravou komoru. Terapie myxomu srdce chirurgická. V literatuře jsou zaznamenány recidivy srdečního myxomu v rozmezí 3 měsíců až 14 let.

Kasuistika: Pacientka, stáří 73 let. V roce 2003 vyšetřovaná pro proběhlou TIA, s nálezem myxomu levé síně srdeční. Pac. byla operovaná $\mathrm{v}$ tomtéž roce Diagnóza myxomu ověřena histologicky, popsán solitární útvar $8 \times 5 \times 5 \mathrm{~cm}$ tenkou stopkou přisedlý $\mathrm{k}$ mezisíňovému septu. Následně byla pac. sledovaná ambulantně na kardiologické ambulanci, zpočátku $4 \times$ ročně, poté po 6 měsících.

Po operaci se pacientka plně rehabilitovala. Při kardiologických kontrolách bez významného patologického nálezu. 3. 3. 2006 pravidelná kontrola, pac. bez akutních obtíží, ná- lez ECHO s chron. mitrální regurgitací hemodynamicky nevýznamnou, bez nálezu nitrosrdečních útvarů (stacionární stav). 8. 8. 2006 pacientka hospitalizovaná na neurologickém oddělení pro proběhlou TIA. ECHO s nálezem nitrosrdečního útvaru levé síně. 21. 8. 2006 operovaná na Oddělení kardiovaskulární chirurgie Kardiovaskulárního centra pro dospělé FN v Motole. Histologicky opět potvrzen myxom $3 \times 3 \times 3 \mathrm{~cm}$, široce přisedlý $\mathrm{k}$ septu levé síně. Pooperačně bez komplikací, rychlá pooperační rehabilitace.

Závěr: Srdeční myxom je onemocnění, které může být klinicky němé, může se ale manifestovat četnými komplikacemi. Při sledování pac. s anamnézou operačně odstraněného myxomu srdce je třeba myslet na možnost časné recidivy již několik měsíců po operačním zákroku, či s pozdními recidivami v odstupu i mnoha let. Frekvenci sledování je třeba přizpůsobit možnosti rychlého nárůstu myxomu v řádu několika měsíců.

\section{ECHOKARDIOGRAFICKÉ A KLINICKÉ SLEDOVÁNÍ PACIENTŮ STARŠÍCH 75 ROKŮ S VÝZNAMNOU MITRÁLNÍ INSUFICIENCÍ (3. A 4. STUPNĚ), KTER̆İ JSOU KONTRAINDIKOVÁNI KE KARDIOCHIRURGICKÉ OPERACI NEBO JI ODMÍTAJÍ}

VYMĚTAL P

Kardiologická ambulance, Uničov

Soubor: Soubor kasuistik 8 pacientů.

Metodika: Soubor 8 pacientů v jednoročním sledování klinických (AP, NYHA, tolerance zátěže a extrakardiální limitace výkonnosti) a echokardiografických parametrů (stupeň MR, morfologie mitrální chlopně, parametry LK a LS, plicní hypertenze, přidružené chlopenní vady).

Výsledky: U každého pacienta hodnoceny klinické, echokardiografické parametry, současná medikace a důvod konzervativního postupu, dále je hodnoceno i riziko př́padné kardiochirurgické operace.

Závěr: Práce hodnotí skupinu pacientů starších 75 roků s pozdně diagnostikovanou významnou mitrální insuficiencí (3. a 4. stupně), u kterých je kardiochirurgická operace bud’ kontraindikována nebo je odmítána pacienty.

\section{VZTAH PULSNÍHO TLAKU, NEMOCNIČNÍ MORTALITY A KARDIOVASKULÁRNÍ MORBIDITY U PACIENTŮ PR̆IJÍMANÝCH NA INTERNÍ ODDĚLENİ*}

VYSOČANOVÁ P, ŠPINAR J, KUBKOVÁ L, PRYMUSOVÁ K, SEPŠI M, DVOŘÁKOVÁ E

Interní-kardiologická klinika, FN Brno, Brno

*Podpořeno grantem IGA MZ ČR 1A 8605-5.

Hodnota pulsního tlaku (PP) je uznávána jako rizikový faktor kardiovaskulárních chorob a její zvýšení je indikátorem snížení poddajnosti aorty a velkých tepen a známkou aterosklerózy. Hodnota PP v sobě zahrnuje jak dopad zvýšeného systolického krevního tlaku (TKs), tak stále diskutovaný možný negativní vliv snížení diastolického tlaku (TKd). Hodnotili jsme, zda existuje vztah mezi PP a aktuálním zdravotním stavem nemocných přijímaných na interní oddělení, přítomností kardiovaskulárních onemocnění a současně hospitalizační mortalitou.

V naší práci jsme analyzovali soubor 3800 pacientů, hospitalizovaných na naší klinice v průběhu roku 2005, jejichž 
údaje byly zadány v naší databázi. Tento soubor jsme rozdělili na 10 skupin podle hodnoty PP, získané jako rozdíl TKs a TKd při přijetí pacienta, od 30 do $110 \mathrm{~mm} \mathrm{Hg.} \mathrm{Sledovali}$ jsme věk, nemocniční mortalitu, výskyt závažných onemocnění jako je ischemická choroba srdeční (ICHS), hypertenze, chronické srdeční selhání (CHSS), cévní mozkové př́ihody (CMP), či diabetes mellitus (DM), dále parametry vypovídající o aktuální zdravotním stavu nemocného - hladinu hemoglobinu (HGB), kreatinin, hmotnost či ejekční frakci (EF).

Nejvyšší mortalita byla ve skupině s PP 40 mm Hg a nižším a vyšším než $100 \mathrm{~mm}$ Hg. Ve skupinách s hodnotou PP 40 až 110 a více $\mathrm{s}$ narůstajícím PP stoupá věk, klesá váha, hodnota HGB mírně klesá a kreatinin stoupá. Přítomnost všech kardiovaskulárních onemocnění jednoznačně vzrůstá s hodnotou PP.

Nemocniční mortalita, a rovněž výskyt kardiovaskulárních onemocnění, měly charakter křivky J. Zvýšená hodnota PP při přijetí je spojena s vyšším výskytem kardiovaskulární onemocnění, s vyšším věkem a zhoršeným aktuálním zdravotním stavem. Zvláštní pozornost zasluhuje skupina s nízkým PP - pod 40 mm HG, jejíž nemocniční mortalita i morbidita je nejvyšší a aktuální zdravotní stav nejhorší.

\section{FAKTORY OVLIVŇUJÍCÍ HODNOTY NT-prOBNP U STARŠÍ POPULACE S NORMÁLNÍ SYSTOLICKOU FUNKCÍ LEVÉ KOMORY BEZ ZNÁMEK SRDEČNIIHO SELHÁNİ*}

VYTISKA M, KALA P, BOČEK O, JEŘÁBEK P, NEUGEBAUER P, POLOCZEK M, PAŘENICA J, LUDKA O, ŠPINAR J

Interní-kardiologická klinika,

FN Brno Bohunice, Brno

*Práce vznikla s podporou grantu č. 8481-3 IGA $M Z \check{C} R$

Úvod: Zvýšené hodnoty NT-proBNP dobře korelují s funkční třídou NYHA, ejekční frakcí levé komory (LK) a prognózou u pacientů se srdečním selháním (SS) v důsledku systolické dysfunkce levé komory. U pacientů bez syndromu SS je zvýšení NT-proBNP považováno za prognosticky významné, pokud jde o mortalitu a výskyt kardiovaskulární př́ihody, a to bez ohledu na funkci (LK).

Cílem práce: Poukázat na faktory ovlivňující hodnoty NT-proBNP u starší populace bez syndromu SS s normální systolickou funkcí LK.

Metody: Soubor tvořilo 267 elektivních pacientů ve věku 50-82 let, průměr 62 let, $\mathrm{z}$ toho $47 \%$ žen. Zařazení pacienti byli hemodynamicky stabilní, bez anamnézy infarktu myokardu a s normální systolickou funkcí LK. Ve stejný den byly provedeny: levostranná srdeční katetrizace, odběr NT-proBNP a echokardiografické vyšetření srdce. Diabetes, hypertenze, ICHS, obezita, věk, pohlaví, medikace a enddiastolický tlak v levé komoře byly vybrány jako faktory s možným dopadem na hladinu NT-proBNP. Z ECHO-parametrů jsme hodnotili velikost levé síně, indexovanou masu LK a poměr $\mathrm{E} / \mathrm{Ea}$.

Výsledky: Střední hodnota NT-proBNP byla $112,5 \mathrm{pg} / \mathrm{ml}$ (min. 11; max. 1 943). Z celkového počtu vyšetřených pacientů mělo zvýšené hodnoty NT-proBNP (>125pg/ml) 119 pacientů ( $45 \%)$. $Z$ výše uvedených faktorů měli věk a pohlaví významný dopad na hladinu NT-proBNP $(p>0,01)$, obezita měla trend $\mathrm{k}$ její ovlivnění $(p=0,06)$. Z ECHO-parametrů měly těsný vztah $\mathrm{k}$ naměřené hodnotě NT-proBNP velikost levé síně a poměr $\mathrm{E} / \mathrm{Ea}(p<0,01)$.

Závěr: Hladina NT-proBNP je výsledkem činnosti kardiorenální osy. Její aktivita pravděpodobně nezávisí pouze na stavu hemodynamiky, ale i na mnoha dalších faktorech se vztahem ke kardiovaskulárnímu aparátu.

\section{COMPARISON OF TWO METHODS TO IDENTIFY COMPLEX FRACTIONATED ATRIAL ELECTROGRAMS}

WICHTERLE D, KREMEN V, ČIHÁK R, PEICHL P, MLČOCHOVÁ H, KAUTZNER J

Department of Cardiology, Institute for Clinical and Experimental Medicine, Faculty of Electrical Engineering. Czech Technical University, Department of Cardiology, Institute for Clinical and Experimental Medicine, Prague

Purpose: Complex fractionated atrial electrograms (CFAEs) represent the electrophysiologic substrate for atrial fibrillation (AF). Progress in signal processing algorithms to identify CFAEs sites is crucial for the development of AF ablation strategies.

Methods: We compared two methods to discriminate atrial electrograms (A-EGMs) with different degree of fractionation. First method (M-1) assessed the average interval between discrete A-EGM spikes detected based on peak-to-peak voltage sensitivity, signal width and refractory interval criteria (algorithm previously implemented in commercially available electroanatomic mapping system). Second method (M-2) employed simple non-parametric description of distribution of peak-to-peak atrial signal differences. Head-to-head comparison of both methods was performed using representative set of $1.5 \mathrm{~s}$ A-EGMs $(\mathrm{n}=113)$ ranked by an expert into 4 categories: 1 - organized atrial activity; 2 - mild; 3 - intermediate; 4 - high degree of fractionation.

Results: Although input parameters of M-1 method were comprehensively optimized (peak-to-peak sensitivity of 0.02 $\mathrm{mV}$, signal width of $8 \mathrm{~ms}$, and refractory interval of $14 \mathrm{~ms}$ ) with respect to particular experimental dataset, discriminative power of M-1 method to detect CFAEs was not superior to that provided by the newly introduced M-2 algorithm. Correlations between A-EGM categories and M-1 and M-2 indices of fractionation are shown in the Figure.

Conclusions: Novel method of A-EGMs classification offers operator-independent definition of electrogram complexity. It may easily be incorporated into real-time mapping systems to facilitate the CFAEs identification and guide the $\mathrm{AF}$ substrate ablation.
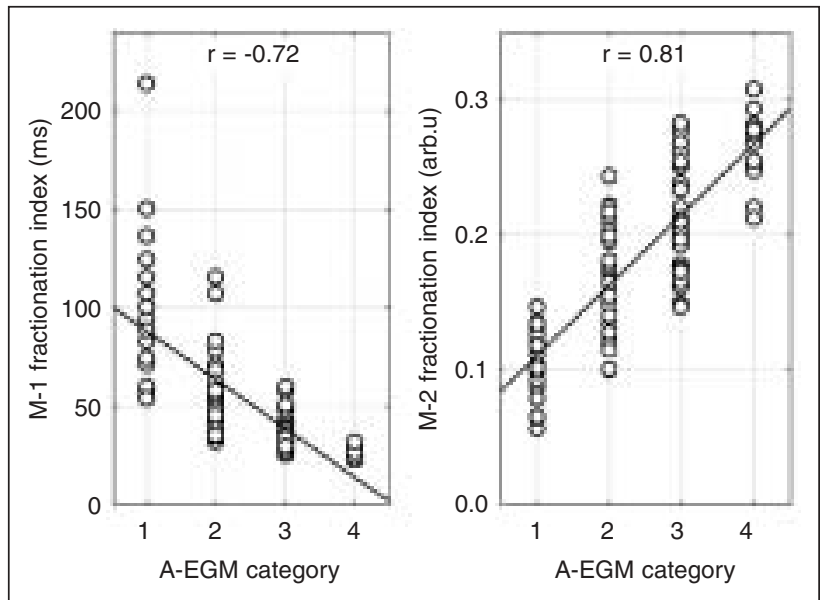

\section{COMPOSITE HOLTER-BASED RISK STRATIFIER IDENTIFIES LOW-RISK POSTINFARCTION PATIENTS WITH LEFT VENTRICULAR DYSFUNCTION}

WICHTERLE D, LAROVERE M, SCHWARTZ P, CAMM J, MALIK M

Department of Cardiology, Institute for Clinical and Experimental Medicine, Prague, 
Division of Cardiology, Fondazione "S. Maugeri" IRCCS, Montescano, Department of Cardiology, Policlinico S. Matteo IRCCS and University of Pavia, Pavia, Italy, Cardiac and Vascular Sciences, St. George's Hospital, University of London, London, UK

Background: Implantable cardioverter defibrillator (ICD) therapy has recently been expanded for the prevention of sudden cardiac death based on the results of SCD-HeFT trial. We assessed the hypothesis that combination of Holter-based risk predictors may identify low-risk postinfarction patients with LV dysfunction unlikely to benefit from ICD therapy.

Methods: Heart rate turbulence after ventricular and atrial premature beats, short-term scaling exponent alfa, mean deceleration magnitude, and prevalent low-frequency oscillation of heart rate were calculated from 24-h Holter recordings in patients with $\mathrm{LVEF} \leq 35 \%$ in the population of EMIAT and ATRAMI trials. Composite risk predictor based on combination of risk factors, which were individually dichotomized to achieve high negative predictive value for cardiac events, was defined in EMIAT and validated in ATRAMI population. Cox proportional hazard survival analysis was performed for both populations with mean follow-up of 22 months.

Results: Total 143/444 (32.2\%) and $71 / 177$ (40.1\%) patients belonged to low-risk group in EMIAT and ATRAMI trial, respectively. In low-risk group, only 5 cardiac (2 arrhythmic, 3 non arrhythmic) deaths were observed in EMIAT and 2 events ( 1 nonfatal cardiac arrest, 1 non-arrhythmic death) were observed in ATRAMI.

Conclusion: Holter-based risk stratification can identify a significant proportion of postinfarction patients with $\mathrm{LV}$ dysfunction who are at very low risk (< 1\%/year) of preventable death. of DF. This artificial signal is fed into the CARTO system (Biosense Webster) as a bogus intracardiac lead that is manually annotated during left atrial mapping. In such way, colour-coded electroanatomical map of DF is directly created.

Results: We investigated 10 patients with paroxysmal/ persistent AF. In agreement with previous studies, we documented hierarchical distribution of DF reflecting one or more left atrium mother rotors. In case of paroxysmal AF, single driver within a pulmonary vein antrum was usually identified with centrifugal DF gradient (Figure). In persistent AF,

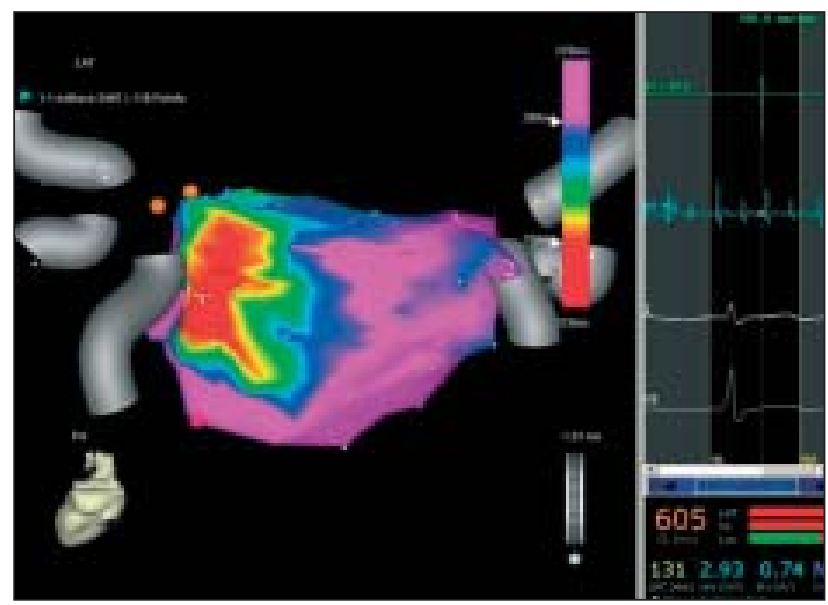

we observed more disperse distribution of sites with high-frequency activity with predilection at interatrial septum.

Conclusions: Real-time dominant frequency mapping of atrial fibrillation is technically feasible. This may have a practical value for guiding the RF ablation of arrhythmogenic substrate, particularly in persistent AF.

Tabulka k abstraktu MUDr. Wichterleho: Composite ...

\begin{tabular}{|c|c|c|c|c|}
\hline & Low-risk group & Rest of population & Hazard ratio for low-risk group & Log rank $p$ \\
\hline EMIAT $(\mathrm{n}=444)$ & $5 / 143(3.3 \%)$ & $58 / 301(19.3 \%)$ & 0.16 & 0.0001 \\
\hline ATRAMI $(\mathrm{n}=177)$ & $2 / 71 \quad(2.8 \%)$ & 16/106 (15.1\%) & 0.18 & 0.02 \\
\hline
\end{tabular}

\section{REAL-TIME DOMINANT FREQUENCY MAPPING OF ATRIAL FIBRILLATION - FEASIBILITY STUDY} WICHTERLE D, PECA M, ČIHÁK R, ŠIMEK J,
BULKOVÁ V, HOLDOVÁ K, KAUTZNER J

Department of Cardiology, Institute for Clinical and Experimental Medicine, Faculty of Electrical Engineering, Czech Technical University, 2nd Department of Medicine, General University Hospital and 1st Medical School, Prague

Purpose: Analysis of local dominant frequency of atrial fibrillation (AF) identifies the sites of high-frequency activity with acceptable temporal and spacial stability that represent the substrate for arrhythmia perpetuation.

Methods: We developed a system that analyzes bipolar mapping signal sampled at $1 \mathrm{kHz}$, digitally filtered (infinite impulse response, high-pass $30-40 \mathrm{~Hz}$ ), and rectified. Obtained signal envelope is processed by discrete Fourier transform applied to 3 Hanning-weighted 1-second segments with $50 \%$ overlap. Dominant frequency (DF) is calculated by autocorrelation function (inverse Fourier transform) in order to suppress the impact of higher harmonic spectral components. The system detects QRS complexes as reference and generates voltage impulses with the delay relative to QRS reference and proportional to the instantaneous value

\section{PREVALENCE A KLINICKÁ CHARAKTERISTIKA REZISTENTNÍ HYPERTENZE}

WIDIMSKÝ J jr., PIKUS T, HOLAJ R, ZELINKA T, ŠTRAUCH B, PETRAK O

\section{III. interni klinika, VFN a 1. LF UK, Praha}

Cíl práce: Posoudit výskyt skutečně rezistentní hypertenze /true resistance/ v preselektované populaci nemocných s těžkou hypertenzí doporučených do Centra pro hypertenzi.

Materiál a metodika: Vyšetřili jsme za hospitalizace konsekutivně 500 nemocných s těžkou hypertenzí (průměrný věk $51 \pm 10$ roků), kteří byli odesláni do Centra s podezřením na sekundární hypertenzi. U všech pacientů bylo provedeno fyzikální a komplexní laboratorní vyšetření se zřetelem na možné prŕíčiny hypertenze.

Výsledky: Ve vyšetřeném vzoku nemocných jsme zjistili skutečně rezistentní hypertenzi u 54 nemocných průměrného věku $55 \pm 8$ roků, $z$ toho u 29 žen. Prevalence skutečně rezistentní hypertenze (krevní tlak v domácím prostředí nad 135/85 mm Hg a/nebo 24 hod. TK nad 130/80 mm Hg při nejméně trojkombinaci antihypertenziv včetně diuretik) činila $11 \%$.

Průměrná známá délka trvání hypertenze činila $16 \pm 9$ roků. Klinický krevní tlak při vstupním vyšetření činil 189 
$\pm 23 / 103 \pm 18$ mm Hg, BMI $31 \pm 5.91$ \% nemocných užíva-

lo čtyř a více kombinaci antihypertenziv.

Průměrná hodnota sérového kreatininu byla $90 \pm 28 \mu \mathrm{mol} / \mathrm{l}$, plazmatické reninové aktivity $1,3 \pm 1,9 \mathrm{ng} / \mathrm{ml} / \mathrm{hod}$. a plazmatického aldosteronu $139 \pm 101 \mathrm{pg} / \mathrm{ml}$.

Výskyt poškození KV cílových orgánů byl následující: aterogenní změny karotid $68 \%$, koncentrická remodelace levé komory (LKS) ve $43 \%$, hypertrofie LKS ve $31 \%$.

Závěr: Skutečně rezistentní arteriální hypertenze (RH) není v klinické praxi vzácná a je doprovázena vysokým výskytem poškození cílových orgánů. RH je stejně častá u nízko-, normo- i hyperreninové populace hypertoniků.

\section{MODERN IMAGING OF CARDIAC MASSES*}

WOLF J, DOBŠÁK P, SIEGELOVÁ J,

BARTHEZ O, EICHER J

Centre de Cardiologie Clinique et Interventionelle, Hopital du Bocage, Dijon, France, Klinika funkční diagnostiky a rehabilitace, FN U sv. Anny, Brno

*Support: MSM0021622402.

Before the era of imaging techniques, the diagnosis of cardiac masses was extremely difficult and often not made antemortem.

With the advence of modern imaging modalities such as echocardiography (TTE, TEE) computed tomography (CT) and MRI, direct visualisation of this pathology has become a reality. Although echocardiography is still the first line modality used, imaging is often subobtimal especially in non echogenic patients. Computed tomography and MRI are second line imaging modalities that have the ability to overcome the limitations of echocardiography.

The major aim of this brief revue is to highlight the role of MRI in the detection and differenciation of cardiac masses (primary and secondary tumors, non tumoral masses, variants of normal anatomy ...), comparing this technique with the other imaging techniques.

\section{EXTRAKORPORÁLNÍ ELIMINAČNÍ METODY - NOVÁ MODALITA V LÉČBĔ CHRONICKÉ KONČETINOVÉ ISCHEMIE*}

ZAJÍC J, BLÁHA M, BLÁHA V, MALÝ R

Klinika gerontologická a metabolická, II. interní klinika, I. interní klinika, FN Hradec Králové a LF UK, Hradec Králové

*Práce byla podporována výzkumnými projekty IGA MZ ČR č. 8505-3, č. 9103-4, č. 9118-3, MZO 00179906, MSM 0021620820.

Úvod: Klinické důsledky aterosklerózy jsou vedoucími příčinami morbidity a mortality $\mathrm{v}$ průmyslově vyspělých zemích. Část nemocných vykazuje nedostatečný efekt konvenční léčby. Jedná se např́klad o ischemickou chorobu srdeční a poruchy cévního zásobení končetin. Průběh onemocnění lze stabilizovat či dokonce zlepšit zásahem do oblasti mikrocirkulace.

Metodika a soubor: Použili jsme vlastní modifikaci hemoreoferetické léčby kaskádovou metodou. Plazma prostá buněčných elementů po vysokootáčkové centrifugaci pomocí separátoru (Cobe-Spectra) je proháněna „druhým stupněm” - filtrem. Jako sekundární filtry jsme použili filtry Evaflux 4A a 5A (Kuraray). Průtok plazmy je kontinuální, antikoagulace prováděna heparinem, základní množství zpracovávané plazmy činí 1,5násobek tělního objemu. Efektivita metody byla dosud ověřována na souboru 12 nemocných, který tvořili: a) 3 nemocní s těžkou formou heterozy- gotní familiární hypercholesterolemie, kde standardní léčba nebyla úspěšná, b) 1 nemocný s homozygotní formou familiární hypercholesterolemie, c) 6 nemocných s věkem podmíněnou makulární degenerací sítnice (ARMD = age-related macular degeneration), d) 2 s nemocní s kritickou chronickou končetinovou ischemií.

Výsledky: Velikost pórů filtru umožňuje záchyt statisticky významného množství LDL-cholesterolu, lipoproteinu(a), dále dochází ke snížení hladiny fibrinogenu, alfa-2-makroglobulinu. Série léčebných procedur byla dosud ukončena u prvních dvou pacientů s kritickou chronickou končetinovou ischemií.

Závěr: Zavedená modifikace hemoreoferézy má prokazatelné účinky na zlepšení reologických parametrů u nemocných s chronickou končetinovou ischemií. Je technicky dobře proveditelná. Dosud jsme nezaznamenali závažnější klinické komplikace.

\section{LÉČBA SRDEČNÍ SLABOSTI PACIENTA S MORBIDNÍ OBEZITOU}

ZAJÍČEK P, HOLUBOVÁ L, LIČENÍKOVÁ-BUBLÍKOVÁ M, ŠTĚPÁNKOVÁ J, WIESNER R, PRODĚLAL P

Interní oddělení,

Nemocnice Valašské Meziřičí, a. s., Valašské Meziříčí

Autoři předkládají kasuistiku věnovanou problematice léčby 52letého muže s morbidní obezitou (váha $217 \mathrm{~kg}$, BMI $67 \mathrm{~kg} / \mathrm{m}^{2}$ ) hospitalizovaného na lůžko jednotky intenzivní péče $\mathrm{v}$ těžkém kardiorespiračním selhání. $\mathrm{V}$ následujícím průběhu se komplexní péčí kardiologa a obezitologa podařilo klinický stav zkompenzovat a postupně v následujících měsícich i výrazně redukovat původní hmotnost pacienta.

\section{SESTERSKÁ SEKCE}

\section{PERIOPERAČNÍ PÉČE O PACIENTY $S$ DIABETES MELLITUS PODSTUPUJÍCÍCH KARDIOCHIRURGICKOU OPERACI}

\section{ZÁMEČNÍKOVÁ J, SVOZILOVÁ D, BEZDĚKOVÁ M.}

Kardiochirurgická klinika, FN Olomouc a LF UP, Olomouc

Nemocní s diabetem patří do skupiny nemocných podstupujících srdeční operaci, kteří jsou ohroženi vyšším rizikem pooperačních komplikací, jako například cévní mozkovou př́ihodou, poruchou hojení ran a sklonem $\mathrm{k}$ infekčním komplikacím.

Tématem sdělení je jak předoperační příprava diabetiků, s cílem předcházet možným komplikacím zlepšením kompenzace diabetu, tak pooperační management zahrnující řadu léčebných modalit, jako jsou např. dietní opatření, intenzifikovaný inzulinový režim, resp. kontinuální inzulinoterapie.

\section{PRIMÁRNÍ HYPERALDOSTERONISMUS JAKO PR̆ÍC̆INA MALIGNÍCH ARYTMIÍ*}

ZELINKA T, HOLAJ R, VANČURA V,
MELENOVSKÝ V, WIDIMSKÝ J jr.

III. interní klinika, VFN a 3. LF UK, Klinika kardiologie, IKEM, Praha

*S podporou grantu IGA ČR č. 8155-5.

Hypokalemie se $\mathrm{v}$ poslední době díky časnějšímu záchytu primárního hyperaldosteronismu (PA) vyskytuje méně čas- 
to, přesto může být vedoucím příznakem onemocnění a dokonce i příčinou závažných arytmií.

Uvádíme kasuistiky 3 pacientů, u nichž se PA manifestoval maligními arytmiemi.

Případ č. 1: 58letá pacientka sledovaná pro hypertenzi a hypokalemii byla přijatá po resuscitaci. Při přijetí zjištěna hypokalemie $1,8 \mathrm{mmol} / 1$ a tachykardie torsade de pointes (TdP). Následně potvrzen PA (tabulka) a provedena adrenalektomie vpravo s úpravou všech parametrů.

\begin{tabular}{lccc}
\hline \hline Pacient & $\begin{array}{c}\text { Kalemie } \\
\text { (mmol/1) }\end{array}$ & $\begin{array}{c}\text { Plazmatická reninová } \\
\text { aktivita }(\boldsymbol{\mu g} / \mathbf{1 / h})\end{array}$ & $\begin{array}{c}\text { Plazmatický } \\
\text { aldosteron (ng/1) }\end{array}$ \\
\hline 1 & 1,8 & 0,6 & 235 \\
2 & 2,5 & 0,7 & 528 \\
3 & 3,1 & 0,25 & 915 \\
\hline \hline
\end{tabular}

Případ č. 2. 42letá pacientka byla zresuscitována pro fibrilaci komor při hypokalemii $2,5 \mathrm{mmol} / 1$. Posléze byla pacientka přeložena bez údaje o hypokalemii, kde byl implantován kardioverter-defibrilátor (ICD). 5 let po implantaci ICD byl přidán $\mathrm{k}$ terapii indapamid a pacientka byla přijata pro recidivu TdP při kalemii $2,1 \mathrm{mmol} / 1$. V dalším vyšetření potvrzen PA (viz tabulka) a provedena adrenalektomie vpravo s normalizací laboratorních nálezů.

Případ č. 3: 50letý pacient s metabolickým syndromem byl přjiatý po synkopě s hypokalemií 3,1 mmol/1. Následně byl resuscitován pro fibrilaci komor s následnými arytmiemi TdP. I s ohledem na dlouhý interval QT implantován ICD; 3,5 roku po implantaci ICD byl přijat pro recidivu komorových arytmií při viróze a terapii thiazidy při hypokalemii. I zde byl prokázán PA (tabulka). Zatím je pacient léčen konzervativně vzhledem k normálnímu nálezu na CT.

Závěr: Domníváme se, že by měla být každá závažnější hypokalemie, která se vyskytne u pacientů se závažnými arytmiemi, dovyšetřena s ohledem na možnost diagnostiky léčitelných stavů jako je např́iklad PA.

\section{ČASNÁ POSTHOSPITALIZAČNÍ REHABILITACE KARDIAKŮ V OKRESNICCH NEMOCNICÍCH, ANO ČI NE?}

ZEMAN K, GISTINGER T, MRÓZEK V, GOLUCH A, PAVLAS I, TALAFA V, KOLOŠOVÁ R

Interní oddělení, Rehabilitační oddělení, Nemocnice Frýdek-Místek, Frýdek-Mistek

Cíl: Analyzovat dosavadní výsledky, snaha o optimalizaci provozu s posouzením možnosti dalšího rozšiř́ení.

Soubor: Od dubna 2004 do prosince 2006 prošlo tříměsíčním programem 87 kardiaků ve věkovém rozmezí 41-77 let. Jednalo se o pacienty hospitalizované pro AKS a jedince po kardiochirurgických operacích. PCI $69 \%$, CABG $21 \%$, zákrok na chlopních $4 \%$, konzervativní postup v $10 \%$ případů. Inkompletní revaskularizace $62 \%$, EF 20-60 \%.

Hodnocené parametry: Přidružená onemocnění: hypertenze 94 \%, HLP 95 \%, DM $35 \%$, obezita $51 \%$, arytmie 20 \%, CHSS $56 \%$, ICHDKK 4 \%, stp. CMP $7 \%$, kuřáci $10 \%$, bývalí kuřáci $22 \%$.

Vstupní farmakoterapie: ASA či warfarin $100 \%$, ACE-I $77 \%$, BB $88 \%$, statiny $86 \%$, fibráty $22 \%$, žádné hypolipidemikum $13 \%$, diuretika $51 \%$, nitráty $37 \%$, Ca antagonista $28 \%$, AA $6 \%$, digitalis $1 \%$, trimetazidin $6 \%$. Úprava farmakoterapie u $19 \%$ jedinců.

Předčasné ukončení programu: 15 \%, vůbec nenastoupilo $14 \%$ zařazených.

Výkonnost: Zvýšena u 55 \%, snížena u 11 \%, nezměněna u $34 \%$ rehabilitovaných.
Komplikace: Závažné 0 \%, hlášené u 37 \% (dušnost, bolesti na hrudi, subkolapsy, hypoglykemie, hypotenze, hypertenze, vertigo, synkopa, bolesti kloubů, infekt, otoky DKK).

Nutnost časné rekoronarografie s PCI: ve $4 \%$ případi̊.

Závěr: Zavádění takovýchto programů je prospěšné i v menších nemocnicích. Při zachování doporučených kontraindikací jde o programy bezpečné, nenákladné a pacienty velice kladně vnímané. Našim záměrem je zařazovat do budoucna více zejména rizikovějších pacientů se závažnějším kardiálním postižením.

\section{DIASTOLICKÁ FUNKCE LEVÉ KOMORY U HYPERTROFICKÉ KARDIOMYOPATIE - VLIV GRADIENTU VE VÝTOKOVÉM TRAKTU}

\section{ZEMÁNEK D, LINHARTOVA K, TIŠEROVÁ M, VESELKA J}

Kardiologická klinika, FN Motol, Praha

Úvod: Hypertrofická kardiomyopatie (HCM) je charakterizována hypertrofií myokardu srdce. Echokardiograficky je již časně přítomna také porucha diastolické funkce, která je dána strukturálním postižením. Naším cílem je prokázat vliv obstrukce v LVOT, jako dalšího faktoru vedoucího $\mathrm{k}$ poruše diastolické funkce.

Metoda: V našem souboru s HCM s obstrukcí po provedené septální alkoholové ablaci jsme retrospektivně porovnali skupinu pacientů bez reziduálního gradientu v LVOT se skupinou pacientů s významným gradientem v LVOT. Vylučovacím kritériem byla souběžná př́itomnost jiného srdečního onemocnění (ICHS, chlopenní vady, implantace PM a čas menší než 1 rok od výkonu). Skupinu A pacientů bez gradientu ve LVOT tvořilo 11 nemocných $(6$ mužů, 5 žen, věk $53,9 \pm 11,3)$, skupinu B s významným reziduálním gradientem tvořilo 8 pacientů ( 3 muži, 5 žen, věk 56,3 $\pm 9,7$ ). $\mathrm{U}$ těchto pacientů jsme hodnotily tyto parametry (velikost LK, hypertrofie LK, ejekční frakce LK, gradient v LVOT v klidu a po provokaci NTG, diastolické parametry levé komory E, A, E', A', DCT, IVRT).

Výsledky: Skupiny pacientů se statisticky signifikantně nelišily v žádném parametru LK (EDD 44,6 \pm 3,7 u skupiny A proti $42,1 \pm 2,3$ u skupiny $B$, šíře septa $18,4 \pm 2,8$ versus $21,1 \pm 4,2$, či zadní stěny $14,4 \pm 1,1$ versus $14,9 \pm 1,4)$. $Z$ diastolických parametrů levé komory se skupiny statisticky významně lišily pouze u velikosti vlny E' měřené u mitrálního anulu $(5,59 \pm 1,38$ u pacientů bez gradientu proti 4,28 $\pm 1,02$, $p<0,05)$, na hranici statistické významnosti pak vyšlo $\mathrm{E} / \mathrm{E}$ ' u mitrálního anulu $(13,7 \pm 4,7 \mathrm{u}$ pacientů bez gradientu, $16,6 \pm 4,5)$. Poněkud překvapivě toto nevyšlo u laterální části mitrálního anulu.

Závěr: Naše pozorování potvrdilo, že u HCM je přítomna porucha diastolické funkce a naznačilo, že na její velikost může mít vliv přítomná obstrukce. $\mathrm{K}$ jednoznačnému zhodnocení by bylo třeba prospektivního srovnání a většího souboru.

\section{SESTERSKÁ SEKCE}

\section{OŠETŘOVATELSKÁ PÉČE U PACIENTŮ $S$ DIABETEM PO KARDIOCHIRURGICKÝCH VÝKONECH V KARDIOLOGICKÉ AMBULANCI}

ZINKOVÁ B, BARTƯŇKOVÁ V, BARTU゚NĚK L, KOTRŠÁLOVÁ I

\section{Kardiologická ambulance Rokycany, Rokycany}

Úvod: Velkou část pacientů v kardiologické ambulanci tvoří pacienti před kardiochirurgickým výkonem a po kardiochi- 
rurgickém výkonu. Před operací srdce je základním cílem péče o pacienta normalizace TK, kompenzace diabetu, redukce hmotnosti, dechová cvičení a psychologická příprava pacienta $\mathrm{k}$ výkonu, včetně specifických vyšetření před CABG a především před operacemi chlopní. $V$ pooperační péči se pak jedná o péči o sternotomie a safenektomie, kontroly pleurálních a perikardiálních výpotků, kontroly a normalizace vnitřního prostředí a systematické vedení a kontroly v rehabilitační péči. Obzvlášṫ důslednou péči je nutno věnovat pacientům $\mathrm{s}$ diabetem, $\mathrm{u}$ nichž je riziko pooperačních komplikací významně zvýšené.

Soubor a metodika: Autoři retrospektivně zhodnotili 48 pacientů, kteří podstoupili kardiochirurgický výkon v letech 2005-2006. $Z$ nich bylo 27 diabetiků či pacientů s poruchou glukózové tolerance (tj. 56,3\%) a 21 (tj. 43,7 \%) nediabetiků. Diabetici byli starší (66,3 vs. 61,4 let), měli vyšší výskyt dyslipidemie (96,3 \% vs. 85,7 \%) a vyšší výskyt hypertenze (88,9 \% vs. $81,0 \%$ ). Ze závažných neinfekčních komplikací v pooperační péči jsme zachytili 2 pacienty se srdeční tamponádou s nutností odeslání k akutnímu provedení perikardiocentézy. Závažné pooperační infekční komplikace zvláště charakteru mediastinitidy se u našich pacientů v pooperačním období nevyskytly. U diabetiků byl vyšší výskyt jakéhokoli sekundárního hojení ran (55,6 \% vs. 38,1 \%) a významnějších pleurálních výpotků $\mathrm{s}$ nutností pleurální punkce (14,8\% vs. 4,8\%). Nebyl rozdíl v pooperačních parézách bránice mezi diabetiky a nediabeticky (18,5 \% vs. 19,0\%).

Závěr: Vysoký podíl diabetiků a pacientů $\mathrm{s}$ poruchou glukózové homeostázy u pacientů v kardiologické ambulanci nutí $\mathrm{k}$ individuálnímu a specializovanému přístupu v léčbě a pooperační péči vzhledem ke zvýšenému riziku pooperačních komplikací u těchto pacientů. 


\section{Tritace \\ ramipril}

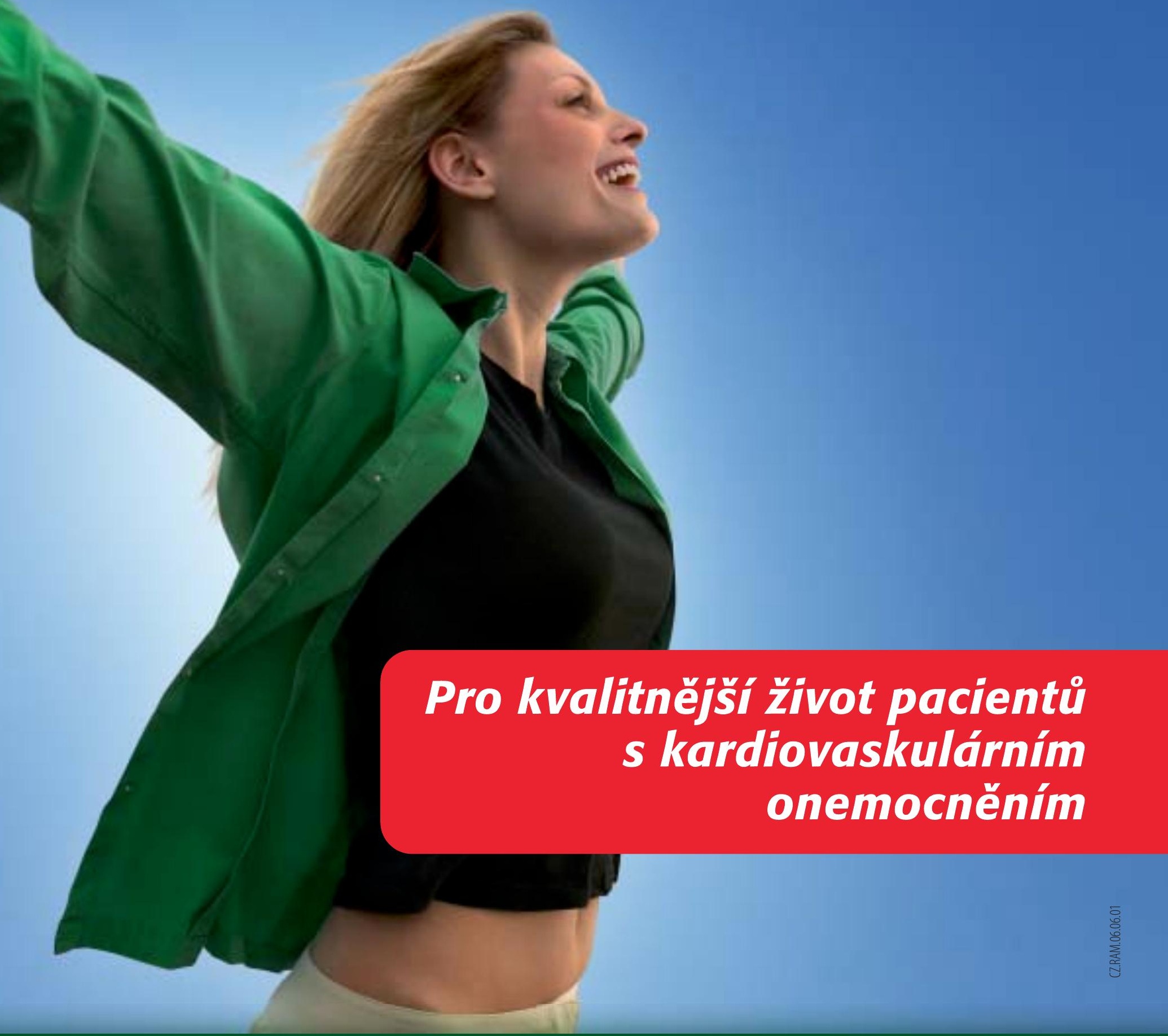

Zkrácená informace o prípravku Tritace

Antihypertenzívum, ACE inhibitor. Ramipril 1,25 mg, 2,5 mg, $5 \mathrm{mg}$ a $10 \mathrm{mg}$ v 1 tabletě. Indikace: hypertenze, srdeční selhání, diabetická i nediab. nefropatie, prevence kardiovaskulárních (KV) přhhod u pacientu se zvýšeným KV rizikem, prevence KV př́hod u diab. pacientü, snižení mortality po infarktu myokardu. Dávkováni: 2,5-10 mg 1X d, event. $2 \times$ d. U nefropatie a srd. selháni úvodní dávka 1,25 mg. Max. denní dávka $10 \mathrm{mg}$. Kontraindikace: preceitlivělost na ramipril, angioneurotický edém v anamnéze, významná překážka odtoku nebo př́toku levésrdeční komory (napri. aortální nebo mitrálnístenóza), renálnístenóza, hypotenze nebo hemodynamická nestabilita, , ěhotenství, kojení. Zvláštní upozorněni: Před zahájením léčby nutno upravit dehydrataci, hypovolemii nebo nedostatek soli. Zvláš̌ě v úvodu léčby nutno sledovat renální funkce a sérovou hladinu draslíku. Interakce: soli kalia, kalium šetřici diuretika. Nežádoucí účinky: hypotenze, suchý kašel, zhoršení renálních funkcí, vzácně angioneurotický edém. Uchováváni: Tritace 1,25, Tritace 2,5, Tritace 5: prì teplotě 10-25 ${ }^{\circ} \mathrm{C}$. Tritace 10: prí teplotě do $25^{\circ} \mathrm{C}$. Balení: 30,50 tablet. Držitel rozhodnutí o registraci: Aventis Pharma s. r. . ., Praha 4, Česká republika. Tablety $10 \mathrm{mg}$ : Aventis Pharma Deutschland GmbH, Frankfurt am Main, SRN. Registrační čsla: Tritace 1,25: 58/124/98-C. Tritace 2,5: 58/125/98-C. Tritace 5: 58/126/98-C. Tritace 10: 58/092/03-C. Datum registrace: 22. 7. 1998, tablety $10 \mathrm{mg}: 5$. 3. 2003. Datum revize textu: 10. 8. 2005. Před použitím prípravku se seznamte s úplnou informací 0 prípravku. Jen na lékařský predpis. Převážně hrazeno z prostřeaků veřejného zdravotního pojištění. Souhrn údajü o prípravku obdržte na adrese: sanofi-aventis, Evropská 2590/33c, 16000 Praha 6, tel:: 233086 111, fax: 233086222 , www.sanofi-aventis.cz. 


\section{Triasyn}

\section{Snižujte tlak, chráníte život}

Zkrácená informace o prípravku TRIASYN

Kombinované antihypertenzivum, ACE inhibitor ramipril a kalciový blokátor felodipin. 2,5 mg ramiprilu a 2,5 mg felodipinu nebo $5 \mathrm{mg}$ ramiprilu a 5 mg felodipinu 1 tabletěs řizeným uvolñováním. Indikace: arteriání hypertenze u pacientů nedostatečně reagujíćch na monoterapii. Dávkování: 2,5 mg ramiprilu/2,5 mg felodipinu, možno zvy̌šit na 5 mg ramiprilu/5 mg felodipinu 1x denně. Maximální denní dávka je $10 \mathrm{mg}$ ramiprilu/10 mg felodipinu 1x denně. Kontraindikace: precitlivělost na kteroukoliv složku prírpravku a jiné ACE inhibitory, angioneurotický edém (i v anamnéze), hemodynamicky významná oboustranná stenóza renálních artérí, jednostranná stenóza renální artérie u solitární ledviny, hemodynamická nestabilita, kardiovaskulárni šok, neléčené srdeční selhání, akutní infarkt myokardu, nestabilní angína pektoris, cévní mozková príhoda, AV blok Il. nebo III. st., těhotenstvía kojení. Zvláštní upozorněni: Pred zahájením lécby vhodné upravit dehydrataci, hypovolemii nebo nedostatek solí. Zvláště v úvodu lécby nutno sledovat renální funkce

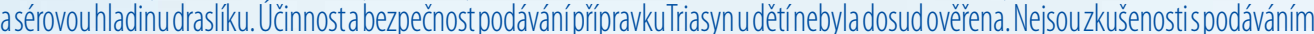
prípravkuTriasyn pacientům s postižením renálnífunkcías clearance kreatininunižšínež $20 \mathrm{~m} / \mathrm{min}$. a dialyzovaným pacientưm. Rovněž nejsou zkušenosti s podáváním prírpravku Triasyn pacientưm s tě̌zou hepatálníi nsuficiencí. Interakce: soli kalia, kalium šetrící diuretika. Nežádoucí účinky: hypotenze, suchýkašel, zhoršenírenálních funkcí, hyperkalémie, periferní otoky, zrudnutív obličeji (flush), palpitace, vzácně angioneurotický edém. Uchovávání: pri teplotě do $25^{\circ} \mathrm{C}$. Balení: 30 tablet. Držitel rozhodnutí o registraci: Aventis Pharma Deutschland GmbH, Frankfurt am Main, Německo. Registrační čísla: TRIASYN 2,5 mg/2,5 mg: 58/820/99-C. TRIASYN $5 \mathrm{mg} / 5 \mathrm{mg}$ : 58/821/99-C. Datum registrace:1.12.1999. Datum revizetextu:22.9.2004. Před pouzuitím príipravkuseseznamtesúplnouinformać

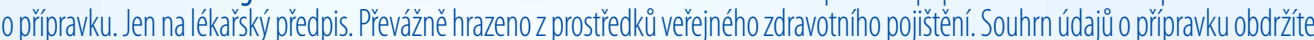
na adrese: sanofi-aventis, Evropská 2590/33c, 16000 Praha 6, tel. 233086 111, fax 233086 222, www.sanofi-aventis.cz. 